UNIVERSIDADE DE SÃO PAULO

FACULDADE DE FILOSOFIA, LETRAS E CIÊNCIAS HUMANAS DEPARTAMENTO DE HISTÓRIA PROGRAMA DE PÓS-GRADUAÇÃO EM HISTÓRIA SOCIAL

FLÁVIO LUÍS RODRIGUES

\title{
MARINHEIROS CONTRA A DITADURA BRASILEIRA AMFNB, prisão, guerrilha - Nacionalismo e revolução?
}

Tese de Doutoramento em História Social, apresentada à FFLCH/USP,

Sob a orientação do Prof. Dr. Marcos Silva

Versão corrigida 


\section{Versão corrigida \\ "De acordo" Prof. Dr. Marcos Silva}

Autorizo a reprodução e divulgaçầo total ou parcıal deste trabalho, por qualquer melo convenclonal ou eletrónico, para flns de estudo e pesqulsa, desde que citada a fonte. 


\section{RESUMO}

Nas páginas desta Tese, procuramos entender o surgimento e a trajetória de um grupo de ex-marinheiros, que participou da diretoria da Associação dos Marinheiros e Fuzileiros Navais do Brasil, AMFNB, entre maio de 1963 e o Golpe de 1964. Suas origens remontam à crise de 1961, quando os ministros militares brasileiros tentaram impedir a posse do vicepresidente João Goulart, após a renúncia de Jânio Quadros. $\quad$ Esse grupo, que denominamos Coletivo, inseriu-se no movimento mais amplo dos militares subalternos das Forças Armadas, que teve seu auge na chamada Revolta dos Sargentos de setembro de 1963. A partir do Golpe de 1964, o Coletivo entrou nas organizações guerrilheiras, passando por uma transição de nacionalistas a revolucionários. Os membros desse Coletivo, algumas vezes, estiveram dispersos, mas voltavam sempre a se reunir como se estivessem ligados a um compromisso surgido nos tempos da AMFNB. O grupo foi preso e encaminhado para a Penitenciária Professor Lemos Brito. Nesse lugar, ocupando pontos estratégicos na Administração Penitenciária, pode executar atividades que melhoraram a vida dos presos comuns, bem como de preparar sua fuga da prisão. Para a execução do plano de fuga, denominado Operação Liberdade, criou-se uma organização guerrilheira clandestina, com o sugestivo nome MAR - Movimento de Ação Revolucionária (a sigla se confundia com o substantivo mar), envolvendo várias pessoas de fora da Penitenciária. Sua fuga da prisão não significou afastamento da política. Ingressaram novamente na guerrilha no combate à ditadura civil-militar. Alguns de seus membros foram presos novamente, outros saíram do país e seu líder, Marcos Antônio da Silva Lima, foi morto numa emboscada da polícia, quando militava no PCBR.

O caminho percorrido pelo Coletivo, após o Golpe, permite compreender as estratégias e a ideia que tinham as organizações guerrilheiras de revolução. Realizando as entrevistas com membros desse Coletivo, conseguimos acesso a suas avaliações sobre as organizações guerrilheiras pelas quais passaram e sobre aquela jornada histórica.

Palavras-chave: militares subalternos; luta armada; marinheiros; ditadura civil-militar brasileira; organizações guerrilheiras; sistema prisional; Movimento de Ação Revolucionária - MAR; AMFNB. 


\begin{abstract}
This thesis tries to understand the emergence and trajectory of a ex-sailors group who attended the board of the Association of Sailors and Marines of Brazil (Associação dos Marinheiros e Fuzileiros Navais do Brasil, AMFNB) from May 1963 to the coup of 1964. Its origins date back to the 1961 crisis, when Brazilian military ministers tried to prevent the vice-president João Goulart possession, after the resign of president Janio Quadros.

This group, which we call Collective, was part of the broader movement of the subaltern Armed Forces personnel, which had its heyday in the named Revolt of the Sergeants September 1963. From the 1964 coup, the Collective entered guerrilla organizations, through a transition from the nationalist to revolutionaries. The members of this Collective sometimes been dispersed, but they always returned to meet as if they were connected to a compromise emerged in AMFNB times.
\end{abstract}

The group was arrested and taken to the Penitentiary Teacher Lemos Brito. There, occupying strategic points in Prison Administration, it could perform activities that improved the lives of ordinary prisoners, and to prepare his escape from prison.

They created for the implementation of the escape plan, called Freedom Operation, a clandestine guerilla organization, with the suggestive name MAR - Revolutionary Action Movement (the acronym was confused with the noun SEA), involving several people outside the penitentiary. Their prison break did not mean retirement from politics. Once again joined the guerrillas in fighting Brazilian civil-military dictatorship. Some of its members were arrested again, others left the country and its leader, Marcos Antonio da Silva Lima, was killed in a police ambush, when militated in PCBR.

The path taken by the Collective after the coup allows us to understand the strategies and the concept of revolution which guerrilla organizations had. We got access to their reviews of the guerrilla organizations through which passed and on that historic journey conducting interviews with members of the Collective,

Keywords: junior military; armed struggle; sailors; brazilian civil-military dictatorship; guerrilla organizations; prison system; Revolutionary Action Movement - MAR; AMFNB. 


\section{SUMÁRIO}

APRESENTAÇÃO: “QUANDO O MAR TEM MAIS SEGREDO” - MARINHEIROS, POLÍTICA E SOCIEDADE .6

CAPÍTULO I: ONDAS - O PROTESTO DOS MILITARES SUBALTERNOS E A FORMAÇÃO DO COLETIVO .29

CAPÍTULO II: DIANTE DA TEMPESTADE - O PÓS-GOLPE E O INGRESSO NA GUERRILHA .91

CAPÍTULO III: MAR É CONTRA A DITADURA 161

CAPÍTULO IV: LIBERDADE QUERIDA E DESEJADA .256

CONCLUSÕES: “UM DESERTO E SEUS TEMORES” - PERSPECTIVAS .352

BIBLIOGRAFIA 356

ENTREVISTAS .363 


\section{“MAIS SEGREDO" - MARINHEIROS, POLÍTICA E SOCIEDADE (APRESENTAÇÃO)}

"Quando o mar tem mais segredo é quando é calmaria." (Suely Costa e Cacaso, “Amor, amor”)

"Fui bailar No meu batel Além do mar cruel." (Canção do Mar, Frederico de Brito e Ferrer Trindade)

A tese que ora apresentamos é o resultado de pesquisa, cujo objeto é a trajetória de um grupo de militares subalternos, da Marinha do Brasil, que ousou questionar os regulamentos disciplinares, considerados anacrônicos. Essa ousadia colocava em relevo a questão da obediência à disciplina e à hierarquia, tão caras aos militares. Seus integrantes não estavam sós nesses questionamentos. Esse grupo estava inserido em um movimento mais amplo, de militares de outras Forças Armadas, que se organizaram em associações, para lutarem por melhores condições de trabalho e mudanças dos regulamentos internos, como também pelo direito a concorrerem a cargos legislativos (deputados e vereadores).

O que observamos, e tentaremos demonstrar, é que esses homens, muito jovens ainda, se envolveram com a política nacional, levados pela conjuntura de intensa mobilização e interação cultural e social, do início dos anos 1960. O mundo em torno deles estava em plena mutação: mudança comportamental, nas relações de trabalho, nas comunicações, nas tecnologias, na possibilidade da revolução, que se tornou realidade com a experiência cubana, e na "descoberta do povo".

No entanto, por serem militares, deveriam manter suas atenções voltadas para a Marinha de Guerra, apenas. As Forças Armadas já foram entendidas como instituições totais ${ }^{1}$, ou seja, aquelas em que seus membros são constituídos por iguais e agem, pensam e se comportam uniformemente. Doutrinados, seus membros são desclassizados ${ }^{2}$ e seu tempo, presente e futuro, passa a pertencer à instituição. Incorporados neste invólucro, são obrigados a seguirem regras iguais para todos, como, por exemplo, casarem-se apenas com autorização

\footnotetext{
${ }^{1}$ GOFFMAN, Erving. Citado por CARVALHO, 2005, 13.

${ }^{2}$ FERNANDES, Heloisa Rodrigues. Citado por MACIEL, 2009, 32.
} 
da instituição; não questionarem as ordens de seus superiores; não questionarem as transferências para lugares distantes; não falarem em partidos políticos e muito menos participarem deles; não darem entrevistas sobre a instituição; muito menos devem desertar e estarem dispostos a morrer pela instituição.

Esse grupo, no entanto, começou a refletir não apenas sobre seu presente e futuro, mas também, sobre o seu passado pobre, ligado ao campo, muitas vezes no interior do Nordeste ou Norte, onde ainda estavam seus familiares. Passaram, também, a abrir-se para um mundo fora do ambiente da Marinha, como o dos estudantes universitários, dos artistas, dos políticos e pessoas de organizações de esquerda. Aproximaram-se da política, pois perceberam que seria a partir dela que se poderia mudar a realidade de um país tão pobre. A rebeldia desses homens os afastou, cada vez mais, de seus superiores.

Através das discussões que faziam na Associação dos Marinheiros e Fuzileiros Navais do Brasil - AMFNB -, da qual eram diretores, identificaram que havia uma distância entre o projeto do então atual governo, João Goulart, e o de seus oficiais superiores, que sempre faziam críticas ao Presidente. O que provocou a radicalização entre a Administração Naval e os diretores da AMFNB foi exatamente sua tomada de partido, do lado das Reformas de Base e do trabalhismo reformista ${ }^{3}$ de Leonel Brizola.

Esse grupo, que dirigiu a AMFNB a partir de maio de 1963 até o Golpe de 1964, cujos membros tinham as mesmas origens sociais, majoritariamente nordestinos ou nortistas, ligados ao campo, teve, também, a mesma formação política. Como a Associação passou a realizar atividades que atendiam às demandas dos marinheiros e de suas famílias, o número de sócios passou de centenas a milhares. Cada vez mais, a Associação se tornou uma referência para os marinheiros. E o grupo passou a ampliar seus conhecimentos, através dos contatos com universitários e membros do governo. As relações entre seus membros foram, num crescendo, se estreitando e fortalecendo: as decisões eram tomadas em conjunto; as leituras, para aumentar o repertório, eram as mesmas; as pessoas que tinham como referências eram praticamente as mesmas. Por isso, consideramos mais adequado nos referirmos a eles como Coletivo.

Durante nossa pesquisa de Mestrado, quando pesquisamos a trajetória da Associação dos Marinheiros e fuzileiros Navais do Brasil ${ }^{4}$, conforme entrevistávamos os ex-marinheiros

\footnotetext{
${ }^{3}$ Neves, Lucília de Almeida. Trabalhismo, Nacionalismo e desenvolvimentismo: um projeto para o Brasil (19451964). In: Ferreira, Jorge: O populismo e sua história. Rio de Janeiro, Civilização brasileira, 2001, p. 177-179. ${ }^{4}$ RODRIGUES, Flávio Luís. Vozes do Mar: a trajetória da Associação dos Marinheiros e Fuzileiros Navais do Brasil (1962-1964). Dissertação de Mestrado. Universidade de São Paulo. São Paulo: 2003. Publicada com o título: Vozes do mar: o movimento dos marinheiros e o Golpe de 1964. São Paulo: Cortez, 2004.
} 
que participaram da AMFNB, ouvíamos seus relatos sobre a participação na luta armada, suas prisões, torturas, um longo período na cadeia, convivendo com marginais perigosos e a cinematográfica fuga da penitenciária pela porta da frente. Isso só ampliou nossa curiosidade por pesquisar a trajetória desse grupo após 1964 e conhecer por dentro as organizações guerrilheiras e de outras modalidades pelas quais seus membros passaram.

Dessa forma, a vontade de perquirir minuciosamente tal período, da crise política do governo João Goulart até à morte do líder do Coletivo, Marcos Antônio da Silva Lima, em 14 de janeiro de 1970, procurando entender a participação dos marinheiros nas organizações guerrilheiras e similares, seu encontro com o Marxismo, sua ideia de revolução, seus projetos sociais e políticos e suas vidas clandestinas, levou-nos a definir nosso objeto de pesquisa de doutoramento. Partiremos das origens da organização dos militares subalternos e de seu contato com a política nacional, ou seja, dos acontecimentos de agosto-setembro de 1961, decorrentes da renúncia de Jânio Quadros, quando os ministros militares tentaram impedir a posse do Vice-presidente João Goulart. Durante essa crise político-militar, os militares subalternos, em sua maioria sargentos das três Forças, reagiram contra a inconstitucionalidade das ações da Junta Militar em ameaçar prender Jango, caso ele entrasse no Brasil - O Vicepresidente estava em viagem oficial à China e à União Soviética. Aquilo que ficou conhecido como Campanha da Legalidade, cujo principal protagonista foi o governador do Rio Grande do Sul na época, Leonel Brizola, teve participação decisiva dos subalternos militares. A divisão do Exército, quando o III Exército se recusou a cumprir as ordens do Ministro da Guerra Odílio Denys de bombardear o Palácio Piratini e prender o governador Brizola com as tropas do $18^{\circ}$ Regimento de Infantaria, deve-se muito ao boicote que os sargentos fizeram, impedindo que os jatos decolassem e recusando-se a marcharem até o Piratini para depor o governador. A essa participação dos subalternos em defesa da Constituição e sua posterior mobilização para tornarem-se elegíveis a cargos legislativos, bem como sua atuação em defesa das Reformas de Base, denominaremos de protesto dos militares subalternos. Toda essa mobilização nos quartéis atingiu, também, o ambiente da Marinha do Brasil. Parte do Coletivo, solidário aos sargentos, criou sua associação, em 25 de março de 1962. A Associação dos Marinheiros e Fuzileiros Navais do Brasil - AMFNB, portanto, faz parte desse movimento mais amplo de subalternos das Forças Armadas do Brasil.

Com o Golpe de 1964, a diretoria da AMFNB e a maioria dos que participaram da Revolta dos Marinheiros em março de 1964, cerca de 1.200 pessoas, foi expulsa da Marinha e a Associação foi fechada. Jovens que tinham participado intensamente das reuniões e das campanhas da Associação por justiça e conquista de direitos viram, de repente e 
inacreditavelmente, o mundo desabar. Sem emprego, processados pela Justiça Militar, decepcionados com a omissão daqueles que prometiam defender o governo de um golpe eles próprios avisaram ao "dispositivo militar" janguista sobre o perigo várias vezes -, vagavam sem rumo, procurando orientação e ajuda. Nesse momento, outros civis e militares organizavam-se em represália ao Golpe e à ditadura que se instalava. Nossos protagonistas, ex-marinheiros integrantes da segunda diretoria da AMFNB, aproximaram-se de organizações clandestinas e tentaram, a todo custo e solidariamente, reunir o antigo coletivo da associação. Eles tiveram vida agitada: roubaram bancos (chamavam de "expropriações bancárias"), roubaram armas, criaram "aparelhos", tentaram criar acampamentos revolucionários, participaram de treinamento de guerrilha urbana e rural em Cuba, foram presos, fugiram da cadeia, foram feridos, foram torturados, foram cantados por Jorge Ben Jor, desapareceram. Alguns sobreviveram, outros morreram.

A trajetória desse grupo dos marinheiros que dirigiram a segunda gestão da Associação dos Marinheiros e Fuzileiros Navais do Brasil, no período dos governos Castelo Branco, Costa e Silva e os primeiros três meses do governo Médici, será o objeto de nossa pesquisa. O estudo de suas atividades após o Golpe de 1964 ampliará nossos conhecimentos a respeito das várias organizações guerrilheiras e similares com as quais tiveram contato.

Esse coletivo, durante o período em que esteve na Penitenciária Professor Lemos Brito, foi ampliado pelo ingresso de novos membros. Passaram a integrá-lo os exmarinheiros José Adeildo Ramos e Benedito Alves Campos, o líder da Revolta dos Sargentos de setembro de 1963, o ex-sargento da Aeronáutica, Antônio Prestes de Paula, os presos comuns Edison Duarte de Melo, José André Borges, José Michel Godoy e, mais tarde, Roberto Cietto. Além desses, outros militantes se relacionaram com o coletivo, na ocasião do planejamento e execução da fuga da penitenciária, em maio de 1969: Wilson do Nascimento Barbosa, Flávio Aristides Freitas Tavares, Edvaldo Celestino da Silva, Júlio Cesar Senra Barros, Elio Sá Rego, José Ferreira e vários mais. Alguns desses contribuíram com o coletivo para fundar uma organização revolucionária na prisão, o Movimento de Ação Revolucionária (sugestivamente, MAR), para organizar a fuga e criar, em seguida, um acampamento guerrilheiro próximo à cidade de Angra dos Reis. A fuga foi bem-sucedida e pelo portão central da Penitenciária. O acampamento para onde os fugitivos foram, uma cabana chamada Jacu na serra de Angra dos Reis, no entanto, seria descoberto pela Marinha e desbaratado com apenas uma prisão pelos Fuzileiros Navais.

Realizamos entrevistas com quase todos os membros do Coletivo. Não conseguimos entrevistar Marcos Antônio da Silva Lima, Antônio Prestes de Paula, Roberto Cietto e José 
Michel Godoy porque já morreram; Benedito Alves Campos, porque “desapareceu”, não localizamos sequer quem pudesse dar informações sobre seu paradeiro; e José Duarte dos Santos que, por princípio, não concede entrevista. Tentamos várias vezes contatá-lo para pedir um encontro, mas em nenhum momento ligou de volta. Nem com o pedido de familiares e amigos quis atender a nosso convite. Como veremos, suas informações seriam muito importantes para elucidar acontecimentos que, infelizmente, ficaram restritos a suposições e informações de seus amigos.

Eis as pessoas que nos cederam entrevista:

\section{1- Antônio Geraldo Costa.}

Natural do interior do Estado do Alagoas, foi um dos fundadores da Associação dos Marinheiros e Fuzileiros Navais do Brasil, AMFNB, e um dos articuladores da ascensão do coletivo à diretoria da Associação. Foi Delegado Geral da segunda diretoria da AMFNB. Antes de 1964, esteve na Organização Revolucionária Marxista - Política Operária - ORMPolop. Após o Golpe, ingressou no Movimento Nacionalista Revolucionário - MNR, liderado por Leonel Brizola, passou rapidamente pela Vanguarda Popular Revolucionária - VPR e, finalmente, na Ação Libertadora Nacional - ALN, recebendo o codinome "Tigre”.

\section{2- José Adeildo Ramos.}

Natural do interior da Paraíba, foi baleado por oficiais na ocasião da chamada Revolta dos Marinheiros, quando estava em passeata na frente do Ministério da Marinha, a caminho do Sindicato dos Metalúrgicos, onde se encontravam rebelados cerca de três mil marujos. Julgado culpado por tribunal militar, foi um dos primeiros marinheiros a chegar à Penitenciária Lemos Brito.

\section{3- $\quad$ Avelino Biden Capitani.}

Natural do interior do Rio Grande do Sul, ocupou o cargo de Segundo Vice-presidente da AMFNB. Depois do Golpe, ingressou no MNR de Leonel Brizola no Uruguai. Foi para Cuba, onde fez treinamento de guerrilha e sobrevivência na selva, juntamente com outros marinheiros. Voltando ao Brasil, participou da Guerrilha de Caparaó, plano foquista do MNR. Preso, enviaram-no de Juiz de Fora para a Penitenciária Lemos Brito, onde foi recebido por um comitê de recepção, formado por seus colegas da diretoria da Associação que o aguardavam. Após a fuga da Lemos Brito, ele e os demais fugitivos criaram um acampamento de treinamento de guerrilha na Serra de Angra dos Reis. Descobertos pela 
Marinha, conseguiram escapar do cerco dos Fuzileiros Navais e ingressaram - ele, Marco Antônio, Preste de Paula, José Adeildo e Antonio Duarte - no PCBR. Numa ação, foi ferido e perseguido nos morros de Rio de Janeiro, conseguindo furar o cerco e fugir. Essa fuga (da qual falaremos em nossa Tese), cinematográfica, foi divulgada na grande Imprensa, que o chamava de "Charles", e inspirou Jorge Ben Jor a fazer a música "Charles Anjo 45". Através de Antônio Duarte, Capitani se aproximou, por pouco tempo, do MR8, antes de deixar o País.

\section{4- $\quad$ Pedro França Viegas.}

Natural de São Luis, Maranhão, entrou na AMFNB em 1963 como jornalista do periódico A Tribuna do Mar. Depois do Golpe, enquanto corria seu processo nos tribunais militares, trabalhava em jornais e ajudava seus colegas da extinta Associação, dando guarida a eles em sua casa, por exemplo. Condenado pelo Inquérito Policial Militar, passou a levar vida clandestina até sua prisão definitiva em fevereiro de 1967. Depois de passar pelo Presídio do Estado da Guanabara, foi enviado para a Lemos Brito.

\section{5- $\quad$ Antônio Duarte dos Santos.}

Natural do Rio Grande do Norte, foi Presidente do Conselho Deliberativo da Associação dos Marinheiros e Fuzileiros Navais do Brasil. Depois do Golpe, integrou o MNR de Leonel Brizola. Após a fuga da Penitenciária Lemos Brito e da tentativa de se criar um acampamento guerrilheiro na Serra de Angra dos Reis, teve passagem rápida pelo Partido Comunista Brasileiro Revolucionário - PCBR e pelo Movimento 8 de Outubro - MR8.

\section{6- $\quad$ Edison Duarte de Melo.}

Natural do Rio de Janeiro, preso em 1958, “acusado por uma série de delitos, que achava que não era nada, fiquei 20 anos lá”. Foi para Lemos Brito, onde se integrou ao coletivo e ao planejamento da fuga da penitenciária. No dia da fuga, no entanto, não conseguiu escapar (explicaremos porque na Tese). Seu depoimento foi importante para entendermos como era a vida do presidiário na Lemos Brito.

\section{7- José André Borges.}

Natural do interior do Pará, filho de índia abandonada pelo marido, que muda para Belém. Em Belém, se “desencaminhou” e foi preso. Fugiu da cadeia, passou por São Luis, onde também “arranjou algumas confusões”, e voltou para Belém, quando novamente foi 
preso e, mais uma vez fugiu da prisão. No Rio de Janeiro, por “arrumar algumas confusões” (assaltos, “nunca matei ninguém”), foi definitivamente preso na Penitenciária Lemos Brito, para cumprir pena de 30 anos, em 1958. Integrou o coletivo dos marinheiros, participou do planejamento da "operação liberdade” (fuga da prisão) e, após a fuga, participou de vários assaltos a bancos ("expropriações") para financiar as organizações guerrilheiras. Preso numa dessas ações, foi para o Presídio de Ilha Grande.

Através dessas entrevistas, observamos a importância que os ex-marinheiros tiveram na luta armada, ocupando funções de peso nas organizações guerrilheiras em que atuaram, principalmente em operações táticas armadas. Tais entrevistas levaram-nos a compreender melhor as estruturas de comando e ações armadas das diversas organizações no período estudado.

Esses ex-marinheiros, mesmo expulsos da Marinha e dissolvida a AMFNB, mantiveram-se quase sempre unidos, como se estivessem ligados por um compromisso assumido nos tempos da Associação.

Vale a pena, então, falarmos brevemente da AMFNB.

Durante a Semana Santa de março de 1964, mais de mil marinheiros se concentraram no Sindicato dos Metalúrgicos da Guanabara, conhecido como "Palácio de Aço", para comemorarem o segundo aniversário da Associação dos Marinheiros e Fuzileiros Navais do Brasil - AMFNB -, com refrigerantes, apresentações musicais e discursos de associados e convidados. O que deveria ter sido uma alegre confraternização transformou-se, no entanto, num protesto de militares que pediam o imediato reconhecimento da associação pela Administração Naval - apesar de não caber a ela tal reconhecimento, visto que a AMFNB possuía registro civil -, além de outras reivindicações. Durante o encontro, representantes da associação discursaram, informando sobre a prisão de parte dos diretores da entidade e o ataque contra alguns de seus associados, que se dirigiam em passeata para o evento, por tiros de metralhadora disparados por oficiais da Marinha, a partir das janelas do prédio do Ministério dessa Arma. Chegava a esse desfecho um conflito que se arrastava desde setembro de 1963 entre os marinheiros dirigentes da Associação e os oficiais burocratas do Ministério. Os marinheiros não aceitavam as perseguições que a Marinha fazia, já que se consideravam participantes do "dispositivo militar" do governo João Goulart. Estavam acostumados a frequentar os gabinetes dos ministérios do Governo Federal, sempre bem recebidos por aliados, como o Chefe da Casa Civil da Presidência da República, professor Darcy Ribeiro, um dos integrantes mais importantes do governo. Como se vê, um paradoxo que os 
marinheiros atribuíam à resistência do Almirantado - conservador e golpista segundo suas avaliações - às reformas pretendidas por Goulart.

A Associação dos Marinheiros e Fuzileiros Navais do Brasil - AMFNB - nasceu em março de 1962 como entidade civil, fundada por um grupo de cabos da Marinha que pretendia proporcionar assistência social, médica e jurídica aos marujos desprovidos de qualquer representação no ambiente fuzinauta. Essa primeira diretoria era tolerada pela Administração Naval, uma vez que suas atividades eram assistencialistas e educativas, convenientes, de certa forma, para auxiliar no controle da marujada.

Em $1^{\circ}$ de maio de 1963, no entanto, assume outra diretoria na AMFNB que se posicionou criticamente em relação aos dirigentes anteriores, considerados excessivamente amistosos com os oficiais da burocracia naval. Essa nova diretoria imprimiu uma linha de atuação menos assistencialista e mais política à associação. Seus integrantes eram mais jovens, marinheiros de Primeira Classe ou marujos, em contraste com os anteriores, mais velhos e majoritariamente cabos. Havia entre os novos dirigentes, seguramente, vários cabos, como Antônio Geraldo Costa, Moacir Omena e Pedro Viegas, de quem falaremos adiante. Esses moços, fogosos no que se refere a conquistar melhorias em suas condições de trabalho, eram, ao mesmo tempo, solidários com os outros militares das demais Armas (como os sargentos do Exército ou os praças da Polícia Militar da Guanabara) que pretendiam fundar suas associações. Eram comuns as reuniões com outras associações de militares subalternos na sede da AMFNB. Discutiam-se abertamente as reformas pretendidas pelo governo. Seu presidente, José Anselmo dos Santos, conhecido erroneamente como "Cabo" Anselmo (era marinheiro de Primeira Classe e esperava então promoção para cabo), tinha facilidade de comunicar-se, sendo considerado bom orador e muito simpático nas relações pessoais. Mas não era quem dava a última palavra nas decisões da associação. Segundo depoimentos de exmarinheiros que participaram da diretoria, as decisões da AMFNB eram tomadas por um coletivo que se reunia em torno da Vice-Presidência, ocupada por Marcos Antônio da Silva Lima e que se encontrava frequentemente com os delegados representantes da AMFNB nas diversas unidades da Marinha. Quase sempre, as discussões eram contempladas por análises da conjuntura política nacional, feitas pelos mais "estudados".

Essa segunda diretoria era composta por José Anselmo dos Santos (presidente), Marcos Antônio da Silva Lima (vice-presidente), Avelino Biden Capitani (segundo vicepresidente), Antônio Duarte dos Santos (presidente do Conselho Deliberativo), José Pinheiro Guimarães (tesoureiro), Pedro França Viegas (redator do jornal Tribuna do Mar), Moacir Omena (editor do Tribuna do Mar), Adilson Aquilino (secretário-geral). Além desses, José 
Duarte dos Santos, Cláudio Ribeiro, Antônio Geraldo Costa (Delegado Geral), Edgar Duarte, Raul Alves Nascimento, José Alípio, João Ataíde Gomes e muitos outros frequentavam assiduamente as reuniões na AMFNB e participavam ativamente de suas ações. Tais moços imprimiram intensa atividade à associação, oferecendo aos associados assistência jurídica, eventos culturais e acesso à leitura, através da criação de bibliotecas, escolas de preparação para exames de promoção na carreira (geralmente ministrados por estudantes da UNE), orientação psicológica e de higiene, assim como matrimonial, etc. Eles criaram um jornal, o Tribuna do Mar, dirigido por Moacir Omena, com a ajuda do marinheiro-jornalista Pedro Viegas (sua última edição foi de 15 mil exemplares). Por conseguinte, tornaram-se referência política no seio das Forças Armadas, assustando deveras a oficialidade conservadora.

A maioria absoluta dos marujos que ingressavam na Escola de Aprendizes em 1962 era de origem nortista e nordestina, principalmente dos estados do Ceara, Pernambuco, Maranhão e Bahia. Existiam marujos de outros estados (como Capitani, do Rio Grande do Sul), naturalmente, mas eram minoritários. Outra tipologia era a relação que o grupo tinha com o campo. Geralmente, os ingressantes eram do interior, muito pobres e perfeitamente suscetíveis aos apelos da Marinha, que fazia propaganda dirigida a esse público. Em vários depoimentos que colhemos em nossa pesquisa de Mestrado, os narradores admitiram que a propaganda da Marinha foi fundamental para sua decisão, pois, através dela, sonhavam com viagens maravilhosas para diferentes países. Como dizia a propaganda, eles iriam "conhecer o mundo". Desgraçadamente, quando ingressavam na Marinha, percebiam que tratava-se de uma farsa. As viagens para o exterior eram raras. A vida a bordo era cansativa, monótona e sofrível: o banho era controlado, a comida era diferenciada da dos oficiais, o preconceito prevalecia, visto que a Marinha, historicamente, era a mais elitista das Forças Armadas. Além disso, quando em dia de folga, não podiam sair do navio sem a farda, senão eram presos pelos fuzileiros navais. Toda embarcação tinha seu Livro de Castigo, que aterrorizava os marinheiros e conferia um poder extraordinário aos oficiais. Era ali que o oficial de plantão anotava as contravenções - ou aquilo que ele considerava contravenção - que os marinheiros cometiam (se é que cometiam). Acima de determinado número de anotações, o marinheiro “contraventor" era compulsoriamente expulso da Marinha. Ou então, estando "fichado", ficaria com sua carreira funcional seriamente comprometida. Percebe-se o caráter absolutamente pessoal da ação. E inteiramente descabido. O Regulamento Disciplinar para a Marinha (RDM) estipulava setenta e duas contravenções. Por exemplo: "dirigir-se ao superior de modo desrespeitoso"; "censurar ato de superior"; "responder de maneira desatenciosa ao superior"; "deixar, quando estiver sentado, de oferecer seu lugar ao 
superior, ressalvadas as exceções previstas no Regulamento de Honras e Sinais de Respeito das Forças Armadas"; "postar-se sem compostura em lugar público"; "simular doença para se esquivar a qualquer dever militar"; “casar sem licença da autoridade competente”; "introduzir ou estar de posse a bordo, de publicações prejudiciais à moral ou à disciplina" (ALMEIDA, 2010: 37-38). Os dirigentes da AMFNB ouviam diariamente reclamações de marinheiros que se queixavam de perseguição dos oficiais. Cada vez mais, ficava claro para os diretores que o confronto com a oficialidade conservadora seria inevitável.

Em nossa pesquisa de mestrado, observamos a afinidade da diretoria com o projeto do trabalhismo reformista de João Goulart e Leonel Brizola. Enquanto estavam atuando na associação, os marinheiros não tinham vinculação política com partidos ou organizações clandestinas. Havia, isso sim, um apoio convicto às reformas pretendidas pelo governo Jango e uma admiração especial por Leonel Brizola. Aos poucos, dada a politização que a atuação na AMFNB permitia, através de vários contatos com partidos políticos, organizações, sindicatos, estudantes e intelectuais, os dirigentes se aproximaram das entidades de esquerda, como a Organização Revolucionária Marxista - Polop (nome de seu jornal, Política Operária) e o Partido Comunista Brasileiro - PCB. Um exemplo desses contatos foi Carlos Marighella, que ajudou a fazer o discurso que Anselmo leu no Sindicato dos Metalúrgicos na ocasião da revolta. Ele era do Partido Comunista - PCB - e fundou, mais tarde, a Ação Libertadora Nacional, ALN, organização que abrigou, no final dos anos 60, vários marinheiros.

As atividades da AMFNB já vinham preocupando o Almirantado conservador e, nessa altura, muitos de seus membros mantinham contatos com políticos que procuravam uma via inconstitucional para depor Jango e seus assessores "comunistas". Quando pesquisamos o Arquivo da Marinha, no Rio de Janeiro, encontramos vários documentos pessoais (cartas principalmente) que indicavam explicitamente uma conspiração entre militares e civis, já em 1962. Não admitiam que subalternos tivessem envolvimento em atividades políticas e que o governo lhes garantisse impunidade. A Administração Naval tentava manter contato com os marinheiros para ter, de certa forma, controle sobre suas ações. Prometia estudar a possibilidade, por exemplo, de permitir à associação recolher mensalidades dos associados através de suas folhas de pagamento. Essa relação cordial era, inclusive, orientada pelo Gabinete da Presidência da República. A esse respeito, é elucidativa a passagem em que o Presidente João Goulart resolveu prestigiar os marinheiros mandando o Ministro da Justiça, Abelardo Jurema, representá-lo na festa de comemoração do segundo aniversário da AMFNB, em 25 de março de 1964, recomendando ao ministro cautela e que "procurasse contornar, 
pois se já o Governo não dispunha do Almirantado, não poderia perder a simpatia dos inferiores" (JUREMA, 1966: 152)

Em setembro de 1963, no entanto, um acontecimento provocou uma inflexão na relação relativamente aprazível que a Administração Naval vinha mantendo com a AMFNB. A chamada Revolta dos Sargentos, liderada pelo Sargento Antônio Prestes de Paula, de quem falaremos adiante, aconteceu em Brasília, quando cerca de 600 praças trocaram tiros com tropas do Exército e tomaram prédios públicos, inconformados com a resolução do Supremo Tribunal Federal de não permitir o registro de candidaturas de sargentos às próximas eleições. O governo, através de seu Ministro da Justiça, conseguiu controlar a situação. Mas, na Marinha, o evento desencadeou uma série de perseguições por parte de oficiais autoritários, descontentes com a "ousadia” dos marinheiros. A Administração Naval começou, também, a perseguir insistentemente a diretoria da AMFNB, tentando dispersar seus diretores pelas várias unidades navais: ela não queria correr o risco de ver seus marujos rebelados, como acontecera em Brasília com os sargentos. As prisões de diretores se tornaram comuns e a resposta dos marinheiros podia ser percebida no jornal da entidade, A Tribuna do Mar: através de artigos politizados, marinheiros acusavam a radicalização da hierarquia da Marinha, vinculando suas ações à tentativa de atingir indiretamente o governo de João Goulart. Aliás, os marinheiros chegaram a se reunir com Leonel Brizola para alertá-lo a respeito de um encontro sigiloso acontecido numa corveta, de oficiais navais com o governador do Estado da Guanabara, Carlos Lacerda. O golpe estava a caminho e, para os marinheiros, parte dos oficiais da Marinha era constituída por "gorilas" golpistas.

A Revolta dos Sargentos foi de maior complexidade, pois tratou-se de movimento de suboficiais que já vinha se arrastando pelo menos desde 1961, ocasião em que se posicionaram a favor da posse de João Goulart, apoiando, portanto, a iniciativa do governador do Rio Grande do Sul, Leonel Brizola de resistir ao golpe militar. Nesta Tese, tentaremos mostrar a imbricação desse movimento com o coletivo dos marinheiros. Podemos adiantar que, em nosso entendimento, o movimento dos suboficiais foi determinante para a adesão dos marinheiros, nossos protagonistas, ao trabalhismo reformista de Brizola.

Logo após o Golpe de 1964, todos os integrantes da diretoria da AMFNB e cerca de mil e duzentos marinheiros foram expulsos da Marinha. Destes, cerca de trezentos foram condenados pela Justiça Militar, num processo que durou mais de dois anos. Os marinheiros findaram espalhados por prisões comuns no município do Rio de Janeiro. As penas foram altas, dependendo do processo, de dois a quinze anos de reclusão. Segundo o ex-marinheiro Antônio Duarte, 
"existiam três processos: o 'motim', o processo contra a 'Associação dos Marinheiros', incluída a diretoria da Associação, e o processo das 'Células Comunistas nos navios'. Ninguém escapava de um destes processos" (DUARTE, 2005: 275).

Antes de serem presos, porém, os marinheiros se engajaram em organizações clandestinas. Alguns foram para o Uruguai juntar-se a Brizola para preparar a revolução. De lá, vários partiriam para Cuba, como Marcos Antônio, Capitani, José Duarte e, mais tarde, Anselmo. Outros ficaram no Brasil, mantendo-se, no entanto, ligados a Brizola. Antônio Geraldo Costa, o "Neguinho", que iniciou sua militância clandestina na ORM-Polop, dissidência do PCB, passou a integrar o Movimento Nacionalista Revolucionário - MNR, atuando em São Paulo. Mais tarde, ingressaria na Ação Libertadora Nacional - ALN. Pedro Viegas, também expulso da Marinha e esperando condenação por participar da AMFNB, manteve suas atividades jornalísticas, o que não o dispensou de participar, mesmo indiretamente, de operações clandestinas. Foi chamado a depor no CENIMAR, órgão de informação da Marinha, por ter dado guarida a Antônio Geraldo Costa e Antônio Duarte, já procurados pela polícia por suas ações "subversivas".

Mais tarde, os marinheiros foram reunidos na Penitenciária Professor Lemos Brito, reagrupando o antigo coletivo, agora ampliado por presos comuns, e que passaria a discutir os caminhos para a revolução brasileira. Preparavam, então, a Operação Liberdade, nome que deram à preparação da fuga da prisão. Após a fuga, eles se engajariam na luta armada contra a ditadura.

A Operação Liberdade foi bem-sucedida, mesmo contando com a morte de um soldado, o que não estava nos planos dos fugitivos. Ganhando a rua, nove presos, além do motorista, se espremeram num Aero Willys, que já os esperava. Várias pessoas participaram da preparação da fuga, entre elas o jornalista Flávio Tavares e outros ligados principalmente à Ação Libertadora Nacional - ALN -, como Wilson do Nascimento Barbosa, que na época era formado em História, "brilhante, bom orador e agitador”, nas palavras de Antônio Duarte (DUARTE, 2005: 66).

$\mathrm{Na}$ preparação da Operação Liberdade, teve importante participação um grupo pequeno de comunistas "independentes", que procurava uma organização à qual se incorporar. Segundo o ex-marinheiro Pedro Viegas,

"Esse grupo vinha de longa experiência sindical e sua origem estava nos transportes coletivos.

Eram ex-funcionários da Light, que operavam os bondes quando estes existiam, transferidos para a Companhia de Transportes Coletivos (CTC) quando esse meio de transporte foi extinto" (VIEGAS, 2004: 79). 
Denominado pelos marinheiros como Grupo Mallet, devido ao bairro carioca onde ele foi organizado, o coletivo se integrou ao MAR e participou do transporte dos fugitivos, bem como de seu futuro esconderijo.

Nesta Tese, pretendemos apresentar os resultados de nossas pesquisas, levando em conta depoimentos de militares subalternos de outros núcleos das Forças Armadas, tendo em vista a multiplicidade de posturas dessa parcela da sociedade, uma vez que muitos militares foram contrários à experiência ditatorial, lutaram para que ela não tivesse continuidade e sofreram diferentes represálias por essas atitudes - exílio, prisão, até morte. Na realidade, o que aqui apresentamos é a pesquisa sobre um período posterior àquele que abordamos em nossa dissertação - março de 1962 a março de 1964, redirecionando o recorte, com enfoque naqueles militares que se posicionaram militantemente contra a ditadura. Nossos protagonistas, "trabalhistas pragmáticos reformistas" (NEVES, 2001) até o Golpe; na clandestinidade, migraram do "nacionalismo radical" (RIDENTI, 1993) dos suboficiais que acompanhavam Brizola, para a postura de "revolucionários", principalmente na ocasião da criação do Movimento de Ação Revolucionária - MAR.

Apresentaremos as conclusões a que chegamos através das entrevistas dos membros da antiga AMFNB, bem como de outros militares ou civis ligados a seu círculo, que tiveram participação direta ou indireta nas atividades do Movimento de Ação Revolucionária - MAR , além de outras organizações de esquerda e demais grupos que se opuseram à ditadura. Procuramos confrontar essas narrações com a documentação dos Inquéritos Policiais Militares - IPM -, assim como aquela existente a respeito da passagem dos marinheiros pela Penitenciária Lemos Brito e uma avaliação da historiografia e da literatura memorialística que diz respeito à atuação política dos militares que se opuseram à ditadura.

Entendemos que a linha de pesquisa desta Tese está inserida no campo da História Política, pois seus protagonistas agiam em função da conquista do poder, na medida em que se posicionaram afirmativamente e militantemente contra a ditadura civil-militar. (RÉMOND, 2003: 444).

Jacques Le Goff, ao escrever sobre um esboço de uma nova história política, reconhece sua importância, por muitos anos relegada, mas admite que ela deve interagir com

\footnotetext{
${ }^{5}$ A autora aponta as três principais tendências do trabalhismo que se integravam ao PTB: os Getulistas pragmáticos, hegemônicos no PTB em seus primeiros anos - sua principal referência foi o próprio Getúlio Vargas; os Doutrinários trabalhistas, intelectuais orgânicos do petebismo, com orientação trabalhista socializante; e os Pragmáticos reformistas, envolvendo características da tendência getulista e doutrinária (João Goulart, Darcy Ribeiro e outros).
} 
outros campos da História e com outras ciências humanas: Ela não deve se considerar a ossatura da História, mas continua sendo o seu núcleo.

"Embora a história política possa ser renovada e regenerada pelas outras ciências humanas, ela não pode aspirar à autonomia. Dividir um só ramo do saber em compartimentos separados é mais inadmissivel do que nunca numa época de pluridisciplinaridade. O comentário de Lucien Febvre, co-fundador dos Annales d'histoire économique et sociale, é agora mais verdadeiro que nunca: 'não há mais nada para além da história econômica e social. A história está toda aqui'. Mas é igualmente verdade que os modelos da nova história geral devem conceder à dimensão política o mesmo lugar que é ocupado na sociedade pelo fenômeno do poder, que é a encarnação epistemológica da política no presente. Para passar da época da anatomia para a do átomo, a história política não pode continuar a considerar-se a ossatura da história mas continua a ser no entanto o seu núcleo" (LE GOFF, 2010: 209-210).

A área de concentração de nossa pesquisa é História Social e pode também ser inserida no campo da história do presente ou do passado recente, o que, no caso desta pesquisa que envolveu mais de uma dezena de pessoas, trouxe muita dificuldade.

O que queremos dizer é que a história do tempo presente possibilita ao pesquisador um acesso a fontes até excessivamente variadas, enquanto noutros períodos temporalmente mais distantes elas são limitadas. No entanto, no tempo presente, geralmente as ações que pesquisamos são de homens ainda vivos - imagina, então, pesquisar a trajetória, ou a vivência, de treze! É comum esses homens não se reconhecerem na narrativa do historiador, mesmo se o que narramos foi baseado em seus próprios testemunhos. Voltaremos a esse ponto mais à frente.

\section{$* * *$}

Intentamos mostrar nesta Tese, portanto, a importância que tiveram esses exmarinheiros no período em que a ditadura era supostamente "envergonhada", mas não obstante, "já era ditadura". 6 Nesse sentido, considerando que o período estudado era inquestionavelmente ditatorial, autoritário e revanchista, quando os ditadores, seletivamente, destruíram aqueles que identificavam como trabalhistas ou, para não irmos tão longe, nacionalistas ligados ao antigo governo, nós nos oporemos a uma revisão historiográfica que

\footnotetext{
${ }^{6}$ Quem definiu a ditadura no período em que estudamos como "envergonhada" foi Elio Gaspari, no primeiro de seus volumes sobre a ditadura brasileira. É importante ressaltar, porém, que o Brasil já vivia, então, uma ditadura, como demonstra a coletânea organizada por Marcos Silva, Brasil, 1964/1968: a ditadura já era ditadura (São Paulo, LCTE Editora, 2006). Ver também, de Marcos Silva, "Jornalismo retrospectivo e quaseHistória: Imaginem se a ditadura fosse desavergonhada!". Resenha de A ditadura envergonhada, de Elio Gaspari (São Paulo: Cia. das Letras, 2002). Revista ADUSP. São Paulo: ADUSP, 34: 80/84, maio de 2005.
} 
pretende villanizar ${ }^{7}$ a ação de Castelistas e Costistas, ou seja, amenizar seu ataque contra a democracia e as reformas. No texto, trazemos exemplos do "vale tudo" de oficiais militares, que agiam sem limites, acima da Justiça, não reconhecendo direitos, leis ou Constituição. Essa prática despótica começou já no dia 2 de abril de 1964, um dia depois do Golpe, conforme veremos no caso de Adônias Antunes Vieira.

O contato com pessoas ligadas à academia, aos partidos políticos, aos meios de comunicação e ao governo mudou definitivamente a vida daqueles jovens marinheiros. Envolvidos em tal contexto de intensa mobilização e aturdidos com a rapidez como eram levados pelos acontecimentos ao encontro de um mundo turbilhonado de debates, pessoas, assembleias, reuniões, audiências, nossos protagonistas passaram, também, a fazer parte de mais projetos coletivos. Eles começaram a formar grupos para discutir textos filosóficos, sociológicos e de teoria política. Daí, o encontro, decisivo, com a política. Passaram a acreditar, afirmativamente, na importância da ação de indivíduos conscientes, como julgavam ser, para intervir no curso da história.

A efervescência cultural desses anos finais da década de 1960 e seu impacto junto aos marinheiros foram decisivos para seu pleno ingresso na política. Foram anos de grande criatividade artística. A censura existia, mas ainda em fase inicial. Ela era socialmente seletiva. Segundo Carlos Fico, "tudo poderia ser censurado, bastando ao governo lançar mão desta ou daquela dubiedade da legislação" (FICO, 2012:188). Os militares não tinham ainda, pelo menos até o AI-5 em dezembro de 1968, mecanismos de controle suficientemente eficientes para calar as vozes dos artistas - até porque não seria conveniente a quem prometeu à classe média defender a democracia e salvar o país do comunismo... Exemplo emblemático foi a peça Liberdade, liberdade, de Millôr Fernandes e Flávio Rangel, permitida pela censura em 1965 e proibida em seguida, por provocar a ira de oficiais conservadores, que fecharam o Teatro Oficina. A canção "Mestre-sala dos mares", de João Bosco e Aldir Blanc, criada mais tarde, em 1975, gravada com sucesso por Elis Regina, aborda a Revolta da Chibata (1910), mas faz uma referência indireta aos marinheiros de baixa patente como população oprimida e lutadora. Aí, no entanto, o País passava pela "abertura” do presidente Ernesto Geisel. Mesmo assim, os autores tiveram de excluir termos como "negro" (por "santos"), "marinheiro" (por "feiticeiro"), "almirante" (por "navegante"), "navegar" (por “acenar"), "tripulação" (por "pessoal do porão") e "fragatas" (por "regatas"). No final da década de 1960, parte do coletivo estava presa, mas nem por isso deixou também de participar desses lampejos

\footnotetext{
${ }^{7}$ Fazemos trocadilho com o nome do historiador Marco Antonio Villa.
} 
culturais. Na Lemos Brito, organizaram festivais de música e poesia, como também, naturalmente, um torneio de futebol.

Esse grupo se constituiu num coletivo, ou seja, num núcleo organizado, e mesmo hierarquizado, como bons militares, de orientação prática e teórica: todo dia havia reunião vespertina, em que se discutiam ações a serem tomadas, dividiam tarefas, faziam análise de conjuntura, distribuíam textos para discussões futuras. Várias pessoas frequentavam essas discussões. Algumas transitavam, outras estavam sempre presentes. As últimas constituíam o "núcleo duro", como ainda hoje se referem ao "comando" da AMFNB. Desse núcleo, faziam parte o vice-presidente da Associação Marco Antônio da Silva Lima, líder incontestável e muito admirado pelos marujos, Pedro Viegas, Capitani, Neguinho, José Duarte, Antônio Duarte, Cláudio Ribeiro, Raul Nascimento, José Anselmo dos Santos e poucos outros.

Depois do Golpe de 1964, o coletivo se dispersou, mas seus integrantes nunca deixaram de se comunicar e tentar rearticular o grupo. Foi o que aconteceu no Uruguai, sob a liderança de Brizola, e em outras ocasiões. Por fim, sem o desejar, naturalmente, o coletivo se reencontra, ampliado, na Penitenciária Professor Lemos Brito. Dessa vez, as discussões se voltam para guerrilha armada. A revolução socialista faz parte das análises feitas nos debates na cadeia. Porém, antes da revolução, deveriam resolver um problema imediato: como sair daquela cadeia?

Por dois anos, nossos protagonistas planejaram a fuga da prisão. No dia 26 de maio de 1969, às 17h:30min, colocaram em prática a Operação Liberdade: fugiram pelo portão central, na frente da penitenciária.

Após a fuga, os marinheiros se esconderam em uma cabana de difícil acesso na Serra do Mar. Ali, começaram a colocar em prática suas teorias do foquismo, se bem que hoje, alguns deles negam que era essa a intenção. Dizem que ali, na Serra de Angra dos Reis, apenas estavam escondidos para reintegrarem-se à guerrilha mais tarde. Mas a ideia de foco estava muito disseminada entre às esquerdas guerrilheiras. $\mathrm{O}$ modelo cubano de revolução havia impregnado nossos protagonistas, já que três deles fizeram curso de guerrilha em Cuba (José Duarte dos Santos, Marcos Antônio e Capitani). Eram nove presos fugitivos, que mantinham uma disciplina militar rígida. Marcos Antônio era o comandante, auxiliado por Avelino Capitani, que praticava o que aprendera em Cuba e na Guerrilha de Caparaó. Tinham retaguarda de militantes de uma cidadezinha próxima, Conceição do Jacareí, que lhes proviam de comida, roupas e informações. Quando seus amigos de cadeia José Duarte e André Borges foram presos, roubando um banco para arrecadar dinheiro a fim de manter as organizações (MAR e ALN), a polícia encontrou com José Duarte carta de seu irmão, Antônio Duarte, que 
citava o nome de um estaleiro perto do local onde estavam na Serra ${ }^{8}$. Mas, como veremos, as delações foram fundamentais para que várias pessoas que davam retaguarda ao grupo caíssem e os fuzileiros navais invadissem a Cabana do Jacu, esconderijo dos marinheiros. Houve troca de tiros e apenas um ferido (e preso), Pedro Viegas. O restante do grupo conseguiu escapar ao cerco e se reintegrar à guerrilha, através do PCBR. Foi nessa organização que Marcos Antônio morreu, em janeiro de 1970. E aqui encerramos nossa pesquisa, com a dispersão dos militantes para o exterior, para a prisão ou para o cemitério.

Estudar a trajetória de um grupo de militares subalternos pode contribuir historiograficamente para esclarecer os conflitos que então ocorriam dentro das Forças Armadas, lembrando que no período da "Ditadura envergonhada", ou "desavergonhada", nem todos os militares aderiram a ela.

Por fim, acreditamos na oportunidade desta pesquisa para corrigir um anacronismo cometido, desinteressadamente, por historiadores e jornalistas, nos anos iniciais da década de 1980, quando surgiram livros e artigos denunciando corretamente a traição de Anselmo, mas condenando, retrospectivamente, nossos protagonistas de forma definitiva, como se todo militar (e, ainda mais, aquele coletivo de marinheiros) fosse desleal e golpista.

No decurso do trabalho de pesquisa, desenvolvemos levantamentos de caráter documental e realizamos a coleta de narrações no exercício da História Oral, como também analisamos outras fontes de informação, capazes de enriquecerem o estudo que nos propomos realizar.

A experiência de trabalhar com fontes orais foi, sem dúvidas, positiva. Elas permitiram a aproximação com o passado vivido por nossos protagonistas e repensado em suas narrações. No entanto, as lembranças que chegavam à superfície, geralmente surgiam ora fragmentadas, ora talvez involuntariamente falsificadas, ou mesmo, muitas vezes nem surgiam. Nossos protagonistas, que nos ofereceram generosamente seus testemunhos, estão mais ou menos 50 anos à frente dos acontecimentos que procuravam rememorar. Os rastros que ficaram são mais fortes para alguns e menos para outros. Lembranças boas e más. Por diversos motivos, principalmente para esses homens, o apagamento dos rastros, o esquecimento, de determinados eventos, deveu-se às impressões vivenciadas, ou aos traumas, daquilo que a memória se recusou a lembrar.

Noutros casos, a lembrança se revelou clara, definida. Mesmo assim, às vezes ela não correspondia à realidade. Um exemplo: perguntado sobre sua função durante a fuga da

\footnotetext{
${ }^{8}$ Segundo depoimento de Pedro Viegas.
} 
Penitenciária Lemos Brito, Adeildo Ramos falou com toda convicção que ele foi o último a sair da cadeia, colocando um cadeado no portão para evitar que os guardas os perseguissem. Os testemunhos de seus colegas atribuíram essa função a Michel Godoy. O depoimento de Godoy e as falas de outros no Inquérito Policial Militar confirmam que não foi Adeildo. Todos afirmaram que Adeildo foi o primeiro a entrar no carro, logo, a sair da penitenciária. Então, Adeildo mentiu? Não acreditamos. Por algum motivo, ele tomou para si o protagonismo da ação. Vários outros casos poderíamos citar como exemplo do que chamamos de "armadilhas da memória", das quais falaremos no decorrer da Tese.

Existe uma passagem nos Diálogos de Platão, Teeteto, muito conhecida e, tal como a fábula Funes, o memorioso, de Jorge Luis Borges, muito citada pelos estudiosos da memória. Sócrates responde a Teeteto que a qualidade da lembrança deve-se à qualidade da impressão das sensações deixadas no bloco de cera da alma. Se as sensações, ou as percepções não são nítidas, não tiveram boa impressão na cera, pode acontecer da pessoa se enganar, “como quem troca os pés ao calçar os sapatos, e aplique a impressão visual de um na marca do outro, ou que seja vítima da ilusão própria dos espelhos, em que fica no lado direito o que está no esquerdo: nesses casos pode tomar-se uma coisa por outra e haver opinião falsa” (PLATÃO, 2001, 113). Segue o texto:

"Suponhamos, agora, só para argumentar, que na alma há um cunho de cera; numas pessoas, maior; noutras, menor; nalguns casos, de cera limpa; noutros, com impurezas, ou mais dura ou mais úmida, conforme o tipo, senão mesmo de boa consistência, como é preciso que seja.

[...] Diremos, pois, que se trata de uma dádiva de Mnemenosine, mãe das musas, e que sempre que queremos lembrar-nos de algo visto ou ouvido, ou mesmo pensados calcamos a cera mole sobre nossas sensações ou pensamentos e nela os gravamos em relevo, como se dá com os sinetes dos anéis. Do que fica impresso, temos lembrança e conhecimento enquanto persiste a imagem; o que se apaga ou não pôde ser impresso, esquecemos e ignoramos.

[...] Quando a cera que se tem na alma é profunda e abundante, branda e suficientemente amassada, tudo o que se transmite pelo canal das sensações vai gravar-se no coração da alma, como diz Homero, aludindo à sua semelhança com a cera, saindo puras as impressões aí deixadas, bastante profundas e duradouras os indivíduos com semelhante disposição aprendem facilmente e de tudo se recordam e sempre formam pensamentos verdadeiros, sem virem jamais a confundir as marcas de suas sensações. Sendo nítidas e bem espaçadas todas as impressões, com facilidade põem em relação cada imagem com a correspondente 
marca, as coisas reais, como lhes chamam. São esses os denominados sábios" (PLATÃO, 2001, pp. 110-115).

O texto de Platão faz, indiretamente, alusão ao rastro deixado na memória. Mas não menciona a função decisiva do tempo na sua preservação. Relaciona, também, a memória ao erro e ao falso, o que a torna, no mínimo suspeita. Tanto o erro quanto o falso são causas das más impressões e percepções da alma. Isso sugere que o esquecimento relaciona-se com o falso. Seguindo as pegadas de Platão: "Mas, justamente nas coisas que sabemos e que percebemos é que a opinião vira e se muda, ficando, a revezes, falsa e verdadeira: quando ela ajusta direta e exatamente a cada objeto o cunho e sua imagem, é verdadeira; será falsa, quando os liga de través e obliquamente” (PLATÃO, 2001, 114).

Ao citar Platão, não estamos com isso aceitando acriticamente seu ponto de vista. Apenas consideramos que, originariamente, ele colocou questões sobre a memória, o esquecimento e, principalmente, mas não intencionalmente, a de rastro, que tem permitido a realização, nos dias de hoje, de debates importantes sobre o tema. Hoje, sabemos que o esquecimento pode ter várias causas, como a neurológica ou a psíquica, além de continuar " $a$ ser a inquietante ameaça que se delineia no plano de fundo da fenomenologia da memória e da epistemologia da história”. Ricoeur, mais à frente, acrescenta: “de início e maciçamente, é como dano à confiabilidade da memória que o esquecimento é sentido. Dano, fraqueza, lacuna. Sob esse aspecto, a própria memória se defini, pelo menos numa primeira instância, como luta contra o esquecimento. (...) Foi, entre outras finalidades, para conjurar essa ameaça de apagamento que se instituiu o arquivo”. (RICOEUR, 2007, pp. 423-425).

Durante nossa pesquisa, cotejando as informações da grande imprensa e dos IPMs com as dos testemunhos, veio à tona a problemática do esquecimento, ou a do apagamento do rastro.

Atentos a isso, e levando em consideração que estamos distantes 50 anos das sensações e percepções vivenciadas pelos integrantes do Coletivo, procuramos trabalhar com muita cautela no exercício da História Oral, pois a chance de engano é maior, assim como a chance da "marca" ter perdido sua nitidez. De qualquer forma, ao historiador, diante disso, resta o cotejamento com outras fontes, ou testemunhos. Às vezes tem sorte na procura. Às vezes, se resigna a continuar sua cosedura sem as respostas que procurava.

Temos de considerar, também, que os homens que estamos investigando são "demasiado humanos"” e que, por vezes, inflam sua participação em determinados momentos,

\footnotetext{
${ }^{9}$ Referência ao nome, mas não à obra de Friedrich Nietzsche, Humano, demasiado humano: um livro para espíritos livres.
} 
tornam-se protagonistas em ações que não tiveram participação ou mesmo, com dificuldades em lembrar algum acontecimento, respondem ao que "acham", no presente, o que aconteceu. Tivemos cuidado com essas "armadilhas da memória", principalmente ao que se convencionou chamar de "sacralização do testemunho".

É importante ressaltar que nos propomos realizar o trabalho de coleta de depoimentos seguindo os parâmetros teóricos e metodológicos da História Oral, incluindo, por exemplo, a organização prévia de pautas de entrevista, a formulação de questões não indutivas aos entrevistados e a apropriada transcrição de seus depoimentos, a serem revistos pelos narradores, como fizemos em nossa pesquisa de mestrado.

Utilizamos, também, como fonte para nossa pesquisa o Inquérito Policial Militar IPM - instaurado em cinco de junho de 1969, para investigar a fuga do Coletivo da Penitenciária Professor Lemos Brito, cujo Encarregado foi o Contra-Almirante Julio de Sá Bierrenbach.

O trabalho com inquérito policial pode ser de grande utilidade, pois permite confrontar informações encontradas em outras fontes. Por exemplo, no inquérito pode-se encontrar um laudo cadavérico, que traz as causas de uma morte; um laudo pericial da trajetória balística, que identifica de onde partiu um tiro e qual a arma usada; um laudo de sanidade mental, que pode ajudar a conhecer melhor os investigados.

Mas os inquéritos policiais podem sofrer manipulação, tanto do Encarregado, como dos depoentes, que mentem para diminuir sua pena, ou para não incriminar um amigo. No caso de nossa pesquisa, isso de fato aconteceu. No depoimento de José Duarte ao Encarregado, ele falou que quem roubou o carro para a fuga do Coletivo foi Wilson do Nascimento Barbosa. Quando ele prestou seu depoimento, Barbosa estava fora do Brasil, no Uruguai. Dessa forma, para não imputar mais um crime a Flávio Tavares, quem de fato roubou o carro, Duarte mentiu, dizendo que foi Barbosa, já que este, por estar fora do Brasil, não seria penalizado. Acontece que Barbosa foi deportado para o Brasil e teve de responder por um crime que, ao que tudo indica, não cometeu.

Outro caso estranho que ocorreu no IPM foi o sumiço do depoimento de Flávio Tavares. Em seu livro, Memórias do esquecimento, Tavares dá detalhes desse depoimento que, no entanto, não consta do Inquérito. Então, se se podia omitir um depoimento, o que impedia o Encarregado de manipular depoimentos a seu bel interesse? Pode-se retrucar lembrando que o depoente assinava o que tinha dito. Mas, quem escrevia, portanto escolhia, as palavras do depoimento? Era o escrivão. Determinadas palavras parecidas têm, no entanto, significados diferentes. Lembramos do depoimento de Kátia do Prado Valladares, mulher de 
Marcos Antônio: "a depoente declara ser de ideologia esquerdista, porém nega ter qualquer ligação com o Partido Comunista. É nacionalista e ama a sua terra, achava que eram lícitas e certas as atitudes do governo [Jango] para estatizar não somente o Petróleo, mas todos os minerais, mais ou menos o que se está tentando fazer agora, conforme palavras textuais da depoente". ${ }^{10} \mathrm{O}$ escrivão interferiu na fala de Valladares, ao dizer "conforme palavras textuais da depoente", pretendendo ressaltar uma passagem do depoimento para quem fosse lê-lo. Não faria falta se ele omitisse a frase, porque tudo que a depoente disse, afinal, foi através de "palavras textuais".

Sérgio Lúcio de Oliveira Cruz, estudante quintoanista de Direito, filho de renomado Juiz, participou ativamente do plano para libertar os presos na Lemos Brito. Quando foi chamado a depor, em seu primeiro depoimento, se colocou como vítima do carisma de Marcos Antônio. Apenas queria ajudá-lo, falou. ${ }^{11}$ Tentou resguardar pessoas. Já nos depoimentos seguintes, não tinha mais como esconder certos detalhes, porque ele não sabia o que os outros indiciados haviam "aberto" ao Encarregado. Ali, diante do Contra-Almirante Julio de Sá Bierrenbach, conforme Flávio Tavares, havia civilidade. O Encarregado não usava farda. Mas, seu assessor, segundo Tavares, assistiu a seu depoimento no pau de arara, na Polícia do Exército. Era ali que se tiravam as respostas que os militares queriam. Diante do Encarregado do Inquérito, era arriscado mentir, pois, geralmente ele tinha mais informações do que o depoente.

Outras fontes nos auxiliaram para a cozedura da narrativa. Usamos os principais jornais cariocas na época, como Jornal do Brasil, Diário Carioca, O Globo, Correio da Manhã, Diário de Notícias, Jornal da Noite, Correio Braziliense e o Jornal do Commercio. Os jornais Última Hora e O Dia não puderam ser pesquisados, pois não houve tempo para retornar ao Rio de Janeiro.

Pesquisamos, junto ao Arquivo do Estado, no Rio de Janeiro, a documentação do antigo Serviço Nacional de Informação - SNI. Esses documentos foram transferidos da Secretaria da Justiça para o Arquivo do Estado. Bem pouco ajudaram porque esperávamos encontrar ali documentos referentes ao órgão de informação da Marinha na época, o CENIMAR. Não foi possível, no entanto, encontrar qualquer documento produzido no ambiente do CENIMAR. Possivelmente, a documentação dos centros de informações das três Forças Armadas já tenha sido destruída. Na Biblioteca Nacional, encontramos as fontes que

\footnotetext{
${ }^{10}$ Depoimento de Kátia do Prado Valladares em 06 de agosto de 1969. AEL - BNM - 414, caixa 1, volume 1, números da folha não identificado.

${ }^{11}$ AEL - BNM, 414, caixa 1, volume 2, folhas 327 a 343.
} 
nos permitiram inserir as trajetórias de nossos protagonistas no contexto de rápidas transformações tecnológicas e comportamentais que aconteciam no mundo e no Brasil.

Localizamos no Arquivo Edgard Leuenroth, UNICAMP, o Inquérito Policial Militar criado para investigar a fuga do Coletivo da Lemos Brito. Esse IPM e vários outros fazem parte do acervo do Brasil: Nunca Mais, xerocopiado e organizado pela Arquidiocese de São Paulo, e ele nos premiou com os depoimentos dos marinheiros na ocasião da fuga. Através do conteúdo desses inquéritos, pudemos, com a devida cautela, confrontá-los com as narrativas colhidas oralmente dos ex-marinheiros.

$* * *$

Gostaríamos de agradecer às pessoas que contribuíram para a elaboração desta Tese de doutorado. Neste caso, para demonstrar nossa grande gratidão, abandonamos o Plural Majestático, e passamos a utilizar a primeira pessoa, mais particular, mais amiga e mais familiar.

Primeiramente ao meu orientador, Prof. Dr. Marcos Silva, que sempre me auxiliou quando precisei, com sugestões inteligentes, mostrando seu enorme repertório diante do conhecimento histórico. Agradeço a Marcos, também, pelo incentivo, nos momentos de desânimo e pela generosidade, quando cedeu seu precioso tempo para realizar as diversas revisões do texto.

Ao Prof. Dr. Wilson do Nascimento Barbosa, que está muito presente nesta Tese, meu sincero agradecimento pelas sugestões dadas na ocasião do meu Exame de Qualificação, que procurei inserir nesta Tese.

Aos amigos e familiares, que sempre me estimularam e não deixaram de me oferecer apoio, nos momentos mais difíceis: Queridos irmãos Augusto Luís Rodrigues e Jânua Celi Rodrigues, Antônio Cláudio de Medeiros Borges, Isabela Barretto Santos, José Augusto Dias Júnior e Mateus Pinheiro de Souza, cuja colaboração foi inestimável.

Aos protagonistas desta Tese, que generosamente me concederam seus testemunhos, alguns, inclusive, várias vezes, sem os quais não seria possível a realização da pesquisa: Antônio Duarte dos Santos (in memoriam), Antônio Geraldo Costa, Avelino Biden Capitani, Edison Duarte de Mello, José Adeildo Ramos, José André Borges e Pedro França Viegas, sempre solícito e atencioso. 
Gostaria, enfim, de dedicar esta Tese, como uma singela homenagem e prova de admiração e respeito, aos amigos Prof. Dr. Ulysses Telles Guariba Netto, in memoriam, e Antônio Duarte dos Santos, in memoriam. 


\title{
CAPÍTULO I: ONDAS
}

\section{O PROTESTO DOS MILITARES SUBALTERNOS E A FORMAÇÃO DO COLETIVO}

\author{
"Belo como a última onda \\ Que o fim do mar sempre adia" \\ (João Cabral de Melo Neto, "Morte e vida \\ Severina")
}

O título deste capítulo pretende explicitar um processo de politização de militares subalternos das três Forças Armadas Brasileiras, durante a primeira metade da década de 1960. Foi então que surgiram várias entidades representativas que buscavam estender aos associados - praças, cabos e sargentos - direitos a votarem em candidatos militares, que os representassem nas Câmaras Municipais, nas Assembleias Legislativas e na Câmara Federal reivindicação de plena cidadania para aqueles homens, portanto. Esses militares passaram a refletir sobre as condições sociais e econômicas de seus familiares, a maioria constituída de trabalhadores rurais pobres, no interior do Norte ou Nordeste do país. Criou-se uma onda, que designaremos como protesto, envolvendo militares de vários matizes ideológicos, mas preferencialmente de esquerda, que encontram no trabalhismo reformista uma orientação política, considerada por eles mais próxima de suas realidades. Em sua maioria, são nacionalistas reformistas, demandando reformas dos regimentos militares e da Constituição de 1946.

Por militar subalterno de esquerda, entendemos, naquele contexto, o militar que se posicionava a favor de reformas profundas, inclusive nas Forças Armadas, e do resgate à condição de cidadão do homem trabalhador pobre, do campo ou da cidade. Defende políticas de distribuição de renda, tão concentrada, beneficiando o "povo" humilde e sofredor (como seus parentes). Opõe-se às declarações negativas dos oficiais a respeito do Presidente João Goulart, claro acinte à disciplina e ao respeito à hierarquia. Também aceitamos a designação de Norberto Bobbio, para quem, para uma pessoa de esquerda "qualquer forma de desigualdade precisa ser de algum modo justificada, ao passo que, para a pessoa de direita, vale exatamente o contrário, ou seja, que a desigualdade é a regra e que, se alguma relação de igualdade deve ser acolhida, ela precisa ser devidamente justificada" (Apud: MACIEL, 2009, p.11).

Entendemos por trabalhismo reformista uma orientação política, herdeira do getulismo, que tinha como pontos programáticos a defesa de políticas desenvolvimentistas, 
distributivistas, nacionalistas e reformistas. Segundo seus seguidores - como Darcy Ribeiro, Leonel Brizola e João Goulart -, o desenvolvimento do país só seria atingido plenamente com investimentos no homem e, para isso, seria imprescindível a concretização de reformas, tais como a agrária, a universitária, a bancária, a política, dentre outras. De acordo com Darcy Ribeiro, o trabalhismo tinha um viés socializante e consistia em um verdadeiro projeto de revolução social:

"passei a ver o socialismo como a progressão do trabalhismo através da incorporação do campesinato ao sistema econômico e político brasileiro pela reforma agrária e através do controle das multinacionais. Esse é o caminho da revolução social. Não uma revolução cerebrinamente socialista, mas concretamente socialista, porque pós-capitalista, pela impotência do capitalismo para promover uma prosperidade generalizável". (RIBEIRO, 1998, p. 292).

Esse protesto, ou ação mobilizadora, não se limitou apenas a um acontecimento. Foi através de um processo de tomada de consciência das condições materiais em que vivam os militares e seus familiares que, a partir principalmente de 1961, tais homens tiveram contato com a política. O que pretendemos dizer é que houve um movimento aglutinador, primeiramente entre os sargentos e cabos das três Forças Armadas, que galvanizou e deu sentido àqueles interesses de mudança, seja nas condições de vida do subalterno, seja na reforma da política e do Estado. Assim, compreendemos as motivações daqueles cabos da Marinha que fundaram a Associação dos Marinheiros e Fuzileiros Navais do Brasil, em 25 de março de 1962. Eles não estavam sós: faziam parte do protesto que avançava decididamente também noutros setores da sociedade brasileira. Com eles, não esqueçamos, caminhavam estudantes, sindicalistas, políticos, artistas, camponeses organizados, comunistas, juventude católica, dentre outros setores daquela sociedade. Este início da década de 1960 foi de grande ebulição política no Brasil e nossos protagonistas estavam inseridos nela. Afinal, como já lembrara Marc Bloch, citando um provérbio árabe, "os homens se parecem mais com sua época do que com seus pais" (BLOCH, 2001, p. 60).

Falar em protesto de militares subalternos exige, antes, uma justificação da terminologia, que não deixa de ser, também, de natureza historiográfica. Em trabalho anterior (RODRIGUES, 2004), já nos referimos à revolta dos marinheiros, para designar o movimento desses homens em março de 1964, quando mais de mil marujos decidiram não deixar as dependências do Sindicato dos Metalúrgicos do Estado da Guanabara, onde comemoravam o aniversário de sua entidade, a Associação dos Marinheiros e Fuzileiros Navais do Brasil - AMFNB, enquanto a Administração Naval não soltasse alguns diretores da 
Associação que estavam presos por “desobedecerem” às ordens do Ministro da Marinha para que não realizassem a tal comemoração e, também, por terem participado de reunião anterior, onde foram feitos discursos considerados radicais pelo Ministro. Como o evento aconteceu, o que era para ter sido uma festa de confraternização acabou por se transformar em grave confronto entre subalternos e oficiais, com o governo tentando mediar a crise. Isto aconteceu nos dias 25, 26 e 27 de março, plena Semana Santa e vésperas do Golpe civil-militar de 1964.

Marc Bloch, em Apologia da História, seu último e inacabado livro (BLOCH, 2001), destinou várias páginas para discorrer sobre os perigos dos usos descuidados de termos na escrita da história. Esse receio também nos ocorre e, de antemão, queremos registrar que o uso de protesto não deve ser entendido como uma intenção de criar mais uma expressão no rol das inúmeras da nomenclatura histórica. Este termo surgiu na ocasião de nosso Exame de qualificação, quando o professor Wilson do Nascimento Barbosa usou-o em suas inteligentes colocações.

A passagem abaixo vem ao encontro desta preocupação que temos. Segundo Bloch,

"[...] Todos lembram da bonita frase de Fontenelle: Leibniz, dizia, 'formula definições exatas, que o privam da agradável liberdade de abusar dos termos nessas ocasiões'. Agradável, não sei, perigosa certamente; é uma liberdade bastante familiar a nós. O historiador raramente define. Poderia, com efeito, julgar esse cuidado supérfluo se bebesse num uso ele próprio de sentido estrito. Como não é esse o caso, não tem, até no emprego de suas palavras-chaves, nenhum outro guia a não ser seu instinto pessoal. Ele estende, restringe, deforma despoticamente as significações, sem advertir o leitor, sem nem sempre ele próprio se dar conta. Quantos 'feudalismos', mundo afora, desde a China até a Grécia dos aqueus das belas cnêmidas? Em sua grande parte, não se parecem em nada. É que cada historiador, ou quase isso, compreende o nome a seu bel-prazer. [...] Dia virá, sem dúvida, em que uma série de acordos permitirá precisar a nomenclatura, depois, de etapa em etapa, refiná-la. Então a própria iniciativa do pesquisador conservará seus direitos; aprofundando a análise, ele remaneja necessariamente a linguagem. O essencial é que o espírito de equipe viva entre nós. É preciso que o historiador renuncie a desviar intempestivamente de seus sentidos as palavras já recebidas (mais vale, se for preciso, uma franca criação); que evite rejeitar, por capricho, aquelas já experimentadas; que, ao usar definições escrupulosas, faça-o com o cuidado de tornar seu vocabulário constantemente utilizável para todos. A torre de Babel forneceu a um irônico Demiurgo um espetáculo bastante satisfatório. Seria, para a ciência, um modelo deplorável" (BLOCH, 2001, pp. 145-146). 
Pois bem, quando redigimos nossa dissertação, utilizamos o termo revolta para designar o movimento dos marinheiros de março de 1964, por parecer-nos mais adequado, já que era de uso corrente por historiadores e cientistas sociais, além de ser o vocábulo que os próprios diretores da AMFNB utilizavam para referir-se àquele movimento, conforme pudemos observar através de seus testemunhos.

Em 2010, no entanto, uma dissertação da Universidade Federal Fluminense questionou a validade de seu uso. Anderson da Silva Almeida, seu autor, recorreu ao Código Penal Militar (CPM) de 1944 para refutar o termo. Segundo o Código, revolta designaria um movimento no qual seus agentes portariam armas, quando não foi o caso em março de 1964 (ALMEIDA, 2010). Almeida considera mais adequado o termo rebelião. Para sua defesa o autor recorre ao Dicionário de Ciências Sociais, da Editora da FGV, que traz o seguinte verbete:

[...] se refere a confronto e oposição, mais ou menos violentos, ao estabelecido. É frequente relacionar-se com a juventude [...]. Concebida num plano mais geral, a rebelião é um 'modo de adaptação... que leva a pensar e a tentar implantar uma estrutura social nova, i.e., muito modificada. Supõe o abandono das metas e normas existentes, que são consideradas puramente arbitrárias'. [...] Ela é uma resposta à sociedade, a qual tenta transformar para a satisfação das reivindicações que lhe são negadas. É um movimento sócio-político que nasce como consequência da negação de reivindicações de parte da sociedade e da consciência de que elas jamais serão atendidas enquanto essa sociedade prevalecer. [...] As rebeliões quase sempre se identificam com mobilizações de massa contra um governo, tendo um caráter violento, mas esse termo também pode ser aplicado com referência a sublevações que não chegam a conseguir a participação das massas e permanecem em um nível de minorias. Assim acontece com as sublevações encabeçadas pelas Forças Armadas. (DICIONÁRIO, apud ANDERSON, p 20. Colchetes usados pelo autor)

Almeida também evoca Locke, conforme passagem abaixo:

Acreditamos que esse conceito [rebelião] seja o mais adequado para a percepção da agitação dos marujos, principalmente sua parte final, quando se refere aos movimentos de minorias sem a participação das massas. No entanto, ele não está presente na legislação militar. Isso se deve, possivelmente, pelo fato de o conceito de Rebelião ter sido legitimado por Locke, como sendo um direito àqueles que se sintam explorados ou traídos por seus governantes. E aqui, no caso dos marinheiros, seus governantes seriam os oficiais - mais precisamente seus comandantes e almirantes responsáveis pela administração naval (ALMEIDA, 2010, p. 20). 
O termo motim, por seu turno, foi afastado por Almeida, seguindo mais uma vez a definição do Código Penal Militar, que associa ao termo a desobediência de quatro ou mais militares de ordens recebidas de seus superiores, "ou negando-se a cumpri-las; e recusar obediência ao superior, quando esteja agindo sem ordem ou praticando violência” (IDEM, Idem, p. 20).

Na procura de um termo adequado ao evento de março de 1964, Almeida chega a "A Grande Rebelião". Mesmo que tenha tomado de empréstimo de Georges Lefebvre - $O$ Grande Medo de 1789 -, o termo pode parecer adequado a uma temporalidade curta, como de fato foi a do movimento em destaque. Mas será mesmo apropriado para caracterizar o que aconteceu no interior do Sindicato dos Metalúrgicos naqueles dias finais de março de 1964 ? Estavam os marinheiros absolutamente convictos de que sua decisão era a mais sensata naquele momento? Não temiam consequências desastrosas para eles? Acreditavam mesmo que, tendo o apoio de pessoas próximas de Jango, como também de várias entidades civis e militares, podiam desafiar seus superiores? Estavam na ofensiva, emparedando o Almirantado para cederem a suas antigas reivindicações? São questões que responderíamos com muita cautela.

Vamos seguir os rastros deixados por Bloch. Não pensamos que o uso desses termos esteja errado. Muitos já os utilizaram. Todavia, se aprofundarmos a análise, perscrutarmos os acontecimentos, como sugere Bloch, ficaremos receosos para afirmar que naqueles dias em que os marinheiros estiveram exigindo pleitos perfeitamente aceitáveis e exequíveis, como o próprio Ministro da Marinha admitiu ao Ministro da Justiça, Abelardo Jurema ${ }^{12}$, tenha havido uma rebelião, um motim ou mesmo uma revolta. Embora já tenhamos utilizado estes conceitos em publicações anteriores, pensamos que na conjuntura dos idos de março de 1964, aquelas centenas de marinheiros, ao se recusarem a deixar o Sindicato dos Metalúrgicos da Guanabara, não estavam intencionalmente se revoltando ou se rebelando: Eles foram comemorar o aniversário da Associação, que desde janeiro já divulgava o evento em seu jornal A Tribuna do Mar, como o anúncio abaixo:

\section{"Departamento Social informa}

\footnotetext{
${ }^{12}$ Segundo Abelardo Jurema o então Ministro da Marinha, Silvio Mota, declarou-lhe: “as várias reivindicações dos marinheiros (casamento, vestir paisana fora do serviço, melhoria de salário, reconhecimento dos estatutos da Associação com pequenas modificações) já estavam aceitas e me mostrou estudos reservados, realizados pelo seu 'staff', e que indicavam o atendimento daqueles pontos". In: JUREMA, Abelardo. Sexta-feira 13; os últimos dias do governo Goulart. Rio de Janeiro: Edições O Cruzeiro, 1966, pp. 154-155.
} 
O Departamento Social comunica aos seus associados e digníssimas famílias, que a Associação fará realizar, na semana de 18 a 25 de março próximo, uma programação em comemoração do $2^{\circ}$ aniversário de sua fundação.

O ponto alto da programação do dia 25, será o baile, cujo local divulgaremos posteriormente".

A festa, regada a guaraná e pão com mortadela, já havia começado, quando chegou a notícia da prisão, pelo Ministério da Marinha, de parte da diretoria da AMFNB. A Marinha havia proibido a realização do evento, por não "reconhecer" a entidade marinheira. Comoção generalizada! Discursos inflamados, desnorteamento dos diretores presentes... emparedamento! Não emparedaram o Almirantado, mas, com suas decisões que não admitiam retorno, emparedaram a si próprios!

No contexto democrático em que viviam aqueles homens, eles não tinham obrigação de pedir autorização à Marinha para se reunirem, pois o local do evento não era uma repartição militar; a AMFNB era uma entidade civil, registrada em cartório civil, e os marujos estavam em sua folga. Mostramos em nossa Dissertação que o Ministro da Marinha podia ter evitado um desfecho radical. Preferiu outro caminho, que gerou sua renúncia. Talvez fosse exatamente o que desejasse, dada a pressão pela qual passava. O fato é que, desde setembro de 1963, quando ocorreu a chamada Revolta dos Sargentos, acontecimento que marcou uma inflexão na relação entre a Administração Naval e os marinheiros da Associação, a Marinha perseguia os diretores da Associação, dispersando-os pelas várias embarcações e convocandoos frequentemente para depoimentos na sede do CENIMAR - Centro de Informação da Marinha: não queria, evidentemente, que ocorresse na Marinha o que acontecera em Brasília: a chamada Revolta dos Sargentos aconteceu na madrugada de 11 para 12 de setembro de 1963, quando cerca de 600 militares, sob a orientação do Comando Militar Revolucionário de Brasília, tomaram vários prédios públicos e prenderam várias autoridades em Brasília, como reação à decisão do Supremo Tribunal Federal, confirmando definitivamente a inelegibilidade dos sargentos. Esta situação, em si, já era explosiva. Junte-se a isto a oposição que se criou entre marinheiros e oficiais, os primeiros defendendo as reformas do governo Goulart e os últimos criticando abertamente o governo. Antônio Duarte lembra o discurso que o comandante do Cruzador Tamandaré, capitão-de-mar-e-guerra José Uzeda, fez para a guarnição reunida no convés, após o Comício das Reformas, de 13 de março de 1964:

"[...] pronunciou um violento discurso contra o governo João Goulart, responsabilizando-o pela 'anarquia que dominava a vida política do país', atribuindo ao presidente também a responsabilidade da indisciplina e quebra de hierarquia nos quartéis. Apesar de o discurso em si se constituir em uma indisciplina contra o comandante-em-chefe das Forças Armadas, o 
presidente, esse senhor não foi demitido e, ao contrário, permaneceu no comando do navio e na articulação do golpe, de forma que, meses mais tarde, foi ele quem mandou me prender, punindo-me com 10 dias de prisão rigorosa e expulsando-me do navio" (DUARTE:, 2009, p. 37).

Falar em rebeldia naqueles tempos não é, portanto, tarefa fácil: o que fizeram, afinal, os oficiais das três armas ao devolverem as condecorações recebidas do Presidente João Goulart, Comandante-em-Chefe das Forças Armadas, somente porque também as receberam pessoas que julgavam não merecedoras, como o Almirante Cândido Aragão, em dezembro de 1963, senão uma rebeldia? O historiador e militar Nelson Werneck Sodré colocou a questão nestes termos:

"O mais grave, porém, aquilo que a análise desapaixonada não pode ignorar, é que a disciplina é inteiriça: não há uma disciplina para oficiais e outra para marinheiros; não há uma disciplina para superiores, e outra para inferiores. E a disciplina nas Forças Armadas, e na Marinha, portanto, vinha sendo ferida, e especialmente por oficiais, e os mais graduados, os mais responsáveis, pelos seus postos, em episódios numerosos, de que o último fora a restituição acintosa e coletiva de condecorações, por motivo de terem sido julgados merecedores das mesmas pessoas que os oficiais assim insubordinados reputavam indignas de recebê-las. Só esse julgamento constituía indisciplina, pois cabe às autoridades constituídas ajuizar da distribuição das condecorações, e não os componentes de uma força armada" (SODRÉ, 2010, pp.470,471).

Nas entrevistas que fizemos para nossa dissertação, ex-marinheiros que participaram ativamente da diretoria da Associação dos Marinheiros e Fuzileiros Navais do Brasil foram taxativos em afirmar que nos dias em que ficaram no Sindicato dos Metalúrgicos, viveram momentos de grande aflição, quando era comum encontrar marujos chorando pelos cantos, diante da incerteza do desfecho. Quando o cabo Otacílio dos Anjos Santos, o Tatá, pessoa querida dentre a marujada, discursou, não conseguiu segurar as lágrimas. Foi ele, aliás, emocionado, que propôs a vigília, até que os diretores presos fossem soltos. Também o presidente da AMFNB, José Anselmo dos Santos, estava desesperado. Antônio Duarte dos Santos, presidente do Conselho Deliberativo, descreve este momento:

"O Anselmo Estava quase chorando quando deram a notícia que tinham sido metralhados os marinheiros lá no Arsenal da Marinha. Ele estava querendo começar a soluçar... Eu dei umas cutucadas nele assim [imitando com as mãos] e disse: 'olha, Anselmo, você não pode agora perder a coisa aqui diante do pessoal'. A turma já tinha, através do discurso chorando e já 
agitado do Tatá, tinha realmente descontrolado a situação". (Entrevista a Flavio Rodrigues, 13 de novembro de 2003)

O ambiente era aflitivo. O Ministro da Marinha já tinha ordenado a prisão dos diretores por dez dias, o que significava para alguns, como o presidente da AMFNB José Anselmo dos Santos, a expulsão imediata da Marinha. Os marinheiros estavam, portanto, mais na defensiva do que na ofensiva. O próprio Antônio Duarte afirmou que a diretoria estava desnorteada diante das ameaças do Almirantado, que chegou inclusive a mandar 90 fuzileiros navais para invadir o sindicato. Se 26 fuzileiros não tivessem aderido ao movimento dos marinheiros, deixando armas e capacetes no chão, e entrado no sindicato, podemos imaginar a carnificina que seria! Duarte se lembra da tensão e da perda de controle da diretoria:

"A Revolta foi transformada em uma grande confusão, que a diretoria da associação, com Anselmo, Marco Antônio [vice-presidente da entidade] e outros diretores presentes perderam o controle. Desde o inicio, quando o cabo Otacílio, o "Tatá", pronunciou aquele discurso inflamado, pontilhado de reações emocionais e descontroladas, desestabilizando a reunião, até o final da Assembleia dos Marinheiros, a diretoria foi obrigada a atuar na defensiva" ${ }^{13}$

A edição de 27 de março do Jornal do Brasil traz uma entrevista com Anselmo em que reforça as declarações de Duarte: “jamais pensamos em chegar a esta situação”. Segundo o jornal, Anselmo adiantou que não mais podia controlar os seus colegas, de vez que "o aperto se fazia cada vez maior, e as prisões disciplinares se sucediam diariamente, pelo simples protesto de que a comida estava podre".

O uso do termo protesto tem também outra motivação: a de evitar o anacronismo. As palavras dão significação, ou ressignificação, aos acontecimentos, para o bem ou para o mal. Um historiador medievalista, por exemplo, não pode prescindir do estudo da linguagem, escrita e falada, corrente na Idade Média. Bloch lembra o caso da escrita do Domesday Book, encomendado por Guilherme o Conquistador ${ }^{14}$ aos clérigos normandos, ou do Maine: "eles não apenas descreveram instituições especificamente inglesas em latim; primeiro, repensaram-nas em francês. [...] O que eram os colliberti, os bordarii do Domesday Book? Despojadas de seus ouropéis latinos, as palavras deixam-se facilmente reconstituir nos falares da França do Oeste: 'cuverts', 'bordiers"” (BLOCH, 2001, p.140). Da mesma forma, se

\footnotetext{
${ }^{13}$ SANTOS, Antônio Duarte dos. O Mar contra os Mariscos. Nota explicativa. p. 16. Artigo não publicado, enviado por e-mail a Flávio Luís Rodrigues no dia 28 de janeiro de 2002 e transformado em livro - A luta dos marinheiros. Rio de Janeiro: INVERTA, 2005. Em 2009 o livro foi reeditado com o nome: 1964: A luta dos marinheiros, pela Diorama editora, Natal, Rio Grande do Norte.

${ }^{14}$ Duque da Normandia para quem Eduardo, seu primo e rei da Inglaterra, prometera o trono. Guilherme invadiu a Inglaterra em 1066, levando consigo várias pessoas da Normandia e do Maine para ajudá-lo a governar. Foram estes "letrados" que escreveram o Domesday Book, importante registro histórico, onde se podem encontrar informações sobre as propriedades e bens da Inglaterra na segunda metade do século XI.
} 
observarmos os qualificativos usados pela maioria dos jornais e oficiais militares para caracterizar o movimento dos marinheiros, não duvidemos, eram depreciativos, insultuosos mesmo. E quantas destas palavras não acabaram sendo incorporadas pela historiografia?

Por exemplo, no abaixo-assinado publicado pelo Almirantado, enquanto os marinheiros estavam angustiados no interior do Palácio de Aço, como era conhecido o Sindicato dos Metalúrgicos da Guanabara, usa-se dos termos Rebeldia, rebelião e amotinados:

"Os almirantes abaixo assinados, em reunião, na sala do Conselho do Almirantado, para examinarem os graves acontecimentos surgidos com a atitude dos marinheiros e soldados, em franca e ostensiva rebeldia, na sede do Sindicato dos Metalúrgicos, resolveram levar a S. Ex $\underline{\text {. o }}$ Sr. Ministro da Marinha o seu ponto de vista para fazer cessar uma situação que fere frontal e totalmente a estrutura disciplinar da Marinha.

"Assim, é opinião unânime dos Almirantes e a levam como sugestão ao Sr. Ministro ao qual prestam integral apoio, haver imperiosa necessidade de ser totalmente extinto o foco de rebelião ali implantado, sendo, portanto, indispensável a adoção de providências para a detenção imediata de todos os amotinados, para a competente apuração de responsabilidades.

"Julgam também imprescindível que seja mantido, em caráter definitivo, o afastamento do Comando Geral de Fuzileiros Navais do Vice-Almirante (FN) Cândido da Costa Aragão, por suas persistentes atitudes contrárias às tradições e à disciplina da Marinha." ${ }^{15}$

O jornal $O$ Globo, que nestas alturas já se tornara um panfleto contra o governo, na edição de 28 de março, usa os termos amotinados, rebelados e sublevados. Na edição do dia 30 - não houve edição no dia 29 -, a manchete foi: "punição dos rebeldes e afastamento do Alm. Aragão, exige a oficialidade". No dia seguinte, a manchete de primeira página cita frase do líder do Partido Social Democrático, PSD, Deputado Martins Rodrigues: "Criou-se um soviete na Marinha de Guerra". Também o Jornal do Brasil, na edição de 27, fez uso dos mesmos termos: "Mota demite Aragão, sai e governo não consegue abafar rebelião dos marinheiros". Na mesma edição, o jornal divulga nota do Ministério da Marinha em que afirma que o movimento dos marinheiros "trata-se de tentativa de subversão e indisciplina que será coibida de acordo com a Lei e as diretrizes do governo".

O protesto dos militares subalternos, que toma formato organizativo após a tentativa de golpe de 1961, principalmente com a criação do Clube dos Suboficiais, Subtenentes e Sargentos das Forças Armadas e Auxiliares do Brasil (CSSSFAA), pelo sargento da

\footnotetext{
${ }^{15}$ Documento pertencente ao arquivo pessoal do ex-Ministro da Marinha Ernesto de Mello Baptista e consultado no Arquivo do Ministério da Marinha, no Rio de Janeiro, em julho de 2001.
} 
Aeronáutica Antônio Prestes de Paula, um de nossos protagonistas, além de ter sido conspurcado durante a (e pela) Ditadura Civil-Militar, foi praticamente ignorado pela historiografia, quando não, também por ela, envilecido: basta lembrar que até muito recentemente, o Movimento dos Marinheiros foi interpretado enviezadamente como tramado pela CIA, sem que houvesse tido uma investigação mais aprofundada.

Quando fizemos nossa graduação em história, no início da década de 1980, pela Universidade de São Paulo, em plena redemocratização, não se falou uma única vez destes movimentos. Podemos afirmar com convicção que, atualmente, os livros didáticos fazem alguma referência a tais protestos? Não cremos.

Este protesto incentivou militares a aderirem a seu projeto, que passava afirmativamente pela política. Foi o que aconteceu com um grupo de marinheiros que participou da segunda diretoria da Associação dos Marinheiros e Fuzileiros Navais do Brasil. Este grupo, que denominaremos de coletivo, faz parte do protesto dos militares subalternos. Esse coletivo será protagonista nesta tese de Doutorado. Antes de falarmos dele, convém discorrermos sobre as origens do movimento dos militares subalternos.

\section{$* * *$}

Movimentos contestatórios de militares subalternos são recorrentes na história do Brasil. Não são, entretanto, divulgados pelos oficiais das Forças Armadas. Estes apostam no esquecimento, omitindo documentos para que o historiador não possa investigá-los.

Celso Castro (CASTRO, 2012, pp. 13-28) lembra que já no início da República, houve resistência de praças ao novo regime. Cita como exemplo a chamada Revolta em Desterro, ocorrida em 17 e 18 de novembro de 1889, quando 42 praças realizaram uma passeata pela cidade, com banda de música e dando vivas à monarquia. Ao retornar ao quartel, foram recebidos a bala. Houve mortes. 40 foram presos em Santos.

Outra manifestação similar foi a pouco conhecida Revolta de Rio de Janeiro, em 18 de dezembro de 1889: Cerca de 80 praças, embriagados, aproveitando a ausência dos oficiais, estenderam a bandeira do Império e deram vivas ao imperador, levantando barricadas na caserna. Cercados por tropas leais ao governo seguiu-se um tiroteio que teria durado cerca de meia hora e feito vários mortos, todos os soldados pretos ou mulatos. Desfecho: 58 praças presos; 10 condenados à pena capital; 6 condenados à prisão perpétua; 8 condenados à prisão por 20 anos; 13 condenados a galés com 10 anos de prisão; 8 condenados a galés com 5 anos 
de prisão e 13 condenados a galés com dois anos de prisão. Em 22 de fevereiro de 1890, os condenados à morte foram convertidos a prisão perpétua.

Ainda segundo Castro, em 20 de dezembro de 1889, aconteceu outra ação coletiva de igual natureza: a Revolta no Destacamento Militar da Foz do Rio APA (MT). A notícia da República chega ali apenas no dia 20 de dezembro e os soldados do $2^{\circ}$ Batalhão de Artilharia Anastácio José da Vera Cruz e José Mateus de Brito “aliciaram alguns praças para darem morras à República e vivas à Monarquia, declarando que não aderiram à nova forma de governo, porque eram libertos em 13 de maio pela princesa Isabel”. O alferes deu-lhes ordens de prisão, mas eles resistiram. Seguiram-se lutas e feridos. Um morto. Durante a madrugada, soldados puseram fogo no quartel. Quando escreveu a carta ao Ministro da Guerra, o alferes estava preso, esperando o conselho de investigação.

Os movimentos citados acima podem ter relação com a popularidade desfrutada por D. Pedro II quando do advento da República. José Murilo de Carvalho, a respeito, acrescenta:

"Eu diria mesmo que a Monarquia caiu quando atingia seu ponto mais alto de popularidade entre esta gente [proletariado da capital], em parte como consequência da abolição da escravidão. A abolição deu ensejo a imensos festejos populares que duraram uma semana e se repetiram no ano seguinte, cinco meses antes da proclamação da República. A simpatia popular se dirigia não só à princesa Isabel, mas também a Pedro II, como ficou evidenciado por ocasião da comemoração do aniversário do velho imperador, a 2 de dezembro de 1888" (CARVALHO, 1987, p. 29).

A popularidade de D.Pedro II também é notada no importante trabalho de história cultural realizado por Eduardo Silva ${ }^{16}$, em que, a partir da trajetória do alferes Cândido da Fonseca Galvão, conhecido como Dom Obá II d'África, contribui para trazer à tona um contexto histórico marcado por profundas transformações: a segunda metade do século XIX, em que ocorrem a abolição do tráfico de escravos, a Guerra do Paraguai, a abolição gradual da escravidão e o golpe que levou à fundação da República.

João Quartim de Moraes (MORAES, 2005, pp.171-173) lembra as revoltas ocorridas em 1915 e 1916 no Rio de Janeiro: na primeira, duzentos e cinquenta sargentos foram expulsos do Exército e deportados do Rio; a segunda foi reprimida fortemente.

Mais uma revolta - e o termo é recorrentemente usado -, a que ficou conhecida como Revolta da Chibata, de 1910, pode ser lembrada também como uma contestação aos rigorosos regimentos, que transformavam os subalternos em coisas animadas, cuja única função era a

\footnotetext{
${ }^{16}$ SILVA, Eduardo. Dom Obá II D'África, o Príncipe do Povo: vida, tempo e pensamento de um homem livre de cor. São Paulo: Companhia das Letras, 1997.
} 
obediência sem contestação. Este movimento, liderado pelo marinheiro João Cândido, que, aliás, recebia uma pensão da Associação dos Marinheiros e Fuzileiros Navais no início de 1964, teve forte impacto no momento em que subia à Presidência da República um militar, Hermes da Fonseca. Nem por isso, estes revoltosos foram poupados. Iludidos com um acordo mediado por um deputado oficial da Marinha, em que se assegurava mudança nos regulamentos e dignidade ao marinheiro, assim como a promessa de que não haveria retaliação, com a aprovação da anistia pelo Congresso, estes marinheiros foram duramente reprimidos, muitos expulsos da Marinha, outros mortos nas prisões e ainda mandados para a Amazônia para a extração do látex dos seringais, após entregarem as embarcações e as armas.

A Revolta da Chibata tem, para o trabalho que estamos realizando, especial relevo: um dos livros mais lidos pela marujada era o de Edmar Morel, A Revolta da Chibata - subsídios para a história da sublevação na esquadra pelo marinheiro João Cândido em 1910, pioneiro sobre o movimento. Marcos Silva, que se dedicou a estudá-la em livros publicados, aponta que a historiografia enviesou o movimento, ao analisá-lo através da perspectiva dos oficiais: "Sutil, ardilosa ou ingenuamente, esses analistas assumiram o ponto de vista próprio à oficialidade (fornecedora das fontes para essas opiniões, por meio de memórias e outros escritos pessoais), que só percebiam nos praças aquelas dimensões" (SILVA, 2002, pp. 25,26). À mesma conclusão chegamos, em nosso Mestrado, ao estudarmos a chamada Revolta dos Marinheiros de 1964.

Mas foi o movimento dos sargentos do início da década de 1960 que, a nosso ver, teve maior impacto e ressonância na política brasileira. Muitos atribuem a ele a derrubada de João Goulart pelos oficiais militares, inconformados com a grave crise hierárquica dentro das Forças Armadas, com a leniência do Presidente. Pode-se considerar insuficiente apontar esse vínculo, uma vez que o Golpe de 1964 abrangeu a ação de importantes grupos civis muito bem articulados, mas vale lembrar o peso do tema para os argumentos ideológicos dos golpistas civis e militares.

Algumas narrações sobre este movimento indicam que seu início remonta ao catastrófico desfecho do governo de Getúlio Vargas, em 1954. O suicídio de Vargas teria provocado uma fissura grave nas Forças Armadas. De um lado, por separar politicamente oficiais e subalternos e, por outro, com a tentativa de oficiais e civis anti-varguistas de impedir a posse de Juscelino Kubitschek no ano seguinte, de antagonizar os setores das Forças Armadas entre si. A respeito, José Murilo de Carvalho declara:

Para as Forças Armadas, o 11 de novembro [quando o Marechal Henrique Lott abortou o golpe em andamento] foi traumático. Dividiu o Exército internamente e o incompatibilizou com a 
Marinha e Aeronáutica. Na Marinha, quase todo o almirantado era anti-Vargas. Na Aeronáutica, o inconformismo atingiu o ponto mais alto. (CARVALHO, 2005, p. 115)

De fato, quase a maioria dos sargentos entrevistados atribui ao suicídio de Vargas e à carta testamento tornada pública mais tarde seu encontro com a política.

As crises políticas e militares de 1954 e 1955 foram decisivas para os sargentos refletirem sobre a política nacional. O suicídio de Getúlio Vargas provocou grande comoção e indignação entre suboficiais e seus familiares, pessoas de origens simples, muitas das quais eleitoras de Vargas. Foi o caso do ex-sargento fuzileiro naval Eunício Percílio Cavalcante, que relaciona seu encontro com a política ao trágico acontecimento. Lembra que, às vésperas do suicídio, os oficiais faziam discursos nas embarcações contra o "caos" político e a "manipulação" dos trabalhadores por Vargas. Ou seja, discurso contra o Trabalhismo e sua prática de mobilização, que muitos estudiosos denominam de populismo.

Outro ex-sargento, uma das lideranças dos sargentos na primeira metade da década de 1960, Almoré Zoch Cavalheiro, também atribui seu interesse pela política ao trágico fim de Vargas. Filho de camponeses, o pai "trabalhista e getulista", sendo o chefe político do local Distrito do Alvoredo, a $40 \mathrm{~km}$ da cidade de São Gabriel -, acompanhou com entusiasmo a campanha $O$ Petróleo é nosso! e o crescimento do movimento nacionalista "contra a ação imperialista americana". Mas foram os últimos dias de Vargas, a campanha sistemática contrária ao governo por parte do "imperialismo", da imprensa e do Congresso, juntamente com a pressão dos militares antivarguistas, que o levaram à ação política. Segundo Cavalheiro,

"Nesse quadro do sistema político mundial, em 24 de agosto de 1954, aconteceu o suicídio de Getúlio Vargas. A comoção no Brasil foi a um grau inacreditável. E as correntes nacionalistas que ainda estavam adormecidas também despertaram. Naquele dia, acordei em definitivo. Chorava como grande parte do povo brasileiro, sentindo imensa decepção com a alegria incontida da maioria dos oficiais do meu Regimento. E a partir daí, ao invés de esmorecer, com apenas 23 anos, decidi agir, deixando vir à tona meu DNA político". (CAVALHEIRO, 2011, p. 33)

Foi ainda naquele ano de 1954 que Cavalheiro ingressou no Partido Comunista do Brasil, já que as teses do partido em relação à política nacional eram muito próximas das suas reflexões políticas: a luta deveria ser preferencialmente contra o imperialismo espoliativo e a favor da libertação nacional. "O objetivo não era implantar o comunismo nem mesmo o socialismo no Brasil. O PCB deveria apoiar todo e qualquer brasileiro que batalhasse pela libertação nacional do jugo imperialista”. 
O paraibano Paulo Conserva, ex-sargento da Marinha, conta trajetória parecida com a de Cavalheiro. Filho de "modesto comerciante do interior da Paraíba", natural da pequena Itaporanga, Conserva estava destinado a seguir carreira sacerdotal até que soube do suicídio de Getúlio Vargas, no seminário onde estudava:

"Também foi no Seminário do Crato que comecei a despertar interesse por questões políticas, especialmente após o trágico sacrifício pessoal do Presidente Vargas, cuja Carta-Testamento passou a ser mais importante para mim do que os Dez Mandamentos da Lei de Deus. Decorei-a de cabo a rabo. Quantas vezes, na hora do terço diário, distrai-me do Credo ou da Ave-Maria, rememorando passagens daquele histórico documento. Minha aparente vocação sacerdotal começava a fugir. O certo é que na madrugada de 24 de agosto de 1954 pude acompanhar de perto o noticiário das emissoras de rádio, graças à preocupação pessoal do meu reitor, que junto aos demais sacerdotes reunidos em seu gabinete, queria saber como andava a situação política do País, ameaçado, por um iminente golpe militar insuflado - entre outros $e$ principalmente - pelo temperamental jornalista Carlos Lacerda". (CONSERVA, 1991, pp. 1920)

Outra liderança dos sargentos, ex-subtenente paraquedista do Exército, o gaúcho Jelcy Rodrigues Corrêa, neto de getulista, conta um episódio que o aproximou ainda mais do trabalhismo: mandado para o batalhão no Palácio do Catete, que cuidava da guarda presidencial da Getúlio Vargas, em fevereiro de 1952, certa madrugada de outono, viu diante da neblina uma "figura baixinha, chapéu gelot, sobretudo, cachecol, charuto na boca e as mãos para trás”, o presidente Getúlio Vargas. Depois da continência, Getúlio puxou a conversa, reconhecendo pelo sotaque que eram conterrâneos. Quando Jelcy falou o nome de sua cidade gaúcha, Vargas lembrou-lhe de um amigo da cidade, coronel Joaquim Pompeu Corrêa, avô de Jelcy. Em narrativa a José Caldas da Costa, Jelcy falou:

"Eu me arrepiei e não segurei as lágrimas. O presidente perguntou como estava meu avô, eu dei informações superficiais, disse que ele estava morando em Rio Grande, e o presidente disse assim:

- Quando estiver com ele, dê meu abraço. Não diga que é do presidente, diga que é do Getúlio". (COSTA, 2007, pp. 23-24)

A data de 24 de agosto de 1954, ao que tudo indica, foi um marco para muitos sargentos que, posteriormente, teriam participação relevante na organização dos companheiros de farda em associações, como também no movimento que ficou conhecido como Revolta dos Sargentos, em 12 de setembro de 1963. As narrações a que tivemos acesso são consensuais a respeito. Os narradores lembram, também, da importância do Marechal Henrique Lott, que 
frustrou um golpe civil-militar em andamento para impedir a posse do presidente Juscelino Kubitschek, em 11 de novembro de 1955, conhecido como "novembrada".

O contragolpe do General Lott, contou com a participação de sargentos, como Antônio Garcia Filho, que mais tarde se elegeria Deputado Federal, representando seus colegas de patente. Garcia ficou responsável pelo quartel, enquanto seu comandante foi retomar a Base Aérea do Galeão, ocupada pelo (golpista) Brigadeiro Eduardo Gomes. (PARUCKER, 2009, pp. 50-51).

José Caldas da Costa, ao escrever seu livro Caparaó, a primeira guerrilha contra a ditadura, procurou entrevistar todas as pessoas que participaram direta ou indiretamente dessa luta, ocorrida entre julho de 1966 a $1^{\circ}$ de abril de 1967. Quase todos sargentos, já nesta altura expulsos das Forças Armadas, eram integrantes do Movimento Nacionalista Revolucionário (MNR), cujo comando estava no Uruguai, sob a liderança de Leonel Brizola. Dentre os entrevistados, encontramos alguns líderes do movimento dos sargentos do pré-golpe de 1964, como o próprio Jelcy, Amadeu Felipe da Luz Ferreira, Araken Vaz Galvão e os irmãos D’Ornellas.

Galvão, baiano de Jequié, presenciou a crise de novembro de 1955. Ele conta que "na crise do 11 de novembro, o regimento do qual eu era cabo recebeu ordem para se deslocar para a Quinta da Boa Vista. Como eu servia na Bateria de Serviços, fiquei no quartel, no apoio. Os oficiais que estavam lá foram para a Quinta da Boa Vista e, da Quinta, receberam um aviso para se deslocarem para o Palácio do Catete. Eles se rebelaram e voltaram para o quartel. Aí, deu o zunzunzum. Parece que só dois quartéis se rebelaram contra a ordem, e o nosso Regimento Escola de Artilharia foi um deles". (COSTA, 2007, p. 26)

Nesse relato, Araken lembra que os sargentos, no governo de Juscelino Kubitschek, se fortaleceram, principalmente com as medidas tomadas pelo Ministro da Guerra, Marechal Henrique Lott, criando o Quadro Auxiliar de Oficiais, que permitia ao sargento chegar, por promoção, à patente de capitão. Segundo Costa, além desta importante medida de Lott, outra que valorizava os sargentos foi a da mudança no sistema de sua promoção, incentivando-os a estudar:

"Antes, o sargento acumulava quatro pontos por ano, se não cometesse faltas. Se doasse sangue, ganhava mais um ponto. Lott decidiu que quem fizesse o ginásio ganharia cinco pontos e que quem fizesse o científico (correspondente, à época, ao ensino médio de hoje) ganharia quinze pontos. Isso significava antecipar em três anos a promoção". (COSTA, 2007, p. 26).

Jelcy Rodrigues Corrêa lembra que o sargento, no período em que o Marechal Henrique Lott foi Ministro da Guerra, “conquistou (...) várias coisas: a estabilidade com dez anos de 
serviço; (...) incorporou-se as férias dos sargentos, as férias passaram a ser de trinta dias como a dos oficiais, porque era de vinte dias" (SANTOS, 2010, p. 128). Diante disto, podemos inferir a importância que Lott passou a ter para eles. Nas palavras de Araken: "Essa etapa da politização dos sargentos, que terminou em 1964, não há dúvida de que começou com o contragolpe de 1955. Agora, tinha raízes muito profundas na história” (COSTA, 2007, p. 26). Segundo Cavalheiro, a respeito das medidas de Lott que beneficiaram os sargentos, "esse conjunto de fatores, além de outros, abriram muitos horizontes para os sargentos e contribuíram para que eles se conscientizassem de que eram cidadãos aptos ao exercício dos direitos e deveres daí decorrentes". (CAVALHEIRO, 2011, p. 45)

Ainda na fala desse narrador, comunista com "raizes trabalhistas", "mais simpático ao Partido Trabalhista do que ao Comunista”, o contragolpe em 11 de novembro de 1955 "contribuiu muito para que a conscientização politica dos sargentos fosse outra vez alavancada" e as revoltas de Aragarças e Jacareacanga, articuladas por oficiais da Aeronáutica para derrubar Juscelino Kubitschek, só aproximaram os sargentos dos oficiais nacionalistas. Por exemplo, quando o Marechal Henrique Lott saiu candidato a Presidente da República, não apenas Cavalheiro o apoiou com entusiasmo, mas a maioria dos sargentos:

"a maioria dos sargentos, por todas as formas possíveis, participou intensamente da campanha pela a eleição do Gen. Lott. E o processo de conscientização política alcançou grandes proporções entre a classe. Já entre os oficiais, o apoio a Jânio Quadros era nitidamente majoritário".

E continua:

"Até parecia uma contradição: enquanto os sargentos apoiavam o General candidato, os oficiais apoiavam o civil Jânio Quadros. Convém notar que entre os oficiais generais, a esmagadora maioria apoiava Jânio” (CAVALHEIRO, 2011, pp. 36-39).

Outro ex-sargento, José Nóbrega, em entrevista à historiadora Wilma Antunes Maciel, conta sua experiência no início da carreira militar:

"quando entrei no Exército já tinha participação política. Participei das manifestações de rua na morte de Getúlio. Na tentativa de golpe em 56 [sic] quando o general Lott garantiu a posse de Juscelino. Fui metalúrgico aos 16 anos e já participava do sindicato. Quando fui para o Exército a ideia inicial era servir a pátria. A minha educação na escola foi de formação cívica. $O$ Getúlio deu isso, a gente cantava o hino nacional, tinha fanfarra, a educação era boa, eu tinha aquele sentimento de nacionalismo, fui para Exército com esse sentimento" (MACIEL, 2009, pp. 64-65). 
Um expressivo testemunho do período do último governo Vargas, principalmente do impacto das campanhas nacionalistas junto aos militares subalternos, foi o de Daltro Jacques D’Ornellas, ex-terceiro-sargento do Exército, ao historiador Stefan Freitas dos Santos. Nele, percebe-se a resistência que setores nacionalistas tinham aos EUA:

“Em 1951, Getúlio Vargas assume o governo na época da Guerra da Coréia, e tem duas coisas que são fundamentais para confirmar a luta de resistência da população brasileira frente ao poder hegemônico e imperialista dos EUA. Uma era que Getúlio Vargas e as forças populares foram contra o envio de soldados brasileiros para a Guerra da Coréia. A pressão exercida pelos EUA contra o Brasil foi muito forte, mas nós vencemos - eu era guri e já atuava no movimento contra o envio de soldados brasileiros para a Guerra da Coréia - e a outra, da qual também participamos, foi da campanha popular pelo monopólio estatal do petróleo e pela criação da Petrobras, que veio a ocorrer em 1952. (...) Depois vem 1954, em outro agosto, Getúlio Vargas escreve a "Carta Testamento" e se suicida com um tiro no peito. A carta-testamento é um documento memorável, porque mostrava a realidade da política de espoliação econômica praticada pelos EUA contra o Brasil. A comoção popular presenciada em todo o país com a morte de Getúlio Vargas reforçou a posição dos oficiais e sargentos nacionalistas. Foi essa emoção popular que criou as condições para o general Henrique Teixeira Lott promover o contragolpe em 11 de novembro de 1955, com o apoio dos sargentos e oficiais nacionalistas, derrotando a oficialidade golpista, o que possibilitou a garantia da posse de Juscelino Kubitschek na presidência da República no ano seguinte" (SANTOS, 2010, pp. 89-90).

O que estamos tentando demostrar é que, bem antes da crise de 1961, marco que muitos pesquisadores indicam como o começo do movimento dos sargentos, e mesmo do Golpe de 1964, militares subalternos, aqui incluídos sargentos, cabos, marinheiros e suboficiais das três Forças, já eram simpatizantes do trabalhismo, por influência familiar principalmente, até antes de entrarem para as Forças Armadas. Vários deles vivenciaram a morte de Getúlio e sabiam identificar os que o levaram ao suicídio. Com o passar dos anos, perceberam que muitos de seus comandantes continuaram fazendo discursos antinacionalistas, ou melhor, antitrabalhistas diante das tropas. Ou seja, faziam abusadamente, segundo seus relatos, proselitismo de uma política conservadora e elitista. O que se tratava, naquele contexto, de sério desrespeito à hierarquia, pois as pesadas críticas eram contra o comandante-em-chefe das Forças Armadas, o Presidente da República, Getúlio Vargas e, posteriormente, Juscelino Kubitscheck.

Estes jovens não tinham assistido às mudanças sociais que ocorreram no País a partir de 1930. Mas seus pais certamente viveram o momento de transição entre a Primeira República e 
o período que se lhe seguiu. Mesmo que fossem do campo, menos atingido pelas medidas getulistas, percebiam que algo estava em andamento para melhorar suas vidas, ou acreditavam nisso. É ilustrativo o depoimento do alagoano, cabo da Marinha, Antônio Geraldo Costa sobre sua infância e "formação" política. Diz ele que era ainda muito novo quando seus tios se engajaram voluntariamente na milícia de Juarez Távora, lutando no Nordeste contra os jagunços dos coronéis, logo depois da Revolução de 1930.

"O tenente Juarez saiu pelo Nordeste recrutando os pelotões e batalhões de civis de voluntários para sustentar o movimento revolucionário de 1930. E meus tios se engajaram, dois deles, se engajaram no movimento. (...) Quando os meus tios foram desmobilizados e voltaram para a fazenda [onde a família trabalhava], voltaram para as suas origens, eles já voltaram bastante esclarecidos e começaram a exigir mais direitos. Por exemplo, quando a minha família trabalhava os três dias, era de sol a sol e, no movimento getulista eles já tinham uma proposta de regulamentar o trabalho no campo e nas indústrias, oito horas de trabalho, que regulamentaram depois, levou muito tempo, mas já se fazia propaganda em torno disso" (Entrevista a Flávio Luis Rodrigues em 15 de dezembro de 2009, na cidade de São Paulo).

Antônio Geraldo Costa, mais conhecido como Neguinho, um de nossos protagonistas, conta que seus familiares foram expulsos da fazenda, considerados "negros abusados", por reivindicarem direitos, num mundo em que prevalecia a truculência contra os que deveriam ter apenas deveres. Mesmo assim, Neguinho atribui a essa experiência a maneira como passou a pensar o mundo. Lembra-se da frase da mãe, já em Maceió depois da necessidade de fugir da fazenda, após tiroteio entre seus tios e os jagunços do dono da fazenda: “Ó, meu filho, a única voz que a gente tem, é a voz do bacamarte" (espécie de rifle, também conhecido como papo-amarelo). E complementa:

"Quando eu comecei a estudar a noite, isso, bom, a minha mãe já falava sobre a voz do bacamarte, já falava em senhor Getúlio, do Juarez Távora, e a gente teve ideia das injustiças, né. Aquilo se chamava de opressão, as injustiças monstruosas em cima dos trabalhadores do campo, dos pobres em geral, que não tinham emprego, principalmente, e a minha mãe sempre, com aquela revolta e, sim, na minha família nós tínhamos o privilégio de, mesmo no interior, sermos alfabetizados. Quer dizer, sabia ler um pouco, né. Era alfabetizada, pelo menos lia".

Entendemos que, após a Segunda Guerra Mundial, com o retorno dos militares da FEB que lutaram ao lado de colegas dos EUA, houve uma divisão entre os oficiais das Forças Armadas, principalmente do Exército brasileiro. Influenciados pelo liberalismo americano e impressionados com o poder militar demostrado pelos EUA, esses oficiais passaram a 
defender uma aproximação maior do Brasil com aquele país. Isto significava uma oposição ao que defendia o trabalhismo de Getúlio, ou seja, maior presença do Estado na economia e nas relações entre capital e trabalho; defesa dos minérios atômicos e outros de empresas estrangeiras; leis trabalhistas; incentivo à sindicalização; aumentos do salário mínimo próximos da inflação; planos de alcançar autossuficiência energética, com a criação de empresas estatais, como a Petrobras; controle das remessas de lucros das empresas estrangeiras. A este modelo de gestão se opõe o dos militares antinacionalistas: redução da presença do Estado na economia; incentivo à iniciativa privada, através do estímulo à livre concorrência; pouca interferência do Estado nas relações capital/trabalho; contenção dos aumentos dos salários e restrição ao crédito, através de juros elevados, para controlar a liquidez e evitar a inflação; impedir a mobilização dos trabalhadores, cuja organização é considerada perniciosa ao capitalismo; estímulo à entrada de investimentos estrangeiros, por exemplo na prospecção de petróleo, garantindo acesso às novas tecnologias; garantir às Forças Armadas controle de eventuais inimigos internos, orientados pelos termos da Doutrina de Segurança Nacional.

As tentativas de golpe por oficiais antinacionalistas, em 1954 e 1955, e os discursos que faziam contra o presidente eleito legalmente pelo voto popular levaram setores dos militares subalternos a questionar as ações de seus comandantes. Não deveriam, como bons profissionais, obediência à hierarquia? Então, ao se envolverem em conspirações contra o seu superior, não estariam seus comandantes subvertendo a disciplina?

Vencendo as eleições de 1960, Jânio Quadros levou para seu ministério militares conservadores. Como Ministro da Guerra, por exemplo, nomeou o General Odílio Denys, que em 1955 apoiou o Marechal Lott contra a tentativa de golpe para impedir a posse de Kubitschek, mas que, no entanto, em 1961 tentaria impedir a posse de João Goulart, quando ocorreu a renúncia de Jânio. Contradição que talvez faça sentido se lembrarmos de que João Goulart era o político vivo que mais fora ligado a Vargas, tendo sido seu Ministro do Trabalho em 1953.

Os militares subalternos que participaram da campanha do Marechal Henrique Lott para a presidência da República, cujo vice na chapa era justamente João Goulart, durante o curto mandato de Jânio Quadros sofreram perseguição implacável por seus comandantes. Como lembra Cavalheiro,

"como regra geral, os sargentos viveram um período muito difícil, com muita perseguição por parte da oficialidade mais radical da direita, sofrendo prisões disciplinares, transferências para regiões distantes e de fronteiras do Brasil, bloqueios de promoções e toda sorte de castigos 
frequentemente mascarados com muito cinismo e hipocrisia. Quando o alvo era um sargento mais definido como político nacionalista, a coisa era sempre pior ainda". (CAVALHEIRO, 2011, p. 40).

Estas perseguições fizeram com que os sargentos tomassem mais cuidado com suas atitudes. Deveriam "aperfeiçoar aspectos da vida profissional”, acrescenta Cavalheiro, elucidando a conduta que passaram a intensificar:

"um sargento nacionalista deveria ser muito disciplinado, ser estudioso das matérias militares, seu uniforme deveria estar impecável, seus coturnos brilhantes, sua dedicação às tarefas profissionais deveria ser exemplar e ele deveria ser sempre bom exemplo para os demais. Assim ele seria um profissional necessário e adquiriria o direito e teria moral para exercer a sua cidadania" (CAVALHEIRO, 2011, p. 40).

Mas também aproximaram ainda mais os sargentos dos setores nacionalistas, militares ou civis. Dênis de Moraes diz que muitos destes militares se iniciaram na política através dos cursos ministrados no ISEB, Instituto Superior de Estudos Brasileiros, "que oferecia cursos gratuitos em que discutiam as grandes questões nacionais sob uma ótica progressista" (MORAES, 1989, pp. 94-95). Cita, por exemplo, o testemunho do ex-subtenente Jelcy, um dos frequentadores assíduos. Ora, estes cursos eram frequentados por várias pessoas com viés nacionalista, economistas, sociólogos, acadêmicos, militares, estudantes, etc. E, por mais que algumas medidas de Jânio fossem ambíguas - como sua política externa -, seus apoios políticos eram bem identificados: a UDN e setores civis conservadores e moralistas.

Vale relembrar aquele provérbio árabe citado por Marc Bloch, como alerta: "os homens se parecem mais com sua época do que com seus pais" (BLOCH, 2001, p. 60). E a época em que viveram estes militares subalternos era de profundas transformações. A passagem da década de 1950 para a de 1960, Era de Ouro, como a definiu Eric Hobsbawm, o Ocidente passava por transformações surpreendentes, com o aparecimento de novas tecnologias que impactaram decisivamente a vida de milhões de pessoas, alterando seus padrões de comportamento e de consumo. Hobsbawm cita o surgimento da pílula anticoncepcional, que permitiu às mulheres mais autonomia na escolha de seus parceiros, bem como na opção por casamento e procriação. Segundo o autor, este fato trouxe mudanças significativas em relação às famílias, colocando a típica família nuclear - pai, mãe e fillhos - em xeque, ao mesmo tempo em que as residências de moradores sós se tornaram cada vez mais comuns. Ele lembra ainda que nesse período, os jovens passaram a conviver cada vez mais em grupos, suas roupas agora se diferenciavam das de seus pais, principalmente com a nova utilização do jeans (antes, apenas roupa de trabalhador pobre), e seu gosto musical aproximou-se de sons 
metalizados, que provocavam os corpos a acompanhar o ritmo da bateria e os acordes da guitarra. Chegava o rock.

Estes "ventos modernizantes" atingiram o Brasil, principalmente os grandes centros urbanos. Aqui, nossos estudantes passaram a debater ainda mais os caminhos para a revolução brasileira, assim como uma nova cultura popular, que chegasse ao autêntico povo brasileiro, aquele do interior, do campo, das pequenas cidades esquecidas. Esta descoberta da política também incluía grupos de artistas, trabalhadores urbanos, jovens católicos, trabalhadores agrícolas, professores, intelectuais - chegaram mesmo a criar o Comando dos Trabalhadores Intelectuais, em 1963 -, e, por que não? os militares subalternos. Jorge Silva, ex-sargento da Marinha, salienta a importância da televisão para o acesso às informações, principalmente no Repórter Esso: "Era ali que tomávamos conhecimento das notícias da guerra da libertação na Argélia e nas possessões portuguesas. A gente achava aquilo fantástico. Você lia de manhã e de noite via na televisão a notícia. No outro dia, todo mundo comentava" (COSTA, 2007, p. 33). Dênis de Moraes realça que o Brasil destes tempos brindava com uma "espécie de triunfalismo nacional", citando vários acontecimentos para corroborar tal afirmação: A seleção brasileira de futebol conquistou os títulos nas copas de 1958 e 1962; Éder Jofre, o "galinho de ouro", brilhava no ringue; Maria Ester Bueno, com sua afiada raquete, destacavase no tênis internacional; o comovente filme $O$ pagador de promessas foi premiado em Cannes; a brasileira Ieda Maria Vargas conquistou o título de Miss Universo de 1963; a construção de Brasília foi bem-sucedida; a euforia desenvolvimentista dava a tônica dos debates políticos; Fidel Castro esteve no Brasil em 1959 e Che Guevara, em 1961; em documento de 1963, a CNBB coloca como prioridade a reforma agrária; ocorreu a criação do Centro Popular de Cultura pela UNE; floresceram os grupos teatrais Arena e Oficina; houve uma visita de Jean Paul Sartre e Simone de Beauvoir ao Brasil (agosto de 1960) que, ciceroneados por Jorge Amado e Zélia Gattai, estenderam sua viagem até novembro, etc. Resumindo, ainda segundo Moraes, citando Roberto Schwarz: o Brasil se tornou “irreconhecivelmente inteligente" (MORAES, 1989, pp. 23-41). Enfim, um mundo em ebulição, em que a palavra de ordem passa a ser a ação, a ida às ruas, o contato com o povo. Aliás, o lema da UNE na gestão de José Serra era justamente “a hora é de ação". Diante desse turbilhão, principalmente nas grandes cidades, os militares não ficaram alheios. Mais tarde, quando reivindicarem seus direitos de representação no Congresso, usarão o jargão "soldado também é povo".

Em início dos anos 60, Jânio da Silva Quadros vence as eleições contra o Marechal Henrique Lott. Eleições aparentemente limpas, democráticas, o que dava legitimidade ao 
presidente eleito colocar em prática o seu programa de governo. Como vice-presidente, elegeu-se João Goulart, da chapa do Marechal Lott. Na época, o voto para presidente e vicepresidente era desvinculado.

Jânio herdou de seu antecessor um país com sérios problemas econômicos: inflação crescente e uma dívida externa de 3 bilhões e 802 milhões de dólares, quando em 1955 a dívida estava em 2 bilhões e 367 milhões de dólares. Segundo o historiador Jorge Ferreira, Jânio, em seu governo, "teria que saldar, em moeda estrangeira, compromissos que alcançavam 2 bilhões de dólares. Em novembro de 1961, não haveria como pagar 47 milhões e 700 mil dólares ao FMI e outros 28 milhões ao Eximbank” (FERREIRA, 2011, p. 219). Além das dificuldades econômicas, as políticas também não eram desprezíveis. Sem maioria no Congresso, fato que exigiria do presidente flexibilidade e transigência com os parlamentares, para garantir governabilidade e desenvolvimento de seu programa de governo, Jânio, no entanto, preferiu o caminho do confronto e da intimidação, com a criação, já no segundo dia da posse, de cinco comissões de sindicância, seguidas, mais tarde por dezenas de outras. Ainda segundo Ferreira,

"ao atingir diretamente o vice-presidente da República, as comissões, como era de esperar, passaram a denunciar deputados e senadores por atos de corrupção, favoritismo e desvio de recursos públicos. (...) Jânio não contemporizava, recusava-se a acordos, a alianças e a entendimentos. Sua política era a dele mesmo, embora com o risco de isolamento dos partidos" (FERREIRA, 2011, pp. 222-223).

O isolamento do presidente não aconteceu apenas da parte dos partidos da oposição. Os aliados, políticos da UDN, por exemplo, ficaram no mínimo confusos com sua política externa. Pretendia o presidente, possivelmente, projetar-se como estadista no cenário internacional. Talvez por isso tenha conduzido sua política externa com independência, não alinhando necessariamente a um ou a outro bloco, liderados pelos EUA ou URSS. Com estas orientações, Jânio procurou buscar acordos comerciais com vários países socialistas, a começar por China de Mao Tsé-Tung, URSS, de Khrushchev e Cuba, de Fidel Castro. Carlos Lacerda, governador da Guanabara, udenista e anticomunista ferrenho, não poderia aceitar o que considerava um despautério: passou a criticar o presidente, através de seu jornal Tribuna da Imprensa e, no dia 24 de agosto anunciou, pela televisão, que Jânio preparava um golpe de Estado. No dia seguinte, através de uma carta enviada ao Congresso, Jânio comunicava sua renúncia.

Não é nossa intenção discutir os significados da renúncia, mas seus efeitos. E, para tanto, partiremos do suposto que as instituições democráticas ainda não estavam totalmente 
seguras, o que nos remete às anteriores tentativas de golpe por parte dos militares. Mas apesar deste perigo sempre próximo na história republicana do país, o que se sucedeu à renúncia foi a demonstração de um Congresso que não se vergou às intimidações dos ministros militares de Jânio para que votasse imediatamente o impeachment de João Goulart. Pelo contrário, os congressistas procrastinaram ao máximo qualquer decisão, enquanto tentavam amenizar os efeitos da crise instaurada. Primeiramente, o Congresso aceitou de imediato a renúncia e o presidente da Câmara, deputado Ranieri Mazzilli, assumiu a presidência da República. Posteriormente, apenas no dia 30, votou o impeachment, que foi rejeitado por 299 votos a 14, o que indica que vários deputados da UDN ficaram a favor da legalidade (FERREIRA, 2011, p. 247).

A queda de braço entre a Junta Militar - que se formou a partir do conselho de Jânio para seus três Ministros militares, da Guerra, Marinha e Aeronáutica -, e o Congresso, se estendeu enquanto João Goulart fazia intencionalmente várias escalas de regresso ao Brasil (estava em viagem oficial à China e à URSS). A Junta Militar estava decidida a não permitir a posse de Jango. Odílio Denys, Ministro da Guerra, no noticiário Repórter Esso, da rádio Nacional, "declarara que a escolha entre a posse ou a impeachment de Goulart significava, na verdade, uma escolha entre o comunismo e a democracia no Brasil" (FERREIRA, GOMES, 2014, p. 35). O mesmo discurso era utilizado pelo governador Carlos Lacerda, que em 28 de agosto, em seu jornal Tribuna da Imprensa, publicou na primeira página: "Denys, agora é escolher: comunismo ou democracia” (FERREIRA, 2011, p. 243). Lacerda, entusiasta do golpe, colocou sua polícia para reprimir violentamente os movimentos de resistência, ao mesmo tempo que censurou todos os jornais de publicarem matérias opositoras aos golpistas. Além de Lacerda, os Jornais O Estado de São Paulo e O Globo apoiaram a decisão da Junta Militar.

O golpe em curso, promovido pela Junta Militar, não contou com a maioria das Forças Armadas. Muitas mensagens, telefônicas ou telegráficas, foram feitas pelos golpistas às várias unidades das Forças Armadas. Todas comunicando a decisão já tomada pelo alto comando. No entanto, não havia uma base legal para tal medida. A Constituição de 1946 era explícita a respeito: na renúncia do presidente, assume o vice. $\mathrm{O}$ argumento usado pela Junta de que o vice era comunista, sendo seu programa de governo diferente daquele escolhido pelos eleitores - o de Jânio Quadros -, e que, portanto, o impedimento seria a expressão da vontade do povo não era juridicamente suficiente. E ademais, quem podia acreditar que Jango, um dos maiores estancieiros do Brasil, era de fato comunista? A saída para o sucesso do golpe seria o Congresso votar imediatamente o impeachment, mas este tergiversava. Vários oficiais 
comandantes ficaram numa situação difícil, pois sabiam que, ao obedecer às decisões do alto comando, estariam descumprindo seus juramentos de defender a Constituição. Por outro lado, a desobediência contrariaria o espírito de corpo entre os militares, ou seja, seria uma afronta à hierarquia, uma indisciplina que teria efeitos perversos em suas carreiras.

A saída para o imbróglio veio do Sul, através de dois movimentos simultâneos: a ação do Governador Leonel Brizola, conclamando a população do Rio Grande do Sul a resistir ao golpe; e a defesa da legalidade por parte de vários sargentos e oficiais de unidades do Exército, pressionando o Comandante do III Exército a tomar posição a favor da Carta Magna.

Quando Leonel Brizola soube da renúncia, pensou logo que Jânio tivesse sido deposto. Conjecturou, inclusive, em chamá-lo para resistirem em seu Estado. Ficando claro o que acontecia, prometeu reação. Paulo Schilling, na época assessor do governador, em depoimento a José Caldas da Costa, conta o que presenciou logo que souberam da decisão da Junta Militar:

“[...] quando chego lá [no Palácio Piratini], o Brizola me recebe assim:

- Como é alemão, vamos resistir?

E eu digo:

- Tá louco, tchê: Resistir a um golpe militar?

Tínhamos alguma coisa de força, a Brigada Militar, uns dez mil homens, distribuídos trinta em cada município. O Brizola, naquele jeito gaúcho dele de falar, diz:

- Não tchê. Esses caras não são de nada, nós vamos resistir e eles vão ter que brigar. Não vão dar golpe por telefone.

O Brizola imediatamente mandou que o Regimento Bento Gonçalves, da Brigada Militar, viesse para o palácio, fortificar as aberturas do palácio com sacos de areia e aquela coisa toda, $e$ resolvemos resistir. E aí se lançou uma arma secreta: o rádio. $O$ Brizola mandou requisitar a principal estação de rádio do estado, a Farroupilhas, falando com um microfone instalado no palácio. E mandou outro pelotão da brigada ocupar as torres, para garantir a transmissão. Os ministros militares podiam ter liquidado conosco, botavam umas centenas de cargas no palácio e não tinha como resistir. O III Exército representava na época cerca de $40 \%$ do Exército nacional" (COSTA, 2007, p. 49)

Outras providências foram tomadas. Brizola sabia que, se não tivesse o apoio de militares seria muito difícil reverter o golpe em andamento. Pôs-se, então, a telefonar para vários comandantes. O do III Exército, General José Machado Lopes, disse-lhe que era soldado e que ficaria com o Exército. Do Comandante do IV Exército, General Artur da Costa 
e Silva, "o governador ouviu tão somente impropérios, devolvidos na mesma altura" (FERREIRA, 2011, p. 230). Em conversa com o marechal Henrique Teixeira Lott, que no mesmo dia da renúncia tinha lançado um manifesto, conclamando "todas as forças vivas do país [...] para tomar posição decisiva e enérgica no respeito à Constituição”, o que lhe valeu a prisão, Brizola foi orientado a contatar militares nacionalistas no Rio Grande do Sul. Segundo, ainda, o historiador Jorge Ferreira, o General Amaury Kruel foi clandestino para Porto Alegre, ficando hospedado no Palácio Piratini. Mas, sem comando de tropa, pouco podia fazer.

Enquanto o Congresso resistia em acatar a orientação da Junta Militar para a votação do impeachment de Jango, Brizola avançava utilizando o rádio para informar a população sobre o que se passava, através de discursos inflamados e carregados de emoção. Uma multidão logo se formou em frente ao Palácio. Tudo isto certamente não estava nos planos dos golpistas, pois percebiam que o tempo não era seu aliado. A radicalização foi ao limite, quando a Junta Militar, em 27 de agosto, "ordenou ao comandante do III Exército que fosse ao Palácio Piratini e depusesse o governador”. Os historiadores Ângela de Castro Gomes e Jorge Ferreira continuam: "se ele resistisse, o Palácio deveria ser bombardeado por tanques ou pela aviação de caça. Uma frota da Marinha de Guerra ia ser enviada para o Sul" (FERREIRA e GOMES, 2014, p. 34).

A mensagem enviada ao Comandante do III Exército pelo Ministro da Guerra corrobora o que está escrito acima:

O GEN ORLANDO GEISEL TRANSMITE AO GEN MACHADO LOPES, CMT III EX, A SEGUINTE ORDEM DO MINISTRO DA GUERRA:

O III EXÉRCITO DEVE COMPELIR IMEDIATAMENTE O SR LEONEL BRIZOLA A PÔR TERMO A AÇÃO SUBVERSIVA QUE VEM DESENVOLVENDO E QUE SE TRADUZ PELO DESLOCAMENTO E CONCENTRAÇÃO DE TROPAS E OUTRAS MEDIDAS QUE COMPETEM EXCLUSIVAMENTE ÀS FORÇAS ARMADAS.

O GOVERNADOR COLOCOU-SE, ASSIM, FORA DA LEGALIDADE. O CMT DO III EX ATUE COM A MÁXIMA ENERGIA E PRESTEZA.

FAÇA CONVERGIR SOBRE PORTO ALEGRE TODA A TROPA DO RIO GRANDE DO SUL QUE JULGAR CONVENIENTE, INCLUSIVE A $5^{a}$ DI, SE NECESSÁRIO.

EMPREGUE A AERONÁUTICA, REALIZANDO INCLUSIVE O BOMBARDEIO, SE NECESSÁRIO.

ESTÁ A CAMINHO DO RGS UMA FORÇA-TAREFA DA MARINHA.

QUAL O REFORÇO DE TROPA QUE NECESSITA? 
AQUI HÁ UM BOATO DE QUE O GEN MURICY VIRIA AO RIO. O MINISTRO DA GUERRA NÃO QUER ACREDITAR NESTA NOTÍCIA E JULGA QUE O MOMENTO NÃO É MAIS PARA PARLAMENTAR, MAS REQUER AÇÃO FIRME E IMEDIATA. O MINISTRO DA GUERRA CONFIA EM QUE A TROPA DO III EX CUMPRIRÁ O SEU DEVER ${ }^{17}$

O Ministro da Guerra felizmente estava enganado. O III Exército não "cumpriu o seu dever", ou o suposto dever que o ministro lhe atribuía.

O Comandante, General José Machado Lopes, ligou para o governador Brizola, dizendo-lhe que estava a caminho do Palácio para conversarem. Brizola não precisou perguntar do que já havia sido informado pelo funcionário dos Correios e Telégrafos João Carlos Caragna, que vinha interceptando as mensagens dirigidas ao QG do III Exército: seria deposto. Foi ao microfone da Rede da Legalidade e, "com a voz trêmula e embargada”, fez um discurso exaltado, comunicando que o Comandante iria visitá-lo e

"se ocorrer a eventualidade do ultimato, ocorrerão, também, consequências muito sérias. Porque nós não submeteremos a nenhum golpe. A nenhuma resolução arbitrária. Não pretendemos nos submeter. Que nos esmaguem! Que nos destruam! Que nos chacinem, neste Palácio! Chacinado estará o Brasil com a imposição de uma ditadura contra a vontade de seu povo. Esta rádio será silenciada. O certo porém é que não será silenciada sem balas" (FERREIRA, 2011, p. 234).

Com a chegada do Comandante e todos os generais do III Exército, sendo observados por dezenas de milhares de pessoas apreensivas, alguns gritaram insultos, outros "Brizola", "legalidade", "resistência". Enquanto subiam as escadas do Piratini,

"um profundo silêncio se seguiu. Mas bastou uma única pessoa começar a cantar o primeiro verso do Hino Nacional para toda a multidão, em uma mesma voz, acompanhá-la. Nesse momento, o general Machado Lopes interrompeu sua caminhada nas escadas do Piratini e, emocionado e trêmulo, ao lado de seus oficiais, também cantou, junto com o povo. A atitude do general havia sido entendida por aqueles milhares de pessoas. Homens e mulheres, abraçados, começaram a chorar, sem interromper, porém, o Hino" (FERREIRA, 2011, pp. 238-239).

O III Exército, a mais poderosa unidade do Exército Brasileiro, ficou do lado da legalidade. Seu comandante, então, comunicou a seus superiores o que havia sido tratado no interior do Palácio:

\footnotetext{
${ }^{17}$ Boletim Especial n n $^{\text {1, de }} 15$ de outubro de 1961, do III Exército. In: O Cruzeiro. 2 de dezembro de 1961. P. 8. Cit. ROLIM, César Daniel de Assis. Leonel Brizola e os setores subalternos das Forças Armadas Brasileiras: 1961-1964. Dissertação defendida pela Universidade Federal do Rio Grande do Sul. Porto Alegre: 2009, p. 147.
} 
O CMT III EX COMPARECE AO PALÁCIO PIRATINI PARA LEVAR AO CONHECIMENTO DO GOVERNADOR BRIZOLA A DECISÃO QUE VINHA DE TOMAR, BEM COMO SOLICITAR AO GOVERNADOR DO ESTADO AS PROVIDÊNCIAS NECESSÁRIAS PARA QUE MODERASSE OS ATOS DE EXALTAÇÃO REVOLUCIONÁRIA QUE VINHA PRATICANDO, INCLUSIVE A DEVOLUÇÃO DA RÁDIO GUAÍBA.

PELO GOVERNADOR BRIZOLA FOI-LHE PROMETIDO O ACATAMENTO A ESSAS SOLICITAÇÕES. (Citado em ROLIM, p 148)

Em outra mensagem, o Comandante deixaria explícita a sua decisão:

MINISTRO GUERRA - RIO - No 264 E2 DE 30 AGO 61 - TERCEIRO EXÉRCITO PERFEITAMENTE COESO NÃO MAIS ACATARÁ ORDENS V EXCIA ET AGIRAH POR CONTA PRÓPRIA DENTRO DA IDEIA DE MANTER O REGIME LIBERAL DEMOCRATA CRISTÃO VG ASSEGURANDO INTEGRAL EXECUÇÃO DA CONSTITUIÇÃO VIGENTE SEM QUALQUER MODIFICAÇÃO NELA SEJA PORVENTURA INTRODUZIDA PR GEN MACHADO LOPES, cmt III Ex. (IDEM, p 148)

A atuação de Brizola em defesa da legalidade, mobilizando a população de seu estado, principalmente, para resistir ao golpe, ao utilizar o rádio para que as pessoas se informassem das artimanhas do alto comando militar, sem dúvida, foi fundamental para o desfecho da crise. Mas, se o Terceiro Exército não aderisse ao movimento da legalidade, será que Jango assumiria, mesmo através de um sistema parlamentarista? Difícil responder. Segundo Brizola, em entrevista a Paulo Markun e Duda Hamilton, os governadores de vários estados já estavam conformados com a situação de golpe:

"Os três ministros militares, ministros do Exército, da Marinha e da Aeronáutica, já haviam formado uma junta e estavam controlando o país, ditando todas as regras, então foi a primeira vez que surgiu na periferia do país, por que o Rio Grande do Sul, ele está lá como uma espécie de fim de linha, uma resistência que surpreendeu toda aquela ordem de poder já estabelecida, porque os governadores já estavam conformados. Aqui no Rio de Janeiro até a censura à imprensa já havia sido estabelecida; o governador Carvalho Pinto, em São Paulo, já estava conformado; o de Minas estava colaborando; o Lacerda aqui era um factótum do regime a partir da renúncia do presidente". (Citado em ROLIM, p 148)

Se vários políticos já estavam considerando fato consumado o impedimento de Jango, até quando o Congresso resistiria em não votar o impeachment? Se o Comandante do III Exército continuasse como "soldado que ficaria com o Exército", o movimento pela legalidade teria alguma chance de sucesso? Temos que considerar, neste exercício de história 
contra factual, que a opinião pública, com o decorrer do tempo, foi assumindo posição favorável à posse, através de manifestações como greves de trabalhadores, editoriais de jornais, manifestos da Ordem dos Advogados do Brasil (OAB) e a Conferência Nacional dos Bispos do Brasil (CNBB). Gomes e Ferreira citam uma pesquisa do IBOPE, realizada no estado da Guanabara, publicada no Jornal do Brasil do dia 2 de setembro, cujo resultado foi: $81 \%$ dos eleitores desejavam que Goulart tomasse posse no regime presidencialista; $10 \%$ no regime parlamentarista, $9 \%$ não souberam responder. Entre os eleitores do governador Carlos Lacerda, 69\% desejavam que Goulart assumisse a presidência da República no regime presidencialista (FERREIRA e GOMES, 2014, p. 45). Os militares golpistas sentiam que o time para o sucesso do golpe estava passando e, mesmo com o Congresso vetando a proposta de impedimento, em 29 de agosto, não recuaram na disposição de prender Jango, caso desembarcasse no país.

A posição do III Exército - e não apenas de seu comandante - pela legalidade, no entanto, cindiu irrecuperavelmente os militares. Mais comandantes, de outras unidades do Exército, seguiram os oficiais do Rio Grande do Sul, Santa Catarina e Paraná, área de atuação do Terceiro Exército, o mais poderoso e estratégico para a segurança nacional. Segundo Gomes e Ferreira, ele "era o mais equipado que todos os outros três juntos, em função de estar situado em área de fronteira no Prata, considerada mais vulnerável devido à proximidade da Argentina” (FERREIRA e GOMES, 2014, p. 32).

$\mathrm{O}$ que teria levado o Comandante e seus generais a desobedecerem às ordens do Ministro da Guerra?

O Comandante, general José Machado Lopes, atribui sua decisão às imponderáveis consequências de se iniciar um movimento armado no Rio Grande do Sul e este se espalhar pelo restante do país, "tal o estado de politização em que se encontrava o povo, motivado pela legitimidade de o Sr. João Goulart empossar-se como presidente da República" (ROLIM, 2009, p. 17).

A decisão de Lopes também foi amparada pela posição de generais de sua unidade, como o general-de-brigada Oromar Osório, da $1^{\text {a }}$ Divisão de Cavalaria, general Sílvio Santa Rosa, coronel Assis Brasil e o general-de-divisão Peri Bevilacqua, comandante da $3^{\mathrm{a}}$ Divisão de Infantaria. Brizola lembra a importância destes generais: "o que decidiu mesmo foi toda a movimentação armada. Só se decidiu quando o general Oromar Osório se deslocou armado com uma divisão que devia ter oito mil homens e que marcharam",18

\footnotetext{
${ }^{18}$ Entrevista a Paulo Markun e Duda Hamilton. Citado por ROLIM, César Daniel de Assis. Op.cit. p. 17.
} 
Paulo Schilling entende que o general José Machado Lopes foi levado a aderir, porque não lhe restava alternativa.

"O Machado Lopes escreveu um livro [O III Exército na crise da renúncia de Jânio Quadros: um depoimento] onde diz que aderiu por ser democrata, mas ele aderiu porque não tinha mais tropa para comandar. Os sargentos dominaram tudo. Se a coisa se esparramasse pelo país, iria ser uma revolução, ao mesmo tempo pacífica" (COSTA, 2007, p. 50).

Schilling menciona o surgimento, nestes dias tensos de fins de agosto de 1961, de um movimento inédito na história do Brasil: sargentos das Forças Armadas se oporem militarmente a seus oficiais, pelo fato destes não cumprirem o juramento de defender a Constituição Brasileira. Ou seja, subalternos chegarem a prender seus comandantes por grave indisciplina e desrespeito à hierarquia, já que o comandante-em-chefe das Forças Armadas, segundo a Carta Magna, era agora o Presidente João Goulart.

Poderíamos citar vários exemplos de movimentos espontâneos de sargentos que se organizaram para resistir às ordens absurdas de seus oficiais. No entanto, muitas pesquisas já foram realizadas sobre o que se convencionou chamar de Campanha da Legalidade. O que pretendemos mostrar a seguir é como estas ações de subalternos, certamente corajosas, colaboraram, principalmente porque foram bem-sucedidas, com a organização institucional dos sargentos, em associações e representação política no Congresso. E também, naturalmente, como este ambiente de euforia contagiou a Marinha e os integrantes do Coletivo, nosso objeto de pesquisa.

Citaremos poucos exemplos de ações dos sargentos que contribuíram para respaldar a resistência ao golpe praticado pela Junta Militar.

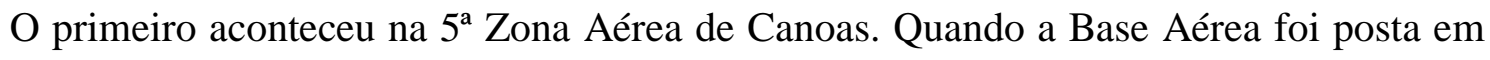
regime de prontidão, já no dia 25 de agosto, sem esclarecimento pelos oficiais, os sargentos estranharam e procuraram entender o que se passava. Foi então que souberam da mensagem do Ministério da Guerra, que ordenava o bombardeio do Piratini, "se necessário for".

Segundo José Wilson da Silva, em seu livro O Tenente Vermelho, havia na pista, pronto para decolar,

"cerca de dezesseis Gloster Meteor F-8, abastecidos e municiados, armados com quatro canhões de $20 \mathrm{~mm}$, duas bombas de 250 libras cada e alguns com duas metralhadoras (...) A vigilância dos graduados prolongou-se por longas horas, mas já entrada a noite, quase madrugada, os sargentos resolveram deixar os aviões em terra sem possibilidade de levantar voo, esvaziando os pneus, tirando as espoletas das bombas, etc. (...) Os sargentos perceberam a gravidade da situação e resolveram enviar uma comissão composta por Álvaro, Ney Calixto e 
Moacir Paluszkeivz, conduzidos pelo sargento Golbery, para falar com Brizola...disseram pretenderem ir ao general Machado Lopes, Comandante do 3o Exército (...) Brizola comunicouse com o general e os encaminhou". ${ }^{19}$

Ney de Moura Calixto assim narra o que presenciou:

"Moacir e eu fomos para o Palácio e Álvaro voltou à Base para relatar os contatos para os demais. Quando o major Léo Etchegoyen chegou até a base, enviado pelo III Exército, percebeu que o controle estava nas mãos dos suboficiais e sargentos. Os aviões já tinham sido desarmados". ${ }^{20}$

Outro exemplo foi a organização dos sargentos do $18^{\circ}$ Regimento de Infantaria para impedir que seus comandantes levassem à frente as ordens da Junta Militar. Segundo Amadeu Felipe da Luz Ferreira, sargento do Exército, o $18^{\circ}$ Regimento de Infantaria era o que tinha número maior de militares e alguns oficiais tinham "uma tradição direitista muito forte". Quando souberam da reação do Brizola ao golpe, mantiveram-se atentos a seus comandantes para ver de que lado ficariam. Foi quando tomaram conhecimento de que o comandante do Regimento havia saído para uma reunião, na $6^{\mathrm{a}}$ Divisão, cujo comandante, Nestor Souto, era golpista do conhecimento de todos. Ali, receberia orientações de procedimento.

Amadeu Felipe conta que, sabendo que todos os sargentos do Regimento eram favoráveis à legalidade, planejou interceptar o jipe do comandante quando este retornasse para saber sua posição. Se ele não viesse, o oficial que chegasse à guarda da barreira seria preso. E foi o que aconteceu. Chegando o jipe sem o comandante, Amadeu Felipe e o segundosargento Bengoechea deram ordem de prisão ao capitão Alencastro Guimarães, por não acreditarem na sua versão de que o comandante teria ido para casa. Mais tarde, perceberiam que ele estava falando a verdade. Mas, com a prisão do capitão, "virou insurreição".

Quando os demais oficiais souberam da prisão do capitão, tentaram reagir, mandando prender o sargento Felipe Amadeu.

Segundo ainda Ferreira,

"A sargentada começou a tomar conta da situação nas dez companhias.

Começaram a colocar a soldadesca em forma, assumir o armamento, o comando de suas unidades. Os oficiais correram todos para o pavilhão do comando e a tropa cercou o local. E eu mantendo o Alencastro preso. Mandamos avisar o Brizola, o III Exército [já sabiam da adesão do comandante do III Exército], ligamos para os jornais, rádios e avisamos: o 18ㅇ RI está pela legalidade; os sargentos estão no comando. Isso criou uma confusão danada. O coronel

\footnotetext{
${ }^{19}$ Citado por CAVALHEIRO, op. Cit., p. 56-59.

${ }^{20}$ Entrevista a ROLIM. Op. Cit. P. 151.
} 
[comandante do 18 이, num primeiro momento, não sabia o que fazer. Ele acabou chegando à unidade umas três horas da manhã e o Alencastro estava preso desde as nove da noite. Ele chegou e foi lá me ver:

- Amadeu, o que está acontecendo?

Eu disse:

- Olha, prendemos o Alencastro e assumimos a legalidade. Confiamos que o senhor venha assumir a legalidade porque queremos que o senhor esteja a frente.

Aí o coronel Peri me abraçou e chorou achando que era fidelidade a ele. E eu disse:

- Olha, coronel, não é isso. É fidelidade à democracia, mas o senhor é nosso representante nesse negócio e queremos, agora, que a cada reunião no quartel-general, em vez de o senhor levar os oficiais, vá com uma comissão de sargentos.

Era a chance que a gente tinha de chegar ao quartel-general, e conversar com os outros sargentos, interferir na reunião. Foi a primeira vez que aconteceu isso no Brasil, tenho certeza" (SANTOS, 2007, 56).

Jelcy Rodrigues Corrêa, na época da Campanha da Legalidade, era primeiro-sargento do Exército, no Batalhão da Polícia do Exército. Conta que certo dia, no refeitório onde almoçavam cerca de 300 sargentos, subiu numa cadeira e dirigiu-se aos companheiros, dizendo:

"Olha, eu não sei o que vocês pensam, com o que eu penso, eu não quero saber se o Jango é comunista ou não sei o quê. Se não podia ser candidato, que não deixassem ser candidato; mas ele foi eleito e com mais voto que o Jânio e nós sargentos juramos à Constituição, não juramos obedecer este ou aquele general - o nosso juramento é à Constituição - e a Constituição diz que é ele que tem que assumir, o resto não me diz respeito" (SANTOS, 2010, p. 130).

Levado diante do comandante, general Paulo Torres, Jelcy se justificou falando:

"General, não pratiquei nenhuma indisciplina. Eu disse que eu jurei a Constituição e é ela que eu tenho que obedecer. Se o senhor me mandar matar alguém, eu vou pedir justificativa. Uma guerra é uma guerra, mas um troço desses, não dá. A constituição diz que é o vice-presidente; as razões..."

Neste momento, chega esbaforido o subtenente Itamar Maximiano Gomes e se apresentou ao general:

- Se o senhor não soltar os dois sargentos em dez minutos, a tropa não obedece mais o comando".

Aí o general pediu calma e tal, disse: 
- Voltem, mantenham a tropa tranquila, não vai acontecer nada, que eu não vou levar ninguém para o suicídio".

Aí nós voltamos, e lá conversando com os outros sargentos, ficamos sabendo que não foram os sargentos, mas que foram os cabos e soldados que tomaram a iniciativa de pressionar os sargentos" (SANTOS, 2010, pp. 130-131).

O testemunho acima é muito elucidativo da grande aderência que a Campanha da Legalidade teve. Também soldados e cabos participaram de ações nestes momentos de tensão. Esses protestos certamente representavam falta grave no interior das Forças Armadas e trouxeram constrangimento aos comandantes. Quando se chegou à solução do Parlamentarismo para amainar os golpistas, não tardou a acontecer aquilo que Cavalheiro chamou de Segunda Perseguição: vários líderes sargentos foram punidos pelos seus oficiais. Por exemplo, Jelcy foi transferido para Ponta Porã, MT, e Amadeu Felipe, para o Rio de Janeiro.

O historiador e militar Nelson Werneck Sodré acompanhou os acontecimentos após a posse de João Goulart e seu testemunho é importante porque trata-se de análise de profissional que conhece bem os meandros dos quartéis, ao mesmo tempo que conhece o método histórico. Diz ele:

"Neutralizar a influência dos sargentos, destruir as formas de organização que haviam alcançado, isolar os elementos mais destacados na resistência aos desmandos dos ministros subversivos, impor uma disciplina rígida de obediência, depurar o quadro de sargentos $e$ exercer sobre ele estreita vigilância, passaram a ser as grandes preocupações da cúpula militar, onde os elementos golpistas permaneciam em paradoxo aparente. É variada e numerosa a série de fatos que assinalam a anomalia curiosa: vencidos pareciam vencedores, os militares que haviam assegurado a continuidade democrática passavam a ser perseguidos e marcados como elementos perigosos, particularmente os sargentos. [...] Sargento pensar, sargento estudar, sargento participar, sargento ter direitos de julgamento pareceram formas subversivas, a que era necessário atender de pronto, não no sentido de encaminhá-las, de colocá-las a serviço da estrutura militar e do país, mas no sentido de reprimi-las, de vigiá-las, de considerá-las marginais e condenáveis". ${ }^{21}$

Mesmo diante deste quadro "anômalo", as ações promovidas pelos sargentos, seguidas do sucesso da Campanha da Legalidade - ou seja, da posse de João Goulart, apesar de se dar com seus poderes limitados pelo sistema parlamentarista, o que enfureceu Leonel Brizola -, trouxeram um sentimento de euforia junto aos subalternos. Perceberam que suas iniciativas

${ }^{21}$ SODRÉ, 1965, p. 384-385, 387-388. Apud. SANTOS, op. Cit. P. 47. 
influíram na política nacional, para o bem. Sabiam, agora, a força que tinham. Fizeram o que um soldado tinha que fazer: defender a Constituição, a democracia, a pátria, o povo. Mas, talvez o mais importante: agora sabiam identificar seus inimigos, aqueles responsáveis por manterem seus parentes na pobreza, sem expectativa de uma vida melhor, aqueles que os mantinham sob regimentos rígidos e anacrônicos. E por quê? Porque o Exército modernizarase; seus armamentos eram mais complexos de manusear e as guerras modernas exigiam inteligência. Os sargentos passaram a estudar porque a instituição exigia. Jelcy comenta que seus instrutores eram muito qualificados e "a estrutura de aprendizado era boa, tinha material, nós tínhamos bastante estudo, exigentes" (SANTOS, 2010, p. 121). Daí, a anomalia de que Sodré fala. Comandantes inexperientes, ao invés de "colocar a serviço da estrutura militar e do país" a capacidade de bons sargentos, penalizaram-nos por pensarem e falarem em direitos.

Mas havia algo mais em jogo. Não se tratava apenas da manutenção da ordem nas unidades militares, da defesa do imprescindível respeito à disciplina e à hierarquia, tão caras ao militar. Tudo isto é compreensível e, de fato, importante no seio das Forças Armadas. Até para a defesa da democracia, exige-se o cumprimento dos regimentos disciplinares, bem entendidos, dentro dos quartéis. A ilegalidade da Junta Militar, condenada pelos sargentos, estava justamente em esperar do militar que aceitasse o assalto que praticaram ao poder.

Mesmo com o Congresso reprovando o impeachment de João Goulart, a Junta Militar não recuou e, em nota do dia 30 de agosto, mostrou exatamente o que estava por trás de tanta ousadia:

“No cumprimento de seu dever constitucional de responsável pela manutenção da ordem, da lei e das próprias instituições democráticas, as forças armadas do Brasil, através, da palavra autorizada de seus ministros, manifestaram a S. exa. o presidente da República, como já foi amplamente divulgado, a absoluta inconveniência, na atual situação, de regresso ao país do vice-presidente Sr. João Goulart. Já em tempo em que exercera o cargo de ministro de Trabalho, o Sr. João Goulart demonstrara, bem às claras, suas tendências ideológicas, incentivando e mesmo promovendo agitações sucessivas e frequentes nos meios sindicais, com objetivos evidentes políticos e em prejuízo mesmo dos reais interesses de nossas classes trabalhadoras. No cargo de vice-presidente, sabido é que usou sempre de sua influência para animar e apoiar, mesmo ostensivamente, manifestações grevistas promovidas por conhecidos agitadores. E, ainda há pouco, como representante oficial, em viagem à URSS e à China comunista, tornou clara e patente sua incontida admiração ao regime desses países, exaltando o êxito das comunas populares. Na Presidência da República, em regime que atribui ampla 
autoridade e poder pessoal ao chefe do governo, o Sr. João Goulart constituir-se-á, sem dúvida alguma, no mais evidente incentivo a todos aqueles que desejam ver o país mergulhado no caos, na anarquia, na luta civil. As próprias Forças Armadas, infiltradas e domesticadas, transformar-se-iam, como tem acontecido noutros países, em simples milícias comunistas. As Forças Armadas estão certas da compreensão do povo cristão, ordeiro e patriota do Brasil. E permanecem serenas e decididas, na manutenção da ordem pública.

Rio de Janeiro, GB, 30 de agosto de 1961. Vice-almirante Sylvio Heck, ministro da Marinha; marechal Odylio Denys, ministro da Guerra; brigadeiro-do-ar Gabriel Grun Moss, ministro da Aeronáutica" (ROLIM, 2009, p. 149).

"No Cumprimento de seu dever constitucional”, a Junta Militar imputou-se no direito de escarnecer a Constituição, de intervir no processo político, afrontando a democracia, para a manutenção "das próprias instituições democráticas".

Os mesmos militares que fizeram o "Memorial dos Coronéis" em fevereiro de 1954, levando Getúlio Vargas a depor João Goulart do Ministério do Trabalho; que levaram Vargas ao suicídio, em agosto de 1954; que tentaram impedir a posse de Juscelino Kubitscheck em 1955 e que, com o mesmo discurso de defesa da democracia, apelando à "compreensão do povo cristão", deram o Golpe de 1964: são estes que, chegando ao poder por via legal, com Jânio Quadros, não permitiram serem substituídos pelo “inconveniente” João Goulart.

O que levou o marechal Odylio Denys à ilegalidade, quando, em 1955 teve participação de relevo no contragolpe liderado pelo marechal Henrique Lott, do lado da legalidade? O que levou este militar a tomar medidas absolutamente autoritárias, como mandar prender o seu antigo comandante, que já estava na Reserva, o marechal Lott, em condições constrangedoras, como descritas por Nelson Werneck Sodré? (SODRÉ, 1988, pp. 242-244) Aliás, mandou prender também o historiador militar. $\mathrm{O}$ que lhe dava a certeza de que não haveria resistência civil ou militar? Como entender as ordens por ele dadas de invadir o Congresso com paraquedistas, conforme testemunho de Jelcy Rodrigues Corrêa, ou as de bombardear o Palácio Piratini, no momento em que à sua frente se encontravam cerca de 70 mil pessoas?

Nelson Werneck Sodré, em seu livro Do Estado Novo à Ditadura Militar - Memórias de um soldado, atribui a "endireitização" do marechal Denys ao período em que Lott era Ministro da Guerra de Kubitscheck e Denys, muito próximo do Ministro e crescendo a sua sombra, colocou, pouco a pouco, em cargos estratégicos, oficiais antivarguistas que, ironicamente, tinham participado do golpe que pretendia impedir a posse de Juscelino Kubitschek, como os irmãos Orlando e Ernesto Geisel. Com a saída de Lott do Ministério da Guerra para concorrer às eleições de 1960, Denys, que ainda não havia assumido o lugar de 
Lott, fizera seu chefe de Estado-Maior o general Orlando Geisel. Dias depois, Sodré ficou sabendo por um amigo, que o coronel Ernesto Geisel iria ocupar a chefia do Serviço Secreto.

"Era forte. O marechal Odílio Denys dava preferência, agora, a oficial de posição política inconfundível, e do outro lado. Mas era preciso esperar pelos fatos. Os fatos comprovaram tudo, sem uma falha: o novo ministro da Guerra, em poucos dias, desmontava todo o dispositivo que o seu antecessor levara anos a montar, com meticuloso cuidado em cada escolha, particularmente quando se tratava de comandos na tropa. la entregando esses comandos, apressadamente, a oficiais que nunca haviam escondido suas posições políticas, sua ação conspirativa, suas atividades partidárias e que se distinguiam, particularmente, pela aversão que votavam ao marechal Teixeira Lott - promovido e transferido para a reserva, então - como as simpatias que tinham pelo candidato Jânio Quadros, não apenas as legítimas que cada um era livre de ter, mas aquelas fundadas em entendimentos, em visitas, em conversas, em contatos, em compromissos" (SODRÉ, 1988, pp. 218-219).

Sodré afirma, ainda, que, antes de Denys assumir o Ministério da Guerra, mantinha contatos constantes com ele, tendo acesso livre a sua sala. "Passei um ano de conversas constantes com eles [Lott e Denys], reservadas e, ao fim de tudo, percebi que aquele homem [Denys] guardava terrível e dramático ressentimento: ter sido o segundo, e não o primeiro, em 11 de novembro". 22

As declarações de Sodré deixam claras suas impressões sobre a personalidade ímproba de Denys. Mas, voltando à Nota por ele divulgada, percebemos que, em 1961, já não era o marechal Teixeira Lott que tanto o preocupava. Claro, foi preciso prendê-lo para afastá-lo dos oficiais das Forças Armadas que o tinham ainda como um exemplo de militar profissional. Porém, o que lhe preocupava era a "absoluta inconveniência" da posse de João Goulart. O que significaria esta posse? Por que temiam Jango?

Nas entrelinhas da Nota, podemos identificar os motivos desta apreensão: Jango, enquanto Ministro do Trabalho, "demonstrara as suas tendências ideológicas, incentivando e mesmo promovendo agitações sucessivas e frequentes nos meios sindicais". E, como vicepresidente, "é sabido que usou sempre de sua influência para animar e apoiar, mesmo ostensivamente, manifestações grevistas promovidas por conhecidos agitadores". Quanta preocupação com os trabalhadores! Provavelmente, os militares guardavam a lembrança dos discursos de Vargas dirigidos a milhares de trabalhadores, no estádio de São Januário. Ou de Vargas incentivando a sindicalização, outorgando as leis trabalhistas, ou criando o Imposto

\footnotetext{
${ }^{22}$ SODRÉ, Nelson Weneck. Do Estado Novo à Ditadura Militar - memórias de um soldado. Petrópolis: Vozes, 1988. P.205.
} 
Sindical. Sabiam que João Goulart devia sua formação política a Getúlio Vargas. Certamente, tinham a lembrança de quando, Ministro do Trabalho, Jango recebia no Hotel Glória vários sindicalistas: comunistas, liberais, pelegos, trabalhistas, etc. E que também propôs $100 \%$ de aumento no salário mínimo, motivo da divulgação do Memorial dos Coronéis, assinado por estes mesmos militares, dizendo que o aumento era irresponsável, pois alimentaria a inflação e defasaria ainda mais os vencimentos dos quadros inferiores, dificultando o recrutamento pelo Exército.

O que estes homens que se apoderaram do poder não admitiam era a mobilização política de trabalhadores, era a ampliação de sua cidadania, sua inclusão na política - os militares faziam clara opção de classe. Ângela de Castro Gomes, em livro que discute as estratégias de Vargas e assessores, principalmente Alexandre Marcondes Filho, para realizar a transição da ditadura do Estado Novo para um sistema de democracia representativa, fala da importância da mobilização dos trabalhadores em sindicatos, inclusive trocando alguns líderes pelegos, acomodados, por novas lideranças ativas, que pudessem constituir-se na base de um futuro partido varguista. A passagem a seguir é ilustrativa do quanto interessava a mobilização política dos trabalhadores:

"O sindicalismo corporativista, desta forma, iria ser realmente implementado, não no momento autoritário por excelência do Estado Novo, mas no período de "transição" do pós-42, quando a questão da mobilização de apoios sociais tornou-se uma necessidade inadiável ante a própria transformação do regime.

Dentro desta linha de reflexão, é possível constatar que, no Brasil, a dimensão política do projeto corporativista foi acionada para respaldar um regime que buscava a saída do autoritarismo. Desta forma, o objetivo da propaganda do corporativismo brasileiro do pós-42 não era mais simplesmente criar uma massa que seguisse a proposta do Estado por ausência de alternativas. Era, em certo sentido específico, mobilizar, preparando lideranças e criando seguidores. O problema da adesão das massas trabalhadoras ao sindicalismo, e especialmente sua vinculação com Vargas, não se restringia a uma lógica meramente repressiva, ou de concessão de benefícios materiais. Ele envolvia a existência e a importância de um sofisticado discurso de difusão ideológica que comportava níveis não desprezíveis de mobilização política" (GOMES, 2005, pp. 254-255).

O Jango que retornaria ao país para assumir a Presidência, não era o jovem getulista Ministro do Trabalho. Jango assumiria com um modelo econômico distributivista, democrático e reformista. Jorge Ferreira diz que, antes da viagem de Jango para a China e a 
URSS, ele propôs a realização de um Congresso trabalhista e que, para sua preparação, San Tiago Dantas e Hermes Lima

"alinhavaram a proposta de uma linha de ação política e doutrinária. Para eles, a posição fundamental do partido é a de um instrumento de reforma, de mudança, de superação da estrutura social brasileira. O PTB não quer corrigir apenas a estrutura social existente. Quer mudá-la para melhor, torná-la favorável à incorporação do povo brasileiro em níveis de educação, produtividade e consumo tão superiores que são, por isso mesmo, diferentes em qualidade e finalidade dos atuais. Por isso, O PTB deve afirmar-se como um partido de esquerda, um partido de massa, que se dispões a liderar a transformação da estrutura social brasileira por métodos democráticos, até onde for indispensável ao bem-estar do povo" (FERREIRA, 2011, p. 223).

O "inconveniente", que deveria ser preso assim que pisasse em solo brasileiro, defendia reformas profundas, "incorporando o povo brasileiro" a um nível de vida mais elevado, através de "métodos democráticos". Era isto que estava em jogo: o que os golpistas não admitiam eram reformas, mobilização, incorporação na política de setores "inferiores", de uma democracia ampliada, participativa, cidadã enfim. Foi deste modelo que os subalternos se aproximaram, porque entenderam que, assim como foram imprescindíveis para a manutenção da democracia, também se tornaram reféns dela. Ou seja, a democracia passou a ser imprescindível para manutenção de suas carreiras.

Algumas ações atribuídas aos sargentos durante o golpe - como sua atuação de barrar a “operação mosquito", organizada por oficiais para derrubar o avião de Jango, impedindo sua posse -, foram largamente divulgadas nos quartéis, como também nas embarcações da Marinha. O ex-sargento Antônio Prestes de Paula, em entrevista a Parucker, revela que a "Operação flit" ocorreu da seguinte maneira:

"vazou para os sargentos a informação de que o avião que trazia Goulart a Brasília seria abatido por oficiais golpistas da FAB. Quatro caças F-8 teriam, inclusive, sido deslocados da Base Aérea de Santa Cruz, no Rio, para a Capital Federal. O dado técnico: como nenhum desses voava na faixa do avião presidencial, este teria que ser abatido próximo do aeroporto, já na fase de descida. Os sargentos tentaram uma sabotagem dos caças: sem interferir no dispositivo de voo, desligaram os mecanismos que comandavam o armamento. No entanto, foram descobertos. Na nova equipe de manutenção escolhida, sem embargo, constavam dois sargentos ligados aos antigolpistas, os quais deram sequência à sabotagem. Por precaução, o grupo dos sargentos prendeu os oficiais e garantiu, pelas armas, a aterrissagem de Goulart" (PARUCKER, 2009 pp. 55-56). 
1961 deu ao conjunto dos sargentos uma autoconfiança, por suas ações corajosas em defesa da legalidade, que destoava das perseguições praticadas pelos oficiais, através, principalmente, de transferências com o objetivo de afastar as lideranças de suas tropas. Estas duas consequências de 1961 - o sentimento de euforia e autoconfiança, seguido do sentimento de revolta com as perseguições que se sucederam - levaram os sargentos e subalternos das três Forças a se organizarem institucionalmente, bem como a refletirem sobre como suas condições profissionais eram precárias e os regimentos, muito rígidos. Cavalheiro diz que, neste período, os sargentos passaram a reivindicar melhorias nas condições de trabalho e reforma dos regimentos:

"Devíamos [os sargentos ligados ao PCB] apoiar as reivindicações específicas dos sargentos, como aumento dos salários, menor prazo para promoções, direito de casar [o sargento só podia casar-se depois de 5 anos de graduação como sargento e com mais de 25 anos], direito de frequentar cursos superiores, estabilidade no emprego, matrícula compulsória no curso de aperfeiçoamento de sargentos, abolição ou critério justo para a classificação do comportamento profissional, estender à $F A B$ o quadro de oficiais especialista e administrativo, prioridade no ingresso da Escola de Saúde, Veterinária ou Técnica do Exército, conclusão das obras da Policlínica Militar de Porto Alegre, prioridade para o ingresso de sargentos na AMAN (Academia Militar das Agulhas Negras), desde que tivessem o curso científico ou equivalente. Também o direito de ser votado para cargos eletivos, já que era claro apenas o direito de votar"

(CAVALHEIRO, 2011, pp. 35-36)

Reivindicações perfeitamente plausíveis de serem atendidas, mas que, naquele contexto, foram recebidas como ato de ousadia e insubordinação pelos oficiais antinacionalistas. Cada vez ficava mais claro o caminho a ser trilhado. Parucker diz, em sua Dissertação já citada, que "o fato é que o movimento dos praças encontrou nos clubes, um meio de articular-se organicamente". O autor cita a fala do $1^{\circ}$ sargento Antônio Prestes de Paula - que se incorporaria ao Coletivo que estamos estudando -, encontrado no BNM 140, vol. 5; RJ, 16.10.1963, em que diz que o Clube dos Suboficiais, Subtenentes e Sargentos das Forças Armadas e Auxiliares do Brasil (CSSSFAA) foi fundado em outubro de 1961, sendo ele mesmo seu primeiro presidente. (PARUCKER, 2009, pp. 108-109)

As discussões que se davam nos clubes e o contato que os sargentos passaram a ter com outras associações militares, ou mesmo civis, levaram estes homens a pensarem nas suas condições de profissionais militares, "desclassizados" doutrinariamente, desde sua entrada para as Forças Armadas. Maciel, em Tese já mencionada, diz que "a formação do militar 
puro tem como objetivo que as suas atividades sejam desenvolvidas sem um sentimento de pertencimento à sua classe social’. E reforça, citando Heloisa Rodrigues Fernandes:

[...] "para ser um bom militar, este deve renegar os projetos de sua própria classe e incorporar o projeto do Estado 'acima das classes', é necessário que a vivência da instituição se dê em termos da negação da sua própria mediação pelas classes sociais, ou seja, como se a instituição permanecesse refratária a elas".

(MACIEL, 2009, p. 32)

A fala do então sargento Antônio Garcia Filho a Parucker é ilustrativa de como os sargentos passaram a relacionar suas reivindicações às reivindicações do povo brasileiro. Diz ele que

“(...) também não podia abrir mão das minhas origens, que era filho de ferroviário, de operário, que aquilo pesava mais alto do que minha condição de sargento. Então, (...) nós íamos tirar, junto das nossas reivindicações, as reivindicações de todo o povo sofrido que existia no país $(,,)^{\prime \prime}$. (PARUCKER, 2009, p. 58).

Foi nesse contexto de politização de parte expressiva dos sargentos e subalternos das Forças Armadas que se colocou a questão da participação da "classe dos sargentos" nas eleições para o Congresso Nacional.

Antes de continuarmos a explanação, é importante afirmar que os sargentos não se constituíam num grupo ideologicamente homogêneo. Parucker afirma que, dentre os sargentos mais ativos, politizados, a maioria era nacionalista, mas que existiam várias tendências: aqueles ligados ao PCB, à Organização Revolucionária Marxista - Política Operária, ao Partido Comunista do Brasil (PC do B), ao Partido Operário Revolucionário Trotskista (PORT) - o autor cita Ridenti (RIDENTI, 1993) e Gorender (GORENDER, 1987) - e um número expressivo de sargentos integralistas tardios (A AIB, como entidade política, fora extinta em 1937), que não se constituíam, entretanto, em núcleos organizados.

No início de 1962, os sargentos começaram a discutir a escolha de candidatos para concorrer às eleições de outubro, para o Congresso Nacional.

Cavalheiro conta que

"foi estabelecido um processo de escolha no qual concorreriam todos os pretendentes a candidatos. (...) Após a seleção dos candidatos nas diversas unidades, inclusive fora da capital [Porto Alegre], foi convocada uma convenção para escolha dos candidatos a Deputado Federal e a Estadual. Ficou estabelecido que o candidato deveria ter maioria absoluta $(50 \%+1)$ dos participantes da convenção. Para deputado estadual concorriam vários candidatos e no 
primeiro escrutínio cheguei a $75 \%$ dos votos convencionais, sendo escolhido para concorrer $\grave{a}$ Assembleia Legislativa do Rio Grande do Sul" (CAVALHEIRO, 2011, pp. 65-66).

Tal processo de escolha de candidatos sargentos para a Assembleia Legislativa e a Câmara dos Deputados ocorreu no Estado do Rio Grande do Sul. Cavalheiro, preferido como candidato a deputado estadual dos sargentos, concorreu pela sigla do PTB, enquanto o candidato sargento a deputado federal, sargento Leão Serrano de Oliveira Brito, concorreu pelo Partido Democrata Cristão, PDC.

A campanha de Cavalheiro foi organizada a partir do Comando da Renascença, que coordenava e "custeava a campanha". Parucker fala que os sargentos gaúchos lançaram panfleto apresentando seus candidatos e suas propostas, "em nome do comitê central do "comando da renascença"”. O programa do candidato Cavalheiro, que Parucker diz ter encontrado em José Wilson da Silva (SILVA, J. W, 1987, p. 37), é o seguinte:

“1) reforma agrária urgente (para aumento da produção, barateamento dos custos, elevação do nível de vida do camponês e do operário), com posse da terra, crédito, assistência técnica, educação, legislação trabalhista, cooperativas e 'companhias agrárias no Exército (projeto mal. Lott); 2) eliminação do capital estrangeiro nos setores básicos e serviços públicos, nacionalização dos depósitos bancários e limitação à remessa de lucro; 3) 'taxação dos lucros extraordinários e participação dos operários no lucro das empresas'; 4) 'monopólio estatal das fontes básicas de energia'; 5) 'política externa independente', contra 'qualquer forma de colonialismo e imperialismo'; 6) distribuição justa da riqueza nacional; 7) cédula única nas eleições" (PARUCKER, 2011, pp. 101-102).

Podemos observar no programa a predileção por propostas reformistas, com certo viés socializante, relacionadas à melhoria da vida das pessoas. Isto faz jus à preocupação que os sargentos passaram a ter com a política nacional, com a necessidade de reformas estruturais para o país desenvolver sua economia com distribuição justa da renda. O slogan dos sargentos passou a ser "sargento também é povo". Nacionalista e reformista, o programa sinalizava para uma questão muito delicada para nossas elites: no país, ainda não havia um estatuto da terra. Vargas e Kubitscheck não ousaram levar à frente reformas nas relações de trabalho no campo. Parucker não apresentou as reivindicações profissionais do panfleto, mas imaginamos que eram as mesmas que já citamos anteriormente. De qualquer forma, as propostas acima deviam ser consideradas, no mínimo, histriônicas, ou mesmo temerárias, aos oficiais militares.

No Rio de Janeiro, ocorreu processo semelhante. Benito Brito e Amadeu Felipe Luz Ferreira, transferidos do $18^{\circ} \mathrm{RI}$ para o Rio de Janeiro, reforçaram a campanha para escolha de 
candidatos sargentos. Segundo Cavalheiro, daí resultou a escolha do sargento Antônio Garcia Filho para candidato a deputado federal.

Nas eleições de 7 de outubro de 1962, sargento Garcia teve votação expressiva para a época: 16.510 votos nominais, o quarto mais votado do PTB. Mas sua diplomação foi muito debatida, diante da dubiedade da Constituição a respeito, que dava margem a interpretações diferentes sobre a elegibilidade de sargentos. Cavalheiro, por exemplo, só pode concorrer com um mandato de segurança decidido em liminar (PARUCKER). Enquanto Garcia Filho foi diplomado como deputado federal, Cavalheiro teve impedimento pela Justiça Eleitoral do Rio Grande do Sul. Ele explica:

"Criou-se então uma situação muito intrigante. Para a Justiça Eleitoral do Rio de Janeiro, sargento era elegível, mas para a Justiça Eleitoral do Rio Grande do Sul, sargento era inelegível. Havia outro precedente no Ceará, em que um sargento havia sido eleito e empossado como prefeito em um município cearense"

(CAVALHEIRO, 2011, p. 76).

Iniciou-se, então, uma campanha nacional pela elegibilidade dos sargentos para cargos eletivos, principalmente depois do parecer do Tribunal Superior Eleitoral, em 27 de novembro de 1962, contrário à elegibilidade. Um pouco antes do parecer, o presidente do Clube dos Suboficiais, Subtenentes e Sargentos das Forças Armadas e Auxiliares do Brasil (CSSSFAA), sargento Antônio Prestes de Paula, convocou uma assembleia para discutir uma pauta de ações para pressionar o Judiciário a aprovar a elegibilidade dos sargentos. Criou-se, então, a Comissão de Defesa da Elegibilidade dos Sargentos, Codes, cujo presidente eleito foi justamente Prestes de Paula.

A mobilização dos sargentos e seus contatos com outras entidades (como a UNE, o Comando Geral dos Trabalhadores - CGT - e a Frente Parlamentar Nacionalista - FPN) levaram ao inevitável conflito com o alto comando das Forças Armadas, que não admitiam a politização de seus subalternos. Em maio de 1963, por exemplo, numa homenagem ao General Osvino Ferreira Alves - que aliás, precavido, não compareceu -, os discursos já anunciavam o grau de radicalização a que chegaram os sargentos. Caso do discurso do subtenente Gelcy Rodrigues Correia, que em determinado momento, estrondeou:

“(...) pegaremos em nossos instrumentos de trabalho e faremos as reformas juntamente com o povo, e lembrem-se os senhores reacionários de que o instrumento de trabalho do militar é o fuzil" (PARUCKER, 2009, p. 66).

Foi também em maio de 1963 - portanto no momento em que os sargentos já tinham agregado às suas propostas a defesa de reformas mais profundas para o País - que tomou 
posse parte do Coletivo que estamos pesquisando, na direção da Associação dos Marinheiros e Fuzileiros Navais do Brasil - AMFNB.

Antônio Duarte, presidente do Conselho Deliberativo desta segunda diretoria da AMFNB e um de nossos protagonistas, atribui ao discurso do subtenente Gelcy Rodrigues Correia a aproximação da Associação ao movimento dos sargentos. Diz ele:

"Depois daquele discurso incendiário de Gelcy, em uma assembleia do Clube de Subtenentes e Sargentos do Exército, a influência do movimento nacionalista e legalista aumentou no meio marinheiro. Na sede da Associação, reunimos a diretoria e ouvimos relatos do Marco Antonio, vice-presidente da Associação dos Marinheiros, sobre os contatos com o movimento dos sargentos. (...) A eleição de Antonio Garcia Filho, para Deputado Federal, aumentou a autoestima e a confiança política dos soldados, confirmando e fortalecendo a visão reformista de que era possivel uma transformação da estrutura conservadora das Forças Armadas. (...) A radicalização do movimento dos sargentos, no exemplo da Assembleia de 11 de maio de 1963, aproximou a Associação dos Marinheiros desse movimento" (DUARTE, 2009, pp. 52-53).

Parece bem datado, a partir do testemunho de Duarte, o encontro da Associação dos Marinheiros com o movimento dos sargentos. Também evidencia o trânsito que o vicepresidente da AMFNB, Marcos Antônio Silva Lima, tinha com as entidades representativas de suboficiais de outras Forças e de sua liderança entre os marinheiros. Não foi Anselmo, presidente da AMFNB, quem reuniu os marinheiros para repassar o ocorrido na assembleia dos sargentos, mas Marco Antônio. Ele era quem, na entidade marinheira, fazia o contato com outras entidades civis ou militares.

Percebe-se ainda no discurso de Gelcy que as propostas dos sargentos começaram a extrapolar o espaço da caserna e do "aceitável" para os valores hierárquicos dos militares. As perseguições e prisões não demoraram a acontecer. O Judiciário, por sua vez, passou a negar registros de candidaturas de sargentos. O caso do sargento Almoré Zoch Cavalheiro ilustra esta mudança nas decisões dos Tribunais Regionais Eleitorais (TREs): conseguido o registro de sua candidatura através de liminar no Tribunal Superior Eleitoral e eleito deputado estadual, não lhe foi permitida, no entanto, a diplomação. Recorrendo ao Supremo Tribunal Federal, STF, este recusou o recurso, confirmando definitivamente a inelegibilidade dos sargentos (PARUCKER, p. 72).

A decisão do Supremo Tribunal Federal pela inelegibilidade dos sargentos foi no dia 11 de setembro de 1963. Na mesma data, por volta das 20 horas, Antônio Prestes de Paula, presidente do CSSSFAA e da Codes, iniciou reunião com aproximadamente 30 homens, que decidiu por um protesto armado. Segundo Prestes, em depoimento citado por Parucker, 
"Surgiu a oportunidade de ser feito um protesto que tivesse bastante ressonância e várias fórmulas de protesto foram apresentadas e discutidas, entre elas a queima dos títulos eleitorais em praça pública, uma denúncia em termos enérgicos na imprensa contra um ato que julgavam discriminatório, mas o protesto mais aceito era por meio de uma rebelião armada (...) um ato de legítima defesa contra a cassação de um direito de cidadania dos sargentos, ao ser perdido um direito político". (depoimento do indiciado 1S Q AT PI Antônio de Prestes de Paula; BNM 692, vol. 6. In: PARUCKER, p.136)

Deflagrou-se, então, a chamada Revolta dos Sargentos, que nas palavras de Prestes de Paula, tratou-se de um protesto, liderada por integrante do Coletivo que estamos estudando. Criado o Comando Militar Revolucionário de Brasília, começaram verdadeiras manobras militares, como a tomada da Base Aérea, do Grupamento de Fuzileiros Navais, do Ministério da Marinha, do Congresso Nacional, o corte da telefonia (prejudicando inclusive os revoltosos) etc.

Segundo Parucker, pesquisando os depoimentos dos indiciados no processo BNM 692 (processos Brasil Nunca Mais, no Arquivo Edgard Leuenroth), cerca de 270 subalternos da Marinha participaram do levante. De 172 respostas à pergunta se os depoentes participavam como sócios de alguma associação militar ou civil, 72 responderam que eram sócios da AMFNB (RJ), 32 do CSSSFAA (Brasília), 29 do CCSFAA (Brasília), 9 da Caixa Beneficente dos Sargentos da Marinha (CBSM-RJ), 3 da Associação dos Taifeiros da Armada (ATA-RJ) e 19 de outras associações. É notável a presença de subalternos da Marinha que serviam em Brasília, sócios da Associação dos Marinheiros e Fuzileiros Navais do Brasil. Isto só reforça nosso argumento de que o movimento dos sargentos extrapolou a corporação e estendeu seus tentáculos a outras entidades militares, como a AMFNB, ao mesmo tempo em que deu a senha para que estas entidades incorporassem aos seus discursos a necessidade das reformas sociais e populares, indo ao encontro das origens também populares dos subalternos. Afinal, como já foi dito, o lema dos sargentos não era "Sargento também é povo"?

Também os marinheiros se consideravam "soldados do povo". No dia 12 de setembro, a direção da AMFNB se reuniu e decidiu apoiar o movimento dos sargentos. Temia-se que pudesse ocorrer um golpe de estado e a Marinha desencadeasse repressão sobre a Associação. Avelino Capitani conta expressiva passagem a respeito:

“(...) Não consegui participar da reunião, e Marco Antônio mandou-me uma mensagem.

- Capitani, se até a uma da madrugada não chegar uma contraordem da Associação, você deve tomar o Quartel dos Marinheiros. 
Não questionei a ordem e agi rapidamente. Conversei com todos os marinheiros de confiança:

- vamos agir com calma, sem levantar suspeita. Vocês ficarão de prontidão no Quartel. Os sentinelas de serviço naquele horário que não forem de inteira confiança não serão acordados e deveremos substituí-los por outros companheiros.

O mensageiro não chegou na hora combinada. Avisei os sentinelas.

- a partir deste momento, o quartel está sob o comando da Associação e eu sou o responsável.

Em seguida, fui à Guarda. Todos já estavam acordados à espera de ordens. Quando estava indo ao camarote do oficial de serviço pensava "se ele não reagir poderá ficar recolhido em seus aposentos, conservando sua arma", sem munição. O sargento de serviço estava dormindo em seu alojamento. Eu o conhecia e acreditava que não iria criar problemas.

Nesse instante, chegou o mensageiro, o companheiro Adilson, trazendo a contraordem $e$ dizendo que o perigo tinha passado.

(...) Era uma e quinze da madrugada, um estado de tensão pairava sobre toda a repartição. Foi muito difícil não levantar suspeitas. A tentativa fracassada dos sargentos repercutiu intensamente e agitou tudo. O Alto Comando da Marinha sabia que a Associação estava envolvida nos acontecimentos, e não apenas na sub-sede de Brasília.

(...) A partir desse momento, as pressões e perseguições contra a Associação que, era apenas internas, passaram a ser públicas" (CAPITANI, 1997, p. 42-43).

Antônio Duarte narra que as consequências da Revolta dos Sargentos para a AMFNB não tardariam a chegar.

"Quase a totalidade dos fuzileiros navais, revoltados no grupamento de fuzileiros em Brasília, eram associados à entidade marinheira, obrigando a diretoria a redobrar esforços no sentido de promover ajuda jurídica nos processos militares que se abriram contra os revoltosos. $A$ direita militar recebeu a notícia da revolta com satisfação, utilizando-a como um instrumento eficiente na luta contra todas as organizações de militares praças, desde as dos sargentos de Brasília, em função do chefe da revolta, Prestes de Paula, ser presidente do Clube de Sargentos e Suboficiais de Brasília, até o Clube dos Cabos e Soldados, da Polícia Militar do Rio de Janeiro, que não tinha qualquer ligação com os acontecimentos da capital federal.

(...) A revolta dos sargentos veio ao encontro do processo de construção do golpe reacionário em andamento contra o governo, da mesma forma que, mais tarde, a 'Revolta dos Marinheiros' seria utilizada como pretexto pelos golpistas" (DUARTE: 2009, pp. 34-35). 
No dia seguinte ao protesto dos sargentos, a imprensa começou a manifestar seu desconforto com os atos de indisciplina por parte dos subalternos das Forças Armadas. Foi o caso do Jornal do Brasil. Vale a pena transcrever parte de seu editorial do dia 13 de setembro de 1963, para intuirmos o "ambiente" em que os marinheiros dirigentes da AMFNB, nossos protagonistas, viviam e se formavam politicamente.

"Antes que cheguemos à Revolução, digamos um BASTA! Digamos enquanto existem organizadas, coesas e disciplinadas Forças Armadas brasileiras e democráticas, para sustentar pela presença de suas armas o próprio BASTA! Chegou o momento - e agora mais do que antes com a revolta dos sargentos... - de pôr termo no seio do próprio governo à existência de duas políticas: uma legal, sem eficiência e resultado administrativo democrático, e outra ilegal, visivelmente subversiva, montada nesse apêndice ilegal do governo, chamado Comando Geral dos Trabalhadores - CGT [...]. Registramos o óbito da falsa política de conciliação de classes por sortilégios e bruxarias do presidente da República [...] a paciência nacional tem limites. Ela saberá preservar sempre, nos momentos oportunos e pelos meios constitucionais a Ordem. A bandeira da legalidade hoje, se confunde com a bandeira da Ordem. Com nenhuma outra, fique isso bem claro. Os que estão se solidarizando hoje com os sublevados em Brasília estão do outro lado da barricada" (apud: NAPOLITANO, 2014, p 46). ${ }^{23}$

É bem sugestiva a ameaça do editorial em seu final: "a bandeira da legalidade hoje, se confunde com a bandeira da Ordem. Com nenhuma outra, fique isso bem claro". Ou seja, os tempos são outros, e a legalidade de hoje já não é a mesma de 1961. Lá foi permitida a ousadia dos subalternos; hoje, o comando é das "coesas e disciplinadas Forças Armadas Brasileiras", dos oficiais superiores. Se o editorial se resumisse a criticar a ação precipitada dos sargentos em sitiar Brasília, e os próprios participantes perceberam que foi um protesto desmedido, seria compreensível. Mas aquele texto vai além da crítica aos subalternos: a intenção aparente é imputar a culpa ao governo e à forma como João Goulart vinha governando o país. Aproveitou-se a oportunidade para incriminar a tolerância do governo com o Comando Geral dos Trabalhadores - CGT - e com a democracia.

Porque é inequívoco no editorial seu apelo ao impedimento, ilegal, do presidente João Goulart. A imprensa, a partir daí, foi singularmente solidária: segundo estudo de Alfred Stepan (STEPAN, 1975, pp. 75-92), dos nove principais jornais do país, apenas o Última Hora considerava que o impedimento do presidente era ilegal e o apoiava entusiasticamente. Os jornais Correio da Manhã, Jornal do Brasil, O Globo e Diário de Notícias achavam que

\footnotetext{
${ }^{23}$ Jornal do Brasil, 13 set. 1963, p. 6. Apud. NAPOLITANO, Marcos. 2014, p. 46.
} 
Jango não tinha mais autoridade para continuar no poder, enquanto os periódicos $O$ Jornal, $O$ Estado de São Paulo e a Tribuna da Imprensa pediam a renúncia imediata do presidente. O Diário Carioca era neutro.

Em nossa pesquisa de Mestrado, chamamos a atenção para a forma como a Administração Naval passou a tratar a diretoria da AMFNB, após o protesto dos sargentos de setembro de 1963. A partir do levante, o Ministério da Marinha começou a perseguir a diretoria da entidade e a acompanhar de perto as ações de seus diretores, através do CENIMAR - Centro de Informação da Marinha. Ao longo das páginas do jornal A Tribuna do Mar, da Associação, percebe-se a reação dos marinheiros, com artigos mais radicais, revidando às várias transferências de diretores da Associação para lugares afastados do Rio de Janeiro.

Antes de setembro de 1963, os artigos do A Tribuna do Mar eram apaziguadores no trato com a Administração Naval. Evitavam publicar textos que pudessem ser entendidos como políticos pelo Ministério da Marinha. Ou seja, tentavam manter certa proximidade com os oficiais, pelo menos não lhes dando álibi para taxá-los de comunistas ou algo parecido. $\mathrm{O}$ protesto de setembro dos sargentos trouxe grande preocupação entre os almirantes, dada a expressiva participação de praças da Marinha no evento. Segundo o livro Brasil: nunca mais, publicado pela Arquidiocese de São Paulo, "53 militares [foram processados] como réus e outros 196 como indiciados na fase de inquérito. Eram suboficiais, cabos, e soldados da Marinha, e um civil". Já no mês de agosto de 1963, percebemos uma ostensiva intenção da Administração Naval no sentido de limitar as ações da diretoria da Associação.

O ofício do Chefe do Estado Maior da Armada da Marinha, comunicando o informe secreto do CENIMAR n 315 de 12 de agosto de 1963, em que noticia a ida de Anselmo a São Paulo para participar de uma reunião "à qual compareceram presidentes de sindicatos e representantes de várias outras associações”, é muito significativo, pois sugere que a Marinha estava atenta às atividades da diretoria da associação, ao mesmo tempo que deixa clara a intensa mobilização das entidades sindicais, incluindo a AMFNB, no período. Em relação ainda a esse ofício, ele também traz uma polêmica entre os oficiais a respeito da movimentação de Anselmo fora do ambiente da Marinha. O Almirante José Luis da Silva Junior, Chefe do Estado Maior da Armada, culpa o comandante do Centro de Instrução “Almirante Wandenkolk", CMG Adolpho Barroso de Vasconcellos, superior de Anselmo, por tê-lo deixado ir a São Paulo. No ofício, o comandante rebate ao Chefe do Estado Maior da Armada: 
"cumpre salientar, todavia, que a falha verificada, em si, é corriqueira e de relativamente pouca importância, e certamente, deve ocorrer em larga escala em toda a MB [Marinha do Brasil]. O presente fato só ganhou destaque por se tratar do 1ํㅡ Classe José Anselmo e devido às suas atividades extra Marinha".

Não satisfeito com a resposta do comandante de Anselmo, o Chefe do Estado Maior, então, repisou:

"Parece que o CMG Adolpho Barroso de Vasconcellos ainda não entendeu que é justamente pelo destaque das atividades que vem exercendo esse marinheiro que tudo que a ele se relaciona é realmente de grande importância e, nas circunstâncias atuais, suas atividades precisam ser vigiadas e policiadas". ${ }^{24}$

Esta polêmica ilustra o conflito velado que ocorria na Marinha no governo Goulart, pelo menos entre seus oficiais. O comandante de Anselmo não considerava falta grave sua liberação para atividades fora da Marinha, enquanto o Chefe do Estado Maior da Armada estava estarrecido com o que ocorrera. Conforme os testemunhos de ex-marinheiros, existiam oficiais que de fato deixavam os membros da diretoria exercerem atividades ligadas à entidade, ao invés de mantê-los ocupados em suas obrigações nos navios ou em terra. Mas eles eram minoria. Podemos supor que o comandante de Anselmo o liberava porque reconhecia a legitimidade da AMFNB e, naqueles idos de setembro, Anselmo já era muito conhecido - aliás, erradamente, como "Cabo Anselmo", quando era ainda $1^{\text {a }}$ Classe e estava aguardando promoção a cabo - e assediado por jornalistas, militares, sindicalistas e políticos. Por outro lado, o Chefe do Estado Maior da Armada deixa bem claro que Anselmo, pela notoriedade que a Associação ensejou, deveria ser vigiado e policiado.

\section{$* * *$}

Para entendermos melhor o anacronismo relacionado à história da AMFNB e à formação de um grupo de marinheiros que se unia solidariamente na defesa da dignidade de seus companheiros, convém historiarmos brevemente a trajetória da Associação até o Golpe de 1964, quando ela desapareceu fisicamente, mantendo, no entanto, um coletivo que levaria suas experiências e convicções bem mais à frente. Antes, porém, precisamos deixar claro que José Anselmo dos Santos não faz parte do coletivo que estudaremos nesta pesquisa de

\footnotetext{
${ }^{24}$ Primeiro Despacho $n^{\circ} 2930$ de 06 de outubro de 1963, secreto, do chefe do Estado Maior da Armada ao Ministro da Marinha. Arquivo do Ministério da Marinha, Rio de Janeiro.
} 
Doutorado. Primeiro, porque Anselmo não representava o coletivo, entendido como um grupo de pessoas que tiveram uma formação política durante a gestão da Associação e que se reuniria em 1967 na Penitenciária Lemos Brito: quem dirigia a Associação era o vicepresidente, Marco Antônio da Silva Lima, com quem todos falavam e resolviam os problemas da entidade. Na pesquisa de mestrado, entrevistamos os ex-diretores da Associação e, unanimemente, disseram que Anselmo só se tornou presidente da Associação porque Marco Antônio não quis se candidatar ao cargo (líder nato, tinha, no entanto, dificuldades para falar para grande público), como também não o quiseram outros indicados (Antônio Geraldo Costa, o Neguinho, Antônio Duarte dos Santos e Moacir Omena de Oliveira, diretor do jornal A Tribuna do Mar). Anselmo foi lembrado porque era simpático, escrevia poesias, organizara uma biblioteca e, principalmente, se comunicava com desenvoltura em assembleias. Ou seja, era um bom relações públicas, apenas. Segundo, porque Anselmo não militou nas esquerdas com a acuidade dos outros. Ele ficou mais de três anos em Cuba, entre agosto de 1967 e outubro de 1970, enquanto seus amigos de diretoria militavam nas organizações clandestinas. A práxis política do coletivo deu mais fundamento teórico ao grupo: o contato com várias pessoas de diferentes organizações e debates acalorados, como falaremos adiante, só contribuíram para maior convicção na luta em que estavam envoltos. Foram presos, torturados e se mantiveram ligados ao projeto da revolução. Anselmo, ao que tudo indica, não teve esta fundamentação teórica, esta convicção na luta solidária para o Socialismo, apesar de sua temporada em Cuba. Em entrevista ao jornalista Percival de Souza, ele confessou seu estranhamento com Cuba: "Eu estava confuso e muito longe de perceber os labirintos da política, os interesses envolvidos na luta pelo poder. A rapidez dos acontecimentos impedia o raciocínio claro" (SOUZA, 1999, pp. 108-109).

A Associação dos Marinheiros e Fuzileiros Navais do Brasil - AMFNB - surgiu da iniciativa de um grupo de cabos da Marinha, que se reuniam assiduamente nos dias de folga em clubes ou bares para conversar, bebericar e paquerar. Quatro deles, que comporiam a futura diretoria, dividiam apartamento no bairro de Botafogo. Eram pessoas mais escolarizadas, mais experientes, que acompanharam as crises de 1954, de novembro de 1955 e, principalmente, de agosto de 1961 e questionavam a ausência de uma associação que os representasse, como era o caso da Associação dos sargentos da Marinha ou dos taifeiros. Por que não criar uma associação que congregasse marinheiros e fuzileiros navais? Pensavam que não teriam problemas com a Administração Naval, que já havia reconhecido as associações citadas acima. Ademais, seria até interessante para a Marinha contar com uma associação que cuidasse do bem-estar de marinheiros e fuzileiros navais e pudesse tirá-los de bares pouco 
aconselháveis, das "bocas de fumo" ou de bordéis, lugares geralmente frequentados por eles em folgas.

Destes encontros, surgiu a AMFNB. Mas não sem divergências sobre como deveria ser organizada.

Antônio Duarte comenta que existiam dois pontos de vistas em relação à organização da futura entidade. O primeiro, defendido pelas pessoas próximas a João Barbosa de Almeida, que será o primeiro presidente da AMFNB, sustentava que deveria manter relações amistosas com a Administração Naval e tirar proveito disto: por exemplo, conseguindo recursos para montar uma sede que permitisse entretenimentos aos associados, como também o reconhecimento da Associação pela Marinha, para que pudesse recolher as mensalidades diretamente dos holerites dos marinheiros. Portanto, assistencialista. Nas palavras de Duarte:

"A preocupação do grupo do cabo João Barbosa, como ficou demonstrada pela sua maneira de agir, era a de afastar a nova associação do campo "perigoso" da política e da revolta, evitando conflitos com a administração naval" (DUARTE, 2009, p. 28).

O segundo ponto de vista, geralmente defendido por embarcados, portanto mais presentes no dia-a-dia dos marinheiros e de suas reivindicações, defendia uma entidade estruturada através de comitês, “com uma organização de caráter militar”. Desta forma, no caso de uma crise militar ou política, ela estaria mais preparada para agir. Portanto, queriam uma entidade, além de recreativa e assistencialista, política e militante. Dentre estes opositores a João Barbosa, estavam o cabo Olímpio, o cabo-sinaleiro Antônio Geraldo Costa, o "Neguinho", também nosso protagonista, e o marinheiro Raul Alves do Nascimento.

Neguinho, segundo Antônio Duarte, já vinha reunindo um grupo, distinto daquele dos cabos citados acima, e discutindo a ideia de criar uma associação marinheira, quando um amigo lhe falou de João Barbosa:

"- Levo você. Conheço o João. Disse um dos participantes.

Na casa do João Barbosa, um apartamento no bairro de Botafogo no Rio, Antônio Geraldo foi apresentado.

- Escutei falar sobre você. Seja bem-vindo.

Quem levou o Geraldo até a casa do João foi o Esmael.

Ingressei na Associação na casa do João."

(DUARTE, 2009, p. 64)

No primeiro momento, Neguinho ocupou o cargo de Delegado da AMFNB no Cruzador Barroso, ampliando sensivelmente o número de associados. Aliás, foi ele quem 
“cooptou” Pedro Viegas, no início de 1963. Mais tarde, participaria da diretoria da Associação como vice-presidente e proporia a fundação de um jornal para a entidade.

No mesmo dia em que a AMFNB foi registrada em cartório civil, 25 de março de 1962, sua primeira diretoria tomou posse, tendo como presidente o cabo João Barbosa de Almeida, que servia no Centro de Armamento da Marinha. Conciliador, Barbosa circulava bem entre os marinheiros e seus comandantes. Mesmo assim, não conseguiu que o Ministério da Marinha permitisse o recolhimento das mensalidades nas folhas de pagamento. Isto foi um agravante na expansão das atividades da entidade, pois aquele recolhimento era manual, individual e muito trabalhoso. Mesmo assim, a associação fundou seu jornal. A Tribuna do Mar, dirigido pelo cabo Moacir Omena, secretário-geral da Associação, logo no primeiro número - em novembro de 1962 - listou as atividades já realizadas pela entidade: assistência médica - ginecológica, de ambulatório, clínica e análise; distribuição gratuita de remédios; assistência jurídica: contratação de quatro advogados; convênio com agências de viagens da Guanabara (para facilitar as visitas dos marinheiros a seus familiares), sendo a Associação a "fiadora"; criação de cursos de português e matemática para preparar os candidatos à promoção para sargento; curso de inglês e taquigrafia; criação de carteira de pecúlio para auxílio funerário e prêmio à natalidade (não especificado).

Estas atividades se concretizaram graças à supervisão da dirigente da Diretoria de Serviço Social, Érica Bayer In Roth, responsável em grande parte pela dinamização da AMFNB, atendendo às expectativas de seus sócios e lhes garantindo dignidade.

Dada a importância desta mulher para a formação do Coletivo, objeto de nosso estudo, vale a pena falarmos um pouco mais sobre ela. Para tanto, recorreremos à entrevista que nos concedeu, em 23 de novembro de 2003, em Teresópolis, quando tinha já 86 anos de vida e praticava psicoterapia em seu consultório, desejo que a perseguiu desde que chegou ao Brasil e realizado apenas aos 82 anos de vida!

De origem húngara, Érica Roth morou em Bolonha, Itália, onde fez seu doutorado em Física Pura. Em 1939, casou-se com Augusto Bayer Roth, recém-formado em Medicina pela mesma universidade de Bolonha, militante do Partido Comunista Romeno. Em sua viagem de lua de mel, em Veneza, tiveram informação de que a Itália entraria na Guerra. Imediatamente, retornam a Bolonha e procuraram lugares para onde pudessem emigrar, fugindo do antissemitismo crescente na época. Escolhido o Brasil como destino, chegaram em 06 de junho de 1940, "cinco dias antes do ingresso da Itália na Guerra e no último navio de italianos [autorizados a sair da Itália]”. 
No Brasil, Roth não teve problemas em encontrar emprego como professora de Geometria Analítica, em faculdade não especificada. Mesma sorte não teve seu marido, já que seu diploma não foi reconhecido, não podendo, portanto, exercer a Medicina. Tornou-se empresário no ramo de minerais.

Érica Roth conta que gostava muito do magistério, mas que, quando começou a trabalhar em física química, percebeu que não estava satisfeita, não era o que queria continuar fazendo. Na verdade, confessa que não sabia o que queria fazer. Havia ainda a alternativa de dar aulas de piano ou matemática, coisa que fazia desde os 12 anos de idade para complementar a renda da família em uma Europa semidestruída pela Primeira Guerra Mundial. Daí é que lhe ocorreu fazer psicanálise, área pela qual era apaixonada e lhe era familiar: em Bolonha, já havia começado a estudar esse campo de conhecimento, através da leitura de Freud e outros autores. Começou, então, sua análise "com a primeira psicanalista que chegou ao Brasil”. Foi através da análise que descobriu que queria trabalhar com gente, mais especificamente com delinquência juvenil. Ficou conhecida pelo trabalho que realizou na Casa do Menor Trabalhador. Mais tarde, começou a estudar outra área, a da família. Foi professora de Serviço Social na UERJ por vinte anos (aliás, discorda do termo "assistente social"; propõe "dinamizadora social"). Na data em que foi entrevistada, Roth estava muito satisfeita com seu consultório de psicoterapeuta. Em 7 de outubro de 2009, Érica Bayer In Roth faleceu de infarto, aos 92 anos e trabalhando como voluntária na Vara da Infância, do Idoso e da Juventude em Teresópolis, RJ.

A trajetória de Érica Roth, sempre interessada em compreender o comportamento humano, e sua atenção pelas humanidades, como a música e a psicanálise (naquele tempo!), pressagiava já aonde chegariam seus conhecimentos e perquirições: no Marxismo. E seu encontro com Marx e o comunismo deveu-se à influência do marido. "[Antes de conhecer o marido] era uma burra perfeita, a ignorante, do verbo ignorar em italiano, perdida".

Perguntada se, ao chegar ao Brasil, tivera contato com o Partido Comunista e participara de alguma "célula", respondeu que nem ela, nem o marido tiveram militância política, e emendou: "tem várias maneiras de exercer o comunismo. Comunista é aquele que, na práxis, exerce. Agora, tem várias maneiras de exercer. Eu acho que exerci”.

Seu relacionamento com os marinheiros foi marcado por uma troca: ela estava necessitando de alguma coisa que a preenchesse e eles também. Nas suas palavras:

"A gente tem necessidades, desejos, sonhos. Necessidade não é um buraco que a gente preenche. Necessidade é um impulso da pessoa, de fazer tudo que a necessidade manda fazer. Necessidade é uma força, quer dizer, eu pessoalmente, quando comecei a pensar, 
quando comecei a ter uma posição filosófica, materialista, politicamente também tinha tomado uma posição, eu estava necessitando de alguma coisa dentro de mim. Estes marinheiros estavam perdidos, estavam necessitando também de alguma coisa. Então, juntou a "fome com a vontade de comer".

Quando chegou à Associação, encontrou-a como um lugar para "bater papo": "tinha gente sem trabalhar e o que queria era conversar dentro da Associação".

Percebeu, então, que teria muito trabalho e que este seria essencialmente técnico: precisaria criar condições para atender às expectativas dos sócios.

Conta Roth que nas conversas com os marinheiros, no dia-a-dia, percebeu que deveria organizar a Associação através de seções. A primeira foi a da Saúde. Procurou na Pró-Mater e noutros lugares voluntários de "boa vontade, não precisava ser comunista" para conseguir médicos gratuitos, laboratórios clínicos (ela mesma tinha experiência), medicamentos, etc. Outra seção importante: a da Família. Tratava-se de orientação familiar. Neste sentido, segundo Roth, o contato com a comunidade foi-lhe essencial, assim como a especialização que realizara na PUC-RJ em organização de comunidade. Também criou a seção da Educação, pois eram muitos os que não sabiam escrever cartas. Montou um mutirão entre os marinheiros para reformar uma escola estadual e, com a permissão da Secretária da Educação do Estado da Guanabara, Sandra Cavalcanti, passou a utilizar aquele espaço no período noturno, recebendo ajuda de estudantes de faculdades que ensinavam matemática e português à marujada.

Érica Roth, que encontrara a Associação desestruturada, “com pessoas em funções mal definidas e atividades mal planejadas" e não preparada para atender às expectativas dos sócios, começou pouco-a-pouco a organizá-la. E passou a ser referência para os marinheiros.

"Pouco a pouco foram feitas seções e te digo que, de 300 [sócios], passou para 3.000 em pouco tempo. Por quê? Porque a associação estava preenchendo as expectativas que as pessoas queriam. [...] o desenvolvimento, você não pode ter fragmentado. Aparentemente é aqui, aqui, aqui [batendo com o dedo sobre a mesa], mas tem uma ligação, uma rede. Então o desenvolvimento aconteceu em todos os sentidos e aconteceu no último sentido, que é o sentido político. Eles tomaram posição".

Referindo-se à opção política, de esquerda, seguida pelos integrantes da associação marinheira, quando expressamos o interesse em entender como marinheiros sem educação formal chegaram a exercer ações complexas e a participar de discussões que exigiam conhecimentos articulados, Érica Roth respondeu: 
"não precisa de educação formal para compreender as coisas erradas e as coisas certas. $O$ que aconteceu ali? Eles queriam lutar. Emocionalmente, em cima da própria pele sentiam, mas não estavam colocando isto dentro de um posicionamento geral. Era uma coisa individual. Então, quando eles começaram a ver que não só eu, mas o outro, mais o outro, mais o outro, começaram a ter um aspecto social e quando começou a ter um aspecto social, eles sentiram a necessidade de ter um embasamento, porque se sentiam perdidos e este embasamento parece que me atribuem. Colocar as ideias no lugar certo, porque não adianta você se revoltar, se você não pensa: por que é assim? Se você não pensa: poderia ser diferente? Se você não pensa em comparações - onde, como é - se você não pensa: isto é uma coisa só minha? Quer dizer, quando você começa a ver isto como uma coisa social, então você se engaja nisto".

O trabalho de Érica Roth na Associação foi recebido como um afeto, que só poderia partir de uma mulher, de uma mãe. Neste ambiente predominantemente masculino e de pessoas afastadas de seus parentes - aqueles solteiros vindos do Norte ou Nordeste, que era a maioria dos marinheiros - e desconsiderados por seus comandantes, a AMFNB passou a ocupar o lugar da família, que provia, orientava, aconselhava e protegia, pois havia uma seção jurídica, como já foi dito, muito ativa. Também por isso, passou a ser muito frequentada. Todas as tardes, havia reuniões para discutir assuntos diversos entre os delegados das embarcações ou das escolas, os informes, seguidos das análises de conjuntura e pauta para o dia seguinte.

As várias atividades que a Associação passou a realizar e sua dinâmica envolvendo grupos de marinheiros - porque era solicitada a dedicação de seus sócios na empreitada de se organizar uma entidade ativa - sensibilizaram os marinheiros que, antes desgarrados, agora se uniam, solidariamente, em prol do fortalecimento daquilo que julgavam lhes pertencer.

O reconhecimento do trabalho de Érica Roth para o fortalecimento da entidade e para a expansão de seu quadro de associados é consensual entre os marinheiros que entrevistamos (24 ex-marinheiros, 1 ex-tenente e 2 ex-fuzileiros navais). Antônio Duarte, por exemplo, escreveu o seguinte:

"O trabalho importante da professora de Serviço Social Érica Roth constituiu-se numa alavanca poderosa da organização dos marinheiros e conscientização dos seus direitos mais elementares: tratamento de saúde às famílias, aos filhos e aos próprios marinheiros. Utilizando dos serviços oferecidos pelo estado e de algumas organizações que não tinham o caráter governamental, por meio das ações organizativas de Érica, possibilitaram o acesso de 
benefícios, como maternidade, exames de saúde e laboratórios, aos sócios da Associação". (DUARTE, 2009, p. 50)

Alguns entrevistados atribuem a Roth a orientação bibliográfica sobre temas como filosofia, sociologia e política. Questionada a respeito, Roth comentou:

"Lógico que eles [marinheiros] perguntavam o que ler! Eu achava muito mais importante, no caso deles, eles discutirem comigo as coisas nas reuniões do que eles lerem essas coisas, porque aí surge, quando a gente lê coisas, muitas coisas que o autor quis dizer com aquilo que você não quer [inaudível]. O que acontecia lá? Tudo que eles queriam saber eles perguntavam para mim. Nem sempre eu era capaz de responder. Mas eu, com toda facilidade, dizia: 'amanhã eu falo, amanhã eu respondo, deixe eu pensar'. Quer dizer, não tem uma orientação bibliográfica".

A considerar a opinião de Antônio Duarte, o contexto turbilhonante destes anos iniciais da década de 1960, principalmente com o envolvimento dos sargentos na política partidária e a eleição de deputados sargentos, permitia uma ampliação da sociabilidade dos subalternos e o eventual interesse pela política. Eles passaram a ter contatos frequentes com os estudantes de Ciências Humanas, por exemplo. Duarte lembra que teve acesso ao livro Princípios Fundamentais da Filosofia, de Georges Politzer, através de Raul Nascimento - que havia, por sua vez, recebido o volume de outra pessoa. A leitura deste livro foi importante para sua orientação política:

"Terminei a leitura do livro Princípios Fundamentais de Filosofia. O resultado foi um crescente interesse por tudo o que se relaciona à política. Isto se devia ao fato de que meu interesse por história, era coisa da época de estudante, em Natal, na Escola Industrial. Passei a frequentar as livrarias e ficava lendo o que podia comprar" (DUARTE, 2009, p. 241).

Muitos livros circulavam nas embarcações, através das pessoas mais politizadas, geralmente os delegados da AMFNB que, ao que tudo indica, veiculavam as ideias com forte conteúdo político, surgidas das reuniões na sede da Associação. Inclusive, Duarte lembra quando a Associação, em sua segunda diretoria - a do Coletivo -, pediu a Érica Roth que desse um curso de princípios gerais de Filosofia e de Serviço Social a dois delegados que não tinham qualquer formação ou noções de política e precisavam "lidar com as pessoas". ${ }^{25}$

A respeito da importância de Érica Roth na politização dos marinheiros, Antônio Duarte lembra que a própria condição dos marinheiros e das normas arbitrárias da Marinha, como o impedimento do marinheiro de sair da embarcação, na sua folga, sem a farda (numa época em que o marinheiro era confundido como usuário de drogas e frequentador de bordéis

\footnotetext{
${ }^{25}$ Entrevista a Flávio Luís Rodrigues em 13 de dezembro de 2003.
} 
do Baixo Meretrício), ou a proibição do casamento antes de um longo tempo de marinhagem ou mesmo a desconsideração como os oficiais tratavam os marinheiros eram motivos de discussões nas embarcações. Isto levou à politização. Neste sentido, Duarte diz que

"a politização nossa não teve nada a ver com a presença dela [Érica Roth] lá. Muito pelo contrário, a presença dela lá tem muito a ver com a nossa politização. [A politização tem a ver] com as discussões que nós tínhamos nos navios e nossa preocupação de ler e procurar ler. Por exemplo, nós íamos naquelas feiras de livros que tinham muito no Rio de Janeiro". ${ }^{26}$

Duarte lembra, ainda, que na Associação participavam pessoas ligadas ao Partido Comunista Brasileiro - PCB -, como José Ataíde e José Raimundo da Costa, que recomendavam leituras marxistas. Mesmo em contato com textos marxistas, Duarte ressalta que "nós não pregávamos nenhuma revolução socialista. Nossa ideia era mais como um instrumento de consciência social". Defendiam as reformas de base do presidente João Goulart, pois acreditavam que com elas aconteceria a reforma na Marinha. Também sentiam a iminência de um golpe de direita, contra seus interesses, e se posicionavam ao lado do governo.

Antônio Duarte conta ainda que havia um grupo de estudantes da Faculdade de Filosofia do Rio de Janeiro que dava aulas na escola que os marinheiros usavam à noite - já citada -, de matemática, história,

"tinha um oficial do Gabinete do Aragão [Comandante do Corpo de Fuzileiros Navais] que dava português (...) e o grupo de filosofia era a base do Partido Comunista na filosofia (....) sabemos disto através de um ex-marinheiro (...) esse cara estudava astronomia, chamava-se Élio [Élio Sá Rêgo], o 'Elinho', que era da base da filosofia levou os amigos, levou o Wilson do Nascimento Barbosa, e algumas pessoas lá da base da filosofia. Eles ajudaram no nosso processo. Era uma espécie de ligação muito interessante, porque eles davam aulas de graça, não cobravam nada das aulas que davam na escola que fizemos". ${ }^{27}$

Aos poucos, foi se formando um grupo em torno de Marco Antônio, vice-presidente da segunda diretoria da AMFNB, que passou a exercer uma liderança inconteste entre os diretores da Associação - mais adiante, falaremos desta liderança. Esse núcleo, aproveitando o termo de Duarte e Viegas, discutia a resistência ao golpe que se avizinhava, principalmente após o movimento dos sargentos de setembro de 1963, quando as posições se radicalizaram.

\footnotetext{
${ }^{26}$ Idem.

27 Idem.
} 
O Coletivo estava se formando. Neguinho, por exemplo, convenceu Pedro Viegas, no início de 1963, a participar da Associação. Viegas, curioso, resolveu passar na Associação. Ele conta o que presenciou:

"A movimentação das pessoas na Associação era intensa, criando um clima contagiante em quem por ali passasse. Discutiam-se muitas coisas, como a melhora de um serviço jurídico já existente, a assistência social, a criação de um biblioteca e de cursos que pudessem contribuir para a ascensão dos marinheiros em sua carreira. (...) Após ver toda aquela disposição de luta e ter conversado durante bom tempo com Omena, foi-me impossível não aderir. A partir desse momento, meus finais de tarde e parte da noite passaram a ter novo endereço: Rua São José, 84, 3o andar. Antes - e muitas vezes até depois das aulas [curso de jornalismo], que se encerravam as dez horas da noite - lá estava eu contribuindo, com muito afinco, com o que podia. O esforço maior, entretanto, era dirigido ao que concernia à elaboração do jornal. O fervor só tinha como entraves os limites de minha própria inexperiência, que não era pequena". (VIEGAS, 2004, pp. 42-44).

Capitani, por seu turno, chegou à Associação no final de 1962, através de amigos que o levaram para conhecê-la. Segundo ele,

"voltei ao quartel, procurei o enfermeiro, que era o delegado da Associação e filiei-me. Passei a participar ativamente dos debates, reuniões e assembleias. Logo fui nomeado Delegado do Quartel em substituição ao enfermeiro que era muito lento. Tomei um caminho sem volta. Fiz uma campanha de filiação e associei quase o efetivo inteiro. Foram momentos de intensos debates entre os marinheiros. As ideias foram esparramando-se e os que estavam indecisos passaram a participar. Tudo era baseado na força de vontade, no exemplo e no poder criativo. Muito esforço, muitos problemas e reivindicações e pequenas vitórias". (CAPITANI, 1997, p. 24).

Também em 1962, Antônio Duarte fez seu ingresso na AMFNB, através de Raul Alves do Nascimento, um dos fundadores da entidade, que o apresentou a Antônio Geraldo Costa, o Neguinho, na ocasião em que este era candidato a vice-presidente da Associação, no lugar de José Olímpio da Silva, renunciante ao cargo. Duarte achou engraçada a forma como foi recebido por Neguinho: "seja bem vindo a Associação e vote no Antônio Geraldo”.

O Coletivo começou a participar da Associação. Nos primeiros meses, seus membros ainda não se conheciam bem. Na verdade, Antônio Duarte, José Anselmo e Marcos Antônio já se conheciam do tempo em que trabalhavam na embarcação Rijo. Segundo Duarte, Marcos Antônio era o capitão do time de futebol e Anselmo era poeta, que vivia reclamando da sua condição de "bastardo": "Anselmo era muito duro quando falava de sua vida pessoal, não 
perdoava a familia pelo que sofria na Marinha” (DUARTE, 2009, p. 196). Mais tarde Duarte levou Anselmo a se associar à AMFNB.

Pedro Viegas, por ser cabo sinaleiro, conhecia Neguinho, com quem se comunicava constantemente através dos sinais que trocavam entre suas embarcações. Neguinho era cabo sinaleiro do Cruzador Barroso, capitânia da esquadra, e Viegas trabalhava no contratorpedeiro Greenhalgh. Neste momento, inícios de 1963, pouco se encontravam pessoalmente: "Servindo em unidades diferentes e dificilmente nos vendo, não poderíamos nos considerar amigos". Após sua entrada na AMFNB, no entanto, o contato entre os dois passou a ser intenso.

Quando a participação dos membros do Coletivo na Associação passou a ser mais efetiva, foi se formando em torno deles um grupo de marujos embarcados, ou seja, que trabalhavam nas embarcações e conheciam mais profundamente as demandas de seus companheiros. Não tardou para que se confrontasse com o que considerava moderação excessiva do presidente da entidade, João Barbosa de Almeida. Segundo Pedro Viegas,

"O presidente em exercício, o cabo João Barbosa, nessa função desde a fundação da AMFNB, passou a ser alvo da acusação de conciliar com o Conselho do Almirantado e de outras supostas atitudes até mais graves e nunca comprovadas, como a de ter entregue documentos internos da entidade ao Centro de Informação da Marinha (Cenimar)" (VIEGAS, 2004, p. 44).

As discussões na sede da entidade passaram a girar em torno da aproximação do seu presidente com os oficiais da Administração Naval. Barbosa admitia que, com a Associação ligada ao Ministério da Marinha, conseguiria mais recursos para desenvolver outras atividades, como também a oportunidade de se criar uma nova sede para a AMFNB. Havia uma demanda da Associação junto à Administração, de se permitir descontar as mensalidades dos associados em seus holerites, poupando um dispendioso trabalho de recolhimento individual nas embarcações e nas escolas.

Estes conflitos internos na Associação foram colocados da seguinte forma pelo excabo Raimundo Porfírio Costa, que foi o delegado da AMFNB no navio Bracuí, na segunda diretoria da entidade:

"Existiam várias posições, e contra a posição de João Barbosa, que era tida como conservadora; os progressistas começavam a chegar dentro da entidade, mas com o objetivo de tomar posição, de dar outra cara à entidade, dar uma outra filosofia, que seria a filosofia 
do momento, o envolvimento político; (...) já os cabos, mais velhos, mais experientes, tinham receio, porque sentiam que o negócio estava se radicalizando. A pressão foi tão grande para mudar de filosofia que o João Barbosa foi obrigado a entregar o mandato muito antes do tempo. (...) Então eles - o Marco Antônio, o Geraldinho, o Duarte, a doutora Érica, o Raul resolveram fazer um acordo com o João: ele renunciava e seria convocada uma nova eleição. Porque o João tinha uma proposta que não era do agrado de todos, [que] era [a de] entregar a Associação aos almirantes. Ele teve diversas reuniões, diz que ele esteve até no Clube Naval - tinha um Almirante que estava sempre conversando com ele com o intuito daquela entidade não ficar solta nas mãos dos marinheiros e trazer problemas amanhã ou depois, no tocante à questão política. E o João já estava cedendo, tanto que quando ele reivindicou a questão desses benefícios, para a entidade, aquilo já foi do acordo e esse grupo começou a entender isso: 'olha, nós vamos ficar atrelados ao Ministério da Marinha se continuarmos com o João'. Com isso, houve aquela movimentação para cooptar o Anselmo..."28

Como o estatuto da AMFNB previa novas eleições no caso de renúncia do presidente antes de um ano de mandato, os marinheiros decidiram em assembleia, com a presença de João Barbosa, realizá-las para a escolha da nova diretoria, em 27 de abril de 1963. Em $1^{\circ}$ de maio, assumiu essa nova diretoria, contando dentre seus membros, aquele "núcleo duro", como denominou Viegas, e cuja trajetória é nosso objeto de estudo: Presidente: José Anselmo dos Santos; Vice-Presidente, Marco Antônio da Silva Lima; Secretário geral: Adilson Aquilino; $2^{\circ}$ vice-presidente: Avelino Capitani; Tesoureiro geral: José Pinheiro Guimarães; Presidente do Conselho Deliberativo, Antônio Duarte dos Santos.

Essa segunda diretoria da AMFNB introduziu uma linha de ação mais política e menos assistencialista. A intenção era permitir ampliar os conhecimentos do marinheiro e orientá-lo em assuntos diversos, que faziam parte de seu cotidiano: família, sexo, drogas, etc. Por exemplo, com a colaboração de Érica Roth, criaram cursos de formação do marinheiro, para que pudesse ampliar seus conhecimentos e tivesse condições de prestar concurso para sargento. Também, nesse sentido, criaram a "Patrulha Social", que circulava pelas ruas do Rio de Janeiro, principalmente nas regiões de prostituição e de consumo de drogas, à procura de marinheiros "desgarrados". Essa patrulha convidava os marujos a frequentarem a Associação e, ali, incorporar-se ao grupo de marinheiros que procurava melhorar suas condições de trabalho.

\footnotetext{
${ }^{28}$ Entrevista a Flávio Luís Rodrigues. Rio de Janeiro, 10 e 11 de julho de 2001.
} 
A nova diretoria implantou um sistema mais democrático de administração, elegendo delegados nos diversos navios e nas unidades de terra da Marinha, como as escolas, onde se concentrava grande parte do efetivo marinheiro. Todas as tardes de sábado, os delegados se reuniam na sede da Associação com Anselmo, Érica Roth e o Delegado Geral, João do Carmo, posteriormente substituído por Neguinho.

Diariamente, às 16 horas, acontecia reunião entre aqueles que se encontrassem na sede da Associação, principalmente os diretores que estivessem em terra. A presença de Marcos Antônio era certa e era a ele que os outros se reportavam.

É interessante a mudança ocorrida em Marcos Antônio. Duarte diz que, quando trabalhavam juntos no Rijo eram, como disse Roth, ignorantes, ou seja, "perdidos" em política. Marcos entendia de futebol, mas não fazia ideia do que acontecia na política nacional, ou internacional. Quando entrou na AMFNB, no entanto, passou a exercer uma liderança incontestável sobre o grupo que se formou em torno dele. Passou a articular consensos, e mesmo dissensos, como no caso de João Barbosa, e a comunicar-se com dirigentes de outras entidades, militares e civis, como também com políticos e representantes do governo. Duarte fala desse "avanço": "[o negócio de Marcos] Era organizar futebol e jogar futebol. Ele era um líder no futebol. Não, eu ainda ficava naquelas discussões bestas com Anselmo, aquele idiota. Mas, ele [Marcos] não. Mas, de repente, quando ele chega lá e vai participar daquela Diretoria, o que acontece? Ele avança. "29

A comunicação entre a nova diretoria da AMFNB e a Administração Naval foi conflituosa, principalmente quando começou a ter certa preeminência nos contatos com outras entidades de classe. Aliás, por falar em classe, a Marinha considerou o estatuto da Associação "atentatório à disciplina" por nele constar esta palavra. É o que percebemos através da leitura do Ofício $N^{\circ}$ 4161, de 30 de agosto de 1963, dirigido pelo Ministro da Marinha ao Chefe do Estado Maior da Armada:

“(...) No que tange às suas atividades, pelo simples exame dos documentos que constitui o anexo ' $D$ ' do presente expediente, considero-as atentatórias à disciplina militar e no que concerne aos seus Estatutos, julgo-os, igualmente, atentatórios à disciplina e, além disso, inconstitucionais. Atentatório à disciplina porque, analisando-se logo de início o título com o qual se apresenta a Associação em seus Estatutos: 'ORGÃO DE REPRESENTAÇÃO SOCIAL DAS CLASSES', no entender dessa chefia, um órgão desta natureza não pode existir no seio de uma

\footnotetext{
${ }^{29}$ Entrevista a Flávio Luís Rodrigues. Rio de Janeiro, 11 de julho de 2012.
} 
Força Armada, seja ela qual for. Além do mais, tendo em vista o Artigo 30 dos Estatutos dos Militares que diz: 'os membros das Forças Armadas não constituem casta social mas formam uma classe especial, una e indivisivel, de SERVIDORES DA PÁTRIA, DENOMINADA A CLASSE DOS MILITARES', não será lícito de forma alguma admitir-se a existência de uma 'classe' de marinheiros, uma 'classe' de fuzileiros com ou que 'classe' seja. Dizem ainda os seus estatutos no seu Artigo 30 letra ' $D$ ': 'pugnar pela democracia e liberdades fundamentais, dentro da AMFNB, sem distinção de graduação, raça e nível cultural'"' (...).

O protesto dos sargentos em setembro de 1963 marcou uma inflexão na relação entre a AMFNB e a Administração Naval. Se antes dele a Marinha se dedicava apenas a controlar as ações dos diretores da Associação, por exemplo através do monitoramento de suas atividades pelos agentes do CENIMAR, depois dele, a situação tornou-se crítica, com perseguições e transferências de seus membros para lugares distantes, como aconteceu com Neguinho e Anselmo. Além disso, a Marinha passou a considerar a AMFNB ilegal, já que seus estatutos eram “inconstitucionais". Estava resoluta na decisão de por fim à Associação, se sua diretoria não alterasse os estatutos e "se ocupasse única e exclusivamente com a promoção e estímulo entre seus associados da prática de atividades cívicas, recreativas, culturais, artísticas, beneficentes e desportivas”. O Ofício No 4393, de 16 de setembro de 1963, do Ministro da Marinha, dirigido ao Chefe do Estado Maior da Armada, mostra bem a preocupação que a Marinha passou a ter com o Coletivo, convocando Anselmo a comparecer junto ao Diretor Geral do Pessoal da Marinha:

“O EXMO. SR. Diretor Geral do Pessoal da Marinha deverá determinar o comparecimento ao seu gabinete de trabalho do atual presidente da Associação dos Marinheiros e Fuzileiros Navais do Brasil (AMFNB) e, à luz dos estudos feitos no oficio inicial, onde se comprovou, no que concerne aos Estatutos da AMFNB, sua inconstitucionalidade e, no que diz respeito a maneira por que vem a aludida Associação desenvolvendo as suas atividades, como atentatória a disciplina militar e lhe seja dado ciência do seguinte:

"1 - A alta administração naval vem observando, desde algum tempo, a maneira pela qual vem a AMFNB exercendo suas atividades e do exame dos documentos que vem a Associação distribuindo, com linguagem sindical, cheia de reivindicações para 'classe' e vários deles com sentido duplo, classifica algumas destas atividades como atentatórias à disciplina militar.

"2 - A alta administração naval não pode aceitar os Estatutos da AMFNB tal como estão redigidos (os citados Estatutos apresentam a Associação como: 'ORGÃO DE REPRESENTAÇÃO SOCIAL DAS CLASSES'...) (...). 
"3 - A AMFNB deverá, dentro do prazo de 30 dias, a contar da data desta notificação, modificar seus Estatutos, dele escoimando tudo que não diga respeito a problemas de natureza cívica, recreativa, cultural, beneficente e desportiva, a semelhança do previsto nos Estatutos da Associação dos SO e SG dos taifeiros da Armada, sob pena de ter a Alta Administração Naval que tomar outras providências de caráter mais urgente e enérgico, com amparo na própria Constituição Federal, no sentido de preservar, a qualquer custo, a disciplina da Marinha.

"4 - Mesmo após a notificação de seus Estatutos ora determinada, serão as atividades da AMFNB fiscalizadas e policiadas pela administração naval, porque, sendo sócio da aludida Associação dos Marinheiros e Fuzileiros Navais do Brasil até cabo, seu corpo social será sempre, transitório e composto de homens de pouca idade, sem a necessária experiência e serenidade para dirigir convenientemente os destinos de uma organização de tamanho vulto e que, por isso, correrá o risco de cair em mãos de elementos aproveitadores, arvorando-se em seus mentores, passem a explorar a ingenuidade de nossos homens, tal como vem ocorrendo em outros setores da coletividade brasileira e a Marinha, positivamente, não poderá correr este risco.

“5 - Finalmente, seja dito ao presidente da AMFNB que a alta administração naval teria a maior satisfação de poder reconhecer uma associação de marinheiros e fuzileiros que se ocupasse única e exclusivamente com a promoção e estímulo entre seus associados da prática de atividades cívicas, recreativas, culturais, artísticas, beneficentes e desportivas, à semelhança da Associação de SO e SG que, durante toda a sua existência, jamais atentou contra a disciplina e jamais trouxe qualquer preocupação à Marinha."

Os documentos "que vem a Associação distribuindo, com linguagem sindical, cheia de reivindicações para 'classe' e vários deles com sentido duplo”, a que se refere o Ofício, são o jornal da Associação A Tribuna do Mar, que de fato passou a publicar matérias mais ofensivas à Marinha, como resposta às prisões e perseguições que vinham acontecendo com seus diretores. Pedro Viegas, por exemplo, escreveu artigo denunciando tais perseguições, matéria que mais tarde, depois do golpe de 1964, irá incriminá-lo e levá-lo à prisão por dois anos.

"Perseguição e Onda de Prisão na Associação Fuzinauta":

“(...) mesmo sem surpresa, não deixamos de sentir de modo deplorável envoltos pela inquietude natural dessa inefável situação em que se acham os mais atingidos, qual seja a privação das suas liberdades, cingidos pela exiguidade de limites dos quatro cantos de uma cela. 
"Como esta, tudo leva a crer na formação gradativa de um tempestuoso e vislumbrante porvir quanto aos destinos da Associação. Já não se pode esperar o sonhado apoio dos nossos superiores, quando vemos desabar de encontro a nós, todo o peso da arrogância que se funda em uma dúvida propositada que por mais nos esforcemos para elidi-la, mais toma proporções no ponto de vista sumarizante de quem nunca faltamos com o devido respeito.

"Tudo o que vem ocorrendo é puro fruto da incompreensão desde o primórdio da nossa fundação - 25 de março de 1962 - começando por não sermos reconhecidos e sim, tidos apenas como um insulto à soberania das nossas autoridades. Nada, no entanto, veio de encontro a qualquer item dos regulamentos pelos quais somos regidos. ${ }^{\prime 30}$

A radicalização de ambas as partes só cresceu. Não era simples para a Marinha fechar a Associação de milhares de marinheiros. Isso levaria certamente a um trauma, com consequências imprevisíveis. A situação se tornava mais complexa ainda, dada a boa relação que tinha o Coletivo com membros do alto escalão do governo João Goulart, como o Ministro da Casa Civil, Darcy Ribeiro, que chegou a recebê-los em sua casa. O governo tentava contemporizar com os oficiais da Marinha, através do Ministro, para que a Associação continuasse a existir e seus diretores fossem poupados de punições. O Ministro, no entanto, sofria pressão por parte do Conselho do Almirantado para que fechasse a Associação e punisse seus diretores.

O feriado da Semana Santa de 1964 coincidiu com o segundo aniversário da AMFNB, 25 de março de 1964, quando a diretoria organizou uma grande confraternização no amplo espaço do Sindicato dos Metalúrgicos da Guanabara, reunindo centenas de marinheiros, alegres, a beberem guaraná e conversarem banalidades. Não faltaram sanduíches de mortadela e as presenças de pessoas importantes, como deputados, líderes sindicais, jornalistas e até um representante do Presidente João Goulart.

Não sabiam, porém, que alguns diretores da Associação estavam presos por desobedecerem às ordens do Ministro de não realizarem aquele agradável evento.

Quando a informação da prisão chegou ao conhecimento da marujada, toda aquela descontração deu lugar à indignação, à cólera, seguida de um alvoroço e agitação que Anselmo, Marcos Antônio e Antônio Duarte, ali presentes - não foram presos somente porque se esconderam -, se viram totalmente desorientados e com medo, principalmente quando a Marinha passou a exercer toda sua truculenta autoridade.

\footnotetext{
${ }^{30}$ A Tribuna do Mar, Ano II, No 12, fevereiro de 1964, p. 2.
} 


\title{
CAPÍTULO II: DIANTE DA TEMPESTADE O PÓS-GOLPE E O INGRESSO NA GUERRILHA
}

\author{
"Vou p'ra rua e bebo a tempestade" \\ (Chico Buarque, "Bom conselho") \\ "- Se a Marinha fechar a Associação, ela \\ continuará na clandestinidade. \\ - Onde houver um diretor, \\ a Associação estará viva..." \\ (Avelino Capitani)
}

Desde a Revolta dos Sargentos, em setembro de 1963, a Administração Naval tentou separar os integrantes da diretoria da Associação dos Marinheiros e Fuzileiros Navais do Brasil, transferindo-os para lugares distantes, de forma a se tornar cada vez mais difícil sua reunião.

Assim foi com Anselmo, transferido em janeiro de 1964 "da Ilha, do Centro de Instrução da Marinha, para uma pequena unidade em terra. Totalmente isolado do grande contingente marinheiro" (DUARTE, 2009, p. 39).

Antônio Duarte, expulso do Cruzador Tamandaré depois de cumprir dez dias de prisão no presídio Naval, por ordem do capitão-de-mar-e-guerra José Uzeda, foi transferido para a Escola de Aprendizes Marinheiros do Espírito Santo.

Antônio Geraldo Costa, cabo-sinaleiro do Cruzador Barroso, foi preso já em dezembro de 1963, sem que seu comandante lhe desse explicações sobre os motivos para tal decisão: “não tenho que dar explicações a você. Você é um perigo". (DUARTE, 2009, p. 65). Essa recusa já era uma explicação... Em seguida, foi transferido para o contratorpedeiro Bauru em Recife, vaso de guerra bem menor que o Cruzador Barroso em que Neguinho era Delegado da AMFNB, um dos maiores da esquadra brasileira. Mais tarde, enquanto acontecia o protesto dos marinheiros, em fins de março de 1964, Neguinho voltou a ser preso em Recife, a bordo do mesmo contratorpedeiro. A ordem de prisão partiu do Ministério da Marinha para o Terceiro Distrito Naval, cujo comandante era conhecido de Neguinho, dos tempos em que, como Chefe de Pessoal da Marinha, estivera na sede da AMFNB pessoalmente para "vistoriar" o que faziam os marinheiros naquele lugar. Segundo relato de Neguinho:

"Eu não era mais Vice-Presidente, mas era Delegado, enfim. Como ele chegou dando esporro, eu tomei a iniciativa: 'com todo o respeito, senhor Almirante. Aqui é a Associação dos Marinheiros, aqui quem manda são os marinheiros, o senhor não está convidado'. 'Não senhor, o senhor não foi convidado para vir aqui'. Realmente ele não foi, entende? Ele: 'Não, 
eu vim aqui para dialogar com vocês, para dar conselhos', eu disse, 'com todo respeito, senhor Almirante, o senhor não foi convidado'. Mas, mesmo assim, aí o outro pessoal: 'não, Almirante, pode sentar aí. Ele sentou-se ali, trouxeram um copo de água para ele. Não foi convidado e chegou dando esporro! "31 $^{31}$

Pois o destino uniu novamente essas duas pessoas em Recife, às vésperas do Golpe de 1964. Na ocasião, o comandante do Terceiro Distrito Naval, Almirante Dias Fernandes, ainda segundo Neguinho, lembrou-se do ocorrido na sede da associação e lhe falou:

"'Olha, você está preso, eu posso mandar soltar-Ihe'. 'Mas, senhor almirante, a ordem é do Rio de Janeiro'. Ele disse: 'não, mas eu posso mandar-Ihe soltar'. E já tinha na gaveta um documento, ele puxou da gaveta e disse assim: 'leia isso aqui'. Era uma condenação, eu condenando o movimento dos marinheiros. 'Eu posso mandar-lhe soltar, agora, leia isso e assina'. Aí estava assim: 'Eu, cabo SI Antônio Geraldo Costa, tal, condeno o movimento dos marinheiros'. [...] Li e disse: 'senhor Almirante, eu não posso assinar'. 'É uma ordem!' Eu digo: 'não, senhor, não posso, eu tenho compromisso com a Associação dos Marinheiros, eu não posso assinar, eu não vou assinar isso, não vou!' 'Você está desobedecendo a ordem, tem que assinar!' 'Não senhor, eu não assino'. E não assinei. [...] Aí, ele disse assim: 'é, tira ele da minha frente'. Me pegaram no braço, eu me retirei. E a escolta me levou a bordo do navio, para o navio, né" 32 .

Neguinho voltou para a prisão a bordo do navio.

No dia da celebração do $2^{\circ}$ aniversário da Associação, 25 de março de 1964, como a Administração Naval proibira o evento e os diretores resolveram realizá-lo mesmo assim, o Ministro autorizou a prisão dos representantes. Sabedora da ordem de prisão, a diretoria resolveu que três diretores ficariam escondidos, para que pudessem participar da festa: Antônio Duarte dos Santos, José Anselmo dos Santos e Marcos Antônio da Silva Lima. Avelino Capitani, José Inglês dos Santos e José Duarte dos Santos foram presos no Corpo de Fuzileiros Navais. Vale lembrar que Antônio Duarte, Marcos Antônio, Anselmo e Neguinho já haviam sido transferidos para embarcações ou Centros de Instruções da Marinha. A "rebeldia" da direção da Associação se deu porque não entendia como justa, ou legal, as ordens da Marinha: era Semana Santa, quando muitos dos marujos estavam de folga; a festa foi planejada para ser realizada fora do ambiente da Marinha, ou de qualquer prédio público; A AMFNB era uma entidade civil, não ligada à Marinha. Que justificativa teria a proibição da festa? Quando foi feita a chamada dos diretores, nome por nome, três não responderam,

\footnotetext{
${ }^{31}$ Entrevista de Antônio Geraldo Costa a Flávio Luis Rodrigues. Maceió, 19 de julho de 2011.

${ }^{32}$ Idem.
} 
porque estavam presos. Foi a gota d'água que marcou o desfecho de um processo que já vinha se arrastando há tempo, de perseguição, intimidação e truculência, que resultou no protesto de 25 a 27 de março.

Nesse momento em que ocorria o protesto, onde estava o restante do coletivo que estamos estudando?

Antônio Prestes de Paula estava preso na Penitenciária Milton Dias Moreira, pelo protagonismo que exerceu na chamada Revolta dos Sargentos, ou protesto, de setembro de 1963.

José Adeildo Ramos estava a bordo do Porta Aviões Minas Gerais. Era Delegado da AMFNB na Divisão de Caldeiras, dos Serviços Gerais de Máquinas, no navio. Conta ele que, na noite do dia 25, quando os marinheiros souberam pelo rádio do que ocorria dentro do Sindicato dos Metalúrgicos - do protesto contra as prisões, principalmente -, criou-se um pânico entre os marujos pelo sentimento de que pudessem ser presos pelos oficiais, para que não deixassem o navio em direção ao protesto. A origem do medo foi um boato de que alguns camburões de leite que chegaram ao dique em que estava o navio, passando por limpeza e reparo, traziam algemas para prendê-los.

Amedrontados e aborrecidos com a prisão dos diretores, resolveram os marinheiros não dormir em seus beliches, mas no Convés de voo, para se protegerem de algum atentado a suas vidas. Pegaram, então, seus colchões de espuma e os colocaram lado a lado na grande pista de pouso do Minas Gerais. Vendo a cena, o comandante "avisou pelo alto falante do navio que os marinheiros estavam permitidos, [já que] estava fazendo calor, era permitido levar seus colchões e dormir ao Convés de voo", 33

No Sindicato dos Metalúrgicos, os discursos iam se tornando cada vez mais radicais em relação à Marinha, já que a Administração Naval se recusava a negociar uma saída para a crise. Ao contrário, mandou para o Sindicato 90 fuzileiros navais para prender os que protestavam à força - o que não aconteceu porque 26 dos fuzileiros aderiram ao protesto, deixando suas armas e capacetes no chão e entrando no prédio, onde foram recebidos com o Hino Nacional e levados nos ombros dos marinheiros até o palco, com a bandeira nacional tremulando. Enquanto isso, nos navios, a tensão não era menor.

Ramos conta que quando seus amigos do Minas Gerais souberam da notícia da adesão dos fuzileiros ao movimento, resolveram deixar o navio na manhã seguinte e engrossar o protesto. Diz ele:

\footnotetext{
${ }^{33}$ Entrevista a Flávio Luis Rodrigues. João Pessoa, 21 de julho de 2011.
} 
"os fuzileiros navais abandonaram as armas na rua e entraram e, aí a imprensa noticiava, entendeu? Quer dizer, isso criava mais um clima de revolta. Então, lá vai a gente... sim, aí o pessoal, já algumas pessoas [falaram]: 'olha, amanhã vamos sair todos e vamos nos juntar ao pessoal lá no sindicato. Então a gente deve sair com o uniforme 3', que era um de manga comprida, camisa mescla, calça mescla e camisa comprida. $O$ [uniforme] 2 é bermuda com camiseta, que é o normal, que é do trabalho. Então, quando a gente estava saindo já tinha um pessoal embaixo já ajeitando e chamando o pessoal: 'olha, vamos todos, ninguém volta para o navio, ninguém volta para o navio, vamos todos, daqui mesmo a gente sai e vamos para o Sindicato dos Metalúrgicos'”. ${ }^{34}$

Quando o grupo deixou o Minas Gerais em passeata, convocando os marinheiros dos outros navios atracados a engrossar o ato, uma pessoa pegou a bandeira do Brasil de um pequeno navio e, segurando-a, caminharam cantando o Hino Nacional. Segundo Ramos, uns trezentos marinheiros, "muitos, muitos marinheiros, muitos mesmo".

Não podiam imaginar os marinheiros que caminhavam ao encontro de uma insana armadilha. Nas palavras de Adeildo:

"A gente tinha passado pelo portão dos marinheiros, tentaram impedir, mas a gente avançou e o sargento viu que não tinha como impedir, e ele não ia... a única coisa que ele podia fazer é tentar impedir com arma de fogo, né? Mas ele não usou, nem ele nem os marujos dele. Ele sentiu que não dava para fazer. Aí fomos então para o outro portão, que era o portão dos fuzileiros navais. Na frente do portão eles tinham botado, assim, uma fileira de mais ou menos dez fuzileiros navais, todos armados de metralhadoras, e ficaram parados ali. Não sei qual seria a reação deles se a gente tivesse chegado até eles, porque não chegamos, porque os oficiais lá em cima, no quinto andar [do prédio do Ministério da Marinha]... Deixa eu te explicar [desenhando numa folha de papel]: está aqui o edifício, a gente tinha que passar por aqui. Aqui está o portão dos fuzileiros navais, a gente tem que passar por aqui. Então, eles botaram uma fila de fuzileiros navais aqui, armados de metralhadora. Para cá é o muro, para lá é o cais, é água, tem que passar por esse portão. Então, aqui, antes da gente chegar aqui, eles [os oficiais que estavam no quinto andar do prédio da Ministério da Marinha] começaram a atirar na gente, entendeu? Começaram a atirar. Eu fui baleado, levei um tiro no pé, fomos três... dois marinheiros, eu mais o cabo Luiz Gonzaga da Silva, e o fuzileiro naval Oziel, não me lembro mais o nome todo dele. Nós fomos baleados, né, e ali ficamos. Muitos caíram n'água. Aquela dispersão, a maioria correu em direção a ponte voltando para o Arsenal da Marinha. Muitos caíram dentro d'água, pularam por causa do tiroteio, inclusive

\footnotetext{
34 Idem.
} 
alguns desses que pularam dentro d'água nadaram, deram a volta e terminaram chegando lá na assembleia".

Ou seja, os oficiais atraíram os marinheiros que desejavam participar do protesto a uma emboscada, encurralando-os, facilitando o que certamente seria uma chacina. Dois dos marinheiros que caíram n'água nadaram até o continente e chegaram ao Sindicato, molhados e esbaforidos. Alcides Santos de Souza, o "Charuto", e José Stalin Machado narraram a tragédia aos amigos em vigília: alvoroço generalizado! Discursos inflamados, marinheiros nos cantos chorando, pânico em relação ao que poderia acontecer. Mesmo os diretores, como já falamos, ficaram desnorteados, sem saber como orientar os marinheiros presentes.

Adeildo Ramos e seus amigos alvejados foram levados ao hospital da Marinha, podendo receber visitas - inclusive a do Almirante Cândido Aragão. Mas isso por pouquíssimo tempo. No terceiro dia após o Golpe, passaram a ter a companhia de fuzileiros navais, seus carcereiros: "vocês estão presos aqui dentro do Comando”. Mesmo tendo sido ferido, vítima de uma aberração, Ramos foi condenado a três anos de prisão.

Pedro França Viegas conta que participou do protesto da Semana Santa de 1964 e pode voltar ao navio, sem impedimento por parte do comandante, diferentemente do que aconteceu à maioria dos marinheiros que estiveram no Sindicato dos Metalúrgicos. Segundo ele:

“(...) no meu navio não estava havendo, como não houve, nem nos dias da rebelião não houve hostilidade. Os acessos fecharam, entendeu, ao contrário do que aconteceu em outros, quando terminou e o pessoal começou a se apresentar. Teve navios em que os oficiais ficaram de armas em punho, impedindo que as pessoas voltassem para bordo, entrassem no navio. No meu não, nem me perguntaram, o que já seria, vamos dizer assim, algo estranho, porque se você falta um dia, chega uma hora atrasado, você já tem que se explicar. E eu passar aqueles 3 ou 4 dias fora, voltar e ninguém nem perguntar nada... é como se o comando tivesse determinado, 'olha, que a justiça resolva'. A única coisa é que, depois o meu encarregado de comunicação, que eu era de comunicações, chegou para mim uma certa hora e não no primeiro dia: 'Viegas quero falar contigo' e perguntou, 'só me responde, sim ou não, você participou da rebelião?' Eu participei e até falei pra eles, olha, eu acredito até que não participei de uma rebelião, eu participei de uma comemoração que degenerou, [resposta às] opressões das próprias autoridades. Porque tudo que houve, se decretaram a prisão dos diretores para impedir que houvesse a rebelião, então foi uma rebelião provocada, e 
provocada porque interessava em provocar, foi a única conversa. Então ele falou, 'tudo bem', aí já discutiu comigo, já tinha umas tarefas para mim"35.

André Borges, enquanto os marinheiros protestavam, estava preso na Penitenciária Lemos Brito, por assalto "e muitas trapalhadas, mas assassinato não, nunca matei ninguém ${ }^{\text {,36 }}$, em 1957, para cumprir a pena de 30 anos de prisão.

O desfecho do protesto dos marinheiros se deu com a anistia oferecida pelo novo Ministro da Marinha, Almirante Paulo Mário da Cunha Rodrigues, aos marinheiros revoltosos, o que trouxe grande refutação pelo Almirantado. A anistia aos marinheiros é atribuída, pela historiografia, ao Presidente João Goulart. No entanto, pesquisando o Arquivo do Ministério da Marinha, no tempo em que realizávamos os estudos para Mestrado, encontramos um interessante documento, com o título "Aspectos dos Acontecimentos Político-Militares de 25 de Março a $1^{\circ}$ de Abril de 1964”, datilografado e sem assinatura e com o cabeçalho escrito Ministério da Marinha - Estado-Maior da Armada, como se se tratasse de relatório para consumo interno:

"15:30 [do dia 27 de março] - Posse do Almirante Paulo Mário no cargo de MM. Logo após a cerimônia o Almirante José Luiz chama os Almirantes AZAMBUJA, NUNES, SINAY e TOSCANO para serem apresentados ao novo Ministro. $O$ grupo se reúne no vestiário do Ministro. $O$ Ministro declara que já conhecia a todos. O Almirante NUNES ao saber que seria dado regime normal pede para ser mantido regime 2. O MM não concorda. Diz que o regime será normal, que as forças serão retiradas e que será concedida anistia geral. Há um silêncio de reprovação. O Almirante JOSÉ LUIZ pondera que havia um compromisso entre o Presidente da República e o Ministro Motta de que os marinheiros e fuzileiros seriam punidos. O MM diz textualmente: 'Eu sei. Mas, o Presidente deu-me carta branca e eu vou usá-la. Portanto, a anistia é geral. Se não der resultado eu deixo a pasta e volto para o Tribunal Marítimo onde sou vitalício'., ${ }^{37}$

O diálogo acima, que deixa claro que a decisão da anistia foi do Ministro Paulo Mário, coincide com as declarações do Ministro da Justiça na época, Abelardo Jurema, em seu livro memorialístico Sexta-feira 13: os últimos dias do governo Goulart. Segundo Jurema, a anistia partiu do Ministro Paulo Mário, em discordância às decisões de João Goulart “de determinar

\footnotetext{
${ }^{35}$ Entrevista a Flávio Luís Rodrigues. Iperó, 9 de outubro de 2008.

${ }^{36}$ Entrevista a Flávio Luís Rodrigues. Rio de Janeiro, 18 de julho de 2011.

${ }^{37}$ Documentação "secreta e confidencial" do Ministro Ernesto de Mello Baptista, encontrada no Arquivo do Ministério da Marinha, Rio de Janeiro.
} 
a abertura de inquéritos e de fazer com que marinheiros e oficiais, indistintamente, voltassem ao serviço no início da semana seguinte

Seja como for, quando os marinheiros saíram do quartel do Exército, para onde tinham sido levados, e ganharam as ruas comemorando, sem a punição desejada pelos oficiais, a tensão no seio da Marinha cresceu. A perseguição aos marinheiros "subversistas" foi implacável. Vários oficiais não permitiram a entrada dos marinheiros em suas embarcações. Boatos de que oficiais matariam marinheiros assim que estivessem a bordo se espalharam com muita rapidez. A alegria da vitória deu lugar ao medo e à desorientação. Os marinheiros procuravam ajuda dos diretores da Associação para conseguir lugar para dormir até à próxima segunda-feira, quando deveriam se apresentar ao comandante de seus navios. Com a colaboração de alguns sindicatos, a AMFNB conseguiu instalar vários marinheiros em acampamentos. Capitani conta que foi ao Clube dos Sargentos para ajudar a diretoria a coordenar "a enorme quantidade de marinheiros que chegavam com informações sobre os problemas de suas unidades ou em busca de orientação” (CAPITANI, 1997, p. 58). Antônio Duarte relata que as ordens do Ministro de retornarem apenas na segunda-feira aos navios não eram tão simples de serem cumpridas. Primeiro, porque centenas de marinheiros dormiam a bordo dos navios. Segundo, porque havia medo real para cumpri-las:

A situação era caótica. O comandante [Paulo Werneck, chefe de gabinete do novo ministro] repetiu as ordens do ministro [de retornarem aos navios apenas na segunda-feira] e nos alertou para o fato de oficiais, armados e rebelados contra a nomeação do novo ministro, praticarem atos de violência contra os dirigentes da Associação. Anselmo, segundo informações de oficiais, seria executado por oficiais revoltados. O comandante Paulo Werneck, do gabinete do novo ministro, preocupado com nossa segurança, nos entregou duas pistolas. (DUARTE, 2009, p. 45)

O inconformismo dos oficiais em relação às decisões do Ministro Paulo Mário ganhou os jornais. Reunidos no Clube Naval - que, como sinal de protesto à anistia dada à marujada, tinha em sua faixada uma bandeira preta hasteada -, os almirantes fizeram publicar em jornais o manifesto "Aviso à Nação", onde deixavam claras suas posições perante o governo João Goulart:

"Em lugar de promover-se a devida punição disciplinar, licenciam-se marinheiros amotinados que não representam absolutamente os dignos suboficiais, sargentos, marinheiros $e$ fuzileiros, que em compacta maioria continuaram e continuam fiéis ao seu juramento de disciplina e dedicação à Marinha. O que este golpe representa de ameaça a todas as

\footnotetext{
${ }^{38}$ JUREMA, Abelardo. Op. Cit. P. 160. Apud: RODRIGUES, Flávio Luis. 2004, p. 116.
} 
instituições do país está patente, na forma e na essência, e só nos resta alertar a Nação para que se defenda, enquanto estão de pé as instituições e os cidadãos dignos da liberdade e da Pátria. Continuamos unidos e dispostos a resistir por todos os meios ao nosso alcance às tentativas de comunização do País". ${ }^{39}$

$\mathrm{Na}$ altura dos acontecimentos, o Almirantado já não media palavras para demonstrar que almejava derrubar o governo e frear o "golpe" em andamento, "tentativa de comunização do País". Mais tarde, quando de fato se concretizou o que esperavam, justificaram o Golpe, que implantou uma longa ditadura no Brasil, como sendo um contragolpe, uma "revolução" democrática que evitou a bolchevização do país. Lembremos que alguns historiadores também consideram o Golpe de 1964 como um contragolpe às pretensões continuístas de João Goulart. ${ }^{40}$

Os últimos dias do mês de março de 1964, entre o desfecho do protesto dos marinheiros na Semana Santa, dia 27, e o golpe militar em primeiro de abril, o coletivo da AMFNB se dispersou e seus integrantes vagavam desatinados. O golpe contra Jango já era pressentido pelo coletivo. Notícias de reuniões de civis e militares golpistas em navios da Marinha vinham acontecendo há dias, sempre relatadas pelos marinheiros à cúpula do governo. Nossos protagonistas, inclusive, chegaram a pedir uma reunião com Leonel Brizola e lideranças sindicais para deixá-los a par dos encontros dos golpistas nos navios e organizarem a resistência. Capitani comenta que a Associação vinha acompanhando as movimentações dos golpistas e que o protesto dos marinheiros da Semana Santa de 1964, antes de ser o leitmotiv do golpe, como querem alguns cientistas políticos, na verdade foi reação a priori ao Golpe que avizinhava.

"No fundo, nos últimos tempos, a gente passou a acompanhar os movimentos do golpe. Tanto que um dia chegamos e o Brizola disse "Precisamos dos marinheiros urgente". A questão do Golpe já era uma questão que estava na rua, estava em tudo na sociedade. Ali começou o choque direto. Tinha que haver uma definição. Ou um ou outro. Muitos dizem hoje que a rebelião dos marinheiros foi a responsável pelo Golpe. Mas nada mais bobo do que isso. Exatamente a rebelião dos marinheiros foi uma reação para tentar impedir o Golpe ${ }^{\prime 41}$

No dia 31 de março, os membros do Coletivo tentavam se unir e procurar algum comando de resistência ao Golpe em curso. Antônio Duarte e José Anselmo souberam que as pessoas estavam se reunindo nos Correios e Telégrafo, dirigido pelo coronel Dagoberto

\footnotetext{
${ }^{39}$ O Globo, 30 de março de 1964, p. 22.

${ }^{40}$ GORENDER, Jacob. Era o Golpe inevitável? In: TOLEDO, Caio Navarro de. 1964: visões críticas do golpe: democracia e reformas no populismo. Campinas: Editora da Unicamp, 1997.

${ }^{41}$ Entrevista a Flávio Luís Rodrigues. Porto Alegre, 12 de julho de 2011.
} 
Rodrigues, nacionalista, muito próximo de Leonel Brizola. Ali, havia sido criado um Comando de resistência. Para lá, foram e encontraram Marcos Antônio, Capitani e José Duarte. As informações chegavam de todo o País. Coronel Dagoberto conversava com vários comandantes das Forças Armadas e as informações eram cada vez mais desanimadoras. Duarte lembra ter ouvido a conversa do Coronel com outra pessoa pelo telefone, quando este sentenciou: “então, só resta tocar a marcha fúnebre?”. Duarte continua:

"Parecia ter sido, segundo fomos informados depois, a comunicação de oficiais do EstadoMaior do Regimento Sampaio que se constituía na última esperança do governo. Eles aderiram ao golpe. Com aquelas palavras pareceu ter sido, pelo menos naquele reduto do Rio, o desfecho do golpe e da 'resistência'". (DUARTE, 2009, pp. 75-76)

Angustiados e percebendo que as pessoas que se encontravam nos Correios e Telégrafos apenas se resignavam ao fato consumado de que nada mais teriam a fazer, nossos protagonistas fizeram uma reunião em um canto de uma das salas e decidiram procurar as entidades que pudessem organizar uma resistência armada. Nas palavras de Capitani:

[...] O Coronel Dagoberto e os demais pediram para que acompanhássemos os acontecimentos dali [tenente fuzileiro Arinos informou que prendeu caminhonetes do Lacerda cheia de armamento e soldados]. Formamos mais um pequeno grupo em um canto da sala, e acabei descobrindo que meus colegas compartilhavam as mesmas apreensões $e$ dúvidas. Concluímos que no Comando de Resistência não havia o que comandar. Não era nada mais do que um centro de informações, um seguro refúgio sob nossa proteção.

Traçamos um plano e saímos, discretamente, do prédio. Anselmo tentaria organizar um batalhão com operários marítimos voluntários. Duarte e outros iriam a UNE para convocar os estudantes. Marco Antônio e eu deveríamos ir ao Corpo de fuzileiros Navais onde tínhamos organizado um sistema de comunicações com os navios e repartições". (CAPITANI, 1997, pp. 63-64)

Na UNE, Antônio Duarte e o Tenente Arinos encontraram os estudantes acompanhando o andamento do Golpe pela televisão. Acreditavam que o Primeiro Exército conteria a tropa do General Mourão e que eles, os estudantes, venceriam qualquer tanque que chegasse ao Rio com coquetel Molotov. Decepcionados com o que presenciaram, os dois marinheiros deixaram o prédio e ganharam a rua. (CAPITANI, 1997, p. 64)

José Duarte, por seu turno, procurou os portuários, a fim de organizar, juntamente com as Ligas Camponesas do Estado do Rio de Janeiro, resistência às "tropas do governo que haviam aderido ao golpe”. (DUARTE, 2009, p. 76) 
Neste dia 31 de março, Marcos Antônio e Capitani foram ao Corpo de Fuzileiros Navais, onde esperavam organizar uma rede de comunicação com os navios e repartições. "Rapidamente, fizemos o levantamento do armamento disponível para as unidades civis que deveriam engrossar nossas fileiras. Concluímos que o armamento era escasso e velho". (CAPITANI, 1997, p. 64). Mesmo assim, levaram algumas caixas de armas para a frente do Ministério da Marinha, onde se encontravam oficiais favoráveis ao golpe e que, com o correr dos acontecimentos, estavam eufóricos com o provável sucesso daquilo. Capitani conta que Marcos Antônio deixou o Corpo de Fuzileiros Navais para buscar reforços civis. A ideia era distribuir as armas aos civis que pretendessem lutar. Segundo Capitani, somente o presidente do Sindicato dos Enfermeiros passou para buscar armas - "entre 10 e 13 metralhadoras 'Ina',', que posteriormente foram usadas na guerrilha urbana.

$\mathrm{O} 1^{\circ}$ de abril surgiu sinistro: as notícias da adesão de vários comandantes de unidades do Exército, Almirantes e Brigadeiros chegavam continuamente. Capitani lembra que, "sem orientação do Comando de Resistência e com a diretoria dispersa, sentia-me muito só”. Mesmo assim, tentou organizar batalhões de marinheiros, mandando mensageiros nas unidades da Marinha para elevar os ânimos e mobilizar o máximo de homens, que deveriam se concentrar diante do Ministério da Marinha:

[...] Em poucas horas, uma pequena multidão estava entre o Ministério da Marinha e o mar. Três mil marinheiros moviam-se silenciosamente, agrupando-se em torno de alguns rádios em busca de notícias. Esperavam ordens que, segundo o combinado, deveriam vir dos diretores da Associação. Mas, da diretoria, só estava eu. Comecei a agir". [conta que pensou em preparar pelotões, companhias e batalhões. Mas, sem armas e sem preparo, não tinha o que fazer - "o marinheiro entende de navio, mas muito pouco de combate terrestre"]. (CAPITANI, 1997, p. 65).

Quando a notícia da rendição do Ministro Paulo Mário e do Comandante do Corpo dos Fuzileiros Navais, Almirante Aragão, chegou à multidão de marujos, a gritaria foi generalizada. Alguns choravam, outros pediam para não esmorecer, e gritavam palavras de estímulo à luta. Foi quando Capitani, subindo em um "pequeno cepo de ferro", gritou: “vamos lutar!”. Ele narra o que ocorreu em seguida:

"Nesse momento, Aragão chegou trazendo o restante dos fuzileiros em retirada, acompanhado por um grupo de sargentos, dos quais muitos eram meus conhecidos. Percebendo o impasse, disse:

- Capitani, não faça isso. Perdemos uma batalha, mas não a guerra. Vai ser um massacre!

- Almirante, nós vamos lutar. 
O grupo de sargentos rodeou-me.

- vamos até o Comando, discutimos a situação e traçamos um plano -, diziam. Fui empurrado para dentro do carro, junto com Aragão. Ele e os sargentos estavam quietos, olhando para o vazio. Percebia que todos choravam e que, mesmo à beira de uma explosão emocional, a disciplina militar reprimia tudo. Sequei as lágrimas e tentei me recompor.

Quando chegamos ao Comando do Corpo de Fuzileiros, Aragão disse:

- Tu ouviste as notícias e as informações. O Presidente nos abandonou. Entregou tudo, está no Uruguai ou dirigindo-se para lá. Brizola deverá acompanhá-lo em seguida. Sem o presidente é impossivel qualquer resistência. Ficamos sós. Não vou te deixar sair daqui, tu vais levar todos à morte.

[...] Eu estava mais calmo e tomei consciência de que estava agindo com emoção e não com razão. Eles estavam certos. Perguntei:

- O que vamos fazer?

Aragão respondeu:

- Manda um bilhete, um recado para os marinheiros pedindo que voltem às suas unidades.

Diz que perdemos uma batalha e não a guerra -, repetiu.

De uma janela do Corpo de Fuzileiros, vimos a massa de marinheiros, lentamente, subindo para os barcos e dispersando-se em várias direções.

- Eu vou embora -, disse Aragão.

- Para onde? Para casa? -, perguntei.

Alguém na sala sugeriu que poderíamos tomar um ou mais navios e sair para alto-mar. Mas, ir para onde? Exterior? Qual país? Ninguém gostou da ideia.

- Não. Ele vai para um lugar seguro que já tenho pensado -, disse um sargento.

Ao sair, acompanhado de alguns sargentos, Aragão perguntou:

- Capitani, queres ir junto comigo?

- Não senhor, obrigado.

- Cuidem do Capitani para que ele não faça uma loucura.

Aragão deu o que acredito ter sido sua última ordem e foi embora". (CAPITANI, 1997, pp. 66-68).

A citação acima revela o momento em que os marinheiros perceberam que "os gorilas", como chamavam os militares golpistas, tinham vencido. A luta liderada pela AMFNB, pela reforma dos Regimentos da Marinha e melhoria nas condições de trabalho do marinheiro, haveria de cessar. Percebe-se também o descontentamento de Aragão em relação a João Goulart, que teria deixado o País sem ordenar repressão aos golpistas. Como se sabe, o 
Golpe aconteceu sem que o "dispositivo militar" do General Assis Brasil, Chefe da Casa Militar, lhe oferecesse resistência. Os diretores da Associação vinham armando um esquema de comunicação entre as unidades da Marinha, através de seus delegados, para boicotar qualquer tentativa da Marinha de participar de um golpe contra o presidente. Quando o momento chegou, alguns marinheiros a bordo "puseram areia nas caldeiras e retiraram as agulhas percutoras dos canhões, jogando-as ao mar" (CAPITANI, 1997, p. 65). Importantes e corajosas ações que se mostraram, contudo, insuficientes.

Mais uma vez, o Coletivo se dispersou. Marcos Antônio e José Duarte se exilaram na embaixada do México, juntamente com José Anselmo.

Retornando da UNE, Antônio Duarte dirige-se ao Ministério da Marinha, encontrando Capitani no quartel de Comando do Corpo de Fuzileiros.

"Capitani estava muito revoltado, mas demonstrava calma. Discutimos o que fazer. Decidimos abandonar o Rio de Janeiro e tentar chegar ao Rio Grande do Sul. Imaginávamos que Brizola não ia se entregar sem luta. Ainda estavam em nossa cabeça os episódios da resistência ao golpe contra a posse de João Goulart, em 1961". (DUARTE, 2009, p. 76)

Duarte e Capitani foram para o município de Lageado Estrela, onde Capitani tinha passado sua infância. Junto com eles, foi o marinheiro Carlos Alcides, o "macarrão" - apelido mencionado por Antônio Duarte; Capitani fala em "Mosquito". A intenção era a de encontrar Brizola e começar um movimento ofensivo contra os golpistas. Mas Brizola já não estava no Rio Grande do Sul: atravessara a fronteira, exilando-se no Uruguai. Antes de chegarem a Lageado, no entanto, passaram por São Paulo, onde ficaram na casa de um parente de Carlos Alcides. Ali, Capitani ficou sabendo, pelo Jornal do Brasil de 9 de abril que os diretores da Associação haviam sido expulsos da Marinha.

Pedro Viegas continuou trabalhando em seu navio. Como era cabo sinaleiro, sempre o convocavam para participar de exames de novatos em sinais. Viegas atribui a sua manutenção por mais tempo na Marinha - os outros diretores da AMFNB foram expulsos em 8 de abril de 1964, enquanto Viegas somente em novembro do mesmo ano - a sua experiência na realização de exames de recepção e transmissão de sinais. A respeito, conta:

"Eles falavam: 'tem uns exames ai para serem feitos'. Eles faziam o texto da pessoa que ia ser examinada, tinha que receber o texto em linguagem clara, português e uma cifrada. Então, a pessoa que ia receber, o examinado, tinha que ter confiança no que ia transmitir e depois ele ia transmitir, porque tinha a parte também dele e ele precisava ter confiança em quem era o 
receptor, quem iria ser o receptor, porque qualquer erro, ou na transmissão, ou na recepção, quem ia levar ferro no caso era ele, né, no caso ser reprovado, coisa e tal ${ }^{142}$.

Contra Viegas, houve o processo por ter participado do protesto. (...) "a peça de acusação era o jornal", ou seja, um artigo que ele havia escrito no jornal da AMFNB, A Tribuna do Mar, reproduzido no primeiro capítulo, considerado "esquerdista". Ele sabia que seria expulso da Marinha e, enquanto isso, continuou fazendo curso de jornalismo de um ano. Em seguida, começou a fazer estágio em jornal diário "pela minha classificação ao seu término, e já estava em desespero [queria sair logo da Marinha] porque tinha prazo para cumpri-lo [o estágio]”. (VIEGAS, 2004, p. 50)

Enquanto Viegas levava uma vida legal, sem acreditar que escaparia da expulsão da Marinha e da condenação por ter participado da Associação dos Marinheiros e Fuzileiros Navais do Brasil, Antônio Geraldo Costa já havia sido expulso, na ocasião em que os outros diretores da entidade marinheira também o foram, através das portarias do novo Ministro da Marinha, que realizou verdadeira faxina nesse setor militar.

A limpeza na Marinha foi profunda e teve início subsequente à posse do Ministro Augusto Hamann Rademaker Grünewald, quando assinou a portaria $n^{\circ} 540$, de 03 de abril de 1964, instaurando inquérito para apurar os fatos ocorridos no Sindicato dos Metalúrgicos na Semana Santa então recente. Em seguida, aos 07 de abril, assinou a portaria $n^{\circ} 555$, que solicitava ao superintendente da Moeda e do Crédito a suspensão das movimentações em contas da AMFNB, em qualquer banco do território nacional. Continuando com a "faxina", em 08 de abril, pela portaria $\mathrm{n}^{\mathrm{o}} 556$, comunica o diretor-geral do Pessoal da Marinha a expulsão dos membros da Associação dos Marinheiros e Fuzileiros Navais do Brasil dos quadros daquela arma. Em 10 de abril, através da portaria $n^{\circ} 572$, o Ministro comunica ao comandante-geral do Corpo de Fuzileiros Navais a expulsão dos 26 fuzileiros navais que aderiram ao movimento dos marinheiros, "por terem deposto as armas quando fazendo parte de destacamento que cercava o Sindicato dos Metalúrgicos no dia 26 de março, e terem se bandeado para o lado dos marinheiros e fuzileiros que lá se encontravam amotinados”. Em 11 de abril, através da portaria $n^{\circ} 576$, Rademaker instaurou inquérito policial "para apurar os fatos e responsabilidades relacionadas com indisciplina no meio naval". Seu sucessor, Ministro Ernesto de Mello Baptista, em 06 de outubro, comunica ao presidente da República que cinco oficiais da Marinha foram demitidos e oito reformados, "em decorrência das diligências dos inquéritos e das investigações posteriores àquele ato” (Ato n. 3, de 11 de

\footnotetext{
${ }^{42}$ Entrevista a Flávio Luis Rodrigues. Iperó, 09 de outubro de 2008.
} 
abril de 1964). Enfim, em 29 de julho, a União entrou com um mandado para averbação de dissolução da AMFNB, no Juízo de Direito da Terceira Vara da Fazenda Pública, julgada procedente pelo juiz Renato Lomba, em 23 de novembro de 1964, já que

"a associação nascida sob bom signo e destinada a justas e normais finalidades sociais da classe, que, por inadvertência ou conivência de sua diretoria, passou a ser instrumento de subversão e da intranquilidade social, levando a inquietação e a indisciplina a uma classe tradicionalmente ordeira e integrada plenamente em suas nobres tarefas de altas finalidades cívicas e de defesa nacional". ${ }^{43}$

O mais grave dessa "limpeza" foi a severidade com que a Marinha penalizou aqueles marinheiros que alegremente foram festejar o segundo aniversário de sua entidade e que se viram diante de um cenário certamente não previsto, de radicalização e profunda consternação pela forma como a Administração Naval vinha tratando os marinheiros e, agora, com a prisão dos diretores da AMFNB. Segundo o livro Brasil: Nunca Mais,

"o mais gigantesco desses processos resultou de IPM determinado, a 3 de abril de 1964, pelo recém-empossado ministro da Marinha, Augusto Rademaker Grünewald, atingindo a espantosa cifra de 1.123 indiciados, dos quais 284 foram judicialmente processados, todos eles marinheiros e fuzileiros navais. O objetivo do IPM era apurar os acontecimentos ocorridos entre 25 e 27 de março de 1964, no Sindicato dos Metalúrgicos do Rio de Janeiro. (...) Em julho de 1966, cerca de 250 dos réus desse processo foram condenados a penas superiores a 5 anos". ${ }^{44}$

Esses números coincidem com os que o próprio Ministro Rademaker citou, em discurso de posse de seu sucessor no ministério:

"Como prevíamos, porque éramos e somos contrários à instalação da Associação dos Marinheiros e Fuzileiros, iniciaram-se os atos de indisciplina por uma minoria, culminando com o lamentável espetáculo no Sindicato dos Metalúrgicos.

Aos olhos do público, parecia que a Marinha estava em plena indisciplina. Mas, na verdade, ela como sempre continuava na sua estável disciplina, pois, de cerca de 40.000 o seu efetivo, não chegavam a 1.200 os indisciplinados! E a reação da maioria foi imediata: todos os navios e repartições continuavam fieis sem um único ato de rebeldia; a Associação dos suboficiais e Sargentos logo se manifestou contrária à indisciplina; e os Clubes Naval, Militar e da Aeronáutica se solidarizaram na repressão à rebeldia. Foi dignificante constatar no Clube

\footnotetext{
${ }^{43}$ Pesquisa realizada no Ministério da Marinha, Rio de Janeiro, na ocasião de nossas pesquisas para Dissertação. Flávio luís Rodrigues, 2004, pp. 128 e 129.

${ }^{44}$ Brasil: Nunca Mais. Arquidiocese de São Paulo. Petrópolis: Editora Vozes, p. 120.
} 
Naval todos os oficiais de todas as idades, de todas as patentes, da ativa, da reserva e reformados, de todos os quadros e corpos, unirem-se e manifestarem-se solidários, protestando contra a indisciplina e contra os atos esquerdistas. A Marinha continuava unida". ${ }^{45}$

Capitani traz outros números, bem mais elevados do que os mencionados acima. Segundo ele, 400 marinheiros e fuzileiros navais foram expulsos, processados e condenados e 963 foram licenciados ex-ofício

"por terem sido indiciados nos IPMs que apuraram as ocorrências na Assembleia dos Marinheiros realizada em março de 1964, na sede do Sindicato dos Metalúrgicos do Rio de Janeiro. Destes, duzentos tinham, na época, mais de dez anos de serviço e foram considerados mortos. Seus dependentes recebem pensão militar como se eles tivessem falecido" (CAPITANI, 1997, p. 71).

O Autor, no entanto, não cita as fontes de onde tirou tais números. Podemos, contudo, intuir como agiram os militares que passaram a mandar no Brasil a partir de primeiro de abril de 1964. A limpeza foi, sem dúvida, maior na Marinha. O livro Brasil: Nunca Mais atribui o fato da Marinha ter sido a que sofreu maior número de processos punitivos ao "grau mais avançado de organização política que suas bases alcançaram, principalmente após a criação, em 1962, da Associação dos Marinheiros e Fuzileiros Navais do Brasil". "46 A organização política, na verdade, se deu após maio de 1963, quando o Coletivo assumiu a direção da AMFNB.

Para termos uma ideia mais precisa da perseguição sofrida pelos marinheiros, como também para entendermos que a ditadura nunca foi "branda" desde o seu começo, vale a pena ler o depoimento do marinheiro Adônias Antunes Vieira, encontrado no livro de Márcio Moreira Alves, Torturas e torturados, editado em 1965:

[...] "No contratorpedeiro Bauru, onde servia, fui preso na madrugada de 2 de abril de 1964, juntamente com 15 outros companheiros e levado sob forte escolta de metralhadoras para o Presídio da Marinha, onde nos jogaram numa cela que mal nos cabia de pé. Ali ficamos entre as frias paredes de pedra, até à tarde do dia seguinte, quando nos ordenaram que passássemos para uma cela maior, onde ficamos em promiscuidade com os presos comuns até o dia 23 do mesmo mês.

Após o depoimento, na Escola de Guerra Naval sobre a Assembleia do Sindicato dos Metalúrgicos, a que comparecemos, fomos conduzidos para o Quartel dos Marinheiros e

\footnotetext{
${ }^{45}$ A Marinha em Revista, mar./jun. 1964, pp. 29-30. Apud: RODRIGUES, op. cit. 2004, p. 130.

${ }^{46}$ Brasil: Nunca Mais. P. 120.
} 
liberados. No dia seguinte, [entretanto] eu e o ex-marinheiro Giovani Verazeno de Souza, fomos surpreendidos com outra prisão, desta vez por ordem do capitão-tenente Oscar Freitas Câmara, Imediato do navio em que servíamos. Jogaram-nos num cubículo daquele quartel, entre maconheiros e débeis mentais. Em junho, dois meses depois da prisão, fui interrogado pelo capitão-tenente Oscar Freitas Câmara que, na ocasião, usou palavras de baixo calão, mantendo-me sob tensão, ameaçando Côrte Marcial e fuzilamento, chamando-me de 'criminoso', 'monstro', 'mentiroso', 'sem vergonha', assumindo atitudes e dizendo coisas que me pejo de repetir. Neguei-me a assinar um depoimento pré-fabricado, que o citado capitão queria impor, e assim fui conduzido à cadeia.

Dias depois, mandaram-me para o navio Custódio de Mello, que servia de prisão a outros militares. Dois meses depois, nova transferência de cadeia. Dessa vez para o Centro de Armamento da Marinha, em companhia de 50 outros presos políticos, todos militares, que foram aos poucos sendo liberados ou transferidos de prisão. Restamos eu, o ex-sargento Moacir Omena de Oliveira [editor do jornal A Tribuna do Mar, da AMFNB] e o ex-marinheiro Inácio Pereira da Silva, que fomos jogados num cubículo cuja temperatura nos fazia transpirar dia e noite. Aí passamos cerca de um mês, sem nada saber a respeito da situação jurídica. No início do corrente ano, fui transferido para o Presídio da Marinha, onde me colocaram entre os presos comuns, raparam-me a cabeça e me fizeram vestir uniforme de presidiário. Obrigado a cumprir rotina militar, não obstante já estivesse expulso. Quebrei e carreguei pedra. Por qualquer engano ou ponderação junto ao comandante Eni, diretor daquela prisão, era jogado na oitava prisão, um pequeno compartimento, cavado na rocha, sem iluminação e completamente vedado por uma porta de cimento, forrada de ladrilhos brancos. O sanitário ali existente não tinha descarga. Ali tinha de ficar somente de cuecas e só abriam para entregar uma bandeja com alimento, sem fornecer talheres. Durante o tempo que passei no Presídio Naval, não me foram permitidas visitas. Por três vezes procurei o capitão-de-corveta Eni, protestando contra o tratamento recebido e, principalmente, contra trabalhos forçados: quebrar e carregar pedras, varrer o grande pátio central do quartel dos Fuzileiros, etc.; pedi-Ihe que ao menos considerasse a minha condição de preso político. $O$ comandante Eni limitou-se a responder que eu não tinha nenhum direito.

Transferido daquele presídio para outro da Polícia da Guanabara, em fevereiro de 1965, não me foi devolvida a quantia de 130.000 cruzeiros, que tomaram 'para guardar' à minha chegada.

No CENIMAR fui pressionado por dois oficiais, que desejavam de mim a confissão de pretensas ligações com o almirante Aragão e, desse, com elementos comunistas etc. 
Disseram que 'algumas metralhadoras ou um passeio me fariam falar...' Confundiram-me de tal maneira, que cheguei a perder temporariamente a faculdade de falar.

Fui, por fim, indiciado como um dos cabeças do movimento de rebeldia, a bordo do Contratorpedeiro Bauru, por ocasião dos acontecimentos de março-abril sendo o único preso dos que respondem àquele processo".

(ALVES, 1967, pp. 168-170)

Apesar de longo, o depoimento acima é importante para ilustrar a exasperação nas ações dos oficiais em relação a todos aqueles que, direta ou indiretamente, estavam ligados à Associação dos Marinheiros e Fuzileiros Navais do Brasil e permite perceber o total desprezo pelo marinheiro, sendo levado de uma prisão a outra sem que pudesse ver respeitados seus direitos a uma defesa judicial. A humilhação por que passou ao ser obrigado a varrer o "grande pátio central do quartel dos fuzileiros" mais lembra a exposição pública a que estavam sujeitos os criminosos no século XVII, através de suplícios inenarráveis, como aqueles reportados por Michel Foucault (FOUCAULT, 2010), coerentemente com episódios terríveis como a tortura pública de Gregório Bezerra, arrastado por um veículo, nos primeiros dias da ditadura.

Consideremos a data em que aconteceram as prisões, 2 de abril. Nesse momento, o novo governo sequer estava empossado e, talvez até por isso, os oficiais retaliativos da Marinha, alocados no Centro de Informações da Marinha - CENIMAR, partiram para uma caçada implacável a seus desafetos baderneiros. O que chama a atenção de quem lê o livro de Márcio Moreira Alves, que traz vários outros depoimentos parecidos com o de Adônias Antunes Vieira, é a absoluta falta de legalidade nas ações dos oficiais, através principalmente dos órgãos de informações. O vale tudo sobrepôs-se à Justiça. Inutilmente, Adônias pede que o comandante considere sua condição de preso político. Bem sabia que sua prisão era injusta e ilegal. Mas de que adiantaria reclamar da arbitrariedade desse ato? A resposta já estava dada a Adônias e a muitos outros: eles não tinham "nenhum direito".

O respaldo que Adônias provavelmente encontrava na AMFNB, durante o governo de João Goulart, acabara. Seu relato expõe a forma cesarista como seus oficiais passaram a lidar com os subalternos logo após o Golpe. Eles eram a Lei, representantes da "revolução", do "Poder Constituinte". É o que observamos nas medidas do Capitão-tenente Oscar Freitas Câmara, imediato no contratorpedeiro Bauru, onde Adônias servia, quando fez valer a força de sua autoridade, mandando prender o marinheiro que, somente após dois meses enclausurado em meio a marginais, dignou-se chamar para interrogatório. Na ocasião, aliás, o obrigou a assinar um "depoimento pré-fabricado", certamente com os mesmos dizeres 
daquele que Neguinho também havia se recusado a assinar. Não conseguimos identificar a relação de Adônias com a AMFNB, mas é possível que fosse o delegado da entidade no navio onde servia e, por isso, a perseguição do oficial, seu conhecido.

A truculência, portanto, começada logo nos primeiros dias da "revolução" dos militares era de amedrontar qualquer democrata. Já no dia dois de abril, o General Arthur da Costa e Silva criou o Comando Supremo da Revolução, do qual faziam parte, além do General, o Tenente Brigadeiro Francisco de Assis Correia de Mello e o Vice-Almirante que fez a faxina na Marinha, citada acima, Augusto Hamann Rademaker Grunewald. No dia 9 de abril de 1964, O Comando editou o Ato Adicional n ${ }^{\circ}$ 1. Através dele, o Executivo passou a ter poderes sobre os demais, pois "A revolução vitoriosa se investe no exercício do Poder Constituinte”. No dia seguinte, em seu Ato $\mathrm{n}^{\circ} 1$, o Comando Supremo da Revolução, baseando-se no artigo 10 do AI-1, suspendeu os direitos políticos por dez anos de 100 pessoas, dentre as quais João Goulart, Jânio Quadros, Miguel Arrais, Darci Ribeiro e Leonel Brizola. No mesmo dia, através do Ato $\mathrm{n}^{\circ} 2$ do Comando, foram cassados 40 membros do Congresso Nacional. Ficaram claros os poderes que os militares se imputaram: "Fica, assim, bem claro que a revolução não procura legitimar-se através do Congresso. Este é que recebe deste Ato Institucional, resultante do exercício do Poder Constituinte, inerente a todas as revoluções, a sua legitimação". ${ }^{47}$

"Fica, assim, bem claro", a forma impositiva, autocrática, nada "envergonhada", como os militares governaram o País desde o início da ditadura. Os outros Atos Institucionais, o Segundo, o Terceiro e o Quarto, foram criados no governo do General Castelo Branco, do grupo da chamada "Sorbonne", "intelectualizado", que se opunha aos "linha dura", revanchistas, etc. Através deles, ficava concluída a arquitetura jurídica da ditadura: fim do pluripartidarismo; fim das eleições diretas para a Presidência da República e para governadores dos Estados, bem como de suas capitais; censura à imprensa; autorização para o Executivo governar por decreto, cassar mandatos e decretar Estado de Sítio, bem como fechar o Congresso, as Assembleias Legislativas e as Câmaras Municipais; suspensão dos direitos políticos; instituição de mais de 700 Inquéritos Policial Militar - IPMs. Segundo Marcos Napolitano, dos 5.517 punidos pelos Atos Institucionais, 3.644 (65\%) o foram durante o governo de Castelo Branco. Quanto aos militares simpatizantes do governo João Goulart, 90\% das 1.230 punições foram executadas no mesmo governo "ilustrado". Ainda segundo Napolitano,

\footnotetext{
${ }^{47}$ Ato Institucional $\mathrm{N}^{\circ} 1$, de 9 de abril de 1964. Consultado em: http://www.planalto.gov.br/ccivil_03/AIT/ait01-64.htm
} 
"Embora tenha passado à história como o maior representante da 'ditabranda', o governo Castelo Branco foi o verdadeiro construtor institucional do regime autoritário. Nele foram editados 4 Atos Institucionais [na verdade, como vimos, o Primeiro foi editado antes da posse de Castelo Branco, e dispunha sobre a eleição indireta para a Presidência, que deveria se realizar a dois dias daquele Ato], a Lei de Imprensa e a nova Constituição, que selava o princípio de segurança nacional e que, doravante, deveria nortear a vida brasileira" (NAPOLITANO, 2014, p. 73).

Nos primeiros dias de abril de 1964, o País estava entregue ao comando de uma junta militar composta por três oficiais das Forças Armadas, ávidos por "revolucionar" a política e "restaurar" a ordem dentro dos quarteis. Custasse o que custasse. Haveriam de extinguir o cancro do nazicomunismo, como denominavam os simpatizantes do governo anterior. E assim propagavam um discurso perigosamente arrivista. Diante dele, centenas de marinheiros sendo caçados, como quem almeja adquirir um troféu. Vários Adônias procurando proteção e ajuda, sem emprego e sem coragem de voltar para as casas dos pais, quase todos moradores dos sertões nordestinos.

Nossos protagonistas acompanhavam a tudo isto, com ansiedade e um sentimento de impotência. Expulsos da Marinha, procuravam agora aglutinar os membros da Associação e definir novas ações, principalmente ajudando os marinheiros que os procuravam precisando de ajuda, de emprego e moradia. Sabiam também que eram procurados pelo órgão de informação da Marinha, o CENIMAR, pois já estava em andamento o processo contra eles. Aliás, em relação ao processo, Antônio Duarte diz que existiam três modelos: “o 'motim'; o processo contra a 'Associação dos Marinheiros', incluída a diretoria da associação; e o processo das 'Células Comunistas nos navios'. Ninguém escapava de um desses processos”.

Pelas palavras de Antônio Duarte, percebemos a farsa que eram os Inquéritos Policiais Militares - IPMs -, pois primeiramente estabeleciam as penas, para depois realizarem as investigações e os inquéritos. Mais uma vez recorrendo ao livro Brasil: Nunca Mais, que em sua página 172 reforça o que Antônio Duarte disse:

"Ao princípio segundo o qual 'ninguém poderá ser condenado duas vezes pelo mesmo crime', a Justiça militar respondeu com a subdivisão das acusações, especialmente no Rio de Janeiro e em Recife, multiplicando as condenações. Assim, uma pessoa que era acusada de ser integrante de um grupo político considerado subversivo que, na sua militância, usava identidade falsa e que, ao ser presa, guardava material de propaganda da organização, muitas vezes acabava sendo condenado pelos três fatos: 1) integrar partido clandestino; 2) uso de documentos falsos; e 3) posse de material subversivo. Tudo isso acontecia em 
desrespeito à norma legal que determina a unidade do processo, por 'conexão dos feitos'. Em outras palavras, os processos muitas vezes foram desmembrados para que a condenação fosse mais rigorosa".

Antônio Geraldo Costa, expulso e perseguido, voltou para o Rio de Janeiro com a intenção de reagrupar o Coletivo. Sabia que lá estariam os membros da AMFNB e precisava ajudar, também, os marinheiros desamparados. Perguntado sobre seu papel no pós-Golpe, quando muitos marinheiros entraram em organizações clandestinas, Neguinho fala convictamente da sua importância para reagrupar o Coletivo e indicar organizações de esquerda para seus membros ingressarem:

"Aí, outra coisa que você queria saber, sobre o meu papel. Primeiro, que os marinheiros ficaram acéfalos, a bordo dos navios. Acéfalos, porque a liderança foi castrada. (...) Por que [os marinheiros] ficaram acéfalos nos navios? Porque a liderança estava dispersa. E nós, os marinheiros, a liderança dos marinheiros, nós éramos líderes dentro daquela massa de marinheiros, entendeu? Já expulsos, não podia entrar a bordo mais. A gente tinha que estar a bordo para poder resistir, se fosse realmente o caso de uma confrontação [como reação ao Golpe]. Ficamos acéfalos, e começamos a nos reunir para fazer o que? (...) E eu passei a ser um centro aglutinador dos ex-marinheiros, porque viajava muito e tinha contato, conseguia, vamos dizer assim, na clandestinidade, o alojamento para essas pessoas. Muitos marinheiros ficaram perdidos, sem saber o que fazer, expulsos da Marinha, sem saber o que fazer da vida. Gente jovem. E nós nos sentimos responsáveis por essa gente, conseguir trabalho, é, para não ficarem a mercê dos ventos. E isso ajudou muito esses companheiros. Foi isso que levou muitos ex-marinheiros a entrar nas organizações armadas. Porque nós ajudávamos, arranjávamos, vamos dizer assim, condições para eles sobreviverem. ${ }^{48}$

Já comentamos anteriormente a vocação política de Neguinho, que vinha da sua experiência familiar ainda criança: ter assistido a sua família em confronto com o dono da fazenda, que mandava roubar seus porcos e cabras e a troca de tiros dos capangas com seus tios, politizados pela sua participação na Revolução de 1930, como milícia de Juarez Távora. Sua mãe, por quem tem profundo respeito, foi a principal responsável por sua alfabetização e tomada de consciência de classe. Diz ele:

"Cortaram nossos pés de jaqueiras, bananeiras. Então, quando eu entrei para a Marinha, eu já estava mais ou menos politizado. Eu fui alfabetizado com quatorze anos em Maceió,

\footnotetext{
${ }^{48}$ Entrevista de Antônio Geraldo Costa a Flávio Luís Rodrigues. Maceió, 19 de julho de 2011.
} 
graças a minha mãe. Minha mãe disse assim: "oh, meu filho, eles - são os fazendeiros -, só entendem a voz do bacamarte" [fuzil, também conhecido como "papo amarelo"]. ${ }^{49}$

Sua experiência recente, como um dos fundadores da AMFNB, e a sua atuação de "propaganda e agitação" no meio naval, contribuíram para ampliar os seus contatos políticos com várias entidades de classe, militares e civis, como também com partidos de esquerda. Neguinho desde cedo participava das reuniões da POLOP - ORM-PO, Organização Revolucionária Marxista - Política Operária, sobre a qual falaremos adiante. Diz ele que a sua "grande escola foi a POLOP".

Essa liderança e a credibilidade de Antônio Geraldo Costa são reconhecidas por seus companheiros marinheiros. Antônio Duarte, por exemplo, lembra quando entrou na sede da AMFNB pela primeira vez: na porta, como anfitrião para recebê-lo, estava Neguinho.

"Foi nesse período [em que estava na Escola de Eletricidade] que me convidou [Raul Alves do Nascimento Filho] para participar de discussões sobre a Associação dos Marinheiros, e me apresentou ao cabo-sinaleiro Antônio Geraldo Costa que era candidato à eleição de vicepresidente na primeira diretoria, presidida por João Barbosa de Almeida. Geraldo ficava na porta da sede para cumprimentar os que chegavam. Lembro-me de quando o Raul me apresentou, sem mais delongas, ele, dirigindo-se a mim disse: 'seja bem vindo a Associação e vote no Antônio Geraldo'. Achei muito engraçada a forma da propaganda eleitoral do Geraldo. E a partir daquele momento nos tornamos amigos, e companheiros de lutas". (DUARTE, 2009, p. 204).

Antônio Duarte fala da importância de Neguinho para a união do Coletivo, sendo uma referência para todos:

"O Geraldo não era um bom organizador. Ele era articulador e até agitador, mas ele tinha um senso incrivel para descobrir as pessoas, para se unir às outras pessoas. E descobria. Ele era ideológico nesse sentido: descobria o que tinha na cabeça daqueles amigos dele. Então, foi por isso que ele propôs [criar um jornal da Associação], 'você só agita uma coisa se você tiver um certo debate ideológico e esse debate ideológico tem que ter um instrumento" e esse grupo começou a se, uma espécie de, 'satelizar' em volta dele, no primeiro momento". ${ }^{50}$

A ideia de reagrupar os diretores da AMFNB e atrair um grupo de marinheiros mais politizados para participarem de uma resistência organizada contra a ditadura passou a ser cada vez mais aceita pelo Coletivo. Antônio Duarte manifesta essa preocupação quando, juntamente com Capitani, voltou do Rio Grande do Sul para o Rio de Janeiro, para "tentar

\footnotetext{
${ }^{49}$ Entrevista a Flávio Luís Rodrigues. Maceió, 19 de julho de 2011.

${ }^{50}$ Entrevista a Flávio Luís Rodrigues. Rio de Janeiro, 11 de julho de 2012.
} 
rearticular os marinheiros e todos aqueles que sabíamos que existiam lá". 51 A convicção de que somente a luta armada levaria à derrubada da ditadura e que o grupo deveria integrar uma organização clandestina para lutar já estava amadurecida para Antônio Geraldo Costa, assim que chegou ao Rio de Janeiro: "tinha que ser uma guerra civil. Eu era a favor [para resistir ao golpe]". Capitani, por sua vez, fala que a preocupação, como dirigentes de uma entidade que congregava e liderava muitos marinheiros, com centenas deles expulsos da Marinha, fez com que o Coletivo pensasse em integrá-los num projeto mais amplo, de guerrilha: "Não é que ela [massa de marinheiros] se infiltra, ela se integra, até mesmo é orientada 'pessoal, onde vocês estiverem, o que aparecer [organizações guerrilheiras], apoiem, vamos embora dar apoio ", 52 Seria como se a Associação continuasse existindo, assim como seus ideais. Sua estratégia agora era lutar pela democracia. Em suas palavras:

"sempre com a ideia de continuar a luta da Associação, nosso objetivo era orientar os marujos processados e expulsos em massa da Marinha. Todos procuravam encontrar-se, apoiar-se mutualmente, sair da sensação de estar flutuando em um espaço vazio, sem saber o que fazer, havia um forte desejo de manter viva a Associação e continuar a luta.

Tanto tempo lutando para conseguir uma organização [a AMFNB]. Não podíamos perdê-la! Por isso, mesmo sem dinheiro ou documentos, conseguimos contatar um grupo de 20 marujos em alguns dias.

Os marujos continuavam respondendo aos antigos dirigentes, e os diretores da Associação estavam sempre rodeados por um grupo de companheiros. Nos anos seguintes, grupos importantes de marinheiros combatentes integraram-se às organizações revolucionárias em formação e lutaram na linha de frente". (CAPITANI, 1997, p. 80).

A questão ideológica não era, ainda, consensual. Neguinho já tinha uma experiência política em organizações socialistas. Como já afirmamos, antes mesmo do Golpe, já participava das reuniões da POLOP. Suas críticas ao PCB eram ríspidas, principalmente em relação aos marinheiros comunistas que faziam parte da AMFNB que, em momentos de crise, como a da Semana Santa de 1964, "se retiraram, sumiram!" Costa criticava o Partido por sua linha pacifista, de sempre tentar convencê-los a não radicalizarem, não confrontar os oficiais, respeitar a hierarquia, pois o mais importante era o apoio ao governo democrático de João Goulart. Diz ele:

"Eu nunca fui do Partido Comunista, mas eu tive ligações assim, eu acompanhei o Partido. Eu sempre tive admiração, e tenho ainda hoje, pelo Partido Comunista daquela época, pela

\footnotetext{
${ }^{51}$ Idem.

${ }^{52}$ Entrevista a Flávio Luis Rodrigues. Porto Alegre, 12 de julho de 2011.
} 
capacidade enorme que tem de organização, de uma maneira errada, certa e errada ao mesmo tempo. Chegou um momento em que o Partido Comunista Brasileiro, o PCB, passou a fazer apenas a política da União Soviética. O que interessava para a União Soviética naquela época não interessava para o Brasil, mas o Partido Comunista achava assim: 'a linha do Partido que foi decidida lá em Moscou'. Eles achavam que era aplicável aqui". ${ }^{33}$

Capitani não era socialista, estava próximo do Nacional-trabalhismo de Brizola. Tinha preocupação em reorganizar a marujada, para resistir ao Golpe, mesmo atraído pelas propostas da POLOP.

"A POLOP declarava-se socialista e queria 'Socialismo já'! Eu aceitava o Socialismo e achava que seria uma saída válida mas, naquele momento, o principal era a derrubada da ditadura militar e a volta de um governo democrático mais perfeito e sem os erros anteriores". (CAPITANI, 1997, p. 80).

Antônio Duarte dos Santos, enquanto diretor da Associação, mantinha contato com o pessoal do Partido Comunista Brasileiro (PCB), que era a grande referência para ele, naquele momento. Mais tarde, como veremos, fará várias críticas ao Partido. Através de José Athaide e José Raimundo, do Conselho Deliberativo da AMFNB, discutia as propostas de revolução do Partido. Foi nessa ocasião que leu Doença infantil do esquerdismo no comunismo, de Lênin, recomendado por Athaide para afastá-lo de suas posições esquerdistas e aceitar as teses do Partido. Mas, ainda segundo Duarte, as pessoas do PCB com quem mais mantinha contato e respeitava eram da base da Faculdade de Filosofia, da Universidade do Brasil: "os estudantes do Partido Comunista, na base de Filosofia, estavam lá discutindo conosco, em um nível muito mais aberto, menos rígidos do que o camarada cabo Humberto [com quem morou, para ampliar seus conhecimentos das propostas do PCB para o Socialismo].

"Mas, foi o estudante Hélio Ferreira Rego [Élio Sá Rêgo], um ex-cabo, que havia saído da Marinha, por livre iniciativa, e que estudava Astronomia, amigo de Moacir Omena, diretor do jornal Tribuna do Mar, editado por nós, que fazia a ponte de contato com os estudantes. Foi Hélio [Élio] quem nos colocou em contato com alguns membros da base do partido na faculdade de Filosofia. Conhecíamos Wilson Barbosa do Nascimento, estudante de História, brilhante, bom orador e agitador, Edir, da Física, e muitos outros". (DUARTE, 2009, p. 74).

Mesmo "stalinista", como afirma, custava a aceitar a linha pacifista do Partido, "numa pregação de Democracia, Paz e Socialismo”, seguindo as orientações do Quinto Congresso, "recheada das contradições então dominantes, a polêmica entre os partidos comunistas da União Soviética e da China, e análise da Revolução Cubana”. (DUARTE, 2009, p. 72).

\footnotetext{
${ }^{53}$ Entrevista a Flávio Luís Rodrigues. Maceió, 19 de julho de 2011.
} 
Pedro França Viegas conta que, na época em que fazia parte do jornal A Tribuna do Mar, não possuía o mesmo repertório teórico que os irmãos Duarte, José Athaide e José Raimundo. Tinha muito interesse, mas faltava-lhe tempo para dedicar-se às leituras marxistas, já que a prioridade era terminar o curso de jornalismo que estava fazendo. Após o Golpe, no entanto, passou a ler $O$ Capital e outros livros marxistas, que lhe permitiram pensar nos caminhos da revolução brasileira. O encontro com o Socialismo se deu, segundo ele, após sua condenação no julgamento do processo:

"Com o Golpe, as coisas se clarearam um tanto mais e principalmente quando veio, quando chegou o momento do julgamento de tudo aquilo, aí para mim clareou muito mais ainda. Então, naquele momento, deu para ver claramente as posições de classe. Mas, ainda aí, sem leitura, etc. Mas eu comecei [a ler textos marxistas] a partir daí - porque a minha casa passou a ser uma espécie de passagem obrigatória para os clandestinos marinheiros. Alguns da direção da Associação já estavam em Cuba. Primeiro foram para o México e depois para Cuba, treinaram guerrilhas e etc. Nesse momento eu comecei a me encontrar com as primeiras obras marxistas, como 0 que fazer? por ai". ${ }^{54}$

Desde então, assim como seus companheiros do Coletivo, passou a tecer críticas ao Partido Comunista Brasileiro, PCB, por sua linha pacifista e reformista, que não lhe havia permitido preparar-se para uma reação a um possível golpe de Estado.

Durante a gestão da segunda diretoria da AMFNB, a maioria dos integrantes do Coletivo não tinha vinculação alguma com organizações de esquerda. Estava próxima do trabalhismo de Leonel Brizola, principalmente após seu protagonismo contra o Golpe de 1961 e o apoio às reivindicações dos sargentos das Forças Armadas. Identificava-se com os setores nacionalistas e reformistas e esperava mudanças nos regimentos internos da Marinha, bem como na conquista do direito de votar em deputados soldados, representantes de seus interesses.

Dos membros do Coletivo que estavam engajados em organizações de esquerda, apenas Antônio Geraldo Costa, que já frequentava as reuniões da POLOP, e Antônio Duarte, que chegou a passar por um processo de "aprendizado" das teses do Partido Comunista Brasileiro, como já falamos anteriormente. Pedro Viegas afirma que José Duarte também simpatizava com o Partido Comunista, mas nunca chegou a entrar em suas fileiras. Os comunistas na AMFNB eram os irmãos Athaide e José Raimundo, que, segundo Neguinho, participavam das reuniões da Associação sem nunca terem se associado a ela.

\footnotetext{
${ }^{54}$ Entrevista a Flávio Luís Rodrigues. Iperó, nove de outubro de 2008.
} 
Apesar do respeito que tinham pelo Partido Comunista Brasileiro e por seus membros, havia, no entanto, uma resistência dos integrantes do Coletivo às teses do V Congresso do Partido, de agosto de 1960. Nesse Congresso, os comunistas redefiniram as ações do Partido, a partir da "Declaração de Março" de 1958, priorizando a valorização da democracia política, participando mais ativamente da política institucional do país, ao mesmo tempo em que defendiam reformas estruturais, que pudessem desenvolver ainda mais as forças produtivas e a expansão dos direitos dos brasileiros. Para tanto, viam a necessidade de se criar uma frente única, democrática, que contasse com todos que fossem contrários ao Imperialismo e aos entreguistas. Para chegar ao Socialismo, não haveria necessariamente de haver rupturas institucionais. A via pacífica era o melhor caminho.

Principalmente após o Golpe de 1964, nossos protagonistas se opunham ao etapismo e ao pacifismo propagados pelo $\mathrm{PCB}$. Como tantos, acreditavam que o Partido errou ao não se preparar para um eventual golpe de estado. Criticavam os acordos "por cima" dos comunistas. Neguinho, por exemplo, ao narrar um encontro com Luis Carlos Prestes, afirma que os comunistas não conheciam os problemas dos marinheiros, pois estavam mais preocupados com as articulações com os oficiais. Percebemos, também, a irritação que causava neles serem chamados de "meninos", tanto por Prestes, quanto por Marighela (mais tarde, quando Neguinho estiver na ALN).

"Luis Carlos Prestes me recebia e outros marinheiros, mas nos tratava como meninos, marinheiros, [inaudivel]. E a gente tocava no assunto e eles diziam assim: "não meninos". Sempre nos tratou como meninos. 'Olha, quando nós fizermos a revolução, toda essa problemática'... Ah, sim, eu levantava o problema do racismo no Brasil: 'racismo no Brasil? isso não existe!'. Bom, na teoria do Partido, em nenhum documento do Partido Comunista Brasileiro e em nenhuma organização chamada revolucionária do Brasil, o Partido Comunista, o PCdoB, o PC não sei das quantas, eles nunca levantaram o problema do racismo no Brasil! Que existe de fato". 55

Esses comentários são ilustrativos, porque sugerem que um tema tão importante, como o racismo e toda a herança escravista, não fazia parte da pauta do Partido Comunista da época. Neguinho sentia certo preconceito da parte dos próprios dirigentes comunistas, como Carlos Marighella, em relação a suas origens. Em encontro com Marighella, ele e "outro companheiro que era da classe média", sentiu que era tratado com certa inferioridade em relação ao amigo:

\footnotetext{
${ }^{55}$ Entrevista a Flávio Luis Rodrigues. Maceió, 20 de julho de 2011.
} 
"Uma coisa que sempre me encheu o saco é [estes caras] me chamando de menino, entendeu? 'Isso é uma loucura menino'. Ele sabia do meu nome de clandestinidade, com eu sabia o nome dele. Pô, mas chega o momento que dá uma daquela de 'sou eu que sei de tudo'. 'Uma loucura menino'. Pô, por que me chamava de menino? Estou aqui conversando com o cara no mesmo nível, na mais suprema clandestinidade. Mas chega o momento que aí você tem que perceber. Olha, se eu fui contatar o cara, eu e outra pessoa fomos contatar o Marighella, que ele confiava em mim e naquela outra pessoa, troço sério, danado, mas chega o momento que o cara se julga tão superior e diz assim, quando ele nega tudo: 'isso é uma loucura menino'. Se dirigiu a mim. O outro companheiro, que era da classe média, revolucionário, [inaudível] ele não chamou de menino, mas a mim. Eu sempre fui muito sensivel a isso". 56

Como sabemos, Carlos Marighella era negro. Quando ele chamou Neguinho de menino, este tentava convencê-lo a envolver a ANL na fuga do Coletivo da Penitenciária Lemos Brito. Marighella não concordava com a participação de presos comuns na fuga, por isso chamou a ideia de loucura. O ressentimento de Neguinho passa mais provavelmente por sua formação familiar, como mencionamos. Difícil imaginar Marighella com preconceito de cor. Ademais, sobre a questão do racismo, a própria Literatura comunista de Jorge Amado já ultrapassara esse problema e até incorporara dimensões de cultura afro-brasileira como fundamentais na luta revolucionária. Esse romancista, quando deputado federal pelo PCB, apresentou o projeto de Lei garantindo a Liberdade de Culto no Brasil (Constituição de 1946), que muito significou para os praticantes de Candomblé, vítimas de repressão racista.

Neguinho sempre se manteve próximo dos membros do Partido, sem pertencer a ele, pelas razões já colocadas. Também sempre teve respeito por seus quadros e sua organização. No entanto, até pela trajetória de vida que tivera, sua opção foi a POLOP. Perguntado sobre como foi seu encontro com esse núcleo político, Neguinho conta que, bem antes do Golpe de 1964, foi convidado a participar de reuniões de um grupo de jovens intelectuais, que discutia os grandes problemas brasileiros de uma forma muito acessível e realista. A identidade com o grupo polopista se deu principalmente a partir das discussões sobre o campo e a questão agrária no Brasil, tão próxima a sua trajetória anterior à Marinha. Mais tarde, quando retornou de Recife, já expulso da Marinha, Neguinho procurou a Organização para integrar-se novamente.

"Como que eu participei da POLOP? Eu, que sempre fui interessado por política, eu soube, através de não sei quem realmente: 'olha, tem um grupo de estudantes de esquerda, chama-

\footnotetext{
${ }^{56}$ Idem.
} 
se POLOP, que vai esclarecer sobre o problema da sociedade brasileira, da revolução do Brasil'. E, com muito cuidado, eu cheguei lá. Conheci um dos grandes pensadores da POLOP, Ruy Mauro Marini, escreveu bastante. Depois conheci o Theotonio dos Santos, foi um grande intelectual do Rio de Janeiro, ele tem muitos livros escritos; Vânia Bambirra. Era um grupo de Minas Gerais, um grupo de São Paulo e um grupo do Rio de Janeiro, que saiu do Partido e formaram a Política Operária, que se propunha no futuro a fazer uma revolução socialista. $E$ a crítica principal desse grupo era sobre a política internacional da União Soviética, que era o Stalinismo.

Mas, como era colocada para nós, que não éramos intelectuais, a perspectiva de uma revolução socialista no Brasil, uma revolução armada naturalmente, fazendo as devidas críticas ao Capitalismo e o que se chamava de Comunismo Soviético. Eles explicavam a dinâmica do problema do campo e isso me interessou, porque, como eu vinha do campo, e daí eu li muito. É por isso que eu digo, a minha politização e de outros marinheiros se deu na POLOP". 57

A Organização Revolucionária Marxista - ORM/POLOP tem suas origens em escritos de Eric Sachs, comunista austríaco radicado no Brasil, na revista por ele criada O Movimento Socialista, já na década de 1950. Suas ideias de lutar por um movimento operário não tutelado, ou aliado, aos partidos políticos burgueses, teve grande acolhida entre intelectuais de esquerda, que não concordavam com as Teses do V Congresso do Partido Comunista Brasileiro, de avançar rumo ao Socialismo através da criação de uma frente única, que incluísse todos os democratas e nacionalistas, inclusive a burguesia nacional. Em fins da década de 1950, começou a circular um boletim quinzenal, Política Operária, transformado em jornal semanal a partir de dezembro de 1963. Devido ao nome do jornal, a ORM passou a ser chamada de POLOP por seus integrantes e simpatizantes.

Segundo Daniel Aarão Reis, o grupo de intelectuais fundadores da POLOP era principalmente do "Rio de Janeiro (dissidentes do trabalhismo), São Paulo (um grupo que reivindicava a herança intelectual de Rosa de Luxemburgo), Rio de Janeiro (egressos da juventude Socialista do PSB) e da Bahia”. (AARÃO REIS, 2007, p. 56). Jacob Gorender afirma que os polopistas "aceitavam as ideias de Trotski sem rigor dogmático e buscaram outras fontes de inspiração em Rosa Luxemburgo, Bukharin e Talheirmer". (GORENDER, 1987, p. 35).

A Organização Revolucionária Marxista - ORM/Polop colocava na ordem do dia o Socialismo, criticando, portanto, as alianças que o PCB e o PTB faziam com a burguesia e

\footnotetext{
${ }^{57}$ Entrevista a Flávio Luís Rodrigues. Maceió, 19 de julho de 2011.
} 
com o governo. Para seus membros, ao invés da frente única proposta pelo PCB, o caminho para o Socialismo passaria pela criação de uma Frente Revolucionária de Esquerda, que pudesse conscientizar a classe operária de sua condição histórica e formar um partido da classe operária.

Considerando o Capitalismo já desenvolvido no Brasil, para a POLOP, segundo Marcelo Ridenti,

"haveria uma interdependência entre os setores 'modernos' e 'atrasados', num processo de desenvolvimento desigual e combinado que implicaria íntima ligação entre latifundiários, imperialistas e a burguesia nacional. Portanto, a proposta de revolução burguesa seria descabida: tratava-se de fazer a revolução socialista". (RIDENTI, 2007 B, p. 118).

Maria do Carmo Brito, em livro memorialístico escrito por Martha Vianna, conta que, em um congresso da POLOP que terminou no dia 30 de março de 1964, houve uma discussão sobre um possível golpe em marcha. O comando se dividiu: de um lado, liderados por Theotônio dos Santos, os que acreditavam "estar em marcha um golpe bonapartista, armado pelo próprio Jango, e que todos deveriam se unir contra isso”. O outro grupo, liderado por Ruy Mauro Marini e Arnaldo Mourthé, "dizia que o golpe que estava sendo tramado era de direita, e que há muito tempo eles já deveriam estar organizando os Grupos dos Onze, com Brizola. Maria do Carmo concordava com essa última posição, que foi derrotada por um voto". (VIANNA, 2003, p. 34).

Contando com quadros reduzidos, praticamente restrita ao ambiente universitário, a POLOP não conseguiu se inserir no movimento operário ou camponês, apesar das tentativas. Gorender, na época membro do Comitê Central do PCB, atribui o isolamento dos polopistas a sua recusa em defender as reformas democráticas, como a reforma agrária, pois pensavam que "do seu triunfo teria origem inevitável um campesinato conservador e anti-socialista" (GORENDER, 1987, p. 36). Não podemos negar, no entanto, a importância desse grupo de intelectuais $^{58}$ na ampliação das discussões sobre alternativas socialistas às teses do PCB. Certamente, a Revolução Cubana teve sua contribuição, assim como o pontificado do Papa João XXIII e suas encíclicas, mas a repercussão dos textos e a apresentação de novos teóricos de esquerda, assim como o hábito das reuniões realizadas pelos polopistas, como as que atraíram Antônio Geraldo Costa, foram fundamentais para a formação política de muitas pessoas e para a decisão de participarem da guerrilha contra a ditadura, depois do Golpe de 1964. Assim aconteceu com parte do Coletivo.

\footnotetext{
${ }^{58}$ Theotônio dos Santos, Vânia Bambirra, Moniz Bandeira, Juarez Guimarães de Brito, Ruy mauro Marini, Eder Sader, Emir Sader, Eric Sachs, Galeno de Freitas, Arnaldo Mourthé, Guido Noire, dentre outros.
} 
Na ocasião em que Capitani e Antônio Duarte estavam no Rio Grande do Sul, Mosquito foi ao encontro deles e falou que muitos marinheiros estavam sendo presos no Rio de Janeiro e que "todos procuravam a diretoria para saber o que fazer”. Foi quando Capitani respondeu: “- Se a Marinha fechar a Associação, ela continuará na clandestinidade. - Onde houver um diretor, a Associação estará viva..." (CAPITANI, 1997, pp. 77-78)

Ao voltarem para o Rio de Janeiro com o propósito de tentar reagrupar o Coletivo e procurar os marinheiros em dificuldades, souberam que muitos haviam se exilado nas embaixadas, inclusive Marcos Antônio, José Duarte e José Anselmo, padre Alípio de Freitas e outros, que estavam na embaixada do México. Segundo Antônio Duarte,

"entrei em contato com os remanescentes da diretoria da Associação e com um grupo de marinheiros sob a orientação de Edson Neves Quaresma. (...) A intenção era de tentar rearticular os marinheiros e todos aqueles que sabíamos que existiam lá [no Rio de Janeiro]". 59

Antônio Duarte e Avelino Capitani procuraram Antônio Geraldo Costa e souberam que este já estava integrado à POLOP: "localizamos no Rio o Geraldo, que nessa época morava acho que na casa do Viegas". ${ }^{60}$ Através de Neguinho, os dois passaram a frequentar também os quadros da organização.

Antônio Duarte conta que ficou surpreso em saber que Neguinho já fazia parte da POLOP bem antes do Golpe de 1964. Achou estranho, pois Neguinho, quando foram apresentados, tinha grande simpatia por Stalin, como ele:

"continuei fiel à ideia do 'Stalinismo', pois achava absurdo que todo aquele doutrinarismo contra Stalin não passava de uma forma de combater o Comunismo. Mas o que me atraía na POLOP era o combate que faziam à intoxicação reformista do PCB no movimento operário. Para mim, as teses de Kruschov eram heresias". (DUARTE, 2009, pp. 79-80).

Interessante observar que Antônio Geraldo, apesar de sua popularidade dentre os marinheiros e seu modo extrovertido e comunicativo, não contou para ninguém que estava incorporado à POLOP. Como veremos, Neguinho tinha uma preocupação muito grande com o sigilo e o anonimato, para proteger a si mesmo e ao grupo, principalmente após sua prisão em julho de 1964. Por isso, às vezes, ele desaparecia, impunha dificuldades aos contatos, geralmente realizados por terceiros, ou "quartos"... Diz ele: "eu era o mais perto elo de ligação. Mas esse contato de vez em quando se rompia, por questões de segurança.

\footnotetext{
${ }^{59}$ Entrevista a Flávio Luís Rodrigues. Rio de Janeiro, 11 de julho de 2012.

${ }^{60}$ Idem.
} 
Rompiam-se os contatos por questões de segurança. Nem sempre eu sabia e nem eles sabiam onde eu dormia", 61

Outro aspecto que chama a atenção na declaração de Antônio Duarte, a de que considerava Neguinho stalinista, não corresponde ao que Geraldo falou na entrevista que citamos anteriormente, sobre a POLOP: (...) "e a crítica principal desse grupo era sobre a política internacional da União Soviética, que era o Stalinismo”. Neguinho fazia objeções ao Partido Comunista Brasileiro por seguir precisamente as determinações de Moscou. Mas, nas entrevistas que nos concedeu, não fez críticas diretas ao stalinismo, talvez porque já considerava superada a questão, com o debate que se seguiu ao informe confidencial de Khruschev no XX Congresso do PCUS, em fevereiro de 1956.

A ideia de entrar na vida clandestina da luta armada ainda não estava totalmente clara para Antônio Duarte e Capitani, quando resolveram voltar para o Rio de Janeiro. O contato indireto com os exilados na embaixada do México e o encontro com Neguinho foram decisivos para se incorporarem à POLOP.

Avelino Capitani conta que, no convívio com vários marinheiros desgarrados e com o pessoal da POLOP, através de Neguinho, a ideia de o que fazer, amadureceu.

A opção pela resistência à ditadura militar e por um governo democrático destoava do programa da POLOP. Mas a sinceridade de Capitani ajuda a entender que muitos marinheiros ainda não estavam convencidos da luta pelo Socialismo. Alguns, como ele mesmo, não contavam com bagagem teórica que permitisse acompanhar as discussões acaloradas sobre uma sociedade futura. Durante a gestão da AMFNB, Antônio Duarte era o que mais lia textos marxistas, seguido do Viegas. Não sabemos se José Duarte possuía o mesmo interesse do irmão, pois não tivemos a oportunidade de entrevistá-lo. Pedro Viegas diz que os irmãos estiveram "namorando" o PCB. Já dissemos que Antônio Duarte esteve fazendo um "estágio" no Partido, sem, no entanto, incorporar-se a seus quadros. Quanto a Marcos Antônio, muito raramente era visto lendo livros. Mas sempre lia revistas e jornais.

Quando Capitani e Antônio Duarte se incorporaram à POLOP, a entidade estava organizando uma ação guerrilheira e a presença deles, por serem militares, era muito oportuna. Capitani conta que começaram a treinar para a guerrilha:

"Mesmo que, nos acordos iniciais, nós fossemos os encarregados do treinamento militar, foi a POLOP que acabou responsável por essa tarefa. Estavam com a guerrilha na cabeça. Chegaram ao interior do estado do Rio e começaram a 'treinar' segurando facas entre os dentes e andando agachados no meio do capim." (CAPITANI, 1997, p. 81)

\footnotetext{
${ }^{61}$ Entrevista a Flávio Luís Rodrigues. Maceió, 19 de julho de 2011.
} 
Em que pese a importância da experiência política que os marinheiros tiveram com os polopistas, não demorou, no entanto, para perceberem as falhas de organização e de estrutura da POLOP. Antônio Duarte fala do paradoxo que havia entre os militantes, que se preparavam para a guerrilha sem, no entanto, possuir armas.

“Então, nessa região [de Minas Gerais, provavelmente Caparaó] eles tinham chamado um especialista, que era Jaime Cebalos, um colombiano, que trouxeram com eles. E esse colombiano era um dos elementos que seria, naturalmente, instrutor desse grupo guerrilheiro que iam formar nessa região rural. Que nós não sabíamos [o local]. Essas reuniões e essas articulações com a POLOP duraram alguns meses, porque na verdade eles eram, digamos assim, um pouco, num certo sentido desaparelhados. Eles não tinham armas". ${ }^{62}$

Na clandestinidade, Antônio Duarte e Avelino Capitani ingressaram numa rotina que já era familiar a Antônio Geraldo Costa: nunca ficar muito tempo em uma única casa, ou “aparelho". A POLOP disponibilizava apartamentos para seus militantes pernoitarem e, mesmo, reunirem-se. Foi assim que Antônio Duarte foi parar no apartamento do cientista político Luiz Alberto de Vianna Moniz Bandeira, que pertencia ao comando da POLOP. Duarte não se sentia seguro, pois o fluxo de pessoas no apartamento era grande. A POLOP costumava fazer reuniões ampliadas em apartamentos, como os de Botafogo e Leme. O contato constante com desconhecidos deixava Antônio Duarte, num momento em que estava “assustado até com a minha própria sombra”, com medo.

O mesmo receio tinha Capitani, que evitou morar em apartamentos em Copacabana e dividiu um pequeno apartamento no bairro da Tijuca:

"Eu deveria estar nos apartamentos de Copacabana, mas como não era meu meio, não me sentia bem. Achava que o esquema montado não era seguro e fui morar por uns dias junto com dois rapazes em um pequeno apartamento na Tijuca. Logo após, fui para a casa de um operário em Jacarepaguá". (CAPITANI, 1997, p. 81).

Com o objetivo de criar frentes de guerrilha contra a ditadura, o comando da POLOP organizou vários encontros de militantes, em julho de 1964, para viabilizar as ações que levassem à criação de infraestrutura necessária, com a finalidade de prepararem a resistência armada. No entanto, não sabiam os polopistas que, dentre eles, havia agentes dos órgãos de informações das Forças Armadas infiltrados. "O único feito prático de porte, no qual a organização se empenhara depois da vitória da ditadura”, nas palavras de Aarão Reis, foi abortado de uma forma trágica, com a prisão de mais de setenta militantes, inclusive Neguinho. Seguiu-se, a partir daí, uma caçada implacável aos polopistas, chegando a Capitani

\footnotetext{
${ }^{62}$ Entrevista a Flávio Luis Rodrigues. Rio de Janeiro, 11 de julho de 2012.
} 
e a Pedro Viegas, que não pertencia à Polop e levava uma vida legal, trabalhando na Marinha, enquanto esperava o julgamento do processo contra ele, em andamento.

Quando aconteceu a queda de Copacabana, Antônio Duarte e Neguinho estavam escondidos na casa de Pedro Viegas, que morava com a mulher e, solidariamente, hospedou os amigos clandestinos. A ida de Antônio Duarte para a casa de Viegas passou por Antônio Geraldo. Duarte conta como foi:

"Uma semana antes, preocupado com a superlotação nos lugares onde nos escondíamos, principalmente no apartamento de Capacabana, solicitei ao Geraldo, que não dormia por lá, só aparecia em reuniões ou para contados, que arranjasse um lugar seguro para mim. Claro que eu estava inseguro. Tinha medo, pelo fato de que sempre as pessoas assim reagem por natureza. Dava-me uma enorme insegurança não saber quais as pessoas que sabiam onde morávamos. Era época do medo. Andava assustado até com minha própria sombra.

Geraldo, então, levou-me para onde ele vivia com uma condição que não ficasse lá muito tempo, pois, segundo ele, a pessoa era legal. Fiquei surpreso quando chegamos ao lugar, em Vila Valqueire. Era a casa de Pedro Viegas!" (DUARTE, 2009, 80)

A presença dos dois polopistas, companheiros de Viegas desde a AMFNB, em sua casa pôs fim ao sossego do anfitrião. Conta ele que os dois amigos ficavam o dia todo fora. Apareciam à noite, às vezes. Preocupado com a segurança de todos, Viegas reuniu os dois clandestinos e combinaram que todo material sigiloso que pudesse incriminá-los deveria estar reunido em um único lugar, de forma a poder danificá-lo rapidamente, caso houvesse uma revista policial. O lugar foi estabelecido - a escrivaninha do quarto em que dormiam - e o "acordo" fechado: "em caso de problemas, eu e Leda poderíamos juntar facilmente o que fosse e encontrar um meio de dar sumiço ao pacote” (VIEGAS, 2004, p. 51).

Um descuido, no entanto, fez com que o "acordo" não se cumprisse, ocasionando grande transtorno a Viegas. Para receber cartas de sua mãe, Neguinho deu-lhe o endereço de Viegas, recomendando que pusesse como destinatária Leda, mulher de Viegas. Certo dia, exatamente o da queda de Copacabana, Neguinho colocou a carta recentemente recebida no bolso e saiu para a reunião no apartamento de Copacabana. Preso, Neguinho não teve tempo de destruir a carta que, nas mãos dos agentes do CENIMAR, levou-os à casa de Viegas. Lá, encontraram documentos comprometedores, como várias carteiras de identidade de uma associação de policiais militares, em branco e assinadas, fora do lugar combinado. Leda, por isso, não pode destruí-las. Intimado a depor, Viegas ficou estarrecido com o que viu: “descobri naquele instante que Geraldo e Duarte haviam rompido um de nossos acordos". 
Durante o interrogatório no CENIMAR, os agentes perguntaram por outros marinheiros envolvidos, além de Neguinho. Viegas foi encaminhado para o Presídio Naval, na Ilha das Cobras, onde ficou incomunicável por 13 dias e depois foi solto.

Em relação à queda de Copacabana, Viegas conta um caso pitoresco:

"os dois [agentes que o interrogavam] foram a uma reunião que o CENIMAR, por infiltração, sabia o dia, a hora e o local em que iria acontecer. Por isso seus agentes anteciparam-se, prenderam os residentes do apartamento e montaram seu esquema. Cada vez que a campainha tocava, um repressor abria rápido a porta e outro, mais rápido ainda, saltava sobre o recém-chegado, arrastando-o para dentro e o algemando ao pé de uma cama. Isto se repetiu até que chegou Dona Maria, a lavadeira. Quando voaram sobre ela, a pobre senhora institivamente pôs as mãos protetoras entre as coxas e gritou: 'Pelo amor de Deus, não façam isso. Estou muito velha pra essas coisas'!. Ela acreditou que estava sendo atacada por um bando de tarados sexuais querendo estuprá-la. Não era sem razão. Naqueles tempos a 'curra' figurava entre os deleites dos 'play boys', rebentos, na maioria dos casos, das classes abastadas, com maior atuação na Zona Sul do Rio" (VIEGAS, 2004, p. 53).

A versão de Antônio Duarte sobre o ocorrido na casa de Viegas é um pouco destoante. Diz ele que, preocupado por Neguinho não ter dormido na casa de Viegas, recolheu o que pode e partiu à procura de Capitani:

"Muito cedo, no dia seguinte às prisões em Copacabana, saí e comprei o Jornal do Brasil. Vi as notícias espalhafatosas sob o título: 'os guerrilheiros de Copacabana'. Estava lá todo o noticiário. Preocupado, pelo fato de Antônio Geraldo Costa não ter dormido naquela noite em Vila Valqueire, resolvi salvar o que podia" - grifo final nosso (DUARTE, 2009, pp. 80-81).

Duarte e Capitani, entendendo que corriam perigo e que os lugares onde se escondiam já estariam sendo monitorados pelos militares, resolveram sair do Rio de Janeiro. Antes, porém, resolveram "noticiar mais algumas pessoas e o Capitani dispunha de um lugar onde ele se escondia, que era um sitio na Estrada dos Bandeirantes" ${ }^{\text {"63 }}$, onde acreditavam que era seguro.

Partiram, então, rumo ao sítio onde Capitani estava hospedado, na estrada dos Bandeirantes, em Jacarepaguá. Tomaram um ônibus até Cascadura e mais outro, até próximo ao sítio. (...) "já era noite, umas nove e meia, talvez” (DUARTE, 2009, p. 81). Saltaram do ônibus um quilômetro antes do local e caminharam a pé, até uma distância de 300 metros do ponto, quando os dois, por precaução, se separaram. Capitani, que conhecia a região, "disse para que eu seguisse até a estrada, depois de esperar alguns minutos. Em caso de haver

\footnotetext{
${ }^{63}$ Entrevista a Flávio Luís Rodrigues. Rio de Janeiro, 11 de julho de 2012.
} 
estranhos no local, deveria recuar, pois estávamos desarmados". Ele saiu na frente, seguido por Antônio Duarte a certa distância. Entregou a arma (Duarte diz que estavam desarmados), dinheiro e uma pequena mala a Duarte e pegou a estrada.

"Peguei a estrada, e perto da casa, caíram uns dez em cima de mim, sem perder tempo perguntando minha identidade. O Duarte viu tudo, mas tinha ordem para não reagir. Eles começaram a bater porque sabiam que Antônio estava comigo. Primeiro, neguei repetidamente, mas logo entendi que o importante era tirá-los dali para que não cercassem o local e prendessem o Duarte também. Confirmei que tinha um encontro com Duarte na cidade. Eles montaram seu esquema, não encontraram Antônio e desconfiaram que a informação não era verdadeira" (CAPITANI, 1997, pp. 81-82).

Como os militares insistissem em perguntar por Duarte, Capitani inventou que tinha um contato marcado com ele em um hotel na cidade. A ideia era tirá-los dali, para que Duarte pudesse fugir. No hotel, fizeram muita maldade, prenderam hóspedes, revistaram tudo, viraram o hotel. Entre três e quatro horas da manhã, levaram-me para o Cenimar" (CAPITANI, 1997, p. 82)

De fato, Antônio Duarte acompanhou tudo bem próximo. Por pouco, não foi preso também. Seguindo Capitani a certa distância, quando ouviu os gritos dos policiais - "mãos na cabeça!” -, percebeu que Capitani havia caído. Imediatamente, escondeu-se no matagal e lá ficou por um tempo.

"Os policiais estavam em várias viaturas. Do meu esconderijo, mergulhado quase até o pescoço num pântano, vi-os passar em caravana com os presos. Aguardei um momento para me retirar da área. passei a noite no matagal. Fazia muito frio. Às duas horas da manhã, cheguei a um lugar à beira da estrada, que parecia um depósito de máquinas, ou canteiro de obras. Lavei-me e limpei a lama das roupas. Encostei-me em uma máquina, protegido pelo pneus, e dormi um sono curto e agitado. Às cinco horas, ouvi o ronco do primeiro ônibus, arrisquei-me e tomei-o para Cascadura. Fui até a Central do Brasil. Às sete horas, telefonei para o Helinho [Elinho] (Hélio Ferreira Rego [Élio Sá Rêgo]) que em contato conosco morava em apartamento que não era da infraestrutura da POLOP. Fomos os poucos que escapamos" (DUARTE, 2009, p. 81).

Capitani foi levado às dependências do Centro de Informações da Marinha CENIMAR, onde já se encontrava Antônio Geraldo Costa, todo desfigurado pela tortura que recebera. Capitani diz que, ao vê-lo, quase que não o reconheceu: "quando me levaram para o interrogatório, vi Geraldo pela primeira vez depois desses meses de clandestinidade. Passou ao meu lado, mas não era mais o 'Neguinho'. Estava roxo e 
vermelho por causa das torturas. Geraldo e eu estávamos entre as pessoas mais marcadas porque o CENIMAR descobrira que éramos os responsáveis pelas questões militares e de organização do grupo [POLOP]. A tortura foi concentrada em nós" (CAPITANI, 1997, p. 87).

Neguinho, quando foi preso no apartamento de Copacabana, foi levado diretamente para o CENIMAR, por agentes que ele já conhecia dos tempos da AMFNB, quando eram conduzidos a intermináveis interrogatórios. Em uma carta dirigida ao deputado Cid Carvalho, datada de 23 de setembro de 1964 e reproduzida por Márcio Moreira Alves, Neguinho narra as sessões de tortura que sofreu:

(...) "Os espancamentos eram com mais frequência na cabeça e no abdômen, socos e pontapés no estômago. Estes espancamentos foram entremeados de três sessões de aplicações de choques elétricos em todo o corpo, em particular nas partes genitais. Várias ameaças foram feitas contra minha vida, pelos torturadores. Já quase desfalecido, fui arrastado para outra sala pelo agente Sérgio Alex Toledo, o mesmo dizendo que havia no ca is do Ministério da Marinha uma lancha com uma guarnição de confiança, pois eu seria jogado no meio da baía da Guanabara, pois era alta madrugada e ninguém tomaria conhecimento. $E$ assim, Senhor deputado, sob todo este terror, prestei o depoimento que eles queriam.

Certa vez apelei para a honra e a dignidade do capitão-de-corveta Darcy, como oficial da Marinha, ele respondeu que esse negócio de honra e dignidade tinha acabado, isso era invenção dos comunistas, pois tinha ganho uma revolução democrática e podia dispor de minha vida como quisesse" (ALVES, 1967, pp. 173-174).

Essas torturas aconteceram na madrugada de 23 de julho de 1964 e explicitam a violência com que os agentes militares tratavam os presos políticos, e a total impunidade de seus atos. Não agiriam assim, entendemos, se seus superiores não lhes dessem respaldo. Sequer tinham a preocupação de omitir seus nomes - talvez se orgulhassem daquelas "façanhas"... A lista dos agentes torturadores do CENIMAR, que nesse momento agiam juntamente com o DOPS, não é grande: "Capitão-de-corveta Darcy e os agentes do DOPS, Sérgio Alex Toledo, Boneschi e Solimar”. Todos conheciam esses nomes, já nos tempos da AMFNB. E, no entanto, nenhum deles foi punido. Os agentes Boneschi e Solimar acompanhavam de perto as atividades da diretoria da Associação. Foram os mesmos que interrogaram Viegas, na ocasião da queda de Neguinho.

Há outro aspecto importante no relato de Neguinho ao deputado: a resposta que o Capitão-de-corveta lhe deu, quando lembrado da dignidade de seu cargo, oficial da honrosa Marinha, que "esse negócio de honra e dignidade tinha acabado, isso era invenção dos comunistas, pois tinha ganho uma revolução democrática e podia dispor de minha vida como 
quisesse", argumento que lembra o ocorrido com o marinheiro Adônias Antunes Vieira, quando este pediu ao comandante que considerasse sua condição de preso político, ouvindo como resposta, que ele não tinha nenhum direito. A mesma arrogância, o mesmo autoritarismo, o mesmo descaso com o Estado de Direito, a mesma certeza da impunidade. Mais uma vez, a democracia é arrolada para defender ações de truculência, justificando o Golpe de 1964. Sempre o discurso de que, em prol da democracia, vale o golpe sobre a Constituição.

Capitani não teve melhor sorte. Chegando ao CENIMAR, em 22 de julho de 1964, foi torturado entre duas e quatro horas da manhã, pelas mesmas pessoas e no mesmo local: quinto andar do Ministério da Marinha, nas dependências do CENIMAR. Ele conta:

“(...) comigo começaram com choque elétrico.

- Fala!

- Não vou falar!

Também inventava qualquer coisa para ganhar tempo. Uma vez, estava quase inconsciente, mas como não dizia o que o torturador queria, ele ficou num histerismo tal que aumentou a voltagem e eu desmaiei, não sei por quanto tempo. A minha saúde piorou rapidamente. Estava com febre muito alta, tinha quase todos os dentes e uma constela quebrada, o corpo tomado por hematomas e já desidratando. Chegou uma hora em que comecei a delirar e dizer besteiras" (CAPITANI, 1997, p. 88).

Juntamente com Neguinho e Capitani, foram presos os marinheiros Severino Vieira De Souza e Raul do Nascimento, também barbaramente torturados. Os quatro ficaram trancafiados no DOPS, na rua da Relação, à disposição do CENIMAR. Cada vez que eram transferidos para o Ministério da Marinha, sabiam que seriam torturados.

Enviados para o Presídio Naval, na Ilha das Cobras, os quatros marinheiros dividiram uma pequena cela, "muito úmida", com mais 8 presos. Frequentemente, os agentes do CENIMAR apareciam para levá-los para interrogatório. Já sabiam: “vai para a tortura. Será que volta?" (CAPITANI, 1997, p. 89).

Márcio Moreira Alves cita uma notícia no Jornal do Brasil, do dia 13 de setembro, em que informa uma greve de fome dos quatro marinheiros contra os maus tratos por eles sofridos no Presídio Naval, por 40 dias.

"Estão agora incomunicáveis no xadrez da rua da Relação. São eles, Avelino Capitani, Severino Vieira de Souza, Raul do Nascimento e Antônio Geraldo Costa. Depois de passarem 40 dias na llha das Cobras sofrendo torturas e humilhações praticadas por elementos do CENIMAR, (Centro de Informações da Marinha) e policiais do DOPS, decidiram entrar em 
greve de fome, que só terminou quando o encarregado do IPM, comandante Branco, prometeu cessar as violências, a incomunicabilidade e permitir visitas. Há cerca de 15 dias foram transferidos para a Rua da Relação e encerrados em cubículos sem ar e sem luz, por ordem do detetive Alberto Amazonas" (ALVES, 1967, pp. 160-161).

A matéria fala ainda que, além dos marinheiros, outros 35 presos políticos protestaram por intermédio de suas famílias:

“(...) contra medidas consideradas 'arbitrárias e odiosas' que vêm sendo adotadas pelo novo encarregado daquela prisão, Detetive Alberto Amazonas. Ele trancou todas as celas $e$ mantem os presos em completo isolamento.

Devido a essa providência, uma série de problemas graves foi criado: detentos em grupos de seis a 12 ficam fechados em cubículos estreitos, alguns sem janela, privados de luz e ar. As celas não dispõem de instalações sanitárias e algumas não possuem nem água". ${ }^{64}$

Transferidos para a prisão Alto da Boa Vista, ali encontraram vários companheiros presos na ocasião da "guerrilha de Copacabana". Neste momento, começaram os Inquéritos Policial Militares - IPMs - e frequentemente eram levados para o Tribunal da Auditoria da Marinha, ao lado do prédio do Ministério da Marinha, para interrogatórios.

Não sabemos se o marinheiro Severino Vieira de Souza também estava na Prisão Alto da Boa Vista, pois nossos protagonistas não o mencionam em seus relatos. Quando falam do planejamento e da fuga da Prisão, não o incluem. E ela foi bem atípica.

Os três marinheiros - Neguinho, Raul e Capitani - sempre eram levados juntos à Auditoria da Marinha para audiência com o juiz. Observaram, então, que, ao chegarem ao prédio, os soldados e os agentes do DOPS que os acompanhavam no camburão sempre tiravam suas algemas e os entregavam aos fuzileiros navais, que a partir daí fariam sua guarda. O local onde aguardavam pela audiência era muito movimentado, tendo uma sala grande e um corredor também longo. Não ficavam algemados e nem com roupas de presidiários. Quando terminava a audiência, os fuzileiros navais os levavam até à saída e os entregavam aos soldados, que recolocavam as algemas, e voltavam para a prisão.

Elaboraram então um plano para a fuga. Deixaram o cabelo crescer, fizeram documentos falsos, para o caso de emergência, e providenciaram roupas melhores, com as pessoas que os visitavam. No dia da audiência, lá foram eles preparados para fugir. Capitani conta sua versão:

"Como sempre, o Tribunal estava cheio. Ficamos alerta, esperando a troca da guarda. A audiência chegava ao fim, houve um intervalo. Advogados e jornalistas saíam

\footnotetext{
${ }^{64}$ Jornal do Brasil. 13 de setembro de 1964, primeiro caderno, página 4.
} 
apressadamente da sala. Eu peguei uma pastinha e, ao sinal combinado, os companheiros se aproximaram e começamos a sair juntos. Com muita segurança, passamos pelo guarda da frente, que não nos reconheceu. Não reparou que éramos os três presos que deveriam ficar. (...) Teve gente que nos viu saindo junto com os civis, mas ninguém imaginou que estávamos fugindo" (CAPITANI, 1997, p. 92).

Antônio Geraldo Costa conta uma versão um pouco diferente, onde aparece como o mentor da ação:

"Preparamos todo o esquema, porque o interessante é o seguinte: lá dentro da Auditoria da Marinha, todos desalgemados, porque não se pode entrar na sala do Juiz algemado e aí eu observei o seguinte: nos corredores, tinha uma guarda de Fuzileiros - no meu caso, do Raul e do Capitani, quando nós entramos, observamos que duas daquelas guardas eram exmembros da Associação dos Marinheiros que não tinham sido descobertos. E eles estavam lá dentro, com pistolas e fuzis. Quando nós entramos, eles olharam assim e eu pisquei o olho a um deles, como quem diz, "pô, eu estou vendo vocês". E o que aconteceu? quando tiraram as algemas, minha, do Capitani e do Raul, não sei se o Capitani lembra desse detalhe, e olhamos no corredor assim, eu falei para o Capitani: "olha, eu saio primeiro, vou caminhando por esse corredor aí. Se os caras me barrarem, vocês não saem, fiquem ai". Era uma sala enorme, entendeu, e um corredor enorme. Aí eu fui passando pela guarda, não tinha trocado de guarda, os caras viram eu entrar algemado, estou saindo e naquele corredor passando muita gente, civis, ex-militares e o diabo a quatro, advogados. Daí eu passei, pisquei o olho de novo para aquela guarda. Bom, aí o Capitani de lá viu, foi, foi. Quando chegamos na rua, realmente o apoio estava nos esperando, aí cada um foi para um canto". ${ }^{65}$

Assim que Neguinho saiu da cadeia, foi para a casa de Pedro Viegas pegar as roupas que deixara lá. Chegando próximo da casa, pediu a uma criança que avisasse os donos para virem à esquina onde se encontrava - como foragido, achou melhor ficar anônimo. Viegas narra esse engraçado acontecimento:

"A velha campainha soou. Eu estava no trabalho, a essa altura já livre da Marinha, e iniciava no O Jornal. Leda abriu a porta e apareceu uma menininha dizendo: 'Tem uma moça ali na esquina querendo falar com a senhora'. Intrigada, Leda disse que estava bem, mas ficou imaginando quem poderia estar tão perto mandando recado que queria vê-la, podendo ir direto à nossa casa. Mas, já um tanto vivida nesses 'mistérios', decidiu dar uma checada até à esquina indicada. Não podia ser outra pessoa. A 'moça' era o Geraldo. Raul e Duarte [possivelmente há um engano de Viegas, pois Antônio Duarte estava voltando para o Rio de

\footnotetext{
${ }^{65}$ Entrevista a Flávio Luís Rodrigues. Maceió, 19 de julho de 2011.
} 
Janeiro, como falaremos adiante] observavam de longe. Geraldo informou sobre a fuga, foi com Leda até o apartamento para pegar uma muda de roupa, que restava conosco, e sumiu. Todos sumiram à procura de um refúgio". (VIEGAS, 2004, p. 57)

Neguinho, então, foi para São Paulo e contatou a POLOP, que lhe deu guarida por pouco tempo, pois a organização passava por séria crise. Segundo Neguinho, "depois a POLOP se esfacelou, desapareceu”.

Capitani, por sua vez, tomou outro caminho. "Com a saúde abalada pelas torturas", Capitani foi para o Rio Grande do Sul procurar seus parentes para se restabelecer. Como estava sendo caçado pela polícia, resolveu tomar o caminho do Uruguai, onde ficou próximo da fronteira, em Artigas. De lá, com a ajuda de um amigo de seu tio, que contatou o governador da província, foi para Montevidéu, acompanhado por um policial.

Como Neguinho, Capitani e Antônio Duarte avaliam hoje as teorias e práticas da POLOP?

São unânimes em afirmar a importância da organização para suas formações políticas. Consideram-na importante, também, para o movimento de esquerda em geral, que pôde pensar uma estratégia de revolução alternativa à do PCB, hegemônica antes do Golpe. Após a implantação da ditadura, por influência de Neguinho e por falta de opções, já que estavam decididos a participar da resistência armada contra a ditadura, os três se ligaram à POLOP e passaram a ter função importante dentro dela, a de cuidar das questões militares da organização.

Não poupam, no entanto, críticas mais duras aos polopistas. Apontam a falta de cuidados com a preservação de nomes legais, quando se deveria usar sempre codinomes, e com o desleixo em relação a regras básicas de vida na clandestinidade. Por exemplo, Capitani e Duarte falam que pernoitavam em apartamentos onde havia um grande fluxo de pessoas desconhecidas e, ao mesmo tempo, ainda se realizavam reuniões estratégicas. Antônio Duarte critica também as contradições da organização, quando diz que "a análise política da POLOP não era das melhores. Falava de luta armada sem, no entanto, ter meios para iniciá-la”. Neguinho, sempre agitador, diz que "a POLOP ficou também muito na teoria".

Enquanto Neguinho e Capitani estavam presos, muitas coisas aconteceram com Antônio Duarte. Após a queda de Capitani, ele e Elinho tentaram deixar o país, atravessando a fronteira com o Uruguai. Foram, no entanto, presos pelo Exército uruguaio, que os soltou 
após interrogatório. Os dois se dispersaram: Elinho foi para o Rio Grande do Sul e Duarte voltou para o Rio de Janeiro, onde fez contato com um grupo de sargentos, "remanescentes do comando de subalternos que tentou uma revolta na Vila Militar, nos idos de 8 de abril, de 1964" (DUARTE, 2009, p. 82).

Duarte conheceu o sargento Barroso, da Marinha, e com ele realizou algumas ações, como a de transportar fuzis que conseguiram das Ligas Camponesas. Mas a permanência no Rio de Janeiro o deixava ansioso, pois não se sentia seguro. Como se encontrava escondido na casa do sargento Américo, membro do Partido Comunista Brasileiro, expôs a ele seus receios. Consultando a direção do Partido, Américo conseguiu que Duarte fosse enviado em segurança para São Paulo, por meio do juiz Carlos Sá, do Tribunal do Trabalho, que dirigiu o veículo, "mas, somente vim saber que era juiz muito tempo depois. Ele estava acompanhado da mulher Ditinha”. (DUARTE, 2009, p. 82)

Chegando a São Paulo, Duarte foi colocado em contato com o sargento Onofre Pinto, cuja moradia, no bairro do Ipiranga, estava cheia de sargentos do Exército, alguns já expulsos e outros ainda na ativa. Mais parecia uma "república de estudante".

Duarte se integrou a esse "coletivo do Ipiranga", que já estava em contato com Leonel Brizola, em Montevidéu. Depois de alguns meses (não diz quantos, "já mais de meados de $1965^{\prime \prime), ~ D u a r t e, ~ c o m ~ o ~ c o n s e n t i m e n t o ~ d e ~ O n o f r e ~ P i n t o, ~ v i a j o u ~ p a r a ~ M o n t e v i d e ́ u, ~ e n c o n t r a n d o ~}$ várias pessoas conhecidas, como Batistinha, do Comando Geral dos Trabalhadores - CGT, Darcy Ribeiro e outros. Sob a liderança de Brizola, estava sendo criado um movimento de “insurreição popular militar”, que chamavam de Movimento Nacionalista Revolucionário MNR. A esse movimento, nossos protagonistas se incorporaram. Quando os ex-militares tiveram contatos com Brizola, ele pensava em organizar movimentos insurrecionais, que atingiriam vários pontos do País, principalmente os quartéis e, com apoio popular, chegariam a seu ápice com a entrada de Brizola no Brasil e a tomada do poder.

Em entrevista a um jornal, o ex-sargento Amadeu Felipe conta que houve uma reunião de cerca de 50 pessoas, no Rio de Janeiro, a maioria sargentos do Exército, para "organizar a fase de organização da luta guerrilheira no campo brasileiro". Resolveram mandar emissários para expor tais planos a Leonel Brizola. Segundo Amadeu Felipe, "Brizola concordou com nosso plano de guerrilha, mas insistiu que haveria a possibilidade, antes, de se tentar a insurreição no Rio Grande do Sul”. (RIDENTI, 1993, pp. 212-213)

Em março de 1965, todavia, aconteceu uma insurreição, conhecida como "Coluna Cardim", liderada pelo Coronel do Exército Jefferson Cardim, comandando 22 homens, que partiu do Rio Grande do Sul, passou por Santa Catarina, chegando até o Paraná. Desejava-se 
a incorporação da população à Coluna, o que não ocorreu. Depois de confrontos com o Exército, percebeu-se que não havia condições para seguir em frente.

O fracasso dessa insurreição como também a repressão aos oficiais militares com quem Brizola mantinha contatos no Brasil levaram à revisão da estratégia revolucionária. Flávio Tavares conta quando Brizola aderiu à estratégia do foquismo, muito influenciada pela experiência cubana:

“Em meados de 1965, viajei a chamado 'urgente' de Brizola (...). Ele abandonara a ideia inicial de 'rebelião nos quartéis' e não necessitou de muitos argumentos para me convencer de que o foco de guerrilha era a nova alternativa. Brizola estava literalmente inundado pela concepção de guerrilha, lia revistas do Vietnã do Norte e me contou, inclusive, que fazia exercícios de tiro e assalto a baioneta. (seu instrutor, coronel Atilo Escobar, da Brigada Militar gaúcha, com formação convencional de quartel, mesmo sendo homem de pouca leitura, já estava lendo - ou prometera ler - o manual de guerrilhas do Che Guevara. Toda a veemência dos seus 43 anos concentrava-se em defender 'o foco'. Nesse quadro, ele me apresentou aqueles dois moços recém-chegados da 'ilha', tão bem treinados que já não eram gente, 'mas bichos como macacos, que ficam uma semana em cima de uma árvore, escondidos'". (TAVARES, 2005, pp. 199-200)

Os "dois bichos" que pareciam macacos eram José Duarte e Marcos Antônio da Silva Lima, que haviam chegado de Cuba recentemente, de quem falaremos adiante.

O Movimento Nacionalista Revolucionário era formado por várias tendências que almejavam derrubar a ditadura e se reuniram em torno da liderança de Leonel Brizola. Faziam parte desse movimento os nacionalistas que integravam o governo de João Goulart; os exmilitares subalternos que participaram dos protestos de 1961, 1963 (movimento de Brasília) e 1964 (movimento dos marinheiros); membros da POLOP, do Partido Socialista, da Ala Vermelha e da Ação Popular - AP, organização guerrilheira que já existia antes do golpe de 1964, com origens nos movimentos jovens da Igreja Católica.

Segundo Flávio Tavares, a AP teve participação fundamental no MNR, principalmente na intermediação entre a organização de Brizola e Fidel Castro.

"Betinho tinha trazido a primeira ajuda concreta, em dinheiro: dólares enviados por Fidel Castro, nenhuma quantia descomunal, apenas alguns milhares, suficientes para pôr em prática as tarefas iniciais de organização. Naquele primeiro ano e meio após o golpe, a AP era suporte ideológico e doutrinário de Brizola no exílio. Além de Betinho, estava em Montevidéu o goiano Aldo Arantes, que fora presidente da UNE e tinha transferido a sede dessa entidade do Rio de Janeiro para Porto Alegre na crise da renúncia de Jânio Quadros, em 1961, quando 
Brizola desencadeou a 'Campanha da Legalidade' pela posse do vice-presidente João Goulart. Desde então, Aldo se tornou um dos próximos mais próximos e Brizola o tratava com profunda admiração. Betinho era uma espécie de seu irmão siamês, preocupado com as subtilezas doutrinárias dessa organização (a AP) que nascera da JEC [Juventude Estudantil Católica] e da JUC [Juventude Universitária Católica], no ventre da Igreja Católica, mas que encontrara na 'plus valia' do marxismo o caminho terreno para estar ao lado dos oprimidos".

(TAVARES, 2005, pp. 122-123).

A aproximação de Brizola com Fidel Castro garantiu, além de dólares para viabilizar os focos guerrilheiros, treinamento de guerrilha na Ilha. Vários jovens foram enviados para Cuba, por intermédio desses contatos. Possivelmente, a origem desses treinamentos de brasileiros em Cuba esteja relacionada com as conversas que Marcos Antônio e José Duarte tiveram com Ernesto Che Guevara, no período em que permaneceram na Ilha.

Capitani relata diálogo com Brizola, assim que chegou ao Uruguai. Disse-lhe que seu plano de organizar insurreições era impossível naquele momento, pois as forças que acreditava possuir no Brasil já não existiam - "Foram desmanteladas, estão desorganizadas" (CAPITANI, 1997, p. 95) - e que o caminho deveria ser outro.

Assim que chegou a Montevidéu, com os dentes quebrados e muitas dores no estômago, Capitani foi morar numa casa abandonada. Era espaçosa, mas com problemas em sua estrutura, o que poderia causar uma tragédia a qualquer momento. Mesmo assim, conta Capitani, ali se estabeleceram ele e os vários marinheiros que chegavam do Brasil. Foi ali, também, que um exilado paraguaio consertou seus dentes e Cesar, um médico gaúcho, tratou de suas costelas e seu estômago. A convivência novamente com marinheiros levou Capitani a pensar que, ali naquele casarão, pudessem reavivar alguns intentos da saudosa AMFNB.

A precariedade do casarão levou seus "hóspedes" a se mudarem para uma casa que havia sido recentemente desocupada, cujo aluguel era pago por João Goulart. Aliás, nossos protagonistas contam que Jango e Brizola não se falavam no exílio, mesmo estando no mesmo país e muito próximos. Jango ajudava financeiramente os que precisavam, alugando casas ou garantindo a alimentação, mas sempre recolhido. Neguinho, a respeito, fala que

\footnotetext{
"Nenhum marinheiro jamais procurou, pode até isoladamente, mas como ex-marinheiro, ninguém procurou o Jango. Procuraram o Brizola, porque o nosso contato era com Brizola. A gente conhecia e confiava no Brizola. O governo de João Goulart, governo Trabalhista, governo Nacionalista. Mas ele não inspirava confiança como líder, essa é que é a verdade.
} 
Não inspirava. O Brizola inspirava confiança. Os marinheiros jamais procuraram e tivemos a oportunidade de encontrá-lo lá no exílio". ${ }^{66}$

A ideia de formar uma frente guerrilheira composta só por ex-marinheiros chegou a ser discutida pelos marujos. Muitos ex-sócios da AMFNB estavam se reunindo em torno de Capitani, no Uruguai, de Neguinho, em São Paulo, e de Antônio Duarte, no Rio de Janeiro. Quando os três se incorporaram ao MNR, eles encaminharam a maior parte desse efetivo para fazer treinamento em Cuba.

Capitani conta que a reunião de ex-marinheiros no Uruguai foi uma segunda tentativa, depois do Golpe, de reorganização da AMFNB:

"O primeiro contato com o Brasil foi o Neguinho e um estudante, o Josino. Ele tinha conseguido fixar-se em São Paulo, mantendo um bom relacionamento com vários grupos de oposição, inclusive estruturando um grupo de marinheiros. Em Montevidéu, a nossa turma já era conhecida. Com a chegada de mais alguns marinheiros - Amaranto, Severino e Hélio formamos um grupo. Inclusive a casa onde passamos a morar - em Pocitos, um bairro de Montevidéu - passou a ser chamada de 'Viet-Cong'. Ali ninguém nos incomodava. Éramos 'o pessoal da pesada, o pessoal que está defendendo a guerrilha'. Naquele momento, o trabalho mais importante era melhorar a organização e as comunicações. Neguinho foi até o Uruguai, preparamos a chegada de outros marinheiros. Depois do golpe, esta era a segunda tentativa de reorganização clandestina da Associação [AMFNB]". (CAPITANI, 1997, p. 97)

Após a fuga da Auditoria Militar, Neguinho foi para São Paulo e integrou-se ao MNR, tendo como função participar da cooptação de novos quadros dentre os marinheiros, enviá-los para o Uruguai e, posteriormente, para Cuba. Diz ele que ficou como um "aglutinador dos marinheiros e um elo também de ligação com, vamos dizer, os chefões, os caras da cúpula do governo de João Goulart", 67

Função parecida teve Antônio Duarte dos Santos. Assim que presenciou a queda de Capitani, e dos polopistas, Duarte e Élio tomaram o rumo do Uruguai. Na fronteira, no entanto, foram presos pelo Exército uruguaio, mas soltos em seguida, como já dissemos. Voltaram para o Brasil. Elinho foi para o Rio Grande do Sul e Duarte para o Rio de Janeiro. Do Rio, receoso com sua segurança, Duarte partiu para São Paulo e se juntou ao grupo de Onofre Pinto, o "Coletivo do Ipiranga". Retornando do Uruguai, no Rio de Janeiro, Duarte passou a recrutar companheiros marinheiros para o MNR. Nas palavras de Duarte,

\footnotetext{
${ }^{66}$ Entrevista a Flávio Luis Rodrigues. Maceió, 20 de julho de 2011.

${ }^{67}$ IDEM.
} 
"Aí, é nesse momento que está realmente bem fortalecido o MNR. Já mais de meados de 1965. Aí, quando eu voltei, já voltei dentro de uma missão que era recrutar as pessoas para esse exército do Brizola, que era mandar treinar em Cuba. Então, eu vim aqui para o Rio de Janeiro, aqui junto com o Cláudio de Souza Ribeiro, aqueles marinheiros mais conscientes $e$ que tinham sido da Diretoria [da AMFNB]". 68

Com a decisão de adotar a guerra de guerrilha, através de focos guerrilheiros, o Estado-Maior do MNR, composto por Leonel Brizola, Coronel Dagoberto Rodrigues, o exdeputado Neiva Moreira, o assessor no governo no Rio Grande do Sul, Paulo Schilling e o exdeputado pelo PSB, Max da Costa Santos (ROLLEMBERG, 2001, p. 28), resolveu organizar três focos no interior do Brasil, que contariam com a presença dos ex-marinheiros, nossos protagonistas.

Os focos eram: um no Brasil Central, que incialmente seria em Goiás, mas que depois foi transferido para Imperatriz do Maranhão, comandado por José Duarte, tendo Flávio Tavares na retaguarda e apoio do Partido Socialista; outro em Mato Grosso, próximo da fronteira com a Bolívia, liderado por Marcos Antônio da Silva Lima, com apoio da POLOP; e o foco guerrilheiro do Sul, liderado por Paulo Schilling, com o apoio da Ala Vermelha. O último foco, nas palavras de Flávio Tavares, era

"uma espécie de encantada menina dos olhos de Brizola, que lhe deu dadivosos fundos $e$ armamentos. Formado por antigos sub-oficiais do Exército, sob a chefia do ex-sargento Amadeu da Luz (neto de Hercílio Luz, a figura dominante da política catarinense nos anos 1921-30), o grupo tinha como área de eclosão o norte do Rio Grande do Sul e sudoeste de Santa Catarina, mas mudou os planos quando, no inverno de 1965, seu sub-comandante, o ex-sargento Manuel Raimundo Soares, foi preso, torturado e morto pela polícia em Porto Alegre". (TAVARES, 2005, p. 219)

Com esse imprevisto, o foco do Sul foi substituído por Caparaó, no Parque Nacional do Caparaó, região serrana localizada na divisa dos Estados de Minas Gerais e Espírito Santo. Comandado pelo ex-sargento Amadeu Felipe, contava com uma dezena de ex-militares, inclusive Capitani.

Capitani diz que os focos de Mato Grosso e da zona fronteiriça do Sul "tinham como objetivo manter a conexão com Che na Bolívia”. Isso sugere que os focos criados pelo MNR faziam parte de uma estratégia de revolução na América Latina, que passava por Cuba e pela ida de Guevara para a Bolívia. Ou seja, num determinado momento, vários focos se

\footnotetext{
${ }^{68}$ Entrevista a Flávio Luís Rodrigues. Rio de Janeiro, 11 de julho de 2012.
} 
levantariam na América Latina, tornando impossível o controle pelos EUA. Seriam vários Vietnãs. Se os EUA não puderam com um, imagine com vários!

Denise Rollemberg cita a entrevista que realizou com Paulo Schilling, em que ele foi categórico ao afirmar que as escolhas dos focos, principalmente o de Caparaó, não passou por entendimento com Cuba e que ficaram surpresos com a notícia da presença de Guevara na Bolívia. Também o socialista Bayard Boiteux, que coordenou o foco de Caparaó, foi taxativo ao afirmar que "Caparaó foi uma iniciativa exclusiva de brasileiros". (ROLLEMBERG, 2001, p. 36)

Do Coletivo que estamos estudando, três estiveram em Cuba para realizar treinamento de sobrevivência na selva e organização de focos guerrilheiros. Além de Capitani, sobre quem temos mais informações a respeito, também foram Marcos Antônio e José Duarte, que não deixaram qualquer registro sobre a experiência, pelo menos que seja de nosso conhecimento. $\mathrm{O}$ primeiro porque morreu durante a luta armada, e o segundo porque evita falar sobre o assunto.

Capitani sugere que sua ida para Cuba não passou pelo esquema MNR/Cuba, mas pelo grupo de militantes que já havia formado no Uruguai e no Brasil. Diz ele:

"Nesse cenário, surgiu a discussão sobre a necessidade de compor uma frente [enquanto estavam na casa conhecida como Viet-Cong]. Passamos a participar como mais um grupo interessado. Já tínhamos reaglutinado um grupo considerável no Brasil e no exterior. A frente foi aumentando, tomando forma e acolhendo de cristãos a trotsquistas. No Uruguai, nosso principal trabalho era com questões militares, organizando os grupos que fariam treinamento em Cuba. As negociações políticas ficaram para Marco Antônio, que estava no México. Ele se exilou na Embaixada dias depois do Golpe".

(CAPITANI, 1997, pp. 97-98)

O relato acima é oportuno porque alude à formação de um grupo de brasileiros exilados no Uruguai que não estava inserido no esquema do MNR e que tinha Cuba como referencial. Capitani chama esse grupo de Frente Popular. Tal entidade discordava das teorias insurrecionais de Brizola, defendendo a luta armada através de focos guerrilheiros, mesmo que a ideia foquista ainda não estivesse madura para ele. Segundo Capitani, "nosso objetivo era formar uma frente guerrilheira composta essencialmente por marinheiros e baseada na identidade política forjada na história da Associação [AMFNB]"” (CAPITANI, 1997, 101). A experiência da Associação sempre é recorrente nos relatos do coletivo que estudamos aqui. 
A narrativa chama atenção, também, ao dizer que era Marcos Antônio o responsável pelas articulações políticas do grupo, mesmo estando distante do Uruguai. Talvez isso explique a ida de Marcos Antônio e José Duarte para Cuba, fora do âmbito do MNR.

Capitani partiu para Cuba às vésperas do Natal de 1965, para realizar treinamento rígido por cinco meses.

"Tivemos aulas teóricas na cidade e depois fomos praticar nas montanhas. Voltamos à cidade e fomos separados em dois grupos para estudar mais teoria de guerrilha urbana e rural. $O$ curso dava algumas noções sobre armamentos, explosivos, minas e bombas". (CAPITANI, 1997, p. 99)

Em entrevista a Denise Rollemberg, Capitani conta que seu grupo ajudou a construir uma escola de treinamento, pois os cubanos treinavam os exilados de forma improvisada.

"Não havia uma escola organizada, construída com equipamentos, com especialistas. Era muito ainda no improviso, no idealismo, no romantismo. As coisas eram muito feitas dessa maneira. Começaram a estruturar uma escola de treinamento, de armamento, de explosivo, na época. Nós ajudamos a construir essa escola". (ROLLEMBERG, 2001, p. 32)

A permanência em Cuba, que passava por um processo de transição para o Socialismo, levou o grupo a ajudar os cubanos nas instalações de prédios e outras coisas mais. A sensação de estar contribuindo para a construção do Socialismo deve ter influenciado tais homens a definirem táticas de luta mais objetivas, que envolvessem uma organização mais ampla e com maiores recursos. Foi em Cuba, segundo o relato de Capitani, que esse grupo de marinheiros resolveu aderir ao MNR.

Há uma aparente contradição entre os relatos de Capitani e Flávio Tavares. Enquanto o primeiro fala que não concordava com as táticas de Brizola para fazer a revolução, baseadas na "insurreição popular", e que isto foi pessoalmente colocado, o segundo diz que nesse mesmo período em que Capitani conta ter encontrado Brizola e formado a Frente Popular meados de 1965 -, o ex-deputado federal e ex-governador do Rio Grande do Sul já era partidário entusiasta do foquismo. Isso sugere que, quando Capitani e seu grupo foram para Cuba, Brizola já era "foquista".

Com que fito, então, a Frente Popular, de que fala Capitani, foi criada? Se Brizola defendia as mesmas táticas da Frente, onde estava a contradição entre ambas? Talvez na concepção de revolução de Brizola, com a qual os marinheiros não concordavam. Para isso, não temos respostas. Mas existe mais uma indicação de contradição entre os relatos: na entrevista que Capitani nos concedeu, ele conta que já estavam no MNR quando os 
marinheiros resolveram fazer treinamento em Cuba. Pelo menos é o que entendemos através de seu relato:

"E a conclusão que se chegou no geral [entre os marinheiros expulsos e procurados pela polícia] é que tinha que partir realmente para luta armada e se preparar para isso, principalmente para guerrilha urbana. Surge o Brizola no Uruguai com o nacionalismo dele, com a ideia de invadir o Brasil. Ele nunca tirou essa ideia da cabeça. Ele achava que ainda tinha prestigio suficiente para fazer um levante militar e de massa. E não tinha. E alguns grupos se aliavam com o Brizola, né. E o Brizola era uma bandeira importante. Então tem um movimento que eles se organizaram, os grupos de marinheiros se organizaram em maior resistência, ligados numa certa coordenação com o Brizola. E o Brizola fundou o MNR, Movimento Nacional Revolucionário. Nós começamos a participar desse movimento e a nos preparar para a guerrilha urbana. Tanto que eu fui para Cuba fazer treinamento. Então surge uma nova realidade, esses grupos armados". ${ }^{69}$

Um pouco antes da partida do grupo de Capitani para Cuba, Marcos Antônio e José Duarte lá estiveram. Logo após o Golpe, exilaram-se na embaixada do México e, em seguida, partiram para aquele outro país. Não temos, infelizmente, informações sobre a permanência dos dois protagonistas em Cuba pelas razões já citadas.

Pensávamos que os dois marinheiros estivessem integrados ao MNR, quando partiram para Cuba. Somente em nosso Exame de Qualificação no Programa de Doutorado, tivemos informação, através do Prof. Dr. Wilson do Nascimento Barbosa, de que ambos foram por conta própria, a partir do exílio no México. Na ocasião, inclusive, o Professor Barbosa contou uma passagem envolvendo os dois marinheiros, que José Duarte lhe relatou: em uma noite em Havana, os dois passeavam pelas ruas da cidade, quando tiveram uma surpresa ao ver Ernesto Che Guevara de sentinela diante do Ministério da Indústria. Seria ele mesmo? José Duarte, encafifado, perguntou ao guarda se ele era Che Guevara e este confirmou. Então, indagaram por que estava ali de sentinela e ele respondeu que todos ali cumpriam a guarda, inclusive o ministro. Solicitando uma audiência, Guevara pediu para que viessem no dia seguinte. Pontualmente, lá se apresentaram, diante de Che, atrás da mesa, sem ao menos cumprimentálos. Falaram ao ministro que queriam fazer treinamento de guerrilha, para derrubarem a ditadura no Brasil. Guevara respondeu: "vocês não deveriam se meter nisto. Vocês deveriam cuidar da vida de vocês. Porque um guerrilheiro precisa ser um sujeito muito rígido, muito duro, forte, saudável. Vocês não estão preparados para isso”. Nossos marinheiros, um pouco decepcionados insistiam que conseguiriam. Então Che arrematou: "um guerrilheiro precisa

\footnotetext{
${ }^{69}$ Entrevista a Flávio Luis Rodrigues. Porto Alegre, 12 de julho de 2011.
} 
ter um corpo de aço numa alma de aço”. Cabisbaixos, desiludidos, não tendo como argumentar, os dois veem uma cena inusitada: Che Guevara abre uma gaveta da mesa, tira uma bombinha de asma e aspira-a prostrado. Então, percebendo o embaraço dos visitantes, Che Guevara pergunta, com um sorriso maroto: vocês quase acreditaram, n'é? Todos riram e Guevara despachou os dois para combinarem o treinamento.

No retorno de Cuba, Marcos Antônio e José Duarte se integraram ao esquema brizolista, ocasião, inclusive, em que Brizola se referiu a eles como "dois bichos", que podiam ficar sobre uma árvore por uma semana, escondidos.

Como dissemos, Marcos Antônio assumiu o comando do foco de Mato Grosso e José Duarte o do Brasil Central. Junto com Marcos Antônio, foi seu companheiro dos tempos da Associação, Otacílio Pereira da Silva. Pouco se conhece sobre como e com quem Marcos Antônio organizou o foco de Mato Grosso. Sabemos apenas que não apresentou êxito.

Quanto a José Duarte, Flávio Tavares explica como foi a organização do foco do Brasil Central, cujo comandante era Duarte e que teve por membros vários marinheiros.

"Teríamos de esconder dois 'comandantes vindos da ilha' [José Duarte e um estudante goiano, chamado Olímpio] e criar-Ihes o suporte para, a médio prazo, implantar um foco combatente, escolhendo a área, conseguindo as armas e o resto do pessoal. Os fundos financeiros, liberados diretamente por Brizola, viriam de Montevidéu, o que era uma forma de disfarçar a procedência cubana daquelas cédulas de 100 dólares (pouco usuais na época) que nos chegariam meia dúzia de vezes". (TAVARES, 2005, p. 201).

Flávio Tavares levou os dois "comandantes" para seu apartamento e lá ficaram, enquanto esperavam recursos financeiros e, principalmente, o recrutamento de mais homens para a tarefa. Após dez dias de estada em Brasília, sozinhos e não podendo deixar o apartamento antes da noite, os dois se impacientaram. O estudante saiu para visitar os pais e não mais voltou e José Duarte, cada vez mais tenso, se desesperou ao ver a polícia cercando o prédio em que estava. Ligou, então, para Tavares relatando o que estava acontecendo, dizendo-se cercado e preparado para saltar pela janela, "mesmo que seja me atirando”. Ele estava no terceiro andar. Flávio Tavares conta que foi rapidamente para o local e constatou que "Victor" estava certo, pois havia muitos policiais. Perguntando sobre o que havia acontecido, disseram-lhe que os policiais estavam cercando o prédio para impedir que os "sem teto" invadissem os apartamentos que se encontravam vazios.

José Duarte, por conseguinte, parte para o interior de Goiás, juntamente com o camponês Zezé. Os dois tomaram o rumo Norte do estado, mas logo se desentenderam. Tavares dá nova missão a Zezé, seguindo orientação da cúpula do MNR, a de construir um 
campo de pouso de 600 metros, onde pudesse descer um avião DC-3 vindo da Guiana, carregado de armas. Depois de sete meses Zezé comunica que já havia construído o campo, porém com 500 metros. Tavares avisa o QG brizolista e não obtém mais retorno.

Enquanto isto, Victor se estabelece em Imperatriz, no estado do Maranhão e aguarda os companheiros guerrilheiros. Chegaram 15 homens e foram se entrosando, com o cuidado necessário para não levantar suspeitas. Tavares conta:

"No início, 15 homens que chegaram aos poucos e foram se encontrando e se reunindo como se houvesse travado amizade por lá mesmo, ou na viagem longa pela estrada esburacada, que alternava pó e lama. [...] os recrutados em Brasília eram todos ex-fuzileiros navais ou exmarinheiros, filhos de camponeses do Nordeste, tal qual Víctor, mas sem nenhum curso 'na Ilha'. [...] não tinham a destreza de Víctor em desarmar e rearmar uma carabina de olhos fechados, mas repetiam ao pé da letra o aprendizado daqueles treinamentos exaustivos, em que emagreciam muitos quilos e sabiam tudo de combate, sabotagem ou sobrevivência na selva, mas desconheciam tudo o que um camponês sabe do mato, da terra, das plantas, da lua ou da vida". (TAVARES, 2005, pp. 215-216)

Chama a atenção no relato acima a quantidade de ex-marinheiros que participaram da formação desse foco. O MNR, de fato, tinha um componente militar muito forte. $\mathrm{E}$ a tendência dos marinheiros expulsos da Marinha que entraram na luta armada foi seguir os diretores da antiga AMFNB, nossos protagonistas.

Apesar de os marinheiros serem, geralmente, filhos de camponeses, não tinham mais a familiaridade com a vida no campo. Ao mesmo tempo, os homens treinados em Cuba tinham uma "visão caolha da realidade". Nas palavras de Tavares, "estavam impregnados da ideia de desembarcar do Granma e começar a guerrilha e a revolução nas semanas seguintes, mesmo não tendo contra quem lutar”. Logo, as contradições apareceram. Tavares atribui a saída de José Duarte do foco aos desentendimentos desses dois grupos que se formaram em Imperatriz: dos marinheiros e dos "comandantes" treinados em Cuba. Os primeiros, por terem mais facilidade de inserção no mundo rural, dadas suas origens. Os segundos, por estarem ansiosos para começar a guerrilha, para a qual foram treinados. Tavares não fala como Duarte reagiu a esses desentendimentos, mas registra que ele fazia muitas críticas ao andamento da preparação do foco.

Antônio Duarte conta que, quando esteve em Imperatriz, só encontrou dificuldades e muito pouca ajuda do QG do MNR.

"A cidade escolhida foi Imperatriz, às margens do Rio Tocantins, cortada pela estrada BelémBrasilia. Não havia recursos. Sobrevivíamos de alugar a 'Kombi Wolksvagnen', de propriedade 
de Jovino [Jovino Morais Júnior, estudante comunista que acompanhou Antônio Duarte até Imperatriz. Não traz mais detalhes], para transportar pessoas de lugares dentro do município. Não existia transporte coletivo, naquele mundo quente da Amazônia. Depois de algum tempo, nos retiramos da região por pura incapacidade de sobrevivência. Deixamos os contatos para outros do MNR, que nos substituíram. Jovino voltou a São Paulo e depois se refugiou no Uruguai". (DUARTE, 2009, p. 85)

Tais dificuldades e desentendimentos se agravaram, e a questão foi levada para uma reunião de avaliação da evolução dos focos, ocorrida em Montevidéu, em fevereiro de 1966. Flávio Tavares, presente à reunião, conta:

"Estávamos em plena crise de implantação do foco no Brasil Central quando Pedrinho [Leonel Brizola] nos convocou para uma 'reunião urgente' no Uruguai, em fevereiro de 1966, e eu compareci com Victor [José Duarte]. 'Pedrinho' era o nome que dávamos a Brizola. Num casarão junto à praia de Carrasco, em Montevidéu, alugado para o veraneio, encontramos de fato um 'congresso' dos três 'focos' guerrilheiros do MNR com a cúpula que rodeava Brizola no exílio. (...) Expus nossas dificuldades de integração, Victor acrescentou outro tanto e, logo, o representante do segundo foco, um ex-fuzileiro vindo do Mato Grosso, próximo à fronteira com a Bolívia, descreveu com otimismo a situação da sua área. Ao longo da reunião, porém, admitiu que as dificuldades eram imensas, iguais às do Brasil Central. Em contraste com esse cauto pessimismo, ouvimos também uma exuberante análise de otimismo, que nos fez sentir pequenos e incapazes:

- Estamos em crise, sim, mas em crise de crescimento! - começou dizendo Paulo Schilling, que, com o ex-deputado Neiva Moreira e o coronel Dagoberto Rodrigues compunha a cúpula brizolista no exílio. Especialista em economia agrária, Schilling era o contato do foco guerrilheiro do Sul".

(TAVARES, 2005, pp. 218-219)

Em fevereiro de 1966, enquanto Capitani estava em Cuba e Neguinho em São Paulo, no esquema de cooptar homens para o MNR, em Montevidéu, a cúpula da organização discutia as dificuldades na implantação dos focos. Apesar das avaliações negativas dos “comandantes", o otimismo ainda prevalecia no QG brizolista.

Na citação de Tavares, fica a suspeita de que o "representante do segundo foco, um ex-fuzileiro vindo do Mato Grosso" era o próprio Marcos Antônio. Mais à frente, em seu livro, ele se refere a Marcos Antônio como "do foco mato-grossense" e ex-fuzileiro novamente, quando na verdade Marcos era marinheiro. 
De qualquer forma, de volta a suas regiões, os "comandantes" continuaram tendo problemas. O foco de Imperatriz, em que pesem as dificuldades, aparentemente crescia com a chegada de mais homens, geralmente ex-marinheiros. Porém, "inchava sem crescer", nas palavras de Tavares. Resolveram, assim, dividir o grupo e uma coluna entrou selva adentro "para conhecer o terreno em busca de uma base de treinamento e operações".

Em fevereiro de 1967, as dificuldades do foco de Imperatriz, fizeram José Duarte voltar para Brasília. Coincidentemente, nesse mesmo momento, Marcos Antônio retornou de Mato Grosso definitivamente, já que as condições de formação de um foco mostravam-se inexequíveis. Tomou o rumo de São Paulo.

Em Brasília, José Duarte resolveu partir para São Paulo e, pedindo uma mala para a faxineira do apartamento de Flávio Tavares, ela pegou a primeira à vista. Mal sabia Victor que a mala era de fundo falso, e nele havia várias notas de cem dólares que foram enviadas por Brizola a Flávio Tavares.

Em São Paulo, José Duarte e Marcos Antônio se encontraram e foram morar provisoriamente no Bairro do Limão, com os dois ainda no esquema do MNR. Ficavam amoitados durante o dia e à noite saíam para espairecer. Esperavam orientações para novas ações. Numa noite, no quarto dia da chegada de José Duarte a São Paulo, 8 de fevereiro de 1967, os dois amigos saíram para um encontro com Neguinho e outras pessoas do MNR. Já sabiam da prisão de Antônio Duarte e podemos intuir que estavam chateados, principalmente o irmão José Duarte. Antes de seguirmos com a narrativa envolvendo Marcos Antônio e José Duarte, convém falarmos da prisão de Antônio Duarte e, mais à frente, retornarmos aos dois transeuntes em São Paulo.

Quando Antônio Duarte voltou de Imperatriz, foi para o Rio de Janeiro com a mesma missão de Neguinho em São Paulo, a “de receber os 'soldados' do MNR e de encaminhá-los para o Uruguai, para a devida viagem de treinamento em Cuba". No Rio, Antônio Duarte se encontrou com o ex-marinheiro Cláudio de Souza Ribeiro e começaram a "remontar a organização marinheira". Eram muitos os marinheiros que tinham sido expulsos, ou aguardavam nos quarteis de marinheiros serem licenciados. Segundo Duarte, muitos deles se ligaram ao Partido Socialista do professor Bayard Demaria Boiteux, que efetivamente os ajudava

"Com dinheiro para passagens, para articulações. Dinheiro, assim, para ajudar esses, no caso, os marinheiros que estavam lá no quartel de marinheiros para serem expulsos. Esse pessoal, por exemplo, ainda comia lá [na sede do Partido, do PSB] e tudo, mas eles tinham outros 
problemas: como arranjar emprego. Muitos deles até arranjaram, através desse grupo do Bayard, do grupo do Partido Socialista". ${ }^{70}$

Antônio Duarte e Cláudio Ribeiro faziam contatos com esses marinheiros e, através de entrevistas, preveniam que a realidade da guerrilha era difícil,

"A minha estrutura aqui, junto com o Cláudio, era mandar todos aqueles que nós fazíamos uma entrevista com a pessoa. Aqueles que queriam ir para luta, iam. Nós recrutávamos, mas discutíamos com eles: 'olha, vocês vão ter que sair do Brasil, abandonar o emprego. Nós estamos organizando uma resistência e é isso...' O cara escolhia." ${ }^{\prime 11}$

Num destes contatos, porém, o recrutado, que tinha uma vida legal - trabalhava no Banco da Bahia -, pediu a Duarte "para ajudar a irmã dele a tirar umas coisas de um lugar onde ele morava” (pois já tinha abandonado o local). Enquanto Antônio Duarte estava dentro da casa, o CENIMAR a cercou e o prendeu. A prisão de Antônio Duarte, ocorrida em junho de 1966, demonstra como, naquela época, os militantes não tomavam ainda cuidados necessários para se preservarem. Duarte atribui sua prisão a esses recorrentes descuidos: "naquele momento as estruturas eram muito precárias, não havia uma prática de ilegalidade assim rígida, orgânica, partidária, com certa experiência, e nós fazíamos só improvisações", 72

Como o CENIMAR soube de sua presença na casa? Duarte acredita que, por ter uma vida legal, o jovem recrutado certamente deu seu endereço ao Banco onde trabalhava, como é praxe. De posse do endereço, o serviço secreto da Marinha começou a monitorar a casa e, possivelmente, pediu para a vizinha avisá-lo da presença de alguma pessoa no local. E a vizinha avisou.

Antônio Duarte foi levado para o presídio da Ilha das Cobras, onde passou dois meses sendo interrogado. Seus inquiridores queriam notícias de Anselmo. Perguntaram a ele, "vocês do Partido", onde tinham enterrado o corpo de Anselmo. Acreditavam que o "Partido" - PCB - tinha mandado matar Anselmo e dar sumiço no cadáver.

Em agosto de 1966, Duarte chegou ao Presídio Lemos Brito, para cumprir pena que totalizaria 15 anos! "Começava uma nova vida. A vida no cárcere foi uma escola de política e opressão. Encerrou-se em definitivo minha carreira na Marinha. Começava minha trajetória política" (DUARTE, 2009, p. 89). Sobre essa "vida no cárcere" falaremos no próximo capítulo.

\footnotetext{
${ }^{70}$ Entrevista a Flávio Luis Rodrigues. Rio de Janeiro, 11 de julho de 2012.

71 Idem.

${ }^{72}$ Idem.
} 
Antônio Geraldo Costa, em São Paulo, passou por apuros nesse momento em que os órgãos de informações começaram a adquirir mais recursos e experiência. Duarte confirma o perigo pelo qual Neguinho passou, ao mesmo tempo em que reforça a forma como ele militava para o MNR:

"Quando eu fui preso aqui, ele quase era preso em São Paulo, porque os caras pegaram algumas dessas pessoas, né?, e muitos contatos. E ele, de lá de São Paulo, despachava as pessoas para o Rio Grande do Sul junto com o Onofre [ex-sargento Onofre Pinto]. Eles escondiam o pessoal. Eles tinham um sistema orgânico de locais de esconderijos e depois de transporte". $^{73}$

Quanto a Viegas, já expulso da Marinha, levava uma vida clandestina, trabalhando n' O Jornal de Rio de Janeiro, mas não envolvido na guerrilha. Esperava o resultado de seu julgamento, que certamente o condenaria, e a esse respeito não tinha ilusões. A expectativa era saber a quantos anos de prisão seria condenado. Quando chegou o dia do julgamento, veio o resultado: três anos de reclusão! Diante disso, Viegas expôs para seu chefe a situação e ele, solidariamente, o transferiu para Florianópolis. Mas sua insegurança aumentou quando encontrou um amigo, oficial da Marinha, que sabia de sua condenação e lhe sugeriu que deixasse a cidade e partisse para uma maior, onde o anonimato o protegeria. No mesmo dia, Viegas retornou para o Rio de Janeiro.

No Rio de Janeiro, Viegas sabia que não poderia se expor e seu chefe, n' O Jornal, ajudou-o nesse sentido, dando-lhe tarefas a serem realizadas noutros estados. No entanto, quando estava preparando sua ida para Fortaleza, onde faria uma matéria encomendada pelo chefe, soube que sua mulher havia sofrido um aborto involuntário, o que exigia sua presença para levá-la ao hospital. Desmarcada a viagem, e de volta do hospital, Viegas e a mulher foram para a casa, para que ela pudesse se restabelecer. Nesse momento tão difícil para ambos, sofrendo com o ocorrido, toca a campainha: "soou forte, insistente, no interior daquele apartamento da Vila Valqueire". Eram os policiais da delegacia Invernada de Olaria procurando por Viegas. Não adiantou Leda, sua mulher, dizer que Viegas não estava. Um dos policiais, à paisana, inventou que trabalhava num escritório de cobrança e estava ali para comunicar a Viegas que ele deveria saldar uma dívida, pois senão seu nome iria para o Serviço de Proteção ao Crédito. Viegas mordeu a isca, e saiu para dizer que não fizera compra alguma. Foi preso no dia 8 de fevereiro de 1967.

Nesse mesmo dia, em São Paulo, Marcos Antônio e José Duarte caminhavam para um encontro com Neguinho e outros integrantes do MNR quando, a duzentos metros do endereço

\footnotetext{
${ }^{73}$ Idem.
} 
marcado, uma radiopatrulha policial passou por eles bem devagar e resolveu interceptá-los. A reação dos dois foi a pior possível. Pensando terem sido reconhecidos, os dois correram dos policiais, aumentando as suspeitas de que eram marginais e, por isso, levados à delegacia para averiguação.

Neguinho diz que foi ideia sua trazer os dois para São Paulo e encaminhá-los para outras missões. Para isso estava marcada a reunião.

“(...) eu estou falando porque participei dessa decisão: 'vamos retirar os companheiros de Mato Grosso. Eles se retiram e se espalham para outras regiões'. O Zé Duarte e o Marco Antônio, vieram para São Paulo para me encontrar, a mim e outros companheiros, $e$ aconteceu o incidente deles serem confundidos como marginal, quer dizer, a polícia olhou assim, 'vamos ver esse cara aí'. O Marco Antônio, um crioulo, quer dizer, crioulo não, mulato né, fortão, chamava muita atenção. (...) O Marcos Antônio e o Duarte, Zé Duarte, quando chegaram a São Paulo, eles foram para um endereço e, ao cruzar a rua, passou um carro da patrulha. Eles olharam, aquele jeito, eles estavam meio com medo, não conheciam bem, porque o cara vem chegando de Mato Grosso, não conheciam bem São Paulo. Aliás, não conheciam bem não, não conheciam São Paulo, porque São Paulo dá medo. (...) Então deu o desastre com eles, foram confundidos com bandidos comuns, porque a polícia parte do princípio que, só porque você é mulato, tem cara de índio e está meio assustado, 'pô, o cara é bandido', foi isso que aconteceu com eles. Eles estavam perto do local para onde eles iam, a distância de dois quarteirões". ${ }^{74}$

Que dia este 8 de fevereiro de 1967! Dois revolucionários e um simpatizante da guerrilha presos por tolice! Viegas, porque não resistiu à curiosidade da história contada pelo estranho: "Leda hesitou. Senti seu embaraço e apareci frente à porta, intrigado com a história. Em parte por sentir os brios feridos. Afinal, não havia nada e nem devia a ninguém”. Dando as caras, foi logo preso. Marcos Antônio e José Duarte também erraram, segundo Neguinho, pois tinham a recomendação de não andarem juntos. Nas palavras de Neguinho:

"E caíram de graça na mão do CENIMAR, diante da reação. Uma coisa assim, um incidente terrível! Eles não estavam psicologicamente preparados para se movimentar em São Paulo. Primeiro que eles tinham que seguir instrução: Marco Antônio e Zé Duarte, quando chegassem a São Paulo, não fossem os dois juntos ao mesmo tempo para o local. Cometeram esse erro, de sempre os dois estarem juntos". ${ }^{75}$

\footnotetext{
${ }^{74}$ Entrevista a Flávio Luís Rodrigues. Maceió, 19 de julho de 2011.

75 Idem.
} 
Chegando à delegacia, tentaram de todas as formas convencer o delegado de que não eram quem ele pensava serem. Dizendo virem de Mato Grosso, não conseguiam, todavia, responder ao delegado o que estavam fazendo em São Paulo. A situação complicou mais quando falaram a verdade: eram revolucionários. Nesse caso, já não era da competência do delegado. Quando ele falou que os enviaria para o DOPS, e isso significaria serem despachados para o CENIMAR, os dois tentaram barganhar com a autoridade. Nas palavras de Flávio Tavares,

"Ao anoitecer, saíram caminhando da favela onde se hospedavam na zona oeste e, ao avistarem uma radiopatrulha, correram, dominados pelo reflexo condicionado do horror à polícia. Marco Antônio, negro, e Víctor, rosto indígena, foram presos metros adiante, confundidos com traficantes e levados a uma delegacia comum. Ambos tinham documentação apócrifa mas perfeita e tentaram convencer o delegado a soltá-los, explicando que eram perseguidos políticos. E foram adiante: além de todo o dinheiro que traziam (e que fora arrebanhado de imediato), se comprometiam a entregar-lhe ainda mais. O policial pensou por alguns instantes, excitado, e logo Ihes disse 'não', que os entregaria ao DOPS 'para subir na carreira'". (TAVARES, 2005, pp. 221-222)

No dia seguinte, 9 de fevereiro de 1967, a prisão de nossos protagonistas já era notícia de jornais. O jornal $O$ Estado de São Paulo publicou, em sua página 10, matéria com a manchete "Presos dois subversivos":

"quando perambulavam pelas vias públicas do bairro do limão, foram presos por agentes da delegacia de repressão à vadiagem ontem dois subversivos que já estavam condenados pela justiça militar. Marcos Antônio da Silva Lima e José Duarte dos Santos, que foram dirigentes de Associação dos Marinheiros e Fuzileiros Navais do Brasil até a eclosão do movimento de 31 de março, foram encaminhados ao DI, de onde deverão ser levados sob escolta para Guanabara. O primeiro está condenado a doze anos de prisão e o segundo a dois anos e seis meses. Ambos tinham documentos falsos, que afirmaram terem sido fornecidos por um certo 'comitê de repatriação', que estaria agindo na fronteira do Brasil com o Uruguai, de onde ambos vieram".

Segundo Flávio Tavares, que ficou chateado por perder as centenas de dólares que estavam na mala de fundo falso, Marcos Antônio e José Duarte convenceram o CENIMAR de que haviam chegado de Cuba no dia anterior e que, já condenados pelo inquérito militar, foram enviados diretamente para a penitenciária. Neguinho conta que os dois amigos não "abriram" o ponto de encontro, o que poupou vários militantes de serem presos, inclusive ele. 
Enquanto os dois foram encaminhados para a Penitenciária Milton Dias Moreira e logo transferidos para a Penitenciária vizinha, a Lemos Brito - penitenciárias que faziam parte do Complexo Penitenciário Frei Caneca, já implodido -, onde já se encontravam vários marinheiros, inclusive Antônio Duarte e Antônio Prestes de Paula, Pedro Viegas foi remetido para a Delegacia de Vigilância e Capturas da Rua Marechal Floriano, e logo transferido para o Presídio do Estado da Guanabara (PEG). O que presenciou ao ser depositado numa cela de presos comuns o deixou estarrecido: "Éramos cerca de 30 presos socados numa sala de paredes revestidas com azulejos brancos até o teto e com janelas pelas alturas, fora do alcance visual". Pouco depois, foi transferido para outra cela, que seria a definitiva. Viegas descreve seu novo aposento:

"Do teto, pendiam cordas improvisadas em que penduravam sacos de roupas e outras tranqueiras. Eram presas no outro extremo à grade do teto, de ferro, fixada em toda a área da cela para impedir tentativas de fuga. A um canto, uma mureta tornava menos devassada a 'boca do boi', isto é, a privada. Os odores misturavam-se, nauseantes: suor, urina, fezes, cigarros... Mas o que mais impressionava eram as figuras humanas. No centro da cela, estava um grupo com toucas de meias femininas enterradas na cabeça, cobrindo as orelhas. Ninguém 'deu bola' para o recém-chegado. Seus componentes empenhavam-se num jogo de cartas. (...) As paredes laterais e em especial os cantos eram privativos dos 'considerados', pessoas com penas altas à espera de transferência para as penitenciárias, em geral envolvidas em assassinatos, latrocínios e outros crimes hediondos. Os estrados de madeira, que cobriam o cimento do chão e serviam de cama, eram removidos a cada manhã, exceto os que contornavam as paredes. Alguns armavam tendas com lençóis, para maior conforto e alguma privacidade. Era também sinal de prestígio. O 'miolo' era reservado aos 'otários', aqueles que não pertenciam ao mundo do crime e que, por qualquer infortúnio, encontravam-se ali. Por essa forma organizativa, os 'otários' deitavam-se mais tarde $e$ levantavam-se mais cedo, pois seus estrados eram os últimos a serem colocados à noite e os primeiros a serem retirados ao amanhecer, para abrir passagem à movimentação do dia.

Uma cena particular chamou-me a atenção ao pôr os pés dentro da cela. Num dos cantos como já disse, um dos bastiões de privilégio - estava deitado um tipo forte, pelos 30 anos de idade, branco, com traços ibéricos. Havia acabado de tomar banho, outro privilégio (do cano sem chuveiro poucas vezes vertia água, cujo uso, quando acontecia, era prioridade dos 'considerados'). Completamente nu, um crioulo, do tamanho de um armário, o abanava com uma toalha. O homem branco sentia calor e tudo o que queria era se refrescar. Nada de homossexualismo, mas de poder mesmo. $O$ crioulo havia cometido algum deslize na cela e 
seu castigo era aquele: servir de babá ao 'xerife'. Pura subversão, porque na cadeia a maioria é negra e se alguém tem que bancar o escravo é o branco. A menos que este seja de valentia reconhecida, para o que conta seu currículo quando em liberdade. E aquele branco era singular. Ele era o 'xerife', uma espécie de delegado da direção da prisão na cela. Um líder. Todos o obedeciam. E digo líder porque não seria suficiente que a direção da prisão designasse este ou aquele nome para a função. A massa carcerária teria que aceitá-lo. 0 designado poderia até morrer se não fosse aceito e se a direção insistisse em impor seu preferido pelo simples uso da autoridade. Aquele era conhecido como 'Jaime da Lalá'". (VIEGAS, 2004, p. 34)

Viegas presenciava cenas de horror que nunca imaginou existirem: aquela promiscuidade, aquela podridão humana, aquela realidade que custou a aceitar. Essa experiência seria determinante para seu ingresso na luta armada. Mas o que mais o chateava era sua permanência num presídio, quando deveria, por já estar condenado, ser encaminhado para uma penitenciária. Também o motivo de sua condenação a três anos de prisão: um artigo que escreveu no jornal da AMFNB, A Tribuna do Mar, no início de 1964.

Para passar o tempo, Viegas escrevia cartas para os presidiários enviarem aos familiares. Isso lhe dava certo respeito, não o suficiente, entretanto, para ser promovido a um 'considerado'.

Numa terça-feira, dia de visitas, quando os presos recebiam doces, bolos, frutas, comida e várias outras coisas de seus familiares, aconteceu um incidente que atingiu, indiretamente, Pedro Viegas. Depois da visita, após os familiares se retirarem, havia sempre a revista que os policiais faziam nos novos pertences dos presos. Nesse dia, porém, os policiais exageraram na maldade. E a pior foi contra Jaime da Lalá, o "xerife". Segundo Viegas:

"Jaime havia recebido muitas coisas, como lençóis e outras peças de roupa e farta quantidade de frutas e doces. Os carcereiros, como se movidos por algum ódio muito especial, exageraram na dose: misturaram tudo, incluindo nisto doces e caldos com roupa. Puseram-no completamente nu e a inspeção no seu corpo não poupou o mais recôndito dos orifícios. Fizeram, sob ameaças de pancadaria, com que ele abrisse as nádegas e não se satisfizeram com um exame visual: meteram o dedo no seu ânus. Foi humilhação demais para o líder. Tudo ficou um tanto mais suspeito quando, inspecionado o Jaime, a revista foi encerrada e todos os presos conduzidos às respectivas celas".

(VIEGAS, 2004, p. 63)

Voltando à cela, a conversa girou em torno da humilhação de Jaime. Por que teriam feito aquilo com ele? Ordens da diretoria para desmoralizá-lo? De qualquer forma, os detidos 
da cela procuravam uma forma para vingarem-se da direção. E encontraram a solução em Viegas. Pediram, então, para que Viegas relatasse o ocorrido à imprensa. Claro, Viegas tergiversou. Como poderia relatar maus tratos de policiais contra os presos e, ainda por cima, de que eles, policiais, introduziam drogas no presídio? O que fariam os policiais e os traficantes com Viegas?

Mas ele teve outra ideia, que provocaria uma reviravolta em sua vida carcerária: Viegas mandaria mensagem para a grande imprensa, denunciando a aberração de estar num presídio para presos comuns, quando deveria, por ser preso político, jornalista e já ter sido julgado, estar numa penitenciária. Isto daria oportunidade para a imprensa ter conhecimento das condições gerais dos presos e das arbitrariedades da direção do presídio. Todos concordaram com a ideia, mas como viabilizá-la? Viegas expôs seu plano:

"Basta que se espere duas visitas. Na primeira, enviaremos para fora alguns pontos para serem usados numa reportagem a ser publicada pelo menos em dois jornais, no mesmo dia. Esse dia deve ser o de visitação, para que não haja revide. Na segunda, a reportagem será publicada e se verá, logo cedo, o que acontecerá. À tarde virão as visitas, e a direção do presídio não disporá de muito espaço para tomar atitudes mais violentas. Se tomar, estará recortando um pedaço de céu que poderá Ihe cair na cabeça". (VIEGAS, 2004, p. 65)

Viegas pôs-se ao trabalho e, na primeira visita, despachou seus escritos. Na segunda, o dia amanheceu tenso! Além de ameaças a Viegas pelos policiais, também proibiram a entrada de jornais no presidio, sinal de que houvera a publicação. Segundo Viegas, Jornal do Brasil, Correio da Manhã e Última Hora publicaram matérias sobre o presídio. E os policiais tinham razão de sobra para estarem furiosos com Viegas. O teor das matérias foi pesado para a direção do Presídio da Guanabara. Mas, pior ainda, para os policiais carcerários. O jornal Correio da Manhã, do dia 3 de março de 1967, trouxe em seu caderno 2, página 5, a denúncia de um "ex-detento" sobre a promiscuidade estimulada pelos guardas carcerários do presídio e o perigo que Viegas corria ali dentro. A manchete: "Ex-detento revela que há jornalista preso sob ameaças". Como se fosse relato de um “ex-detento", a matéria delatava:

"Pedro corre perigo, pois no ambiente em que foi atirado, entre ladrões, assassinos, traficantes de maconha e toxicômanos, prevalece a lei da força e não há qualquer garantia da parte dos policiais que ali servem". E continua, "o tráfico da maconha, as brigas cotidianas e a total omissão dos policiais carcerários, de modo geral presos pelo suborno a marginais tidos como perigosos pela própria justiça, são as ameaças de todo instante a quem é estranho ao meio, conforme o caso do jornalista".

Jaime da Lalá estava vingado e Viegas apreensivo com o que poderia acontecer. 
Logo depois da visitação, contudo, o diretor do presídio mandou chamá-lo. Diante dele, tenso, Viegas ouviu que seria transferido naquela mesma tarde. Foi a sua cela recolher seus pertences e despedir-se dos amigos, e dirigiu-se para o salão onde os presos se comunicavam com seus advogados. Lá estava Paulo Goldrajch, enviado por jornalistas, a esperá-lo. Viegas foi transferido para a Penitenciária Milton Dias Moreira, naquela mesma tarde e, posteriormente, para a Penitenciária Lemos Brito.

Depois de ficar uma semana incomunicável, como era costume para aqueles que chegavam à Penitenciária Milton Dias Moreira, Viegas recebeu em sua cela uma visita inesperada: era Antônio Prestes de Paula a lhe dar as boas-vindas. Contou-lhe que trabalhava como assistente do médico na seção de Biopsicologia da penitenciária, e que já estava marcado, para o dia seguinte seu teste biopsicológico.

Quando Viegas pode sair da cela, encontrou vários amigos do tempo da AMFNB, como Antônio Duarte. Ficou impressionado com o que presenciou: "a situação de abandono dos ex-marinheiros e ex-fuzileiros navais condenados era completa". O Coletivo estava ressurgindo, com todos seus integrantes na mesma cadeia. Quem poderia imaginar que isto ocorreria? Faltavam apenas Capitani e Neguinho.

Vamos entender como Capitani acabou por integrar o Coletivo na Penitenciária Lemos Brito.

Enquanto estava em Cuba, Capitani encontrou-se com Marcos Antônio, que lhe comunicou que estavam preparando focos guerrilheiros no esquema do MNR e que eles, com treinamento de guerrilha em Cuba, deveriam participar: "Nós temos um problema no Brasil. Temos outras frentes guerrilheiras que não têm ninguém treinado em Cuba na arte do foco. E precisamos que alguém vá compor esses grupos”. (COSTA, 2007, p. 129)

Retornando de Cuba, por volta da metade do ano de 1966, Capitani passou pelo Uruguai, onde teve uma conversa com Brizola, naqueles termos em que tivera com Marcos Antônio. Pensava que iria com Marcos Antônio e outros amigos marinheiros para o Mato Grosso. Brizola, no entanto, pediu-lhe para integrar o foco de Caparaó, pois a frente era composta por sargentos que não tinham treinamento de guerrilha. Capitani concordou e começou a se preparar para partir.

Caparaó já estava sendo estudada desde antes do Golpe de 1964 pelos polopistas. Com as seguidas baixas dos militantes da POLOP, esta passou o "ponto" para o MNR.

As pessoas que organizaram o foco de Caparaó, e que seriam seus comandantes, já haviam tentado criar um foco na Serra do Mar, em Santa Catarina, região de Nova Veneza, nos arredores de Criciúma. Chegaram, inclusive, a comprar uma propriedade para concentrar 
os homens que viriam. No entanto, como conta José Caldas da Costa, o grupo fundante da organização - o ex-sargento pára-quedista Jelcy Rodrigues, que participou ativamente do contragolpe de 1961, sobre o qual já falamos no primeiro capítulo, o ex-sargento paraquedista Onier Porto Alegre de Almeida e uma militante de nome Vera - subia a serra constantemente para fazer o reconhecimento da área. Quando um dia houve um roubo na região, envolvendo justamente dois homens e uma mulher, as suspeitas recaíram sobre eles. Onier e Vera foram presos. (COSTA, 2007, pp. 126-127)

Preocupado, Jelcy comunicou à cúpula do MNR que abortaria a operação, transportando as armas para o Rio de Janeiro. Contribuiu, também, para o desmonte do plano de Santa Catarina o levante do coronel Jefferson Cardin, por conta própria, com seus 22 homens, em março de 1966. Chamando a atenção do Exército, o levante frustrado fez com que Brizola mandasse adiar o plano do foco naquela região. Mas não desmobilizou os militares que estavam envolvidos no plano.

Os ex-sargentos que se integraram ao MNR eram militares que, além de participarem da Campanha da Legalidade, tiveram destaque nos protestos dos subalternos das Forças Armadas e que, com o Golpe de 1964, foram rapidamente expulsos da corporação. Nomes que já nos são familiares, como Amadeu Felipe da Luz Ferreira, Jelcy Rodrigues, Araken Vaz Galvão, Edival Mello, que chegou à presidência do Clube dos Suboficiais e Sargentos da Marinha, em 1962 e Amaranto Jorge Rodrigues, que fez parte da direção da AMFNB, regional norte.

No final do mês de outubro de 1966, Capitani fez uma parada em São Paulo, encontrando-se com Neguinho e Onofre Pinto, para preparar a chegada de alguns guerrilheiros de Caparaó. Já havia um grupo de homens em Caparaó, desde agosto, em um sítio de Anivanir Martins Leite, no sopé da serra, última "propriedade legal antes do Parque Nacional do Caparaó”, segundo o ex-sargento Amadeu Felipe da Luz Ferreira, comandante do foco guerrilheiro. Ali, criavam cabras, para não gerar suspeitas dos vizinhos, e, ao mesmo tempo, garantir carne e leite para o grupo. (COSTA, 2007, p. 147). Dali do sítio, partiam, frequentemente, para reconhecimento da área. Até que, quando o grupo de 14 homens estava formado, subiram para formar acampamentos.

Os problemas surgiram já no início. Quase todos são unânimes em afirmar que a escolha do local foi errada: chuvas fortes e constantes, muito frio à noite, sol escaldante durante o dia, vegetação rala, etc. As críticas de Capitani e Amaranto, treinados em Cuba, eram em relação ao despreparo do pessoal, começando pelo comandante, Amadeu Felipe. Falavam muito alto; desciam constantemente a serra para ir às cidadezinhas comprar muitos 
alimentos; ficavam muito tempo parados em acampamentos, quando a regra basilar da guerrilha é a mobilidade. O abastecimento vinha de muito longe, Rio de Janeiro, assim como as decisões, pois quem coordenava a infraestrutura da guerrilha era Amadeu Rocha e o prof. Bayard Demaria Boiteux, secretário do Partido Socialista.

Capitani ficou responsável por fazer os mapas e estabelecer as rotas. Juntamente com Amaranto, faziam depósitos de armamentos e comida, técnicas aprendidas em Cuba. Só os dois sabiam localizar estes depósitos, graças às técnicas de localização nas selvas.

Os contrastes climáticos e as caminhadas exaustivas, subindo e descendo a montanha, provocaram as primeiras desistências. Jelcy Rodrigues conta que as desistências começaram no final do ano de 1966 em virtude da falta de ação, ou seja, pela demora em dar início à guerrilha. Juntam-se a isso o passar do tempo e as dificuldades em adquirir alimentos, as doenças, o cansaço, a desconfiança de que estavam agindo errado, no lugar errado. Jelcy, em entrevista a Costa, fala da escolha errada do lugar: "não havia nada planejado concretamente, até porque, logo em seguida, eu comecei a me dar conta de que estávamos no lugar errado". (COSTA, 2007, p. 193).

Na verdade, a conclusão a que todos estavam chegando era que o comando do foco de Caparaó havia invertido as regras de guerrilha, conforme podiam constatar com a leitura de $A$ Guerra de Guerrilhas, de Che Guevara. Quando primeiramente deveriam realizar um trabalho político junto aos camponeses e demais pessoas da região e, só depois, a guerrilha, os comandantes começaram com treinamentos de guerrilha isolados da população, e com seu estranhamento. Nas cidadezinhas, com toda sua pasmaceira, de repente, começaram a circular pessoas com sotaques estranhos, barbudos, alguns com biotipo diferente do deles, como Capitani, que era loiro de olhos azuis e sotaque gaúcho. Quando apareciam, iam direto para a venda e compravam muita farinha. Natural que as pessoas começassem a comentar sobre a novidade. Amedrontados, não durou muito para que comunicassem às autoridades policiais. A escolha do lugar também foi errada, segundo os depoimentos dos ex-sargentos, porque naquela região não havia tensões sociais, conflitos de terras ou um campesinato politizado. Pelo contrário, tudo indicava que estavam felizes com as suas condições de vida.

Em janeiro de 1967, os conflitos entre os integrantes do comando do foco vieram à superfície, com a ida de Amadeu Rocha ao acampamento e sua discussão com Amadeu Felipe. Foi ríspida e pública. Em 23 de março, Jelcy e Josué Cerejo resolveram abandonar a guerrilha e voltar para o Rio de Janeiro. Tarde demais. Quando estavam cortando o cabelo, enquanto esperavam o ônibus, foram presos, na pequena cidade de Espera Feliz. Triste espera! 
O grupo no acampamento não soube da prisão em Espera Feliz. Mas a partida dos dois abateu os demais. As dificuldades só aumentaram. Capitani, Edival Mello e Jorge Silva, os três marinheiros, adoeceram. Enquanto seus amigos tiveram melhoras, Capitani só piorou, chegando a 39,5 graus de febre, antes que o termômetro caísse e quebrasse. Como Capitani já delirava e não havia antibiótico - o enfermeiro que acompanhava o grupo, não aguentando o ritmo, partiu levando os medicamentos -, Amaranto resolveu descer para buscar remédios. Loucura, disse-lhe Capitani: teria pouca chance de não ser preso. E de fato foi o que aconteceu.

Amaranto desceu de madrugada a serra em direção à cidade de Caparaó. De manhã, ficou a esperar na porta da farmácia que ela abrisse. Quando o farmacêutico Geraldo Lanes chegou, vendeu a Amaranto o antibiótico Benzetacil e, desconfiado, ligou para o delegado. No mesmo dia, 29 de março, Amaranto foi preso. (ALMEIDA, 2014, p. 152)

Em $1^{\circ}$ de abril de 1967, exatos 3 anos do Golpe de 1964, os sete guerrilheiros foram presos por doze membros da Polícia Militar de Minas Gerais, sem tiros ou violência. Apenas uma coronhada por trás de João Jerônimo da Silva, quando tentava engatilhar o fuzil. Dinoráh Lopes Rubim Almeida entrevistou o então Cabo Rocha, do $11^{\circ}$ Batalhão da PM de Minas Gerais, que relata como foi a prisão:

"Aí foi esse grupo da P2, nós estávamos à paisana, não vestia farda, era um grupo de investigação da Polícia. Aí nós saímos do Batalhão às onze horas da noite. O batalhão não dispunha de carro. A única viatura que tinha era um jipe do Comandante, o Coronel Jacinto. (...) Mas nessa ida nossa, nós fomos em uma caminhonete velha emprestada, saímos do Batalhão onze horas da noite, fomos até na encruzilhada ali depois de Pequiá. Ali o motorista deixou nós. Pegamos a Pedra Roxa, atravessamos um rio que é pedra pura. Chegamos na tal Mata da Pedra Roxa e subimos e fomos. Andamos até quatro horas da manhã e chovendo, serração baixa lá em cima e chuva. Aí conseguimos localizar o acampamento deles. Nós já estava arrebentado, carregado metralhadora, fuzil. Se precisasse da gente dá um tiro a nossa arma não funcionava, a munição tava toda molhada. Porque lá serena constantemente, nosso armamento e munição molho tudo. E nós fomos no grupo de doze policiais. Quando chegou lá no alto, lá pra tal da macieira pra cima do Terreirão de Pedra, vimos aquela fumacinha saindo lá do buracão de um abismo. Aquela fumacinha saindo assim na vegetação. Dissemos: É lá. Tenente na frente. (...) O tenente Zezinho era amigo e era companheiro, um homem que sabia comandar. Aí descemos. Cabo Mafort, metido a valente, foi o primeiro que chegou no acampamento, nós ficamos pra trás, ele chegou na frente, $e$ falou: - tem café aí? O Mafort engravatou, dominou o sentinela e disse: - pode chega pessoal, 
tá dominado. Ele não feriu, ele não matou, ele dominou o sentinela. Aí nós chegamos, quando nós chegamos foi aquele alvoroço no acampamento. Um levantava da rede, outro levantava do chão, procurando a arma, o fuzil. Aí nós circulamos o acampamento e desarmamos eles. $A$ Polícia Militar na época, nem algema não usava. Nós arrumamos cabresto de curral lá nas fazendas da Serra do Caparaó e pedaço de cordas pra amarrar eles. Nós estávamos com umas armas quase inútil, porque ela molhou toda". Escrito conforme o original, inclusive os parênteses. (ALMEIDA, 2014, p. 154)

No relato acima, o cabo Rocha fala das dificuldades que o grupo teve em encontrar o acampamento dos guerrilheiros. Caminhada de madrugada com muita chuva, cansaço, até que avistaram fumaça. "É lá!” Cabo Rocha não fala se eles foram com um roteiro já traçado antecipadamente, ou se caminhavam sem direção pré-estabelecida, fazendo uma "caçada" na selva. O oficial não deu orientação para os praças agirem. Foi um cabo "metido a valente" que dominou a sentinela e orientou o grupo a chegar, porque estava "dominado". Antes de dominar a sentinela, no entanto, o cabo Mafort perguntou: "Tem café aí?" Por que teria feito essa pergunta? A impressão que passa é a de que ele não estava muito preocupado com o que encontraria no interior do acampamento. Ou teria sido uma senha? Mas, no caso de ter sido uma senha, não deveria ser o tenente a fazê-la, ao invés de seu subordinado?

A forma como se deu a chegada dos policiais e a facilidade com que dominaram os guerrilheiros são motivo para desconfiança de alguns guerrilheiros, como Jelcy, que já não estava com o grupo, e Capitani. O último diz não ter dúvidas de que o comandante do foco, Amadeu Felipe, junto com Araken, fizeram um acordo com o Coronel Jacinto, comandante do $11^{\circ}$ Batalhão da PM de Minas Gerais. Tanto que, à pergunta do cabo Mafort, Amadeu Felipe teria respondido: "tem, pode vir", e Araken completou: "E tem bala para todo o mundo". Jorge Silva também acha muito estranha a forma como caíram e conta que, pela escala de serviço, estaria de guarda das cinco às sete horas, sucedendo Amadeu Felipe, que estava programado das três às cinco horas. Mas Amadeu trocou a guarda com ele, sem dar satisfação. Quando Jorge acordou Amadeu para assumir o posto, percebeu, depois de um tempo, que ele não havia levantado da rede. Chamando-o novamente, Amadeu respondeu: “está bom." Sentou-se na rede e pegou a arma.

Quando o cabo Mafort perguntou se tinha café e recebeu a resposta, Capitani achou estranho: "esse sentinela não deveria falar tão alto". A confusão tomou conta do grupo por instantes. "Vi o Amadeu tranquilamente sentado na rede, de onde respondia para aquele que eu achava que era o sentinela. Só que lá não havia sentinela nenhum” (COSTA, 2007, p. 204). Em seguida, chegaram os soldados, apontando as armas para o grupo. Não tinha mais o 
que fazer. $\mathrm{O}$ grupo estava sonâmbulo e obedecia às ordens, mecanicamente, de irem para a trilha.

Nas críticas que Capitani faz hoje, não entra no mérito de que foi traição dos dois comandantes. Ele pensa, aliás, que não traíram intencionalmente. Acredita que, ao perceberem que a guerrilha arrefecera-se, resolveram por um ponto final àquele sofrimento, procurando o Coronel e se entregando. Mas deveriam ter consultado o grupo. Capitani diz, convictamente, que tinha preparado uma rota de fuga que poderia levá-los para Rio de Janeiro em duas semanas:

"Chegou aquele momento que realmente a guerrilha começou a ficar inviável né... e inclusive estava chegando mais gente da cidade para ingressar a guerrilha devido às várias pessoas terem ido embora. Ela [a guerrilha] estava sendo reforçada por marinheiros. estava vindo todo um grupo do Rio de Janeiro de marinheiros. (...) A crítica que eu faço a eles... Tudo bem, até a conclusão deles era válida, realmente era muito difícil manter um grupo de guerrilheiros em Caparaó naquelas condições. Mas só que eu mesmo já tinha feito um mapa, que chama de recuo, aprendido lá no curso [em Cuba]. Eu tinha feito já dois mapas, mas principalmente um muito detalhado que era possível sair de Caparaó e chegar ao estado do Rio de Janeiro onde a gente tinha apoio dos camponeses, das Ligas, das juntas sindicais, onde inclusive eu conhecia sem se expor, né. Tinha lombadas que iam embora, e era possível ir só pelos picos, bem no cume delas. la demorar, no meu cálculo, umas duas semanas, mas era possível. Recuava com todo o grupo, não se entregar, ir embora. Chegava, tomava a decisão, chegava à conclusão e "vamos embora". Mas eles preferiram a outra alternativa. Sem consultar o grupo, eles foram fazer um processo de negociação. E isso eu não concordo. Eu concordo que era inviável, não totalmente, mas vamos dizer assim. Nós já tínhamos uma experiência ali no terreno, que começava a ser inviável por questões de doença, porque os sargentos foram embora, começaram a ficar doentes, chegando a conclusão de que, ali, não dava para fazer um grupo guerrilheiro. Mas começaram a não ter peito para peitar, o Amadeu [dizer] "Olha, não dá. Nossa opinião é essa, essa e essa". (...) Podia ter havido esse processo: "Olha, é importante recuar, ir embora". (...) Então, isso não foi discutido e o Amadeu e o Araquém tomaram a decisão individual né, e foram negociar com o pessoal. Isso foi o equívoco, e isso eu não concordo, fizeram errado. Mas não estou dizendo que eles foram traíras, longe disso. No fundo, se acharam superiores e que deveriam se entregar, negociar às costas do grupo. $E$ isso é muito grave. Essa é única crítica que eu tenho. E lógico, todos nós fomos presos, surpreendidos e quase há um desastre violento, né". ${ }^{76}$

\footnotetext{
${ }^{76}$ Entrevista a Flávio Luis Rodrigues. Porto Alegre, 12 de julho de 2011.
} 
O grupo foi levado para o quartel da polícia de Manhuaçu. Ficou ali até a chegada de tropa do Exército, que o transferiu para um quartel de Juiz de Fora. Começaram os interrogatórios, mas sem tortura, completa Capitani. Mais uma transferência, para a Penitenciária de Linhares, também em Juiz de Fora. Aí, aconteceram duas tragédias. A primeira, quando Gregório tentou o suicídio cortando os pulsos. Sobreviveu. A segunda foi o suicídio, de fato, de Milton Soares de Castro, enforcado no cano de água. "Amarrou o pescoço no cano e encolheu as pernas”. Qual explicação para essas duas tentativas de suicídio? Talvez a resposta esteja na declaração do atual coronel de reserva Ralph Grunewald Filho, responsável na época pelos interrogatórios no presídio de Juiz de Fora. Sobre a morte de Milton Soares de Castro, Grunewald diz:

"Olha, pra falar a verdade, acho que sou realmente culpado pela morte do Milton, porque fiz com que ele perdesse completamente o controle emocional com a pressão psicológica que sofreu durante o interrogatório a que foi submetido e cometesse suicídio. [...] não matei ninguém neste processo nem nos outros que dirigi, porque se realmente quisesse dar um fim a algum comunista, ele simplesmente desapareceria. Não ficaria nenhum prova. [...] Milton suicidou-se e quem duvida é só ir ver os três inquéritos, policial, administrativo e militar, instaurados. [...] Eles querem insinuar que o cano onde o preso se enforcou era muito baixo. Mas tenho absoluta certeza de que o baque que ele levou justificaria qualquer gesto".

(RABELLO, 1980, P. 138. apud. ALMEIDA, 2007, p. 170)

Surpreendente a sinceridade do militar. Declara-se torturador com uma tranquilidade espantosa, como quem arrola um tópico importante de currículo! Esse homem, na altura de sua bisonha autoridade, levou dois prisioneiros, que estavam sob sua responsabilidade, a tentar o suicídio, através de uma calculada tortura psicológica. E isto no início do ano de 1967. Podemos imaginar o que terá feito esse servidor da Pátria, após o AI-5!

Como Capitani já havia sido condenado por sua participação na AMFNB a três anos de prisão e corria o processo da "guerrilha" de Copacabana, o Exército resolveu transferi-lo para o Rio de Janeiro, pois seu translado sempre que precisasse comparecer às audiências, estava sendo muito oneroso.

Chegando ao Rio de Janeiro, a escolta levou Capitani diretamente para o Presídio Lemos Brito; "na chegada, havia um comitê de recepção de velhos companheiros: Marco Antônio, os dois irmãos Duarte, o Viegas e o ex-sargento da Aeronáutica Prestes de Paula estavam entre um grupo de 30 marinheiros também presos políticos”. (CAPITANI, 1997, p. 123) 
Nossos protagonistas novamente se reuniram, junto a outros marinheiros que participaram das atividades da Associação, mesmo não pertencendo à diretoria, mas igualmente expulsos da Marinha de Guerra e presos na Lemos Brito. Do Coletivo, apenas Neguinho não estava na Lemos Brito. Por onde andou, durante as quedas de seus amigos?

Quando começaram as dificuldades na organização dos focos guerrilheiros pelo Movimento Nacionalista Revolucionário, Brizola mandou desativar os núcleos de Mato Grosso e de Imperatriz. Caparaó, no entanto, continuava se arrastando, com os problemas já citados. Aos guerrilheiros, não passou despercebida a alteração da atenção que a cúpula dispensava ao foco. As comunicações com o Uruguai passaram a ser menos frequentes, o dinheiro rareava e os alimentos chegavam em menor quantidade. Quando, enfim, a guerrilha de Caparaó caiu, com ela também caiu o MNR.

Neguinho, quando sentiu que o MNR estava ruindo, começou a participar da discussão para criação de uma nova organização guerrilheira, juntamente com os ex-militares remanescentes daquele movimento em crise. Sob o comando de Onofre Pinto, criaram a Organização, também conhecida com a letra $\mathrm{O}$ maiúscula, seguida de um ponto (O.). Mais tarde, em dezembro de 1968, a organização passou a se chamar Vanguarda Popular Revolucionária, VPR. (GORENDER, 1987, p. 131). Antônio Geraldo Costa conta que participou das discussões para a criação da VPR:

"E lá entrei em contato com alguns ex-sargentos, expulsos, e alguns operários. E então, me falaram que existia, tinha um grupo formando uma organização armada, VPR, que inicialmente, a maioria era de ex-militares". ${ }^{77}$

Em sua fala, Neguinho sugere que, mesmo realizando ações no MNR, ele e outros exmilitares já participavam da Organização, futura VPR:

"Bom, aí o que acontece, eu trabalhei na clandestinidade no Rio de Janeiro e em São Paulo, e quando foi formado o MNR, que era uma organização armada, Movimento Nacionalista Revolucionário, daí eu fui e participei. Nesse interim, eu já estava em São Paulo, quando a VPR começa a se formar, se organizar como VPR. O núcleo da VPR inicial eu participei". ${ }^{78}$

Mas Costa não poupa críticas à Organização. Diz ele que não concordava com a ideia de revolução da VPR, e nem de suas táticas de guerrilha. Por isso ficou tão pouco tempo nela, e logo se transferiu para a Ação Libertadora Nacional, ALN.

"Achavam que formando um foco era suficiente para se fazer uma revolução. E quando eu percebi isso, eu disse 'não dá. Primeiro, que o Brasil tinha uma extensão de território, um

\footnotetext{
${ }^{77}$ Entrevista a Flávio Luis Rodrigues. Maceió, 19 de julho de 2011.

78 Idem.
} 
verdadeiro continente, diferente, e a gente partir pro pau só em um foco, não vai'. Isso criou muita discussão. (...) O Quartim de Moraes, quando ele entra, a VPR já está praticamente formada. A grande maioria de ex-sargentos do Exército, ex-marinheiros, alguns operários do Partido Comunista, o pessoal, muitos operários do Partido, PCB, desiludidos com o Partido, deixaram o Partido e foram formando a VPR. (...) Deixei a VPR realmente por uma questão ideológica. Porque a VPR era só o caso de uma revolução militar inspirada em Cuba". ${ }^{79}$

Enquanto seus amigos estavam na prisão, Neguinho continuou, portanto, na luta armada. A ajuda que ele dará ao Coletivo preso, mesmo estando fora da penitenciária, será fundamental para libertá-los. Mas isto veremos no próximo capítulo.

\section{$* * *$}

Entendemos que estudar o MNR na perspectiva de quem dele participou é importante para a historiografia que pesquisa os movimentos guerrilheiros de resistência à ditadura, pois tal movimento foi o primeiro e o deflagrador dos demais, como a VPR, o COLINA, a ALN, o PCBR, a VAR-Palmares e o MR-8. Nossos agentes na trama que estamos narrando participaram destas organizações e seus relatos contribuem para a elucidação de alguns aspectos que ajudam o historiador a montar esse complexo mosaico.

Com a queda de Caparaó, o MNR se esfacelou e seus militantes migraram para outras organizações, ou saíram do país.

A experiência desses marinheiros evidencia um fazer-se de sua prática ao longo do tempo, que não deriva simplesmente da adesão do grupo ao PTB no poder (governo Goulart) ou fora dele (depois de 1964), ao PCB, aos grupos de esquerda alternativos ao PCB e a outros núcleos pré-existentes. Isso fica patente ao se observar a própria diversidade de experiências e opções deles, bem como as diferenças entre suas memórias e balanços sobre tais trajetórias.

Como nossos protagonistas avaliam, passados quase 50 anos, o Movimento Nacionalista Revolucionário?

Percebe-se um consenso entre os ex-marinheiros de que Brizola manteve-se fiel a seus princípios nacionalistas, correndo, inclusive, o risco de vida para fazê-los valer. Acreditam que Brizola, com o tempo, tendeu cada vez mais à esquerda, principalmente quando se aproximou de Fidel Castro e aderiu à ideia do foco guerrilheiro.

\footnotetext{
${ }^{79}$ Idem.
} 
Antônio Duarte critica Brizola por não ter tido pulso para evitar o "racha" dentro do MNR. Identifica seu centralismo como fator de queixas, principalmente entre os militares. Segundo ele, Brizola atropelava seus seguidores, impondo decisões, tanto na esfera política, quanto na militar. Um exemplo que ele dá é o do Almirante Cândido Aragão, que não aceitou ser comandado por uma pessoa de patente inferior (no caso, o coronel Dagoberto Rodrigues) e abandonou o movimento para criar outra organização guerrilheira-militar, a RAN, Resistência Armada Nacionalista.

Outra crítica de Antônio Duarte diz respeito a quando Brizola desistiu da luta armada, tendo centenas de pessoas envolvidas precisando de sua ajuda, e ele praticamente sumiu, sem dar satisfação convincente:

"Bom, ele mandou desarticular todos os grupos e disse: 'olha gente, vão para suas casas, nós não vamos mais tratar disso'. O Brizola, o que ele ia fazer depois eu não sei, ele mandou o cara que veio, percorrer o Brasil para fazer isso foi o Coronel Dagoberto. Ele mandou o Dagoberto. Principalmente nos meios militares". ${ }^{80}$

As críticas de Capitani são dirigidas ao amadorismo com que foi organizado o foco de Caparaó. O lugar foi mal escolhido, os comandantes despreparados, a infraestrutura morosa e deficiente:

"Naquela região do Espírito Santo não tinha nenhum camponês com raiva, num atraso danado, nem sabiam que tinha ditadura praticamente no Brasil. Lá no interior, plantando o cafezinho dele, a vaca dando leite, e era isso, e não havia nenhum espírito de rebeldia, de contestação no meio dos camponeses, o que devia ser a nossa base de sustentação. Senão a gente não se sustenta. Fizemos o esquema de transporte de comida e apetrechos desde a cidade do Rio de janeiro e aí montamos um armazém não sei onde, mas isso foi uma coisa muito artificial, não se sustenta. Nós não tínhamos fonte próxima de abastecimento, então passamos fome, tudo. Então começa uma ideia de que fomos loucos... muitos sargentos começam a ir embora. E esses sargentos estão sendo substituídos por marinheiros. $E$ conversam com eles, para tentar outra alternativa, buscar outro lugar. Mas no fundo ficou decidido assim 'Vamos acabar fazendo um levantamento de toda essa região para ver se tem alguma coisa, algum lugar que atenda as nossas condições de sobrevivência'. E nesse meio tempo houve um processo de esgotamento muito grande". ${ }^{81}$

Quando Caparaó caiu, Brizola mandou desativar o que tivesse de trabalho associado ao MNR, inclusive o foco de Imperatriz. Flávio Tavares, que dirigia o foco de Brasília, ficou

\footnotetext{
${ }^{80}$ Entrevista a Flávio Luis Rodrigues. Rio de Janeiro, 11 de julho de 2012

${ }^{81}$ Entrevista a Flávio Luis Rodrigues. Porto Alegre, 12 de julho de 2011.
} 
chateadíssimo pois não houve explicação e a questão não era tão simples. Ele tinha dezenas de pessoas na região do Maranhão e Amazonas. O que fazer com eles? Esse aborrecimento fica explícito numa passagem de seu livro:

"No inverno de 1967, em plena luta armada, após duros sacrifícios para superar os fracassos, (...) quando Cibilis Viana, numa noite de neblina numa esquina de Copacabana, no Rio, me transmite uma mensagem urgente de Montevidéu. Devíamos retirar todo o pessoal do Brasil Central, vender o barco de 12 toneladas que ia e vinha pelo Tocantins, terminar com tudo. (...) Como terminar o baile e deixar o pessoal dançando? (...) Decepcionado com o fiasco de Caparaó, magoado com o final ridículo daquilo em que havia confiado e se empenhado tanto, Brizola sinalizava e dava a entender, mas não afirmava nem dizia peremptoriamente que não era mais o Pedrinho e que se retirava. No fundo, bem no fundo, ele nunca esteve muito convencido da guerrilha e aceitara tudo, e assimilara tudo, na maré que invadia o exílio uruguaio e ocupava todos os espaços, mentes e raciocínios. Mas e nós? E toda aquela gente que estava lá, pelo Maranhão adentro, pelo Pará e rio Tocantins afora?"

(TAVARES, 2005, pp. 226-228)

Neguinho, por seu turno, avalia que Brizola "era um líder nacionalista, impulsivo, muito personalista, que achava que também era ele o dono da verdade”, mas que, por esses "defeitos", transmitia segurança aos marinheiros. O movimento organizado do Uruguai atraiu os marinheiros porque era Brizola o líder. Neguinho, no entanto, critica a decisão de Brizola partir para o exílio. Ele acha que, se Brizola ficasse no Brasil, sua liderança galvanizaria muitos outros setores da sociedade.

A respeito do dinheiro que Cuba deu a Brizola e a desconfiança de que Brizola não teria repassado todo o montante para a guerrilha, assunto levantado por Denise Rollemberg, tanto Neguinho quanto Capitani isentam Brizola de "apropriação" dos recursos destinados à luta armada. Neguinho diz: "O boato existe, eu não acredito. Eu pessoalmente não acredito. Eu sempre vi no Brizola, uma figura assim, honesta, essa era a impressão, a imagem que eu tenho dele, continua assim, entendeu”. Por seu lado, Capitani pontua que a questão é mais complexa do que aparenta:

"Dizem que Cuba deu Muito dinheiro para o MNR, para o Brizola... Eu não quero culpar o Brizola aqui por isto. Tinha muitas pessoas com famílias e era preciso sustentá-las. Parte deste dinheiro ia para estas famílias. Não teve dinheiro grande para cobrir todas a necessidades. Não houve desvio do dinheiro propositadamente. O dinheiro foi mandado, Cuba diz que mandou, mas não chegava à guerrilha, chegava muito pouco". (ROLLEMBERG, 2001, p. 32) 
$\mathrm{Na}$ entrevista que nos concedeu, Capitani fez um interessante comentário sobre as consequências de Caparaó:

"Mas a surpresa veio depois [da queda de Caparaó]. Não acabou o processo guerrilheiro no Brasil, depois. Então parece que Caparaó foi um grito de revolta e de guerrilha. Dali em diante começou a aparecer os grupos de luta armada. Depois da queda de Caparaó, em vez de desestimular e encerrar o processo de tentativa de guerrilha no Brasil, estimulou, ativou". $^{82}$

A impressão que passa ao ler essas palavras é a de que Capitani desistiu da luta armada e que, depois de Caparaó, jamais voltaria para a clandestinidade guerrilheira.

Ledo engano. Depois de passar mau tempo no inferno da Penitenciária Lemos Brito, aí é que surge o guerrilheiro cantado por Jorge Ben Jor, Charles anjo 45.

O que será que aconteceu nesse tempo em que o Coletivo esteve encarcerado na Lemos Brito?

${ }^{82}$ Idem. 


\title{
CAPÍTULO III: MAR É CONTRA A DITADURA
}

\author{
“Eu sou, mar, tu bem sabes, teu discípulo. \\ Que nunca digas, mar, que não foste meu mestre” \\ (Vinicius de Morais, "Versos soltos no mar") \\ "Renunciai às esperanças, vós que entrais" \\ (Dante Alighieri, A Divina Comédia, tradução de Hernâni Donato)
}

A Penitenciária Lemos Brito tem suas origens num projeto penitenciário de ressocialização, ou correção como se dizia em 1850, quando foi criada a antiga Casa de Correção da Corte. Nela, foi introduzido o conceito de recuperação do preso através do trabalho, do isolamento (uma pessoa apenas por cela) e da disciplina. Quando a Casa de Correção foi demolida, em seu lugar, edificou-se a Lemos Brito, com os mesmos princípios da primeira.

No "Manual do Agente de Segurança Penitenciária", encontramos uma breve trajetória da Penitenciária Lemos Brito:

Inicialmente Casa de Correção da Cidade do Rio de Janeiro, foi criada pela Carta Régia de D. José I, "El Rei". Entretanto, somente em 06/07/1850 foi regularmente estruturada. Em 24/12/1941 recebeu a denominação de Penitenciária Central do Distrito Federal, passando em 19/07/1957 a denominar-se Penitenciária Professor Lemos de Brito. Em 1960, com a criação do Estado da Guanabara passou a subordinar-se ao Governo Estadual. Em 28/04/1970 recebeu o nome de Instituto Penal Lemos de Brito, que ostentou até 22/09/81, quando recebeu a denominação atual. (DESIPE,1998, p. 17. apud CARDOSO. 2008, p. 55)

A Penitenciária Lemos Brito, antes de levar este nome, era conhecida como "Casa de Correção", ou "Casa de Detenção" (ARAÚJO, 2007, 88). Em seu livro Memórias do Cárcere, Graciliano Ramos refere-se a ela como Casa de Correção.

A Lemos Brito foi demolida em 2006, e seus presos transferidos para o Complexo de Gericinó, que segue os mesmos padrões das penitenciárias Bangu. Segundo Cardoso, "esse era o espaço onde funcionou, durante 156 anos, a primeira prisão brasileira a instituir o trabalho como forma de correção. (...) No dia $1^{o}$ de dezembro de 2006, foram transferidos para Bangu 6, os últimos presos que ocuparam o espaço onde outrora funcionou a Casa de Correção da Corte”. (CARDOSO, 2008, p. 81).

A Lemos Brito estava inserida no Complexo Penitenciário Frei Caneca, na época constituído por duas penitenciárias - a Lemos Brito e a Milton Dias Moreira -, um presídio, 
Presídio da Guanabara, e um hospital, Hospital Penal Fabio Soares Maciel, conhecido como Hospital Central (HC).

Possuía três pavilhões de três andares, sendo dois com seis galerias e um com três. Cada galeria tinha 40 celas pequenas, chamadas de cubículos pelos presidiários, 20 de cada lado, com exceção do terceiro pavilhão, que tinha apenas 20 celas.

Uma galeria na Lemos Brito. Observar a disposição dos cubículos, vinte de cada lado

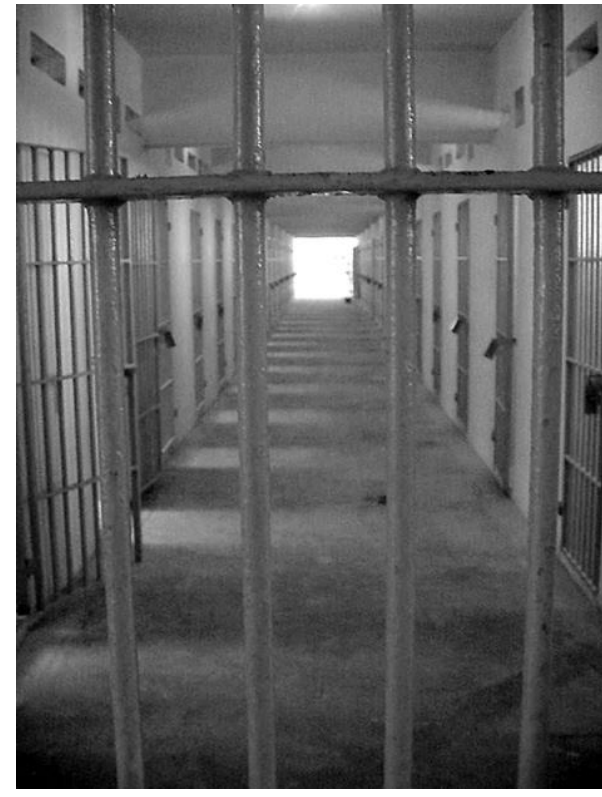

Apud CARDOSO, 2008

Complexo Frei Caneca. Foto recente.

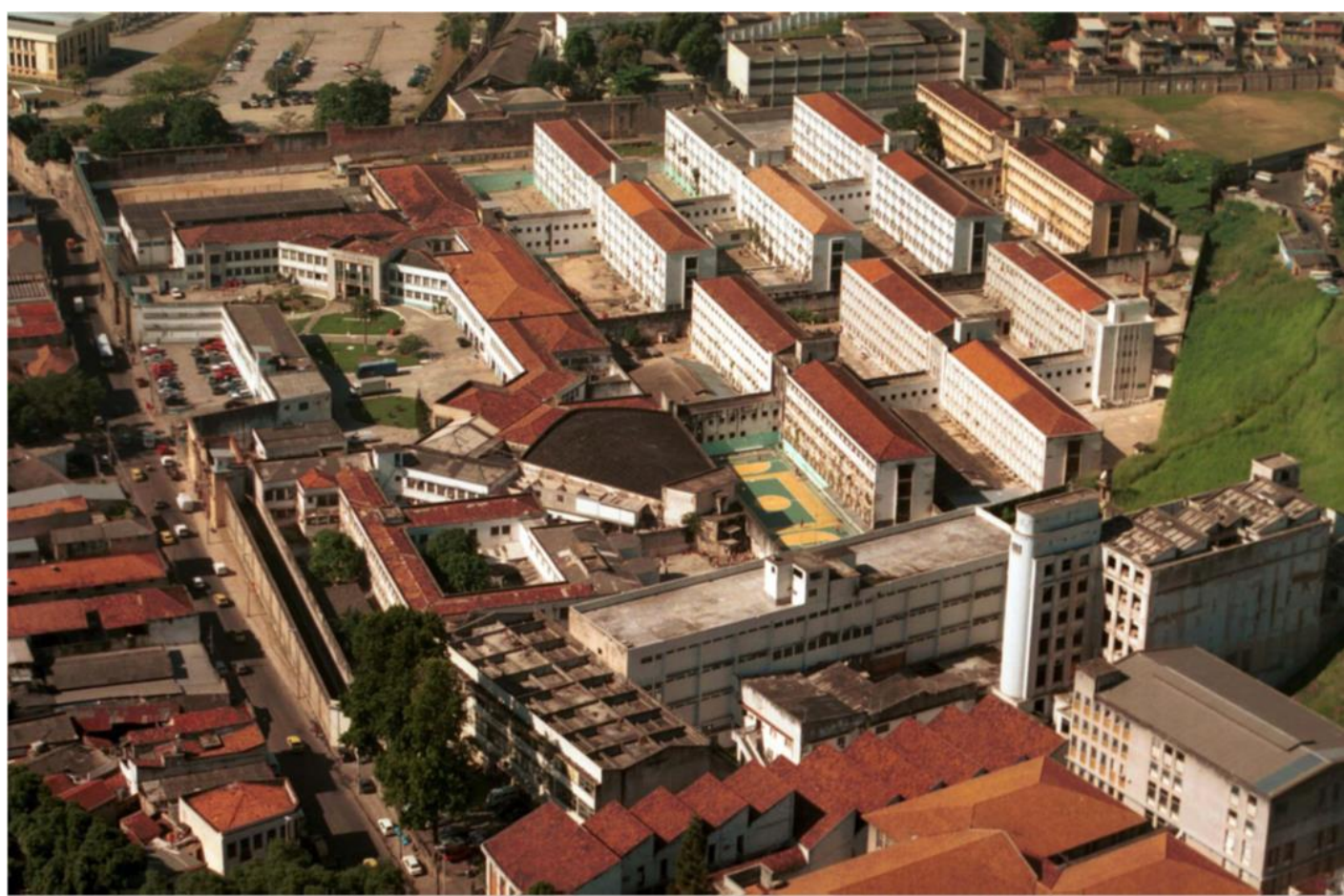

Apud CARDOSO, 2008. 
A mesma foto anterior, com sinalizações (círculos) feitas por CARDOSO. As sinalizações que não forem círculos foram feitas por Flávio Luís Rodrigues

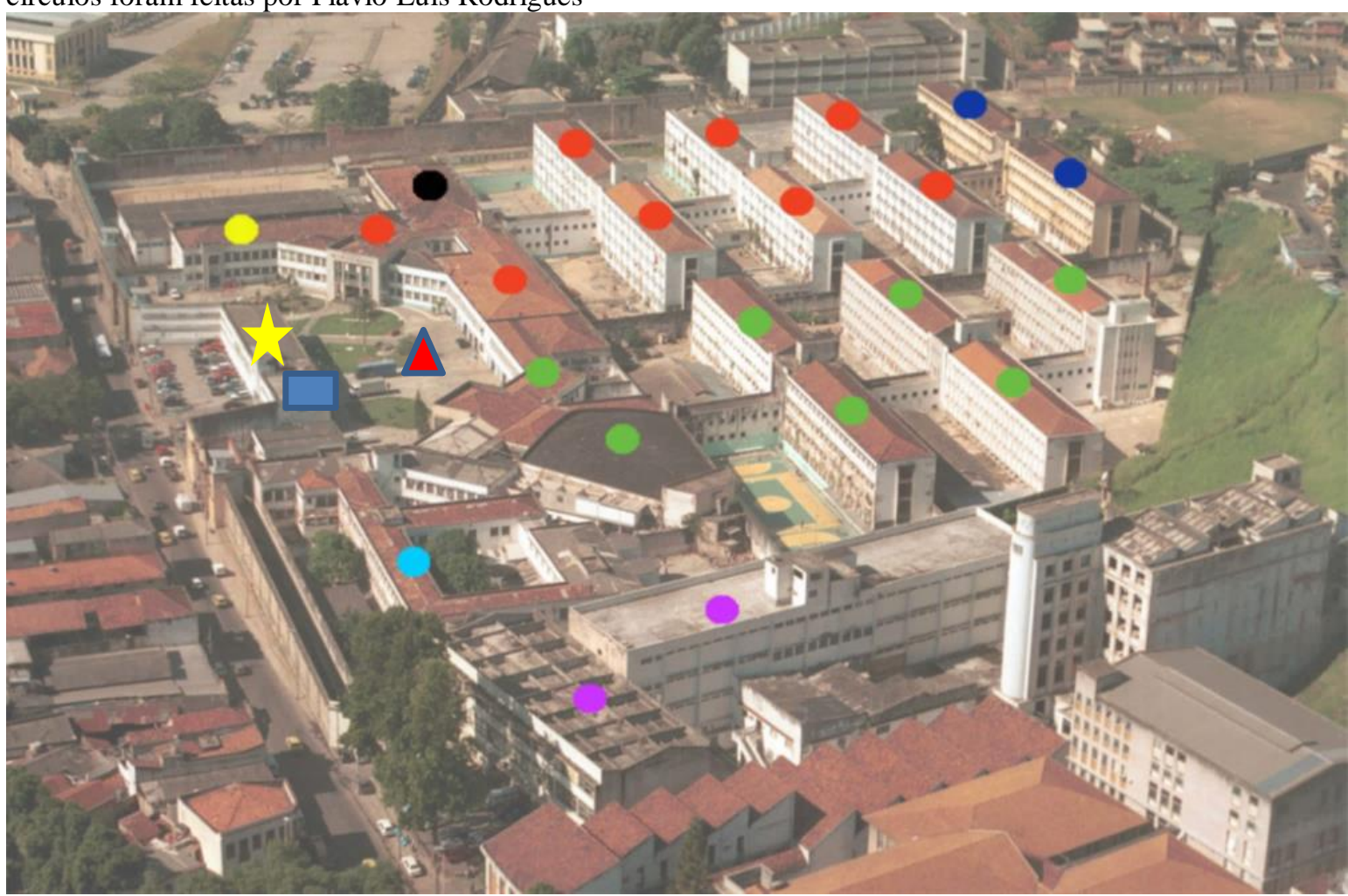

Apud CARDOSO, p. 64.

Circulo verde: Penitenciária Lemos Brito. Observar os pavilhões, os pátios e a quadra de futebol. Abaixo dos pavilhões, ficavam as oficinas.

Círculo vermelho: Penitenciária Milton Dias Moreira. Observar o muro que separam as duas penitenciárias.

Círculo roxo: Antigo Presídio da Guanabara.

Círculo azul: Antigo Hospital Central (HC).

Círculo amarelo: Na época era o Instituto Educacional Muniz Sodré.

Triângulo azul e vermelho: Praça Getúlio Vargas.

Estrela amarela: Portaria.

Quadrado azul: Divisão Legal e Serviço Social.

No térreo de cada pavilhão, existiam oficinas onde os presos trabalhavam durante o dia e, após o jantar, eram recolhidos às celas. $\mathrm{O}$ dia começava às $06 \mathrm{~h} 00 \mathrm{~min}$, quando tocava a sirene para o café da manhã. Ás sete horas, a sirene avisava o horário do trabalho nas oficinas, até às 11 horas, quando era servido o almoço, até às 13 horas. Retomavam-se os trabalhos nas oficinas até às $17 \mathrm{~h} 00 \mathrm{~min}$. Depois do banho, os presos retornavam às $17 \mathrm{~h} 30 \mathrm{~min}$ para o jantar e, ás 18h00min, eram recolhidos às celas. Sempre, eram lembrados pela sirene. Às 21 horas, 
havia o "confere", quando o guarda abria a portinhola da cela para verificar se o preso que respondera "presente", ao ouvir o seu nome, era realmente o mesmo. Enfim, às 22 horas, apagavam-se as luzes. A partir daí, só silêncio.

Havia várias oficinas, onde o preso era orientado por um profissional sobre como realizar o ofício. Por exemplo, na oficina de encadernação e douração de livros, o preso aprendia a encadernar um livro, dourando as letras do título e as laterais do volume; na oficina de alfaiataria, aprendia-se a costurar; na oficina mecânica, a consertar automóveis e fazer funilaria, como mostram as fotos abaixo:

Oficina Mecânica. Fotos recentes. Os presos na Lemos Brito dos anos 1960 usavam camisas brancas e não verdes

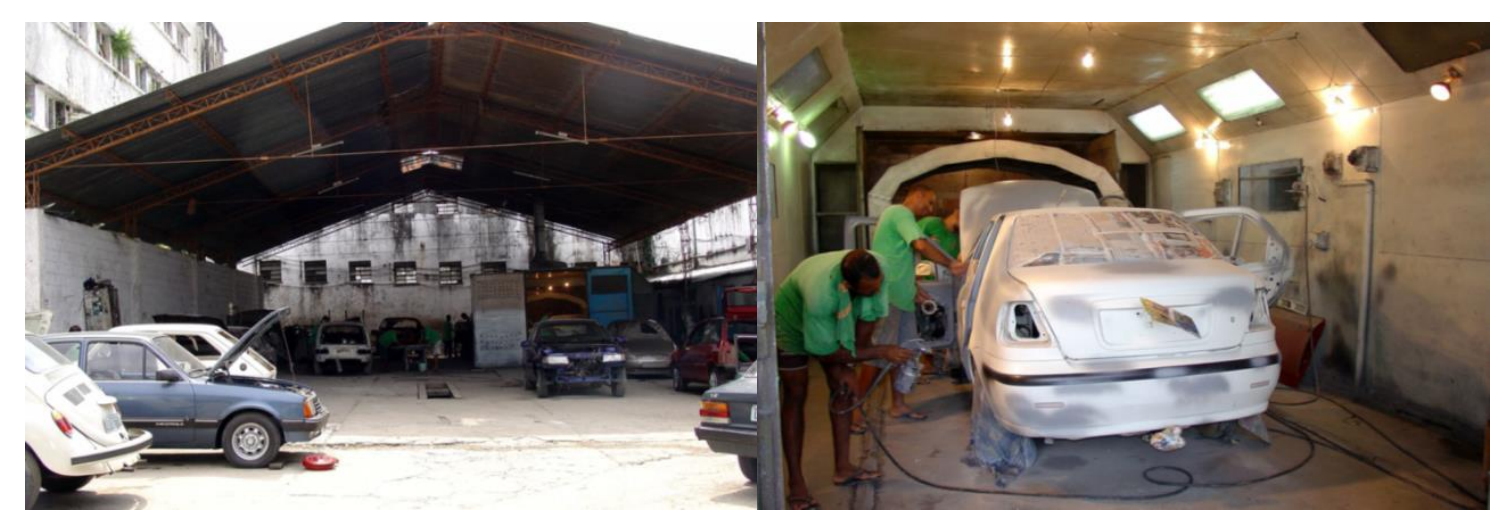

Apud CARDOSO, p. 71.

Segundo o ex-preso Edison Duarte Mello, naquela época, existiam as seguintes oficinas: alfaiataria, carpintaria, colchoaria, encadernação, sapataria, tipografia, oficina mecânica, linotipia, limpeza e reparos, lavanderia, eletricidade, pintura, rouparia, cozinha, biblioteca, almoxarifado.

Os presos que aí trabalhavam - com exceção da lavanderia, rouparia, cozinha, biblioteca e almoxarifado - o faziam para atender à demanda da sociedade, ou seja, das pessoas de fora da penitenciária que encomendavam móveis, conserto de sapatos, douração de livros, funilaria de automóveis etc. Os internos também podiam adquirir esses produtos. Tais presos recebiam por seu trabalho. Mello dá um exemplo de como era a remuneração do preso.

"um cidadão qualquer sofria um acidente com seu carro. Poderia levá-lo à oficina mecânica da Lemos Brito para conserto. Lá, em formulário próprio, era feito um orçamento detalhado do trabalho a ser realizado; do total desse orçamento, 30\% era destinado ao interno, ou internos que efetuassem o trabalho: era o pecúlio. Assim, uma parte da renda era recolhida ao Tesouro e a outra parte ficava em uma espécie de poupança pertencente ao interno, que recebia parte durante o tempo em que estivesse cumprindo pena e a outra parte após ser posto em liberdade. Também aí, muita gente 'enricou'..." (MELLO, p. 372). 
Nem todos recebiam por seu trabalho. Era o caso do faxina. Quem o assumia realizava trabalhos variados junto à Administração: office boys, serviço de café ao diretor, etc. Seu trabalho não era remunerado, mas era compensado pela redução da pena: para cada três dias trabalhados, há remissão de um dia na pena total. (MARQUES, 2007, p. 1).

Além das oficinas, o preso podia trabalhar na Administração penitenciária, realizando trabalhos burocráticos na Divisão Legal, trabalhos assistenciais no Serviço Social, de enfermagem ou assessorando os médicos nos exames de biopsicologia, no Hospital Central. Estes presos, entretanto, deveriam ser da confiança dos diretores, como era o caso de nossos protagonistas.

A proposta de ressocialização dos presos através do trabalho tinha como objetivo preparar o detento para retomar sua vida depois de cumprida sua pena, com dignidade. Ele saia profissional naquele ofício por ele escolhido ${ }^{83}$. Além disso, o preso também podia ajudar a família enquanto estivesse recluso, já que era, muitas vezes, o que a provia de alimento e moradia. Segundo Edna Del Pomo de Araújo, 86,7\% dos presos da Lemos estavam, quando ela escreveu o artigo, pouco antes da unidade ser demolida, envolvidos em alguma atividade laboratorial (ARAÚJO, 2007, p. 88).

A ideia de manter o preso sozinho em uma cela tinha a intenção de levá-lo à reflexão sobre sua vida e a preservação da lembrança de seus familiares. A Administração facilitava o contato do preso com seus familiares, como veremos adiante, através de várias atividades em conjunto. Aliás, a própria localização da penitenciária, próximo ao centro da cidade, facilitava a visita dos familiares que morassem no Rio de janeiro. A respeito destes momentos de privacidade que a Lemos Brito permitia aos detentos, Araújo comenta: "A preservação da individualidade dos internos, por meio dos cubículos individuais possibilita e estimula, em muitos casos, a produção e a execução da prática da chamada 'laborterapia'. Essa é uma atividade imprescindivel para a recuperação e a socialização do indivíduo”. (ARAÚJO. 2007, p. 88).

Isso fazia da Lemos Brito uma penitenciária modelo. Araújo ainda comenta que 78,8\% dos internos que responderam aos questionários disseram que não temiam ser discriminados após a liberdade. "O motivo desta resposta é o suporte psicológico que as atividades existentes na Lemos Brito proporcionam ao indivíduo que, diante de algumas descobertas de

\footnotetext{
${ }^{83}$ CARDOSO trás uma informação diferente da que obtivemos através das pesquisas orais. Diz ela: "É importante ressaltar que os presos que trabalhavam nessas oficinas eram remunerados e que o aprendizado de um ofício não era opcional, havia um instrutor contratado para ensinar os presos por um período de dois anos". Grifo nosso. Possivelmente as regras quanto a escolha do ofício pelo preso tenha mudado.
} 
talento laborativo elou artístico, tem necessariamente sua autoestima elevada" (ARAÚJO, 2007, p. 89).

A unidade Lemos Brito possuía espaços que permitiam a realização de atividades educativas, artísticas e recreativas. Era o caso do auditório que, segundo seu diretor Luciano de Oliveira e Silva, na época em que foi entrevistado por CARDOSO, possuía 1800 lugares. Muito possivelmente o diretor se equivocou. Edison Duarte Mello fala em 500 lugares. Seja como for, aí foram realizadas várias palestras, shows, apresentações de filmes e peças de teatro organizadas por membros do Coletivo que estamos estudando.

Na foto abaixo podemos ter uma ideia de grandeza:

\section{Foto recente do auditório}

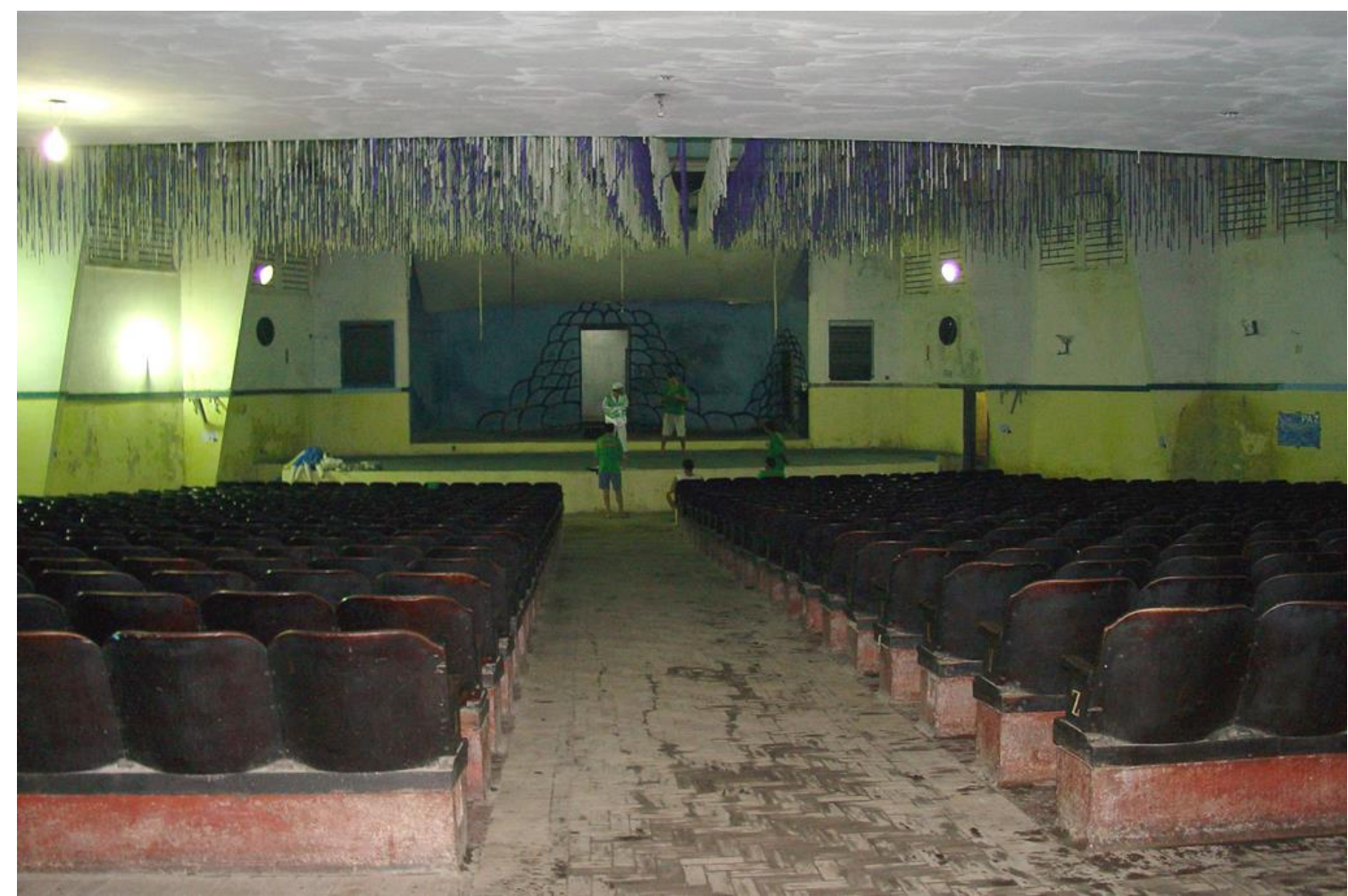

Apud. CARDOSO, 2008.

Na Lemos de Brito, havia, ainda, uma quadra de futebol de salão - coisa que poucas penitenciárias possuem -, onde aconteciam torneios entre os times que representavam várias penitenciárias. Nosso Coletivo criou um time, sugestivamente denominado de "O Popular", que venceu alguns torneios. Era um espaço importante para "descarregar" as tensões e manter o corpo em atividade, evitando doenças relacionadas à ociosidade. Quando os ânimos se exaltavam, as brigas eram inevitáveis. 
Foto recente da quadra poliesportiva da Penitenciária Lemos Brito

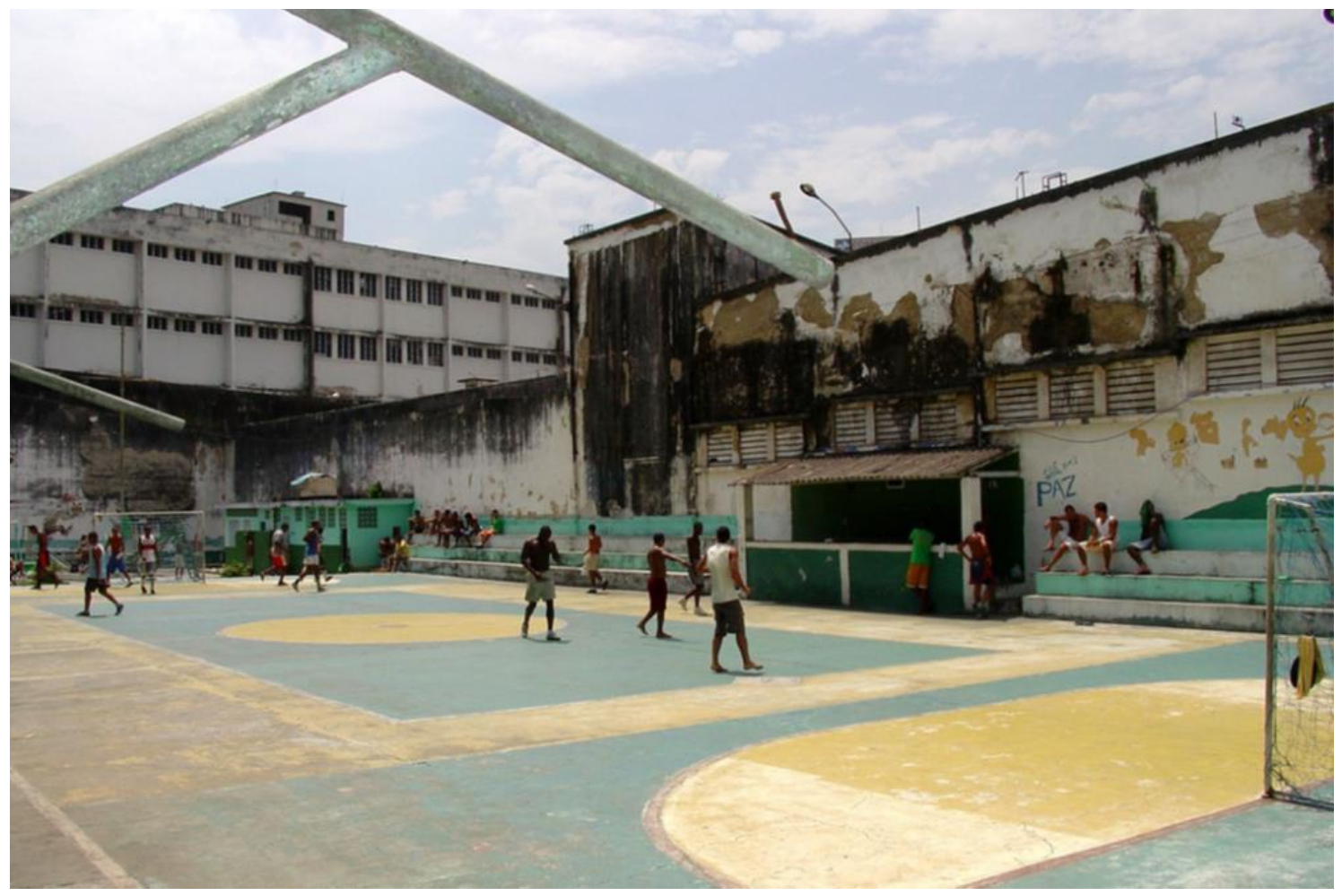

Apud CARDOSO, 2008.

Outro espaço importante para os presos - do qual falaremos adiante, já que o Coletivo teve importância fundamental para torna-lo efetivo - era o Parlatório. Este era o espaço em que o preso podia desfrutar de momentos de privacidade e intimidade com sua companheira. Araújo, em sua pesquisa recente, portanto de temporalidade diferente da nossa, acredita que as visitas íntimas no Parlatório "cumprem uma função importante, no sentido de que a troca de afetos entre o interno e sua companheira ajuda a aliviar um pouco mais o estresse e a depressão provocados pelo ambiente prisional".

Outra singularidade da Lemos Brito era a possibilidade de o preso transitar livremente entre os pavilhões e pátios, ou seja, de não ficarem trancafiados em suas celas quase o dia todo, como é comum noutras penitenciárias. A respeito, CARDOSO comenta:

"Seguindo em frente percebia-se que se tratava realmente de uma unidade diferenciada.

Embora de segurança máxima, os presos permaneciam soltos o dia inteiro, o que não é comum, pois a praxe é o vulgarmente chamado regime de "tranca", onde os presos permanecem nas celas, que normalmente são coletivas, durante todo o dia. Havia um grande portão que dava acesso à parte administrativa da unidade. Esse portão, embora permanecesse aberto, só era atravessado pelos presos-faxina, que usavam camiseta branca [no inicio dos anos 2000, quando a pesquisadora visitou a penitenciária], tratava-se de uma fronteira onde somente alguns presos previamente selecionados através de uma marca, 
poderiam passar sob pena de sofrerem algum tipo de sanção disciplinar. Os presos comuns, de camiseta verde [nos anos 1960 era camisa branca] só o atravessam mediante autorização". (CARDOSO, 2008, p. 74)

O convívio dos presos nos momentos de folga acontecia nos pátios da penitenciária. Havia o pátio da cantina, onde se reuniam logo de manhã, para o café e nos horários das refeições, já que ali ficava, também, o refeitório.

Outro pátio, o pátio-praça, era o preferido pela maioria dos detentos. Ali se formavam as rodinhas, sentados em torno das mesas, ou nos bancos, que praticamente eram privativos de cada grupo. André Borges, um dos presos comuns que se integrou ao Coletivo na penitenciária, conta como se davam estes encontros:

"Não havia, como em outras penitenciárias ou presídios separação por pavilhões. Isso facilitava o convívio e propiciava um intercâmbio social intenso. Em razão disso, o nível de sociabilidade era alto em relação aos outros estabelecimentos penais do país. Alguns presos sentavam-se nos bancos ao longo das paredes, outros em mesas existentes no meio do pátio dividindo-o em duas passarelas, por onde a maioria ficava desfilando em animadas conversas". (BORGES, 2008, p. 24)

Pelo relato acima, podemos imaginar que o espaço do pátio-praça era dividido em duas partes, através de mesas dispostas e alinhadas no meio e, nas laterais, colados às paredes, havia os bancos dos vários grupos. Veremos que nosso Coletivo tinha um. Ali, só sentava se fosse convidado.

Antônio Duarte conta que o pátio era de todos e o fluxo de pessoas era grande. Ali, se divertia e se desentendia. As discussões e as brigas eram comuns, por derrota no jogo ou por vingança por alguma rixa antiga:

"As galerias eram forradas de uma camada negra que se assemelhava ao asfalto. Nos pátios internos, o cimento era usado como pista para os jogos de malha, pelos internos do coletivo dos jogos de azar, em que se perdia tudo, inclusive a vida. Os perdedores podiam ser assassinados pelos comparsas. O pátio, um lugar de todos, durante os longos dias, onde jorravam a vida, os movimentos dos penados e o sangue dos mortos. Muitos se aferravam ao lugar para todo o sempre. (DUARTE, 2009, p. 307)

No período que estamos estudando, os presos tinham a opção de não deixarem as celas, naqueles momentos em que não estavam trabalhando nas oficinas. Por exemplo, como falaremos no decorrer deste capítulo, geralmente, o Coletivo se reunia, na hora do café, na cela de Prestes de Paula, para as discussões políticas, ou para tratar de assuntos acontecidos dentro dos muros da Lemos Brito. 
O marinheiro José Adeildo Ramos, baleado pelos oficiais da Marinha quando tentava, juntamente com centenas de companheiros, chegar ao Sindicato dos Metalúrgicos, passou por um julgamento pela Auditoria da Marinha. No dia 9 de setembro de 1965, contrariando o conselho de seu advogado, Ramos acatou a intimação da Primeira Auditoria da Marinha, participando pessoalmente de seu julgamento. Ele conta: “Aí, eu disse, 'não, eu vou'. E fui. E fui para o julgamento, na data que eles me mandaram, fui. Foi uma grande merda que eu fiz". O processo que corria desde abril de 1964, contra aproximadamente 25 marinheiros do portaaviões Minas Gerais, somente naquela data chegou ao veredicto. Os sete marujos que compareceram à auditoria foram condenados a dois anos de cadeia. Antes Ramos não tivesse comparecido, como a maioria dos marinheiros fizeram! "Dois anos de prisão. Tinha um colega lá, um baiano, que chorava. Aí, sim, é, quando a gente entrou na Auditoria, já fecharam [a porta]. Era uma ratoeira: Entrou, não saía mais. O certo era ter ficado fora esperando o julgamento. (...) entrava em uma embaixada e ia embora. Muitos colegas nossos fizeram isso. Foram para o México, para o Chile. Muitos. Resultado: fecharam, pronto, não tinha mais como sair. Condenado, dois anos. Saímos dali para o Presídio Naval”, ${ }^{4}$

Adeildo e seus colegas foram enviados ao Presídio Naval, porque, além de serem marinheiros, suas penas eram inferiores a dois anos. Se fosse acima disso, seriam encaminhados para uma penitenciária.

No segundo dia no presídio, já se familiarizando com o ambiente e o marinheiro baiano já conformado com a nova situação, Adeildo fez outra "merda". Sentado sobre uma pilha de madeira, a espiar o movimento e conversar com outros marinheiros na mesma situação, Adeildo questionou as ordens de um sargento que passou diante do grupo pedindo para que se levantassem, e prestassem continências a ele. Ao ouvir do oficial "levanta!", Adeildo respondeu: “'Levantar por que sargento?' 'Levanta, não está vendo a autoridade passar?' 'Sargento, eu não sou militar não, eu sou civil' [tinha sido expulso da Marinha em setembro de 1964]. 'Ah, é mesmo!' correu e foi dar parte, falar com o diretor”. Ao serem chamados pelo diretor do presídio, este perguntou o que tinha acontecido. Seguiu-se o seguinte diálogo: "'olha, tem uma denúncia de que vocês estão se comportando mal, eu preciso saber o que está havendo'. 'Tenente, ninguém se comportou mal, o sargento passou e

\footnotetext{
${ }^{84}$ Entrevista a Flávio Luis Rodrigues. João Pessoa, 21 de julho de 2011.
} 
gritou para a gente se levantar'. 'Mas aqui tem que ser, a ordem é essa, quando passar um oficial, um sargento, os presos têm que se levantar, ficar em pé'. 'mas, o que eu respondi a ele eu digo ao senhor: eu não sou militar, eu não sou mais militar, eu sou civil'. 'É, você tem razão, vocês são civis, e não sei por que mandaram vocês para cá, o lugar de vocês não é aqui, o lugar de vocês é na prisão civil'. Isso foi de manhã. De tarde, chegou o camburão da polícia para levar a gente. Levaram a gente para a Penitenciária Lemos de Brito. E aí, alguns colegas já começaram a achar que eu tinha sido o responsável por aquilo, entendeu? Poderia ter ficado ali, no presídio naval, porque era um ambiente ruim, mas era muito melhor, era tudo da Marinha. Aí, eu já fiquei cheio de dedo, né?”.

A chegada dos primeiros marinheiros à Penitenciária Lemos Brito foi desagradável. Logo, os guardas mandaram que ficassem nus. Trouxeram as "fardas", composta de calça cinza e camisa branca. Tiraram fotos e "tocaram piano", deixando suas digitais e partiram para dentro da penitenciária. Cada marinheiro ficou em cela separada por uma semana - é a "prova do silêncio", comum para todos os ingressantes na penitenciária. Terminada a semana de "adaptação", os marujos foram, enfim, introduzidos no submundo da penitenciária:

"Bom, aí, quando botaram a gente para o pátio, no meio dos marginais, um pátio enorme, estava cheio de barracas vendendo tudo, maconha, assim, a solta. Os caras fumando maconha direto, não era escondido não. Fumavam lá, e o guarda vendo e nem ligava. Jogo, tudo, e os piores marginais do Rio de Janeiro. Nessa época, o Rio de Janeiro fazia pouco tempo que tinha deixado de ser a Capital Federal, e os piores marginais, nós podemos dizer assim, do Brasil, estavam ali. Flávio, no primeiro dia que botaram a gente para esse pátio, a gente tinha sentado assim, em volta da parede tinha umas baluarte assim... Mais em cima, uma tábua, que servia de banco. Então, a gente sentado naquele troço ali e lamentando a nossa situação, 'onde é que a gente tá!' Daqui a pouco vem aquele tumulto: eheh! E uma correria danada. Lá vem um cara correndo e outro com uma faca com espeto atrás dele. $O$ cara correu, quando o guarda viu, esse pátio era separado com a grade para o corpo da guarda. O guarda, quando viu aquilo, fechou o portão para o cara não entrar. Tremenda perversidade, porque podia ter esperado, quando o cara passasse ele fechava, deixava o cara do outro lado e o assassino provavelmente ia se intimidar, ou se entrasse para lá eles avançavam para cima do cara. Mas não, ele fechou, o cara agarrou-se na grade, o cara 'trá!', matou ali, ainda sujou Valdir Delgado de sangue, a calça dele ficou com espirros de sangue. A gente ficou apavorado, né. A gente ficou apavorado. Que negócio, onde é que a gente tá!", ${ }^{5}$

\footnotetext{
${ }^{85}$ Idem.
} 
Este foi o "batismo" dos primeiros marinheiros que chegaram à Lemos Brito. Segundo Ramos, os sete eram: Adeildo, Cabo Gonzaga, Valdir Delgado, Jonas de Barro Melo, Luiz Carlos Figueiredo, Osmar de Jesus Barbosa, Josivaldo, “esse que chorava que só”.

O assassinato contado por Adeildo também foi assistido por um preso comum desconhecido, mas que percebeu a chegada dos militares e tomou conhecimento dos motivos pelos quais aqueles marinheiros estavam sendo enviados para a Lemos Brito. Este preso já conhecia outros militares ali presentes, sargentos que participaram da chamada Revolta dos Sargentos de 1963. Inclusive o líder da Revolta, Antônio Prestes de Paula, ali se encontrava. Edison Duarte Mello, preso na Lemos Brito desde 1958, conta o que Adeildo presenciou, numa perspectiva mais trágica:

Eu vi o cara cortar a barriga de um sujeito, cortar a barriga e o pescoço, pegar as tripas todas e botar assim... Chegar na cabine do guarda e dizer assim: 'ó, eu acabei de matar um porco', mostrando a ele as tripas todas tremendo, o coração batendo, o cacete. O guarda ficou meio lelé da cuca. Ele era filho de um inspetor da guarda. Aí, foi ser guarda também e aconteceu isto com ele. E os dois caras, um que matou o outro era unha e carne, um não saía do lado do outro. Um cunhado do outro. O guarda teve um choque tão grande que nunca mais se curou. Ele foi inclusive aposentado. ${ }^{86}$

Esta passagem traumática lembra a contada por Graciliano Ramos no tempo em que passou pela Lemos Brito. A brutalidade consentida e a frieza dos guardas:

"Os gritos daquela noite eram de um garoto violado. Essa declaração me estarreceu. Como podia suceder tal coisa sem que atendessem aos terríveis pedidos de socorro? Muitos guardas eram cumplices, ouvi dizer, e alguns vendiam pequenos delinquentes a velhos presos corrompidos - vinte, trinta, cinquenta mil-réis, conforme a peça" (RAMOS, 1998, 309).

Adeildo e seus colegas, desesperados, começaram a ser bulidos pelos presos comuns, que provocavam: “mas eles que queriam ser almirantes, olha aí o que é que deu”. Eles nada respondiam e a insegurança só aumentava. Sentiam-se desprotegidos, abandonados, desamparados, temendo pelo que poderia acontecer com o grupo. Foi quando os sargentos os procuraram, para aconselhar e unirem-se para protegê-los:

"Aí os sargentos é que chegaram para a gente: 'olha, não queira negócio com esses marginais, não se aproximem deles, não respondam, não queiram negócio, não provoquem eles, mas, também não queiram negócio com eles'. 'E estejam todos unidos porque é um perigo estar no meio desses caras'. Porque, inclusive, a gente, todos novinhos, eu tinha o quê? 20 anos, entendeu? O Luiz Figueiredo era mais novo do que eu, tinha 18 ou 19, tudo

\footnotetext{
${ }^{86}$ Entrevista a Flávio Luis Rodrigues. Rio de Janeiro, 10 de julho de 2012.
} 
novinho. Então, ali os caras são tarados, os marginais, se pegar um cara desses, eles estupram o cara, sabe? Vai com a faca e força o cara a ser o instrumento de sexo dele. Estupra mesmo. Então, o sargento falou: 'oh, nós devemos estar todos juntos, ter muito cuidado com esse pessoal, não facilite com eles'”. ${ }^{87}$

A partir desse, momento os marinheiros juntaram-se aos sargentos, formando um grupo coeso. Mesmo assim, os marinheiros sempre estavam tensos, ansiosos. No curto período em que ali ficaram, antes de serem transferidos para a Presídio Esmeraldino Bandeira, assistiram a vários outros assassinatos, como o do engenheiro civil, "um cabra muito bom”, morto por um dos internos de forma também sórdida, quando tirava um cochilo no banco, após o almoço e o assassino "jogou uma quantidade de gasolina nele e riscou um fósforo. $\mathrm{O}$ cara saiu correndo como uma tocha de fogo. Passou três dias morrendo".

Poucos dias depois, os marinheiros foram transferidos para o Presídio Esmeraldino Bandeira. Na interpretação de Adeildo, isso se deu porque o Esmeraldino abrigava presos com penas pequenas, abaixo de dois anos, como era o caso deles, e também porque a Administração penitenciária queria separá-los dos sargentos.

Enquanto Ramos estava no Presídio Esmeraldino Bandeira, trabalhando na enfermaria, distribuindo remédios para os presos tuberculosos, "um ambiente muito bom, ótimo", outros membros do Coletivo começaram a chegar na Lemos Brito, ou na vizinha Milton Dias Moreira.

O primeiro deles foi Antônio Duarte. Preso em junho de 1966, Duarte passou dois meses prestando depoimentos no Presídio da Ilha das Cobras e foi enviado para a Penitenciária Lemos Brito, aonde chegou em agosto do mesmo ano.

Sua chegada foi marcada pela desolação. Um sentimento de derrota, por ter sido "reduzido à nulidade pela ditadura", ao ver-se igualado à escória da sociedade, traficantes, estupradores, homicidas... "Ali jazia, na eterna inércia da cadeia. A porta de ferro com seu barulho e seus tinidos se fechou, isolando-me do universo maior. Muitos pensamentos me assaltaram, de vazio, frustração, ódio, desespero e contraditoriamente de esperança". (DUARTE, 2009, p. 286)

A esperança, na verdade, foi nascendo com o tempo. Nesse momento de chegada, seus pensamentos talvez estivessem mais próximos da frase que Dante Alighieri colocou na entrada de seu inferno: "Renunciai às esperanças, vós que entrais".

\footnotetext{
${ }^{87}$ Entrevista a Flávio Luis Rodrigues. João Pessoa, 21 de julho de 2011.
} 
Porque esperança está associada à expectativa de futuro e o tempo na cadeia é um eterno presente. Foi nesses termos que Prestes de Paula resumiu aquele lugar, ao ser questionado por Duarte "como você gasta o tempo aqui?"

"O tempo aqui não existe, estamos paralisados no tempo. A cadeia encerra também a passagem do tempo. O negócio é encontrar alguma atividade para enganar a passagem do tempo. Eu, por exemplo, trabalho aqui cuidando dos doentes mentais". (DUARTE, 2009, pp. 290-91)

Resposta parecida foi-lhe dada pelo preso comum, que se integrará ao Coletivo, José Michel Godoy: "Futuro é tempo que não existe, só o presente". (Idem, 322)

Duarte, aos 26 anos, no cubículo onde deveria passar longo, longo tempo, refletia sobre a vida que iniciava. Lembrou-se do momento de sua chegada à Lemos Brito, quando o guarda penitenciário recolheu sua roupa, que acabara de comprar em uma loja da Rua Marechal Floriano, depositando-a, embrulhada num "pequeno saco de papel, enrolado, amarrotado sobre a tábua de pinho velho" e, confiscando seu dinheiro, disse-lhe: "aqui você não precisa de dinheiro!”.

Ali, examinando sua cela, sentado à "cama de ferro, presa na parede, articulada por suportes de ferros e sustentada por correntes presas em argolas que se penduravam da parede branca", Duarte recebeu a sua primeira "visita". O faxina da galeria, que abrira a portinhola da porta de madeira para conhecer o novo "residente", pôs-se a conversar com ele, na estranha linguagem carcerária, que o marujo pouco entendia, perguntando, por exemplo, qual era o seu "artigo". Lá pelas tantas, o faxina estendeu a mão, mostrando-lhe um cigarro aceso de maconha. Duarte recusou, recuando. Foi quando o faxina lhe disse: "você vai precisar disto. É um bom calmante para entrar na cela e dormir bem".

Voltando à solidão da cela, deitando-se na cama com cheiro de mofo das cobertas, Duarte pôs-se a recordar os tempos da vida nos grandes navios de guerra, que não deixava de ser, guardadas as proporções, uma grande prisão ambulante. "Era como se estivesse saindo daquele ambiente dos navios da Marinha, dos beliches, do cheiro de óleo, para outra prisão, como um grande encouraçado de pedra”. (DUARTE, 2009, p. 289)

Assim que Duarte deixou o isolamento da "prova de silêncio", foi imediatamente enviado para exames no Hospital Penitenciário, no setor de biopsicologia, onde, para alegria sua, avistou Antônio Prestes de Paula, assistente do médico. "Sentia algo indescritível. Encontrar ali alguém que havia lutado, como nós, na Marinha, por direitos civis para os soldados". Foi neste momento, quando estavam a sós, que se deu o diálogo sobre o tempo, citado acima. 
Prestes de Paula pareceu-lhe abatido e melancólico. O tempo que já passara na cadeia e o que ainda haveria de passar deixou-lhe uma implacável marca. Já não era aquele líder de setembro de 1963:

"Ele sofria de uma palidez crônica, como se estivesse atacado pela malária. Não olhava com aquele olhar brilhante, das pessoas alegres, parecia que vivia uma existência apagada pela injustiça contra ele praticada, sem poder reagir como queria. Ele tinha mulher e filhos, existência cortada bruscamente por aqueles acontecimentos de setembro de 1963, quando à frente de um grupo que cercava o quartel general do Exército em Brasília, ordenou a retirada. Naquele instante, se convenceu da inutilidade de atacar o quartel com os parcos recursos humanos que dispunha. Sentiu-se traído pelos seus companheiros sargentos do Exército que não cumpriram o acordo em rebelar a unidade aquartelada. Ele era uma pessoa gentil". (DUARTE, 2009, p. 328).

Pedro Viegas demorou um tempo para chegar à Lemos Brito. Preso em 8 de fevereiro de 1967, foi enviado para a Delegacia de Vigilância e Captura, depois transferido para o Presídio do Estado da Guanabara (PEC), onde conheceu o inferno, convivendo com 30 marginais na mesma cela. Ali, passou quase um mês, sendo transferido para a Penitenciária Milton Dias Moreira no dia 3 de março de 1967.

Chegando à Milton Dias Moreira, foi logo conduzido a uma cela individual, onde deveria passar sua primeira semana incomunicável - era a "prova de silêncio".

No dia seguinte, no entanto, foi chamado pelo diretor da penitenciária, que lhe comunicou que, por ordem do Superintendente do Sistema Penitenciário (SUSIPE), o promotor Vicente da Costa Júnior, prestaria serviços na Divisão Legal, logo após sua saída da "Prova de Silêncio".

No penúltimo dia da "Prova de Silêncio", Viegas recebe a visita de Antônio Prestes de Paula. Falou-lhe que trabalhava na Biopsicologia da penitenciária, juntamente com exmarinheiros que participaram da Rebelião dos Marinheiros, Lourenço Bernardino Senna e Raimundo Nonato.

-"Amanhã, tu vais ser retirado da cela para fazer um teste biopsicológico. É normal. Todos fazem", disse-Ihe Prestes de Paula. (VIEGAS, 2004, p. 69).

Saindo, enfim, do isolamento, Viegas dirigiu-se para o pátio, meio tonto. Mas, ao ver a multidão "que se movimentava sem parar pelo pátio, tive a sensação de tonturas e até de náuseas. Parecia que andava sobre as nuvens balouçantes, por vezes desabando em vácuos". 
No meio da multidão, avistou um rosto conhecido e querido: Antônio Duarte. Seguiram-se confraternizações e troca de informações com o grande amigo, desde os tempos da AMFNB.

Duarte apresentou ao amigo os ex-marinheiros e ex-fuzileiros que haviam chegado a pouco. Viegas ficou impressionado com o que viu: $\mathrm{O}$ ambiente era de completa ociosidade para a maioria. Algo que chegava a "ser inacreditável. A única atividade visível era o jogo. Os que trabalhavam podiam considerar-se privilegiados e, de fato, eram. Formavam uma infima minoria, quase não notada”.

Alguns ex-marinheiros já estavam trabalhando em oficinas. Estes só eram vistos às refeições e no final da jornada. Os outros, como ele, ficavam ociosos, conversando ou lendo. "Mas até ler nos era difícil, pela algazarra dos adeptos de jogos como o dominó e um outro, conhecido como malha, que consistia num pedaço de tábua molhada, arremessada ao rés do chão, de um lado para o outro, ao longo da extensão do pátio.” (VIEGAS, 2004, p. 70).

Mas o que mais impressionou e chateou Viegas foi a situação de total abandono dos militares, que não eram tratados como presos políticos, e sim como marginais, como presos comuns. Onde estavam os políticos aliados do tempo da AMFNB? Quede os advogados que haviam prestado serviços à Associação? "Esse abandono era tamanho que afetava o equilíbrio psíquico de alguns".

Viegas conta o caso do marinheiro Luiz Gonzaga, preso por participar do protesto da Semana Santa de 1964, típico caso de abandono e de enxovalhamento dos marinheiros:

"Tratava-se, em suma, de um quadro horrível, em que a personagem mais dramática era vivida por Luiz Gonzaga, completamente dopado e alheio ao mundo, entupido permanentemente de medicamentos antidepressivos violentíssimos. Ele tinha esquizofrenia e, em sua catatonia, arrancava risos do fundo da ignorância de muitos presos comuns e de guardas. Luiz Gonzaga era um dos recém-chegados à Marinha quando veio o golpe e a repressão foi desencadeada. (...) Foi condenado a três anos de prisão, por ter participado do segundo aniversário da Associação dos Marinheiros e Fuzileiros Navais do Brasil. Sua pena acelerou o processo de esquizofrenia". (VIEGAS, 2004, p. 70).

Pouco tempo depois da chegada de Viegas na Milton Dias Moreira, os ex-marinheiros tiveram a notícia de que Marcos Antônio e José Duarte estavam na "prova de silêncio" na mesma penitenciária.

A queda dos dois guerrilheiros se deu em São Paulo, no Bairro do Limão, quando, assustados ao verem uma rádio patrulha, tentaram correr. Foram presos, confundidos com marginais e, após serem identificados, mandados para o DOPS-SP. Como eram militares da 
Marinha e respondiam processo no Rio de Janeiro, para lá foram escoltados. Assim, apesar de terem sido presos no mesmo dia da prisão de Viegas, demoraram um pouco mais de tempo para serem enviados para a Milton Dias Moreira.

Quando os dois ex-marinheiros deixaram o isolamento, encontraram seus amigos a recepcioná-los. Colocaram as informações em dia, mas não deixaram de expressar o desencanto com a situação dos marinheiros. Viegas conta como os recém-chegados ficaram ao ver seus colegas: "Estarrecidos com o estado de abandono dos companheiros da AMFNB. Com eles, começariam as tentativas de buscar o que fazer para que o quadro fosse virado e as primeiras atitudes concretas para que o grupo ganhasse feição de coletivo minimamente organizado para enfrentar aquela situação abjeta”. (VIEGA, 2004, p. 73).

Não tardou para que o grupo de ex-marinheiros presos nas penitenciárias Milton Dias Moreira e Lemos Brito "ganhasse feição de coletivo". Principalmente com a chegada de Capitani, em maio de 1967.

Preso no dia primeiro de abril de 1967, dia da mentira, Capitani estava muito debilitado, acometido de peste bubônica, por ter ingerido comida contaminada pelos ratos do mato, no tempo que passou na Serra de Caparaó.

Assim que deixou o isolamento na Lemos Brito, Capitani foi recebido por um "Comitê de recepção": Marcos Antônio, os dois irmãos Duarte, Viegas e o ex-sargento da Aeronáutica Prestes de Paula estavam entre um grupo de 30 marinheiros também presos políticos. (CAPITANI, 1997, p. 123). Enfim, estava novamente reunido o Coletivo, embora em condições muito desfavoráveis. Do "núcleo duro" da AMFNB, só faltava Antônio Geraldo Costa. Neguinho, estando em São Paulo, tinha notícias frequentes dos amigos detentos. Chegará a hora em que ele vai ajudá-los a se livrarem daquele inferno.

Logo no primeiro dia em contato com o Coletivo, Capitani foi informado por Marcos Antônio das negociações com a Administração penitenciária, para concentrar os marinheiros dispersos nas três penitenciárias - Lemos Brito, Milton Dias Moreira e Esmeraldino Bandeira - em apenas uma, na Lemos Brito e, se possível, na mesma galeria. Além disso, foi informado, também, que o Coletivo planejava a fuga e sua entrada na guerrilha.

O que o Coletivo pretendia era quase impossível e, certamente, demandaria muito tempo. Dadas as circunstâncias em que se encontravam, convivendo com presos perigosos, correndo o perigo real de morrerem, ficarem incapacitados, ou mesmo serem currados, o mais urgente naquele momento era criar um grupo coeso, numeroso, para mostrarem força e união à massa carcerária. Por isso, a necessidade de se unirem todos na Lemos Brito. 
Conseguindo uma audiência com o diretor da penitenciária Milton Dias Moreira, os marinheiros argumentaram que não podiam ficar juntos com os presos comuns, já que eram presos de Auditoria Militar. Que pelo menos os mantivessem unidos numa só carceragem. Como o diretor se mostrou incapaz de resolver assunto tão delicado, prometeu levar o caso ao secretário da Secretaria da Justiça, Professor A. B. Cotrim Neto. Assim o fez, depois, porém, dos marinheiros fazerem chegar à imprensa a situação desumana em que se encontravam. No mesmo dia em que o jornal Correio da Manhã publicou as reclamações dos marujos, 14 de novembro de 1968, o Secretário da Justiça encaminhou o ofício n. 03/JGS ao Governador do Estado da Guanabara, informando-lhe da gravidade de se manter um grupo de subversivos numa mesma penitenciária de segurança média. ${ }^{88}$ Segundo o Secretário, o melhor que poderia ser feito era a transferência desses presos para a Colônia Correcional da Ilha Grande, estabelecimento de segurança máxima. Mas esta alternativa exporia o governo do Estado a "severíssimas críticas", além de desobedecer aos despachos dos Auditores da Justiça Militar, que "invariavelmente declaram que a pena deverá ser cumprida na Penitenciária Professor Lemos Brito”. 89

Apesar dos alertas que fez ao governador sobre a gravidade da situação, Cotrim Neto acabou por conceder audiência ao Coletivo. Não conseguimos informações sobre quais exmarinheiros foram, mas Viegas relata como foi a conversa:

"Chegou o dia esperado da audiência com o Secretário da Segurança [Justiça], Cotrim Neto. Falou-Ihes que sabia o que era uma prisão, já que esteve numa durante o Estado Novo, quando era um jovem integralista. Disse-Ihes também, que conhecia o maior objetivo de quem está preso, principalmente quando se tem uma meta na vida: fugir". (VIEGAS, 2004, p. 75).

$\mathrm{Na}$ audiência, Cotrim Neto salientou que o governador da Guanabara, Negrão de Lima, não tinha interesse "de se chocar com autoridades navais”. Disse, entretanto, que uniria os ex-marinheiros na Lemos de Brito aos poucos. Que tivessem paciência. E assim foi feito. O pessoal que estava na Milton Dias Moreira foi transferido para a Lemos de Brito e,

\footnotetext{
${ }^{88}$ AEL - BNM 141; caixa 1, volume 3, folhas 394 a 397. Quando 6 ex-marinheiros e 3 presos comuns fugiram da Penitenciária Professor Lemos Brito, em 26 de maio de 1969, foi instaurado um Inquérito Policial Militar IPM, através da mensagem 022202Z/jun/69 do Ministro da Marinha, sendo indicado como encarregado do IPM o Contra-Almirante Júlio de Sá Bierrembach. Esse IPM foi arquivado no Superior Tribunal Militar sob o n ${ }^{\circ}$ STM 40.189. Consultamos suas cópias no Arquivo Edgard Leuenroth - AEL, na UNICAMP, que guarda as cópias dos processos políticos que transitaram pela Justiça Militar, na esfera do Supremo Tribunal Militar STM, reunidas pelo projeto de pesquisa "Brasil: Nunca Mais" - BNM, uma iniciativa da Arquidiocese de São Paulo iniciada em 1979.

${ }^{89}$ Idem.
} 
mais tarde, os ex-marinheiros presos na Esmeraldino Bandeira também chegaram à penitenciária.

Viegas ressalta que os internos da Esmeraldino não gostaram de ser transferidos, porque já estavam ambientados ali, e porque sua localização oferecia melhor acesso a seus parentes.

José Adeildo Ramos era um dos que estavam na Penitenciária Esmeraldino Bandeira. Sabia que na Lemos Brito havia muitos ex-marinheiros. Que lá estavam os diretores da antiga AMFNB. Mas, quando recebeu a notícia da sua transferência, ficou surpreso. Ele conta:

"E a gente lá em Bangu. Eles tinham botado a agente para trabalhar, perguntaram se a gente queria trabalhar numa clínica que tinha lá do sistema penitenciário, clínica fisiológica. $A$ gente, "tudo bem". A gente foi trabalhar. Era um ambiente muito bom, ótimo. Era como se fosse um hospital. Era uma clínica para os presos comuns, mas, a gente ficava separado deles. Só isso aí para a gente, já era ótimo. Ficávamos separados deles, porque eles eram tuberculosos né, e a gene ajudando. Eu trabalhava na enfermaria distribuindo remédio para elas. Cada um tinha uma função burocrática lá. Teve até um colega nosso que fugiu de lá. Eu não fugi porque não quis. Mas que tinha ambiente para fugir lá, tinha. Mas não estava a fim de fugir, já estava perto de terminar minha pena, terminar tudo e ir embora. Aí, o pessoal que estava na Lemos Brito reivindicou ao Superintendente do sistema penitenciário que juntasse todos nós na Penitenciária Lemos Brito. Aí, um dia chegou já a ordem. (...) Mas, quando a gente chegou lá, que viu o pessoal, então, a gente viu que era bom. Já tinha o quê? cerca de... A diretoria praticamente, a direção estava na cela [presa], né? A diretoria estava ali. E pronto, foi bom, num clima ótimo. A gente tinha um grupo bem maior. Foi um clima muito bom, a gente gostou. Só teve um que não gostou, que não quis de jeito nenhum ficar, aí foi lá falar com o comandante, queria voltar. E voltou.". 90

Os planos do Coletivo estavam lentamente se concretizando. A concentração de exmarinheiros numa só prisão não deixou de ser notada pela população carcerária. Fortaleceu o Coletivo diante da massa carcerária. “(...) o respeito redobrou. (...) A partir daí, veio a facilidade de diálogo e até a possibilidade de discussões políticas de modo mais ampliado. Pequenos atos hostis praticamente sumiram, e os ex-marinheiros tiveram uma penetração tão grande no seio daquela massa que passaram até a ser uma referência dentro dela". (VIEGAS, 2004, pp. 75-76).

O sentimento de ter sido derrotado pela ditadura, reduzido à nulidade e condenado a viver como marginal dentre marginais, que Antônio Duarte sentiu nos primeiros dias na

\footnotetext{
${ }^{90}$ Entrevista a Flávio Luis Rodrigues, João Pessoa, 21 de julho de 2011.
} 
Lemos Brito, se transformou num desafio a ser enfrentado: mostrar que os membros da AMFNB não se deixariam esmorecer e manteriam de pé, mais do que nunca, sua dignidade e seus princípios.

Mas o que sustentou esses moços unidos e em atividade foi possuírem um projeto de futuro, um "horizonte de expectativas". Acreditavam cada vez mais na Revolução, que derrubaria a ditadura e libertaria o país de suas elites mesquinhas. Daí, procurarem instruir politicamente seus amigos ex-marinheiros, alguns recalcitrantes, para aceitarem a nova realidade:

"Procurávamos manter entre os nossos companheiros mais próximos - aqueles trinta ou quarenta prisioneiros - um brilho de fé no futuro, de rebelião contra o obscurantismo. Também encontrávamos resistência dos pessimistas, dos resignados, a frieza de seus lábios cerrados, das acusações de incautos: 'seguramos num rabo de foguete', diziam-nos". (DUARTE, 2009, p. 284)

Esses homens viviam fazendo planos para atuarem no ambiente carcerário, ações que atingissem o individualismo e o egoísmo daqueles presos miseráveis, na esperança de os fazer, ao menos, refletirem sobre suas vidas.

"Na penitenciária, as ocorrências assumiam, às vezes, contornos de uma peça destinada a censurar os que caíam em desgraça ou em ridicularizar os defeitos, de forma a não dar ao acusado nenhuma possibilidade de defesa. (...) Solidariedade não era palavra conhecida por aqueles homens embrutecidos pelo egoísmo atroz, sem piedade, aquele sentimento que a nossa cultura católica eternamente prega. (...) Marcos e Prestes de Paula permaneceram conversando. Depois decidimos ir, em um pequeno grupo, ao cubículo do Prestes de Paula tomar café e traçar planos. Vivíamos deles, tínhamos conquistado prestígio entre alguns presos e solidificado nossa posição de presos políticos. Não éramos mais otários ou, simplesmente, ex-soldados. Nossa mensagem havia chegado ao grande coletivo penitenciário. 'Os bandidos' respeitavam os 'otários'”. (DUARTE, 2009, pp. 284-285)

Otários: Aqueles que não deveriam estar ali. Que vacilaram, acreditaram na generosidade das pessoas. Os otimistas em relação ao homem, ao futuro da humanidade. Assim eram vistos os marinheiros pelos demais presos. Como conviver com pessoas violentas e egoístas? Haveria como intervir naquela realidade? Mostrar aos presos comuns o nexo entre a criminalidade e suas condições sociais geradas por um capitalismo perverso, seria suficiente? 
A violência era uma realidade, assistida cotidianamente pelos marinheiros. Ainda hoje guardam nítidas estas lembranças negativas. Capitani conta que, em apenas um mês assistiu a três assassinatos pavorosos:

"Entre os chamados presos comuns, as coisas eram, diferentes. Em um mês assisti três atos de violência que me deixaram abalado.

Estava sentado no pátio, em frente a um rapaz jovem que dormia no banco. De repente, outro prisioneiro enfiou um saco de estopa embebido em gasolina na cabeça do rapaz, amarrou e tocou fogo. O rapaz morreu gritando, horas depois. No outro episódio, estava entrando no refeitório para o almoço quando um cozinheiro se aproximou rápido e sorrateiro com uma enorme faca de cortar carne que atravessou o tórax de um preso pego de costas. Em minha galeria, um preso enfiou o estoque na barriga do outro, matou, arrancou as vísceras, desceu as escadas e foi mostrar ao guarda, dizendo que havia matado um cachorro". (CAPITANI, 1997, p. 125).

Interessante a descrição que Capitani fez do último assassinato descrito acima: “arrancou as vísceras... dizendo que havia matado um cachorro". É idêntico ao descrito por Edison e muito parecido com o crime que Adeildo assistiu, assim que chegou á Lemos Brito. Será o mesmo crime? Trata-se de mais uma armadilha da memória? De qualquer forma, as ameaças aos marinheiros eram constantes. Enquanto não houve a unificação dos marinheiros na Lemos Brito, estes viviam sobre grande tensão, evitando ao máximo a aproximação com os presos comuns. Mas, as vezes, era inevitável. Na verdade, os presos tidos como "perigosos" aproveitavam da fama para extorquir os que julgavam mais fracos. Isso aconteceu com o próprio Capitani. Ele conta:

"Algumas vezes, éramos desafiados e, um dia, chegou a minha vez. Recebi da companheira Flora, nossa advogada e minha futura namorada, um pacote de cigarros, artigo precioso no presídio. Um prisioneiro da cela em frente viu o meu presente. Diziam que eram um sujeito de muitos crimes e que precisaria de muitas vidas para cumprir toda a sua pena. Ao entrar em minha cela, ele disse:

- Quero teu pacote de cigarros.

-Não dou, quer fumar?

Ofereci quatro cigarros.

- Não, eu quero o pacote. Se não der por bem, vai dar por mal. 
Ele apanhou o estoque ${ }^{91}$ e veio na minha direção. Entrei na cela, fingi que também tinha apanhado um estoque e disse:

- Posso te matar e tu também podes me matar mas, nesse caso, tu sabes que vais morrer logo. Talvez, amanhã.

Ele recuou. Fazíamos uma guerra psicológica em toda a penitenciária: aquele que matasse um marinheiro não viveria muito. Funcionou mais do que o esperado. Com o tempo, as provocações e ameaças deram lugar a um relacionamento amistoso. (CAPITANI, 1997, pp. 124-125).

Pouco depois da chegada de Capitani à Lemos Brito, o Coletivo, liderado por Marcos Antônio, começou a orientar os ex-marinheiros, agora ali reunidos, a reagirem organizadamente às investidas de outros presos, ou dos guardas penitenciários. O caso da japona de Antônio Duarte é um exemplo, quando ele resolveu colocar uma jaqueta reforçada, que ganhara de seu irmão Olivar, também marinheiro, e foi abordado por um guarda, que estranhou que estivesse com as golas levantadas devido ao intenso frio. $\mathrm{O}$ agente penitenciário segurou a gola, girando-a e disse: "É assim que se foge! Esta não é roupa de preso”. Surpreso com a reação do guarda, Duarte deu-lhe "um safanão na mão do intruso, num gesto de puro reflexo". Foi o bastante para se criar um quiproquó danado! O guarda começou a berrar, chamando outros guardas, que o castigaram e o prenderam na cela de isolamento. A temperatura esquentou. Marcos Antônio, Prestes de Paula e outros protestaram e pediram reunião com o diretor. Diante do diretor, que ouvia as argumentações de uma comissão de dez marinheiros e o guarda, este falou das dificuldades que tinha em proteger presos que não eram delinquentes comuns, mas militares, que deveriam estar sob a guarda da Marinha.

Essa era sempre a ladainha que os ex-marinheiros ouviam das autoridades: não eram presos comuns, mas não podiam ser tratados como presos políticos. E essa era a principal reivindicação do Coletivo: ser reconhecido como um grupo de presos políticos. Era uma questão, porém, que não dependia exclusivamente da administração penitenciária do Estado da Guanabara, como já dissemos. O Secretário da Justiça chegou a encaminhar um ofício ao Delegado Regional do Departamento Federal de Segurança Pública - GB, em 16 de março de 1967, que tratava da descoberta de "material subversivo (esquema de guerrilhas, particularmente)” em posse de Antônio Prestes de Paula:

\footnotetext{
${ }^{91}$ Estoque na definição de Capitani: "O estoque era a arma mais comum e preferida dos prisioneiros. É feito com um pedação de qualquer metal em forma de lâmina ou arredondado, cumprido e pontiagudo. Sendo desafiado por um estoque, tínhamos que enfrentar: era nossa orientação. Se cedêssemos, seria o começo do nosso fim, não só como prisioneiros políticos, mas também como seres ainda humanos". (CAPITANI: 1997, 124)
} 
"Fomos informados pela Secretaria de Segurança de nosso Estado de que o ex-Sargento Prestes trama sua fuga". 92

O ofício acima afirma, ainda, que o "material subversivo" foi apreendido em poder de Lourenço Bernardino Sena e Gilberto Vargas, “os quais trabalhavam com Antônio Prestes de Paula no Serviço de Biopsicologia, do Instituto Médico Penal da SUSIPE, instalado na Penitenciária Milton dias Moreira, na Rua Frei Caneca". Vê-se, pois, que Prestes de Paula era uma preocupação da administração penitenciária, já antes da chegada dos ex-marinheiros. Cotrim Neto recomenda que ele seja monitorado. Porém, Prestes continuou na Biopsicologia e com "livre trânsito" na Praça Getúlio Vargas, que liga as duas penitenciárias, até o dia da fuga do Coletivo da Lemos Brito.

Uma vez que a Auditoria Militar despachou os marinheiros para a Lemos Brito, o sistema prisional do Estado da Guanabara tinha agora um problema para administrar. Como lidar com presos que não eram criminosos? Tratá-los como presos políticos fugia da sua alçada, já que eram militares e, portanto, ligados à Justiça Militar. O Secretário Cotrim Neto chegou a enviar o ofício n. 195, datado de $1^{\circ}$ de abril de 1969, ao Ministro da Justiça, alertando-o sobre o "problema muito grave" que constatara em 1967. Porém, tal ofício só chegou às mãos do Ministro às vésperas da fuga do Coletivo da cadeia. Percebe-se, portanto, que, apesar de alertar para o problema de possuir presos militares em seus estabelecimentos, o secretário não tomou qualquer medida para resolvê-lo. Pelo contrário, permitiu que se concentrassem em uma única penitenciária e tivessem livre trânsito entre a unidade prisional e a Praça Getúlio Vargas. Na verdade, ao ceder às pressões do Coletivo por um tratamento diferenciado, o Secretário não percebeu que estava colaborando com o plano de fuga dos marinheiros.

A preocupação do Coletivo era, pois, encontrar meios que conciliassem ações construtivas direcionadas à massa carcerária e a preparação de seu plano de fuga da Lemos Brito.

Isso ficou mais claro quando Viegas começou a trabalhar na Divisão Legal da unidade, realizando trabalhos burocráticos, como a atualização das informações contidas nas fichas dos detentos. Percebeu, então, que ali era um local muito estratégico, pois lhe permitia maior mobilidade, já que lhe era concedido um crachá autorizando seu livre trânsito na Praça Getúlio Vargas, que separava a penitenciária da portaria de saída para a Rua Frei Caneca. Entendeu, também, que esse crachá fazia com que os guardas lhe abrissem os vários portões

\footnotetext{
${ }^{92}$ AEL - BNM. 414. Caixa 1, volume 3, folha 394.
} 
que separavam sua cela da Praça Getúlio Vargas, sem questionarem nada. Havia, portanto, dois motivos para "ocupar" aquele local: Primeiro por que ficava na parte de cima da portaria, a poucos metros da rua. Portanto, o que os separaria da Rua Frei Caneca seria apenas um portão. Segundo, ali poderiam ajudar aos presos comuns, muitas vezes com penas já vencidas ou naqueles casos em que havia imputação de várias penas atribuídas a um único preso, geralmente obrigados a assinar papéis admitindo crimes sob tortura, nas Delegacias de Polícia. O trabalho de Viegas, por exemplo, era o de identificar esses presos que tinham várias penas e, portanto, vários anos de reclusão, providenciar a unificação das penas, possibilitando reduzir o "total de anos que o condenado tinha a cumprir".

Em agosto de 1967, Viegas pediu a um amigo que trabalhava com ele na Divisão Legal, o ex-marinheiro Geraldo Nobre, que trouxesse José Adeildo Ramos para trabalhar ali. "Viegas pediu ao cara para me chamar para ir. Aí, eu fui. Bom, ali o ambiente era bom, porque a gente passava o dia trabalhando ali, à noite vinha para a penitenciária, todos para sua cela, cada um dormir, só em fim de semana que a gente estava junto. Mas, [durante] o dia, a gente passava fora". 93

Um dia, o chefe de Viegas pediu-lhe que indicasse uma pessoa para trabalhar na Divisão Legal, já que havia acúmulo de trabalho e "reclamações de demora no trâmite de recursos entre os presos comuns". Não pensou duas vezes em indicar Marcos Antônio. Ele conta que a escolha se deu por dois motivos:

"O primeiro, pela própria radicalização das autoridades navais e posta em prática pelos seus juízes. Alguns ex-marinheiros que haviam sido condenados a um ano de reclusão tiveram, ao recorrerem da sentença, suas penas aumentadas para cinco. A única acusação contra eles era a de terem participado da Rebelião dos Marinheiros, no Sindicato dos Metalúrgicos. Não possuíam cargos ou funções na diretoria da entidade. Imagine-se o que fariam com os diretores. Marcos Antônio havia sido vice-presidente da AMFNB e era exatamente contra aquela instância e seus adeptos que desembocava toda a ira da alta oficialidade da Marinha. O segundo motivo estava na opção de levar a luta revolucionária adiante por alguns daqueles companheiros. Marco Antônio, assim como Antônio Duarte e Antônio Prestes de Paula, todos com condenações altas, não tinham motivos para alimentar a menor ilusão de que sua pena poderia ser reduzida por vias legais. Isto, traduzido, equivalia a dizer que a única chance de liberdade seria rebentando os grilhões que lhe privavam os passos e o próprio destino que houvera traçado como opção de vida. A Divisão Legal ficava a poucos metros da rua. Era, portanto, ali o seu lugar. Nome aceito, assumiu a vaga de escriturário". (VIEGAS, 2004, p. 74).

\footnotetext{
${ }^{93}$ Entrevista a Flávio Luis Rodrigues. João Pessoa, 21 de julho de 2011.
} 
Viegas conquistou a confiança de seu chefe, Durval Soares, com sua seriedade e assiduidade. Além disso, o ex-cabo da Marinha não se envolvia com tráfico de papéis, ou seja, não cobrava dos detentos para atender solicitações. "Um preso comum, que trabalhava ali, cobrava do outro lá dentro para fazer um requerimento, fazer um recurso etc., e isso não acontecia conosco. Então, eu ganhei essa confiança e isso facilitava o contato nosso com a rua". 94

Sob a liderança de Marcos Antônio, o Coletivo começou uma série de discussões para definir como alcançariam os pontos chaves próximos da portaria. Após a chegada de Capitani, já estava definido que a fuga seria pela frente da penitenciária, e não pelo muro dos fundos, por onde geralmente os presos tentavam fugir. A preferência que os presos comuns tinham pelos fundos da penitenciária se devia ao fato de que o muro que separava a penitenciária do morro de São Carlos tinha apenas um metro de altura do lado de fora. Portanto, se conseguissem escalar o muro de dez metros, seria tranquilo saltar sobre o chão, do lado de fora da cadeia, e correr. O problema era a vigilância dos guardas, sempre atentos. A fuga pelo portão da frente surpreenderia os guardas da portaria, que jamais imaginariam uma fuga de prisioneiros com autorização de livre trânsito - portanto, da confiança da administração. Capitani conta que, para ter maior influência junto aos internos, era necessário ocupar os lugares administrativos, para ajuda-los a ter uma vida menos miserável, oferecendo-lhes recreações culturais, como teatro, cinema etc. Em relação à ideia de fugirem pela frente da penitenciária, Capitani fala:

"Então ali se construiu, praticamente [o Coletivo] se dominou a penitenciária. Não foi um domínio pela força, foi um domínio pela inteligência, pela organização, por saber criar condições para isso, que viu o melhor para fugir, inclusive pela porta de entrada, que os bandidos lá nunca pensaram isso. Ninguém pensava nisso, nem a penitenciária, ninguém ia fugir pela porta de entrada. As fugas eram subindo a muro, a gente não... aí foi cada um se situando, conseguindo meios para o pessoal trabalhar em determinados pontos que eram importantes para nós. Então isso levou muito tempo, muito jeito, trabalhando pelo que foi designado pelo grupo. Então tudo isso foi sendo construído. Mas é um plano que eu mesmo me admiro, como é que deu certo, porque realmente foi se pensar mesmo naquele tempo da inveja [entre presos comuns que também desejavam fugir]". 95

Para a organização da fuga, seria importante que o Coletivo conhecesse mais profundamente a massa carcerária, seus grupos, suas carências e suas demandas. Na verdade,

\footnotetext{
${ }^{94}$ Entrevista a Flávio Luis Rodrigues. Iperó, 09 de outubro de 2008.

${ }^{95}$ Entrevista a Flávio Luis Rodrigues. Porto Alegre, 12 de julho de 2011.
} 
o Coletivo pretendia criar uma rede de informações que pudesse deixá-los a par do que acontecia entre os muros da Lemos Brito. Segundo Antônio Duarte, o Coletivo tinha seu projeto, que passava pela fuga e integração à guerrilha, através de alguma organização clandestina. Mas, enquanto estivessem presos, pensavam que, como revolucionários, deveriam deixar sementes naquele lugar, onde a carência e a miséria em todos os sentidos eram enormes. Por isso, pretendiam instruir o máximo de presos possível, através de atividades culturais como peças de teatro, sessões de cinema, palestras educativas e formativas, escola, etc. Veremos que, através do Serviço Social, o Coletivo pôde dar ajuda valiosa àqueles “desgarrados”. "O drama que vivíamos agora, na penitenciária, não era nenhuma peça clássica, ou algo semelhante a uma obra de arte. O que pretendíamos era, por meio de certo simbolismo, politizar aqueles desgarrados marginalizados da cidadania. Nós, os marinheiros, também não éramos considerados como tais? Caluniados pela administração Naval?" (DUARTE, 2009, p. 305).

Através da vivência junto aos presos comuns, os marinheiros identificaram alguns que gostavam de leitura, faziam poesias, e se declaravam "de esquerda". Era o caso de André Borges e seus amigos mais próximos. Tendo conhecimento de que esse grupo já era politizado, Marcos Antônio procurou aproximar os dois núcleos, a partir de contanto com o André.

André tinha uma longa pena a cumprir, trinta anos de reclusão, pelos vários delitos cometidos. Encontrava-se frequentemente com outros presos para discutirem política. Sua politização, diz ele, se deu através de diálogos com presos e guardas carcerários ligados ao PCB, e pelas leituras dos livros ali deixados pelos comunistas presos após o movimento de 1935, como Luiz Carlos Prestes. André conta que passaram pela Lemos Brito, além de Prestes, Graciliano Ramos, Agildo Barata, Leônidas Rezende, Hermes Lima, Castro Rebelo e Valério Konder; a cronista Eneida de Moraes, Olga Prestes e Eugenia Moreyra.

De fato, a Lemos Brito já havia abrigado um outro "Coletivo", na segunda metade da década de 1930. Após os levantes comunistas, Getúlio Vargas conseguiu a aprovação pelo Congresso do Estado de Guerra, aproveitando-se para fazer uma perseguição implacável aos comunistas, aliancistas e democratas, que integraram a uma frente antifascista no Brasil. Com a reunião de vários escritores, profissionais liberais, operários sindicalistas, militares comunistas, etc., a Lemos Brito tornou-se uma perfeita arena de debates, que se realizavam frequentemente, segundo Graciliano Ramos, "num grande terraço".

Graciliano Ramos comenta suas impressões sobre as conferências que ali aconteciam: 
"Homem rural, desconfiado e silencioso, propenso a estender-me em compridos monólogos, admirava-me do Coletivo, das lições, especialmente da perícia daqueles citadinos na exposição de ideias em conversas simples e claras. Não conseguiria manifestar-me assim. De ordinário a expressão me fugia, decompunha-se o pensamento, e era uma tortura vencer a estupidez, procurar dizer qualquer coisa gaguejando um vocábulo escasso, miserável". (RAMOS, 1998, 219).

Ali, na Casa de Detenção, também estiveram, no mesmo período que Graciliano Ramos, Apolônio de Carvalho e Delcy Silveira, que também dizem ter aprendido muito com o convívio de pessoas interessantes naqueles anos de cárcere. Sempre havia palestras sobre diversos assuntos. As pessoas interessadas em aprender línguas, podiam escolher entre o inglês, o francês, o russo, o espanhol e o italiano. Segundo Apolônio, a penitenciária era uma verdadeira universidade:

"Não há exagero em afirmar que a prisão foi um importante laboratório político, repleto de comunistas, socialistas, nacionalistas. Havia na prisão muitos oficiais, jornalistas, professores, catedráticos das melhores universidades do país. Tínhamos lá conferências, palestras, enfim, verdadeiros cursos. Foi assim que, de maneira mais elaborada, passei a conhecer a vida política do país. Foi por meio dos comunistas que aprendi a ter uma visão da sociedade dividida em classes, o que era luta de classes e os mecanismos de dominação política e social. (...) Livros entravam lá com frequência, porque as familias visitavam os presos e os traziam junto com outras coisas, no meio de comida e presentes. Então, a gente juntava tudo e lia para depois discutir. Tenho certeza de que qualquer pessoa entrevistada sobre esta experiência vai insistir no fato de a prisão ter sido a primeira grande escola moderna de formação política brasileira. Para mim, que já havia acumulado dúvidas sobre a realidade nacional, que possuía alguma crítica dos contrastes sociais, as lições teóricas ajudaram a organizar meu quadro analítico. Eu carecia de informações sistemáticas sobre doutrina, e o marxismo ensinado atrás das grades fornecia um modelo a ser seguido para compreender esta mudança. Na prisão aprendi os caminhos que já haviam sido trilhados anteriormente em experiências de vários grupos revolucionários. Em suma, foi lá que pude me definir como militante. Como militante político de esquerda". (MEIHY, 2009, 111).

Delcy Silveira também confirma que sua passagem pela cadeia foi decisiva para sua formação política e humanística:

"À época, a prisão era uma verdadeira universidade. Uma escola como nenhuma outra. Uma escola política inigualável. Imagine: tínhamos cursos de inglês, francês, estratégia militar, 
filosofia, enfim, tínhamos o que quiséssemos. Havia professores e oficiais de gabarito presos conosco e que se dispunham a nos dar aulas. No final das contas, considero ter concluído um curso humanístico completo: Letras, História e, principalmente, sobre temas ligados à política. Tudo na cadeia. Até um curso sobre sindicalismo eu tive". (MEIHY, 2009, 135).

Singular esta Penitenciária Lemos Brito: serviu de incubadora de revolucionários, que tiveram reconhecidas atuações contra governos despóticos, como foi o caso de Apolônio de Carvalho e Delcy Silveira, que lutaram contra a ditadura de Franco na Espanha, e contra os nazistas na França, assim como fez o Coletivo que estamos estudando, que se incorporou às organizações guerrilheiras, contra a ditadura civil-militar brasileira.

André Borges ressalta que, quando os comunistas saíram da prisão, deixaram sementes que proliferaram. Quando o Coletivo chegou à Lemos Brito, já havia um grupo que discutia política: "Era um movimento pequeno, mas a chama da consciência política já ardia na pira das prisões". Seu "doutrinador" foi um senhor que dirigia a oficina de douração, Mardoqueu, "profundo conhecedor da literatura revolucionária. Notando o meu interesse pela leitura, iniciou seu trabalho doutrinário me indicando os bons livros no ramo". (BORGES, 2008, pp. 34-35).

Marcos Antônio, então, procurou André para conversar. André conta como foi o encontro:

"O Marcos Antônio me procurou. Estava sentado a uma das mesas no pátio da cantina, quando ele me abordou:

- Você é o André Borges?

- Sim. Em que posso ser útil?

- Precisamos conversar. Amigos disseram para te procurar...

Trazia recomendações de amigos que me conheciam. Assim, teve início a integração do nosso grupo com os presos políticos militares". (BORGES, 2008, pp. 38-39).

André gostava de escrever. Principalmente, poesia. Segundo Antônio Duarte, “André era um tipo de líder, intelectual, além do conhecimento de história e literatura, aperfeiçoavase na arte de escrever. (...) A liberdade de espírito que André adquirira na cadeia baseava-se na sua capacidade de escrever poesias. Fora daquele mundo interno da literatura, do lirismo, era ele uma pessoa sem liberdade. Não aquela liberdade física, aprisionada pelos muros. Por essa razão, era intolerável para ele e seus companheiros negarem-se a essa atividade. Esta era a razão mais forte para sua aproximação do nosso coletivo”. (DUARTE, 2009, p. 325). 
Através de André, outros presos comuns se incorporaram ao Coletivo. Os amigos Edison Duarte Mello e José Michel Godoy mantinham contatos constantes com André e eram de sua absoluta confiança.

Edison foi preso em 1959, “acusado de uma série de delitos, entendeu, e depois, quando eu pensei que não era nada, era muita coisa. Aí, eu fui parar na delegacia, depois eu fui para a vigilância, depósito de presos... Depois fui para Milton Dias Moreira, quando na época ainda nem era Milton Dias Moreira, depois fui para a Detenção, Ilha Grande, Colônia Agrícola. E fui parar lá. E quando eu vi que não era nada, eu fiquei vinte anos lá [na Lemos Brito] ${ }^{96}$ Edison trabalhava numa sala no sótão de um dos pavilhões. Ali, tinha equipamentos para fazer cartões de visita ou de Natal, e estampava figuras em camisetas, ou outros objetos em silk-screen. Dessa forma, podia levantar alguns trocados. Apenas ele e André possuíam a chave dessa sala. Por isso que o Coletivo se reunia ali, na maioria das vezes. Havia uma lousa na parede, utilizada às vezes para traçar estratégias de ação voltadas para a fuga.

Segundo Antônio Duarte, Edison era "muito brilhante. Uma pessoa de muita inteligência e sensibilidade, formava com André uma dupla de poetas do cárcere". (DUARTE, 2009, p. 320). Essa sensibilidade artística foi usada em suas atividades na Diretoria do Serviço Social, sobre as quais falaremos adiante.

José Michel Godoy foi preso pela primeira vez em abril de 1958, quando cumpriu pena de quatro meses e 15 dias e, novamente, em 25 de maio de 1960, por interceptação de aparelhos eletrônicos roubados. A polícia descobriu o depósito onde Godoy guardava aparelhos eletrodomésticos caríssimos na época. Por esses crimes, deveria cumprir pena de 18 anos.

Antônio Duarte descreve Godoy como uma pessoa moderada, que refletia antes de opinar sobre qualquer assunto e que, diferente dos outros presos, não adquirira a gíria penitenciária. "Media suas expressões, procurando seguir um pouco do gênero literário que gostava. Gostava de conversar sobre poesia, teatro e música. Não havia lido os clássicos, a literatura política e filosófica que nós os soldados já dominávamos. Éramos como dois amigos que tínhamos estudado juntos. Vida tão dispare, pois ele dedicara-se a atividade de praticar o capitalismo sem o apoio da lei”. (DUARTE, 2009, p. 318).

Quando o Coletivo chegou à Lemos Brito, Godoy trabalhava na oficina de alfaiataria. Ali, costurava peças sob medida para os internos ou atendendo a encomenda externa.

\footnotetext{
${ }^{96}$ Entrevista a Flávio Luis Rodrigues. Rio de Janeiro, 10 de julho de 2012.
} 
No dia 11 de outubro de 1967, assumiu como chefe do Serviço Social da penitenciária Lemos Brito, a senhora Érica Bayer In Roth, a mesma que foi assistente social da Associação dos Marinheiros e Fuzileiros Navais do Brasil durante sua segunda diretoria, ou seja, na gestão do Coletivo que estamos estudando. Já falamos sobre a Dra. Érica Roth, como a chamavam os marinheiros. Segundo seu depoimento no dia 17 de junho de 1969, diante do encarregado do Inquérito Policial Militar que investigou a fuga do Coletivo da Lemos Brito, Contra-Almirante Júlio de Sá Bierrenbach, Roth disse que ficou surpresa ao saber que ali na Lemos Brito se encontravam os marinheiros da antiga AMFNB e foi imediatamente falar ao Diretor do presídio "que não tinha condições de permanecer no Serviço em consequência dos atritos que anteriormente tivera com os ex-marinheiros". Ela não disse quais atritos, ou pelo menos não foi registrado pelo escrivão. De qualquer forma, o Diretor a tranquilizou, garantindo-lhe que "manteria a disciplina e que lhe daria condições de trabalho sem maiores atritos, o que realmente ocorreu". ${ }^{97}$

No mesmo depoimento, Érica Roth disse ter solicitado ao Dr. Telius Alonso Avelino Memória, então diretor da Lemos Brito, que formalizasse convênio com as faculdades de Serviço Social da UEG e Faculdade de Serviço Social do Rio de Janeiro, pelo qual pudesse contar com estágio oficial para 28 alunas de Serviço Social, que ficariam sob sua supervisão. Voltaremos a falar sobre essas alunas estagiárias.

Não deixa de ser intrigante esse depoimento de Roth, pois permite inferir que ela resistia ao contato com os antigos companheiros da Associação. Num determinado trecho, ela diz que no mês de agosto de 1963 "notou um movimento desusado de estranhos na Associação, observando que havia movimento subversivo, mas que na época não tinha a quem denunciar, motivo pelo qual se demitiu com uma carta em que se manifestou contra aquela politização do Serviço Social, foi então ofendida principalmente pelo marinheiro Marcos Antônio, sendo chamada de fascista e imperialista”. Essas palavras não poderiam partir da Dra. Érica Roth de que falam os membros do Coletivo. A tergiversação dela é clara! Pois, como podia denunciar um movimento subversivo, ou a politização do Serviço Social, se ela mesma, segundo todos os ex-marinheiros a quem entrevistamos, indicava leituras que tinham um forte colorido esquerdizante? Viegas não poupa elogios a essa senhora, que "era fonte de estímulo, antes de mais nada". Suas preocupações com a formação intelectual dos ex-marinheiros era notada na indicação das leituras que fazia. Segundo Viegas, através dela, teve contato com Geografia da fome, de Josué de Castro; Vida Secas e Memórias do Cárcere,

\footnotetext{
${ }^{97}$ AEL - BNM; 414, caixa 1, folhas 79,80.
} 
de Graciliano Ramos; Casa Grande e Senzala, de Gilberto Freire. "Isto para que fiquemos no âmbito dos autores nacionais. Houve muito mais, que envolvia áreas da história e filosofia". (VIEGAS, 2004, p. 77).

Se Roth pensasse mesmo que os marinheiros eram "subversivos" e muito politizados para o seu gosto, não teria aceitado a indicação deles para solicitar ao Diretor da penitenciária, em 11 de dezembro de 1967, a classificação como escriturários, no Serviço Social, "por absoluta necessidade do serviço”, de Antônio Duarte dos Santos, José André Borges e Edison Duarte de Mello, que já estavam trabalhando no setor havia 15 dias, "já perfeitamente entrosados com a natureza do trabalho". ${ }^{98}$ E também não teria solicitado ao chefe da Seção Industrial, em 7 de março de 1968, a transferência de Avelino Capitani “de suas atuais ocupações naquela seção, para escriturário deste Serviço [Social]". 99 É mais provável, portanto, que os argumentos restritivos sobre os marinheiros que ela externou fossem uma estratégia para burlar alguma suspeita da direção do presídio em relação a seus vínculos anteriores com aquele grupo.

Aliás, sobre a ida de Capitani para a diretoria de Serviço Social, ele conta uma conversa que teve com Antônio Duarte bem inusitada:

"Comigo foi mais difícil [transferência para a portaria]. Inicialmente, fiquei na seção industrial. Conseguimos comprar um prisioneiro do serviço social, mas a vaga estava disputadíssima e, como talvez não desse para entrar, jogamos com outro trunfo. A encarregada do serviço social conhecia o Duarte dos tempos da Associação e tinha certa queda por ele.

- Tu tens que cultivar isso. É uma amizade importante. Se ela te der uns abraços, uns beijos, que mal tem?

O Duarte conseguiu a vaga e começou a trabalhar para que eu pudesse entrar também. A Administração viu que era importante mais um marujo no serviço social para fechar o esquema do tóxico e bebida, ficando só o 'oficial mesmo'. E eu entrei".

(CAPITANI, 1997, p. 127).

Quem poderia ser a "encarregada do serviço social" que conhecia Duarte desde os tempos da AMFNB? Só pode ser Érica Roth, que já estava próxima dos 50 anos em 1968. Duarte estava por volta dos 28 anos, bem mais novo que Roth. Mesmo que consideremos a diferença de idade trivial, ainda assim as peças não se encaixam. Duarte, assim como os demais marinheiros, sempre fala de Roth com muito respeito e admiração. Difícil imaginar a

\footnotetext{
${ }^{98} \mathrm{AEL}-\mathrm{BNM}$; 414, caixa 1, volume 1, folha 60.

${ }^{99}$ Idem, folha 63.
} 
"Dra" Érica Roth querendo dar abraços e beijos num seu subordinado. Mais uma vez parece que Capitani caiu nas armadilhas da memória...

A chegada de Érica Roth na Lemos Brito e seu encontro com o Coletivo se reveste de um significado simbólico e, ao mesmo tempo, de uma realidade que já se colocava aos exmarinheiros desde pelo menos a vinda de Capitani: o ressurgimento da antiga Associação dos Marinheiros e Fuzileiros Navais do Brasil, agora ampliada e ressignificada. Os principais diretores da AMFNB ali estavam, ligados organicamente através de um compromisso que vinha de longe. Os marinheiros e os presos comuns incorporados ao Coletivo se reuniam constantemente, em grupos pequenos, trocando informações e discutindo as leituras que faziam. Por exemplo, o livro de Jules Régis Debray circulava muito entre os marinheiros. Inclusive, quando a mulher de Viegas tentou entrar na penitenciária com o livro Revolução na Revolução foi barrada e o volume expropriado pela administração da cadeia.

Os quatro presos que foram solicitados por Érica Roth para trabalhar no Serviço Social seguiam um cálculo estratégico na preparação da fuga. Muito provavelmente, Roth ignoravao. André, por exemplo, conta que a sala onde trabalhava ficava no prédio da portaria, no térreo, "a três ou quatros metros da porta que dava para a rua. Essa era a distância que me separava da almejada liberdade. Com uma forte emoção, dali via pessoas e carros passando lá fora. Via a vida acontecendo a quatro metros de mim”. (BORGES, 2008, p. 44).

Em 28 de dezembro de 1967, A responsável pela Divisão Legal, Sylvia Rodrigues Siqueira, solicitou ao chefe da Seção de Classificação e Readaptação a classificação de Marcos Antônio como escriturário datilógrafo naquela Seção, para trabalhar das 07h00min às 19h30min diariamente, de segunda a sexta-feira. Quando Marcos Antônio chegou à Divisão Legal, ali já estavam Viegas e Adeildo, como já expusemos. Localizada na portaria de saída da penitenciária, apenas uma escada e alguns poucos passos separavam estes homens da Frei Caneca.

Percebe-se que o Coletivo estava cada vez mais próximo de seu principal e mais difícil objetivo: conquistar cargos laborativos na portaria da penitenciária e adquirir carteiras de trânsito livre, que permitissem aos portadores movimentarem-se sem limites pela prisão.

Faltavam apenas Michel Godoy e Benedito Alves Campos serem transferidos para trabalhar fora da penitenciária, próximo à Praça Getúlio Vargas. Godoy e Benedito Campos foram solicitados para trabalhar no Instituto Médico Penal, o primeiro como "colaborador", em 11 de julho de 1968, e Benedito como auxiliar de enfermagem, em 10 de julho do mesmo ano. Pouco mais tarde, em $1^{\circ}$ de outubro de 1968, Antônio Duarte também foi classificado no Instituto Médico Penal. Ali, já trabalhava, desde 14 de setembro de 1965, Antônio Prestes de 
Paula, classificado no Serviço de Biopsicologia. A maioria do Coletivo tinha trânsito livre na Praça Getúlio Vargas. Os únicos que não tinham autorização eram José Michel Godoy e Benedito Alves Campos. Não conseguimos informação se José Duarte dos Santos possuía crachá autorizando trânsito livre. Provavelmente não, pois não trabalhava, conforme depoimento de Sérgio Lúcio de Oliveira Cruz.

Nas discussões sobre a fuga, ficou decidido que apenas aqueles que tivessem penas longas a cumprir fariam parte dela. Aqui se enquadravam Marcos Antônio, Antônio Duarte, Capitani, André, Godoy, Edison, o ex-marinheiro Benedito Alves Campos, Prestes de Paula e Roberto Cietto, de que falaremos adiante. Adeildo Ramos, que no início cumpriria dois anos de reclusão, passou, a pedido dos procuradores do Ministério Público Militar, a uma pena de cinco anos. No dia da fuga, faltavam poucos meses para Adeildo cumprir sua pena. Mesmo assim, quis fazer parte do grupo de fugitivos. Viegas e José Duarte tinham penas pequenas, tanto que saíram na ocasião do Indulto de Natal de dezembro de 1968. A fuga do coletivo, ampliado, da Penitenciária Professor Lemos Brito acontecerá em 26 de maio de 1969.

O que ocorreu com Adeildo, ou seja, ter sua pena aumentada quando faltavam poucos meses para seu final, aconteceu também com alguns integrantes do Coletivo. Para eles, estava claro que a "Justiça" os manteria ali, trancafiados no meio de marginais, enquanto durasse a ditadura. O caso de Duarte é típico. Condenado pela $1^{\mathrm{a}}$ Auditoria da Marinha a cinco anos de reclusão, quando já havia cumprido quase metade de sua pena com "bom comportamento", seu advogado pediu revisão, na esperança de diminuí-la. O promotor, então, pediu sua ampliação para 12 anos! Duarte conta como se deu o combinado:

"Às três horas da tarde [não diz o dia], chegou a vez do promotor, cercado por dois agentes do Cenimar, que passavam por auxiliares. Eu os havia encontrado nos corredores dos interrogatórios. O Promotor, de pé ao lado de minha cadeira. 'minha Nossa Senhora que me perdoe, mas não posso contemporizar com os comunistas'. Apontava para mim, em gesto teatral, algo ridículo: se não fosse pela dramaticidade, pelo ódio que demonstrava, pela soberba. Não olhava direto para mim. Apontava, como quem o faz, indicando um objeto perigoso. Ele folheava as páginas de um grosso volume, o processo encoberto por uma capa verde-claro. Lia, por alguns momentos. Os 'auxiliares' ali, parados, como quem esperava uma grande verdade.

Ele encerrou o volume, massa de papel, arquejando como um lenhador que vai aplicar um golpe com um machado em uma árvore. 'A culpa do acusado é: como agente de comunismo internacional, organizar células comunistas nos navios e amotinar-se'. 
(...) Estava ali porque era forçado. Na melhor das hipóteses, sabia que ele solicitaria a pena máxima. Isto porque não havia pena de morte. O promotor insistia, muito solenemente, em suas conclusões acusatórias. Queria doze anos de prisão.

Por meio de sinais e indicações, parecia conhecer a decisão dos juízes auditores.

Depois do julgamento, fiquei sabendo que a minha pena aumentara para doze anos. Tínhamos que ter coragem!". (DUARTE, 2009, pp. 314, 315).

****

Pedir a um ex-presidiário para contar como era seu cotidiano na prisão é o mesmo que pedir-lhe para recordar o que ele pretende deixar adormecido. Quando pedimos isso a Capitani, ele confessou que, na idade em que se encontrava no dia de nosso encontro, acima dos setenta, era cada vez mais difícil retornar a um passado tão sofrido. Sentia-se cansado, como que tentando cicatrizar uma ferida que se recusava a curar-se. Sempre estaria disponível a ceder entrevistas, pois conhecera de perto uma ditadura sangrenta e violenta, que não poderá jamais ser esquecida. Mas confessou que é difícil retornar a um período que só aconteceram coisas negativas:

"olha, não é fácil, não é fácil isso aí. Eu tenho uma questão de principio talvez... Eu tenho dificuldade de recordar. Foi muito sofrimento, talvez seja bom escutar, até fazer um filme. É muito sofrimento, é muita tensão, é muita adrenalina. Quando hoje eu vejo esse pessoal arriscando a vida para ter adrenalina, poxa vida, devia ter levado ele um dia numa prisão dessas, nas condições que nós estávamos, ele não ia querer pegar adrenalina em lugar nenhum. É muito difícil, tu vives sobre tensão permanente. Dorme e acorda assim. E a necessidade de dominar essa tensão, poder mudar isso aí. Porque não havia alternativa, a gente não sabia quanto tempo, quantos anos iriam durar isso. No meu caso, eu já estava condenado a 30 anos de prisão. E eram esses que estavam com condenação alta que iriam sair em principio. E eram esses que iriam buscar os postos-chaves também no trabalho.

(...) Tanto que hoje eu tenho dificuldade de falar sobre isso, porque vêm as recordações e não tem nenhuma recordação boa. As recordações são de doença, sofrimento, angústia, medo, tensão. Ninguém quer recordar isso. E eu estou chegando numa certa idade que eu quero encerrar essas coisas. Então, cada vez, eu não vou ver filme sobre 64... Tenho até vontade, 
mas quando chego lá, os outro vão vendo o filme, mas eu... Vai passando um outro filme...". 100

Lembrança dolorida, principalmente porque seus juízes eram os mesmos antípodas dos tempos da AMFNB. A estratégia deles estava clara para os ex-marinheiros: iriam destruí-los da pior forma possível, impedindo-os de mobilidade e de realizarem suas vontades, sendo obrigados a viverem com pessoas, horários, ocupações, vestimentas, alimentação e diversões impostas pelas autoridades penitenciárias. Não se esperava a correção, a recuperação, mas o aniquilamento, a destruição do condenado.

Nas reflexões de Michel Foucault sobre as origens do sistema do juízo penal, ele diz que, com o tempo, houve um deslocamento do objeto da ação punitiva. "Não é mais ao corpo que se dirige a punição", mas á alma. A punição não se exerce mais sobre o corpo, através da dor, do suplício, mas sobre a alma. $\mathrm{O}$ aparato da justiça punitiva se atém agora na realidade incorpórea - o alvo é o coração, o intelecto, a vontade, as disposições.

“ Desde a Idade Média construiu, não sem dificuldade e lentidão, a grande procedura do inquérito, julgar era estabelecer a verdade de um crime, era determinar seu autor, era aplicar-Ihe uma sanção legal. Conhecimento da infração, conhecimento do responsável, conhecimento da lei, três condições que permitiam estabelecer um julgamento como verdade bem fundada. Eis, porém, que durante o julgamento penal encontramos inserida agora uma questão bem diferente de verdade. Não mais simplesmente: 'o fato está comprovado, é delituoso?' Mas também: 'O que é realmente esse fato, o que significa essa violência ou esse crime? Em que nível ou em que campo da realidade deverá ser colocado? Fantasma, reação psicótica, episódio de delírio, perversidade?' Não mais simplesmente: 'quem é o autor?' Mas: 'Como citar o processo causal que o produziu? Onde estará, no próprio autor, a origem do crime? Instinto, inconsciente, meio ambiente, hereditariedade?' Não mais simplesmente: 'Que lei sanciona esta infração?' Mas: 'que medida tomar que seja apropriada? Como prever a evolução do sujeito? De que modo será ele mais seguramente corrigido?'” (FOUCAULT, 2010, pp. 21-23)

$\mathrm{Na}$ medida em que os Inquéritos Policiais Militares tornaram-se viciados, pois eram presididos e julgados por militares arrivistas, qualquer nacionalista passou a ser considerado um comunista ligado ao "comunismo internacional". Os integrantes do Coletivo tiveram suas penas aumentadas pelo crime de "constituírem células comunistas nos navios da Marinha". Portanto, os IPMs provocaram um grave retrocesso no "exercício da justiça", na evolução, no “deslocamento do objeto da ação punitiva". Ao não reconhecerem os marinheiros, por

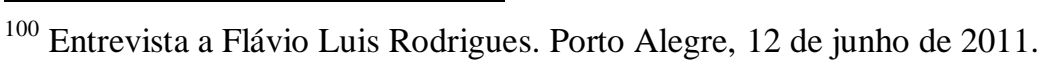


exemplo, como presos políticos, os oficiais justiceiros pretenderam atingir a alma daqueles homens, suas vontades, seus intelectos, como dito por Foucault, tentando transformá-los nos trapos humanos com os quais foram forçados a conviver. Assim todo o Coletivo pensava e seus membros tomaram como seu principal objetivo a resistência às investidas da Auditoria da Marinha em mantê-los ali, no "subterrâneo", para sempre.

Quantos anos os marinheiros passariam fazendo as mesmas coisas todos os dias, circulando pelos mesmos lugares, vendo as mesmas cores, vestindo as mesmas roupas, comendo a comida com o mesmo tempero, sentando nos mesmos bancos e mesas, tomando banhos frios todos os dias, sentindo o cheiro de mofo das cobertas e urina das privadas encardidas? Capitani tinha uma pena de 30 anos a cumprir; Marcos Antônio, de 12 anos e quatro meses, mas que aumentaria com certeza; Antônio Duarte, de 12 anos e assim por diante. Enquanto durasse a ditadura, acreditavam os ex-marinheiros, suas penas seriam mais e mais ampliadas. O dia a dia no cárcere, sem perspectiva de saída, já tinha se tornado uma impaciência eterna. Antônio Duarte conta o caso do ex-marinheiro Israel que, após as despedidas de seus familiares no dia de visita, se vendo novamente rodeado pelos muros e guaritas da Lemos Brito, teve uma explosão emocional, como que uma catarse, um descarrego:

"Israel [após a ida das visitas], em um gesto de revolta, atirou ao chão um pequeno pacote que trazia sob os sovacos. 'Quanto tempo vou ficar neste inferno?!' - esbravejou, chutando a parede. Ele que sofria de ataques, às vezes estirado no chão, em estado cataléptico, esconjurava a cadeia e os guardas. Logo após, surgiu Marcos e ajudou-o a levantar-se. Perguntou o que acontecia. Não respondi. Nada havia a explicar. Os outros companheiros apareceram e tentaram consolá-lo que, levantando, disse algo, causando risos desconcertados. Marcos recolheu o pacote do chão e o entregou a Israel". (DUARTE, 2009, p. 305).

As lembranças negativas de que fala Capitani eram os assassinatos, as ameaças constantes, a saudade dos familiares, a tensão de não ter certeza de nada: se estará estropiado ou morto no dia seguinte. O Coletivo sabia que a prisão "desfibra muita gente", como disse André. No entanto, recusava-se à resignação. Como se expressou Duarte, "era ali onde deveríamos viver. Entretanto, os marinheiros eram homens que não poderiam ser tragados por aquele pântano”. (DUARTE, 2009, 307).

A vida na Lemos Brito decerto que não era boa. Mas poderia ser muito pior. Como falamos no inicio do capítulo, a penitenciária foi planejada para ser uma prisão “correcional” através do trabalho. Em comparação às outras prisões da época, a Lemos era 
tida como modelo. Eram grandes as diferenças: celas individuais, permitindo ao preso certa privacidade e momentos de reflexão, impossíveis quando enjaulado entre vários marginais; não havia separação entre os pavilhões que impedisse ao preso circular entre as oficinas, os pátios, a quadra, a cantina e as celas, facilitando "o convívio e propiciava um intercâmbio social intenso. Em razão disso, o nível de sociabilidade era alto em relação aos outros estabelecimentos penais do país”, segundo André Borges; a possibilidade do preso ganhar dinheiro, através de seu trabalho nas oficinas, para ajudar sua família e, também, de acumular um pecúlio, resgatável no final de sua pena; a possibilidade do preso ter momentos de intimidade com sua companheira, importantes para extravasar as tensões naquele mundo de homens “desfibrados". Este “espaço do amor" era conhecido como Parlatório, idealizado pelo Coletivo, como veremos; enfim, lugares de descontração e lazer, como um anfiteatro, uma quadra poliesportiva, uma biblioteca, um parquinho para as crianças brincarem nos dias de visitas, e outros espaços de convivência que em muitas prisões eram desconhecidos.

Mesmo assim, os marinheiros se sentiam derrotados e impotentes diante da força dos gorilas, oficiais militares golpistas que os tratavam como ralés da sociedade, como se referiu Neguinho. Seus inimigos, não apenas no ambiente militar, mas também no campo da política, desde os tempos da AMFNB. Tinham projetos opostos. Enquanto o Coletivo estava incorporado à Frente Nacional Popular e defendia as reformas de base de João Goulart, seus opositores criticavam abertamente o governo, taxando-o de comunista. Pois bem, esses inimigos, agora, estavam no poder e usavam todas as suas forças para destruí-los. Duarte traduz esse sentimento de impotência nas seguintes palavras: “Angústias, por causa da vitória fácil da ditadura militar, o desengano nostálgico, em busca de uma reação, a resistência à ditadura, que não tínhamos feito, no ato mesmo do golpe militar. Tudo isso misturado com a ânsia que tínhamos de sair daquele subterrâneo onde sofríamos carências de tudo. $O$ tormento de não encontrar as pessoas livremente”. (DUARTE, 2009, p. 303).

Georges Duby, em seu livro A Europa na Idade Média, após expor o problema que o medievalista encontra em relação às fontes, completa com a seguinte frase: "a Europa do ano mil, portanto, é preciso imaginá-la”. Já se falou sobre a ligação por contiguidade entre memória e imaginação: "evocar uma - portanto, imaginar - é evocar a outra, portanto, lembrar-se dela”. (RICOEUR, 2007, p. 25). Para falarmos sobre o cotidiano do Coletivo na Lemos Brito, recorreremos à memória daqueles que lá estiveram, tentando imaginar os espaços e as pessoas por eles descritos. Sempre que houver discrepância entre os relatos sobre um determinado evento, tentaremos entender o que motivou a discordância. 
André Borges, em sua última noite na Lemos Brito antes da fuga, passada às claras pela ansiedade, pôs-se a rememorar seu tempo no claustro. Diante de si, esfumaçado pela emanação dos vários cigarros, um mundo verde: as paredes do cubículo pintadas de verdecana, as toalhas, o cobertor, "verde também a toalha que cobria uma espécie de mesaarmário, que fazia parte do mobiliário da cela. Era um mundo verde, como verdes eram meus sonhos". (André, 2008, pp. 20-21). Ao descrever sua cela, como que se despedindo dela, após longos onze anos, André permite que adentremos nela e a examinemos: "Era uma cela padrão, de quatro metros por dois. Piso de cerâmica vermelha, uma janela gradeada que se abria para o Morro de São Carlos, no bairro do Estácio. Um chuveiro embutido na parede, vaso sanitário e pia. As paredes eram pintadas de verde-cana". Eis a cela em que os integrantes do Coletivo estiveram, enquanto permaneceram na Lemos Brito. Pequena, por isso a chamarem de cubículo. Entre a cama e a pia, a privada e o chuveiro, uma parede pequena. Chuveiro sem cano, para poupar espaço. E sem fio, para poupar energia. No frio, os presos improvisavam uma resistência, "um carretel onde se havia enovelado um fio de cobre. A tartaruga, que toda vez que fervia água queimava um fusível. Ocorrência impopular, os presos protestavam quando se apagavam as luzes!” (DUARTE, 2009, p. 330). A tartaruga servia, também, para fazer café. O Coletivo sempre se reunia na cela de Prestes de Paula, quando este usava a tartaruga para fazer café, quase sempre queimando um fusível.

Nas celas do Coletivo, havia seres indesejáveis, contra os quais os marinheiros nada podiam: os percevejos. Um dia, os marinheiros organizaram um mutirão na penitenciária contra eles. Jogaram creolina em todos os cubículos, tiraram os colchões, lavaram, esfregaram - e nada! Reconheceram a derrota e resignaram-se em tê-los como fiéis companheiros. Mas não havia pulgas, pelo menos. Segundo Adeildo Ramos, "Pulga não tinha não, mas percevejo, tinha percevejo, mais de uma espécie de percevejo. Tinha o percevejo, tinha muquirana, que era um outro tipo de parasita, tinha mosquito né, muriçoca, isso tinha. Barata". ${ }^{101}$

Estes percevejos já eram conhecidos de Graciliano Ramos, quando ali passou maus meses: “(...) E o Pavilhão caiu num sossego lúgubre. O resto da noite os farrapos sujos de notícias loucas me perseguiram, picaram e moeram, associando-se aos percevejos e às traves duras da cama. (...) Nas matanças de percevejos não descansava”. (RAMOS, 1998, 331 e 354).

\footnotetext{
${ }^{101}$ Entrevista a Flávio Luis Rodrigues. João Pessoa, 21 de julho de 2011.
} 
Antônio Duarte lutou muito, também, para acabar com o cheiro horrível da privada encardida. Jogou lá vários produtos químicos trazidos pelas visitas, sem resultado. Paciência. Melhor foi ficar o mínimo possível ali.

Adeildo conta que era possível ler à noite no cubículo, pois existiam interruptores e as portas impediam que a luz incomodasse outros presos. "Tinha interruptor. Você acendia e apagava quando você queria, entendeu? (...) Ficava lendo, dormia escutando o rádio. [A porta era] fechada. Tinha uma janela com grade e a porta de entrada que era para o corredor interno, entendeu? Por exemplo, era uma porta de madeira com uma portinhola”. Quase todo preso tinha o seu rádio. Não era rádio miniaturizado, era ainda "aquele rádio de vela antigo, o bicho estalava mais que o cão!’. Adeildo conta que havia recomendação da administração carcerária para que não ouvissem rádio com volume alto, para não incomodar o vizinho. Mas seu vizinho geralmente o perturbava, ouvindo missa com o volume nas alturas:

"Ele era protestante, e ligava o rádio naquelas rádios protestantes com o volume lá em cima. Mas o rádio dele era daquele rádio de válvula, né. Aí eu descobri que, quando a gente mexia aqui [inaudivel], o rádio falhava. Aí, eu já tinha um fiozinho para tirar da tomada. Aí eu mexia e ele baixava. Quando ele aumentava o volume eu estava lá, ele baixava". ${ }^{102}$

Como quase todos tinham rádio, era comum que muitos dessem problemas, principalmente naquela época em que não havia o transistor. Aí, entrava em ação o exmarinheiro Francisco das Chagas, que trabalhava na oficina de eletrônica. Segundo Adeildo Ramos, "Montou uma oficina mesmo. Todo mundo que tinha rádio para consertar levava para ele. Ganhava, ganhava dinheiro. Tinha um cinema [sessões de filmes no auditório], ele que era responsável pelo cinema. Ele e um fuzileiro naval chamado Jones, é que ficavam na oficina e no cinema. Chagas! Ei rapaz!",103

Já falamos dos horários que regiam esses prisioneiros. A sirene das seis horas impunha o horário de acordar, era tocada, segundo Adeildo Ramos, no pavilhão da polícia, "um quartel da polícia”, que ficava fora da Lemos Brito, na Rua Frei Caneca. Depois de um breve banho frio, colocavam a camisa de linho branco e a calça de brim cinza-escuro, "aquela espécie de casca pegajosa e peçonhenta que as roupas da prisão deixam em nosso corpo" (ANDRÉ: 2008, 18) e desciam para o Pátio da Cantina, onde ficava o refeitório, para o café: "café, pão com manteiga, às vezes tinha um mungunzá, às vezes assim, um arroz doce, era bem simples o café, entendeu? Não era sofisticado não”. ${ }^{104}$ Quem quisesse, e tivesse dinheiro, podia tomar

\footnotetext{
102 Idem

103 Idem

104 Idem.
} 
café na cantina. No refeitório, serviam o café, o almoço e o jantar, em longas mesas de mármore, ou outra pedra que lembrava mármore. Enquanto não tocava a sirene das sete horas, os presos geralmente ficavam ali no Pátio da Cantina, uma multidão que vendia, comprava ou observava algo. Aquele espaço se transformava num grande mercado persa, onde se podia encontrar quase tudo nas várias barraquinhas espalhadas:

"Comprava-se e vendia-se maconha, cachaça, 'cheirinho-da-loló' e joias. Jogava-se no bicho e na corrida de cavalos, apostava-se no futebol. Um verdadeiro mercado persa. Além disso, liase jornais, ouvia-se os noticiários matutinos das rádios, discutia-se os últimos acontecimentos políticos. Isso acontecia três vezes ao dia: café, almoço e janta. Antes e após as refeições, tinha essa movimentação. Quando a sirene anunciava o início do expediente, o pátio ia se esvaziando". (BORGES, 2008, p. 23).

O preso que quisesse ficar na cela, se fosse estrela verde ${ }^{105}$, era só pedir para os funcionários da cantina para levarem seu café, ou refeições a ele. Claro, mediante pagamento.

Sempre após o café, o almoço ou o jantar, o Coletivo se reunia em um determinado ponto, que todos conheciam, presos políticos e presos comuns. "Todo mundo já sabia, já saindo da cela ia já para aquele ponto”, geralmente no Pátio da Praça, onde o Coletivo tinha um banco encostado na parede, que somente ele usava.

Todo grupo de presos procurava possuir um banco para receberem suas visitas, nos finais de semana, ou para conversarem, se agruparem, nos dias de semana. Esses bancos eram comprados de outros presos, que trabalhavam na oficina de carpintaria. O Coletivo encomendou o seu, mandou pintar de uma determinada cor - que não conseguimos saber qual era -, como todos os outros grupos, o que era uma forma de relacionar o banco ao respectivo grupo. Se um preso sentasse no banco de outro, a briga era certa. Aconteceu com o Coletivo, que diplomaticamente e ameaçadoramente, contornou a situação. Adeildo Ramos conta como foi:

"A gente comprou o banco, que é para nossas visitas, e o preso comum lá entendeu de tomar. Marco Antônio foi lá: 'não quero briga com vocês, mas, se quiser tá comprando briga com todo mundo'. Nós já éramos assim, uns quarenta. Eles diziam que a gente agia de patota. Claro, para a gente se defender contra eles, tinha que ser em conjunto". ${ }^{106}$

\footnotetext{
${ }^{105}$ Estrela verde, segundo André, "presos de ótimo comportamento, que tinham os cubículos abertos às 6 horas e transitavam livremente até às 21 horas. Em geral, os internos eram trancados nos seus cubículos às 18 horas". Segundo Adeildo Ramos, existia também a Estrela Azul, acima da verde, podendo o preso fazer serviço fora do Complexo Penitenciário Frei Caneca, que conglomerava as penitenciárias Lemos Brito e Milton Dias Moreira. 106 Idem
} 
Quando os primeiros marinheiros chegaram, eles tinham a opção de não trabalhar, ficando soltos nos pátios, das seis horas às 18:00. O Coletivo era contra ficar na ociosidade. Preferiram trabalhar, ocupando o tempo e os espaços. Viegas conta que, assim que começou a trabalhar na Divisão Legal, percebeu que era interessante, pois não eram recolhidos às 18 horas, como os outros, mas às 19:00. Então, depois do jantar, ele retornava à Divisão Legal, "porque lá era a hora que começava a chegar os alvarás, chegar essas coisas, era hora que precisava de alguém que datilografasse, essas coisas. Quer dizer, então desafogou [о trabalho da Divisão Legal]". ${ }^{107}$ Essa disponibilidade para o trabalho, para ajudar a Administração carcerária na parte burocrática e recreativa, fazia parte do plano de fuga. $\mathrm{O}$ Coletivo precisava ganhar a confiança da direção da Lemos Brito. O que de fato aconteceu. Foi dessa forma que conseguiu aproximar-se cada vez mais da portaria. No Inquérito Policial Militar aberto para investigar a fuga do Coletivo da penitenciária em maio de 1969, aparecem vários elogios dos chefes aos marinheiros, através de cópias de circulares ou memorandos, e recomendações para a autorização do salvo conduto, permitindo a mobilidade na penitenciária, principalmente na Praça Getúlio Vargas.

Enquanto nos dias da semana o Coletivo trabalhava, cada qual em seu posto, nos "horários de recreio" e feriados seus membros ficavam "no pátio, sempre no mesmo canto, junto a um banco fixo. No território dos marinheiros ninguém entrava sem pedir licença”, segundo Capitani. (CAPITANI, 1997, p. 124). Já nos finais de semana eram dias das tão aguardadas visitas.

André, por sinal, faz uma interessante reflexão sobre a importância das visitas no ambiente carcerário. Cria-se, segundo ele, uma espécie de segregação entre os que têm visitas e os que não têm. Diz ele:

"Então, a visita que, para alguns é motivo de alegrias, para outros é motivo de tristezas e constrangimentos, porque acentua o real estado de miséria e de abandono a que estão relegados. De maneira que, para o estabelecimento de qualquer novo relacionamento entre presos, surge, quase sempre instintivamente, a clássica pergunta:

- Você tem visita?

Tal comportamento tem suas variantes entre os presos, especialmente entre os políticos, por terem maior grau de sociabilidade e o sentimento de solidariedade mais desenvolvido, sem, contudo, anular esse fenômeno social. O certo é que ter visita na prisão significa ter vínculos com o mundo exterior, comunicação e possibilidade de receber coisas da rua. E, no mundo de miséria da prisão, isso representa status". (BORGES, 2008, pp. 18-20).

\footnotetext{
${ }^{107}$ Entrevista a Flávio Luis Rodrigues. Iperó, 09 de outubro de 2008.
} 
No caso dos marinheiros, quase todos nordestinos, com suas famílias distantes, vez ou outra recebiam visitas de parentes. Mas havia uma diferença. Como se constituíam num grupo coeso, a visita de um deles, era compartilhada com os demais. Assim, quando Lêda, mulher do Viegas, ia a Lemos Brito era para encontrar-se com todos os marinheiros. Se levava doces ou pães, logo eram compartilhados entre todos. Aliás, estes quitutes eram oferecidos também aos presos comuns, na estratégia do Coletivo de aproximar-se da massa carcerária e torná-la, na medida do possível, mais permeável à ideia da solidariedade e que pudesse, enfim, refletir sobre o egoísmo reinante na prisão. Viegas conta como agiam junto aos presos comuns:

As "guloseimas", bolos, doces que o Coletivo recebia das visitas, disponibilizava a todos os presos comuns, colocando-as nas compridas mesas de mármore, que iam de um lado ao outro do refeitório. Aos poucos, os presos comuns passaram a receber estas guloseimas, como também a oferecer as suas - importante passo àquelas pessoas envoltas a um egoísmo arraigado, que o cárcere impõe. "E assim, lenta e pacientemente, 'o gelo ia sendo quebrado'". (VIEGAS, 2004, p. 81).

As diversões dos marinheiros eram limitadas. Enquanto os presos comuns jogavam baralho, malhas, palitinho, o coletivo ficava a conversar, discutindo política, preparando planos. Mas, claro, compartilhava uma paixão que era a de todos: o futebol. E neste quesito, eles eram muito respeitados. Criaram um time de futebol de salão, chamado O Popular, cujo técnico era Marcos Antônio. Ganharam vários torneios, envolvendo outras penitenciárias.

Boa parte do tempo livre do Coletivo acontecia numa sala no último andar do Pavilhão, onde se subia uma escadinha que ia para a caixa d'agua e para o telhado. Era a oficina de serigrafia, onde Edison fazia trabalhos em silk screen, como camisetas personalizadas, flâmulas, cartões de Natal etc. para ganhar alguns trocados. Somente Edison e André possuíam a chave daquela sala "camuflada". Ali, era o QG do Coletivo, como já dissemos anteriormente. Discutiam, planejavam as ações, liam e comentavam textos etc. Nela, o coletivo trabalhava para ganhar dinheiro. Sala de 20 metros quadrados, ali os marinheiros lavavam e passavam suas roupas, faziam café, ouviam músicas, discutiam política. "tínhamos também uma biblioteca organizada. Enfim, essa sala acabou se tornando o Quartel General, o QG do nosso grupo. Num quadro negro, passamos a esboçar o plano de ação da fuga. A ideia principal era a tomada da portaria”. (BORGES, 2008, p. 42).

Outro lugar frequentado pelo Coletivo era o cubículo do Prestes de Paula, onde conversavam enquanto tomavam o café feito por Prestes na tartaruga.

Algumas diversões do Coletivo eram bem originais. Como o balão que fizeram, carregado de panfletos "subversivos". Um dia, Marcos Antônio chegou à sala de Edison com 
um papel manuscrito, com sua "péssima letra". Ali, acertou com o grupo que fariam um balão, que seria levado pelo vento para a cidade e, ao queimar-se, despejaria vários panfletos pelas ruas.

Viegas conta como foi esta peripécia:

[lançaram o balão de um pátio, cheio de panfletos que] "ganharam os céus e, por cúmulo de sorte nossa, o vento encarregou-se de levá-lo [o balão] em direção à Central do Brasil, onde despejou sua preciosa carga. Milhares de panfletos espalharam-se pela área, que era de grande concentração popular, principalmente por conter terminais de linhas de trem suburbanos para a Zona Norte e de ônibus para a Zona Sul da cidade. No dia seguinte, estas eram as manchete nos jornais: 'Fusca lança panfletos na Central do Brasil e foge em alta velocidade'! Era a nossa contribuição ao combate à ditadura militar, que lá fora desenvolviase". (VIEGAS, 2004, p. 82).

Outra atividade comum do Coletivo eram as leituras de livros sobre marxismo, guerrilha, revoluções, reflexões sobre o sistema penitenciário etc. Tiveram sorte em encontrar livros de esquerda na biblioteca da penitenciária, deixados pelos comunistas que lá estiveram a partir de 1935. Segundo Viegas, Luis Carlos Prestes deixou ali sua contribuição:

"Luis Carlos Prestes esteve preso ali e deixou vários livros marxistas na biblioteca da penitenciária Lemos Brito. Ali começaram, também, as leituras. (...) Não eram livros escritos por ele, eram livros marxistas que o pessoal mandava pra ele quando estava preso. Quando foi embora ele deixou, doou para a biblioteca. Então, eram livros que ele tinha lido, quer dizer, então a gente fazia nossas discussões e lia livros, principalmente aos sábados e domingos pela manhã". 108

André fala, ainda, que, antes do Coletivo chegar a Lemos, seu grupo lia a coleção "Romance do Povo", organizada por Jorge Amado, nos anos de 1954 a 1956, num total de vinte obras.

Na primeira metade da década de 1968, o Coletivo havia conquistado um dos objetivos. Talvez o mais difícil: seus integrantes estavam trabalhando, com salvo conduto, na portaria da penitenciária: Capitani, André, Edison e Antônio Duarte (que será transferido para o setor onde estava Prestes de Paula mais tarde) estavam lotados no Serviço Social; Marcos Antônio, Pedro Viegas e Adeildo Ramos, na Divisão Legal; Prestes de Paula, Benedito e Godoy no Hospital Penitenciário.

Nas palavras de André, “já estávamos totalmente impregnados pela atmosfera da fuga”. (BORGES, 2008, p. 51). Quem liderava o plano de fuga era Marcos Antônio - que 
recebia as informações das pessoas envolvidas sem, no entanto, repassá-las a ninguém e era também o responsável pelos contatos externos, principalmente com os militantes da ALN e do PCBR.

A liderança de Marcos Antônio era incontestável. Não havia no Coletivo quem não o respeitasse. Sempre que alguém tinha uma informação ou sugestão, era ao Marcos que levava. Ele sempre dava a última palavra. Dava bronca também, mas para reestabelecer a ordem nas discussões (quando todos queriam falar ao mesmo tempo, geralmente nos momentos de ansiedade). Durante a concretização da Operação Liberdade, como denominaram o plano de fuga, o Coletivo se organizou através de uma disciplina rígida, militar, com hierarquia bem definida. É o que conta Antônio Duarte:

"No entanto, entre nós, existia a hierarquia. Desta, não poderíamos fugir. Apesar de esconder a verdade por trás de uma 'direção coletiva', tínhamos que considerar o Marcos Antônio como o 'comandante'. Mas ele estava numa posição correta aos nossos olhos. Prestes de Paula, José Duarte, Avelino Capitani ou Pedro Viegas, ninguém questionava a sua posição de líder, pois ele tinha muito da influência, e do apreço de todos os companheiros. Mesmo quando de nossa fuga da penitenciária, podíamos ler nas cartas ou nos bilhetes que os dois organizadores, Viegas e Duarte [integrantes do apoio externo], remetiam para o Marcos". (DUARTE, 2009, p. 327).

Tentando entender esta facilidade de Marcos Antônio em liderar o grupo, Antônio Duarte, que conviveu durante anos com ele na Marinha - eram da mesma embarcação -, atribui ao fato de ele ter "crescido", não ter se estacionado em termos de conhecimento. Conta Duarte que Marcos Antônio estudou apenas até o segundo ou terceiro ano ginasial, mas que lia muito, principalmente jornais e revistas. O carisma dele vinha, ainda segundo Duarte, de sua experiência de coroinha na Igreja Católica, quando criança. Mas, talvez o mais importante fator de seu carisma seja a paixão por futebol, que sempre teve. E era muito bom jogador. Jogou em times profissionais na Paraíba. Portanto, era ele quem organizava o time dos marinheiros. Nas palavras de Duarte:

"Gostava de futebol. Isso é uma forma de organizar as pessoas também. Por isso que ele era um cara bom de organizar e também era um cara que tinha uma liderança meio carismática, né. E foi ele que articulou lá, no caso, até com os prisioneiros" [a fuga]. ${ }^{109}$

Juntamente com Marcos Antônio, Viegas e Adeildo, trabalhavam na Divisão Legal alguns estudantes de direito que passaram a participar das discussões do Coletivo. Já tinham contatos com organizações armadas e estavam envolvidos, segundo Viegas, nas

\footnotetext{
${ }^{109}$ Entrevista a Flávio Luis Rodrigues. Rio de Janeiro, 11 de julho de 2012.
} 
manifestações estudantis, principalmente após a morte do estudante Edson Luís de Lima Souto, pela Polícia Militar, em 28 de março de 1968. "Esse pessoal vinha orgulhoso por ter participado do movimento estudantil, etc., e mais orgulhoso ainda por ter participado da marcha dos cem mil. Então, eles vinham e, através deles, a gente começou a contatar o $P C B R$, a $A L N$ ". 110 Tais estudantes passaram a fazer contato com o exterior da prisão e a organizar a infraestrutura necessária para a fuga.

Além dos estudantes de Direito, juntaram-se também ao Coletivo algumas estagiárias que trabalhavam no Serviço Social, onde estavam Capitani, Antônio Duarte, Edison e André. Jovens universitárias de Serviço Social, elas colaboraram para a realização de vários projetos levados a termo pelo Serviço Social, que atendiam demandas dos presidiários, como medicamentos gratuitos para suas famílias. Vale lembrar que essas meninas eram supervisionadas por Érica Roth, a chefe do Serviço Social até o dia 21 de setembro de 1968, quando suas rixas com o novo diretor da Lemos Brito chegaram a seu auge: ele a impediu de entrar na Lemos Brito, barrada na portaria. Na ocasião da mudança da direção, em julho de 1968, o novo diretor João Marcelo Araujo trouxe sua equipe de Bangu e ameaçou demitir a equipe de Érica Roth. Só não o conseguiu, naquele momento, porque "500 a 600 internos fizeram um abaixo-assinado à direção da Penitenciária Lemos Brito solicitando a permanência da depoente [Roth] e de sua equipe"."111

As 28 estagiárias que trabalhavam no Serviço Social abalaram as estruturas dos marinheiros. Mas as mais arrebatadoras paixões partiram das estudantes de Direito, que estagiavam na Divisão Legal.

Antônio Duarte conta que se apaixonou por algumas estagiárias, mas que não foi correspondido. Ele fala de uma paixão, que "atazanou" seu coração, por uma estagiária da Divisão Legal, de nome “Ângela Duquesa”. Os nomes usados por Duarte são fictícios, mas parecidos com nomes de estagiárias da Divisão Legal. É o caso do nome "Ângela Duquesa". Segundo Duarte, essa moça foi uma paixão proibida, pois ela se apaixonou por Marcos Antônio, com quem manteve um relacionamento. "Ela desprezou a minha sensibilidade como algo injurioso e feriu-me com farpas. Meu desejo de possuir um bem alheio não deve ter passado despercebido. Disse-me naquela época, só com o pensamento: siga seu destino. Pensei: você é muito bela para mim. (...) Aquela situação embaraçosa resolveu-se com a entrada de Marcos em cena. Ele que era considerado pela repressão política como o

\footnotetext{
${ }^{110}$ Entrevista a Flávio Luis Rodrigues. Iperó, 09 de outubro de 2008.

${ }^{111}$ Depoimento de Érica Roth no IPM que investigou a fuga do Coletivo da Lemos Brito. AEL - BNM 414, caixa 1 , volume 1 , folhas $80-84$.
} 
dirigente daquele coletivo. Aquele paraibano com feições tão habituais se apossou do coração de Ângela Duquesa. Ou talvez, o mais correto, imaginou que havia ganhado aquele coração de jovem aristocrata”. Outra grande paixão de Duarte foi “Ana Leão". Duarte claramente inverteu os nomes de duas estudantes de Direito, propositadamente para despistar. Davam assistência à Divisão Legal as estudantes Ângela Maria Rodrigues Leal e Ana Maria Barão de Assumpção. Quem namorou Marcos Antônio foi Ana Maria Barão de Assumpção (Ângela Duquesa). “Ana Leão”, então, trata-se de Ângela Leal, que para Duarte "era belíssima de uma forma que, para nós pobres mortais na cadeia, provocava desejos concupiscentes. Ela não tinha a beleza de Ângela Duquesa, com aquele sensualismo meio inocente e adolescente, porém, de um viço que me atazanou o coração".

(DUARTE, 2009, pp. 304-308).

Em seu breve depoimento para o encarregado do Inquérito Policial Militar, no dia seis de agosto de 1969, Ana Maria Barão de Assumpção confirmou seu envolvimento com Marcos Antônio. Perguntada se ela ficou decepcionada pelo fato de Marcos Antônio não a ter procurado "nem ao menos por contato telefônico", Assumpção respondeu que não. Ao ser inquirida se sabia que Marcos Antônio era comunista, respondeu que sim e à pergunta se “essa é sua ideologia”, respondeu negativamente. ${ }^{112}$ Sua amiga Ângela Maria Rodrigues Leal, também em depoimento ao IPM, quando lhe perguntaram como começara o envolvimento de Marcos Antônio com Ana Maria, respondeu que foi quando Marcos Antônio pediu à Ana que buscasse seu filho na casa de sua ex-mulher, com quem casou em Cuba, Kátia do Prado Valladares e o levasse à penitenciária. Leal contou que "achava ter sido isto parte de um plano para se aproveitar de Ana, de seu sentimentalismo, como uma 'bobinha', que a depoente vê, como prova disso, o fato de Marcos, que notoriamente adorava Kátia, um mês após a separação, passou a dizer que 'adorava a Ana'; que a depoente achava que a Ana teria confundido a pena, que sentia por ele, com amor". ${ }^{113}$ Tudo indica que a relação de Marcos Antônio com Kátia Valladares foi realmente intensa. Ângela Leal conta, inclusive, que Marcos pediu-lhe que levasse flores para Kátia, mas que ela não pode atendê-lo.

Kátia do Prado Valladares, ex-miss Bangu de 1958 e ex-musa universitária de 1963 (BORGES, 2008, p. 55), asilou-se na Embaixada do México em abril de 1964, onde conheceu Marcos Antônio e, ali, começaram a namorar. Partiram para o México e, em seguida, para Cuba. Segundo seu depoimento ao encarregado do IPM sobre a fuga dos marinheiros da

\footnotetext{
${ }^{112}$ Depoimento da Ana Maria Barão de Assumpção em 06 de agosto de 1969. AEL - BNM, 414, caixa 1, volume 1, folhas não identificadas.

${ }^{113}$ Depoimento de Ângela Maria Rodrigues Leal em quatro de setembro de 1969. AEL - BNM, 414, caixa 1, volume 2 , folhas 382-385.
} 
Penitenciária Lemos Brito, Marcos Antônio “ocupava-se em instrutoria de futebol e a depoente fazia traduções e tinha diversas atividades intelectuais. A vida em Cuba foi, com as devidas restrições, boa". ${ }^{114}$ Por considerar a vida em Cuba tranquila, ela resolveu ficar com o filho que acabara de nascer até agosto de 1967, enquanto Marcos voltou já em Junho de 1964 para o Brasil, contra sua vontade. Quando soube da prisão do Marcos Antônio, Kátia voltou ao Brasil e o visitou assim que pode.

As informações que temos sobre o relacionamento entre Marcos e Kátia foram tiradas de seu depoimento aos militares. Precisamos reforçar que se tratava de depoimento àqueles a quem ela considerava seus inimigos, e vice-versa. Portanto, convém que tenhamos cuidado em tirar conclusões apressadas. De qualquer forma, em seu depoimento, Kátia não escondeu sua opção à "ideologia esquerdista" e nem sua simpatia pelo regime cubano. Corajosa, defendeu as medidas de estatização do petróleo e dos minerais que o governo estava fazendo. Não diz, porém, qual governo. João Goulart? Eis o que o escrivão registrou: "É nacionalista e ama a sua terra, achava que eram lícitas e certas as atitudes do governo para estatizar não somente o petróleo, mas todos os minerais, mais ou menos o que se está tentando fazer agora, conforme palavras textuais da depoente”. Interessante como o escrivão terminou o texto acima. Dá a impressão de que se surpreendeu com as palavras de Kátia.

Em seu depoimento, Kátia Valladares deu informações sobre a crise de seu casamento que nos permite, com toda cautela, naturalmente, aproximarmos da personalidade de Marcos. Ela diz que voltou de Cuba quando soube da prisão de Marcos e para "acertar alguns pontos com ele, para ver se havia ainda possibilidade de viverem juntos em, caso contrário, decidirem a separação. Havia pontos fortes de desacordo entre ambos, que precisavam ser decididos". Abaixo, uma parte do depoimento de Kátia:

"A partir de dezembro de 1968 deixou de visitá-lo, porque ele pediu que ela não mais voltasse. Seus atritos com ele remontam a Cuba. Contudo, agora, agravaram-se. Com ele preso, ao invés da situação melhorar piorou, porque ele é um homem profundamente preocupado com o seu filho e com a depoente, mas a sua preocupação maior - e a depoente considera justo num homem que está preso - era mais em outra coisa [fuga da prisão], do que realmente na familia. [...] Algumas outras divergências foram também motivo de separação. Marcos não concordava com o regresso da depoente sem prévia consulta a ele. Ele tinha grande esperança de conseguir obter um 'habeas corpus', a depoente ajudou-o muito nisto, para que pudessem voltar para Cuba. [...] Ele nunca a considerou uma

\footnotetext{
${ }^{114}$ Depoimento de Kátia do Prado Valladares em 06 de agosto de 1969, no mesmo dia dos depoimentos de Ana Maria Barão de Assumpção e da estudante de direito Maria Amália da Silva Pires Sequeira. As três assinaram o auto como testemunhas. AEL - BNM - 414, caixa 1, volume 1, números das folhas não identificados.
} 
companheira de luta, 'como os senhores chamariam', mas como esposa e mãe do filho dele, o que se os senhores, digo, a família da depoente era contrária a essa união e massacrava muito qualquer pretensão nesse sentido. Por uma série de motivos a sua família hostilizava e o Marcos Antônio, homem de personalidade muito forte, sentia-se humilhado e ofendido. Uma outra coisa que foi motivo de forte abalo é que Marcos Antônio tem, como bom nordestino, aquela noção patriarcal da família, em que o homem manda e desmanda e deve ser consultado antes de qualquer decisão. A depoente ter vindo de Cuba, com o filho, tendo comunicado somente à sua mãe, que foi, afinal, a pessoa que deixou-lhe os dólares necessários à viagem de volta - já que ela fôra visitar em Cuba a depoente - era mais um motivo de humilhação para Marcos Antônio. Marcos não considerava a depoente uma companheira de luta, mas queria que fosse a esposa e mãe do seu filho. [...] Perguntada se a depoente desejaria que ele abandonasse a luta ideológica a que ele estava dedicando, passando a viver em qualquer parte que fosse de um mundo mais comum, mais 'burguês', respondeu que não sabe, pois que grande parte das discussões entre ambos residiam exatamente na discordância dela em relação ao regresso dele, nas condições em que veio, correndo risco, contudo, ele fez uma opção, que era assumir o risco da sua prisão e tentar o 'habeas corpus'. [...] perguntada se o Marcos Antônio, Adeildo e os seus companheiros de luta são comunistas, respondeu que não sabe o que se caracteriza como comunistas. Perguntada se tem admiração por Fidel Castro e sua ideologia, respondeu que sim, mas que falta muita coisa a ser definidas para que se possa dizer que eles são comunistas ou fidelistas". ${ }^{115}$

Os desentendimentos entre os dois não passaram despercebidos por André Borges, que atribui ao contexto tenso de preparação da fuga: "Não me recordo bem dos motivos, mas o relacionamento parecia já estar em crise. Era mais um vínculo sentimental e sanguíneo que a fuga iria pôr à prova. A separação física do casal pela ação da fuga ninguém poderia evitar" (BORGES, 2008, p. 55). Também Adeildo menciona estes desentendimentos entre o casal: "Então, quando ela chegou [de Cuba], inclusive com o menino já grandinho, então, se separaram. Ela é... se desentenderam, separaram. Ele ficou sozinho e começou a namorar com essa menina de Direito lá". ${ }^{116}$ Podemos indagar, considerando que Kátia Valladares foi sincera em seu depoimento, se Marcos Antônio não estava tentando proteger mãe e filho da repressão que poderia se seguir à fuga e quisesse que voltassem para Cuba. $\mathrm{O}$ fato é que o plano de fuga foi mantido em absoluto sigilo. Principalmente os mais próximos do Coletivo

\footnotetext{
115 Idem.

${ }^{116}$ Entrevista a Flávio Luis Rodrigues. João Pessoa, 21 de julho de 2011.
} 
nada souberam da fuga, para a própria segurança deles. André Borges diz que o último final de semana de visitas foi "uma longa e muda despedida". Nada falaram aos visitantes: "o cuidado tinha que ser o máximo para não envolver e nem comprometer pessoas amigas ou parentes com a fuga, prevenindo assim as posteriores consequências que adviriam pela sanha da repressão, quando estivéssemos em liberdade” (BORGES, 2008, pp. 15-16).

Capitani também teve o seu amor no cárcere. Apesar de negar, em entrevista que nos concedeu. Quando perguntamos se ele não paquerou as estagiárias, no Serviço Social onde trabalhava, ele respondeu: "não, não podia. A gente estava no esquema de fuga, não de paquera. (...) Eu estava fazendo tudo aquilo, todo aquele movimento, tudo em função do plano, só que ninguém sabia. E com as estagiárias, lógico que vinham as fofocas. Eu ouvia varias vezes o papo delas 'Esse loiro não quer paquerar com ninguém. Mas como? Eu vou conquistar, eu quero conversar com ele'. Então um monte de curiosidade, só que eu habilmente desconversava". ${ }^{117}$

Talvez seja verdade que ele não tenha "paquerado" nenhuma estagiária do Serviço Social. Mas isso não se aplica às estagiárias da Divisão Legal. Pelo menos a uma, Flora Frisch, estudante de direito que frequentava a Lemos Brito. Segundo seu depoimento no Inquérito Policial Militar, "satisfazendo talvez a uma carência afetiva de ambas as partes, começaram um namoro, um envolvimento emocional. Não havia, ambos sabiam, perspectiva de futuro, nem maior profundidade, mas o ambiente passional ajudou a aproximá-los. Depois veio a irmã dele, do Sul, passou dois meses de férias no Rio, ficou um tempo na casa da depoente, ficou também na casa da Lêda Viegas. O irmão da depoente teve uma paixão súbita e violenta pela irmã do Capitani, tendo viajado, quando ela foi embora, até o Sul, contudo não deu certo e se afastaram". ${ }^{118}$ Os depoimentos de Ana Maria Barão Assumpção, Ângela Leal e Kátia Valladares, mencionam o relacionamento entre Flora Frisch e Capitani. Kátia Valladares inclusive afirmou que entregava o filho para Flora levá-lo para ver o pai.

Adeildo também não escapou aos encantos das estudantes de direito. No entanto, não teve a coragem de se declarar para o seu amor. Tânia, por quem Adeildo era "doidinho", nunca soube deste grande amor "platônico", porque os dois eram tímidos, como nos contou: “eu era tímido demais. Além de ser tímido, eu a ter, sei lá, o complexo de preso, né: eu sou

\footnotetext{
${ }^{117}$ Entrevista a Flávio Luis Rodrigues. Porto Alegre, 12 de junho de 2011.

${ }^{118}$ Depoimento de Flora Frisch em 26 de novembro de 1969. AEL - BNM, 414, caixa 1, $3^{\text {o }}$ volume, folhas 589591.
} 
preso, ela... me aproximar dela não vai... (...) Sentia muito próximo de mim, ela chegava, vinha conversar comigo... Mas, ela era muito tímida e eu também". 119

Adeildo conta que praticamente todos os marinheiros que estavam no Serviço Social ou na Divisão Legal tiveram casos com as estagiárias: “a namorada de Capitani, que era Flora, que era parece de Serviço Social [era da Divisão Legal], e tinha a outra namorada, Geni, que era prima de Flora e era namorada de Antônio Duarte. (...) O Viegas terminou namorando com outra, né. Ele era casado com Leda. E depois rapaz, que Leda tomou conhecimento disso foi um sofrimento para ela. Mas, ela superou. (...) Capitani com Flora e Antônio Duarte com Geni. E eu só de olho grande em cima de Tânia, mas.... Marco Antônio começou a namorar com outra também". 120

Este grupo de jovens estudantes, de Direito e de Serviço Social, foram muito importantes para a realização de várias atividades que o Coletivo, principalmente, mas não só - muito se deve ao dinamismo de Érica Roth, como já falamos -, proporcionou para criar um ambiente mais solidário na penitenciária.

É o caso da "enorme farmácia" de que fala Capitani. Com o aumento do número de estagiárias, que Roth conseguiu, houve um mutirão para possibilitar a doação gratuita de remédios para as famílias dos internos. As meninas passavam nos laboratórios e pegavam amostras grátis. A Administração da penitenciária mandou ofícios para todos os laboratórios pedindo medicação. As famílias dos presidiários retiravam medicamentos apresentando a receita. Capitani conta que "no dia da inauguração da farmácia, a administração chamou os jornais e a televisão" (CAPITANI, 1997, p. 128).

A Seção de Recreação, onde André Borges, Capitani, Antônio Duarte e Edison trabalhavam, juntamente com as estudantes estagiárias, criaram um projeto de programação de filmes, que, segundo Capitani, “em algumas semanas, chegamos a quatro ou cinco sessões com filmes bons e muito bem selecionados, contrariando quem achava que os prisioneiros só gostavam de bang-bang" (CAPITANI, 1997, pp. 128-129). Providenciaram a adaptação de uma máquina de 16 para $35 \mathrm{~mm}$, pelo marinheiro Francisco da Chagas e passaram a procurar doações de filmes bons para serem mostrados aos presos. Contataram a Tabajara, que fazia a distribuição dos filmes soviéticos. Segundo André Borges, "a coletividade pode assistir aos melhores filmes da época, como 'Quando Voam as Cegonhas', o 'Quadragésimo Primeiro Tiro', o 'Encouraçado Potenkin', 'Girassóis da Rússia' e tantos outros filmes inesquecíveis, como ‘Doutor Jivago’ e ‘Zorba, o Grego'” (BORGES, 2008, pp. 44-45).

\footnotetext{
${ }^{119}$ Entrevista a Flávio Luis Rodrigues. João Pessoa, 21 de julho de 2011.

${ }^{120}$ Idem.
} 
Outro projeto exitoso, que teve cobertura de redes de televisão foi o I Festival de Música e Poesia do Encarcerado do Estado da Guanabara. Segundo Pedro Viegas, "O número de inscritos para concorrer ao Festival foi surpreendente. Os pedidos chegavam ao Serviço Social de todas as cadeias". Providenciaram um júri "formado por pessoas reconhecidas nos vários ramos da intelectualidade". André Borges ganhou o troféu Uirapuru dourado, com a poesia "Regresso". Segundo ainda Viegas, "Seu comportamento, ao receber o merecido prêmio em dinheiro, diz tudo: recebeu-o com uma das mãos e, com a outra, passou-o para o núcleo dirigente dos presos políticos” (VIEGAS, 2004, p. 78). Eis o poema de André:

\author{
REGRESSO \\ Enganam-se os que \\ me julgam vencido \\ no desterro dessas grades \\ forjo as armas \\ de combates \\ da batalha do oprimido \\ Crescem-me n'alma \\ os germes dos proscritos \\ irrompe do meu peito \\ um brado de revanche \\ em surdos gritos: \\ - Eu não fui vencido! \\ Repouso num sepulcro \\ sem nunca ter morrido \\ Embora da derrota a lança \\ sangre-me ainda o coração \\ não temerei novas batalhas \\ se empunho agora \\ a arma da Razão \\ Neste desterro \\ de grades guarnecido onde \\ às vezes \\ brilham luzes estelares \\ dos livros sorvo o saber \\ $e$ as lições de lutas milenares \\ Regressarei à vida \\ Onde me espera a luta \\ no corpo \\ levo e execrável \\ estigma das grades \\ no coração
}


uma esperança nova

na alma

uma paixão que arde:

- Liberdade! Liberdade! ${ }^{121}$

A prisão estimulava certas pessoas ditas estranhas também a realizarem, a seu modo, poesias. Pelo menos um refrão com rima e que dizia muito do cárcere com seus muros altos. É o caso do "Andarilho", como era conhecido um tipo "bastante estranho", segundo André: "Cabelo em desalinho, barbas crescidas, unhas grandes, amareladas de nicotina. Ele não se dirigia a ninguém. Andava intermitentemente pra lá e pra cá. Não pedia cigarro, apenas apanhava as 'guimbas' do chão, falando sozinho:

- 'Pá, cimento e areia, pra fazer cadeia...'”' (BORGES, 2008, p. 24).

As atividades do Serviço Social ocupavam as estagiárias quase totalmente. Junto com parte do Coletivo, ampliaram o programa Natal do Presidiário, lançando uma campanha para doações de presentes às crianças dos internos da Lemos Brito. Segundo Capitani, "As estagiárias levaram ofícios, visitaram casas comerciais e empresas. Quando o dia chegou, tínhamos um quartinho cheio de presentes. Fizemos um rigoroso levantamento do número de filhos e preparamos um saco de brinquedos para cada filho de presidiário. Sobraram presentes!" (CAPITANI, 1997, p. 130).

O Coletivo pensou igualmente na escolarização dos presidiários. Os presos só estudavam até o primário, o que corresponderia hoje ao Ensino Fundamental I. conseguiram, então, autorização da diretoria para criar uma campanha de alfabetização da população carcerária. Segundo André Borges, “a Fundação Batista do Amaral ficou encarregada de fornecer o equipamento para projetar filmes e o material didático: cadernos para caligrafia, cartilhas etc. A campanha foi divulgada extramuros, solicitando a participação de quem quisesse ser monitor-professor, voluntariamente. A receptividade foi espetacular e muitas delas procuraram a seção de educação para trabalhar na campanha. (...) Sonhávamos transformar a penitenciária na universidade que a grande maioria dos presos nunca teve" (BORGES, 2008, pp. 57-58).

Além disso, os membros do Coletivo conseguiram que a Administração criasse um curso supletivo de primeiro grau na penitenciária. Viegas conta que "os estagiários do próprio Serviço Social conseguiram professores de fora para lecionar as aulas das distintas disciplinas e uma banca examinadora seria constituída na época dos exames" (VIEGAS, 2004, p. 80). A propósito, Edison menciona, em seu texto de ficção e realidade, um encontro de estudantes da

\footnotetext{
${ }^{121}$ Recebido de André Borges na ocasião de sua entrevista.
} 
FNF (Faculdade Nacional de Filosofia?) de nomes Tarcísio, Luiz Cláudio, Nádia, Antônio Sérgio, Marília e Solange, com André Borges, Acyr (ex-sargento que participou do protesto de setembro de 1963) e "Prates", como Edison denomina Prestes em seu texto. Segundo Edison, Borges falou das necessidades que os presos tinham de um curso que pudesse possibilitar mais oportunidades ao preso, após a conclusão de sua pena e pedia a ajuda deles:

"Uma das nossas necessidades mais prementes é a de termos aqui dentro da prisão um curso ginasial, funcionando mesmo; tal curso dentro dos padrões dos colégios lá de fora é impraticável; um curriculum de quatro anos para nós é impossivel por causa da própria organização administrativa do estabelecimento. Assim, o que verdadeiramente seria melhor, era instalar-se o art. 99; em um ano dar-se-ia possibilidade ao detento de concluir o curso secundário; e nós temos inúmeros companheiros capazes de fazer esse curso e concluí-lo bem; essa é uma das nossas metas; outra é a criação de curso de jornalismo; assim como nós temos companheiros capazes de enfrentar a dureza de um art. 99, também temos outros capazes de enfrentar um curso de jornalismo" (MELLO, 2001, p. 105).

André conta ainda que o Coletivo organizou um círculo de palestras e que, uma delas, foi proferida pelo primeiro embaixador negro do Brasil, Francisco de Souza Dantas. Além disso, incentivaram a direção a criar um curso de desenho e pintura, revelando "excelentes pintores e desenhistas; algumas exposições de artes plásticas foram realizadas fora da penitenciária" (BORGES: 2008, 59). Edison conta que André comunicou a ideia de criar estes cursos para a Dona Elda (não menciona o sobrenome), chefe da Seção de Educação, no seguinte diálogo narrado por Mello:

"- será que a gente não poderia entrar em contato com a direção da Escola Nacional de Belas Artes e solicitar um professor que pudesse dar um pequeno curso intensivo de pintura, aqui, na penitenciária? Existem pelo menos uns vinte interessados que pintam sem maiores conhecimentos de técnicas de pintura e que, naturalmente, ficariam entusiasmados com a instalação de um curso assim" (MELLO, 2001, p. 108).

Ainda segundo Mello, a funcionária de nome Adelma interrompeu o diálogo dizendo que fazia um curso de pintura no liceu e que poderia levar um ofício da direção solicitando professores. E assim foi feito e criado o curso. Aliás, Prestes de Paula possivelmente participou destas aulas de pintura. Duarte conta que retratou o ex-sargento Raimundo Manuel Soares, torturado e morto pela polícia política no Rio Grande do Sul.

Já antes da chegada dos marinheiros na Lemos Brito, André Borges e Edison Mello organizaram um grupo de Teatro Amador Penitenciário, chegando a encenar peças dirigidas 
por José Brasil, "A Pensão dos Tarados", de Ferreira Neto, como podemos observar no programa-convite abaixo.

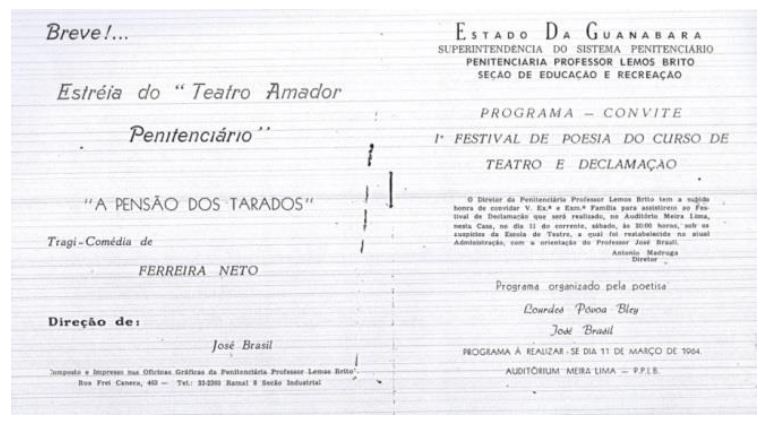

In: Mello: 2001, 214

Ás vésperas do comício da Central do Brasil, 13 de março de 1964, o diretor da Penitenciária Professor Lemos Brito convida a todos para o Primeiro Festival de Poesia do Curso de Teatro e Declamação. Edison conta que neste período estava se formando um grupo de teatro que se reunia todas as segundas, quartas e sextas, das 18 às 21 horas. Além de ensaiarem peças também declamavam poesias e foi assim que organizaram o festival de poesias. Presos recitando poesias? Sim. E Edison comenta a reação dos presidiários diante dos que recitavam: "os que diziam que declamação dentro de uma penitenciária seria tomado como atividade de 'frescos', sofreram a maior decepção. (...) no festival aqueles homens demonstrariam como o ser humano, esteja nas condições em que estiver, estigmatizado pelo quer que seja, jamais perde sua sensibilidade humana; ante os olhos atônitos e os ouvidos atentos de quanto compareceram - o auditório estava lotado - desfilaram Hermes Fontes, Ferro do Lago, Castro Alves, Gilka Machado, Godoy Paiva, Lago Burnett, Alberico Gomes, João Batista da Silva; nas vozes daqueles homens angustiados, sufocados, encarcerados, vilipendiados sempre que possível, saltaram para o ar manifestações das mais nobres do ser humano possa ter" (MELLO, 2001, p. 85).

O programa-convite anuncia ainda para "breve" a estreia do Teatro Amador Penitenciário, com a "tragi-comédia" A Pensão dos Tarados. A estreia se deu logo após o Golpe de 1964, que, ao contrário da peça, foi bem trágico. Edison conta que, apesar da tensão de todo o elenco, tudo saiu melhor do que esperavam: "nos bastidores um clima de expectativa; não uma expectativa calma, serena; nada disso; todos ansiosos, excitados, tensos". Tudo correu bem, e os atores-presidiários amadores, Manso, Vulcano, Kibi e Temístocles "proporcionaram àquele público um divertimento sadio; uma comédia que abriu o gargalhar geral; o sucesso fora total; os aplausos prolongados eram o prêmio desejado" (MELLO, 2001, p. 91). 
Em julho de 1967 André e Edison criaram o jornal O Encontro "órgão do curso de jornalismo do Instituto Educacional Moniz Sodré”, muito bem organizado, com oito páginas bem diagramadas - considerando que na época não havia computador -, e várias seções: editorial; "tópicos carcerários", com notícias sobre a penitenciária; artigos, como "teatro e recuperação" de André Borges; "pingos e respingos", coluna de Michel Godoy; "palavras cruzadas" e entrevistas. André Borges era seu diretor responsável, Edison Mello, o redatorchefe, João Batista da Silva, o secretário e Aderbal Cruz, chefe de reportagem. Abaixo, a primeira página do jornal:

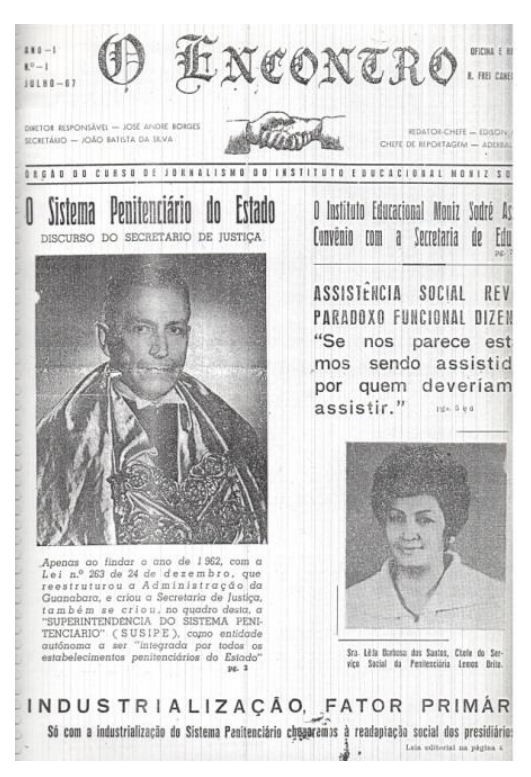

Já dissemos que o Coletivo organizou um time de futebol de salão, chamado " $\mathrm{O}$ Popular", ganhador de vários torneios e que Marcos Antônio era seu capitão. Segundo Viegas, a criação do time foi para "ganhar a simpatia dos presos". Inclusive, participaram também da Liga de Espores da Penitenciária - LEP. Em julho de 1967, o jornal O Encontro noticiou que André Borges e Antônio Prestes de Paula tinham sido eleitos para o Conselho Deliberativo. Pouco mais tarde, André Borges tornou-se seu presidente, sendo seu vice William da Silva Lima. Para secretário da Liga foi eleito "Boxer, um ex-marujo também politizado", nas palavras de Borges.

De todos os projetos que o Coletivo realizou para assegurar uma vida melhor para os prisioneiros, certamente o que mais agradou a massa carcerária foi o Parlatório. Na verdade ele já existia, mas estava ameaçado de ser fechado por causar muita confusão entre os presos, além de ser usado para traficar droga. Tratava-se de um quarto onde o preso de bom comportamento poderia passar uma hora a sós com sua esposa, uma vez por mês. Mas deveriam provar que eram casados ou que já estavam juntos a mais de dois anos. Capitani 
conta que era muito desorganizado e perigoso. Se um preso flagrasse o outro olhando sua mulher, logo puxava o estoque.

O Serviço Social conseguiu apoio da direção para organizar este espaço importante para os presos. A mulher do preso entrava pela portaria e ia direto para o Serviço Social, sem que nenhum preso pudesse vê-la. Seu parceiro encontrava-se com ela no quartinho. Além disso, ampliaram os dias em que o preso pudesse ficar com sua parceira, inclusive a noite toda. Capitani, que participou desta racionalização da utilização do parlatório, conta como foi:

"O parlatório funcionava aos sábados e domingos, das dez da manhã até o entardecer. Os casais tinham direito à uma hora de intimidade, e um casal por dia tinha direito a passar a noite lá. Deu certo e passou a funcionar também às quartas-feiras. A administração respeitava-nos muito.

- Vocês são vinho de outra pipa.

Fizemos um projeto para construir outro quartinho, e a administração aceitou, porque continuava ganhando prestígio. Conseguimos os tijolos gratuitamente e os próprios prisioneiros levantaram as paredes. Assim quase todos os prisioneiros puderam dormir, pelo menos uma vez por mês, com a companheira. Dobramos a capacidade de amor na penitenciária" .

(CAPITANI, 1997, pp. 129-130).

Edison Mello fala do respeito que o projeto do parlatório tinha entre a massa carcerária: "Parlatório, vou dizer uma coisa, você não podia nem falar de parlatório de uma forma, assim, meio de chacota, porque sofria logo uma reação. O parlatório era tido como um local de maior respeito, lá na penitenciária”. ${ }^{122}$

Enquanto o Coletivo ocupava lugares estratégicos junto à portaria da penitenciária, trabalhando para a Administração Penitenciária nos setores da Biopsicologia, do Serviço Social, principalmente no Setor de Recreação e na Divisão Legal, auxiliando os presos na unificação de suas penas, fazendo requerimento e dando informações sobre suas condições jurídicas, ele também ganhava a confiança da massa carcerária, através de seus vários projetos, levados a termo com muita dedicação. Isso também fazia parte do plano de fuga da penitenciária. Ou seja, toda a movimentação dos membros do Coletivo, desde o início de 1967, estava relacionada à fuga. Foram dois longos anos de preparação, com muito cuidado, muita observação, muita atenção ao cotidiano dos guardas e funcionários da cadeia. Por exemplo, detalhes como o número de guardas que ficavam na portaria; o horário da troca de

\footnotetext{
${ }^{122}$ Entrevista a Flávio Luís Rodrigues. Rio de Janeiro, 10 de julho de 2012.
} 
turnos; os guardas das guaritas; quais tipos de armas usadas; horários de menor fluxo de visitantes, etc.

Muitas peças precisariam ser encaixadas neste quebra-cabeça. A saída da penitenciária, por si só, já era muito complexa. Precisavam pensar também na parte externa, ou seja, quando alcançassem as ruas. Como conseguir automóveis para transportar dez pessoas, "uniformizadas" com as roupas do cárcere? Como conseguir um esconderijo para onde os fugitivos pudessem ficar um tempo imprevisível? E a alimentação? E as armas? Se fossem apenas dois ou três fugitivos, tudo seria bem mais simples. Mas, dez homens que precisavam se alimentar, se higienizar, se proteger? Como passariam despercebidos?

Durante os dois anos que passaram "ocupando" os cargos próximos da portaria, pois já estava decidido que a fuga seria pela frente da penitenciária, o Coletivo discutiu sobre seu engajamento na guerrilha, através da criação, a depender da conjuntura, de um foco guerrilheiro. Sabiam, no entanto, que precisariam se incorporar a uma organização, já que eram poucos para começar um processo revolucionário e isto, desde o primeiro momento, estava fora de cogitação.

As discussões realizadas na sala do Edison, na cela do Prestes, ou no canto da quadra de futebol eram tomadas pela revolução. Suas falas, suas ações, seus pensamentos estavam voltados para o futuro. A convicção de que a vida não se resumia naquele cárcere, ou seja, ao se projetarem para o futuro, tornaram aquele presente, também, prospectivo. O que salvou estes homens (o Coletivo) de se tornarem mesquinhos individualistas, de se integrarem ao status quo da penitenciária, consumindo drogas, ou deixando-se levar pelo cotidiano modorrento dos jogos de dama, baralhos, jogo do bicho, e outras ocupações do "agora", foi justamente o questionamento que faziam daquela condição em que eles e os outros miseráveis daquela penitenciária se encontravam. Seu projeto político e seu envolvimento para concretizá-lo faziam com que seu presente apontasse sempre para um horizonte de expectativas. Estavam voltados para o futuro.

Sua vivência, leituras e discussões indicavam que estavam corretos em suas análises, que a Justiça cometera uma injustiça, que eram prisioneiros políticos e como tais agiam, não se igualando à miserável existência dos outros presos. Duarte resume isto da seguinte forma:

"A confirmação da certeza da causa, no otimismo emprestado de nossa juventude. (...) 'A todo vapor', para frente, exaltando nosso projeto de revolução. Porém, sem aquele hábito de sorver as delícias de nossa utopia, pois éramos utópicos, mas com os pés atrás, aguçando nossa vontade em um projeto que considerávamos novo. 
Este era o estímulo de nossa vida que fazia com que as derrotas não se considerassem como tais. Seguíamos o lema daqueles que estavam destinados a substituir os que caíam em combate. Afinal, esse era também o nosso espírito militar, que havíamos aprendido na Marinha!" (DUARTE, 2009, pp. 326-327).

Segundo Adeildo, quando Marcos Antônio lhe abriu sobre o plano de fuga, consultando-o se queria participar, falou nos seguintes termos: "olha, vou te contar um segredo, mas é uma coisa que tem que ficar entre nós. você não pode abrir isso para ninguém', disse, 'nós vamos fugir, organizar uma fuga', e, aí contou o esquema: 'vamos fugir aqui pelo portão, aí você está aqui, você pode participar da fuga, se quiser ou não, mas é importante você ficar sabendo, porque no dia da fuga se você não quiser participar tem que arranjar um jeito de ficar lá dentro [da penitenciária], não vir [para a Divisão Legal]', porque senão, ia ser complicado para mim, né. 'Não, eu quero sair'. (...) 'Olha, se você quiser, ou não quiser, a gente vai montar um grupo de guerrilha, esse é o nosso projeto, montar um grupo de guerrilha. Se você quiser, você vai, se não quiser, você já entra numa Embaixada e vai embora para o exterior'. Bom, eu disse: 'não, eu vou participar, eu vou participar do grupo'. Viegas já veio, aí então Marco contou para Viegas [que havia falado do plano de fuga] e Viegas já veio conversar comigo. Aí eu fiquei sempre mais com o Viegas". 123

O Coletivo, portanto, tinha dois planos: o primeiro era a fuga e o segundo, o ingresso na guerrilha. Para o segundo acontecer, o primeiro era inevitável. Mas, enquanto pensava as estratégias de fuga, não deixava de fazer discussões teóricas sobre a revolução, recorrendo-se a Marx, Lênin, Mao, Fidel, etc. e discutindo experiências concretas, como as revoluções russa, cubana e chinesa.

André e Prestes esboçaram um manual de guerrilha urbana. O manual levou o título de Rede Urbana de Apoio - RUA -, que era debatido em grupo. "Queríamos organizar um manual próprio por não termos às mãos algo semelhante". Além disso, Marcos Antônio dava instruções sobre "luta na Selva e como fazer granadas caseiras. Ensinava várias coisas na arte da guerra" (BORGES, 2008, p. 55). Ou seja, Marcos Antônio repassava ao coletivo o que aprendeu em Cuba. Possivelmente Capitani e José Duarte também contavam suas experiências em Cuba. Na verdade, a lembrança de Cuba e sua colaboração às revoluções na América Latina era uma forma de manter a chama acesa, evitando o esmorecimento daqueles que tinham uma "recaída", na vivência de um presente cheio de violência e desesperanças. André, o mais otimista do Coletivo, apesar dos dez anos de prisão, fala de seus projetos futuros:

\footnotetext{
${ }^{123}$ Entrevista a Flávio Luís Rodrigues. João Pessoa, 21 de julho de 2011.
} 
"Por trás das muralhas, sonhávamos fazer pelo povo algo mais do que vínhamos fazendo nesse reduzido e estranho campo de batalha atrás das grades. Sonhos que se completavam com a nossa participação na guerra de guerrilha" (BORGES, 2008, p. 48).

Antônio Duarte conta que tentavam manter nos marinheiros a fé no futuro, de "rebelião contra o obscurantismo". O que propúnhamos? Pergunta ele. E responde: "A revolução que somente existia como um projeto acalentado, que brilhava nos olhos de todos aqueles companheiros, enquanto confabulávamos nos cubículos estreitos da prisão. Prestes de Paula, Marcos Antônio, José Duarte e, em menor escala, Senna e Adeíldo ouvindo as histórias de Marcos sobre sua experiência em Cuba". (DUARTE, 2009, p. 284).

Que ideia de revolução tinha o Coletivo? Havia algum modelo a ser seguido? Seria através de um foco guerrilheiro? Seria através de um partido? Seria de libertação nacional? Enquadrava o Coletivo nas esquerdas de resistência democrática à ditadura, ou naquelas que defendiam a luta armada ofensiva contra a ditadura, objetivando destruir o capitalismo e instaurar uma ditadura revolucionária? (REIS FILHO, 2004, pp. 29-52).

Acreditamos que o Coletivo evoluiu, com o tempo, de nacionalista a revolucionário, ou seja, seus membros eram nacionalistas no período em que estavam no MNR de Leonel Brizola e se tornaram revolucionário na prisão. As conversas entre os integrantes do Coletivo, marinheiros e presos comuns, eram em torno de uma sociedade socialista, sem exploração e desigualdades sociais. Estavam muito próximos do modelo cubano. Defendiam a revolução armada a partir de focos guerrilheiros, apesar de seus membros não afirmarem literalmente isso em suas entrevistas, na região entre São Paulo e Rio de Janeiro. Defendiam a existência de um partido que dirigisse o processo revolucionário. Estas formulações estavam muito próximas das de Marighella e sua ALN. Antônio Duarte expõe como via essa questão na época:

"Ele [o Coletivo] tinha aquela visão da revolução cubana, mas nós achávamos que tinha que ter um partido. (...) A nossa estratégia era nesse sentido, porque você não ia organizar um exército como Aragão pensou, entendeu? E que esse exército seria um exército revolucionário como está sendo hoje, você vê, na Colômbia. É uma ideia que nós tínhamos, né? A ideia que está sendo aplicada na Colômbia e que foi tentada na Venezuela pelo Douglas Bravo, era isso que a gente pensava: ia para as montanhas e com uma região camponesa e a gente... a nossa visão era a seguinte: não tinha que ir lá para o interior da Amazônia, a gente tinha que fazer aqui no Estado do Rio e São Paulo. (...) Por isso que nós fomos para a serra Bocalho [de Angra dos Reis]. Porque a gente disse assim: 'quando estiver suficientemente forte, a gente fecha a Rio-São Paulo, quero ver se eles vão, qual a indústria que vai funcionar, se você fecha 
Rio-São Paulo'. Então, eles tinham que jogar o exército ali dentro daquela serra, que ali era propício um combate à guerra. Isso era o que a gente pensava: formar um exército de libertação nacional. Um exército. Era esse nosso pensamento" ${ }^{124}$

As palavras de Antônio Duarte vão ao encontro do que nos expôs Antônio Geraldo Costa, que naquele momento em que o Coletivo estava preparando sua fuga da Lemos Brito, era militante da Ação Libertadora Nacional - ALN. Neguinho fala que a estratégia da ALN era organizar "grupos guerrilheiros" nas serras do Mar e de Angra dos Reis, no Vale do Paraíba. Desta forma, pretendia-se parar o Brasil, já que praticamente a força econômica do país estava concentrada ali:

"Fazer guerrilha que poucos daquele grupo [coletivo que estava na Lemos de Brito] sabiam disso, era fazer guerrilha entre Rio de Janeiro e São Paulo, no Vale do Paraíba. Porque o terreno é estratégico. Primeiro, estratégico econômico, estratégico político, geograficamente estratégico. O Vale do Paraíba era e continua sendo um eixo econômico e militar estrategicamente, industrial, entre o Rio de Janeiro e São Paulo. Se nós infernizássemos a ditadura nesse eixo, a gente tinha muito pau para quebrar, porque a ligação entre o Rio de Janeiro e São Paulo é como um [inaudivel] importante. Então, tem-se as duas serras: Mantiqueira e Serra do Mar. Com um trabalho político bem estruturado, e os grupos guerrilheiros espalhados naquela região, não concentrados exatamente ali na [serra de] Angra dos Reis, mas que se espalhasse por entre essas duas cadeias de montanhas. Isso numa perspectiva ampla de trabalho político. Esse era o objetivo. Naturalmente que só quem sabia disso eram alguns elementos da direção" [da antiga AMFNB]. ${ }^{125}$

Mesmo estando militando em São Paulo, Neguinho sempre se manteve informado sobre os planos de seus amigos na Lemos Brito. Mantinha contato com o Marcos Antônio, através de Pedro Viegas. Combinaram que os militantes da ALN de São Paulo e Rio de Janeiro ajudariam na fuga, mesmo contra a vontade de Carlos Marighella, que não aceitava a participação dos presos comuns. Começava a se formar um grupo de militantes fora da cadeia, que será fundamental para o êxito do plano.

Quando o Coletivo já havia "ocupado" a portaria, com salvo-conduto que lhe permitia passar por vários portões da penitenciária - segundo Capitani eram sete portões, de sua cela até a Rua Frei Caneca -, André descobriu que havia outro plano de fuga, organizado por presos comuns. Isso era um problema, que certamente inviabilizaria a “Operação Liberdade”.

\footnotetext{
${ }^{124}$ Entrevista a Flávio Luís Rodrigues. Rio de Janeiro, 11 de julho de 2012.

${ }^{125}$ Entrevista a Flávio Luís Rodrigues. Maceió, 19 e 20 de julho de 2011.
} 
Imagine os cuidados que teriam os guardas penitenciários, quando descobrissem tal plano: muito provavelmente implantariam a partir dali um sistema rigoroso de vigia.

O plano de fuga dos presos comuns era comandado por um funileiro, que trabalhava, junto com outros dois, na oficina mecânica, preparando um enorme caminhão que usariam "para sair arrebentando muros e grades pelo portão da frente". Seu nome: Roberto Cietto, um negro alto, segundo Capitani "um prisioneiro perigoso. Como chefe do bolão da penitenciária, fazia as apostas no jogo de cavalos e era reconhecido como 'durão' e matador”. (CAPITANI, 1997, pp. 131-132). Pedro Viegas apresenta Cietto como "um preso comum de aparência serena muito astuto. Tinha sobre a cabeça muitos anos de reclusão para cumprir e chegara à conclusão que era a hora de reconquistar a liberdade. (...) Ele simpatizava com o Marco Antônio e dessa simpatia nasceu a confiança, após muitas trocas de opiniões".

Era necessário fazer Cietto desistir de seu plano. Como fazê-lo se ele tinha um compromisso com outros dois presos? O Coletivo resolveu conversar francamente com Cietto, falando que também tinha um plano, mais viável do que o dele. Capitani conta como foi a conversa:

- "Cieto, teu plano não é bom, se tu desistes garantimos colocar-te em liberdade no meio da cidade.

- Vou pensar.

Pedimos então que, pelo menos, adiasse o plano e inventasse uma história para os outros.

- pô, os caras vão me matar.

- vou confiar em vocês. O meu plano não vai dar certo mesmo. Vou confiar que vocês vão me levar". (CAPITANI, 1997, p. 131).

Incorporado ao Coletivo, Cietto passou a frequentar o banco dos marinheiros. Ansioso, pedia sempre que os marinheiros the posicionassem sobre o plano e que não o esquecessem. Foi quando, para acalmá-lo, disseram-lhe que nada mais saberia sobre o andamento do plano, dado o grau de confidencialidade. Ele aceitou, mas continuou ansioso:

- Cieto, a partir de agora não vamos te falar mais nada sobre o plano. Fica alerta e, quando receberes o aviso, desce de manhã já arrumado. Uma calça, uma camisa descente, o sapato engraxado, barba feita. Só isto.

Foi engraçado porque, a partir daí, ele ia para o pátio bem arrumado como se estivesse dizendo para não esquecermos dele". (CAPITANI, 1997, pp. 131-132).

Em fins de 1968, o Coletivo estava ampliado, contando com quatro presos comuns, mas sem a certeza ainda de quem realmente participaria da fuga. Ou seja, já tinha definido que sairiam aqueles que tivessem penas mais altas a cumprir, mas não seria possível fugir 
todas as pessoas envolvidas no plano. É o que sugere André: "sentindo nosso plano ameaçado, optamos por cortar alguns companheiros que participariam da ação”. (BORGES, 2008, p. 47).

Foi neste momento, por volta de dezembro de 1968, que o Coletivo resolveu criar uma organização guerrilheira que pudesse, a partir da cadeia, comunicar-se com outras organizações fora da penitenciária, visando o sucesso da fuga. Criou-se, então, o Movimento de Ação Revolucionária, propositalmente chamado por MAR, possivelmente para associá-lo à AMFNB, como se seus diretores pretendessem recriar a entidade, com um nome diferente, resignificada e ampliada por pessoas fora do ambiente marinheiro, como estudantes, jornalistas, guerrilheiros, intelectuais e sindicalistas. Sobre o MAR, Viegas fala que foi uma iniciativa do "núcleo de presos políticos e aliados externos para identificar-se".

Portanto, o Movimento de Ação Revolucionária foi criado com a intenção de organizar a fuga do Coletivo da Penitenciária Lemos Brito, sem pretender, apesar do nome, ser uma nova organização revolucionária. O MAR pretendia preparar a fuga e partir para a luta armada, contra a ditadura. A ideia que tinham era, após a fuga, integrar o MAR a outra organização existente. Neste sentido, foram feitas tratativas com a ALN e com o PCBR. Mas a inclinação dos marinheiros era mesmo ingressar na organização de Marighella, já que ali estavam companheiros de longa jornada, como Neguinho e Elinho.

A AMFNB não deixava de estar presente entre o Coletivo. A lembrança de sua rica experiência política; a tomada de posição do lado da defesa das reformas de base e a constatação de que seus objetivos contrastavam com os de seus oficiais, só reforçaram a certeza de que estavam corretos em suas análises e o Golpe de 1964 e a ditadura civil-militar corroboraram com esta tese.

Antônio Duarte diz que esta certeza de que não foram irresponsáveis e voluntariosos na ocasião do protesto da Semana Santa de março de 1964, como muitos já o acusavam, conclusão a que chegaram através das discussões dentro da cadeia, só reforçou a iniciativa de criar o MAR, e partir para a luta armada contra a ditadura.

"Quer dizer, aquela visão que a gente tinha lá na Associação ficou muito mais fortalecida aí. Então, a gente realmente, nesse momento pensava em um partido, não mais um movimento como a gente fez. Chamamos de Movimento de Ação Revolucionária, porque aí veio aquela influência também cubana né, que você pode se utilizar de estruturas militares para formar 
um partido, né. Porque aí nesse momento é onde a gente não acreditava mais nas estruturas do Partido Comunista. Porque, na verdade, o Partido estava sempre negociando". ${ }^{126}$

Adeildo Ramos acompanhou as discussões sobre a criação do MAR, e diz que o objetivo era criar condições para a deflagração da guerrilha rural, porque as outras organizações guerrilheiras não tinham conseguido executar ainda. A referência, como se pode observar, é a ALN:

"Movimento de Ação Revolucionária. Por que, qual a razão? Porque a ALN estava já fazendo a guerrilha urbana, mas nunca participou, nunca fez guerrilha rural. Então, o que o pessoal disse? "não, tem que partir para a guerrilha rural, o objetivo é a guerrilha rural, a guerrilha urbana é mais para dar apoio à rural". Tanto é que, o projeto da gente era montar a rural e desmontar a urbana. O pessoal, o comandante da urbana era Zé Duarte". ${ }^{127}$

A organização era, nas palavras de Viegas, "uma coisa bem romântica mesmo, sem uma definição programática, sem nada... Surgiu um documento, mas a gente era tão precário intelectualmente para fazer uma análise... Nem documento. Tinha um papelzinho, que era um papel, vamos dizer assim, tão romântico que eu nunca mais vi por onde andou essa coisa. (...) Então, era uma coisa bem romântica mesmo, sem uma definição programática, sem nada. Bom, mas a gente tinha essa perspectiva de que mais na frente iria incorporar numa dessas organizações maiores". ${ }^{128}$ Talvez Viegas esteja se referindo ao "manual de guerrilha urbana" de que André falou que escreveu juntamente com Prestes e que deram a ele o nome de Rede Urbana de Apoio - RUA. De qualquer forma, isso demonstra a preocupação, nas discussões que o Coletivo fazia, de registrar as conclusões a que chegava. Possivelmente este documento foi apreendido pelos policiais depois da fuga da Lemos Brito, conforme mencionado no depoimento do diretor da Penitenciária ao encarregado do Inquérito Policial Militar, criado para investigar a fuga do Coletivo. Segundo ele, nas gavetas das mesas de Marcos Antônio e Adeildo Ramos, na Divisão Legal, foram encontrados documentos "subversistas", tais como: 1 livro de 43 folhas de nome El Mar; 1 livro de no 155 [não diz o que significa este número, possivelmente de alguma coleção] , “A Igreja de Hoje”; 1 livro n 165 "O Desenvolvimento dos Povos"; "O seu horóscopo sem segredos"; "O Brasil e o Mundo"; Acendedor - 1 volume.; 1 volume "problemas do aborto"; "o que o brasileiro em idade militar deve saber" 1 vol.; Seleções - 1 volume; Nosso século, 1 vol.; Revista Veja, 2 volumes; "Memórias de um velho soldado"; Volume datilografado com 20 folhas do Coronel J. Cardin; "Controle da

\footnotetext{
${ }^{126}$ Entrevista a Flávio Luis Rodrigues. Rio de Janeiro, 11 de julho de 2012.

${ }^{127}$ Entrevista a Flávio Luís Rodrigues. João Pessoa, 21 de julho de 2011.

${ }^{128}$ Entrevista a Flávio Luís Rodrigues. Iperó, 09 de outubro de 2008.
} 
natalidade"; "Roteiro para um Brasil mais cristão"; Congresso Pentecostal Internacional"; cópia de "H. Corpus"; "A vida e o drama do homem marginalizado", folheto, 2 folhas; várias cópias de documentos da SUSIPE e dos Auditores da Marinha; "Questionário de Geografia dos Estados Unidos da América do Norte"; um maço de envelopes para cartas aérea; Folha de desenho da Seção de Biopsicologia; caderno de literatura de José Adeildo; Caderno de folhas presas com arame; caderno de Ciências Naturais; carta do Deputado Ernai Satyro; folha de papel almaço contendo tabelas de futebol; vários cartões de identidade do Club Popular; pedaço de papel almaço com anotações; pasta com várias cópias de documentos num total de 66 folhas e inclusive, um envelope contendo a importância de $\mathrm{NCr}$ \$ 60,00 e ainda vários envelopes para cartas aéreas; 1 tubo de pasta dental "Eucalol".

A lista acima, feita pelo chefe de Marcos Antônio e Adeildo Ramos, Durval Soares, e enviada ao Diretor da Penitenciária, logo após a fuga, sugere um ecletismo de leituras admirável. Os pertences de Marcos Antônio e Adeildo Ramos foram misturados, não permitindo identificar em que mesa estava determinado objeto. De qualquer forma, a relação de assuntos que estes marinheiros liam era ampla, destacando os relacionados ao militar, ao cristianismo e a estudos de conjuntura brasileira. Mas não podia faltar na relação o interesse pelo futebol, certamente encontrado na mesa de Marcos Antônio.

Criado o MAR, os marinheiros puseram-se a procurar contatos externos para viabilizar a fuga. Eles corriam contra o tempo, pois vários imprevistos vinham acontecendo, ameaçando o desenlace do plano. Além do caso de Cietto, outros surgiram para deixar o Coletivo preocupado e ansioso para que o "dia D" chegasse logo. Por exemplo, a notícia de que a Secretaria da Justiça iria transferir a Divisão Legal para a SUSIPE, na Rua Senador Dantas, centro do Rio, inviabilizando a saída de Marcos Antônio e Adeildo Ramos, que ali trabalhavam. Outro contratempo foram as obras que a prefeitura começou a fazer na Rua Frei Caneca, abrindo buracos e invertendo o sentido do fluxo de carros. Cada vez mais era urgente a criação de um apoio externo, para organizar a retirada do grupo da cidade e conseguir armas para saírem da penitenciária.

Em dezembro de 1968, José Duarte, Pedro Viegas, e Edvaldo Celestino, que tinham penas pequenas e bom comportamento, foram beneficiados pelo Indulto de Natal. Ganharam a rua com a promessa de tirar o Coletivo do cárcere.

José Duarte passou a comandar as ações externas para libertar os presos: procurou os militantes da ALN, do PCBR e outras pessoas que iam se integrando ao MAR, como o jornalista Flávio Tavares e os estudantes de Direito, que estagiavam na Lemos Brito. A ele cabia fazer entrar as armas na cadeia, conseguir automóveis para o translado do Coletivo e 
planejar ações de expropriações (roubos a bancos) para adquirir recursos necessários para manter um grupo grande de homens por vários dias escondido. A Pedro Viegas ficou a incumbência de encontrar um esconderijo e fazer o trajeto para transportar os presos da penitenciária até ele. Para tanto, Viegas mudou-se para a casa de uma tia, próxima da penitenciária e estudou meticulosamente o movimento das ruas circunvizinhas, a fim de evitar qualquer contratempo no dia da fuga.

Enquanto Viegas pelejava para encontrar um sítio, ou casa, aconteceu um fato interessante, que veio ajudá-lo a atingir seu propósito.

Um dia, no início de 1969, André Borges recebeu uma visita de um ex-preso, "que tínhamos dado consciência política", que fazia parte do grupo de presos comuns que discutiam política com André, antes da chegada do Coletivo, de nome José Gonçalves de Lima. Contou-lhe que assistira pela TV Tupi o I Festival de Música e Poesia do Encarcerado do Estado da Guanabara e elogiara André por sua participação, ocasião em que ganhou o troféu uirapuru dourado. Falou-lhe ainda que não tinha abandonado a luta e que estava integrado num grupo de militantes que fazia parte de uma célula do Partido Comunista Brasileiro na Companhia de Transportes Coletivos (CTC), mas que estavam descontentes com a linha do Partido e que procuravam, naquele momento, outras alternativas de ação. O grupo era residente no bairro Mallet, no Rio de Janeiro. André contou-lhe então que havia um grupo interno na penitenciária, organizado no Movimento de Ação Revolucionária que procurava contatos fora do cárcere e sugeriu que as conversas deveriam prosseguir, quem sabe para a união dos dois grupos.

José Gonçalves contou que ficou incumbido pelo grupo por oferecer apoio aos internos da Lemos Brito: "mandaram saber de você em que poderíamos ser úteis e fazer a ligação". Seu grupo decidira ingressar na luta armada e também procurava contatos. André, então, respondeu:

"Disse-Ihe da fusão dos grupos, buscando melhor desenvolvimento do nosso trabalho. Mesmo tendo alguma influência, precisava consultar os outros companheiros para lhe dar uma resposta. A questão merecia ser discutida e a resposta só seria possível em outra ocasião" (BORGES, 2008, p. 50).

Após a visita, quando José lhe disse que "outro companheiro mais credenciado" voltaria para saber da resposta do Coletivo, André levou a proposta aos marinheiros, que viram aí a solução para o problema do esconderijo do grupo. Neste momento já pensavam em partir para um acampamento, que permitisse a eles fazerem treinamento de guerrilha. 
Na semana seguinte, André recebeu a outra visita - "um moço moreno". Perguntoulhe se ele era André. "Vim a mando do seu João buscar resposta à nossa proposta". Seguiu-se o seguinte diálogo:

- A proposta do trabalho em conjunto foi aceita. Mesmo assim, é necessário discutir certos detalhes - respondi.

- podemos fazê-lo aqui mesmo?

- sim, desde que com algum cuidado - alertei-o"

(BORGES, 2008, p. 52).

Na breve conversa que tiveram, André foi informado de que o Grupo Mallet, como será identificado pelo Coletivo a partir daí, já dispunha de um sítio na Serra de Angra dos Reis, onde pretendia transformá-lo num acampamento de guerrilha. O interlocutor quis saber a visão que o MAR tinha sobre a luta armada. Prometeu, então, voltar na próxima semana, trazendo um posicionamento mais definitivo de seu grupo.

Inteirado sobre as conversas com o Grupo Mallet, Marcos Antônio recomendou a André que estreitasse mais o laço. André deveria pedir contato com uma pessoa que tivesse poder de decisão, "uma vez que via com bons olhos a possibilidade de fusão do nosso grupo com esse pessoal”. Segundo Borges, integrava esta célula do PCB, José Ferreira (seu líder), Leonardo, Francisco, Sílvio, Vadinho, ‘Tio Adão' e 'Seu Zé'.

"Eles se integraram ao MAR. (...) Quando o Artur voltou, na semana seguinte, além de acertarmos tudo acerca do nosso trabalho conjunto, encaminhamos também a alternativa de fundirmos nossos grupos. E para isso demos a ele contato com nosso pessoal na rua [Pedro Viegas, José Duarte e Edvaldo Celestino] para encaminhar certas tarefas práticas e urgentes, como finanças, estrutura da organização e aspectos militares da luta".

(BORGES, 2008, p. 53).

O apoio externo agora se ampliara. Viegas, por recomendação de Marcos Antônio, ficou em contato com o Grupo Mallet e Edvaldo Celestino e José Duarte viabilizariam recursos financeiros e infraestrutura para a fuga, sendo José Duarte o coordenador das ações urbanas.

Enquanto isso, na cadeia, o Coletivo conspirava e acertava todos os detalhes para a fuga. A Divisão Legal passou a ser um ponto de encontro do Coletivo, pois ali estava a pessoa que concentrava todas as informações, internas e externas. Sempre que vinha alguém de fora, por exemplo, o Viegas ou os estagiários, um marinheiro corria para chamar os demais nos outros setores. Para lá iam Prestes, Capitani, Antônio Duarte e André Borges, principalmente. Reuniam-se num canto, no fundo da sala. A desculpa era sempre a de tomar o cafezinho da 
Divisão Legal. Convenhamos que correram um grande risco de serem descobertas as suas tramoias... O Coletivo não fazia ideia de que a direção da penitenciária estava muito preocupada com esta mobilidade toda. A morosidade da burocracia estatal ajudou deveras o grupo, pela lentidão no fluxo de documentos e tomada de decisão. É o que percebemos pelos depoimentos das autoridades no Inquérito Policial Militar, criado para investigar a fuga do Coletivo da Lemos Brito.

Em seu depoimento ao Encarregado do IPM, em nove de junho de 1969, o Superintendente do Sistema Penitenciário do Estado da Guanabara, Antônio Vicente da Costa Junior, disse que sua preocupação com os "presos políticos" era antiga e chegou a mandar um ofício ao Governador do Estado alertando para o perigo destes presos transmitirem "sua ideologia" aos presos comuns, provocando uma sublevação ou uma fuga. Disse ainda que sugeriu ao Secretário da Justiça a remoção destes presos para a Ilha Grande, pois ali na Lemos Brito não havia segurança alguma para mantê-los. Por exemplo, não havia guardas suficientes e estes poucos que ficavam na portaria, não usavam armas, "porque a arma é um perigo para o próprio guarda, de modo que os nossos homens andam desarmados"; que a "maioria dos nossos guardas penitenciários, cerca de $80 \%$ está na faixa dos 45 aos 60 anos"129; que não havia revista às mulheres, por não haver polícia feminina, o que provocava a entrada no presídio de maconha, pinga, armas e outras coisas. "O problema da revista, por exemplo, nunca houve. O problema é que não há guardas para fazerem revista. Tem se batido para ativar a revista, mas não pode tirar o guarda do interior das casas para ficar na portaria para fazer revista, porque isto descobre o interior das casas. Isto preocupa, mas, dada a carência de guardas, não fazemos revistas". ${ }^{130}$ O Superintendente reclamou, também e principalmente, da ausência de revista nos finais das visitas, quando o preso ia para o seu cubículo levando objetos trazidos pelos seus parentes.

O fato dos marinheiros terem sido condenados pela Auditoria da Marinha criava uma situação delicada entre as administrações estadual e federal. Acontece que o governador do Estado da Guanabara, Francisco Negrão de Lima, não era bem visto pelo governo federal, por ser considerado de oposição e o Secretário da Justiça, responsável pelo Sistema Penitenciário do Estado da Guanabara, não tinha autonomia para transferir o Coletivo, que estava respondendo processo na Marinha, portanto, no governo federal. O Superintendente mandara

\footnotetext{
${ }^{129}$ AEL, BNM 414, Caixa $1,1^{\text {o }}$ volume, folhas 11 a 19.

${ }^{130}$ Idem.
} 
dois ofícios aos Auditores da Marinha, pedindo a remoção, mas “os Auditores especificaram que os presos ficassem na Penitenciária Lemos Brito" $" 131$.

Em seu depoimento no IPM, o Secretário da Justiça do Estado da Guanabara, Alberto Bittencourt Cotrim Neto, expos que foi à sua revelia que os Auditores da Marinha mandaram os "presos subversivos" para a Lemos Brito. Disse: "É preciso considerar como um grande erro a remessa de condenados subversivos para a Penitenciária Lemos Brito, contra o que sempre se rebelou [o depoente], porque ela não é uma penitenciária adequada para segurança máxima". Mais a frente o Secretário diz que o pessoal da Lemos Brito não estava preparado para lidar com "criminosos de ideologia", pois são diferentes, "são presos especiais, não são criminosos comuns; são criminosos de ideologia; são homens motivados politicamente. O depoente já foi líder estudantil, já foi agitador, já fez revolução, já conspirou, do outro lado, é claro; sabe a força que uma ideologia incute ao homem, quando ele é um idealista. Certa ou erradamente esses homens multiplicam sua força; não há de ser a barreira de uma prisão que os vai modificar". ${ }^{132}$

No mesmo depoimento, o Secretário afirmou que mandou um ofício ao Governador, expondo-lhe o perigo da concentração de presos políticos juntamente com presos comuns, propondo-lhe duas alternativas. A primeira seria distribui-los para várias prisões. Esta alternativa, porém, seria arriscada, pois os presos poderiam recusar a dispersão, apelando à imprensa, como já haviam feito na ocasião em que Marcos Antônio ficou isolado por alguns dias na "solitária". Além disso, "significará, por certo, a disseminação de um risco que, como o entendem as autoridades penitenciárias do Estado, melhor será enfrentado, se os mantiver circunscrito a um só estabelecimento". ${ }^{133}$ A outra alternativa sugerida seria a transferência dos presos militares para a Colônia Correcional de Ilha Grande. Mas esta também traria consequências: "Porém isso, além de expor a severíssimas críticas o Governo do Estado, poderia ser encarado como desobediência aos próprios termos de despachos dos Auditores da Justiça Militar, os quais - embora, data vênia, não tenham esta competência -, declaram neles, quase invariavelmente, que a pena deverá ser cumprida na Penitenciária Professor Lemos Brito". 134

Percebe-se a preocupação, às vésperas da fuga, que as autoridades penitenciárias tinham com a concentração dos marinheiros numa só penitenciária e seu livre trânsito pela

\footnotetext{
${ }^{131}$ Idem.

${ }^{132}$ AEL, BNM 414, Caixa 1, $2^{\circ}$ volume, folhas 230 a 238.

133 Ofício reservado no 03/JGS, de 14 de novembro de 1968, do Secretário da Justiça ao Governador do Estado da Guanabara. AEL, BNM 414, Caixa 1, $2^{\circ}$ volume, folhas 251 a 254.

${ }^{134}$ Idem.
} 
Praça Getúlio Vargas. Paradoxalmente, o que não permitiu a transferência do Coletivo e, portanto, contribuiu para que se realizasse a fuga foi o Ato Institucional $n^{\circ} 5$, em 13 de dezembro de 1968. Isso, claro, se acreditarmos nas palavras do Secretário da Justiça, Cotrim Neto ao Encarregado do IPM. Ele conta que despachou com o Governador no dia 12 de dezembro, quando foi orientado "que se entendesse, sobre a sugerida remessa dos subversivos para a Ilha Grande, com o Sr. Ministro da Justiça". Porém, no dia seguinte, "no dia 13 de dezembro, o Governo Federal baixou o Ato Institucional e o Sr. Gama e Silva [Ministro da Marinha] tornou-se o homem mais difícil de ser encontrado, por motivos óbvios". Não conseguindo encontra-lo, aguardou até dia 6 de maio de 1969, quando foi convidar pessoalmente o Ministro “a ir assistir em Porto Rico uma Conferência de Notários Públicos”, conforme despacho da Consultoria Jurídica do Ministério da Marinha. Segundo ainda o consultor Renato Ribeiro, dirigindo-se ao Ministro da Marinha, o Secretário Cotrim Neto "é que, ao despedir-se, fez entrega a Vossa Excelência de um envelope contendo o expediente que veio a constituir o presente processo, ocasião em que, não advertiu sobre a importância do assunto, nem confessou haver antedatado de $1^{\circ}$ de abril o ofício JGS-RESERVADO, $\mathrm{n}^{\circ} 195$. Esse expediente Vossa Excelência, por despacho de próprio punho, o remeteu a esta Consultoria em 26/5/1969". ${ }^{135}$

O Coletivo foi salvo pela burocracia e pelos burocratas: o Secretário, que estava tão preocupado com os "criminosos de ideologia", só fez chegar sua apreensão ao Ministro da Marinha, e pessoalmente, no dia 6 de maio, e o Ministro só despachou a inquietude do Secretário dia 26 de maio de 1969, exatamente no dia em que o Coletivo fugiu da Penitenciária Professor Lemos Brito!

Sobre a preocupação que tinha com o Coletivo reunindo-se na Divisão Legal e sua mobilidade, que o livre trânsito permitia, o Diretor da Penitenciária Professor Lemos Brito, João Marcello de Araújo Júnior externou ao Superintendente, através de um relatório que realizou a seu pedido, que vigiava os marinheiros em seu trabalho na Divisão Legal. Disse ele:

"Minha preocupação foi a tal ponto que, após receber do interno Aymoré de Oliveira Martins [que também trabalhava na Divisão Legal] denúncia de que os internos ex-marinheiros que trabalhavam na DIVISÃO LEGAL da SUSIPE estavam se aproximando muito de certos estagiários daquela unidade e recebendo visitas nas dependências daquela unidade. Além de comunicar o fato a Vossa Excelência e ao Exmo. Sr. Diretor da DIVISÃO LEGAL, furtiva e

\footnotetext{
${ }^{135}$ Despacho/CJ/no 300/69, do consultor jurídico do Ministério da Marinha, Renato Ribeiro, ao Ministro da Marinha, em 6/8/1969. AEL, BNM 414, Caixa 1, 2º volume, folhas 278 a 289.
} 
pessoalmente, de meu gabinete (que fica fronteiro à J.S.E.), fotografei pessoas e internos que lá compareciam a fim de poder documentar minhas afirmações. Essas fotografias não são de boa qualidade e, por isso não permitem a identificação das pessoas localizadas. Seja como for anexo ao presente - dez [não está bem legível] fotografias, informando que os negativos estão em meu poder e estão à disposição de Vossa Excelência para uma tentativa de ampliação". ${ }^{136}$ (Escrito conforme o original, com grifos e maiúsculas do autor).

Percebe-se que a direção da Lemos Brito estava bem próxima de descobrir os planos da Operação Liberdade. A confissão do Diretor de que tirava fotografias da janela de seu gabinete para ver quem frequentava a Divisão Legal, sugere que ele monitorava a portaria, ou seja, que ordenara aos guardas que lhe avisassem quando chegassem visitas para os exmarinheiros. De outra forma, como saberia que a pessoa fotografada era visita para os militares? Poderia ser um ex-preso, procurando documentos, atestados, ou visitas para outras pessoas que ali também trabalhavam.

A “ocupação" da Divisão Legal era muito importante para os planos do Coletivo, por um motivo determinante: ali não podia haver revistas dos guardas penitenciários, pois os advogados não permitiam. Logo, seria o lugar mais adequado para esconder as armas até o momento da fuga, como de fato aconteceu.

Não seria exagero se afirmássemos que as ações do Movimento de Ação Revolucionária eram pensadas na Divisão Legal. Ali estavam estagiários que se incorporaram ao MAR, como Milton Castro Filho, Sérgio Lúcio de Oliveira e Cruz - presidente da Associação Universitária de Recuperação de ex-Detentos - AUREX, associação criada pelo Superintendente do Sistema Penitenciário do Estado da Guanabara, Antônio Vicente da Costa Junior -, Júlio Cesar Bueno Brandão, Júlio Cesar Senra Barros. Os estagiários que tinham mais proximidade com o coletivo eram Sérgio Lúcio e Júlio Cesar Barros. Como veremos, os dois deram grande contribuição à fuga do grupo. Pelo menos uma estagiária, Flora Frisch, teve participação na libertação dos presos.

Havia falhas de segurança na penitenciária, como mencionamos, que foram detectadas pelos integrantes do MAR, aproveitando-se delas para concretizar a fuga. Mas havia, também, muita corrupção dos guardas penitenciários e das autoridades coniventes. Conforme foram prosseguindo as oitivas do IPM sobre a fuga do Coletivo, seu Encarregado, Contra-Almirante Júlio de Sá Bierrenbach, teve conhecimento de adulteração de chassis de automóveis roubados na oficina Mecânica, de autorização para que presos com penas acima de setenta

\footnotetext{
${ }^{136}$ Relatório do Diretor da Penitenciária Professor Lemos Brito ao Superintendente do Sistema Penitenciário do Estado da Guanabara. AEL, BNM 414, Caixa 1, $1^{\text {o }}$ volume, folha 29.
} 
anos se ausentassem da penitenciária, de uso político da penitenciária, quando o Superintendente oferecia almoços para homenagear amigos deputados, como foi o caso de Márcio Moreira Alves (justamente quem!), enfim, o suficiente para que o Oficial considerasse mandar prender o Superintendente do Sistema Penitenciário do Estado da Guanabara, Antônio Vicente da Costa Junior e o Diretor da Divisão Legal, Sydney Junqueira Passos.

Enquanto o Coletivo esteve na prisão e mesmo após recebeu valiosa ajuda de Lêda Sheffer Viegas, mulher de Pedro Viegas. Antes de casar-se com Viegas, Lêda trabalhou como enfermeira, apesar de não ser formada, junto às irmãs da Ordem São Francisco de Paula. Quando começaram as quedas dos marinheiros expulsos da Marinha e condenados pela Justiça Militar, Lêda passou a receber cartas de suas mães, querendo notícias dos filhos. Ela respondia ou fazia chegar a carta ao filho da mãe angustiada. Além disso, Lêda introduzia livros na Lemos Brito, a pedido dos presos, tais como o que foi escrito por Jefferson Cardin Osório ou de Régis Debray. Os livros que José Michel Godoy disse ter lido na cadeia, como Guerra de Guerrilha, de Ernesto Guevara, Revolução Dentro da Revolução, de Régis Debray, a biografia de Pancho Vila, Viva Zapata e outros, muito provavelmente foram transpostos por Lêda.

Em seu depoimento ao Encarregado do IPM, Lêda disse que Neguinho sempre ia a sua casa, "sempre nervoso e agitado, temendo estar sendo perseguido", "para saber notícia". ${ }^{137}$ Ela não mencionou, mas possivelmente Neguinho trocava informações com Coletivo através dela. Pelo menos é o que disse Pedro Viegas em seu depoimento: “Geraldo constantemente passava na casa do depoente, mesmo no tempo em que estava na Penitenciária. A sua esposa Lêda Viegas atendia-o e recebia recados do Geraldo, transmitindo-os durante as suas visitas à Penitenciária". 138

A importância de Lêda para o Coletivo encarcerado parece lembrar o que passaram os comunistas na mesma penitenciária, após os levantes comunistas de 1935. Graciliano Ramos registrou a mesma percepção:

"As visitas de minha mulher durante algum tampo quebraram a monotonia da prisão $e$ ligaram-me com inesperados laços ao exterior. Uma vez por semana trinta minutos nos aproximavam na secretaria. Separados, nos bancos, tentando esconder-se em vão, casais segredavam.

Impossiveis as efusões conjugais. No espaço exíguo e no tempo minguado, falavam graves, numa atenção concentrada, remoendo assuntos para que não se perdesse nenhuma palavra.

${ }_{137}$ AEL, BNM 414, Caixa $1,2^{\circ}$ volume, folha 456.
${ }^{138}$ AEL, BNM 414, Caixa $1,2^{\circ}$ volume, folha 349. 
As mulheres funcionavam como agentes de ligação, traziam notícias minuciosas, levavam relatórios, cartas, recados. Naquela meia hora realizava-se uma prestação de contas, liquidavam-se tarefas, surgiam outras, das ninharias individuais às arrojadas combinações políticas" (RAMOS, 1998, 286).

Quando Viegas e José Duarte foram indultados, em dezembro de 1968, passaram a morar na casa de Lêda. José Duarte ficou ali cerca de 20 dias, enquanto procurava outro lugar para morar. Mas as discussões entre Lêda e Duarte foram se tornando insuportáveis, de forma que ela não conseguia mais "se adaptar ao jeito grosseiro e pouco educado e pouco civilizado do José Duarte". ${ }^{139}$ Na ocasião, Viegas pediu a Duarte que evitasse discutir política com Lêda, já que ela discordava das atividades políticas deles e que, "principalmente devido à inabilidade do José Duarte, a sua situação com a mulher ficou muito difícil. (...) As coisas chegaram a tal ponto, que o depoente foi obrigado a alugar um quarto, com o José Duarte em Mesquita, para afastá-lo da sua casa e poderem trabalhar sossegados". ${ }^{140}$

Pouco tempo depois, José Duarte passou a morar no apartamento do estagiário Júlio Cesar Senra Barros, o “Adalto", e lá ficando até sua prisão em 8 de agosto de 1969. Edvaldo Celestino, indultado no mesmo dia que Viegas e Duarte, voltou a morar com a família, mantendo sempre contato com o grupo externo.

Logo que deixou a Lemos Brito, José Duarte assumiu o comando das operações externas, visando a fuga. Procurou Flávio Tavares, que se incorporou ao MAR. Pedro Viegas contou em seu depoimento que, antes deste contato de Duarte, em fins de 1968, "Marcos procurou contato com o Felix e conseguiu, através de Júlio Cesar [Senra Barros] ou do Sérgio [Lúcio de Oliveira e Cruz], quase no fim de 1968. Felix é o apelido do Sr. Flávio Tavares. Ficou assentado que ele não daria apoio à fuga. Incialmente ele não quis, realmente colaborar, mas devida a amizade com o José Duarte, o Flávio Tavares acabou participando da fuga". ${ }^{141}$ Em seu livro memorialístico, Viegas fala que sua participação foi decisiva e que, "procurado por José Duarte, não hesitou em prestar a sua colaboração e não ficou nisso: integrou-se de corpo e alma ao MAR, servindo como uma espécie de parlamentar e, ao mesmo tempo, como combatente". (VIEGAS, 2004, p. 88). Flávio Tavares era uma pessoa que tinha muitos contatos, alguns inclusive e coincidentemente eram próximos dos marinheiros. É o caso de Élio Sá Rêgo, o "Chico", ou "Baixinho". Ele foi marinheiro no tempo da fundação da AMFNB, abandonando a Marinha para fazer o curso de física na Faculdade Nacional de

\footnotetext{
${ }^{139}$ AEL, BNM 414, Caixa 1, $2^{\circ}$ volume, folha 457.

${ }^{140}$ AEL, BNM 414, Caixa 1, $2^{\circ}$ volume, folha 351.

${ }^{141}$ Idem. Folha 348.
} 
Filosofia. Já falamos dele, quando tratamos da formação política dos marinheiros da Associação, no primeiro capítulo e quando foi preso, juntamente com Antônio Duarte na fronteira do Brasil e Uruguai, no segundo capítulo. Élio deu aula para os associados da Associação, juntamente com Wilson do Nascimento Barbosa, estudante de filosofia na época, na mesma faculdade.

Segundo Flávio Tavares em seu depoimento ao Major de Infantaria do Exército, Francisco Moacyr Meyer Fontenelle, Élio lhe procurou pedindo que alugasse uma casa, já que estava "legal", para um grupo de São Paulo, ligado a Marighella. Sugeriu-lhe também a união dos grupos, a fim de realizarem ações de expropriações, ou seja, assalto a bancos, para levantar fundos. Tavares, então, alugou um "aparelho" na Rua Adalgisa Aleixo, em Bento Ribeiro, para este grupo e, a partir daí, por volta de começo de fevereiro, começaram a manter contatos. $^{142}$

O apoio externo ia se organizando, em grupos independentes, que se dividiam basicamente em urbano e rural. Enquanto Viegas cuidava, juntamente com o Grupo Mallet e os estagiários de Direito, do acampamento para onde levariam os presos, José Duarte negociava com os grupos de Flávio Tavares e de Neguinho a retirada dos presos da cadeia. Os dois grupos praticamente não se reuniram. Mantinham contatos, certamente, mas as reuniões eram separadas. Por mais que a casa de José Ferreira, líder do Grupo Mallet, fosse bem frequentada pelos grupos, quem mais a frequentava era Viegas.

Flávio Tavares tinha algumas pessoas que sempre o seguiam: era o caso de Jarbas Silva Marques (o "Silva"), Adail Ivan de Lemos (o "Magalhães") e um tal de Cyro, que, segundo Murillo Mello, era pessoa de Brasília que seguia a orientação do Flávio Tavares. O Grupo de São Paulo, como Viegas e Duarte o denominaram, era composto por Élio Sá Rêgo (Chico ou Baixinho), Wilson do Nascimento Barbosa (Negão), Antônio Geraldo Costa (Neguinho) e Leôncio Queiroz Maia (Macêdo). A eles se uniu Murillo Mello, que morava, entretanto, no Rio de Janeiro. Deste grupo, Neguinho e Élio Rêgo eram liderados por Carlos Marighella, ou seja, eram militantes da Ação Libertadora Nacional, ALN. Não temos certeza se Mello, Leôncio Queiroz Maia ou Wilson Barbosa também eram quadros da ALN.

Wilson do Nascimento Barbosa já é nosso conhecido. Antes do Golpe de 1964 ministrou aulas de história e filosofia aos marinheiros, sugerindo leituras para a diretoria da AMFNB, conforme relatos dos próprios, mencionados no primeiro capítulo desta Tese. Barbosa fazia parte da célula do Partido Comunista Brasileiro na Faculdade de Filosofia da

\footnotetext{
${ }^{142}$ AEL, BNM 414, Caixa 1, $2^{\circ}$ volume, folhas 462 a 469.
} 
Faculdade Nacional de Filosofia, antes de 1964. Não temos informações como se deu seu afastamento do Partido e sua aproximação ao grupo de Carlos Marighella, nem sabemos, aliás, qual o grau de aproximação que tinham. Sabemos que foi expulso da Faculdade Nacional de Filosofia em junho de 1964, acusado de "subversão" e que ministrou aulas de história e geografia em várias escolas, inclusive no Curso do Grêmio da Universidade de São Paulo, em São Paulo até praticamente sua prisão, em fins de novembro de 1969. Barbosa, o Negão, era muito amigo de Élio, como já mencionamos, de Murillo Mello (que também participou da fuga do Coletivo) e de Neguinho.

Este grupo não se integrou ao MAR, mas contribuiu, decisivamente, para a fuga da Lemos Brito. Sua participação seria a de não permitir que o policial militar que portava metralhadora na frente da Penitenciária atirasse nos foragidos. Deveriam estar na porta da Penitenciária, na hora da fuga, para imobilizar este PM. Também ficaram com a incumbência de garantir fundos para viabilizar a fuga e o transporte dos fugitivos, através de assaltos a bancos, que chamavam de "expropriações".

Em nossa pesquisa ao Inquérito Policial Militar que investigou a fuga da Lemos Brito, encontramos nos depoimentos pontos convergentes, mas também divergentes. Em que pese a situação em que se encontravam os depoentes, muitos deles já torturados nas dependências da Polícia do Exército e na defensiva, para a preservação de outras pessoas, ficamos, no entanto, intrigados com certas inquirições, que não deixam de interferir nas interpretações que procuramos realizar sobre o MAR, sobre a liderança de Marcos Antônio e sobre os objetivos reais da união dos grupos que participaram da fuga.

Temos falado da organização de um Coletivo, oriundo das atividades da Associação dos Marinheiros e Fuzileiros Navais do Brasil, e que se consolidou na criação de uma organização clandestina dentro dos muros da Penitenciária Professor Lemos Brito, o Movimento de Ação Revolucionária - MAR. Falamos também da liderança de Marcos Antônio da Silva Lima, já nos tempos da Associação, e posteriormente na cadeia, na elaboração da Operação Liberdade. Os depoimentos de André Borges, Pedro Viegas, José Duarte, Sérgio Lúcio de Oliveira e Cruz e Michel Godoy, ao Encarregado do IPM foram unânimes em afirmar que a liderança do MAR pertencia ao Marcos Antônio, que centralizava todas as informações dos contatos externos. Viegas chegou a dizer que "mesmo os estagiários, que conversavam com todos, na hora dos assuntos políticos quem tratava era o Marcos. $\mathrm{O}$ gênio deste, muito calado, muito trancado, não dando satisfações aos demais dos contatos e andamento das coisas, causava alguns aborrecimentos e contrariedades. Ele, realmente, não 
abria mão dos contatos que fazia. Os maiores contatos eram feitos com o Júlio Cesar, Sergio Lúcio e um outro chamado Tonico, um rapaz bem magro". ${ }^{143}$

Marcos Antônio, então, de dentro da cadeia, usando-se das facilidades que a Divisão Legal lhe permitia, como a de receber pessoas de fora e usar o telefone para fazer contatos externos, exercia uma função de comando, certo? Não totalmente. Precisamos relativizar a liderança do Marcos, principalmente em relação a Flávio Tavares e ao grupo de São Paulo. Quando acertaram o organograma do MAR, para executar o plano de fuga, criaram grupos de ações. Godoy fala em seu depoimento, que a organização constava do "pessoal do mato" (aqueles que, após a fuga, foram para a Serra de Angra dos Reis), "Grupo de Ação Legal" (encarregado do apoio logístico) e o "grupo de choque", "que faria uma espécie de guerrilha urbana", que era o grupo que seria comandado por José Duarte.

Flávio Tavares, no entanto, diante do Major do Exército, apresentou uma organização do MAR estranha, talvez para despistar os inquiridores. Diz ele que o MAR era organizado da seguinte forma: "DIREÇÃO: Chico Baixinho [Élio Sá Rêgo], Neguinho e Macêdo [Leôncio Queiroz Maia]; GRUPO DE ESTUDOS: constituído de cerca de vinte elementos ligados diretamente aos da DIREÇÃO, que recebiam ensinamentos políticos, intelectuais e paramilitares, conforme mencionado anteriormente; GRUPO DE AÇÃO: (Assalto a bancos), constituído pelo depoente, pelos três da direção supra mencionados, pelo Negão, José Duarte, codinome Índio ou Vitor, Jarbas Silva Marques, codinome Silva, Edvaldo Celestino da Silva, codinome Pedro, Simão codinome de Roberto Cietro [Cietto], Prestes, ou seja, Antônio Prestes de Paula e José André Borges, além de Campônio e Adail Ivan de Lemos; GRUPO DE APOIO: constituído por José Ferreira e outros elementos ligados ao dito José Ferreira, desconhecidos pelo depoente, cuja função era levar gêneros, armamento, roupas e informações para os elementos homiziados em Angra dos Reis; GRUPO LEGAL: Constituído pelo depoente, Jarbas e Adail Ivan cujas missões legais eram alugar casas ou apartamentos, compras diversas e transporte eventual do pessoal da DIREÇÃO na Guanabara; GRUPO RURAL: constituído dos elementos fugidos da Penitenciária Lemos de Brito e que se encontravam em Angra dos Reis". ${ }^{144}$

Conforme mencionamos, o depoimento acima não foi dado ao Encarregado do IPM sobre a fuga da Lemos Brito, Contra-Almirante Júlio de Sá Bierrenbach, mas foi produzido nas dependências do Quartel do Primeiro Batalhão de Polícia do Exército, onde Tavares descreve, em seu livro memorialístico, as barbaridades que faziam com ele e com outros,

\footnotetext{
143 AEL, BNM 414, Caixa 1, $2^{\circ}$ volume, folha 347.

${ }^{144}$ AEL, BNM 414, Caixa 1, $2^{\circ}$ volume, folhas 468 e 469.
} 
como José Duarte. Aliás, seu torturador era o mesmo Major Encarregado do IPM em que estava sendo investigado. Por que este depoimento foi parar no processo sobre a fuga da Penitenciária Professor Lemos Brito, dirigido pela Marinha e tendo como Encarregado um oficial graduado da Marinha? Por que não requisitaram ao Exército a presença de Flávio Tavares para a inquirição, como fizeram com Wilson do Nascimento Barbosa? O mais intrigante é que Flávio Tavares descreve com detalhes seu depoimento ao Encarregado Contra-Almirante Júlio de Sá Bierrenbach! Diz ele que "a indagação é minuciosa, mas sem violência e os interrogadores não vestem fardas. Em função do que eu digo, um dos ajudantes ouve a fita de um imenso gravador e passa o audiofono ao Almirante: estão cotejando meu depoimento com o de outros presos e cada vez me sinto mais encurralado". E continua,

"Quanto ao que digo, o almirante e seus ajudantes se irritam: 'Você está mentindo!' (jamais Ihes contarei que os fuzis M-1 que 'os meninos' usaram em Angra lá chegaram nas mãos daquele soldado da Política Militar carioca, da nossa célula de Mallet, em Campo Grande.) Procuram apertar-me em pequenas contradições ou deslizes. Bierrenbach levanta a voz, grita até, mas se comporta como um almirante, com a altives de um adversário. Numa das pausas, um de seus ajudantes se levanta e me diz:

- Eu estava lá naquele sábado e vi tudo o que te fizeram no quartel do Exército. Nós estamos te tratando como gente digna e não como você foi tratado no Exército. E você está tentado nos enganar!" (TAVARES, 2005, pp. 104-106).

O depoimento acima não consta do processo sobre a fuga da Lemos Brito, que pesquisamos cuidadosamente. Em seu relatório final, Bierrenbach diz: "Flávio Tavares também é indiciado no IPM de que é encarregado o Major do Exército Francisco Moacyr Fontenelle, tendo sido banido do Território Nacional por ser um dos quinze elementos exigidos pelo resgate do Embaixador dos Estados Unidos da América. Não tendo prestado depoimento neste IPM, são juntadas às folhas 462 a 469 cópias de suas declarações na Polícia do Exército [ou seja, o depoimento que Tavares deu no Quartel da Polícia do Exército]". ${ }^{145}$

Fica a questão em aberto: será que o depoimento de Tavares não teve utilidade às investigações do IPM sobre a fuga da Lemos Brito, pelas mentiras nele contidas?

De qualquer forma, na tentativa de entender como se deu a inserção do "Grupo de São Paulo" na colaboração à concretização da Operação Liberdade, e quais eram seus objetivos no Rio de Janeiro, nos deparamos com uma questão que passa, a nosso ver, pela disputa pela liderança dos diversos grupos envolvidos. Isso fica sugerido nos depoimentos aos IPMs de Flávio Tavares e Wilson do Nascimento Barbosa. Os dois foram presos e enviados para o

${ }^{145}$ AEL, BNM 414, Caixa 1, $3^{\circ}$ volume, folha 738. 
Quartel da Polícia do Exército. Sobre a queda de Tavares falaremos no próximo capítulo, o que não será possível sobre a prisão de Barbosa, da qual não temos qualquer informação. Mas, seu depoimento no IPM da Marinha - o Encarregado Contra-Almirante Júlio de Sá Bierrenbach requisitou-o ao Exército para inquirição -, é, no mínimo, instigante e coloca questões que apontam a uma ambição de Flávio Tavares a um maior protagonismo no processo de união dos grupos envolvidos na fuga da Lemos Brito. Mais ainda, sugere um entrosamento do Grupo de São Paulo de subordinação à Tavares.

No depoimento de Flávio Tavares, este começou dizendo que foi procurado por Élio Sá Rêgo, em fins de 1968, tentando formar um grupo de ação armada. Wilson do Nascimento Barbosa disse que, em fins de janeiro de 1969, Élio lhe teria levado, juntamente com Neguinho, para conversar com Tavares e unir os grupos, numa perspectiva de ação maior, nacional. "Dias depois", ainda segundo Barbosa, houve outro encontro para acertar planos de assaltos a bancos, quando Negão condicionou sua participação "desde que o dinheiro fosse para o movimento operário, isto é, lutas de sindicatos, para atender às despesas com o pessoal durante greves". ${ }^{146}$

Em seu depoimento, Wilson do Nascimento Barbosa disse que passou a pertencer ao grupo cujo chefe era o Flávio Tavares, "ficando o depoente subordinado ao Élio Rêgo". Leôncio de Queiroz Maia, o "Macedo" - que antes do Golpe estudava economia -, por seu turno, fazia parte da "seção de carros", ou seja, conseguir carros roubados para a execução de assaltos a bancos e a retirada dos presos da Penitenciária. Num sábado, depois que o Grupo de São Paulo realizou os dois primeiros assaltos, houve uma reunião no apartamento de Flávio Tavares, onde participaram, além dele, Neguinho, Élio, Leôncio, José Duarte, Edvaldo Celestino, Jarbas Silva Marques, Murillo Mello e "um rapaz de nome Cyro". Nesta reunião discutiram dois pontos: o primeiro, a "situação desse grupo, chefiado pelo Flávio Tavares" e o segundo, "seria o apoio à fuga de presos a militares da Penitenciária Professor Lemos Brito". 147

Em relação à "situação deste grupo", o documento diz:

"Na primeira parte, Flávio Tavares fez uma exposição de seu encontro com Carlos Marighela, poucos dias antes, tendo ambos feito acordo de trabalharem juntos e ser ele representante do Marighela no Rio. Disse textualmente que Marighela não tinha ninguém no Rio e que, assim, havia necessidade de ser implantado o esquema de subversão no Rio, a fim de se

\footnotetext{
${ }^{146}$ AEL, BNM 414, Caixa $1,3^{\circ}$ volume, folha 594.

147 AEL, BNM 414, Caixa 1, 3º volume, folhas 593 a 597.
} 
integrar no plano nacional. A linha de ação a ser seguida seria a de estabelecer focos de guerrilha rural, que estariam dentro das cogitações de Marighela". ${ }^{148}$

De fato, Flávio Tavares esteve com Marighela, quando lhe pediu que suspendesse as ações da ALN por três semanas, para que a polícia diminuísse sua vigilância. Em seu livro, Tavares conta como foi o encontro, mas não fala nada do acordo declarado por Barbosa:

"Em abril, um mês antes, eu me reuni com Carlos Marighella numa cobertura nas Laranjeiras (o luxuoso apartamento de Jorge Miranda Jordão, acima de qualquer suspeita) e lhe pedi uma trégua de 'pelo menos' três semanas nos assaltos a bancos no Rio, para que pudéssemos atacar a Penitenciária. Os assaltos bancários podiam nos criar problemas táticos numa ação de maior envergadura, pois tinham tornado o policiamento mais rigoroso, a repressão mais ostensiva e os policiais mais nervosos. Nós pretendíamos o contrário: uma distensão repressiva para realizar uma operação nitidamente política, que a população compreenderia. Marighella ouviu em silêncio. Qualificou o plano de 'meio infantil', mas concordou com o pedido e perguntou por onde sairiam os presos.

- pela porta da frente, a única sem vigilância - respondi, e Marighella suspirou, sorrindo.

- Mais do que infantil, isso parece maluquice! - completou. No entanto, reiterou concordar com a trégua e cumpriu". (TAVARES, 2005, pp. 64,65).

Neguinho também esteve com Marighela, a pedir-lhe que ajudasse na fuga da Lemos Brito. Em sua entrevista, Neguinho, que era do Grupo Tático Armado - GTA - da ALN, sequer mencionou Flávio Tavares nas ações em que participou no Rio de Janeiro. Se Tavares tivesse a importância dada a ele no depoimento de Barbosa, não haveria motivos, cremos, de Neguinho não mencioná-lo.

Disse Neguinho:

"Quando eu encontrei o Marighela e outros companheiros, a nossa proposta era a de que o Marighela como líder da ALN, e o chefe supremo, vamos dizer assim, desse o apoio dele e o apoio que era necessário, mandando gente, porque a retirada desse pessoal precisava de carro, precisava de dinheiro, precisava de local, de toda uma estrutura logística que tem que ter uma organização pesada, entendeu? Bem organizada atrás disso. E, isso eu escutei do Marighela, que disse: "Não". Depois, tem uma versão, que eu não participei, que diz que o Marighela no dia da ação mandou, quer dizer, uma semana antes, se alguém da ALN fosse fazer, ou se algum grupo da ALN fosse fazer alguma desapropriação ali na redondeza da penitenciária, que ele mandou suspender isso. Eu não sei até onde isso é verdade, porque eu não participei. Eu participei de uma discussão com ele [Marighela], assim, um encontro, que

${ }^{148}$ Idem. 
ele recusou isso. E ele justificou o seguinte: que era um absurdo, que nós éramos minoria e o poder de fogo da reação... porque a polícia estava lá. E nós fizemos aquilo. Para nós, e para o grupo de São Paulo e para os organizadores ali, era uma questão de prestígio político e foi. Primeiro, os companheiros saíram pela porta da frente, começa por aí; segundo, nas barbas do poder golpista. A Lemos Brito era um símbolo, que ali estava cheio de presos políticos, era um símbolo tradicional de prisão, de tortura, do diabo a quatro, e nós queríamos dar um exemplo assim, da nossa capacidade organizativa, da nossa capacidade de fogo, que não era tão grande assim, mas, que nós estávamos dispostos, realmente, a que aqueles rapazes realmente saíssem dali. E era um prestígio político: sair pela porta da frente, entendeu? Como saíram. Isso para nós era um ponto assim crucial para mostrar, primeiro, ex-marinheiros, mostrar também para a Marinha que nós éramos capazes de fundar a Associação e retirar os marinheiros dali de dentro. Isso, para nós, era um prestígio enorme. E desprestígio para eles. Ficaram loucos da vida. Ficaram desprestigiados por nós. 'Como é que é possível?' Depois a gente ficou sabendo que eles reagiram assim. Acharam um absurdo: 'Como é que esses caras aí, ralé da sociedade são capazes de organizar?. Não foi o Partido Comunista, não foi a ALN". 149

Neguinho termina seu relato dizendo que não foi a ALN que ajudou parte do Coletivo a fugir da cadeia. Marighela não autorizou seu pessoal do Rio de Janeiro a participar da ação. Neguinho deixa claro que foi um grupo da ALN de São Paulo. Ele diz: "Eu participei de uma reunião com o Marighela, um encontro com ele e foi proposta essa... ele pessoalmente se recusou de dar o apoio necessário para o pessoal do Rio de Janeiro, da ALN do Rio de Janeiro que nos apoiava. Ele se negou realmente. Mas o grupo de São Paulo deu apoio. Eu não sei se eles consultaram o Marighela, mas o grupo de São Paulo apoiou. De que maneira? Ajudando com armas, ajudando com apoio logístico". ${ }^{150}$

Se o Grupo de São Paulo era formado por militantes da ALN, pelo menos Neguinho e Élinho, então seu "comandante" era Carlos Marighela e não Flávio Tavares, que estava mais próximo, neste momento, de um nacionalismo radical (RIDENTI: 2007-A, 48) do que do comunismo. O que pretendemos dizer é que nos parece estranho que Marighela tenha indicado como seu representante no Rio de Janeiro uma pessoa que não estava ideologicamente ligada a seu grupo. O que nos parece é que Wilson do Nascimento Barbosa, inteligentemente tentou despistar e confundir seus inquiridores. Ou, então, que tinha informações de um esquema maior, que ultrapassava os limites da fuga da Lemos Brito.

\footnotetext{
${ }^{149}$ Entrevista a Flávio Luís Rodrigues. Maceió, 19 e 20 de julho de 2011.

${ }^{150}$ Idem.
} 
Sabemos, através de outros testemunhos, que Flávio Tavares coordenava o grupo de apoio legal, conseguindo apartamentos (“aparelhos") e automóveis para as ações, e fazia parte do grupo de ação, na organização, junto com o pessoal de São Paulo, de assaltos a bancos e a distribuição do dinheiro para os grupos envolvidos. As entrevistas e depoimentos a que tivemos acesso dão conta do dinamismo de Tavares. Através dele conseguia-se um endereço de "aparelho" para pernoitar, dinheiro, carros e armas. Sua casa recebia a todos e foram lá as principais reuniões para a organização da fuga. Portanto, não seria totalmente improvável que tivesse um esquema de união de grupos de ação armada que passasse pela sua liderança. Pode parecer estranho, mas a ideia não é estapafúrdia.

Em seu depoimento, Wilson do Nascimento Barbosa nos surpreendeu mais uma vez, quando, perguntado se pertencia ao MAR, respondeu afirmativamente, mas que não se tratava do Movimento de Ação Revolucionária, mas ao "Movimento Armado Revolucionário 26 de julho, movimento liderado por Flávio Tavares no Rio de Janeiro, ligado a Carlos Marighela no âmbito nacional". 151

Enquanto a maioria do Coletivo estava encarcerada, as negociações ocorriam fora da cadeia, através principalmente de José Duarte. E a ideia de formar uma organização de ação armada de âmbito nacional era consensual. A tendência do grupo liderado por Marcos Antônio era a de se ligar à Ação Libertadora Nacional, de Carlos Marighela. Antes da fuga, Neguinho mandou vários recados para Marcos Antônio, acertando, inclusive, que o pessoal da ALN de São Paulo estaria esperando, no dia da fuga, parte do grupo fugitivo em automóveis, que os conduziriam para locais seguros. Pedro Viegas conta que a intenção do Coletivo era prioritariamente a de se ligar à ALN. Diz ele:

"O que é importante: a gente nunca pretendeu criar uma organização. A gente passou a ter contatos. A gente pretendia ser assimilados por algumas organizações. No caso, a ALN. Inicialmente, começava os contatos por ali". ${ }^{152}$

José Duarte falou ao Encarregado do IPM da Marinha que seus contatos com o pessoal de São Paulo começou em janeiro de 1969. Na ocasião, Neguinho e Élio Rêgo disseram-lhe que vieram de São Paulo para o Rio de Janeiro para "fazerem assaltos a bancos com finalidades subversivas, convidando o depoente para tomar parte nesse grupo; que após conversar várias vezes aceitou participar, desde que colaborassem na saída dos fugitivos da penitenciária. (...) Disse, ainda que, procurando criar essas condições [para a fuga], assumiu

\footnotetext{
${ }^{151}$ AEL, BNM 414, Caixa $1,3^{\circ}$ volume, folha 596.

${ }^{152}$ Entrevista a Flávio Luís Rodrigues. Iperó, 09 de outubro de 2008.
} 
com o Geraldo e com o Élio, o compromisso de passar a integrar o grupo deles, desde que recebesse apoio no plano da fuga". ${ }^{153}$

O que entendemos desta conversa entre os três, acreditando que ela realmente ocorreu, é que ficou acordado que, após a fuga, o Coletivo se integraria à ALN, o que se aproxima do que foi falado por Neguinho em sua entrevista. Wilson do Nascimento Barbosa, no entanto, diz que chegaram a criar outra organização, sob a liderança de Flávio Tavares, já antes da fuga. Em nossa pesquisa não identificamos, nem em fontes orais, nem escritas, referência a este outro MAR. Mais uma vez, reforçando a afirmação supracitada e baseando-se principalmente nas entrevistas que fizemos, quase unânimes em reconhecer a inteligência de Negão, cremos que Barbosa tentou confundir seus arguidores, omitindo informações que pudessem comprometer outras pessoas e organizações.

A ideia de se criar uma organização clandestina maior, mais organizada, com ações de expropriações, de âmbito nacional também foi sugerida por Tavares a Pedro Viegas, segundo seu depoimento.

"Explicou o Flávio Tavares da Conveniência em trabalharem juntos nesta faixa de desapropriações. Neste dia tiveram um ligeiro desentendimento, porque o depoente explicou que não estava interessado em participar de outro grupo, já que estava ligado ao "MAR" e já estava engajado nas tarefas combinadas desde antes da sua saída da Penitenciária. O Flávio argumentou que a formação deste grupo "MAR" só conseguiria fazer "uma alteração", sem maior profundidade, ao que o depoente contestou, dizendo que todo grupo que se forma, tem uma agenda de tarefas e tarefas prioritárias. O grupo no qual o depoente se situava tinha a tarefa prioritária de colocar os internos em liberdade, depois viriam as demais etapas". 154

Percebe-se que Flávio Tavares procurava maior protagonismo no processo que começou com o planejamento da fuga dos prisioneiros da Lemos de Brito e tomou maior vulto com a integração de vários grupos, como o pessoal do Mallet, o Grupo de São Paulo, os estagiários, o grupo de Flávio Tavares e ex-marinheiros que gravitavam em torno do Coletivo. Este protagonismo também é notado, quando se lê o livro de Flávio Tavares, Memórias do Esquecimento, já citado aqui várias vezes, em que ele se coloca na função de articulador do MAR e da Operação Liberdade. Praticamente não cita Marcos Antônio. As únicas duas vezes em que cita Marcos Antônio em seu livro, não o relaciona com o MAR, quando seria conveniente fazê-lo. Falando do sucesso da fuga, diz: "A ação que quase todos qualificavam

${ }_{153}^{153}$ AEL, BNM 414, Caixa 1, $2^{\circ}$ volume, folha 299.
${ }^{154}$ AEL, BNM 414, Caixa $1,2^{\circ}$ volume, folha 349. 
de 'maluca' tinha concluído com êxito. Eu próprio tive medo. Mas, de dentro do presídio, Marco Antônio Lima, Avelino Capitani e Antônio Duarte dos Santos, ex-marinheiros que lideravam o grupo de presos, insistiam na pressa, sob o temor de que, em junho, fossem transferidos para a Ilha Grande, em pleno oceano, de onde seria impossível fugir". (TAVARES: 2005, 64). Percebe-se, também, que Tavares divide a liderança do grupo entre Capitani, Antônio Duarte e Marcos Antônio, quando vimos que os ex-marinheiros, na totalidade, não questionavam a liderança de Marcos. A outra citação de Marcos trata-se de sua prisão. Na verdade, Flávio Tavares mencionou a prisão e, portanto, Marcos Antônio, porque a sua narrativa era sobre José Duarte, que tinha acabado de deixar o comando do foco do Brasil Central, do MNR, cujo organizador era o próprio Tavares: "Mas Victor não voltou. No quarto dia em São Paulo, encontrou-se com seu velho companheiro da liderança da Associação dos Marinheiros, o ex-fuzileiro naval Marco Antônio Lima, que vinha do foco mato-grossense". (TAVARES, 2005, p. 221).

A impressão que temos é a de que Tavares tinha certa animosidade contra Marcos Antônio, que não passou despercebida a Pedro Viegas quando, em seu depoimento, falou:

"Há uma questão qualquer, referente à falta de confiança do Flávio Tavares no Marcos Antônio, devido a uma denúncia, partida do próprio pessoal da Marinha, de que Marcos teria desviado dinheiro da Associação. Havia esta divergência. Outra acusação é de que o Marcos teria, com dinheiro recebido para subversão, montado uma buate no México" [escrito conforme o original]. ${ }^{155}$

O "próprio pessoal da Marinha" a que Viegas se referiu, pode ser o da Administração Naval, ou o do CENIMAR. Não sabemos, porque ele não indicou. Parece-nos, porém, que se trata de uma acusação com propósitos claros de desmoralizar o Marcos Antônio.

As atividades do apoio externo estavam, então, sendo planejadas, através de Viegas e José Duarte. O último, em conluio com o pessoal de São Paulo e de Flávio Tavares, começou a realizar reuniões geralmente na rua, como no Largo da Glória, Praia do Flamengo e Mourisco. ${ }^{156}$ Mas também na casa de Flávio Tavares e do estudante Júlio Cesar Senra de Barros, na Ilha do Governador. Nestas reuniões se discutiam as ações de "expropriações" e os planos de retirada dos ex-marinheiros da Penitenciária. Viegas, por seu lado, se reunia com o pessoal do grupo Mallet, principalmente seu líder, José Ferreira, para preparar a ida dos presidiários para Mangaratiba e, em seguida, para o acampamento na Serra, que denominavam de Cabana do Jacu. Além disso, Viegas deveria conseguir os carros para

\footnotetext{
${ }^{155}$ Idem.

${ }^{156}$ Depoimento de José Duarte. AEL, BNM 414, Caixa 1, $2^{\circ}$ volume, folha 299.
} 
transportá-los até o destino. As funções que couberam a Viegas viabilizar eram bem complexas. Deixemos o próprio enunciá-las:

"A mim cabia criar condições para que as armas chegassem sem problemas ao interior da penitenciária; levantar e garantir, em sintonia com membros do Grupo Malet designados para isso, a rota que os companheiros libertados deveriam percorrer para atingir o local de segurança preestabelecido; definir o melhor curso do carro (ou carros) que transportaria o pessoal da porta da penitenciária até o ponto de transbordo para outros veículos; e guiá-los do desembarque ao refúgio definitivo, o que implicaria longa e difícil caminhada. $O$ mais importante, porém, porque antecedia a tudo isso, era proceder a um levantamento completo da zona em que iria se dar a operação". (VIEGAS, 2004, p. 92).

A primeira "expropriação", assalto a banco, foi realizada por Wilson Barbosa, Leôncio de Queiroz Maia (Macedo), Neguinho, Élio, José Duarte e Edvaldo Celestino, o último foi o motorista. No dia 17 de março, uma segunda-feira, Negão e Macedo roubaram um automóvel Itamaraty e na quarta-feira, saíram para fazer o assalto, sem qualquer planejamento. Negão, Neguinho, Élio e Macedo estavam armados com revólveres e José Duarte portava uma metralhadora. Edvaldo Celestino, que ficou no carro esperando o retorno do grupo, estava desarmado. Esse assalto ao Banco da Lavoura de Minas Gerais transcorreu tranquilamente, apesar de a agência estar bem movimentada. Neguinho mandou que todos se dirigissem ao banheiro, enquanto Élio e Barbosa limpavam as caixas e a caixa-forte. ${ }^{157}$ Essa expropriação rendeu para o grupo trinta e um mil Cruzeiros Novos, segundo José Duarte em seu depoimento. No domingo, o grupo se encontrou na praia de Ipanema para dividir o dinheiro, que estava com Élio. Como Duarte não pode comparecer, pediu a Celestino que pegasse a quantia de NCr\$10.000,00 para aplicar no plano de fuga. Esta quantia foi passada a Viegas na semana seguinte, que a entregou a Marcos Antônio em parcelas que variavam muito. Perguntado pelo Encarregado do IPM o que Marcos Antônio fazia com o dinheiro na Penitenciária, José Duarte não soube responder. Disse, porém, que achava que era para suborno, "que nisso gastaram cinco mil cruzeiros novos". ${ }^{158}$ Celestino, nesse dia, ficou com NCr\$ 200,00 ${ }^{159}$ e o restante foi destinado ao grupo de São Paulo.

Há uma passagem interessante no depoimento de José Duarte, que se aproxima do que Neguinho falou em nossa entrevista, supracitada: Duarte, ao ser perguntado como fora escolhido o local do assalto, respondeu que foi escolhido “à galega”, sem planejamento, "diante da necessidade de dinheiro e do processo de desmoralização psicológica causada

\footnotetext{
${ }^{157}$ Idem.

158 Idem. Folha 300.

${ }^{159}$ Depoimento de Edvaldo Celestino da Silva. AEL, BNM 414, Caixa 1, 2o volume, folha 373.
} 
pela inatividade do grupo". ${ }^{160}$ Neguinho dissera que tirar o grupo da cadeia era uma questão de honra, para mostrar à Administração Naval do que eram capazes aqueles que julgavam a "ralé da sociedade”, "mostrar também para a Marinha que nós éramos capazes de fundar a Associação e retirar os marinheiros dali de dentro. Isso, para nós, era um prestígio enorme. E desprestígio para eles". ${ }^{161}$ Isso sugere o quanto esses homens ainda estavam ligados ao Coletivo do tempo da Associação, quando se sentiam desprezados pelo oficialato e que, agora, mantinha-os encarcerados numa penitenciária para presos comuns.

O segundo assalto foi realizado em abril pelo mesmo grupo, com a presença de Flávio Tavares. A expropriação do Banco Nacional Brasileiro de Piedade ocorreu da mesma forma que a do Banco da Lavoura de Minas Gerais, com pouca inovação. Nesse assalto, Flávio Tavares, usando bigode e costeletas, ficou do lado de fora, inspecionando o movimento. A ação rendeu NCr\$ 17.000,00, divididos entre o grupo de São Paulo e o grupo Mallet, através de Viegas. Neguinho e Élio, sempre após os assaltos, levavam uma parte para a ALN em São Paulo.

Durante os assaltos, Neguinho (que passou a ser chamado de "Tigre" nesse período), fazia um discurso às pessoas que estavam no banco, dizendo que não eram bandidos e que não estavam roubando dinheiro, mas expropriando o que foi conseguido com o suor do trabalhador brasileiro.

Ao escolher um banco para roubar, o grupo estudava seu movimento externo. Ou seja, se o banco ficava numa rua muito movimentada por veículos, que pudesse prejudicar a saída rápida do banco e se havia policiais próximos. O interior do banco não era motivo para preocupações, pois não havia a segurança que existe hoje, como porta giratória, detector de metais ou câmeras de segurança com armazenamento de imagens, cujas gravações podem servir para identificação e como provas. E a presença de quatro homens armados com revólveres calibre 38 e um portando metralhadora, convenhamos, era assustadora para as pessoas presentes. A tendência era de ninguém reagir ao assalto e obedecer às ordens dadas.

A ausência de um planejamento sério e detalhado antes de cada assalto, por muito pouco não provocou uma tragédia de consequências incalculáveis. Foi quando saíram para assaltar determinada agência bancária e surgiu um imprevisto. Edvaldo Celestino, então na direção do automóvel Itamaraty, "lembrou que no Realengo havia dois bancos próximos,

\footnotetext{
160 AEL, BNM 414, Caixa 1, $2^{\circ}$ volume, folha 299.

${ }^{161}$ Entrevista a Flávio Luís Rodrigues. Maceió, 19 e 20 de julho de 2011.
} 
porém com o inconveniente de ficarem perto de quartéis do Exército. Resolveram assaltá-lo, mesmo não conhecendo o interior do Banco". ${ }^{162}$ Nas palavras de Viegas:

"por qualquer razão, a agência bancária eleita e estudada, como recomenda o rigor, para ser atacada, não oferecia condições na "hora H". Alguma coisa havia mudado. O grupo partiu para outra. Só que a nova eleita ficava dentro da Vila Militar, em Deodoro, portanto, cercada por unidades do Exército, e sem qualquer levantamento prévio. Puro risco, beirando a irresponsabilidade. Agentes do serviço reservado da Polícia do Exército (PE) envolvidos em torturas a presos políticos (aquela unidade já havia se notabilizado pelo extenso currículo que exibia nessa prática), encontravam-se na agência para receber seu pagamento. Ficaram surpresos com a voz de comando 'isto é um assalto!...'. foram os primeiros a ir para o banheiro. Suas declarações depois à imprensa foram de que os assaltantes retiraram os carregadores de suas armas, jogando-as após ao chão, e de que o planejamento da ação fora tão detalhado e preciso que até os sinais do semáforo haviam sido cronometrados, como puderam constatar! Não sabiam, mas a verdade é que, apesar da audácia do ataque, nada havia sido feito de modo mais improvisado do que aquele assalto". (VIEGAS, 2004, p. 91).

Neguinho, ao lembrar-se deste episódio, fica surpreso com seu êxito. Mas, depois da ação, confessa, sentiu um grande alívio.

"Foi planejado rápido, um planejamento muito rápido. Inclusive, foi uma surpresa para nós. $A$ gente sabia que tinha o quartel do Exército ali,, mas que tinha uma delegacia de polícia tão próximo, eu fiquei sabendo depois. E deu um cagaço! Depois é que foi: 'puta que pariu! Como é quê?'. Porque podia... Bom, eu participei disso. E naquela delegacia [agência] tinha policiais, gente do exército, e eles ficaram realmente atordoados". 163

A imprensa, no dia seguinte ao assalto, dia 20 de março, noticiou o assalto: "Assaltantes levam NCr\$ 37 mil do Banco da Lavoura", foi a manchete do Correio da Manhã. Ele ainda informou que um dos assaltantes falou: "Isto é um assalto. Não vamos matar ninguém. Somos do Exército da Libertação. Este dinheiro salvará o País". ${ }^{164} \mathrm{O}$ jornal do Commércio mencionou a presença de militares na agência: "Na agência havia 20 pessoas, entre as quais o Major do Exército, Ubaldino de Oliveira, que nada fez para impedir a ação dos assaltantes, porque eles se achavam fortemente armados". ${ }^{165}$ A presença de militares na agência, também foi noticiada pelo jornal $O$ Globo:

\footnotetext{
${ }^{162}$ AEL, BNM 414, Caixa 1, $2^{\circ}$ volume, folha 373.

${ }^{163}$ Entrevista a Flávio Luís Rodrigues. Maceió, 19 e 20 de julho de 2011.

${ }^{164}$ Correio da Manhã. 20 de março de 1969, página 5.

165 Jornal do Commercio. 20 de março de 1969. Primeira página.
} 
"Militares que estavam no Banco da Lavoura, por ocasião do assalto, e dois funcionários da agência do Realengo estiveram, ontem, na Delegacia de Roubos e furtos, ocasião em que foram feitos dois novos retratos falados, que se aproximam mais da descrição dada para o nortista e para o homem que portava uma das metralhadoras".

A mesma matéria também traz relato de um funcionário do Banco:

"Elson de Souza Lima só viu o homem da metralhadora, que deve medir 1,75m e pesar 80 quilos. Era mulato, de cabelos pretos e tipo de índio. O que parecia nortista foi quem gritou para as vítimas que eles não eram assaltantes e que a ação visava a derrubada do governo". 166

No dia anterior, dia 20 de março, o mesmo jornal noticiou a presença na agência de outro Major, Ênio de Albuquerque Lacerda, da Polícia do Exército, "um dos clientes do Banco na hora do assalto e que prometeu ampla colaboração com as autoridades policiais nas investigações". ${ }^{167}$ Esse mesmo Major, Comandante da $1^{\text {a }}$ Companhia da Polícia do Exército, enviou ao jornal um ofício, pedindo retificação, porque " $A$ bem da verdade, solicito seja retificada por seu jornal a referida notícia, uma vez que o Major Lacerda não se encontrava no banco na hora do assalto. O Major Lacerda compareceu ao banco cerca das 18h30min, para colher informações sobre o assalto havido". ${ }^{168}$ O Grupo de Ação estava bem próximo do inimigo e não sabia. Imaginamos a reação dos militares ao verem a ousadia daquele pequeno grupo ao assaltar a agência em que eles frequentavam! A notícia do jornal do dia 20 de março mencionou que os funcionários consideraram José Duarte "polido":

"Os funcionários da agência assaltada disseram que o último homem a sair foi o da metralhadora [quem portava a metralhadora era José Duarte], que dava ordens aos demais e que, fria mas polidamente, recomendou às vitimas:

- Os senhores têm cinco minutos para permanecerem aí no banheiro ou na área. O primeiro que sair antes do tempo será varrido". ${ }^{169}$

Pois é, ser duro, sem perder a ternura jamais, como disse Guevara.

Havia ainda pendências a resolver para viabilizar a fuga. E a mais urgente era encontrar um lugar para os fugitivos se esconderem. Esse problema começou a ser resolvido, quando Viegas, a mando de Marcos Antônio, foi até um sítio na Serra do Mar, propriedade de integrante do grupo Mallet, de nome Oswaldo Migues de Souza, conhecido como "Vadinho",

\footnotetext{
166 Jornal O Globo. 21 de março de 1969, página 16.

${ }^{167}$ Idem. Dia 20 de março de 1969, página 20.

168 Jornal O Globo. 22 de março de 1969, página 15.

${ }^{169}$ Idem. Dia 20 de março de 1969, página 20.
} 
PM que prestava serviço na Penitenciária Cândido Mendes, na Ilha Grande. ${ }^{170}$ Aparecendo na casa de José Ferreira em Mallet, partiram, então, de trem para Mangaratiba. Lá chegando, pegaram uma lancha até Conceição do Jacareí, uma comunidade de pescadores onde residia Vadinho. Estava chovendo muito, e o grupo subiu a montanha escorregadia, até o esconderijo, onde Viegas encontrou uma cabana, a que chamavam de Jacu. Ali, encontrou José Gonçalves de Lima, o mesmo que iniciou a aproximação do MAR com o grupo Mallet, ex-presidiário que conversara com André Borges sobre a união de esforços. Trabalhava na manutenção da cabana e na plantação de bananas, já que estava desempregado. Viegas descreve o local onde, após a fuga, o Coletivo passou longos dias:

"Uma cabana construída de troncos de palmeiras abertos ao meio e coberta por palhas figurava como ponto ideal para descanso. Em torno, um bananal. O casebre tinha um só cômodo e alguns catres feitos de caibros cobertos por folhas secas de bananeiras à guisa de colchões. O fogão de lenha, a um canto, era composto por três pedras. Revi ali cenários de pedaços de minha infância (em que a casa era de taipa, chão batido, coberta por palhas de babaçu e portas de esteira confeccionadas com as palmas da mesma palmeira, fartura no Maranhão). Fizemos uma vistoria pelos arredores. Caminhamos por algumas trilhas escorregadias por causa das chuvas e também pela natureza íngreme do terreno. A floresta era escura de tão densa, impedindo que se visse o céu de muitos pontos de seu interior. Estava ali um verdadeiro achado para a instalação de nosso ponto de retirada e até para algum tipo de treinamento. O vizinho mais próximo não ficava a menos de um quilômetro. Embora fosse um coronel reformado do Exército, dificilmente iria notar nossa presença, se tomada as devidas cautelas. Defeito: proximidades da costa em caso de permanência demorada". (VIEGAS, 2004, p. 90).

Viegas levou o "relatório" detalhado do que viu e suas impressões para o Coletivo na penitenciária e aos grupos na cidade. Todos foram unânimes em aprová-lo. Menos uma pendência a resolver. Mas continuava a preocupação com a logística de como manter uma dezena de pessoas perseguidas, numa região sem quaisquer recursos, como comida, cobertas, armas, roupas e sapatos adequados, etc. Esta incumbência também cabia a Viegas, que se aproximou ainda mais do grupo Mallet. Seus encontros com José Ferreira e seu pessoal se intensificaram. Mas, também, com José Duarte, pois era o responsável por conseguir recursos financeiros para as diversas despesas, através dos assaltos a banco.

${ }^{170}$ Depoimento de Francisco de Oliveira Rodrigues ao IPM. AEL, BNM 414, Caixa 1, 2º volume, folha 396. 
Houve pelo menos mais uma ida à Cabana do Jacu antes da fuga. É o que diz Sérgio Lúcio de Oliveira e Cruz em seu depoimento, ${ }^{171}$ não citando o dia, porém. Juntamente com Sérgio, viajaram para Mangaratiba Viegas, Luiz Mário Neri, dono da Kombi dirigida por Sérgio Lúcio, José Ferreira, Francisco de Oliveira Rodrigues e Edvaldo Celestino da Silva. A ida de Sérgio Lúcio se justificou para conhecer o caminho, já que ficou definido que, no dia da fuga, ele dirigiria a mesma Kombi de Luiz Mário. No depoimento de Viegas ele não menciona a presença de José Ferreira nesta viagem, mas a de Benedito Luiz Antunes, guarda da Penitenciária Lemos Brito que tinha uma casa em Conceição de Jacareí e um sítio próximo do acampamento de Jacu. Viegas acrescentou que foi Marcos Antônio, que conversava muito com Antunes, quem mandou o guarda procurá-lo para acertar a ida ao acampamento. ${ }^{172}$ Michel Godoy e Luiz Mário Neri confirmam em seus depoimentos a presença do guarda na viagem que fizeram. No Termo de Reconhecimento realizado no dia 8 de dezembro de 1969 , Sérgio Lúcio reconheceu Benedito Antunes como o homem com quem viajou para Mangaratiba, num sábado, um mês antes da fuga, ocasião em que Antunes mostrou as trilhas da região de Conceição de Jacareí, para Pedro Viegas e Luiz Mário Neri. ${ }^{173}$

Definido o esconderijo onde ficariam os presos, surgia outra pendência: como levá-los até a Cabana do Jacu em segurança? Claro, deveria ser através de automóveis. Então, como consegui-los? Para a solução do transporte dos presos entrou em ação tanto Flávio Tavares, responsável pela logística e expropriações, quanto Viegas, responsável pelo transbordo dos presos. Ou seja, necessitavam conseguir dois carros para tirar os presos da penitenciária e os levar até o local do transbordo, e mais dois para o transbordo, conduzindo-os para Mangaratiba, pois os presos não podiam viajar para Mangaratiba no mesmo carro que os tiraria da penitenciária, pois toda a polícia estaria a sua procura. Então, havia a necessidade do transbordo, a troca de carros. Havia em questão duas propostas. A de José Duarte defendia que o transbordo deveria ser bem afastado da penitenciária. A outra proposta, a de Viegas - e a que foi aceita -, pregava que o transbordo dos presos deveria ser o mais próximo possível, e com segurança, da penitenciária. A justificativa de Viegas era a de que o trânsito, no horário da fuga, não permitiria uma rápida mobilidade e que seria muito arriscado ficarem presos no trânsito dentro do carro certamente mais procurado do Rio de Janeiro. Viegas, como já mencionamos, percorrera todas as ruas próximas da penitenciária e encontrara um lugar, a poucas quadras da penitenciária, adequado para a troca segura de automóveis.

\footnotetext{
171 AEL, BNM 414, Caixa 1, $2^{\circ}$ volume, folha 430.

${ }^{172}$ AEL, BNM 414, Caixa 1, $3^{\circ}$ volume, folha 538 e 539.

173 AEL, BNM 414, Caixa 1, $3^{\circ}$ volume, folha 646.
} 
Viegas saiu a campo para conseguir dois carros e dois motoristas, para o transbordo. Lembrou-se de um estagiário que frequentava a Divisão Legal, de quem se tornou amigo, que tinha uma Rural Willys, espécie de perua, adequada para transportar várias pessoas. Seu nome: Júlio Cesar Bueno Brandão. Viegas pediu-lhe que transportasse os fugitivos até Mangaratiba, pois seu carro estava em situação legal, não correndo o risco de ser parado por uma barreira policial. Ele aceitou prontamente. O outro automóvel do transbordo foi conseguido através do grupo Mallet: a perua Kombi de Luiz Mário Neri, que seria dirigida por Sérgio Lúcio, rapaz calmo e cuidadoso, qualidades indispensáveis para transportar carga tão valiosa... para a polícia. O nervosismo, nestas circunstâncias, poderia por tudo a perder.

Foi exatamente por ter essas qualidades, que Edvaldo Celestino foi o eleito para dirigir o automóvel que estacionaria diante da penitenciária para retirar os fugitivos. O segundo automóvel seria dirigido por Leôncio Maia, o "Macedo". Escolhidos os motoristas faltava conseguir os automóveis. Aquele que Leôncio Queiroz Maia dirigiria seria o seu próprio carro, um fusca bege. Faltava mais um. Teria que ser um carro espaçoso e, para consegui-lo, só "expropriando". E foi o que fizeram. Quem conseguiu o aero-willys utilizado na fuga? Quanto a isso não há consenso entre os envolvidos.

No depoimento de José Duarte ele diz que foram Barbosa e Macedo quem roubou o Aero-Willys, enquanto que Pedro Viegas e André Borges atribuem a façanha a Flávio Tavares. Já no livro memorialístico de Avelino Capitani, o autor do roubo aparece como sendo Edvaldo Celestino (CAPITANI, 1997, p. 135).

Em seus depoimentos, Duarte diz:

"O pessoal que daria cobertura na porta não estava pronto, mas o pessoal estava sempre em contato, isto não seria dificuldade. Contudo, como foi desapropriado o Aero-Willys na sextafeira, dia 23 de maio, pelo Negão e Macedo, surgiram finalmente as condições para a operação, já que o outro carro para a porta da Penitenciária seria o do próprio Macedo (Leôncio Queiroz Maia). ${ }^{174}$ (...) Por volta das 13:30 horas foi o depoente ao encontro de Wilson (Neqão) que the disse ter deixado o carro (Aero-Willys) no local, pedindo para entregar as chaves ao Celestino (Pedro), o que fez, uma vez que Celestino estava esperando próximo a Casa da Moeda (na Praça da República), sendo que ainda lhe deu uma sacola com as camisas que os fugitivos vestiriam na viagem" ${ }^{175}$ [Grifos nossos].

Edvaldo celestino, que foi o motorista, confirma que recebeu as chaves de José Duarte, mas diz que foi Flávio Tavares quem lhe mostrou o local onde estava estacionado o carro.

${ }_{174}$ AEL, BNM 414, Caixa $1,3^{\circ}$ volume, folha 541.
175 AEL, BNM 414, Caixa 1, $2^{\circ}$ volume, folha 303. 
"No dia 26, a essa hora e nesse ponto, encontrou-se com o José Duarte, que Ihe entregou a chave do Aero-Willys, um revólver 38 e mais uma bolsa de papel com roupas. Saiu dali, fez um lanche e encontrou-se com o 'Felix' (Flávio Tavares), em frente ao Hospital Souza Aguiar, isto entre às 15:00 e às 16:00 horas. Depois, no carro do 'Felix', foram em direção da penitenciária onde ele lhe mostrou o carro e depois o percurso que deveria fazer com os fugitivos". ${ }^{176}$

Wilson do Nascimento Barbosa, por sua vez, perguntado pelo Encarregado do IPM "se foi o depoente quem entregou a chave do Aero-Willys expropriado pelo seu grupo para a fuga dos presos, respondeu que não". ${ }^{177}$

Pesquisa em inquéritos policiais têm, sem dúvida, sua validade. Mas nunca podemos desprezar sua complexidade e as circunstâncias em que ocorreram os depoimentos. Temos tentado aqui confrontar os depoimentos e, como bem disse Ginzburg, "Para 'escovar a história ao contrário', é preciso aprender a ler os testemunhos às avessas, contra as intenções de quem os produziu”. ${ }^{178}$ É esse cuidado com os testemunhos que estamos tentando ter.

O caso do autor da "expropriação" do Aero-Willys é um exemplo das limitações que os inquéritos policiais têm como fontes históricas. O depoente pode, para se preservar ou resguardar outra pessoa, atribuir o crime a uma terceira personagem. Foi o que aconteceu, muito provavelmente, nesse caso do roubo do carro. Quando José Duarte prestou seu depoimento, Wilson do Nascimento Barbosa estava fora do país, no Uruguai, sem perspectiva de retorno. Então, perguntado sobre quem roubou o Aero-Willys, Duarte não hesitou em responder que foram Negão e Macedo, pensando que os dois estivessem fora do país e que, portanto, livraria Flávio Tavares, ou outra pessoa, de ser denunciado por mais um crime. No entanto, Wilson Barbosa foi preso no Uruguai e deportado para o Brasil, direto para o $1^{\circ}$ Batalhão da Polícia do Exército e, depois, para o Presídio da Ilha das Flores, encontrando ali José Duarte e Viegas. Quando Duarte foi chamado para responder ao Auto de Qualificação e de Interrogatório, em 5 de novembro de 1970, fez constar a seguinte afirmação:

"Que seus depoimentos relativos a fuga da prisão Lemos de Brito foram colocados nomes de pessoas que nada tiveram a haver com a aludida fuga, pois dita fuga foi organizada pelo depoente com a colaboração de Pedro França Viegas e Flávio Aristides Tavares e Antônio Geraldo da Costa; que acusações a outras pessoas na realidade não ocorreram; o apoio

\footnotetext{
${ }^{176}$ AEL, BNM 414, Caixa 1, $2^{\circ}$ volume, folha 374.

177 AEL, BNM 414, Caixa 1, $3^{\circ}$ volume, folha 597.

${ }^{178}$ GINZBURG, Carlo. Relações de força: história, retórica, prova. Tradução de Jônatas Batista Neto. São Paulo: Cia. das Letras, 2008, p. 43. Apud: MACIEL, 2009, p. 23.
} 
material à fuga dos detentos foi dada pelo depoente que organizou a aludida fuga, sendo ela uma ação da Organização MAR, em protesto contra a condenação dos Marinheiros em $1964 " .{ }^{179}$

A quais "pessoas que nada tiveram a haver com a aludida fuga" Duarte está se referindo, senão ao Wilson Barbosa e Leôncio Maia? Podemos estar equivocados, mas acreditamos que José Duarte estava recuando em seus depoimentos anteriores, para corrigir a implicação dos dois no roubo do Aero-Willys. Wilson do Nascimento Barbosa, respondendo à questão "se tem quaisquer outras declarações a fazer?", respondeu:

"Que quando dos fatos narrados na denúncia encontrava-se no Uruguai e esperava naquele país uma bolsa de estudo para Bulgária, sendo seu endereço no Uruguai de conhecimento de Leôncio de Queiroz Maia acusado de pertencer ao Movimento Armado Revolucionário; que segundo declarou ao depoente o acusado José Duarte dos Santos, isto na llha das Flores, que o nome do depoente foi citado em depoimentos, em virtude do depoente encontrar-se no exterior; que o citado José Duarte dos Santos passou-Ihe um bilhete dizendo que tinham descarregado toda culpa nas costas do depoente; que o depoente foi preso no Uruguai e deportado para o Brasil após 50 dias de prisão naquele País; que não admite o ato pelo qual está sendo acusado, conforme consta das suas declarações no inquérito, referente ao roubo de um automóvel". 180

Não temos subsídios para saber a veracidade da resposta de Barbosa, mas, de qualquer maneira, naquelas circunstâncias, era perfeitamente compreensível que os depoentes atribuíssem a culpa àqueles que estavam longe da sanha dos ditadores. Desde que, naturalmente, não houvesse a hipótese de seus retornos, o que não foi o caso de Negão.

Há, ainda, outra explicação para o roubo do automóvel.

Pedro Viegas e André Borges atribuem o roubo do Aero-Willys a Flávio Tavares. No livro de André Borges, há uma passagem em que ele narra, com muito detalhe, a peripécia de Flávio Tavares e Ivan Lemos:

"Considerando a necessidade de carros para encaminhar as tarefas do MAR, os companheiros Ivan Lemos e Flávio Tavares foram inspecionar o estacionamento garagem Auto Cepa Park que até hoje existe na Rua Viveiros de Castro, 157, próximo a Rodolfo Dantas. Tínhamos concluído que o roubo de carro à mão armada possuía vários inconvenientes: além do risco implícito de ser preso na via pública, obrigava o revolucionário a se comportar como um assaltante comum e disfarçar sua identidade. Ele precisava dizer coisas como 'nois vai te

\footnotetext{
${ }^{179}$ AEL, BNM 414, Caixa 2, 4º volume, folhas 1.037 e 1.038 .

${ }^{180}$ AEL, BNM 414, Caixa 2, $4^{\circ}$ volume, folha 1.039.
} 
mata'. Expunha pelo menos dois outros militantes a uma operação de guerrilha pouco significativa em termos de ganho para a organização, mas muito proveitosa para o DOI-CODI caso algum companheiro fosse preso. Por melhor que fosse o disfarce, era possivel ao proprietário do carro identificar algumas incongruências que sugerissem indivíduos de classe média, como por exemplo: incoerência entre a linguagem verbal e a aparência, tal como um indivíduo com óculos último modelo dizendo a grasse citada acima.

Por tudo isso, decidiram 'campanear' o estacionamento e observar as pessoas que saíam com seus carros e seus horários. Flávio logo identificou um Aerowillis novo de cor verde metálica, cujo dono usava o carro nos finais de semana. Em uma segunda-feira, depois de telefonar para o estacionamento, escreveu uma carta autorizando seu falso filho, Jarbas da Silva Marques, para sair com seu carro. E foi enfático: 'só deixe o carro que estou Ihe identificando sair da garagem na quarta-feira mediante autorização por escrito com a minha assinatura'. Bateu a carta à máquina e colocou um garrancho no final. O falso filho se apresentou dois dias depois com o documento verdadeiro e solicitou a saída do carro, que Ihe foi prontamente entregue. Quando foram se encontrar com Jarbas, o Flávio, pão duro como era, perguntou:

-Jarbas, quanto você deu de gorjeta na garagem?

Jarbas respondeu:

- Eu não tinha trocado, portando dei apenas 70 centavos.

Ao que Flávio respondeu:

- pagamos uma fortuna por este carro!

Em seguida, levaram o Aerowillis para descaracterizá-lo. Colocaram uma napa preta na capota e trocaram as placas. Assim, ele parecia outro carro". (BORGES, 2008, pp. 53-54).

Como podemos observar, os testemunhos sobre o carro que transportou os presos até o transbordo não coincidem. A cor do Aero-Willys é outro mistério. Enquanto Borges diz que era verde metálico e com capota de napa preta, Edvaldo Celestino falou que era azul acinzentado e de uma cor só. No Laudo de Exame em Veiculo realizado no Aero-Willys por ordens do Encarregado do IPM, a cor citada é grená. Como sabemos, essa cor é avermelhada, bem distinta das cores citadas por André e Celestino. Por fim, em seu Relatório Final, o Encarregado do IPM considerou que: "Wilson do Nascimento Barbosa e Leôncio Queiroz Maia expropriaram o carro 'Aero-Willys' que foi dirigido por Edvaldo Celestino e que transportou os nove fugitivos da Penitenciária ao ponto de transbordo". ${ }^{181}$

${ }^{181}$ AEL, BNM 414, Caixa 1, $3^{\text {o }}$ volume, folha 739. 
Definidos os automóveis puderam, então, decidir a data da fuga, marcada para dia 26 de maio de 1969, segunda-feira, às 17h30min. A data anterior era dia 19 de maio, mas teve de ser alterada por problemas de conduções.

Outra providência importante seria o ingresso das armas na penitenciária. Como consegui-las e como inseri-las dentro da prisão? Viegas era o responsável por fazer chegar as armas para os presos. Quem ficou com a incumbência de conseguir as armas foi José Duarte e elas chegaram a ele através de Neguinho e Élinho, ou seja, através da ALN. Duarte as reteve por mais ou menos um mês e só as entregou a Viegas, "uns dois dias antes", segundo o próprio. Viegas conta como as armas chegaram aos presos:

"Quando ainda preso, chegou transferida para a Divisão Legal uma funcionária que aos poucos foi se enamorando de Geraldo Nobre. Algumas conversas com o Nobre, a primeira a partir de mim, que tinha maior aproximação com ele, e as demais continuadas por Marco Antônio, fizeram-no convencido a persuadir a namorada a entrar com as armas na bolsa. Sendo funcionária, não passava por revista. E assim o problema foi resolvido". (VIEGAS, 2004, p. 93).

Segundo orientação de Marcos Antônio, Viegas entregou as armas para Júlio Cesar Senra Barros. Não sabemos o dia, mas provavelmente no sábado, dia 24 de maio, que deveria entregar para a funcionária Natelça Passos Guimarães, por volta das 10h00min do dia 26. Viegas conta ao Encarregado como aconteceu:

"Júlio Cesar Senra Barros recebeu a incumbência [de Marcos Antônio] de cerca das dez horas entregar três revólveres calibre trinta e oito, conseguido pelo José Duarte com o grupo de São Paulo, à funcionária Natelça Passos na Divisão Legal. Júlio Cesar Barros encontrou-se com Luiz Mario Neri, que dirigia a sua Kombi, à saída da llha do Governador; Neri conduziu Júlio Cesar Barros até as proximidades da Ponte de Coelho Neto onde se encontraram com a funcionária Natelça Passos que foi transportada até a cidade. As armas foram entregues dentro de uma caixa embrulhada, de acordo com entendimento direto havido entre Marcos Antônio e Natelça. O depoente declara que as armas foram recebidas por Natelça como se fossem clichets para confecção de flâmulas". ${ }^{182}$

Este depoimento foi confirmado por Luiz Mário Neri, que disse, entretanto, não saber que estava transportando armas. Ele conduziu Júlio Cesar e Natelça até a Lemos Brito, "calados". Tem um fato interessante, que envolve estas duas pessoas: tanto Natelça, quanto Neri foram internados em clínicas psiquiátricas. O Encarregado do IPM mandou médicos peritos, oficiais da Marinha, fazerem exames de sanidade mental nos dois e o resultado, nos

${ }^{182}$ AEL, BNM 414, Caixa 1, $3^{\circ}$ volume, folha 536. 
dois casos, foi de que realmente estavam doentes: ela com "quadro de Amnésia Histérica Reativa acompanhada de sintomas ansiosos (...) não sabe onde trabalha, não sabe onde mora, não se recorda de sua vida anterior, há um vazio total em sua mente". ${ }^{183}$ E Neri, com alienação mental, epilepsia psíquica. E concluíram: "ao final do exame, entretanto, apresentou episódio de agitação psicomotora, jogando-se ao chão e atirando-se contra os móveis, tendo que ser contido pelos enfermeiros da clínica". ${ }^{184}$

Em entrevista realizada em 2009, quando esperava Neguinho no Aeroporto vindo da Suécia, Júlio Cesar Senra Barros confirmou sua participação na introdução de armas na Lemos Brito: "introduzi as armas, eles saíram com as armas que eu introduzi”. ${ }^{185}$

Há uma contradição nos depoimentos de Pedro Viegas no IPM, que nos chamou a atenção. Em seu primeiro depoimento, dia 18 de agosto de 1969, Viegas diz que ele pessoalmente entrou com as armas na penitenciária. Para despistar os guardas da portaria, teria levado duas caixas: uma com produtos de higiene e outra com as armas. O guarda verificou superficialmente a caixa com os produtos e ele, então, pode entregar as armas para o Marcos Antônio. Novamente chamado a depor, em 11 de novembro, ele contou a versão em que a funcionária Natelça Passos Guimarães aparece como a protagonista. Possivelmente Viegas, em seu primeiro depoimento, tentou poupar a funcionária, trazendo para si a responsabilidade do ingresso das armas.

Os preparativos para a fuga do Coletivo estavam avançando. O apoio externo precisava resolver algumas questões ainda, sobre a saída dos presos da penitenciária. Os guardas da portaria, como já mencionamos, eram quatro, desarmados. No entanto, na hora do jantar, a partir das 17h30min, dois entravam na penitenciária para respaldar os outros guardas, pois era um momento de concentração de centenas de presos. Ficavam, portanto, apenas dois guardas na portaria. Já que deveriam estar desarmados, não haveria porque os presos se preocupar. No entanto, na rua defronte à penitenciária havia um PM que fazia a ronda, munido de metralhadora. Se este guarda não fosse rendido, não haveria como sair da portaria. Outro problema era o bar do outro lado da Rua Frei Caneca, esquina com a Rua Viscondessa de Pirassununga, geralmente frequentado por policiais do $8^{\circ}$ Distrito Policial, que ficava na Rua Senhor de Matosinho, próximo à Lemos Brito. Também deveriam ter cuidado com um posto de identificação do Félix Pacheco que abrigava a Companhia de policiais militares que se revezavam nas guaritas da penitenciária (VIEGAS, 2004, p. 93).

\footnotetext{
183 AEL, BNM 414, Caixa $1,3^{\circ}$ volume, folha 583.

${ }^{184}$ AEL, BNM 414, Caixa $1,3^{\circ}$ volume, folha 586.

$185 \mathrm{https}: / /$ www.youtube.com/watch?v=-k49G_Kd21M. Consultado em agosto de 2014.
} 
A senha para os internos e externos de que a fuga havia começado era a sirene, que tocava sempre às 17:30 horas. A mesma sirene avisava a hora das refeições e acusava o andamento de uma fuga. Por isso escolheram este horário para fugirem: não alertaria os policiais do Félix Pacheco, nem os próprios guardas penitenciários. Pensariam que a sirene continuava tocando porque era o horário do jantar.

Para acertar os últimos detalhes da fuga, Flávio Tavares reuniu o grupo de São Paulo e outras pessoas no seu apartamento, dia 24 de maio. A pauta da reunião foi o apoio externo na portaria da penitenciária na hora da fuga. Na manhã daquele sábado, estiveram no apartamento de Tavares, José Duarte, Neguinho, Wilson Barbosa, Murilo Mello, Leôncio Queiroz Maia, Élio Rêgo, Edvaldo Celestino, Jarbas Silva Marques e um rapaz ligado a Flávio Tavares chamado Cyro. ${ }^{186}$ Nesta reunião ficou acertado que Neguinho, Negão e Leôncio Maia deveriam segurar e desarmar o PM da metralhadora. Ficariam segurando o PM até Murillo Mello passar com um Volks expropriado pelo pessoal de Tavares e recolhê-los, depois que Celestino e Leôncio Maia saíssem com seus carros transportando os presos em direção ao local do transbordo. Flávio Tavares, por sua vez, acompanhado de Jarbas Silva, passaria em frente à Penitenciária logo após a fuga, para dar cobertura se acontecesse algum imprevisto.

No domingo, dia 25, Viegas e Duarte confirmam com os envolvidos a fuga para o dia seguinte, às $17 \mathrm{~h} 30 \mathrm{~min}$. Todos deveriam estar a postos, conforme combinado. A noite Viegas vai a casa de Celestino, confirmando a fuga e pedindo que este se encontrasse com José Duarte no dia seguinte, dia 26, na Praça da República, às 13:00 horas, para receber mais instruções sobre a retirada dos presos da prisão.

No mesmo domingo, no apartamento de Júlio Cesar Senra Barros, na Ilha do Governador, se reuniram José Duarte, Sérgio Cruz, Júlio Cesar e Viegas, para fazer um levantamento das várias etapas que deveriam ocorrer e dar orientação a Sérgio sobre sua atuação no dia seguinte.

Tudo parecia estar sob controle. Marcos Antônio foi informado por Viegas que estava tudo pronto para segunda-feira e sugeriu que diminuísse o número de pessoas. Marcos se recusou e manteve as dez pessoas, seis militares e quatro presos comuns.

Na madrugada do dia 26, o “dia D”, às 2:00 horas, Viegas e Júlio Cesar Barros foram acordados por José Duarte, afobado, que deu uma péssima notícia: Estavam, ele e Leôncio

\footnotetext{
${ }^{186}$ Depoimento de Wilson do Nascimento Barbosa. AEL, BNM 414, Caixa 1, 3 o volume, folha 595. Em relação aos presentes, o depoimento de José Duarte não acrescenta Élio Rêgo, Edvaldo Celestino, Jarbas Silva e Cyro. Murilo Mello omitiu Edvaldo Celestino.
} 
Maia na Avenida Brasil, na entrada da Ilha do Governador, quando um caminhão chocou-se com o Volks de Maia, destruindo-o, a ponto de ser preciso chamar um guincho para retirá-lo do lugar. A consternação foi geral. O Volks era um dos carros que tiraria os homens da Lemos Brito.

Seria este um indício de que alguma tragédia aconteceria às 17h30min? 


\title{
CAPÍTULO IV: LIBERDADE QUERIDA E DESEJADA.
}

\author{
"Abre as asas sobre mim \\ Oh, Senhora Liberdade! \\ Eu fui condenado, sem merecimento, \\ Por um sentimento, por uma paixão, \\ Violenta emoção pois amar foi meu delito \\ Mas foi um sonho tão bonito!" \\ (Nei Lopes, "Senhora Liberdade")
}

Os internos na Lemos Brito esperavam com ansiedade que o apoio externo resolvesse a questão dos carros, bem como o local de refúgio. Já tinham conhecimento de que a Secretaria da Justiça pretendia transferir a Divisão Legal para prédios no centro da cidade do Rio de Janeiro. Isso significaria o fim do plano de fuga, pois muito dificilmente a Administração penitenciária admitiria presos para o trabalho na SUSIPE. Seria complexo o transporte desses presos todos os dias, acompanhados de escolta. A aflição só aumentava, desde que houve a necessidade do adiamento da data da fuga, do dia 19 para o dia 26 . O Coletivo tinha a certeza de que não havia alternativa senão a fuga, pois suas penas eram longas e não tinham esperança de saírem antes da queda da ditadura.

Enquanto esperavam o apoio externo viabilizar sua retirada, os ex-marinheiros, liderados por Marcos Antônio, realizavam simulações, para que ninguém esquecesse de sua função na hora da fuga. Uma preocupação era Cietto, que não tinha trânsito livre e precisaria ser trazido para a Divisão Legal por volta das 17:00 no dia da fuga. Fizeram, então, uma simulação, que Capitani conta:

"O nosso maior problema era o Cieto. Ele não tinha a carteirinha de livre trânsito e devia ser chamado na hora exata, para estarmos nos portões de saída exatamente às seis e meia [cinco e meia] da tarde, horário da janta. O trabalho deveria ser feito com muito cuidado. Inventaríamos uma história na seção jurídica para que os estagiários [um advogado fictício] chamassem o Cieto para uma revisão de processo.

Chegou o dia do ensaio. Não avisamos o Cieto. Às cinco da tarde, um guarda o levou na seção jurídica para olhar o processo. Depois, ele saiu. No portão de saída, encontrou Marco Antônio. 
- Tranquilo. Ensaio, treinamento". (CAPITANI, 1997, P. 133).

O último final de semana na Lemos Brito foi angustioso para os internos que fugiriam na segunda-feira. Sábado e domingo, 24 e 25 de maio, eram dias de visita, como os demais finais de semana. Mas esse foi opressivo, pois não podiam contar para suas visitas que fugiriam na manhã seguinte. Sabiam que a polícia iria procurá-las para interrogatório, que a imprensa poderia importuná-las, acusando-as de comparsas. André Borges tenta expressar essa aflição: “A segurança de todos era fundamental. Dessa forma, aquele último sábado e domingo, que antecederam a ação, foram dias tensos, de alegrias e tristezas. E, por que não dizer, de conflitos". (BORGES, 2008, p. 16).

Cada pessoa que iria fugir tinha uma função e, geralmente, não sabia a do outro. Tinha que estar concentrada no que deveria fazer. Por exemplo, a função de André, que trabalhava na portaria e era muito conhecido dos guardas - já estava há 11 anos na Lemos Brito -, era observar a rotina daquele espaço. Havia dois portões, tanto na saída para pedestre, como para a de automóveis. Primeiro se abria um, a pessoa que entrava passava por uma revista e, então, abria-se o segundo. André deveria prestar atenção no fluxo de pessoas na hora do jantar, 17h30min; observar quais os guardas que ficavam armados; com quem estava a chave do cofre que guardava as armas e quantos guardas permaneciam nesse horário. Edison deveria passar pelo primeiro portão de automóveis e, em seguida, fechá-lo com cadeado. Michel Godoy deveria passar o cadeado, assim que todos saíssem, no portão de pedestres, como de fato fez, segundo seu depoimento. ${ }^{187}$ Aqui, há uma divergência, com o testemunho de Adeildo Ramos, que disse ser essa tarefa a dele e que, por isso, foi o último a sair da penitenciária: “ $E$ eu fiquei com uma corrente e um cadeado, que eu ia ser o último a sair, né. (...) Então, quando passasse todo mundo, que eu era o último, passava a corrente e cadeado, pronto". ${ }^{188}$ No entanto, André confirmou, em seu depoimento, que foi Godoy quem fechou o portão com cadeado, portanto, o último a sair. ${ }^{189}$ Cietto, incorporado recentemente, não teria uma função específica, assim como Benedito, que também foi incluído por Marcos Antônio na última hora, pensando já no ingresso na guerrilha, visto que ele era enfermeiro. Adeildo, segundo José Duarte, “fugiu de última hora, por ter achado tudo fácil demais”, nem sequer havia participado dos planos. ${ }^{190} \mathrm{O}$ que estava planejado era o Capitani, que estava quase junto ao portão, sair primeiro e render o guarda da portaria de pedestres. Marcos Antônio e Prestes de

\footnotetext{
${ }^{187}$ AEL - BNM 141; caixa 1, $2^{\circ}$ Volume, folha 390.

${ }^{188}$ Entrevista a Flávio Luís Rodrigues. João Pessoa, 21 de julho de 2011.

${ }^{189}$ AEL - BNM 141; caixa 1, $2^{\circ}$ Volume, folha 292.

${ }^{190}$ AEL - BNM 141; caixa $1,2^{\circ}$ Volume, folha 301.
} 
Paula, armados, abririam o caminho, rendendo os guardas, e os outros passariam pela portaria e iriam para o Aero-Willys. Antônio Duarte, por sua parte, daria apoio aos três que estavam armados, não deixando que os guardas os surpreendessem. Não contavam com resistência, pois os guardas da portaria quase sempre estavam desarmados. Portanto, o uso da arma somente em último caso, para inibir e evitar que os guardas reagissem.

Em seu depoimento, André Borges disse que combinara com Marcos Antônio de avisá-lo,

\begin{abstract}
"se notasse qualquer anormalidade, ficando encarregado de manter os portões abertos $e$ desimpedidos, vigiando os guardas; que o portão interno, que dá para o pátio da Praça Getúlio Vargas estava sempre aberto; que não recebera orientação sobre o caso de resistência armada por parte dos guardas. (...) porquanto o portão de entrada costumeiramente fica aberto, talvez, pelo grande movimento de entrada e saídas de pessoas que vão ao conjunto penal, tratar de assuntos ou visitar presos; que, como do plano não constava atirar em ninguém e que as armas era apenas para cobertura, numa eventualidade, embora a fuga fosse fácil, causou surpresa a sequência de tiros...". ${ }^{191}$
\end{abstract}

Do depoimento acima, podemos inferir que, primeiro, os portões não eram fechados a chave, ou cadeado; segundo, os guardas não usavam armas, por orientação da nova política penitenciária levada a cabo pelo Governo Negrão de Lima, através de seu Secretário da Justiça, Alberto Bittencourt Cotrim Neto; terceiro, a orientação era para o grupo não usar as armas, já que acreditavam que seriam desnecessárias. Acreditava, então, que seria tranquila a saída pela portaria em direção à Rua Frei Caneca. Os guardas penitenciários ficavam desarmados, mas se houvesse alguma ocorrência, eles tiravam as armas que ficavam num cofre, ali, na portaria. Mas alguns guardas, geralmente, usavam suas próprias armas, desrespeitando as normas da Administração Penitenciária. Quem deveria portar armas eram os PMs, ou seja, policiais militares do posto de identificação do Félix Pacheco, que estariam na frente da penitenciária com metralhadora, e outros nas guaritas da penitenciária.

A madrugada do dia 26 foi longa para André Borges, com insônia e o pensamento absorto em vários momentos de sua vida carcerária. Lembrou-se de quando a polícia interrompeu seu sono para lhe colocar as algemas, em 1958. A ansiedade dessa longa noite é contada por Borges:

${ }^{191}$ AEL - BNM 141; caixa 1, 2º Volume, folhas 292 e 294. 
"Sentia-me excitado com a perspectiva da fuga. Nesse Estado, não conseguia ler, tampouco dormir. Só conseguia fumar um cigarro atrás do outro. Tentava concentrar o pensamento, imaginar como estaria a rua após esses anos de reclusão e como seria minha vida em liberdade. Finalmente, ia sair da Casa dos Mortos para uma vida agitada lá fora. E, o mais importante, sairia engajado na luta pela libertação do povo brasileiro. (...) Uma longa madrugada [a prisão]. Agora ela começava finalmente a amanhecer. O rubor da aurora já incendiava o horizonte. Certamente era o clarão da liberdade. Meti-me debaixo do chuveiro. o banho frio me tirou o cansaço da noite insone. Só então comecei a sentir fome. Não sabia há quanto tempo não comia nem bebia. Apenas a ânsia da liberdade me mantinha firme. Pareceu-me despertar de um longo e gostoso sonho". (BORGES, 2008, pp. 21 e 22)

A mesma ansiedade deve ter tomado outros participantes da fuga nessa última madrugada no cárcere. Lembramos que, às duas horas, no "aparelho" de Júlio Cesar Barros na Ilha do Governador, Duarte, Viegas e Barros discutiam o que fazer sem o carro que acabara de ser destruído num acidente. Mas o amanhecer também foi tomado por apreensão em não saber se o plano fora descoberto. André conta:

"Soou a sirene anunciando o início de mais um dia, menos um dia. Estranha operação algébrica que os presos conhecem de cor na prisão: mais um dia de cumprido, menos um dia a cumprir. Daí a pouco, ouvi o guarda abrindo as portas, no início da galeria. Quanto mais ele se aproximava, a tensão ia crescendo. 'E se ele não abrisse a minha cela? Se isso acontecesse, certamente algo estaria errado. A rede de informação da administração poderia ter captado algum dado a respeito da fuga. Quem sabe?'

Quando o guarda abriu a minha cela, senti um grande alívio". (BORGES, 2008, pp. 22 e 23)

No café, muitos ainda não tinham certeza de que a fuga seria mesmo naquele dia. Marcos Antônio só confirmou para todos que sairiam com a sirene das 17h30min na hora do almoço. Como já afirmamos, Marcos Antônio era muito cuidadoso e cauteloso no trato com as informações e, muito provavelmente, os outros internos envolvidos na fuga não sabiam para onde iriam depois dessa ação. O fato de terem mantido o plano de ir para Jacareí da Conceição, um povoado próximo de Mangaratiba, mesmo com a desistência de Edison de fugir, na última hora, pode ser indício de que Edison, que foi torturado para que contasse o que sabia da fuga e para onde iriam os fugitivos, não tinha informação a dar para os militares.

Ao lermos o livro de André Borges e seu depoimento, distanciados pelo menos num lapso de 40 anos - e isto é importante para ser levado em conta, já que o presente do André 
que escreveu o livro não era mais o mesmo presente, tão doloroso, de tantos anos atrás, e seu passado já tinha para ele outro significado -, percebemos contradições, como por exemplo, quando narrou a longa madrugada, de vários cigarros e muita ansiedade, porque sabia que começaria uma nova vida - revolucionária - na tarde do mesmo dia. No entanto, em seu depoimento, ele diz que não tinha certeza de que fugiria naquele 26 de maio: "Que só houve confirmação da fuga na segunda-feira, à hora do almoço, pelo Marcos, que deu instruções para que não se ausentasse da Seção da Assistência e Recreação que a fuga seria às dezessete e trinta horas daquele dia, quando tocasse a sirene”. (BORGES, 2008, p. 292).

As autobiografias têm essa ambiguidade: o sujeito que escreve é o mesmo do objeto da escrita. Aquele que fala de si escolhe o que falar e o que omitir. O livro de Antônio Duarte, por exemplo, tem uma longa narração sobre seu tempo de marinheiro, quando estava embarcado no mesmo navio em que trabalhavam Marcos Antônio, José Anselmo dos Santos e José Duarte, acompanhada de reflexões sobre o sentido de várias coisas, como o poder, o militar, a política, o amor, etc. De seu tempo na Lemos Brito, as lembranças são amargas, sofridas. Mesmo quando fala dos seus amores, como vimos, são angustiantes, por não serem correspondidos. Narrativas amargas, porém narradas. No caso da organização e do dia da fuga, ele simplesmente resumiu em um pequeno parágrafo:

"Um dia, surgiu a condição ideal para a fuga: José e Viegas mandaram o recado: 'vamos buscá-los na hora combinada!'. A ação foi sincronizada e rápida. Eles estacionaram na rua em frente à penitenciária. Estourou um tiroteio. Corremos para o carro. Pessoas atiravam em várias direções. Não se via o inimigo! Eles dispararam suas armas sem nos alcançar". (DUARTE, 2009, p. 340).

Não há dúvidas de que Antônio Duarte teve uma participação decisiva, tanto na organização, como na fuga propriamente dita, chegando até a ser ferido no dedo. Por que, então, Duarte não considerou falar sobre o acontecimento? A fuga, que fora preparada, pacientemente, durante dois anos e, sendo exitosa, não seria importante a Duarte descrevê-la? Por que, então, a pouca importância dada ao evento por Duarte, sendo que seus companheiros o descreveram com tintas fortes, reforçando seus protagonismos? É pena. Duarte daria grande contribuição se tratasse do assunto. Não nos ocorreu perguntar isso a ele, nas entrevistas que nos concedeu. Sua morte levou as respostas às questões que gostaríamos de fazê-lo. Para sempre. 
Na manhã de segunda-feira, Viegas foi à Lemos Brito conversar com Marcos Antônio. Encontrou-o na porta da Divisão Legal, aguardando o guarda que deveria abri-la. Contou-lhe da perda de um dos carros de retirada e recomendou, novamente, que diminuísse o número de pessoas. Marcos manteve a fuga e manteve o número de fugitivos. Haveria de caberem no Aero-Willys dirigido por Celestino. Na verdade, com o abalroamento do Volks, veio à tona a resistência que muitas pessoas tinham na participação dos presos comuns na fuga. José Duarte, por exemplo, fez de tudo para convencer Marcos a manter apenas os presos militares dentre os que fugiriam. Quando ele foi procurar a ajuda do Partido Comunista Brasileiro Revolucionário - PCBR, suas lideranças não aceitaram a presença de presos comuns, assim como Marighela, que disse a Neguinho: “não, não, porque eles são bandidos, puxador de carro". 192

Saindo da Lemos Brito, Viegas esteve com José Duarte, às 10h30min, para acertarem todos os detalhes da fuga. Almoçaram e cada qual partiu para fazer contatos com as pessoas envolvidas na fuga. Duarte procurou Wilson do Nascimento Barbosa, segundo seu depoimento, ocasião em que Negão lhe informou onde estava o carro que tinha expropriado e lhe entregou as chaves, para serem repassadas a Celestino. Essa questão de quem expropriou o Aero-Willys, não é consensual, conforme veremos. Como já havia sido combinado com Viegas, na noite anterior, Celestino foi ao encontro de Duarte para receber as chaves do AeroWillys. Além das chaves, José Duarte deu-lhe um revólver 38 e uma bolsa de papel com roupas, para que os presos se trocassem no transbordo. ${ }^{193}$ Essas roupas, camisas coloridas, foram entregues a Duarte por Flora Frisch, estudante de Direito e namorada do Capitani.

Pouco antes, por volta das 10h00min, Júlio Cesar Senra Barros, levando uma embalagem parecida com uma caixa de sapatos, contendo três revólveres calibre 38, encontrou-se com Luis Mário Neri, à saída da Ilha do Governador. Dali, ambos foram para as proximidades da Ponte Coelho Neto, onde estava marcado um encontro entre Barros e a funcionária da Lemos Brito Natelça Passos Guimarães. Neri, em seu depoimento, conta como foi esse encontro:

"No dia 26 de maio, data da fuga, saiu de casa dirigindo a Kombi de sua propriedade e, conforme o combinado com o José Ferreira, encontrou-se com o Júlio Cesar Senra Barros (Adauto), nas proximidades da entrada para a llha do Governador, junto à 'Expansão

\footnotetext{
${ }^{192}$ Entrevista a Flávio Luís Rodrigues. Maceió, 19 e 20 de julho de 2011.

193 Depoimentos de Celestino e de José Duarte. AEL, BNM 414, Caixa 1, 2º volume, folha 373 e folha $302-$ José Duarte.
} 
Mercantil'. Retornaram em direção ao subúrbio e foram até as proximidades do acesso a Duque de Caxias. Ali o depoente aguardou na Kombi enquanto o Júlio Cesar se dirigia ao ponto de ônibus existente nas proximidades, onde esperou durante algum tempo a chegada de uma mulher de meia idade, morena, que portava uma bolsa grande; posteriormente ambos se dirigiram para a Kombi e vieram os três para a cidade. Não falaram nada durante a viagem. A mulher saltou na Presidente Vargas, perto do Hospital São Francisco [próximo da Penitenciária Professor Lemos Brito] ". 194

Neri sustentou em seus depoimentos que não sabia que estava transportando armas e, quando foi colocado diante da Natelça, na Clínica Bela Vista, onde ela estava internada, em dois de dezembro de 1969, disse não estar certo se era a mesma, já que "ela se apresentou [naquele momento, diante dele] para esse reconhecimento mal vestida, despenteada, em condições completamente diferentes daquelas em que a viu, pela única vez, no dia 26 de maio". 195 O caso dessa funcionária é peculiar, porque, como já informamos, pouco depois da fuga da Lemos Brito, ela foi internada numa clínica psiquiátrica, precisando mesmo de cuidados, como os próprio médicos-peritos da Marinha reconheceram. Seu internamento foi muito longo. Várias vezes, os juízes Auditores pediram informações sobre seu estado mental e se havia condições de prestar depoimento. A Clínica de Repouso da Boa Vista, então, respondia remetendo sua ficha médica, que não recomendava sua saída. Um auditor chegou a propor sua transferência para um manicômio, argumentando que ela estava consciente de seus atos, no dia da fuga. Por fim, a sentença final da $1^{\mathrm{a}}$ Auditoria do Exército, $1^{\mathrm{a}}$ Circunscrição Judiciária Militar, em 12 de outubro de 1973, absolveu Natelça, utilizando o depoimento de Pedro Viegas como argumento de sua inocência:

"Quanto a acusada Natelça Passos Guimarães, ficou apenas provado ter ela recebido um embrulho cujo conteúdo ignorava e, destinado a Marco Antônio da Silva Lima. Segundo declarações de Pedro França Viegas a (fls. 352, 536):

'Júlio Cesar Senra Barros recebeu a incumbência de entregar três revólveres à funcionária Natelça. As armas foram entregues dentro de uma caixa embrulhadas. As armas foram recebidas por Natelça como se fossem 'clichets' para a confecção de flâmulas'.

Essas declarações foram confirmadas por Júlio Cesar Senra Barros a (fls. 1189v.).

\footnotetext{
194 AEL, BNM 414, Caixa 1, $2^{\text {o }}$ volume, folha 509.

${ }^{195}$ Termo de reconhecimento de 02 de dezembro de 1969. AEL, BNM 414, Caixa 1, $3^{\text {o }}$ volume, folha 598.
} 
Não exerceu a ré, qualquer atividade relativa ao grupo MAR, que pudesse ser considerada subversiva". ${ }^{196}$

Por volta das 10h30min, Marcos Antônio já tinha posse das armas. Aqui, nova contradição, agora envolvendo o testemunho de Adeildo Ramos. Ele conta, com muita convicção, que Marcos Antônio lhe narrou que já havia conversado com Natelça sobre as armas, e que ela concordara. Pediu-lhe, então, que arranjasse um lugar para esconder tais armamentos. Teve uma ideia: uma vez que era ele quem controlava os materiais, como papéis, canetas, etc. na Divisão Legal, guardados num armário de aço que não tinha chave, resolveu ir até seu chefe, Durval Soares, adverti-lo de que estavam sumindo materiais diversos e que precisava colocar chave no armário. Soares, então, mandou chamar um preso para fazer duas novas chaves do armário, que, quando prontas, imediatamente foram levadas por Adeildo ao chefe, dizendo que ficaria com uma chave, já que era o responsável pelo armário e as pessoas, quando precisassem de algo, pediriam a ele. Durval, então retrucou, dizendo que ficasse com as duas chaves, quando ele precisasse de algo, lhe pediria. Adeildo foi a Marcos Antônio e lhe contou que já havia um lugar para esconder as armas: guardaria no fundo do armário, atrás de muitos papéis, e teria cuidado para que ninguém ali mexesse. E, segundo Ramos, foi isso que fez: Natelça trouxe as armas e ele as guardou no armário, por uns dois meses:

"Mas, até hoje, eu nunca soube quem foi que... [entregou as armas para Natelça] Eu sei que foi ela que levou, porque aí eu fiz parte do esquema. Fui eu que guardei as armas, entendeu? Agora, quem entregou a ela, nunca soube. Bom, então, essas armas ficaram dentro do armário e passaram lá dentro cerca de dois meses, talvez mais. Porque o seguinte, a gente programou a fuga, no dia da fuga, no dia que a gente tinha programado para fugir, a prefeitura mudou o sentido do trânsito na Frei Caneca. A Frei Caneca parece que era mão e contra mão, aí mudaram, ficou só mão ou contra mão, sei lá, eu sei que mudaram o sentido do trânsito, né, em várias ruas dali". 197

Confrontando esse testemunho com os depoimentos de Viegas, Júlio Cesar Barros, Luis Neri, André Borges e José Duarte, fica patente uma discordância. Todos os depoimentos são unânimes em afirmar que a arma entrou na cadeia no dia da fuga. Há divergências, como já mencionamos, no que se refere à pessoa que introduziu as armas. Viegas, em seu primeiro depoimento, diz que foi ele, para no segundo afirmar que foi Natelça. Mas no próprio dia 26 de maio de 1969. Por que Adeildo Ramos fez essa confusão? Ou seja, por que suas

\footnotetext{
${ }^{196}$ AEL, BNM 414, Caixa 2, 5º volume, folha 1.359.

${ }^{197}$ Entrevista a Flávio Luís Rodrigues. João Pessoa, 21 de julho de 2011.
} 
reminiscências associaram a necessidade do adiamento da fuga, o armário de aço, as armas e um período longo de dois meses? É possível que Marcos Antônio tenha pedido a Adeildo, bem antes do dia 26, que ele pensasse num lugar para esconder as armas. Quando Natelça as entregou para Marcos Antônio, possivelmente Marcos repassou a caixa para Ramos escondêla no lugar já definido, ou seja, no armário de aço. A estagiária Maria Amália da Silva Pires Sequeira falou que presenciou Adeildo entrando na Divisão Legal "com um embrulho cor de rosa, com o formato aproximado de uma caixa de sapato. Ele fez questão de explicar que eram sabonetes e outras coisas pessoais". ${ }^{198}$ Ela não lembra, no entanto, se isso ocorreu no dia 26, segunda-feira, ou se foi na sexta-feira, dia 23.

Ainda no início da tarde, depois de se conversar com Wilson do Nascimento Barbosa, José Duarte foi ao encontro de Celestino, como já falamos e, em seguida, por volta das 14h30min, encontrou-se com Flávio Tavares, Jarbas Silva e Sérgio Cruz, próximo do Tribunal de Contas, para as últimas orientações. Enquanto Flávio Tavares partiu para dialogar com Edvaldo Celestino, a fim de lhe mostrar o trajeto que deveria fazer, dirigindo o AeroWillys da Lemos Brito até ao local de transbordo, José Duarte foi para um bar, juntamente com Sérgio Lúcio, a fim de telefonar para Marcos Antônio, avisando-o do local onde o AeroWillys já estava estacionado, na Rua Viscondessa de Pirassununga, quase esquina com a Rua Frei Caneca. Ou seja, praticamente em frente da penitenciária. Quando saíssem da Lemos Brito, os presos atravessariam a Rua Frei Caneca para alcançar o automóvel.

Pedro Viegas, ao sair do almoço com José Duarte, foi tratar de fazer seus contatos com aqueles que estariam no local do transbordo. Primeiramente, para fazer hora, passou na União dos Profissionais da Imprensa, segundo seu depoimento. Dalí, dirigiu-se para o encontro com Júlio Cesar Bueno Brandão, estagiário da Lemos Brito que tinha uma Rural-Willys "legal”, na Rua da Assembleia, esquina com o Departamento dos Correios. Eram 14h00 aproximadamente. Às $14 \mathrm{~h} 20 \mathrm{~min}$, estacionaram o carro na Rua Afonso Cavalcanti, atrás do Hospital, local do transbordo. "A Rural ficou lá, desde 14:20, quando chegaram, até a hora da fuga. Daí o Júlio Cesar foi embora, pois estava com furúnculos debaixo do braço e ia fazer curativos". 199

Às 15h00, Viegas tinha encontro marcado com Élio Rêgo, na “calçada da ótica Lux”. Enquanto esperava Rêgo, Luiz Mário Neri passou por ele, conversaram rápido e Neri saiu

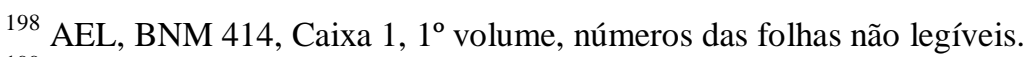

${ }^{199}$ Depoimento de Pedro Viegas em 18 de agosto de 1969. AEL, BNM 414, Caixa 1, 2º volume, folha 353.
} 
para abastecer a Kombi. Chegando Élio, Viegas lhe avisou que "a operação seria realizada aquele dia". ${ }^{200}$ Não sabemos o que mais foi falado.

Como ainda estava cedo, Viegas visitou uma prima que morava próximo do local em que se encontrou com Élio Rêgo e fez um lanche. Às 16h30, partiu para o local do transbordo. Lá, encontrou os carros que deveriam levar os presos até o refúgio, a Kombi de Luiz Mário Neri e a Rural-Willys, de Júlio Cesar Brandão. Ali, estavam o dono da Kombi e Sérgio Lúcio, que dirigiria o veículo até Mangaratiba. Júlio Cesar chegou de taxi e foi, juntamente com Viegas, abastecer e calibrar os pneus da Rural.

Pouco antes, por volta das 16h00, Flávio Tavares encontrou-se com Murillo Mello, na Praça Tiradentes, e pediu-lhe para pegar um Volks no Largo do Estácio, cerca de 17h00, onde receberia mais instruções. No horário combinado, Mello recebeu as chaves do Volks e conheceu o pessoal que deveria imobilizar o PM da metralhadora. Acertaram ali que Mello passaria na frente da penitenciária às $17 \mathrm{~h} 30$, logo após a fuga, para recolhê-los. Em seu depoimento, Mello citou quem estava no Largo do Estácio:

"Macedo (Leôncio Queiroz Maia), Negão (Wilson Barbosa do Nascimento - sic- ), Campônio (um rapaz forte, branco, analfabeto, que fazia parte do 'grupo de choque'), um outro mulato, forte que o depoente supõe ser o José Ferreira (...) todo esse grupo se dirigiu para o local da fuga a pé, ficando combinado que eles seriam recolhidos no ponto do ônibus, no lado oposto à Portaria do Conjunto da Frei Caneca". 201

Segundo Wilson do Nascimento Barbosa, nessa reunião, que já estava programada desde a similar anterior na casa de Tavares, participaram ele, Neguinho, Leôncio e Murillo Mello. Ele não cita os demais mencionados por Mello. Barbosa completa dizendo que, no Largo do Estácio, embarcaram no Volks dirigido por Mello e passaram em frente a Lemos Brito, identificando o local onde Mello os pegaria, após a fuga. ${ }^{202}$ Viegas, por sua vez, incluiu, dentre as pessoas que deveriam imobilizar o soldado da PM, Élio Rêgo e José Duarte.

Como Barbosa foi o único dos três que participou da ação de cobertura aos fugitivos na frente da penitenciária, tendemos a considerar seu depoimento mais verossímil. A não ser que Barbosa tenha omitido Élio de seu depoimento para resguardá-lo. Na conclusão do

\footnotetext{
${ }^{200}$ Idem. Folha 354.

${ }^{201}$ Depoimento de Murillo Mello, em 8 de outubro de 1969. AEL, BNM 414, Caixa 1, $2^{\circ}$ volume, folha 471.

${ }^{202}$ Depoimento de Wilson do Nascimento Barbosa, em 2 de dezembro de 1969. AEL, BNM 414, Caixa 1, $3^{\circ}$ volume, folhas 595 e 596.
} 
Encarregado do IPM sobre a fuga da Penitenciária Professor Lemos Brito, Contra-Almirante Júlio da Sá Bierrenbach, encontramos a versão de Barbosa: Às 17h31 “Wilson Barbosa, Leôncio Maia e Antônio Geraldo da Costa, descem a pé pela Rua Frei Caneca e chegam à guarita não encontrando o PM". 203

Enquanto o Apoio Externo aguardava o momento para entrar em ação, na penitenciária, os internos disfarçavam ao máximo a ansiedade. A orientação de Marcos era para não se movimentarem e manterem-se calmos em suas atividades cotidianas. Até mesmo os estagiários, que iam quase todos os dias na Lemos Brito, nessa segunda-feira não apareceram. Na hora do almoço, Marcos Antônio deu as últimas orientações e acertaram os relógios pelo horário da penitenciária.

Um dos mais ansiosos era Cietto, que não tinha trânsito livre e dependia de requisição para chegar até à Praça Getúlio Vargas. Encontrando Edison, Cietto pediu-lhe para procurar o funcionário Aimoré e solicitar a requisição. Edison já havia pedido isso a Aimoré enquanto tomavam café da manhã. Segundo Aimoré, ele pôs o lembrete no bolso e esqueceu. Por volta das 17h00, Edison foi à Divisão Legal cobrar Aimoré, dizendo que um advogado viria de São Paulo para ver a situação do processo de Cietto. Feito o memorando, Aimoré pegou a assinatura do Diretor da Divisão Legal, Sydney Junqueira Passos, e pediu ao guarda que trouxesse Cietto. Pouco depois, chegou Cietto escoltado pelo guarda Walter de Oliveira Pereira, “com roupa muito limpa e portando no braço esquerdo um relógio grande e muito bonito, que chamou a atenção do depoente". ${ }^{204}$

Pouco antes das 17h00, Prestes de Paula chegou à Divisão Legal, onde ficou conversando com Adeildo, comentando as matérias de uma revista.

Por volta das $17 \mathrm{~h} 15$, André foi até à Divisão Legal pegar a arma de Capitani com Marcos Antônio, conforme estava o combinado. Ele conta:

"Entrei num salão amplo, onde funcionava a Divisão Legal. O Marcos Antônio veio ao meu encontro. Disse-Ihe que era o momento de levar as armas. Ele foi buscar um embrulho e fez sinal para entrar no banheiro. Ali, desembrulhamos o pacote. Em seguida, foram distribuídas aos companheiros. desci novamente para a sala, onde Capitani me aguardava. Entreguei-Ihe

\footnotetext{
${ }^{203}$ Relatório Final do IPM sobre a fuga da Penitenciária Professor Lemos Brito. AEL, BNM 414, Caixa 1, $3^{\circ}$ volume, folha 729.

${ }^{204}$ Depoimento de Aimoré de Oliveira Martins, em 1 de setembro de 1969. AEL, BNM 414, Caixa 1, $1^{\circ}$ volume, folha 137.
} 
um Taurus 38, que ele examinou e tratou de enfiar numa cessa de lixo, sob papéis. Fui ao local em que funcionava a portaria, conferir se tudo corria bem". (BORGES, 2008, p. 26).

Capitani foi até à Seção de Recreação e Assistência, onde trabalhava André, e mentiu ao chefe da Seção, Milton Pena de Azevedo, dizendo que a Assistente Social Carmem Lopes Viana estava lhe procurando. Azevedo deixou a sala às $17 \mathrm{~h} 10$, segundo seu depoimento, ${ }^{205}$ ficando ali somente André e Capitani.

André conta que, nesse momento, por volta das 17h15, ele olhou pela janela e viu os carros parados em sentidos opostos ao bar que existia na esquina da Rua Frei Caneca com a Rua Viscondessa de Pirassununga. Diz ele:

"Em frente à Penitenciária Lemos Brito há um bar, onde alguns companheiros que fariam a cobertura externa da fuga nos esperavam. Do outro lado da calçada, bem em frente a esse bar, os carros parados aguardando. Antes da 'sirene' tocar iniciando a fuga, me comuniquei com os companheiros, através de sinais, fazendo-os entender que tudo corria bem". (BORGES, 2008, P. 25).

O depoimento de Borges soa estranho, pois não havia mais de um carro. Como afirmamos, o outro carro que participaria da retirada dos presos era o carro de Macedo, que sofreu um acidente na madrugada do dia 26. A posição em que estavam "os carros" coincide com outros relatos - se considerarmos apenas o Aero-Willys. O Jornal do Brasil fez um desenho explicativo de como se deu a fuga e nele, o carro de Celestino aparece na Rua Viscondessa de Pirassununga, voltado para a Lemos Brito, conforme descrição de Borges.

Pouco antes das 17h30, o estudante de Direito José Carlos de Almeida Nascimento, que estagiava na Divisão Legal, mas que quase não aparecia por lá, foi buscar seu Volks, que deixara de manhã para consertar na oficina mecânica. Quando chegou à portaria, lembrou-se de apanhar sua arma, que deixara com o guarda, já que não podia entrar armado na penitenciária. Como ele não podia desligar o carro, pois o veículo estava com problema no motor de arranque, ele saiu do carro, deixando-o ligado e as portas abertas. Nesse exato momento, em que seu carro está parado, com o motor ligado, na portaria de veículos e, ainda, as portas abertas, tocou a sirene. Enquanto ele conversava com o guarda Aracy Caetano da Silva sobre sua arma, uma mulher dialogava com o guarda da penitenciária Milton Dias Moreira, Antônio Júlio Sobrinho, no banco entre os dois portões da portaria de pedestres.

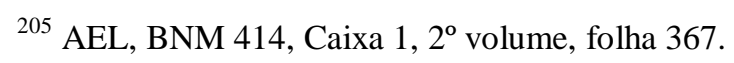


Ao ouvir a sirene, Marcos Antônio desceu a escada que leva à Praça Getúlio Vargas, acompanhado de Prestes de Paula, Adeildo e Cietto. O guarda, desarmado, seguiu atrás de Cietto, para escoltá-lo para a penitenciária, quando o grupo tomou o sentido oposto e caminhou em direção à portaria. O guarda gritou, mandando-o voltar e começou a apitar. A sirene anulou o som do apito.

Enquanto o grupo caminhava em direção à portaria, Antônio Duarte, vindo da Biopsicologia, atravessava, dissimuladamente a Praça. Também Benedito Campos e Michel Godoy chegaram à Praça, vindos do Hospital, andando normalmente, para não alarmar antecipadamente os guardas penitenciários.

Chegando à portaria, Marcos Antônio, Capitani, Prestes de Paula e Antônio Duarte renderam o guarda Aracy Caetano da Silva, distraído em conversa com o estudante sobre sua arma. Segundo o guarda, Marcos Antônio chegou por trás dele e lhe deu uma gravata, dizendo "chega para lá", com uma "arma que lhe pareceu nova”. 206

Entretido em conversar com a mulher que pediu para lhe chamar de Nilza, o guarda Antônio Júlio Sobrinho, ao ver as armas apontadas para ele e para o guarda Aracy, "até pensou que se tratasse de brincadeira de colegas". ${ }^{207}$ Antônio Duarte e Prestes de Paula mandaram que os quatro, ou seja, o guarda Aracy, o guarda Sobrinho, a mulher Nilza e o estudante José Carlos de Almeida Nascimento, entrassem na sala de Recreação e Assistência, que foi fechada em seguida por Prestes. A portaria dos pedestres estava dominada!

Abaixo, fotos tiradas da Praça Getúlio Vargas, onde se percebe a escada que separa a Divisão Legal da portaria. ${ }^{208}$ Trata-se de cópia extraída do Processo 056/69, daí sua falta de nitidez.

\footnotetext{
${ }^{206}$ Depoimento do guarda da Penitenciária Professor Lemos Brito, Aracy Caetano da Silva, em 18 de junho de 1969. AEL, BNM 414, Caixa 1, $1^{\circ}$ volume, folha 102.

${ }^{207}$ Depoimento do guarda da penitenciária Milton Dias Moreira, em 18 de junho de 1969. AEL, BNM 414, Caixa $1,1^{\circ}$ volume, folhas 100 e 101 .

208 AEL, BNM 414, Caixa 1, $3^{\circ}$ volume, folha 675.
} 
3-Prédio da Portaria visto da Penitenciaria Lemos Brito No primeiro plano Praça Getúlio Vargas
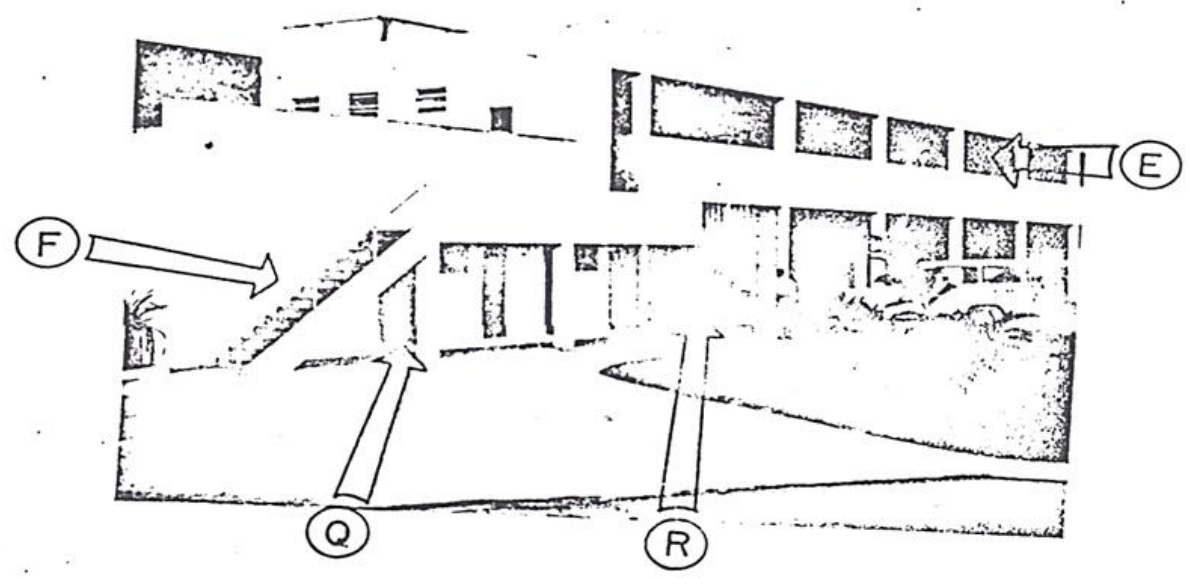

(F) Escada de acesso à Divisão Legal

(E) Divisão Legal

Q - Porta interna da passagem de peciestres

(R) Porta interna da passagem de veículos

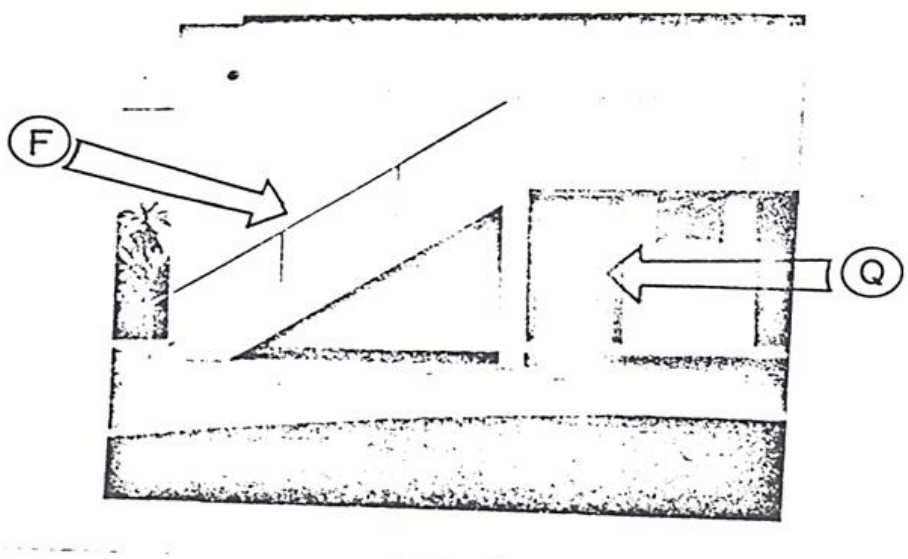

(F)-Acesso `a Divisão Legal

Q - Porta interna de saída de pedestres

André, que deixara sua sala juntamente com Capitani, pegou o molho de chaves que estava nas mãos do guarda Aracy Caetano da Silva e tentou abrir o cofre, para retirar as armas que ali estavam. Não tendo sorte em suas escolhas das chaves, ele começou a ficar impaciente, pois o tempo estava passando. 
Enquanto isso, Marcos Antônio, acompanhado de Capitani, saíram da penitenciária pelo portão de pedestre e, esgueirando a parede em direção à portaria de veículos, surpreenderam os guardas que lá conversavam. O guarda Jorge Felix Barbosa não estava em serviço, apenas aguardava a hora para jantar na Penitenciária Milton Dias Moreira. Conversava com o guarda Airton de Oliveira, que estava dentro da guarita. ${ }^{209}$ Quando Marcos Antônio e Capitani chegaram, dizendo para que não se mexessem, o guarda Airton de Oliveira tentou sacar sua arma particular, mas não conseguiu. Foi o tempo que Marcos Antônio teve para entrar na guarita e segurar a sua mão. O guarda Jorge Felix Barbosa conta o que se sucedeu:

"Que continuou conversando com Airton durante alguns segundos, Airton no interior do abrigo da portaria de viaturas e o depoente ao lado de fora, de costas para à rua. Que ouviu ruídos de passos e virando-se viu dois elementos armados de revólveres que vieram até junto de ambos, tendo intimado a não se mexerem. Airton estava armado com arma particular e tentou sacar a mesma, mas não conseguiu, até que um dos elementos entrou no abrigo e segurou a sua mão. O depoente gritou para Airton não reagir, tendo o segundo elemento, que estava do lado de fora rendendo o depoente, disparado dois ou três tiros contra Airton a uma distância de pouco mais de um metro". ${ }^{210}$

Os tiros de Capitani atingiram a cabeça e o braço do guarda Ailton, que não resistiu e morreu cinco dias depois. Também o guarda Jorge Félix Barbosa foi baleado na nuca. Não sabemos, contudo, como isso ocorreu, os disparos possivelmente partiram da arma de Prestes de Paula.

Antes de correr para o carro, Marcos Antônio fechou o primeiro portão, que dá para a Praça Getúlio Vargas, com cadeado.

Capitani tem sua versão para o acontecimento:

"(...) e abrimos o portão que dava acesso à rua. A três metros, estava o portão para veículos. Já fora da penitenciária, eu e Marco Antônio passamos junto à parede em direção aos guardas do outro portão. Eu dominei um dos guardas, e Marco Antônio dominou o outro. Percebi que estava desarmado e empurrei-o até que sentasse. Olhei para a direita e vi quando o outro guarda reagiu. Marco Antônio mirava o peito do guarda quando recebeu um golpe no braço, que afastou sua arma. O guarda puxou seu revólver e apontou para o peito de Marco. Não tive alternativa e atirei no guarda". (CAPITANI, 1997, p. 134).

\footnotetext{
${ }^{209}$ No Laudo de Exame, solicitado pelo Encarregado do IPM, para realização de perícia para constatação de projéteis de arma de fogo na Lemos Brito, incluiu-se uma foto do interior da guarita, onde aparece uma poça de sangue no chão e espargimento nas paredes. . AEL, BNM 414, Caixa 1, $2^{\circ}$ volume, folha 451.

${ }^{210}$ Depoimento do guarda Jorge Felix Barbosa, em 20 de junho de 1969. AEL, BNM 414, Caixa 1, $1^{\circ}$ volume, folha 110 .
} 
Logo depois da fuga, o guarda Jorge Felix Barbosa foi para o hospital cuidar de seu Ferimento na nuca. No próprio hospital, ele deu uma entrevista ao jornal Correio da Manhã, contando uma versão completamente diferente daquela contada diante do Encarregado do IPM, acima:

"A tarde já estava acabando - conta o guarda Jorge Félix (que tem 27 anos, 2 filhos e que trabalha a 4 anos na penitenciária, ganhando NCr\$250). Eram cinco e meia mais ou menos. Eu estava do lado de fora, desarmado, pois havia deixado o meu '32' no balcão da portaria. de repente, se aproximaram de mim dois elementos, brancos e de estatura mediana. Não me recordo como eles estavam vestidos. Sei que estavam armados. Fiquei paralisado. Vi quando o colega Ayrton que estava um pouco afastado da portaria correu em direção a eles e fez menção de puxar a arma. Ainda gritei para que ele não reagisse, pois nós dois sozinhos não vamos aguentar aquela parada.

Quando o Ayrton botou a mão na cintura, foi atingido com dois tiros a queima-roupa na cabeça. Eu corri para socorrê-lo e levei um tiro na nuca. Cai. Fui, arrastando-me, mesmo ferido, para o balcão da portaria para apanhar a minha arma, mas aí, apareceram três fugitivos que me dominaram. A coisa foi muito rápida. Depois me soltaram e desapareceram. Sinceramente não vi se fugiram de carro como os outros colegas disseram". ${ }^{211}$

Em seu depoimento para o Encarregado do IPM, ele deu versões bem diferentes das de suas entrevistas no "calor da hora". Por exemplo, ele não trabalhava na Lemos Brito, como diz a matéria. Ele trabalhava na clínica tisiológica do Instituto Médico Penal, em Bangu, chegara ao Galpão da Quinta da Boa Vista com uma ambulância e foi ao controle do Instituto Médico Penal, “onde deixou sua arma particular”, afirmou em seu depoimento. Ele diz que estava fazendo hora para jantar no refeitório da Milton Dias Moreira, "cujo rancho é melhor”, enquanto conversava com o guarda Ayrton. Depois dos tiros em Ayrton, ele se agachou e esperou os fugitivos partirem. Só então, quando ouviu outros tiros, foi que se sentiu ferido na nuca. Esse tiro pode ter partido da arma de Prestes de Paula, não temos certeza.

"Depois dos tiros o depoente se encolheu e agachou no canto do abrigo pelo lado externo, protegeu a sua cabeça e notou que os dois passaram perto correndo, quando ouviu novos disparos tendo se sentido ferido na nuca, tendo então se jogado no chão fingindo que estava morto. Que o depoente caiu com o rosto encoberto não tendo observado os lances seguintes. Quando julgou que os dois tivessem distanciados, levantou-se e correu para a portaria de pedestres no intuito de obter uma arma, mas logo ao chegar à porta externa encontrou com

\footnotetext{
${ }^{211}$ Jornal Correio da Manhã. 28 de maio de 1969, p. 6.
} 
outro grupo de fugitivo que saía correndo, eram uns quatro ou cinco, tendo a certeza que um deles era José Michel Godoy, parecendo-Ihe que outro do grupo era Antonio Prestes de Paula, que foi imobilizado novamente, tendo sido apertado junto à guarita de cimento que fica a direita de quem entra na entrada de viaturas, que então ouviu vários disparos enquanto os fugitivos descendo a rampa corriam para a rua Viscondessa de Pirassununga". 212

Quando Capitani atirou no guarda Ayrton, começou o tiroteio, que não estava programado.

André, que não conseguiu achar a chave para abrir o cofre, quando ouviu estampidos de tiros, se desesperou, pois não esperava o uso de armas. Partiu imediatamente para o carro, estacionado na Rua Viscondessa de Pirassununga.

A foto abaixo, retirada das cópias do processo 056/69, mostra a fachada da Lemos Brito do lado de fora, por onde Capitani e Marcos Antônio se deslocaram da portaria de pedestre para a de viaturas. A segunda foto é recente, pouco antes da demolição da penitenciária.

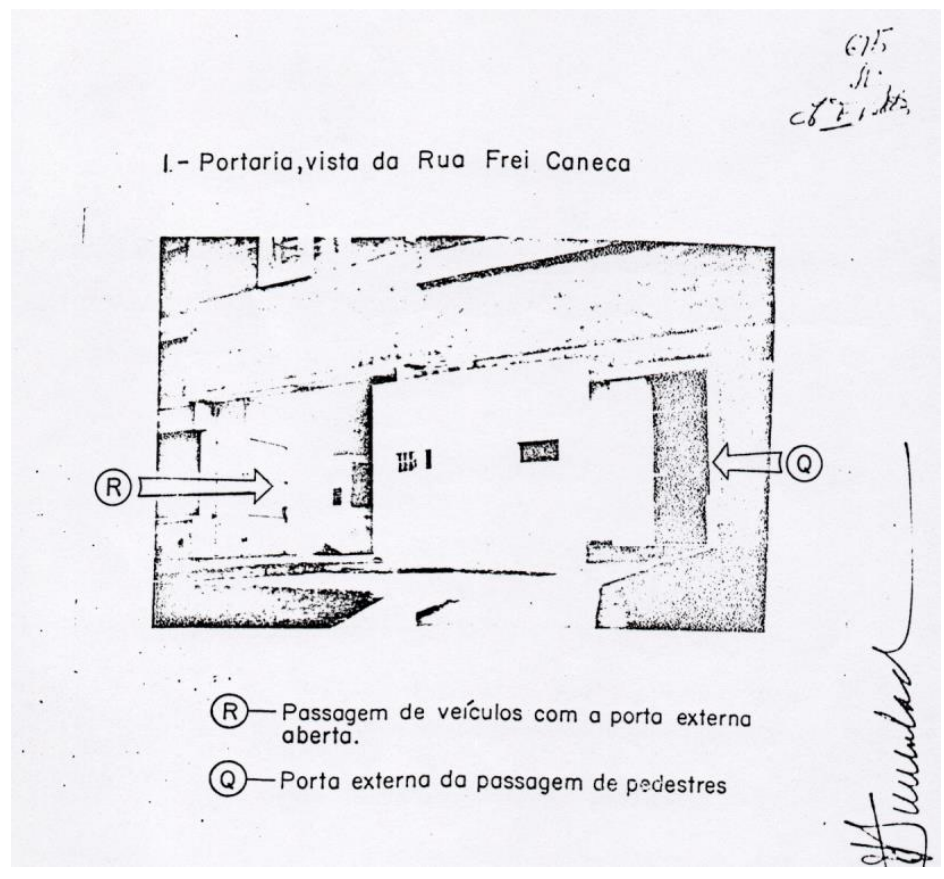

${ }^{212}$ AEL, BNM 414, Caixa $1,1^{\circ}$ volume, folha 110. 


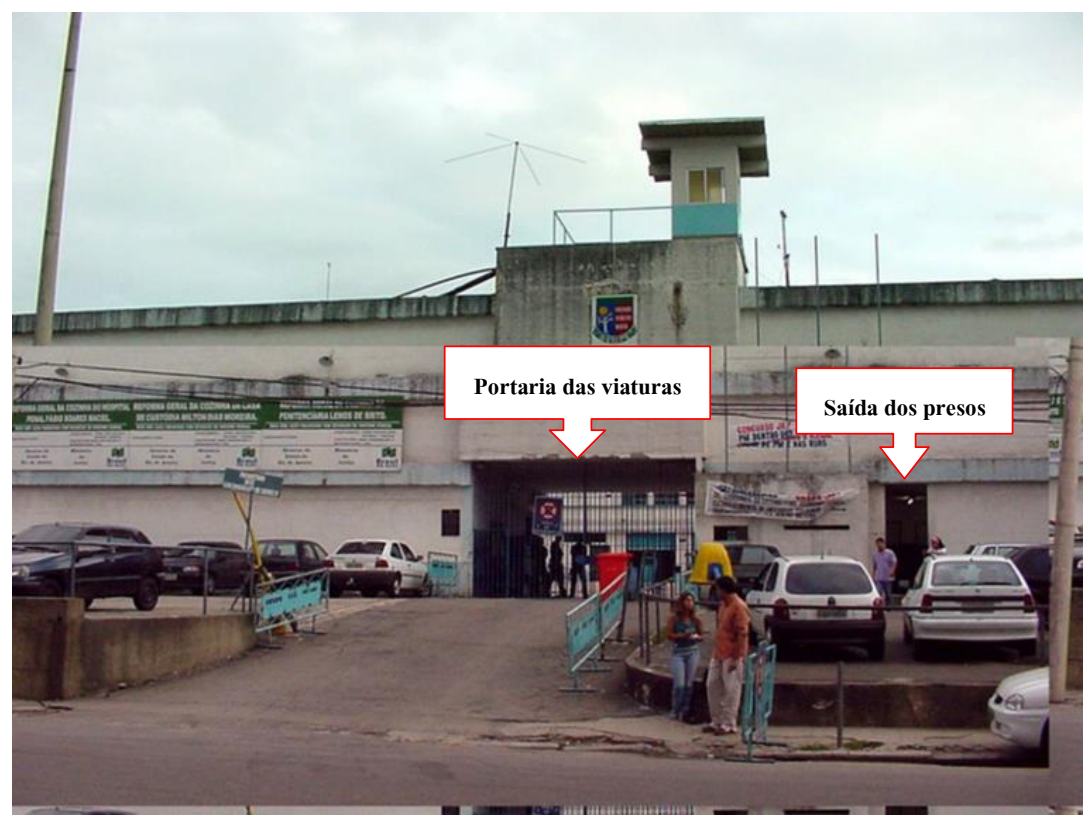

Apud CARDOSO, 2008.

Após os tiros de Capitani, outro PM da guarita no muro, afastada uns 50 metros, começou a atirar. Capitani, encostado na parede entre as duas portarias, avisou a Prestes, que trocou tiros com o guarda, segundo André Borges.

Adeildo foi o primeiro a atravessar a Rua Frei Caneca e a entrar no carro. Em seguida, chegaram Benedito, André Borges e Antônio Duarte, o último ferido no dedo. Celestino viu o momento em que Capitani e Marcos Antônio desceram a rampa, vindos da portaria de viaturas. Antônio Duarte pegou a arma de Celestino e começou a atirar contra o PM da guarita, dando cobertura aos que ainda estavam fora. Enquanto isso, Cietto tentava se desvencilhar do guarda Walter de Oliveira Pereira, o mesmo que o havia escoltado até à Divisão Legal. Cietto derrubou o guarda com um golpe. Teria ele usado algum objeto de ferro? Em seu depoimento, o guarda acusou Cietto de lhe dar uma coronhada. Disse Walter Pereira:

"Que tendo se agarrado novamente com Cietto, observou que esse estava com uma arma na mão e Ihe deu uma coronhada na cabeça, deixando-o atordoado; já nessa altura estavam na sala da Portaria junto a porta externa, e durante esses lances a testemunha ouviu tiros. Que não sabe precisar quanto tempo ficou atordoado pois perdia sangue e logo depois saindo pela porta externa, encaminhou-se para a Portaria de veículos, onde constatou que havia colegas feridos" ${ }^{213}$

Cietto não podia estar armado. Só havia três armas, distribuídas entre os militares. O Exame de Corpo de Delito que o guarda fez revelou "cicatriz, medindo dois milímetros de

\footnotetext{
${ }^{213}$ Depoimento do guarda penitenciário Walter de Oliveira Pereira, em 19 de junho de 1969. AEL, BNM 414, Caixa $1,1^{\circ}$ volume, folha 105 .
} 
comprimento, no supercílio esquerdo". Em relação à pergunta "qual o instrumento ou meio que produziu a ofensa?", a resposta foi: “instrumento contundente”. Imaginamos o quão contundente era o soco de Cietto...

Depois de golpear o guarda Walter, Cietto foi para o carro, atravessando a Rua Frei Caneca, que nessas alturas estava cheia de automóveis parados, com motoristas certamente desesperados.

Os dois últimos a saírem foram Prestes de Paula e Godoy. O primeiro porque tinha como incumbência dar cobertura aos outros fugitivos para entrarem no Aero-Willys, e o segundo, porque era quem passaria o cadeado no primeiro portão de pedestre, assim que todos saíssem. Enquanto Prestes já estava na rua, aconteceu um imprevisto, que deixou Michel Godoy desorientado. Ao fechar o portão para passar o cadeado, ele viu, na Praça Getúlio Vargas, imóvel, cataplético, Edison Mello, que fazia parte do grupo que fugiria da cadeia. A função de Edison era passar o cadeado no portão das viaturas e correr para o automóvel. Ele foi até o local da ação, mas não se incorporou aos fugitivos. Godoy olhou para ele, perguntando com os olhos o que estava acontecendo, e passou o cadeado, deixando Edison, seu amigo pessoal de muitos anos, ali, parado, para viver ainda outros muitos anos naquele inferno.

Edison nos contou sua versão sobre o que aconteceu:

"[por que não saiu na fuga?] "ah! Esse é que é o momento! Porque foi feito tudo direitinho. Aí tocou a sirene para encerrar o trabalho [imita a sirene]. Esse foi o sinal que as pessoas que estavam em determinados pontos da penitenciária, quase todos eles lá na frente, se dirigir à saída, e eu fiquei aqui numa sala pequena, onde ficavam os disjuntores da eletricidade, né. Então, daí eu cheguei, ficava em frente ao portão da viatura. Aí eu tinha que descer até o portão da viatura, pegar uma corrente e passar no portão; pegar o cadeado, prender e sair assim para a esquerda, para entrar também naquela saída, que todos foram [de pedestres]. Daí [imita a sirene] tal, saí. Aí eu fui para botar o cadeado, mas quando eu cheguei para colocar o cadeado, não apareceu ninguém do lado de fora. Se eu passo o cadeado ali, o que ia acontecer? Você consegue deduzir o que ia acontecer? Os caras então saindo por aqui. Aí chega na rua aqui. Aí, para chegar aqui nesse portão das viaturas, né, faz assim para a direita [desenha a frente da penitenciária numa folha]. O portão das viaturas está aqui e eu estou aqui. Se eu passo o cadeado ali, e não aparecer ninguém na porta lá de fora, como é que vai ficar? Não vai fugir ninguém, vai todo mundo é levar tiro na cara. Pô, estou passando o cadeado e tem os guardas ali. O Guilherme e o outro que morreu, o Airton. Aí eu raciocinei rápido e falei: 'Porra, o que é isso?" Aí, dei meia volta, para voltar assim de onde eu vim e 
olhando para trás, para guando alguém chegasse lá no portão da frente, numa dessas olhadas, né? Aí, se chegasse alguém lá, eu voltava correndo, passava o cadeado e ia embora pela porta do lado. Mas acontece que, numa dessas que eu vou olhar... eu estou olhando, não tem ninguém, quando faço assim para virar, apareceu o pessoal lá de fora e já começou o bang-bang. Aí, o chefe da segurança, um tal de Ivanir e o Waldetário [Waldetário Tenório, chefe do Serviço de Segurança] estavam no controle da entrada para a penitenciária para o interior, né? Aí, pá, pá, pá [imitando o tiroteio], eles saíram correndo. Quando saíram correndo... passaram por mim. Só que eu estou aqui, olha só! Eu estou aqui, o portão está aqui, aquele portão por onde todos saíram está aqui. O Godoy que estava aqui, ainda olhou para mim, que estava aqui e passou o cadeado no portão que eu deveria ir para sair. Mas também, não poderia mais ir para lá, pois se eu faço menção de correr para cá, os dois caras que vinha por aqui [Ivanir e Waldetário que correram em direção à portaria na hora do tiroteio] me dariam tanto tiro que eu virar peneira. Aí o André [Godoy] fechou aqui e foi embora. Aí, o que eu fiz? Voltei para trás, quando chego aqui, tinha um canteirinho, assim. Eu peguei o cadeado com a corrente e joguei aqui, eu estava até de japona. Aí eu entrei por aqui, eu entrei pelo controle da entrada efetiva, né, a entrada principal da penitenciária e fui embora para dentro. E o bang-bang está comendo lá fora". 214

Quando estivemos no Rio de Janeiro para registrar a narrativa de Edison Mello, ele estava chateado com outras versões que foram divulgadas, dando conta de que não teve coragem de atravessar o portão da penitenciária. Por isso, mesmo longa, fizemos questão de registrar sua versão sobre o que o impediu de fugir juntamente com os demais.

Até aqui, não mencionamos o PM da metralhadora, porque, para sorte dos evadidos, naquele momento ele estava bem afastado. Podemos imaginar a carnificina que seria se ele estivesse a postos na frente da penitenciária e ouvisse os tiros de Capitani?

O Grupo de Ação que ficara incumbido de neutralizar o PM da metralhadora, chegando adiantado na frente da penitenciária, não o viu, segundo depoimento de Wilson do Nascimento Barbosa:

"Quando voltaram de carro os três [Wilson, Neguinho e Macedo] saltaram em frente à gráfica Bloch, seguindo a pé para a frente do Conjunto Penitenciário. Foram andando, rapidamente, desde uma pracinha triangular que fica em frente à gráfica Bloch, um atrás do outro cerca de dois metros, a fim de melhor imobilizar o PM. Estavam preparados para imobilizá-lo e desarmá-lo totalmente, soltando-o tão logo entrassem no carro [de Murillo]. No entanto, caminharam até a altura da guarita, não encontrando o soldado. Foi nesse ponto

\footnotetext{
${ }^{214}$ Entrevista a Flávio Luís Rodrigues. Rio de Janeiro, 10 de julho de 2012.
} 
que começou o tiroteio, intenso, porém rápido, seguido de movimentação de pessoas atravessando a rua as quais o depoente não distinguiu porque estava sem óculos, já que poderia quebrá-los no impacto com o $P M^{\prime \prime}{ }^{215}$

De fato, o soldado da PM, Anselmo Giudice, que Barbosa e os demais iriam desarmar, não estava na portaria, mas bem distante dela. A área de patrulhamento do PM compreendia o trecho da esquina da Rua Frei Caneca com a Rua Viscondessa de Pirassununga até ao Presídio do Estado da Guanabara (PP), onde se encontrava Giudice. Portanto, no outro extremo de seu patrulhamento. Quando começou o tiroteio, ele não ouviu seus estampidos. Foi alertado por um sargento do Corpo de Bombeiros e dirigiu-se correndo para o local. Quando chegou, a maioria dos fugitivos já estava no carro, mas "ainda viu um interno que atravessava a rua em direção a um carro, um elemento baixo que portava uma bolsa [Michel Godoy]”. Ao vê-lo chegando com a metralhadora, Edvaldo Celestino, antes de passar sua arma para Antônio Duarte, Capitani e Marcos Antônio, começaram a atirar contra ele de dentro do carro. O soldado da PM Anselmo Giudice se escondeu atrás de uma árvore, bem próxima do automóvel. Tentou atingir um fugitivo que estava "na calçada oposta ao botequim, se dirigindo para o carro; que o depoente apontou a arma para o fugitivo e essa engasgou”. Ele estava desesperado e já não conseguia manipular a metralhadora, que resistiu a funcionar. Em seu depoimento, ele diz

"que no carro havia outros elementos que passaram a atirar no depoente enquanto procurava acionar a sub-metralhadora; que ao acionar o gatilho a arma não funcionou porque a bala atravessou na câmara; que nessa ocasião o depoente procurou se abrigar correndo para trás da árvore. (...) perguntado se sua atenção naquela hora não foi condicionada pelo nervosismo, respondeu que sim; que ficou apavorado e depois que a arma enguiçou, procurou se abrigar apenas; que seu despreparo para enfrentar situação idêntica é total; que tem pouco tempo de serviço em policiamento na rua, sendo essa sua primeira ocorrência anormal”. ${ }^{216}$

Giudice não tinha qualquer familiaridade com a arma, uma sub-metralhadora INA. Quando foi perguntado se já havia usado uma metralhadora, respondeu que

"desde que ingressou na corporação há quase um ano, teve durante seu estágio de recruta, adestramento de tiro real com revólver calibre $38 \mathrm{em}$ exercício onde o depoente teve a oportunidade de dar cinco tiros com esse tipo de arma, não tendo atirado com a INA, nessa

\footnotetext{
215 AEL, BNM 414, Caixa 1, $3^{\circ}$ volume, folha 596.

${ }^{216}$ Depoimento do soldado da Polícia Militar do Estado da Guanabara Anselmo Giudice, em 3 de outubro de 1969. AEL, BNM 414, Caixa 1, $3^{\circ}$ volume, folhas 457 a 459.
} 
época; que na Aeronáutica chegara a utilizar a sub-metralhadora dando com ela cerca de quatro tiros compassadamente, não tendo atirado em rajada". ${ }^{217}$

A conclusão do Laudo Pericial, que analisou a arma e os cartuchos, indicou falhas nos projéteis, muito antigos, fabricados em 1954, e que não tinham a menor condição de serem usados por uma arma automática como a INA. Diz o Laudo:

"Concluímos o presente Laudo assegurando que a metralhadora INA № 000017 acha-se em perfeito Estado de conservação e funcionamento. Entretanto, a munição com a qual estava municiada não tinha a menor segurança de funcionamento, sabendo-se que os peritos, digo, que os produtos [inelegível] das espoletas e pólvoras são perecíveis, tendo seu tempo de utilização limitado em consequência não só do tempo decorrido após a época de fabricação, agravado ainda pelo fato de se tratar de munição extremamente manuseada, em decorrência da natureza do serviço policial". ${ }^{218}$

Portanto, o soldado Giudice estava munido de uma arma poderosa que, no entanto, por não se encontrar em condições de uso, colocou a sua vida em perigo. Esse PM, mesmo sofrendo o trauma daquela fuga, teve ainda sua vida vasculhada pela polícia política, obrigado a prestar depoimento no DOPS, sob suspeita de ser comparsa dos fugitivos.

Quando começou o tiroteio, um senhor, funcionário da Light passava na frente da penitenciária, do outro lado da rua. Assustado, correu para se proteger atrás de uma árvore na esquina da Rua Viscondessa de Pirassununga com a Rua Frei Caneca. Percebeu que estava voltado na direção de um carro com pessoas com “atitude esquisita”. João Dias Pereira foi se esconder justamente do lado do Aero-Willys! Quando apareceu o soldado da PM Giudice e o pessoal do carro começou a atirar, ele percebeu que estava no meio do fogo cruzado. Diz João que viu algumas pessoas entrarem no carro e "ouviu os homens do carro gritarem para dois homens que atravessavam a Rua Viscondessa de Pirassununga, em direção ao carro: 'É aqui', 'É aqui'. ${ }^{219}$ Eram Prestes de Paula e Michel Godoy, que erraram o caminho para o carro, indo em direção ao bar, na esquina oposta. Quando Godoy entrou no carro, esse já estava em movimento.

Essa desorientação de Prestes e Godoy na hora de entrarem no carro foi contada da seguinte forma pelo último:

\footnotetext{
${ }^{217}$ Idem.

218 AEL, BNM 414, Caixa 1, $2^{\circ}$ volume, folha 501.

${ }^{219}$ Depoimento de João Dias Pereira, em 30 de setembro de 1969. AEL, BNM 414, Caixa 1, $2^{\circ}$ volume, folha. 423.
} 
"perguntado qual foi sua ação ao sair para a rua, respondeu que olhou logo para o sentinela da PM que, ao contrário do planejado, não fora dominada pelo pessoal do apoio exterior; que não vendo o carro que deveria estar em frente, o depoente tentou correr para o bar, para fugir à ação do PM, o qual procurava manobrar sua metralhadora; o depoente voltou-se então e se dirigiu ao carro; foi o último a entrar no automóvel, com esse já em movimento". 220

No momento em que o carro começou a se deslocar, João Pereira levou um tiro no abdômen, "vindo do carro", segundo seu testemunho. ${ }^{221}$ Segundo o Auto de Exame de Sanidade realizado em 16 de outubro de 1969, João Pereira ficaria incapacitado "de maneira permanente para exercício normal de suas atividades laborativas", 222

Sobre o tiro que acertou o eletricista, Flávio Tavares conta a conversa com Celestino, assim que ele abandonou o Aero-Willys próximo ao Maracanã e foi a seu encontro.

"Chorou muito ao contar e só contou quando deixou de tremer:

-Atirei e matei um velhinho que passava na outra calçada!

Com o carro estacionado a 10 metros, na esquina, Pedro estava ao volante, à espera, quando 'os meninos' escaparam pela porta principal da penitenciária e os guardas começaram a disparar, já na rua. Ele puxou o revólver e, do carro, atirou sobre a polícia. Nesse exato momento, um transeunte na calçada do presídio recebeu o impacto e caiu. O ex-marinheiro Celestino transportou os fugitivos sem se perturbar no trânsito caótico do final da tarde, mas agora estava afogado em prantos:

- como é que eu fui matar um inocente? Mas, também, por que ele se meteu no meio da calçada em pleno tiroteio?” (TAVARES, 2005, pp. 55 e 56).

A figura abaixo foi publicada no Jornal do Brasil e ajuda a entender como foi a fuga, porém, com distorções:

\footnotetext{
${ }^{220}$ Depoimento de José Michel Godoy, em 12 de setembro de 1969. AEL, BNM 414, Caixa 1, $2^{\circ}$ volume, folha 391.

${ }^{221}$ AEL, BNM 414, Caixa 1, $2^{\circ}$ volume, folha. 423

${ }^{222}$ AEL, BNM 414, Caixa 1, $2^{\circ}$ volume, folha 497.
} 


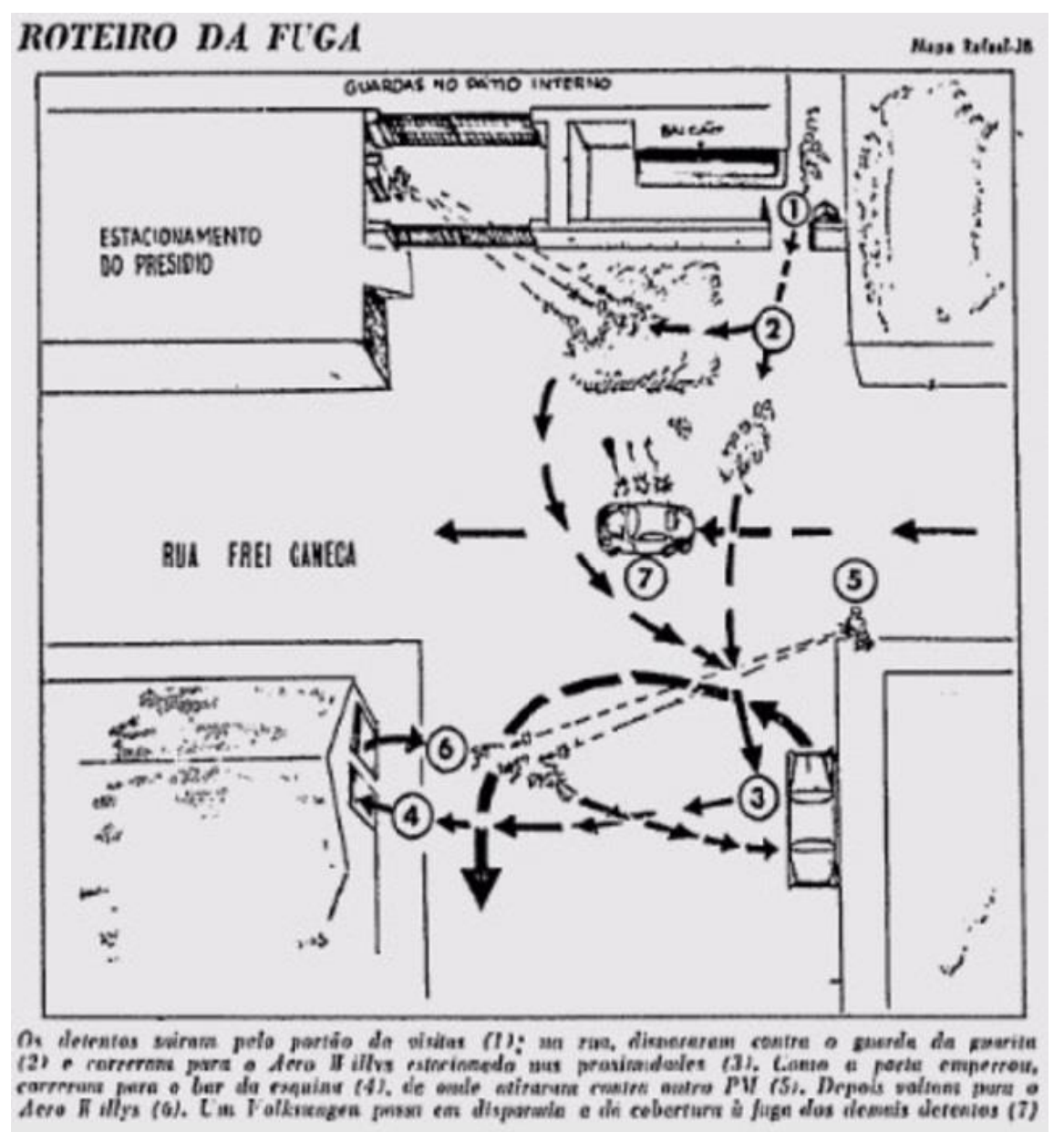

Na simulação do Jornal do Brasil, observamos que havia pessoas do apoio externo no bar da esquina, oposta ao estacionamento do Aero-Willys. Segundo os relatos de Capitani e André, ali, de fato, havia algumas pessoas, possivelmente do grupo Mallet, para ajudar na cobertura da fuga. A respeito, Capitani diz:

"Na realidade, o plano de fuga da prisão previa uma reação, e deveríamos estar preparados. Num bar próximo, havia um grupo de apoio com bombas para serem atiradas se houvesse resistência na prisão. Depois, soubemos que eram bombas muito exageradas $e$, ao invés de cobrir a fuga, iam arrebentar o quarteirão. O grupo acabou ficando com aquelas enormes latas na mão". (CAPITANI, 1997, p. 137).

A ilustração mostra ainda os fugitivos saindo da penitenciária e, da rua, atirando nos guardas da guarita do portão de viaturas. Nós vimos que os guardas foram rendidos por Marcos Antônio e Capitani dentro do portão que dava para a rua. A legenda da ilustração diz que, como a porta do Aero-Willys "emperrou", os fugitivos foram forçados a entrar no bar e, de lá, atiravam no PM. Coisa estranha! O jornalista deve ter concluído que, como houve tiros a partir do bar, logo os fugitivos entraram no bar.... e acrescentou a porta emperrada por conta própria. O volks “que passa em disparada e dá cobertura à fuga dos demais detentos", pode 
ter sido o apoio que chegou para dar cobertura, mencionado por Capitani mais abaixo. Não temos conhecimento de quem estava nele. Sabemos, pelo menos os relatos coincidem, que, depois que o Aero-Willys partiu, houve a passagem, atrasada, de Murillo com o Volks que Flávio Tavares conseguiu. Aliás, Murillo deveria resgatar o pessoal de São Paulo. Quando passou em frente à penitenciária, no entanto, o grupo já havia saído. Pouco mais tarde, passou Flávio Tavares com seu DKV, quando os fugitivos já tinham se deslocado para o transbordo.

A ajuda do apoio externo com automóvel também foi mencionada por André Borges, como podemos observar nessa passagem de seu livro:

"A nossa orientação era de não matar ninguém, só em caso de extrema necessidade. O alarme soou fúnebre. $O$ apoio externo não entrou em ação imediatamente, por não ter podido parar o carro na frente da penitenciária quando chegou, momentos antes. Poderia levantar suspeita. Tiveram que dar uma volta na quadra, momento em que se ouviu o estampido do tiro e foi disparado o alarme". (BORGES, 2008, pp. 28-29).

O ferimento do guarda Jorge Félix Barbosa, atingido na nuca, foi provocado por Prestes de Paula, segundo Capitani:

"Os companheiros começaram a sair. O Prestes vinha na cobertura. Quando ele estava saindo, pareceu que o guarda que eu tinha dominado e colocado no chão iria reagir. Prestes atirou, ferindo-o sem gravidade, e saiu correndo, pulando e dando tiros para cima como se estivesse festejando. Pensou que o tiroteio era a comemoração da vitória. Ele tinha insistido muito para ser o primeiro. Não deixamos porque era um companheiro muito emocional e poderia, desde o início, sair atirando" (CAPITANI, 1997, p.135).

André Borges confirma a versão acima. Temos, no entanto, que considerar até quanto Borges foi sugestionado por Capitani, já que o livro que escreveu narrando esses acontecimentos é posterior ao de Capitani. Viegas, por exemplo, desconhece que Prestes de Paula tenha saído da cadeia festejando. Ele tinha apenas uma arma, com poucas balas.

Quem atirava nos fugitivos da penitenciária? Não eram os guardas das portarias, pois um estava morto, o outro desarmado e ferido na nuca e o terceiro dentro da sala de Recreação e Assistência, também desarmado. As armas estavam trancadas no cofre, cuja chave André levou consigo. O soldado PM Giudice não conseguiu dar um tiro com sua arma, guarnecida com cartuchos velhos. 
As respostas de Capitani e André Borges a essa questão são parecidas, e não satisfazem. Sugerem que o PM Giudice deu vários tiros, o que não confere com o Laudo feito em sua arma, que concluiu que ela "engasgou” por causa de cartuchos mal conservados e antigos. Capitani, no entanto, faz menção a mais um guarda, o PM:

"O apoio externo, involuntariamente, atrasou. Souza [?], Helinho e Zé Duarte formavam o comando especial e chegaram alguns minutos antes. Como não poderiam parar ali na frente, tiveram que dar uma volta na quadra, e a sirene tocou quando estavam na metade do caminho.

Eu gritei para o Marco Antônio:

- Marco, o sentinela.

Havia a orientação de não atirar e não matar. Tiros, só em último caso e, de preferência, nenhum desnecessário. Acertei o pé do sentinela a 50 metros de distância. Estava um pouco escuro, e Marco Antônio também começou a atirar. O sentinela saltou de volta e escondeu-se. Nesse momento, o apoio chegou. Eu e Marco Antônio corremos em direção ao carro, de olho no sentinela e dando cobertura para os companheiros saírem. $O$ sentinela saiu do esconderijo e saltou no meio da rua, buscando em quem atirar. O motorista do carro [Celestino] começou a disparar seu revólver, e nós também. O sentinela ficou entre o fogo cruzado e se escondeu atrás de um rapaz [João Dias Pereira] que, atônito, ficou parado no meio da rua. O rapaz foi ferido, e o sentinela fugiu novamente". (CAPITANI, 1997, p. 135).

Capitani parece estar falando de dois guardas. Não fica claro em sua narrativa se o guarda ferido no pé é o mesmo que "saltou no meio da rua". Giudice levou um tiro em seu coturno, não atingindo o pé. Será que é a ele que Capitani se refere? Anteriormente, Capitani afirmou que Prestes de Paula atingiu Jorge Felix Barbosa. De fato, Barbosa foi ferido na nuca, muito provavelmente por Prestes de Paula. No processo 056/69 que instaurou o IPM, não consta nenhum guarda, ou PM, que tenha sido atingido no pé.

André dá a sua versão, muito parecida com a de Capitani, mas acrescenta que existiam guaritas sobre os muros do Complexo Frei Caneca:

"Marco e Capitani estavam no vão, guarnecidos por dois portões, por onde entram e saem os carros. A guarita da muralha externa ficava a mais ou menos uns 50 metros, à direita desse portão. O Capitani então avisou sobre o perigo do guarda da guarita da muralha. Os companheiros do apoio externo chegaram atirando, estabelecendo-se um fogo cruzado para 
manter a sentinela imobilizada com sua perigosa metralhadora e dar a necessária cobertura à ação, para que os companheiros pudessem sair e atravessar a Rua Frei Caneca, àquela altura já congestionada pelo tiroteio". (BORGES, 2008, P. 29).

A saraivada de balas que quase matou Antônio Duarte, atingindo-o no dedo, e que furou o tanque de gasolina do Aero-willys muito provavelmente veio da primeira guarita à direita da portaria de viatura.

Em seu depoimento ao Encarregado do IPM, o Subtenente Ivo da Silva Costa, da Segunda Companhia do Primeiro Batalhão da Polícia Militar, lotado no Presídio do Estado da Guanabara, disse que as guaritas guarnecidas pelos soldados PMs eram "muito afastadas entre $s i$ ”, o que dificultava a comunicação entre os soldados e o chefe da guarda. ${ }^{223}$

Abaixo, identificamos as guaritas nos muros da frente das penitenciárias, "afastadas entre si", como disse o oficial.

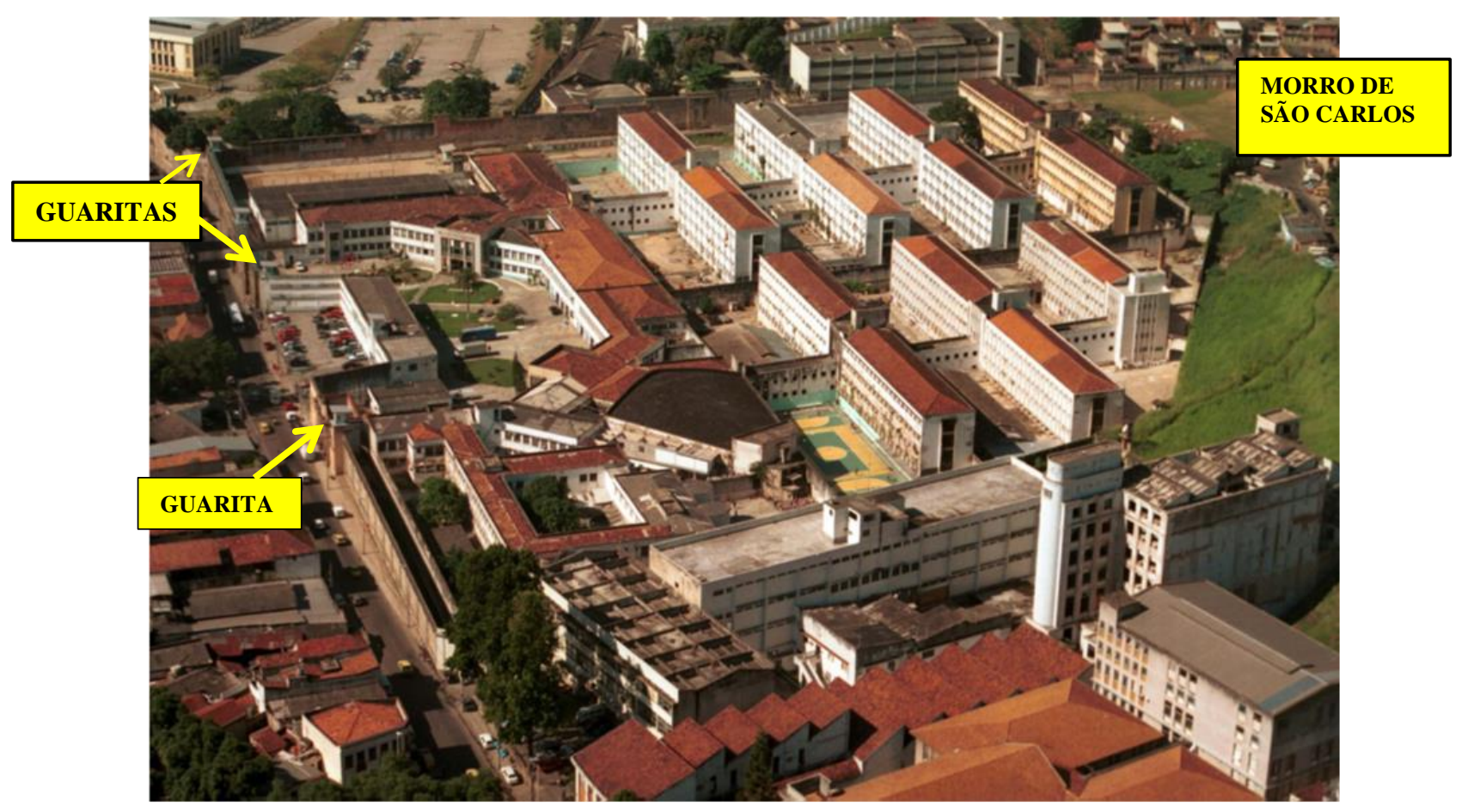

É possível que houvesse soldados PMs nas guaritas à direita da portaria. Mas, à esquerda, em sentido ao Presídio do Estado da Guanabara, tudo indica que não havia vigilância nas guaritas. Pelo menos foi o que entendemos do depoimento do Comandante da Companhia da Polícia Militar que fazia a segurança externa do Complexo Frei Caneca, Capitão Amaro Carlos Alberto Brasil do Nascimento:

${ }^{223}$ AEL, BNM 414, Caixa 1, $2^{\circ}$ volume, folha 489. 
"Que para o posto em frente a portaria ficou estabelecido que o soldado deveria se deslocar continuamente no trecho entre a rua Viscondessa de Pirassununga até o Presídio do Estado da Guanabara [trecho de patrulhamento do soldado Giudice], visando principalmente a vigilância dos muros, já que nas portarias havia quatro homens da Guarda Penitenciária. Nos postos junto ao morro [de São Carlos, atrás da penitenciária, visível na fotografia acima] havia denso matagal que propiciou inclusive a que marginais tomassem a metralhadora de um $P M^{\prime \prime} .224$

Quando todos os nove fugitivos chegaram ao Aero-Willys e se espremeram dentro dele, estando Antônio Duarte, Adeildo, Godoy e André (abaixado no chão) no banco da frente e Benedito, Marcos, Capitani, Prestes e Cietto no banco de trás, Edvaldo Celestino apertou o acelerador e subiu a Rua Viscondessa de Pirassununga, passando a Rua Senhor de Matosinhos, virou à esquerda na Avenida Salvador de Sá. Logo na primeira rua, Correia Vasques, virou à direita, indo até o seu final, uns duzentos metros, quando entrou à esquerda, na Rua Júlio do Carmo e imediatamente à direita, na Rua Amoroso Lima. Na primeira rua, virou à direita, Rua Afonso Cavalcanti, a rua do transbordo, mais ou menos 500 metros da Lemos Brito.

O mapa abaixo mostra o trajeto que o Aero-Willys fez da Lemos Brito até o local do transbordo.

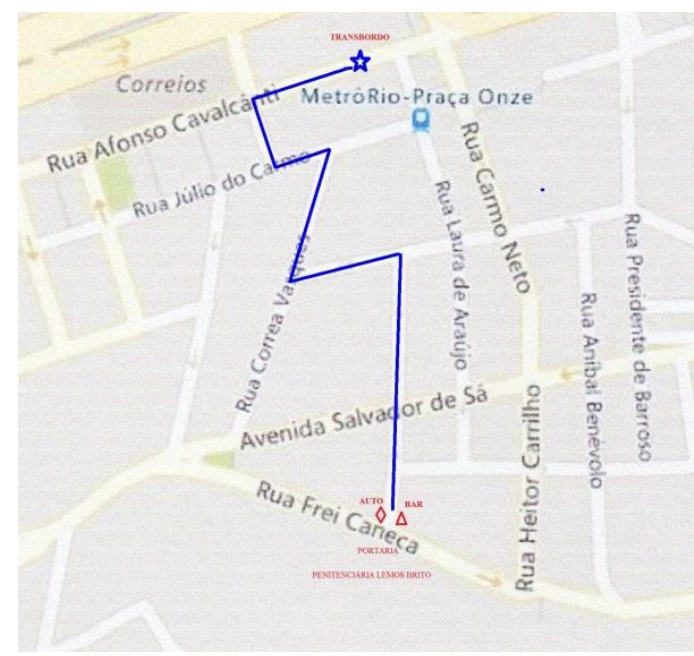

Triângulo: bar; Losango: automóvel; Linha azul: trajeto do Aero-Willys; Estrela: local do transbordo.

Para que não ocorresse nenhuma falha, José Duarte percorreu todos os pontos da ação. Por exemplo, passou na frente da Lemos Brito, viu o Aero-Willys estacionado na Rua 
Viscondessa de Pirassununga e foi para o local de transbordo, onde encontrou os dois carros, a Kombi e a Rural-Willys, com seus motoristas. Ali estavam Viegas, Sérgio Lúcio, Luiz Mário Neri e Júlio Cesar Brandão. ${ }^{225}$ Conversou um pouco com Viegas, que lhe censurou por ter se esquecido de providenciar um segundo automóvel, ${ }^{226}$ e foi embora a pé, "tendo dito que aguardassem que o pessoal chegaria”, segundo Sérgio Lúcio em seu depoimento. ${ }^{227}$

Chegando à Rua Afonso Cavalcanti, atrás do Hospital-Escola São Francisco de Assis, tendo do outro lado da calçada a Escola de Enfermagem Anna Nery, do Aero-Willys, desceram os evadidos rapidamente, alguns com camisas já trocadas durante o trajeto até o transbordo. Na hora de mudarem de automóvel, os fugitivos não seguiram o que estava combinado, ou seja, que cada um entrasse rapidamente no carro previamente designado. Houve um "certo tumulto”. Segundo Viegas, Capitani e Antônio Duarte saíram do AeroWillys de armas nas mãos, o que "serviu para despertar atenção de populares", e eles acabaram por sobrecarregar a Rural-Willys. ${ }^{228}$ Godoy fala em seu depoimento que nessa hora quase todos entraram na Rural, sendo ele o primeiro, "por afobação", 229

Na perua Kombi, foram Sérgio Lúcio, como motorista, Marcos Antônio, Prestes de Paula e o dono da Kombi, Luiz Mário Neri. Na Rural-Willys, se espremeu o restante, sendo que Antônio Duarte e Adeildo Ramos foram camuflados na mala e André Borges deitado no chão do banco traseiro. Júlio Cesar Bueno Brandão, o dono do carro, foi dirigindo, tendo Pedro Viegas ao seu lado. No banco traseiro, sentados, estavam Cietto, Godoy, Capitani e Benedito.

A Kombi saiu rapidamente, seguida pela Rural com destino a Mangaratiba. Segundo Godoy, Júlio Cesar Brandão não conhecia o caminho, ou seja, não sabia como sair da cidade, por isso tinha que acompanhar a Kombi. No entanto, ao perder a Kombi de vista, ficaram sem direção. Godoy conta como foi:

"Respondeu [à pergunta] que largaram, seguindo a Kombi para Mangaratiba; que o rapaz que dirigia não conhecia bem o caminho e depois perderam a Kombi de vista; tiveram de parar para perguntar pelo caminho".

\footnotetext{
${ }^{225}$ Depoimento de Pedro Viegas. AEL, BNM 414, Caixa 1, $2^{\circ}$ volume, folha 352.

${ }^{226}$ Idem. Folha 354.

${ }^{227}$ Depoimento de Sérgio Lúcio de Oliveira Cruz. AEL, BNM 414, Caixa 1, $2^{\circ}$ volume, folha 336.

${ }^{228}$ Depoimento de Pedro Viegas. AEL, BNM 414, Caixa 1, $2^{\circ}$ volume, folha 354.

${ }^{229}$ AEL, BNM 414, Caixa $1,2^{\circ}$ volume, folha 391.
} 
Enquanto os dois automóveis tentavam deixar a cidade, e deveria ser o mais rápido possível, para não dar tempo de a polícia fechar as saídas com barreiras de inspeção, Flavio Tavares, para despistar os policiais, foi a um telefone público e ligou para o Secretário da Segurança, falando espanhol e passando-se pelo Embaixador do Uruguai. Viegas narra a conversa entre o "Embaixador uruguaio" e o oficial:

"Flávio Tavares, Ciro e Jarbas, membros integrantes dessa célula [do MAR], foram a um telefone público. Flávio fala e escreve um espanhol perfeito e fluente, dando-se ao luxo de empregar termos íntimos e regionais desse idioma. Ligou diretamente para o gabinete do secretário da Segurança, cuja pasta era ocupada pelo general Luís de França Oliveira. Utilizando-se de um 'portunhol' proposital, fez-se passar pelo embaixador do Uruguai no Brasil. Do outro lado da linha atendeu o coronel Encarnação, assessor direto do secretário Luís de França, que informou que o general se encontrava ausente. Flávio disse a ele que o assunto somente poderia ser tratado diretamente com o secretário, dada a urgência $e$ gravidade do assunto que pretendia expor. O coronel crescia em curiosidade, argumentando que na ausência do general ele tinha poderes para solucionar qualquer problema. Mas Flávio queria que a panela cerebral do coronel fervesse, criando mais e mais expectativa, enquanto punha alguma lenha a mais na fogueira acesa. Insistia na delicadeza diplomática do problema que o cercava e, por isso, na importância de falar com o general. Quando percebeu que o clima tinha chegado ao seu auge de curiosidade, disse ao coronel, a essa altura dominado pela impaciência, que a embaixada, que permanecia no Rio, no Catete, estava sendo assediada por um grupo de indivíduos suspeitos, que espionavam o jardim. Encarnação exasperou-se e 'matou', a seu ver, 'a charada': 'São bandidos, presos comuns, gente perigosa e da pior espécie. Dentro em pouco terei mobilizada aí o que há de melhor de nossa polícia'. E cumpriu o prometido, mostrando que realmente tinha poderes. Não houve demora para que muitas viaturas chegassem ao local, com imensos contingentes de homens armados. A embaixada foi totalmente cercada por policiais civis $e$ militares". (VIEGAS, 2004, pp. 96 e 97). ${ }^{230}$

Enquanto os policiais iam em direção à embaixada do Uruguai, os evadidos saíam da cidade pelo lado oposto.

Capitani conta um episódio que aconteceu ainda no perímetro urbano, envolvendo Cietto, o preso comum que abriu mão de seu plano para se integrar ao do Coletivo. Na

\footnotetext{
${ }^{230}$ Essa narrativa sobre o telefone encontra-se no livro de Flávio Tavares, (Tavares, 2005), de forma mais alegórica, nas páginas 61 a 64 .
} 
verdade, ele acreditou na palavra de Marcos Antônio e Capitani de que não o deixariam na cadeia, se a fuga fosse exitosa:

“Na Rural, já estávamos de roupa nova. Chegamos no centro. Paramos para dar um 38 para o Cieto.

- Taí, companheiro, era nosso compromisso. Cumprimos nossa palavra, agora tu estás livre e pedes ir para onde quiseres. Arruma tua vida, não temos mais compromisso contigo.

Ele olhou meio enviesado.

- vocês estão loucos. Eu vou junto.

Ficamos em uma situação difícil porque conhecíamos seus problemas de saúde e, além do mais, o Cieto transava muito tóxico, fumava muita maconha, era um viciado.

- vamos para as montanhas, enfrentar combates, ser comidos pelos mosquitos, passar fome, sede. Tu não vais aguentar essa vida, não vais te adaptar. É melhor ficar.

- De jeito nenhum. O que eu tenho para fazer aqui? Pegar esse 38 e sair dando tiro? Vou acabar sendo morto ou preso novamente. Não me interessa nada disso. Eu vou com vocês e o que tiver que passar, eu passo. Ganhei confiança. Vocês cumpriram o compromisso e vou jogar na sorte". (CAPITANI, 1997. P. 136).

Esse relato de Capitani não aparece nos livros memorialísticos de seus companheiros, que também estavam na Rural, Antônio Duarte e André Borges. Viegas e Adeildo disseram em suas entrevistas que a Rural-Willys foi diretamente para a saída da cidade. Não parou no centro, mas, ao contrário, ela partiu do centro para a periferia, e a conversa com Cietto se deu na Cabana do Jacu, conforme os mesmos testemunhos. Há um consenso entre essas narrativas de que, enquanto estavam na Rural-Willys, prevaleceu um silêncio tenso na maior parte do tempo. Todos já tinham trocado de camisa por similares coloridas, bem diferentes das de presidiários. Antônio Duarte conta que recomendaram a Michel Godoy que se deitasse no chão, tal qual André Borges, principalmente quando apareceu à frente do carro uma viatura policial. A tensão subiu às alturas. Antônio Duarte conta o que presenciou:

"Depois da Estação do Maracanã, quase à altura de São Francisco Xavier, surgiu em nossa frente um carro da polícia. Um camburão, como se conhecia na linguagem popular. Era uma camioneta Ford. Não dava para saber quantos policiais viajavam ali. Diminuímos a marcha. $O$ carro de polícia fez o mesmo, mas continuava à nossa frente. Em nosso carro havia certa 
inquietação. Nervosamente, segurávamos os coldres das armas. André Borges e Godoy afundaram no piso do nosso pequeno ônibus [Rural Willys]. Prestes de Paula mantinha a calma, e Marcos [equívoco de Duarte; Marcos Antônio estava na Kombi] olhava nervosamente para o carro em nossa frente, que parecia estar se comunicando pelo rádio com alguma central.

'Porra! Que fazer?' - balbuciou alguém no banco de trás ao meu lado. Minhas mãos apertavam o cabo do revólver de forma tão angustiante que o suor escorria, molhando a arma. Será que eles já sabem de nossa fuga?

Uma voz, vinda do sumiço de nossas almas, comentou desvanecida. 'Será que já nos caçam?' Outro respondeu: 'quem esperava algum passeio de domingo'!

'Entre na primeira rua à esquerda' - gritou alguém muito preocupado. 'calem a boca! Temos motorista. É ele quem dirige, fiquem quietos!' - bradou Marcos [talvez tenha sido Pedro Viegas, que estava no banco da frente]. Prestes de Paula riu, um pouco exaltado pelo momento dramático.

O carro da polícia virou à direita e entrou na ponte da Estação de São Francisco Xavier. A sensação de alívio encheu o carro em que viajávamos". (DUARTE, 2009, pp. 340 e 341)

Enquanto isso, na Kombi onde viajavam Marcos Antônio, Prestes de Paula, Sérgio Lúcio e Luiz Neri, o silêncio durou muito tempo. Marcos Antônio e Prestes de Paula trocaram os uniformes de detentos pelas roupas que estavam na Kombi. Marcos vestiu a calça que Sérgio Lúcio lhe deu, mas ficou curta e apertada. Sérgio Lúcio falou em seu depoimento que Marcos dissera ter havido problema na portaria, "que Capitani teria iniciado um tiroteio e que ele esvaziara seu revólver dando tiros para o alto". ${ }^{231}$ No depoimento de Luiz Mário Neri, ele diz que não conhecia Marcos Antônio e Prestes de Paula. Que havia alugado sua Kombi e estava acompanhando o grupo até Mangaratiba porque foi obrigado, já que conhecia o caminho para o acampamento do Jacu. Quando perguntaram se ouvira comentários sobre a fuga, ele respondeu: "que ouviu apenas quando comentaram 'será que morreu? Precipitaram, não era para fazer isso', que não sabe quem foi o autor do disparo parecendo que não foi nenhum dos que estavam no seu carro”. ${ }^{232}$ À mesma pergunta, Sérgio Lúcio respondeu que Marcos Antônio falou que Capitani começou um “tiroteio desnecessário”.

\footnotetext{
231 AEL, BNM 414, Caixa 1, $2^{\circ}$ volume, folha 340.
}

${ }^{232}$ AEL, BNM 414, Caixa $1,2^{\circ}$ volume, folha 400. 
A Kombi chegou ao destino, próximo de Itaguaí, distante de Mangaratiba aproximadamente trinta quilômetros, por volta das 20h:30. Atravessou a ponte do rio da Guarda e deixou os fugitivos ${ }^{233}$. Prestes de Paula, Marcos Antônio e Luiz Mário Neri ali ficaram esperando os companheiros da Rural. Sérgio Lúcio retornou sozinho com a Kombi e, no caminho, cruzou com a Rural, parando para conversar. Rapidamente, Adeildo e Antônio Duarte foram para a Kombi e os dois automóveis partiram para Itaguaí. Segundo Capitani, assim que os automóveis chegaram ao destino, o motorista da Rural-Willys, Júlio Cesar Brandão, pôs-se a chorar "quase em desespero". Tanto a Rural, quanto a Kombi retornaram para o Rio de Janeiro. Luiz Mário Neri, dono da Kombi, ficou para ensinar o caminho até a Cabana do Jacu.

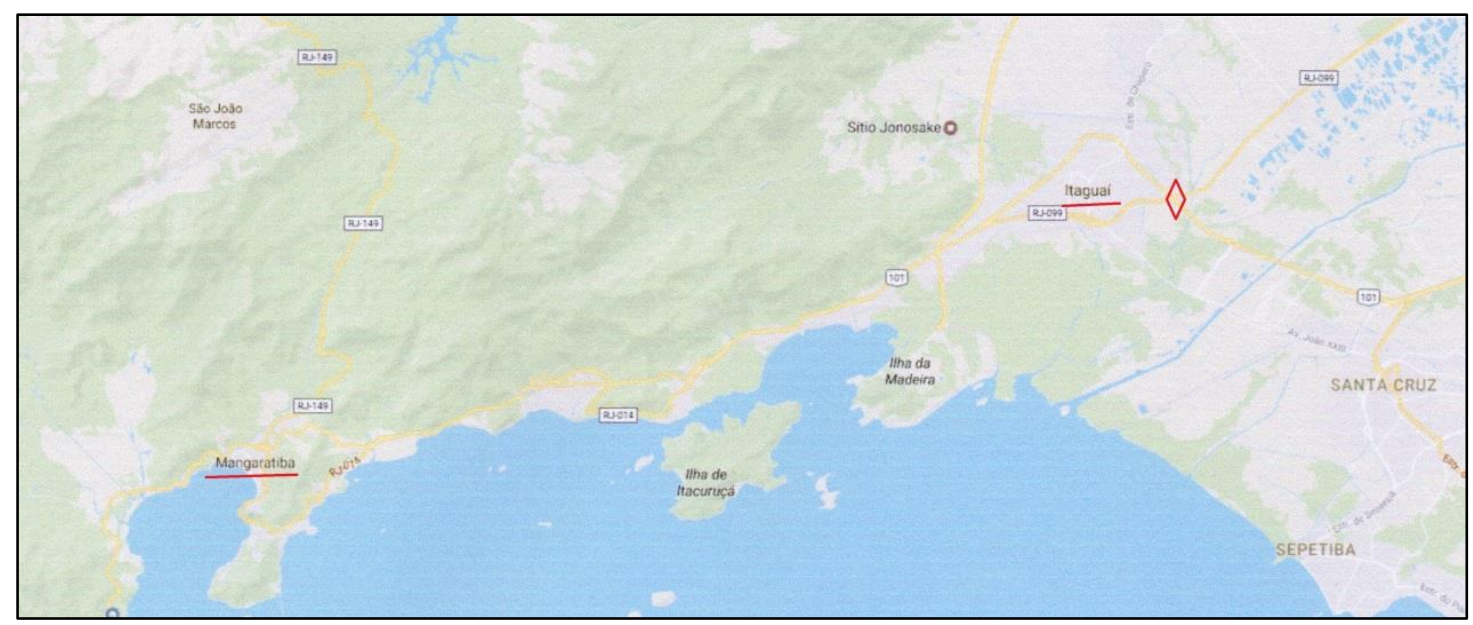

O triângulo vermelho assinala o local onde o Coletivo desembarcou dos carros. Grifado em vermelho, Itaguaí e Mangaratiba

O Coletivo se reunia novamente. Dois anos preparando uma fuga, chegando a criar uma organização que integrou várias pessoas, para reconquistar a liberdade. E ali, diante de uma estrada de terra e de uma mata fechada, os onze homens sentiam que uma nova aventura começava e que seria perigosa, certamente.

No dia seguinte, 27 de maio de 1969, os jornais noticiaram a fuga com informações desencontradas: o jornal $O$ Globo, mais sensacionalista, trouxe a manchete de primeira página "Penitenciária assaltada", dizendo que dois Aero-Willys e um volks "assaltaram" a cadeia para tirar os detentos políticos. Disse ainda que o Guarda penitenciário Airton de Oliveira, sem arma, usando seu apito insistentemente, correu para o portão interno "na tentativa de abri-lo para ter a ajuda dos demais guardas, que queriam ajudá-lo, mas estavam trancados, pelo lado de dentro da Penitenciária. Na corrida, um dos atacantes externos fez pontaria e o

\footnotetext{
${ }^{233}$ Entrevista de José Adeildo Ramos, em 23 de janeiro de 2017.
} 
abateu com um tiro. ${ }^{234} \mathrm{Na}$ mesma página, o jornal diz que "são nove os que escaparam no mais audacioso plano de fuga já executado contra uma cadeia no Brasil: assalto para libertar detentos". O jornal traz, também, as fotos dos evadidos, tendo Prestes de Paula acima dos demais e considerado como seu comandante. Na edição do dia 28, O Globo diz que "uma mulher foi o elemento de ligação de fora para dentro da penitenciária, entre os grupo dos nove fugitivos e os que lhes deram cobertura no plano da escapada. Sua identidade, ainda mantida em sigilo, foi levantada pela credencial de visitas". ${ }^{235} \mathrm{O}$ suspense criado pelo jornal sobre a mulher misteriosa, mantida em sigilo, foi revelado na edição do dia seguinte, 29 de maio, com uma matéria extensa sobre as mulheres subversivas que ajudaram na fuga. Irresponsavelmente, $O$ Globo publicou na primeira página a foto de Kátia Valadares, mulher de Marcos Antônio, abaixo da manchete: "Essa é a bela subversiva do assalto à Penitenciária". Uma manchete sem dúvida chamativa, além de sensacionalista. Ou seja, a bela mulher rica, casada com um negro ex-marinheiro comunista, ajudou na fuga de nove “elementos". Mas, a irresponsabilidade do jornal foi além, envolvendo, também, mais duas "mulheres envolvidas no esquema de fuga”, Érika Bayer Roth e Lêda Viegas. Na primeira página, como que apresentando a priori o veredito da fuga, o jornal diz :

"Érika Bayer Roth, que participava de uma célula comunista, a 'Encouraçado Potemkin', dentro da Lemos Brito, e Lêda Viegas, esposa de outro agitador e que realizava, profissionalmente, visitas a detentos na penitenciária”. Em sua página 16, o jornal dá o caso como resolvido. Sob a manchete "3 mulheres identificadas no assalto à penitenciária”, diz: "três mulheres estão identificadas pelas autoridades como tendo participação ativa, na preparação do assalto à penitenciária e nos planos dos subversivos que formavam a célula 'Encouraçado Potemkin',.' 236

\footnotetext{
234 Jornal $O$ Globo. 27 de maio de 1969, p. 24.

235 Jornal $O$ Globo. 28 de maio de 1969, p. 1.

${ }^{236}$ Jornal O Globo. 29 de maio de 1969, p. 16.
} 

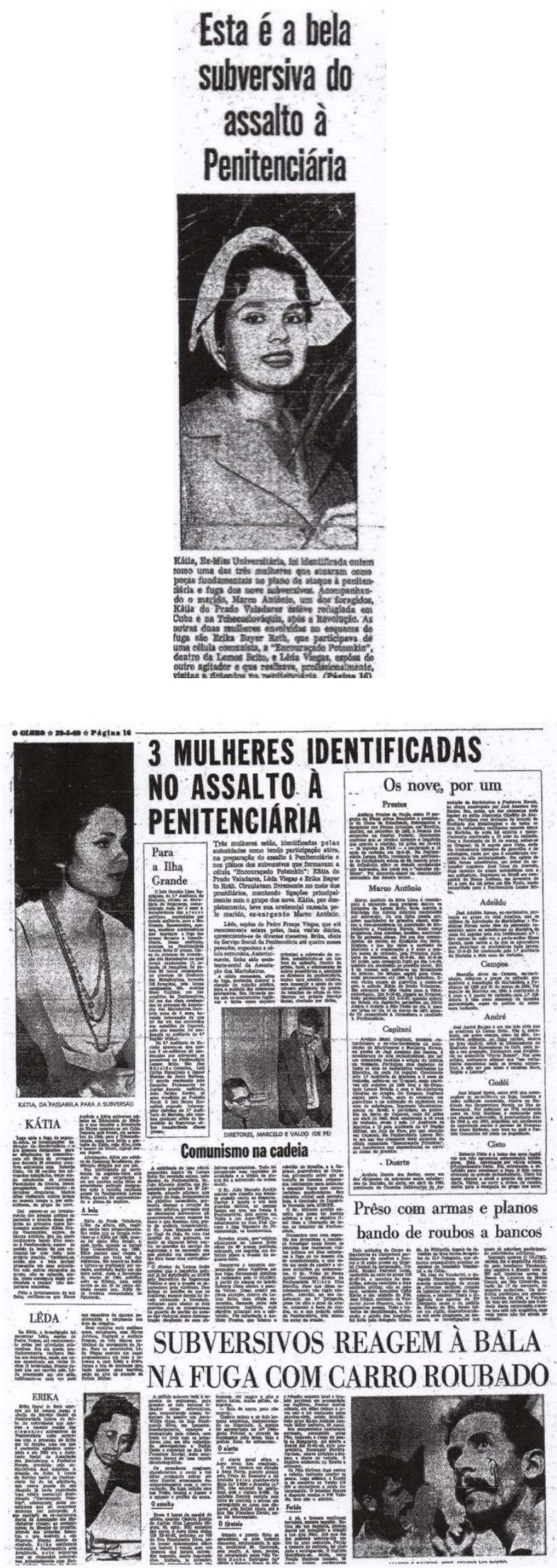

Jornal O Globo, 29 de maio de 1969, p. 16. Observar Érika Roth, que foi até a sede do jornal pedir retratação. 
O Jornal do Brasil foi mais comedido em suas notícias, mesmo assim desorientadas. Como já falamos, ele apresentou um desenho de como teria sido a fuga, não muito diferente do que realmente aconteceu. O jornal entrevistou o guarda Aracy Caetano de Oliveira, que disse suspeitar do estudante de Direito que deixara seu Volks interrompendo a portaria de viaturas e que lhe pediu sua arma, exatamente na hora da fuga. Oliveira disse que o estudante desviou sua atenção, facilitando a ação dos fugitivos. "eu me virei para pegá-la, quando senti um braço em meu pescoço, me sufocando. Quando me voltei estava dominado por três homens que não pude reconhecer. Acabei trancafiado numa sala". ${ }^{237}$ Ainda segundo o Jornal do Brasil, o governo federal se mobilizou para prender os fugitivos. Diz que os organismos de segurança e informação do governo (Serviço Secreto do Exército, Serviço Nacional de Informação e Cenimar) "estão investigando a fuga em todos os detalhes e implicações. $O$ governo acredita que a evasão foi concebida com a ajuda de elementos estranhos ao corpo de funcionários". Sobre o guarda que morreu, o jornal traz sua versão, de que os fugitivos atiraram em Aracy Caetano da Silva sem que esse oferecesse perigo: "sem fazer barulho, três dos nove fugitivos se esgueiraram e dispararam suas armas sobre o guarda”. Veremos mais à frente, que essa versão será utilizada pelas autoridades penitenciárias. Sob a Manchete "Polícia se mobiliza em massa”, o jornal diz que "cerca de 295 homens das polícias civil e militar, armados de metralhadoras e bombas de gás, foram mobilizados pelas autoridades imediatamente após o alarme da fuga. Estavam chefiados pelo delegado de Vigilância, Sr. Moacir de Novais". ${ }^{238}$ Com esse contingente de homens, parece-nos que a orientação aos órgãos de segurança e informação era a de prender imediatamente os fugitivos e desbaratar as organizações que participaram da fuga.

O Correio da Manhã fez uma reconstituição da fuga em 6 "atos", seguindo uma ordem cronológica. O estudante de Direito, José Carlos de Almeida Nascimento, que foi pegar sua arma na portaria, aparece como o principal suspeito. Segundo o jornal, as autoridades policiais desconfiavam de que o advogado que fora conversar com Cietto, apenas para que ele fosse requisitado e pudesse fugir às 17h:30, era o próprio Nascimento. Além disso, ele teria obstruído a passagem das viaturas de propósito. O jornal trouxe, também, no dia 28 de maio, o testemunho de Jorge Félix Barbosa, feito no Hospital onde estava internado, citado na página 272 .

\footnotetext{
237 Jornal do Brasil. 27 de maio de 1969, p. 14.

${ }^{238}$ Idem.
} 
No dia 30 de maio, o Jornal do Brasil, trouxe uma notícia que se contrapunha à de $O$ Globo, quando esse jornal condenou Kátia, Lêda e Érika. Diz a notícia:

“O DOPS inocentou ontem de qualquer suspeita a Sra. Kátia Valadares de haver colaborado na fuga dos detentos da Lemos de Brito. Ela atualmente dedica-se apenas ao filho, ao trabalho e aos estudos, e há quase um ano não vê seu ex-marido, Marcos Antônio Lima, um dos fugitivos. O DOPS negou também a acusação a outras mulheres implicadas no caso [Leda e Érika]". 239

A matéria acima foi apresentada na primeira página do jornal e, também, na sétima, mais ampla, em que fala também de Leda e Érika. O texto diz que o DOPS inocentou as meninas “ontem", exatamente no dia em que $O$ Globo dissera que eram elas as culpadas pela fuga. No dia seguinte, 31 de maio, o jornal Correio da Manhã publicou, em sua página 8, matéria em que a manchete era: "moças denunciadas provam sua inocência”. Diz o jornal: "As autoridades do DOPS, diante das informações de Érika chegaram a conclusão que nem ela nem as outras duas moças apontadas por um vespertino [O Globo?] como implicadas na fuga, não tiveram a mínima participação nos acontecimentos”.

Mesmo com a declaração do DOPS de que as mulheres não tiveram envolvimento na fuga, o jornal $O$ Globo não se retratou. No dia 30, ouvindo do pai de Kátia que ela estava "completamente alheia ao plano de fuga e que desde 1967, quando se separou do marido, Kátia nunca mais se avistou com ele”, o jornal retrucou:

"contrariando o prof. Clarivaldo Prado, as investigações já realizadas pelas autoridades policiais e pela direção da Penitenciária Lemos Brito comprovam que, apesar de Marcos Antônio haver cassado a credencial de sua esposa Kátia, ela continuava frequentando aquele estabelecimento. O pedido de suspensão da credencial, por outro lado, só foi feito há dois ou três meses, contrariando mais uma vez a assertiva do professor, de que sua filha não via o marido desde 1967. (...) quando os guardas que tomam conta do portão central afirmaram que a mulher a quem Ihes foi exibida uma fotografia era mesmo Kátia, e que suas visitas eram constantes". 240

Kátia Valadares afirmou que processaria o jornal que publicara as matérias ofensivas a ela. Devia estar se referindo a $O$ Globo.

\footnotetext{
${ }^{239}$ Jornal de Brasil. 30 de maio de 1969, páginas 1 e 7.

240 Jornal $O$ Globo. 30 de maio de 1969, p. 16.
} 
Na sua edição de 29 de maio, na página 8, o jornal Correio da Manhã trouxe uma entrevista com o diretor da Lemos Brito, João Marcelo de Araújo, em que ele afirma que "os fugitivos formavam uma célula comunista dentro da Penitenciária, cujo objetivo principal, além de doutrinar os outros presos, seria o de provocar uma rebelião geral o que resultaria num prato ideal para os chamados guerrilheiros urbanos". E continua: "o que houve na tarde de segunda-feira, foi um verdadeiro assalto à penitenciária. A fuga foi de fora para dentro e não de dentro para fora. Nós recebemos bala e não desfechamos nenhuma”.

Está claro que o discurso do diretor teve a intenção de tirar de seus ombros a culpa pela fuga. Nesse momento, os podres da penitenciária vieram à superfície, através da imprensa. As facilidades que os presos tinham em adquirir maconha, aguardente e até armas escandalizou a opinião pública. Mas, entendemos, para manter esse discurso de que não havia problemas dentro da penitenciária e que o Mal veio de fora, Marcelo Araújo demonizou os fugitivos, como nessa passagem da matéria, que tem o subtítulo "perversidade":

\begin{abstract}
"Houve - prosseguiu - requintes até mesmo de perversidade para desmoralizar as autoridades e para que a opinião pública fosse informada de que eles, se quisessem, poderiam matar os guardas e promover uma rebelião geral na Penitenciária. A tentativa de homicídio que sofreram os nossos guardas teve requintes de crueldade, totalmente desnecessários, uma vez que eles já se haviam evadido através da portaria de pedestres e retornaram ao portão nas [das] viaturas unicamente para provocar lesões nos guardas, uma
\end{abstract} vez que poderiam, perfeitamente, ter alcançado e entrado nos carros que os esperavam". ${ }^{241}$

Em seu depoimento no Inquérito Policial Militar, Sérgio Lúcio Cruz falou que ficou chocado com a notícia de que os fugitivos, que já estavam na rua, voltaram para atirar nos guardas desarmados. Ele contou que se afastou do grupo por causa disso e que, quando José Duarte lhe pediu para buscar de automóvel Prestes de Paula e Cietto em Mangaratiba, ele recusou. José Duarte confirmou esse encontro e o afastamento de Sérgio Lúcio. Certamente Cruz lera a entrevista acima.

$$
\text { *** }
$$

Assim que os automóveis chegaram a seu destino, em Itaguaí, logo depois da ponte do Rio da Guarda, na época um povoado com suas casas simples e ruas de terra, o Coletivo, novamente unido, entrou na mata da Serra de Angra dos Reis e foi seguindo as trilhas e

\footnotetext{
${ }^{241}$ Jornal Correio da Manhã. 29 de maio de 1969, p. 8.
} 
picadas, tendo como guias Viegas e Luiz Mário Neri. Seguiram em direção a Mangaratiba, distante aproximadamente 30 quilômetros. Caminharam à noite, tropeçando em troncos, escorregando na lama, se arranhando em galhos e folhas. Estava escuro, com o céu encoberto pelas nuvens. Pouco se via à frente.

Aqueles homens ficaram exaustos! Não estavam preparados para longas caminhadas, em trechos tão difíceis como aqueles que faziam. Por mais que fizessem exercícios na cadeia, seus corpos se acostumaram com a inatividade, nos limites dos muros do cárcere.

Próximos a Mangaratiba havia um riacho e uma bifurcação, que confundiram Viegas e Luiz Neri. Viegas já tinha feito esse caminho anteriormente, mas no sentido contrário e durante o dia. Naquela escuridão, seria arriscado caminhar com os homens mais procurados do Estado da Guanabara. Eles não podiam, de forma alguma, ser vistos por populares. Daí, caminharem dentro da mata e à noite. Não podiam, também, andar próximos a povoados, que sempre têm cachorros que dão o alerta ao dono da presença de estranhos.

Por sugestão de Marcos Antônio, o Coletivo ficaria acampado naquele lugar, enquanto Viegas e Luiz Mário Neri iriam até à Cabana do Jacu pedir a José Gonçalves de Lima, aquele amigo de André, ex-presidiário da Lemos de Brito, que contribuiu para a união entre o MAR e o Grupo Mallet, que fosse buscar os homens acampados. José Gonçalves também era conhecido como "Sr. José”, ou “Sr. Zé”, ou ainda, “Zé do Burro”.

Viegas e Luiz partiram imediatamente ${ }^{242}$ para a Cabana do Jacu. Do local onde se encontravam até Conceição de Jacareí, outro povoado de pescadores, onde moravam Sr. José e Oswaldo Migues de Souza, "Vadinho", PM que prestava serviço na Penitenciária Cândido Mendes, na Ilha Grande, a distância aproximada era de 20 quilômetros. No entanto, a partir do povoado de Conceição de Jacareí, eles deveriam subir a serra, no meio do mato, através de picadas e trilhas já conhecidas, mais alguns quilômetros de chão escorregadio, pedras lisas, cipós, troncos no meio do caminho etc. E para lá foram. Imaginamos que esses dois homens andaram na noite, e é bom ressaltar isso, em terrenos com topografia absolutamente irregular, mais ou menos, 60 quilômetros! Viegas conta que, quando lá chegaram, ele estava exausto, mas disposto a voltar naquela noite mesmo para buscar o restante do grupo. Foi desaconselhado pelo Sr. José, conhecedor daquelas plagas. Viegas conta que, mesmo

\footnotetext{
${ }^{242}$ Entrevista de Pedro França Viegas a Flávio Luís Rodrigues. Iperó, 09 de outubro de 2008. José Adeildo Ramos afirmou que Viegas e Luís partiram ao amanhecer - João Pessoa, 21 de julho de 2011.
} 
disposto, não aguentaria caminhar mais, pois seus pés estavam destruídos, por causa de seus tênis ordinários.

"Assim foi feito, mas tive que ficar na cabana porque meus pés se encontravam bastante machucados pelos tênis com número inferior ao que eu calçava. O fato é que eram de qualidade ordinária e haviam encolhido após serem encharcados numa dessas chuvas torrenciais que costumam desabar sobre a Cidade Maravilhosa em determinadas épocas do ano". (VIEGAS, 2004, p. 98).

Logo nos primeiros piados dos pássaros, Sr. José e Luiz Mário desceram a serra em direção a Conceição de Jacareí. Ali, ficou Sr. Zé, a preparar a chegada do Coletivo, enquanto Luiz Mário foi ao encontro do grupo para trazê-lo ao povoado. Levava boa quantidade de farofa para os esfomeados.

De fato, aqueles homens estavam sem qualquer alimentação desde o almoço do dia 26. Depois da caminhada que fizeram, desde Itaguaí, a fome só aumentou. Não podiam sair da caverna onde se encontravam. ${ }^{243}$ Dali, ouviam ao longe pessoas conversando. Seria arriscado saírem para procurar o que comer. A saída, segundo Antônio Duarte foi coser bananas verdes:

"Passamos a noite nessa caverna. Bebemos água de uma fonte que jorrava na montanha. Com as mãos em concha, sorvíamos aquele delicioso líquido. A fome apertou. Não tínhamos nada o que comer, pois achávamos que durante a noite daria tempo de percorrer os vinte quilômetros até a segurança [como temos dito, houve um erro de cálculo, em relação à distância, quase o triplo do que imaginavam]. (...) Escondidos das vistas de eventuais caminhantes da floresta, esperamos dentro daquele abrigo natural até a noite seguinte. Comemos uma 'sopa' de bananas verdes, cozinhando-as até se dissolverem". (DUATE, 2009, p. 342).

Ali passaram o dia 27 todo, esperando o pessoal de Mallet para resgatá-los. Luiz chegou ao final do dia, e logo retornou com o Coletivo, direto para Conceição do Jacareí, mais ou menos 25 quilômetros de distância. Foi outra caminhada difícil. Por dentro da mata, caminhando debaixo de árvores enormes, "tropeçando pelos caminhos, nos arranhando nos espinhos das brenhas, chegamos a uma praia, situada em pequena baía. Eram duas horas da manhã” (DUARTE, 2009, p. 342). Essa praia de que Duarte fala ficava na periferia do

\footnotetext{
${ }^{243}$ Segundo Antônio Duarte e Adeildo. Pedro Viegas diz que eles ficaram acampados no mato.
} 
povoado. Lá estava Sr. José a esperá-los. A emoção foi grande, com discursos empolgados ${ }^{244}$ saudando a revolução. Há divergência em relação à presença de Sr. José na praia. André Borges diz que o encontro com o Sr. José se deu na casa dele, em Conceição de Jacareí.

Antes de atingirem a orla da praia, porém, o grupo aguardou, próximo à praia, um sinal de Viegas e Marcos com a mão.

Enfim, o mar! Há quantos anos aqueles homens não viam e sentiam o cheiro do mar? Eles, que viveram boa parte da vida em sua companhia, que conheceram seus mistérios, estudaram como navegá-lo, agora se reencontravam.

O MAR, criado por homens que conheciam e amavam o mar, permitiu que eles novamente se aproximassem.

O grupo, ali, diante daquele mar imenso, desfrutava tal momento tão esperado de liberdade. André descreve o que sentiu:

"Respiramos o ar gostoso soprado do mar. Imenso mar! O vento marinho ia-se impregnando daquele cheiro da mata próxima.

-Eita, liberdade gostosa! (BORGES, 2008, p. 60).

Dali, caminharam pela areia,

"rente à água, encobertos pela inclinação do terreno, desaparecendo na escuridão da noite. Chegamos a uma casa na encosta do morro, situada a certa distância, na periferia da pequena vila. Todos os homens dormiam. A prudência de se deslocar pela praia evitou o encontro indesejável com os cachorros, guardiões da vila, que na certa nos fustigariam, denunciando nossa presença" (DUARTE, 2009, p. 343).

Depois de longo percurso, exaustos, o grupo chega à casa do Sr. José. Homem que conhecia muito bem a região e, principalmente, as diversas trilhas dentro da mata fechada. Tinha muita experiência nos deslocamentos na selva e na subida da serra, em tempos secos ou úmidos.

Duarte conta que Sr. Zé estava “completamente eufórico”, a contagiar o restante do grupo. Deu várias instruções sobre a subida até à Cabana do Jacu. "descreveu em curtas palavras a nossa caminhada até o topo da serra: 'temos que caminhar em silêncio, nenhuma

${ }^{244}$ Segundo André Borges. Op. Cit. p. 63. 
palavra. Somente eu terei que falar, se necessário, com o burro. Irá carregado, muito pesado, e talvez tenhamos que ajuda-lo, se não suportar a carga. É uma ladeira escarpada. A sorte é que não choveu” (DUARTE, 2009, p. 343). André acrescenta que "na casa, estavam as mochilas e mantimentos. Um burro nos ajudaria a levar a carga mais pesada na subida das montanhas" (BORGES, 2008, p. 63).

Ali na casa do Sr. José, o Coletivo ficou o dia todo descansando. Adeildo disse que estava tão cansado quando chegou à casa, que não teve forças para dar mais alguns passos até o interior da casa, "cai no terreiro e ali fiquei dormindo". Adeildo lembra que não fazia exercícios na Lemos Brito, já que trabalhava o tempo todo sentado, na Divisão Legal. Portanto, estava completamente fora de forma. ${ }^{245}$ A refeição essa noite, segundo Duarte, foi arroz com feijão e carne de porco.

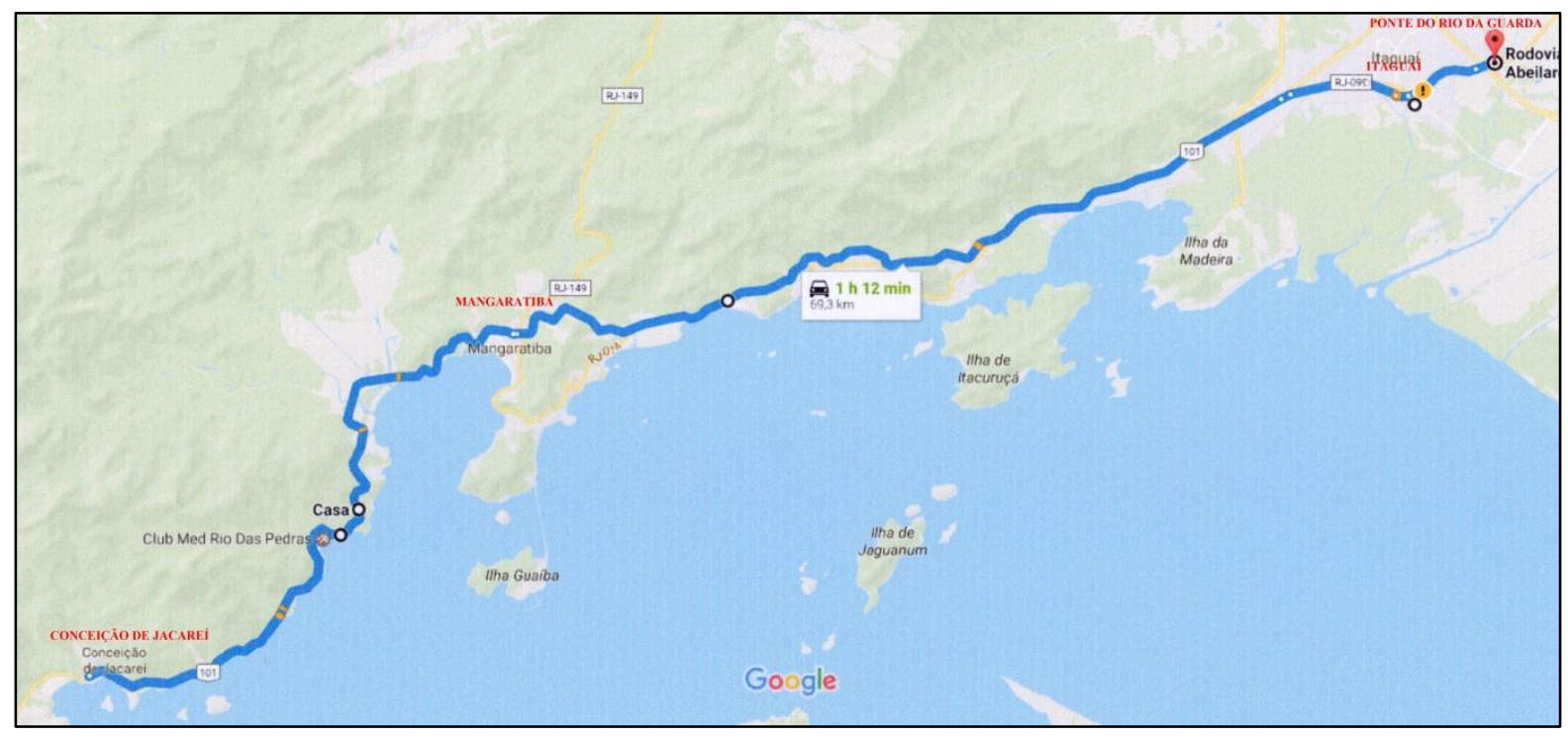

Caminhada do Coletivo da ponte do Rio da Guarda até Conceição de Jacareí. Segundo o Google Maps a distância, por rodovia, é de 69,3 quilômetros. Temos de considerar as dificuldades num terreno sinuoso e geralmente escorregadio, quando o trajeto é feito a pé e dentro da mata.

O povoado de Conceição de Jacareí reveste-se de importância para os planos do Coletivo, pois era dali que o grupo, além de receber notícias da cidade, também se abastecia de alimentos, roupas, calçados e armamentos. Ali, morava Sr. José, que conhecia muito bem a região e suas trilhas e, com seu burro, não deixava faltar o necessário para os homens na Cabana do Jacu. Também morava Oswaldo Migues de Souza, PM penitenciário que era, segundo depoimento de Francisco de Oliveira Rodrigues, "o dono do sítio e que teria alugado para o Ferreira; que quando entrou para a PM deixou o sítio para ser explorado de

\footnotetext{
${ }^{245}$ Entrevista a Flávio Luís Rodrigues, em 23 de janeiro de 2017.
} 
'meia com o Seu José' e que este deixou o sítio a disposição do Ferreira; que o 'Seu Adão', contratado pelo Ferreira, só chegou ao sítio quatro dias antes dos fugitivos". ${ }^{246}$ Oswaldo era conhecido como "Vadinho" e contribuiu muito para que o Coletivo ficasse a par das notícias transmitidas pelas mídias eletrônicas e, também, juntamente com sua mulher, porque ficavam atentos a quaisquer movimentos estranhos no povoado, como a chegada de militares, por exemplo. O Sr. Adão, ou como era mais conhecido, "Tio Adão”, José Sabino Gomes Barbosa, era o responsável por levar os pedidos do grupo até Ferreira, para que este providenciasse a compra. O abastecimento de víveres chegava por Mangaratiba, através de José Leonardo Sobrinho e Silvio Souza Gomes, principalmente. Todos eles ligados ao Grupo Mallet.

No dia 28 todo, o Coletivo ficou enfurnado na casa de Sr. José. Por volta das três horas da madrugada ${ }^{247}$ do dia 29 , descansados e alimentados, o Coletivo tinha agora mais ou menos 10 quilômetros de subida em direção à Cabana do Jacu. Com mochilas cheias de utensílios, como panelas, e alimentos, o grupo partiu. Ali, também receberam as armas. ${ }^{248}$ Sr. José na frente com seu burro, apelidado de "companheiro Azulão"249, e o grupo atrás. Duarte olhou para Marcos, "estava feliz da vida. Seu olhar estava fixo no caminho. Mascava um palito de fósforo" (DUARTE, 2009, p. 343).

A carga que o burrico levava era pesada, e como o terreno era íngreme, com pedras escorregadias, lama e muitos troncos, Azulão de vez em quando deslizava, sendo preciso segurá-lo firme, para que não caísse. Logo, Azulão empacou, se recusando a continuar. "não queria andar de jeito nenhum”, conta Borges, já impaciente com a demora e a chuva que começava a molhar a bagagem. Tentaram forçá-lo, quando Sr. José, com sua experiência, falou: "Deixe que ele mesmo acha o caminho", como de fato aconteceu, segundo Duarte.

Havia uma trilha que saía de Conceição de Jacareí e subia a serra em direção a vários sítios, inclusive o de um Coronel reformado do Exército, que plantava bananas e também se utilizava da trilha para escoar seu produto. Não era larga, mas também não era tão estreita, que não pudesse passar uma carroça pequena. Segundo Duarte, depois de certo ponto, a declividade era amenizada, quando já estavam próximos da Cabana. Viegas diz que a cabana ficava mais ou menos a cem metros da trilha.

\footnotetext{
246 AEL, BNM 414, caixa 1, $2^{\circ}$ Volume, folha 398.

247 Segundo André Borges.

${ }^{248}$ Entrevista de André Borges a Flávio Luís Rodrigues, em 27 de janeiro de 2017.

${ }^{249}$ Segundo André Borges. Viegas diz que o nome do burrico era Zulu.
} 
“Com os primeiros raios do sol, que lutava contra pesadas nuvens", como diz o poeta André Borges, o grupo chegou ao destino e pôs-se a descarregar o burrico e as mochilas. A cabana ficava no meio de um bananal. De certa forma, ela era encoberta pelo bananal, o que permitia certa proteção aos recém-chegados. A cinquenta metros, havia uma bica de água e um pequeno córrego. Muitos pássaros, inclusive uma ave maior, que se parecia com uma galinha, segundo Viegas, e era muito procurada para as refeições. Seu nome: Jacu. Um dia, antes da chegada do Coletivo, Sr. José e Vadinho, enquanto construíam a cabana, derrubando e cortando madeiras, avistaram um Jacu na cumeeira da cabana em construção. Com a fome que estavam, não tiveram dúvidas: abateram a pobre ave. Daí, o nome da Cabana. (VIEGAS, 2004, p. 109.).

No primeiro dia na cabana, 29 de maio, o grupo resolveu conhecer a área, fazendo pequenas caminhadas, não se afastando muito. Os homens descansaram. Então, diante daquele ambiente bucólico, Godoy exclamou: "Que liberdade, querida e desejada" (DUARTE, 2009, 347). O pessoal do Ferreira levou jornais com as matérias sobre a fuga e deu informes sobre como seriam os contatos entre o Coletivo e o Apoio Legal. Também informaram como seria o abastecimento dos víveres de que necessitassem. No final do dia, dividiram os turnos das sentinelas, para a noite que se insinuava. Esticaram suas redes de pano, alguns usando a mochila como travesseiro, dormiram.

No dia seguinte, de manhã, Marcos Antônio chamou todos para uma reunião, para definir o comando e as estratégias de segurança. Nessa ocasião, o Coletivo elegeu Marcos Antônio como Comandante e Capitani Vice Comandante. Na discussão, foi colocada a questão da vulnerabilidade da Cabana do Jacu. Ou seja, se ali ficassem, poderiam ser cercados pelos fuzileiros, fazendo o pente fino pela mata, a partir da orla, e os paraquedistas o mesmo, em sentido contrário. Foi proposto, então, que se fizesse um reconhecimento extenso da área, explorando cada vez mais o interior, no sentido do continente. Decidiu-se dividir o grupo em três esquadras, cada qual com seu comandante, para organizarem expedições de reconhecimento e procurarem lugares que pudessem abrigar as pessoas, no caso de necessidade de rápida retirada. Esses lugares serviriam como referência, com cartas topográficas que permitissem fácil deslocamento. O primeiro "acampamento", que Viegas chama de Zona de Segurança, era um local de muitos bambuzais. Nele, colocaram o nome de "Casa Caiada", segundo Viegas. ${ }^{250}$ À esquadra que encontrava o lugar, ficava a incumbência

\footnotetext{
${ }^{250}$ Entrevista a Flávio Luís Rodrigues, em 23 de janeiro de 2017.
} 
de elaborar um mapa detalhado de como chegar até ele. Por exemplo, anotavam algumas singularidades, como uma arvore torcida de determinada forma; duas montanhas, para quem olhasse para a direita, que lembravam seios; a distância aproximada que o grupo deveria andar até chegar a outro ponto de referência, etc. Dessa forma, a próxima esquadra, munida de tais anotações, chegaria à Zona de Segurança, e continuaria além, procurando outra referência. E assim por diante.

Na reunião do dia 30 de maio, o grupo discutiu, também, a situação de Cietto. Foi colocado para ele que estava livre para escolher seu destino. O Coletivo comprometera-se a colocá-lo fora dos muros da prisão e cumpriu a promessa. Ofereceram-lhe um revolver, mas ele refugou a ideia de ir embora. A conversa com Cietto que Capitani falou ter ocorrido no centro da cidade, na verdade aconteceu nessa reunião, segundo testemunhos de Adeildo, André e Viegas.

Em seu depoimento ao IPM, em 12 de setembro, Michel Godoy disse que as três esquadras estavam assim constituídas: “O depoente, 'Otávio' (Pedro Viegas) e Duarte constituíam um grupo; Capitani, 'Ciro' (Prestes) e 'Ricardo' (André Borges) o outro e finalmente o terceiro com Marcos Antônio, 'Carlos' (Adeildo). 'Barnard' (Benedito) e 'Simão' (Cietto)',. 251

Marcos Antônio e sua esquadra organizaram uma caminhada, que durou oito dias, abrindo picadas, observando rios, montanhas, alimentos - como o palmito, que era abundante -, e sempre anotando tudo, fazendo a carta topográfica. Logo depois, Viegas, Adeildo e Capitani, a partir das anotações de Marcos, foram mais à frente, numa caminhada que durou 11 dias, chegando à cidade de Lídice, distante, em linha reta, aproximadamente 20 quilômetros.

Em determinados pontos do percurso, o grupo da esquadra fazia depósitos de alimentos e de armas, devidamente assinalados nas cartas cartográficas, para que, na eventualidade de não poderem voltar para a Cabana do Jacu, tivessem como ficar mais tempo internados na selva. Era uma técnica de sobrevivência na selva que Marcos Antônio, José Duarte e Capitani aprenderam em Cuba. Capitani, em seu livro memorialístico, abordando a permanência na Serra de Caparaó, fala da importância desses depósitos:

\footnotetext{
${ }^{251}$ AEL, BNM 414, caixa $1,2^{\circ}$ Volume, folha 393.
} 
“(...) um grupo guerrilheiro não pode parar para caçar nem preparar grandes armadilhas ou sair dando tiro em passarinho. É uma ilusão pensar em viver de frutas e raízes, elas não são a base de uma alimentação adequada às necessidades de um grupo guerrilheiro" (CAPITANI, 1997, p. 104).

Tais homens, no entanto, não fizeram treinamento de guerrilhas, como de tiros, emboscadas, etc. $\mathrm{O}$ essencial naquele momento era a segurança. Eram fugitivos tidos como perigosos à segurança nacional e sua fuga não foi digerida pelos oficiais militares, principalmente os da Marinha. Portanto, era preciso muito cuidado.

Não estamos querendo dizer com isso que o Coletivo não pensava na guerra revolucionária, através de guerrilhas. Pelo contrário, consideravam-se guerrilheiros. Isso foi claramente colocado para Cietto: se ele ficasse com o grupo, a vida seria de muitas dificuldades e ele, que tinha problemas de úlcera, talvez não suportasse. A ideia era, mais tarde, deixar a Cabana do Jacu e se estabelecer em outro local, mais afastado da costa.

O objetivo dessas longas caminhadas foi colocado da seguinte forma por Viegas:

"As caminhadas que fazíamos eram cobertas de extrema prudência e seu objetivo resumia-se exclusivamente ao reconhecimento do terreno. Iniciativa, portanto, de autodefesa, pois necessitávamos de boas alternativas para eventuais retiradas em caso de ataque $e$ perseguição. Mais que isto: nossa meta era abandonar a costa e penetrar o mais possível no interior do continente, de onde poderíamos, aí sim, dar início a nossas ações políticomilitares. (...) estávamos apenas em fase inicial de preparação, instante em que todos os cuidados são poucos e todos os riscos de fracasso estão presentes para a guerrilha. Um ponto de vista que no entanto revelava flagrante contradição em nossa concepção de luta. Ora, se nos batíamos ou pretendíamos bater pela emancipação dos explorados e oprimidos, por que então nos escondíamos também deles? É evidente que ao nos esquecermos que 'a emancipação dos explorados é obra dos próprios explorados', nos esquecíamos também que a única proteção segura para um núcleo de indivíduos da vanguarda revolucionária é estar em meio da massa como peixes n'água, o que supõe viver o seu dia-a-dia e estar de fato identificado com todos os seus anseios, tormentos e lutas. Entretanto, tínhamos uma outra visão. Vivíamos o foquismo". (VIEGAS, 2004, p. 107).

A sinceridade de Viegas em dizer que "vivíamos o foquismo" não é compartilhada hoje por todos os que participaram do Coletivo, e que nos forneceram entrevistas. À pergunta "a Cabana do Jacu pretendia ser um foco guerrilheiro?”, a maioria, contando com a 
vantagem da retrovisão, respondeu que não, que era apenas um esconderijo provisório. No entanto, como já falamos anteriormente, a revolução através da guerrilha urbana e rural esteve muito presente nas discussões na Lemos Brito. Tanto que criaram o Movimento de Ação Revolucionária. Neguinho, inclusive, critica as leituras que o Coletivo fazia na cadeia, como Régis Debray e Ernesto Che Guevara, que levaram “os meninos” à guerrilha sem povo. ${ }^{252}$

André Borges, em seu livro, diz que não tinham a intenção de desencadear ali, na Cabana, qualquer ação guerrilheira, mas fazer um levantamento "completo do triângulo Rio/Minas/São Paulo”. Isto fazia parte de um plano mais amplo, passando muito provavelmente pela ALN. O discurso de Borges é muito parecido com o de Neguinho. André diz:

"Acreditávamos que, devido à sua densidade populacional, essa região seria o ponto nevrálgico onde se pudesse desencadear a ação guerrilheira, sem correr o risco dela ficar isolada das massas, como já acontecera com outros movimentos" (BORGES, 2008, p. 66).

Neguinho diz que não entendeu porque o grupo subiu a serra para ficar no meio da selva, não seguindo o que estava acordado com Marcos Antônio, ou seja, a união entre o MAR e a ALN:

"Mandei contato para o Marco Antônio, dizendo que o grupo de São Paulo ia receber uma parte dos companheiros que ia sair da Lemos de Brito. E ficou acertado lá em São Paulo que o pessoal receberia realmente, mas nenhum deles foi para São Paulo. (...) Mas, inicialmente era esse, quer dizer, o programa né, que eles entrassem todos na $A L N^{\prime \prime}{ }^{253}$

Falamos no capítulo anterior da ideia que o Coletivo tinha de revolução. Citamos, inclusive, o testemunho de Neguinho e Antônio Duarte. Capitani também contribui com seu testemunho sobre as intenções de ampliar a atuação do MAR. Em seu livro, ele fala:

"Apesar de estarmos apenas esperando os acertos com Marighela, não ficamos parados no sítio. Fizemos diversas viagens de reconhecimento, caminhamos por toda serra, na região do Estaleiro Verolm. (...) O plano com Marighela ficou acertado, e havia contatos com a VPR num movimento orientado para unificação de todas as forças. Nós iríamos para o Brasil Central" (CAPITANI, 1997, p. 140).

\footnotetext{
${ }^{252}$ Entrevista a Flávio Luís Rodrigues. Maceió, 19 e 20 de julho de 2011.

${ }^{253}$ Idem.
} 
Viegas conta que as explorações que faziam, a partir da Cabana do Jacu, eram ações preparatórias, para quando se deflagrasse a revolução:

"A nossa preocupação: primeiro, estudar bastante o terreno e invadir o máximo que pudesse para o interior, dentro mesmo da floresta. Pegar a floresta, montanha e tudo mais. Daí sim você começar a fazer o que nós chamaríamos de propaganda armada: de chegar e tomar um pequeno povoado, distribuir panfletos, coisa e tal, entendeu? Você tem que tomar o distrito policial que existir e postos armados dos inimigos, né. E fazer o teu proselitismo político com a população". ${ }^{254}$

Enquanto o grupo do campo "estudava bastante o terreno", no Rio de Janeiro, outro núcleo mantinha-se em operação. Continuavam planejando ações de assalto a bancos para conseguir fundos destinados a manter o pessoal na Cabana do Jacu, além da parte da ALN. José Duarte era o comandante, segundo André Borges, "pois Flávio Tavares não tinha a experiência militar de Duarte, treinado em Cuba". ${ }^{255}$ Fizeram mais três assaltos a bancos, bem sucedidos, com o pessoal de São Paulo. "Expropriaram" o banco União de Bancos Brasileiros de Bonsucesso, o Banco do Comércio e Indústria de São Paulo e novamente o Banco Nacional Brasileiro de Piedade, a mesma agência que haviam roubado antes da fuga.

A parte do dinheiro expropriado que cabia ao grupo de ação do campo era dada por José Duarte a José Ferreira, que comprava os produtos necessários, que constassem na lista do "Tio Adão". Portanto, o grupo Mallet continuou ativo, ajudando no abastecimento da Cabana do Jacu. Flávio Tavares e seu pessoal, principalmente Jarbas Silva, continuaram nas ações de expropriações, juntamente com os companheiros de São Paulo. Tavares era o coordenador do grupo de Apoio Legal, alugando "aparelhos" com nomes fictícios. O último assalto com a presença de Wilson do Nascimento Barbosa foi em meados de julho, sem a presença de Neguinho e Élio Rêgo. Nesse momento, Neguinho já se encontrava em Montevidéu, para onde foram também Negão, Macedo e Élio, logo após a expropriação.

Concomitante à ida do grupo de São Paulo a Montevidéu, na Cabana do Jacu, André Borges e Prestes de Paula saíram para fazer um reconhecimento de terreno ${ }^{256}$, conforme orientação do comandante Marcos Antônio. Descuidaram-se com o horário e com a localização geográfica e se perderam, quando começou a escurecer. Resolveram, então, passar a noite dentro de uma Sapopemba, retorcida e com um buraco, como se "tivesse tirado o

\footnotetext{
${ }^{254}$ Entrevista a Flávio Luís Rodrigues, em 22 de janeiro de 2017.

${ }^{255}$ Entrevista a Flávio Luís Rodrigues, em 27 de janeiro de 2017.

${ }^{256} \mathrm{Em}$ seu livro, André fala que saíram para fazer uma caçada. Op. Cit. pp. 69 e 70.
} 
miolo dela". Entraram "dentro" da árvore e ali ficaram a noite toda, fumando e conversando. Ao amanhecer, retomaram a busca da rota que os levaria a Jacu, sem êxito. Até que encontraram uma cachoeira. Beberam água e André propôs que seguissem o curso do riacho até chegar a uma cidade, onde pegariam um trem para o Rio de Janeiro, para retomar contato com o pessoal. André diz que Prestes gostou da ideia, mas não concordou em descer, pois poderia parecer deserção de ambos, e recomendou que André descesse e fizesse contato, enquanto ele continuaria procurando a cabana. André, então, desceu seguindo o riacho, até encontrar uma linha de alta tensão, com suas altas torres, que certamente o levaria até uma cidade. E foi o que aconteceu. André chegou ao litoral, de madrugada, aproveitando para tomar um banho de mar, depois de tanto tempo. Estava em Mangaratiba. Tomou o primeiro trem das 4h30, saltando no Rio de Janeiro. ${ }^{257}$

A chegada de André no Rio de Janeiro foi marcada por grande susto. O único endereço que Borges tinha era a casa de José Ferreira, um endereço "legal”. Quando lá chegou, Ferreira não entendeu sua presença e pensou que tivesse desertado. Depois das explicações, Ferreira fez contato com José Duarte, que foi buscá-lo, levando-o para a casa de um ex-sargento da Marinha em Pedra de Guaratiba e, logo depois, para o "aparelho" da Ilha do Governador. André acabara de ser incorporado ao grupo de ação da cidade. ${ }^{258}$

Ele já havia exposto sua vontade de participar das ações da cidade. Diz André que Marcos Antônio concordou com que ele e Prestes fossem para cidade, enquanto José Duarte viria para o campo, conforme sua vontade. ${ }^{259}$

Surgiu um problema na serra, que apressou a ida de Prestes para a cidade. Piorara a saúde de Roberto Cietto, que havia feito uma cirurgia de úlcera na Lemos Brito e agora tinha seus pontos "estourados", necessitando urgentemente de nova cirurgia.

José Duarte procurou Sérgio Lúcio para ajudá-lo a trazer Prestes e Cietto para o Rio de Janeiro. Foi quando Sérgio lhe comunicou que estava muito decepcionado com os fugitivos

\footnotetext{
${ }^{257}$ Entrevista a Flávio Luís Rodrigues, em 27 de janeiro de 2017.

${ }^{258}$ Depoimento de José Duarte, em 11 de agosto de 1969. AEL, BNM 414, caixa 1, $2^{\circ}$ Volume, folha 305. André Borges. Op. Cit. p. 76.

${ }^{259}$ Depoimento de Pedro Viegas ao IPM, em 18 de agosto de 1969. AEL, BNM 414, caixa 1, $2^{\circ}$ Volume, folhas 359 e 360
} 
porque, quando já se encontravam na rua, voltaram apenas para matar o guarda desarmado. ${ }^{260}$ Sérgio Cruz tinha lido a entrevista com o diretor da Penitenciária.

Duarte pediu, então, a Celestino que fosse buscar os dois, que estariam esperando em Angra dos Reis, "num caminho além do Estaleiro Verolme”. Em seu depoimento ao IPM, Celestino conta que foi para Angra dos Reis dirigindo o Volks de Macedo, acompanhado de José Duarte. Na volta, Geraldo, do grupo Mallet, foi quem dirigiu o Volks, acompanhado de Prestes, Cietto e a irmã do Ferreira. No outro carro, que também voltou de Angra, um Jeep, estavam Adail Ivan Magalhães, do grupo de Flávio Tavares, Celestino e José Duarte. Cietto foi levado para a Ilha do Governador, enquanto Prestes seguiu para o "aparelho" de Copacabana. ${ }^{261}$

Estamos em fins de julho de 1969. Com a saída do núcleo de São Paulo, o grupo de Flávio Tavares tem maior relevância nas ações. Wilson Barbosa diz que os últimos três assaltos a bancos foram dirigidos por Tavares. ${ }^{262}$ Era ele quem planejava e fazia os contatos para a aquisição de armas. José Duarte, quando perguntado pelo Encarregado do IPM, quando começara a desintegração do grupo de assalto, respondeu que acabou "com o afastamento do grupo de São Paulo, aparecia efetivamente o grupo de Flávio Tavares", ${ }^{263}$ Essa saliência, no entanto, não estava sendo bem recebida no campo.

Se considerarmos os depoimentos de Pedro Viegas e José Duarte, percebemos certa animosidade entre os grupos da cidade e do campo. É o que observamos na fala de Duarte, abaixo:

"Como já declarou, o local escolhido não tinha como finalidade instaurar-se nenhuma guerrilha, era apenas local de refúgio. Porém, ao instalarem-se na região, os fugitivos, pela decisão de Marcos Antônio e Avelino Capitani, deram um caráter para-militar ao grupo. Embora a luta armada fosse uma constante nas discussões do grupo, inicialmente Conceição de Jacareí não foi escolhido como local para tal, motivo porque divergiu com Marcos em sucessivas conversas que teve". ${ }^{264}$

Esse desentendimento fica mais explicitado na declaração de Viegas:

\footnotetext{
${ }^{260}$ Depoimento de Sérgio Lúcio Cruz e José Duarte dos Santos. AEL, BNM 414, caixa 1, 2 o Volume, folha 338 para Sérgio Cruz e folha 305 para José Duarte.

${ }_{261}$ AEL, BNM 414, caixa $1,2^{\circ}$ Volume, folha 375.

262 AEL, BNM 414, caixa 1, $3^{\circ}$ Volume, folha 597.

${ }^{263}$ AEL, BNM 414, caixa 1, 20 Volume, folha 306.

${ }^{264}$ Idem. Folha 304.
} 
"A última vez que o José Duarte esteve com o grupo rural, ficou decidido em reunião que a prioridade seria dada ao campo, segundo opinião do grupo, sob a liderança do Marcos Antônio. Outra decisão foi a de pressionar o Marcos, que estava deixando o pessoal da cidade muito à vontade, sem subordinação ao campo, o que estava causando mal estar $e$ preocupação, pois que o apoio era muito falho. (...) Assim, o pessoal da cidade não estava vivendo a importância e a prioridade do pessoal do campo e desobedecendo às ordens. $O$ mesmo se dava com o dinheiro. Mesmo com tudo o que estavam apurando, ainda assim as quotas eram pequenas para manter o pessoal do campo, já que os gastos e a importância enviada para São Paulo eram grandes. Assim, nesta reunião ficou realmente decidido que a cidade trabalharia para o campo. O Neguinho e o Élio, como o Negão, já não eram peças fundamentais para o grupo que fugira, porque viriam lá de cima o Borges, o Cietto e o Prestes, que fariam constituir o grupo de ação na cidade". ${ }^{265}$

Os dois depoimentos colocam uma questão central: depois da fuga, já não era possível manter o grupo que se formou antes dela porque seus integrantes tinham ideias diferentes de revolução. Houve a união com o propósito claro de realizar a fuga da Lemos Brito. Após a fuga, as divergências afloraram. Para Neguinho, como já mencionamos, a via não era o foquismo. O pensamento dele é muito parecido com o que Wilson Barbosa explanou em seu depoimento:

"A impressão deixada por Flávio Tavares [quando expos sua conversa com Marighela e que a linha de ação a ser seguida seria a de estabelecer focos de guerrilha rural] em Leôncio, Geraldo, Élio, no Murillo e no depoente, foi de que ele desejava impor-Ihes a guerrilha como um fato consumado, não considerando a opinião dos demais, que era frontalmente contra. $O$ pessoal achava que a força principal da revolução brasileira de esquerda [este "esquerda" deve ter sido acrescentado pelo escrivão], que visava a criar um governo popular, de caráter agrário e anti-imperialista, modificando o regime do país de forma a adaptá-lo à democracia popular, era a classe operária, que estaria esquecida e marginalizada pela estratégia do Flávio". ${ }^{266}$

Mais à frente, perguntado por que se afastou de Flávio Tavares, Barbosa respondeu: "por não concordar com a perspectiva que se apresentava e tinha em mente a sua bolsa de estudos". 267

\footnotetext{
265 AEL, BNM 414, caixa 1, $2^{\circ}$ Volume, folha 355.

${ }^{266}$ AEL, BNM 414, caixa $1,3^{\circ}$ Volume, folha 595.

${ }^{267}$ Idem. Folha 597.
} 
Com a chegada de Borges, Prestes e Cietto no Rio de Janeiro, o grupo urbano ficou reforçado, compensando, de certa forma, a retirada do grupo de São Paulo. José Duarte continuou como comandante e Flávio Tavares como coordenador do grupo de Ação Legal. Viegas diz em seu depoimento que José Duarte voltaria para o campo, porque ali seria mais útil, já que tinha treinamento de guerrilha em Cuba, e porque também era do desejo dele. Duarte, inclusive, afirmou isso em seu depoimento: "perguntado quem exercia o comando do grupo em São Paulo, que levantava dinheiro, respondeu que não sabia e que sua participação visou apenas obter recursos e apoio para a fuga e que pretendia continuar depois apenas com o grupo da Penitenciária [ficar com Marcos Antônio, seu irmão Antônio Duarte, Capitani e os demais no campo]". ${ }^{268}$

No início de agosto de 1969, André foi procurado por José Duarte, dizendo que precisavam dele para realizar uma "expropriação". Na ocasião, ele estava em Pedra de Guaratiba e foi transferido para o "aparelho" em Copacabana. Ali se encontravam Cietto e Prestes e combinaram o próximo assalto. Seriam dois automóveis e a estreia de Borges, Prestes e Cietto em ações de expropriações políticas.

No dia sete de agosto, o grupo saiu para o assalto. No primeiro automóvel, estavam Cietto, Jarbas Silva, Prestes de Paula e Celestino, que era o motorista. No outro, estavam Flávio Tavares, como motorista, André Borges e José Duarte. Chegando ao banco, às 10h30, Jarbas Silva, Prestes de Paula, Cietto e André entraram, ficando o último na porta, para que ninguém saísse. Celestino permaneceu no carro, enquanto Flávio Tavares e José Duarte se mantiveram no ponto de ônibus em frente. ${ }^{269}$ Prestes anunciou o assalto:

\section{"É um assalto. Se não houver reação, ninguém será ferido". ${ }^{270}$}

Cietto, possivelmente, levou os clientes e bancários para os banheiros, dividindo-os por sexo:

\footnotetext{
"- As mulheres ficam nesse e os homens naquele, dizia o bandido, mandando, depois, que alguns rendidos permanecessem sentados na antessala, devido ao pequeno espaço dos toiletes" $^{\prime 271}$
}

\footnotetext{
${ }^{268}$ AEL, BNM 414, caixa $1,2^{\circ}$ Volume, folha 302.

${ }^{269}$ Depoimento de José Duarte. AEL, BNM 414, caixa 1, $2^{\circ}$ Volume, folha 307.

${ }^{270}$ Jornal $O$ Globo, 8 de agosto de 1969, página 19.

${ }^{271}$ Idem.
} 
Prestes de Paula, portando metralhadora, seguiu o gerente do banco para recolher o dinheiro numa sacola de plástico. O gerente voltou para o banheiro, que estava muito cheio, pois era pequeno. A porta do banheiro, no entanto, ficou entreaberta, permitindo que o gerente visse a movimentação do grupo e a hora em que saíram.

A expropriação foi perfeita, correndo tudo conforme o planejado. Jarbas Silva aproveitou ainda para tirar da parede o retrato do Ministro Magalhães Pinto e jogá-lo no chão, pisando nele várias vezes. Depois, arrancou os fios de telefone, para que não pudessem avisar a polícia rapidamente.

$\mathrm{Na}$ saída, segundo o jornal $O$ Globo, fizeram aos clientes e bancários, uma advertência:

“- ninguém saia daqui antes de meia hora da nossa partida.

Um segundo bandido, porém, alterou o prazo:

- Só saíam de onde estão daqui a quinze minutos". 272

Celestino parou o carro na frente do banco e recolheu Cietto, Prestes e Jarbas, que levaram o dinheiro, um pouco mais de $\mathrm{NCr} \$ 50.000,00$. Flávio Tavares, na direção de um fusca, com Duarte no banco de passageiro, esperou André, que sentou no banco de trás. Aliviados pelo desfecho bem sucedido, arrancaram cantando os pneus, rumo ao centro. Nem imaginavam o que estava por acontecer...

O gerente do banco, Adilson de abreu Bonini, percebendo que os assaltantes tinham saído, foi a sua mesa e pegou uma arma. Juntamente com os bancários Francisco Assis Santos, Antônio Pinto Correa e Odir de Freitas Maia resolveram perseguir o fusca. Entraram no Aero-Willys do contador Luis Carlos, que pisou firme no acelerador. Outro bancário, Albano Gil Fernandes, entrou num Volksvagem e partiram para a caçada. ${ }^{273}$ Logo, avistaram o fusca dirigido por Flávio Tavares.

Os três no fusca, comentando o sucesso da operação, não tinham notado que estavam sendo seguidos, até que os dois carros se aproximaram. Flávio Tavares comentou que achava que estava sendo seguido. Segundo André Borges, Duarte pediu para Flávio diminuir a velocidade para verificar quem era, quando identificaram o gerente. Duarte deu uma rajada de

${ }_{273}^{272}$ Jornal $O$ Globo. 8 de agosto de 1969, página 19.

273 Jornal do Brasil. 8 de agosto de 1969, página 12. 
metralhadora em direção aos automóveis, e resolveram pegar a Avenida Brasil, para distanciarem-se deles. Antes de chegarem à Avenida, no entanto, cruzaram com uma rádiopatrulha que, ao ver o fusca passar tão rápido, parou para ver o que estava acontecendo. Foi quando o gerente avisou aos policiais do assalto à sua agência bancária.

Incorporado à caçada, o potente Chevrolet policial conseguiu emparelhar-se com o fusca. Nesse momento, a polícia do Rio de Janeiro já estava mobilizada para a caça aos assaltantes, usando, inclusive, um helicóptero. Flávio Tavares, cada vez mais nervoso na direção ${ }^{274}$, tomou a Avenida Brasil.

Ele conta o que vivenciou:

"Eu dirigia um lento fusca, que dava cobertura a dois carros em que seguiam os seis outros integrantes de um grupo armado, após uma operação de guerrilha urbana no subúrbio de Irajá, e vi, primeiro pelo retrovisor e, logo, ao meu lado, à esquerda, os fuzis dos policiais nos apontando e disparando, sem nos acertar. Automaticamente, caí sobre o volante e, da janela do motorista, apoiado em minhas costas, Victor revidou disparando a pistola $45 \mathrm{~mm}$ sobre os para-brisas. As viaturas da polícia se espatifaram na mureta da avenida, e eu acelerei o carro em direção ao centro, sem saber que ia ao encontro da maior operação policial-militar montada até então no Rio. Quanto mais eu acelerava, mais o Fusca se grudava no asfalto, até que eu percebi que os fuzis policiais tinham furado um pneu. Estacionei no acostamento e vi adiante, a uns 150 metros, uma barreira que trancava a avenida e helicópteros avançando em reconhecimento aéreo" (TAVARES, 2005, pp. 26 e 27).

Os bancários estavam mesmo decididos a alcançar o fusca dos assaltantes. Eles pensavam que os quatro assaltantes que entraram no banco estavam com o dinheiro naquele fusca que estavam seguindo. Não tinham visto o segundo carro, que partiu antes do último "assaltante" sair do banco, ou seja, André. Quando Duarte descarrega sua arma contra a viatura da polícia, esta, segundo o matutino Jornal do Brasil, "bateu num buraco", imobilizando-se, mas os mesmo não se deu com os policiais, como relata o jornalista:

"Na altura da estação da Penha, o Volkswagen em que viajava o bancário Albano Gil Fernandez deu uma fechada no carro dos assaltantes; a viatura se aproximou mais e um tiro furou o pneu do carro fugitivo; nesse momento a rádiopatrulha bateu num buraco e o Aero Willys dos bancários abalroou-a pela traseira. Diz o policial Valdomiro:

\footnotetext{
${ }^{274}$ Depoimento de José Duarte. AEL, BNM 414, caixa 1, $2^{\circ}$ Volume, folha 307.
} 
- O Aero Willys vermelho nos deu carona e nós continuamos a perseguição, até que o fusca parou em frente ao matadouro". ${ }^{275}$

Quando o Aero Willys se aproximou, Duarte desceu do carro dando rajadas de metralhadora, e chamou André para ajudá-lo. O tiroteio foi intenso. Os dois tentaram atravessar a Avenida Brasil, mas os carros vinham em alta velocidade e, mesmo armados, não paravam para deixá-los passar. Então eles retornaram e entraram em um matagal. Enquanto isso, Flávio Tavares desapareceu, sem que as pessoas notassem. No momento em que os dois tentaram atravessar a Avenida, Tavares saiu no sentido oposto, andando dissimuladamente. Os policiais tinham certeza de que eram três os assaltantes que entraram na mata e que outros dois tomaram um Gordini, que apareceu e desapareceu misteriosamente.

Os policiais da viatura abalroada entraram no matagal atrás de André e Duarte. André Borges atravessou a mata e chegou a um muro, que sem saber como, pulou e correu em direção a um conjunto residencial. ${ }^{276}$ Duarte, sem munição, lutou com o PM Valdomiro e levou a pior, como o soldado conta:

"Eu sai atrás de três, atirando e vendo as balas passarem perto. Dois fugiram num Gordini, que saiu não sei de onde; o Japonês (José Duarte dos Santos) eu consegui agarrar, depois de brigar com ele". ${ }^{277}$

Mas o pior do pior ainda estava por vir. André Borges, depois de pular o muro do matagal, entra em um dos edifícios do Conjunto Residencial, seguido por policiais de outras viaturas que estavam chegando, atendendo ao chamado pelos rádios. Ali, percebendo que estava cercado, pegou um garoto de 4 anos como refém, apontando a arma para a sua cabeça. Já havia em torno muitas pessoas, inclusive jornalistas. A comoção foi generalizada. Segundo o Jornal Correio da Manhã, Borges segurava a criança pelo pescoço, ameaçando matá-la, caso os policiais não parassem de atirar ou se aproximassem:

"estes ficaram estáticos, sem saber o que fazer, mas o menino - mais tarde identificado como Luis Carlos de Souza Barros - que estava apavorado, conseguiu escapar das mãos do assaltante. Disso se aproveitou a polícia para reiniciar a perseguição. $O$ assaltante que estava com o dinheiro estava na frente, com a cobertura dos outros [?] que continuavam atirando

\footnotetext{
275 Jornal do Brasil. 8 de agosto de 1969, página 12.

${ }^{276}$ Entrevista a Flávio Luís Rodrigues, em 27 de janeiro de 2017.

277 Jornal do Brasil. 8 de agosto de 1969, página 12.
} 
contra os policiais, que revidavam. Com boa dianteira, o homem que estava com o dinheiro [?] escapou, enquanto seus companheiros eram dominados e presos". ${ }^{278}$

O testemunho do menino, tomado no dia seguinte pelo mesmo jornal, não coincide com a versão acima. Diz o menino:

"Eu brincava com meu irmão na porta do prédio, quando o bandido me pegou pela mão e disse que ia fugir comigo por causa da polícia. Tive medo, e disse para ele que não havia feito malcriação a ninguém, mas o bandido não me largou, e eu comecei a chorar. Ele não ligou pra mim e correu lá para a 'boiada' (como é conhecido o matadouro da Penha) e com um revólver disse que ia me matar, se eu não ficasse quietinho". E continuou: "Muitos homens chegaram logo e ele correu comigo, mas, ele tropeçou numa moita de capim e caiu, aí, ele me soltou. Eu quis fugir, mas o bandido disse que me matava e eu fiquei parado. $O$ bandido estava no chão e um homem, também com revólver, chegou e começou a bater nele, dandoIhes chutes na cabeça. Depois juntou muita gente e o moço que bateu no bandido me levou pra casa da minha avó, que chorava muito, quando cheguei". 279

O testemunho do garoto confere com o que André Borges nos contou, que apanhou muito dos policiais. O Jornal do Brasil comenta a luta entre André e os policiais:

"Cercado pelos policiais, que já contavam com a ajuda dos moradores, André Borges acabou largando o garoto, mas lutou até ser dominado com coronhadas na cabeça pelos patrulheiros Martins, Serafim e Isaac - que entraram na luta já no final, alertados pelo rádio". ${ }^{280}$

Na mesma edição do Jornal do Brasil, a notícia fala que "os moradores do conjunto queriam até linchar o assaltante, mas acabaram contidos".

De fato, segundo André, quando estava cercado e de posse do garoto, pode observar a ira das pessoas, que se aglomeravam cada vez mais. Mas estava resolutamente decidido a não se entregar. A experiência que tivera fora da cadeia, principalmente o tempo em que passou em Pedra de Guaratiba, numa casa a beira-mar, tendo contato com a comunidade, e possivelmente apaixonado por uma garota de 17 anos - ela o convidara para assistir à chegada dos astronautas da Apolo XI na Lua, em sua casa, juntamente com seus familiares - e a crença de que estava integrado num projeto revolucionário não podiam acabar ali, daquela forma ridícula, sendo ameaçado de linchamento. Mas não podia, também, matar um garoto inocente.

\footnotetext{
${ }^{278}$ Jornal Correio da Manhã. 8 de agosto de 1969, página 6.

279 Jornal Correio da Manhã. 9 de agosto de 1969, página 5.

280 Jornal do Brasil. 8 de agosto de 1969, página 12.
} 
Ele dá seu testemunho sobre o que aconteceu naqueles instantes de desespero, ameaçado de voltar para o cárcere por um tempo ainda mais longo.

"Aí um garoto desceu ouvindo aquela zuada, aquele tiroteio. Aí, desceu pela escada, chegou perto de mim e perguntou:

- moço, você é da polícia?

- Eu não rapaz, a polícia são aqueles caras que estão ali.

Aí, porra, não tinha saída. Estava tudo cercado. Pô, eu não vou jogar a arma da mão e nem vou me entregar. Daí, então, eu queimei todos meus documentos que eu tinha, todos os endereços, queimei, joguei fora ali. Aí, eu peguei o garoto e vim, vim com o garoto no braço até quando terminou o paredão do edifício.

- venha me buscar, disse aos policiais.

- se entrega.

- Eu não vou me entregar porra nenhuma. Venha aqui me pegar.

Aí, começou a juntar gente, repórteres, aquela confusão danada. Aí, quando chegou num campo, uma parte mais descampada, onde terminavam os edifícios, aí eu não tinha mais cobertura por trás, entendeu? Aí começaram a me rodear, gente chutando e tal. Aí, quando eu vi que não tinha outro jeito ali, tal, e que com a criança eu não podia correr, aí eu soltei o garoto. Ai, eu olhei, não tinha lugar para atravessar, porque na frente tinha uma vala grande, um córrego de um metro e pouco de largura. Indeciso no que fazer, recebi uma coronhada na cabeça. E aí, apaguei". ${ }^{281}$

A versão de André é bem diferente das anteriores. Não é nossa intenção julgá-lo, mas entender a significância e o resultado dessas ações. Decerto que é censurável usar uma criança como escudo, apontando sobre sua cabeça uma arma que podia matá-la. André sabe disso, e a impressão que temos é que aqueles momentos ainda o perturbam. Isso é perceptível no relato acima. Como se tratasse de uma brincadeira em que o garoto não percebesse a realidade.

Chegando à delegacia, lá já o esperava uma multidão de jornalistas. Um deles fala dos papéis inutilizados por André: “José André Borges, no momento em que foi detido, tirou um caderno de notas e um pedaço de papel dos bolsos e começou a rasgá-los. A polícia

\footnotetext{
${ }^{281}$ Entrevista a Flávio Luís Rodrigues, em 27 de janeiro de 2017.
} 
conseguiu reconstitui-los e apurou vários nomes de homens e mulheres, entre eles o de Pascoal Carlos Magno ${ }^{282}$. Outro fala que André estava "mais amedrontado" e que "começou a chorar e nada mais falou". 283

A delegacia tornou-se um palco de espetáculo. "As feras" foram apresentas de armas nas mãos, dormindo, agarrados como bichos, sem camisa, etc. Quando André chegou à delegacia, estava com a camisa coberta de sangue, como percebemos na foto abaixo:

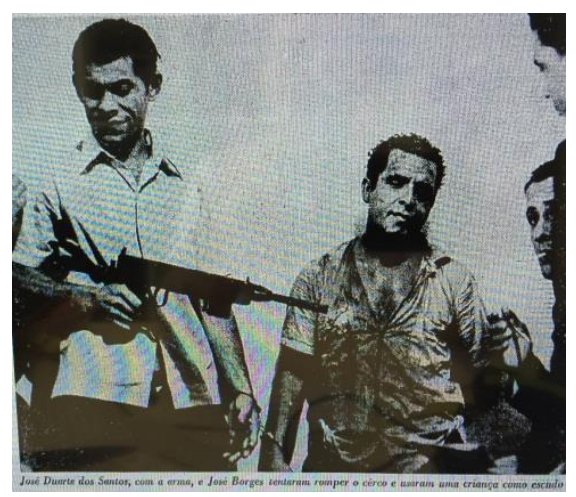

Tal foto saiu na primeira página do Jornal do Brasil. Percebe-se a espetacularização. Por que dar a arma para Duarte, a não ser para fazer a vontade dos jornalistas e, certamente, indicar a periculosidade dos assaltantes? Mas, paradoxalmente, a foto dos dois nas primeiras páginas dos principais jornais foi oportuna: Ela avisaria aos outros da queda e permitiria que abandonassem, a tempo, seus aparelhos.

No início, Duarte parecia desesperado, mas depois, manteve-se calmo e "altivo", como o descreveu um jornalista.

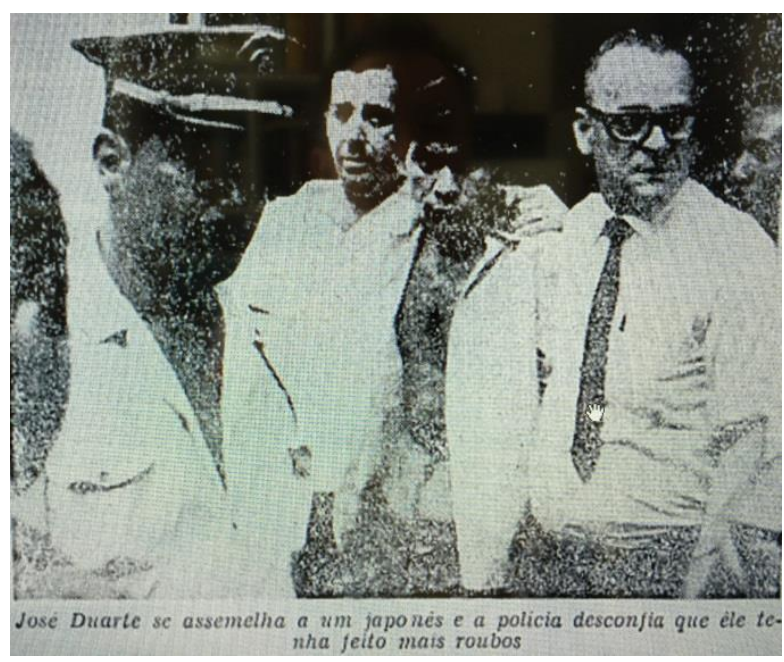

\footnotetext{
${ }^{282}$ Jornal do Brasil. 8 de agosto de 1969, página 12.

${ }^{283}$ Jornal Correio da Manhã. 8 de agosto de 1969, página 6.
} 
A diferença da fisionomia de Duarte nas duas fotos é bem nítida. Na segunda, logo acima, ele tinha acabado de chegar à delegacia, assustado diante dos jornalistas e com a camisa aberta, desleixado. Na primeira foto, ele aparece mais seguro, com a camisa fechada, mas com o olhar para baixo. Não tinha nada a comemorar. Nota-se na primeira foto a algema que prende os dois homens. André, em todas as fotos parece um homem destruído. O seu rosto realmente estava. Não é percebido na foto, mas seu olho esquerdo está tapado pela surra que levou ao ser preso.

Diante do comissário de polícia, e de jornalistas, Duarte tem o seguinte diálogo:

- Esta é a fase mais dura de um revolucionário - disse José Duarte dos Santo ao ser introduzido, após o primeiro interrogatório, numa das salas da 22a $D D$. O comissário Coutinho tentou o diálogo:

- um dia você vai ver que isso é besteira; você vai se recuperar.

- Não, comissário; Vocês recuperam um marginal. Eu não sou marginal: para mim, só o fuzilamento - respondeu José Duarte. ${ }^{284}$

Um pouco mais à frente no diálogo, Duarte menciona, indiretamente, seu tempo na Associação dos Marinheiros e Fuzileiros Navais do Brasil.

- Eu fui marinheiro. Em 1964 fui expulso; desde aquela época já tinha minhas ideias formadas a respeito de política.

Neste mesmo dia e lugar, Duarte "passou" alguns endereços inativos, como o apartamento do Viegas, onde morava Leda, o "aparelho" de Copacabana e um sítio em Angra dos Reis, que não conseguimos identificar. Depois, foram para o DOPS e, após, para o Quartel da Polícia do Exército.

Segundo os testemunhos de Capitani e Viegas, alguns dias antes da queda, Antônio Duarte tinha entregado ao irmão, José, algumas anotações, "um pequeno diário", de acordo com Capitani, que fizera na Cabana do Jacu. Mesmo censurando Antônio por ter colocado a organização em risco, com aqueles escritos, José Duarte não os destruiu e a polícia encontrou-

\footnotetext{
284 Jornal do Brasil. 8 de agosto de 1969, página 12.
} 
os no interior do fusca. Nas anotações, aparecia algo como "e daqui se vê Verolme", ${ }^{285}$ nome do conhecido estaleiro em Angra dos Reis.

Abaixo, as manchetes de jornais do dia seguinte à queda:

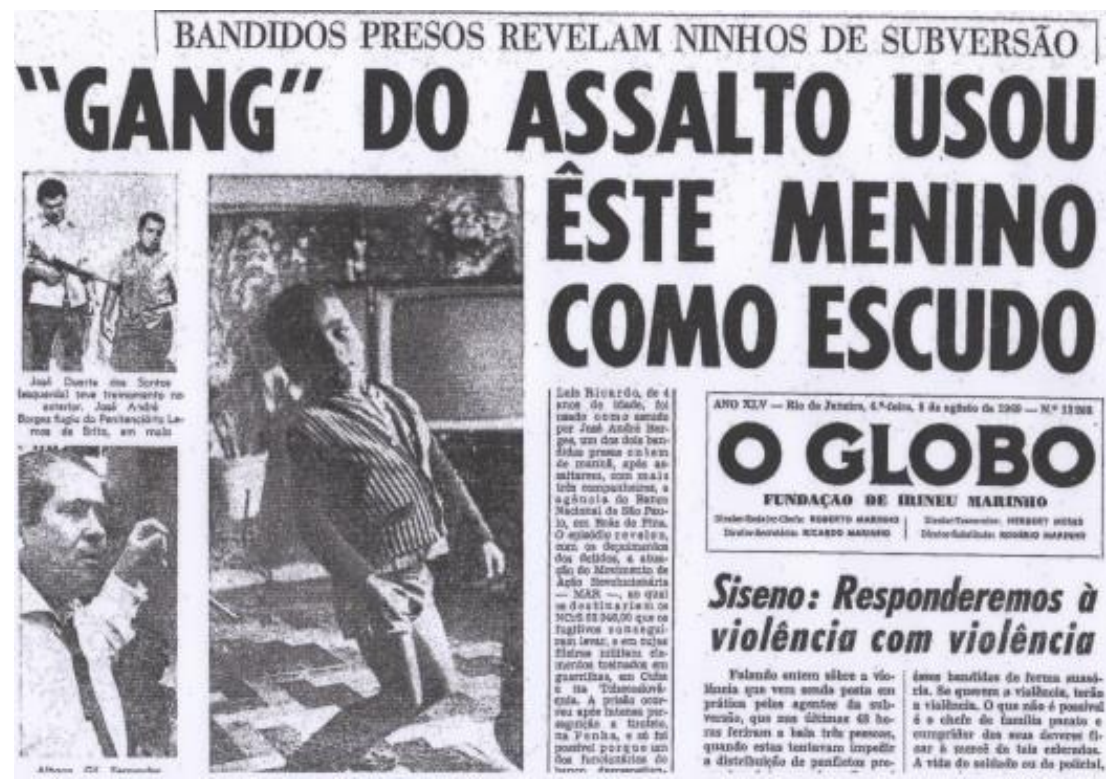

Observar a foto à esquerda em que aparece Duarte segurando a metralhadora. É parecida com a do Jornal do Brasil. Observar, também, a ameaça do General Siseno Sarmento, Comandante do I Exército.

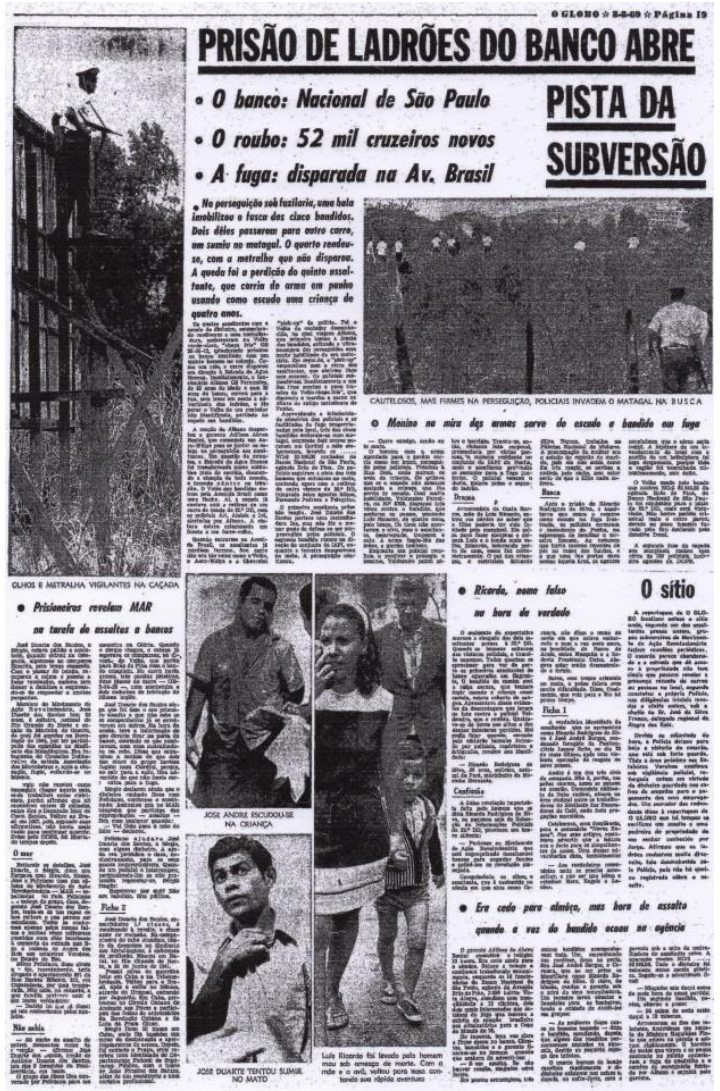

O jornal O Globo trouxe manchetes vinculando Duarte e Borges a marginais, "gang".

${ }^{285}$ Entrevista de Pedro Viegas a Flávio Luís Rodrigues. Iperó, 09 de outubro de 2008. 
Aquela madrugada de 7 para 8 de agosto, nas dependências do quartel da Polícia do Exército, do Primeiro Exército Brasileiro, foi longa para os integrantes do Coletivo, de uma brutalidade que já é do conhecimento de todos.

Flávio Tavares conta que

"Ilesos, sem qualquer arranhão, foram entregues ao Exército e levados ao quartel da rua Barão de Mesquita e aí, em menos de 12 horas, estavam literalmente destruídos pelo choque elétrico e pelo pau-de-arara" (TAVARES, 2005, p. 29).

A queda de André Borges e José Duarte deflagrou uma operação militar sem precedentes no Brasil, mobilizando milhares de soldados do Exército, da Marinha e da Aeronáutica. A promessa do Comandante do Primeiro Exército, que aparece na matéria acima, foi cumprida:

"Doravante - afirmou o General -, não devemos abordar esses bandidos de forma suasória. Se querem a violência, terão a violência. O que não é possível é o chefe de família pacato e cumpridor de seus deveres ficar à mercê de tais celerados. A vida do soldado ou policial, responsáveis pela segurança pública, também não pode continuar a ser arriscada absurdamente. Meus comandados não abordarão mais, com as mãos abanando, esses distribuidores de panfleto [referência aos militantes que entregavam panfletos contra o governo no centro da cidade]. Estarão devidamente armados, prontos para neutralizar botes traiçoeiros" [grifo nosso]. ${ }^{286}$

A imprensa do dia nove de agosto já anuncia a ida de centenas de Fuzileiros Navais para a região de Mangaratiba e Monsuaba. O jornal Correio da Manhã trouxe na primeira página como manchete: "Marinha busca terroristas em Mangaratiba". Diz a matéria:

"Agentes da Polícia Federal, Cenimar e do SNI, mais uma companhia de fuzileiros navais, armados com metralhadoras, fuzis e granadas, e que chegaram em dez caminhões, dez jipões, quatro jipes pequenos, duas caminhonetas e uma ambulância estão ocupando a região entre Angra dos Reis e Mangaratiba, conhecida como Mançuaba, onde se supõe existir um refúgio de elementos subversivos organizados. A partir da ponte de Vila de Água Santa, toda a zona, de cerca de 500 alqueires, está interditada, e na manhã de ontem ouviram-se muitos tiros e rajadas de metralhadora no local. Com o contingente está o ex-marinheiro José Duarte dos Santos, o Japonês, preso anteontem num assalto, a banco, para dar as indicações.

\footnotetext{
${ }^{286}$ Jornal $O$ Globo. 8 de agosto de 1969. Capa.
} 
A região, que deverá ser cortada pela estrada Rio-Santos, é virgem, e nela só pode passar a cavalo ou a pé. Mais á frente, em sua página 5, o jornal informa a quantidade de soldados: "Cerca de 500 homem ocupam a região de Jacuacanga". ${ }^{287}$

A operação estava apenas começando.

Impressiona a rapidez como reagiram os militares, preparando em tão pouco tempo uma operação de centenas de militares e civis, dos serviços secretos. Percebe-se, também, através da matéria acima, que José Duarte, obrigado a servir como guia, levou os fuzileiros até às trilhas que conduziam à Cabana do Jacu. Segundo Pedro Viegas, quando os dois se achavam no Quartel da Policia do Exército, Duarte contou-lhe que, no caminho à Cabana, ele sempre tossia, para alertá-los da presença dos fuzileiros. ${ }^{288}$ As anotações de Antônio Duarte encontradas pela polícia no carro davam a pista do acampamento do Coletivo. Os militares chegariam lá. Era questão de tempo. Por isso que montaram o QG do comando da operação, em Jacaecanga e Monsuaba, orientados muito provavelmente, pelo “diário" de Antônio. Tudo indica, também, que Conceição de Jacareí ainda estava fora do radar dos militares.

Segundo a versão de Viegas, o Coletivo estava reunido na Cabana do Jacu quando recebeu a visita inesperada de Vadinho, contando uma estranha história. Sua mulher teria ouvido pelo rádio que um grupo de assaltantes subversivos tinha sido preso em São Paulo. Pensaram imediatamente em outros grupos guerrilheiros, que militavam naquela cidade. Mas Vadinho tirou do bolso um papel, onde sua mulher anotou os nomes dos presos. Ali, viram os nomes de José Duarte e André Borges. Alguém quis acalmar os demais, dizendo que não tinha nada a ver pois a queda tinha sido em São Paulo. Mas o papel, com a letra semialfabetizada da mulher de Vadinho, não deixava dúvidas de que alguma coisa séria tinha acontecido e que deviam agir rapidamente. Somente mais tarde, entenderam a confusão. A notícia falava que tinham roubado o banco Nacional de São Paulo. A mulher de Vadinho confundiu-se e disse que o assalto tinha sido em São Paulo.

Ainda segundo Viegas, o grupo decidiu se dividir e preparar a retirada. Formaram dois blocos. O grupo que Capitani comandava era formado por Adeildo, Benedito e Godoy. Deveria partir imediatamente para a zona de segurança "distante da cabana entre cinco e seis horas de marcha puxada por uma rota bastante acidentada” (VIEGAS, 2004, p. 105). O grupo de Marcos Antônio, que incluía Antônio Duarte e Viegas, ficaria na Cabana para

\footnotetext{
${ }^{287}$ Jornal Correio da Manhã. 9 de agosto de 1969. Capa.

${ }^{288}$ Entrevista a Flavio Luís Rodrigues, em 31 de janeiro de 2017.
} 
receber o contato da cidade, pois já estava sem suprimentos. O Coletivo tinha enviado uma lista de produtos necessários, através do "Tio Adão", e aguardava o retorno, que estava programado para aquele mesmo dia, ou mais tardar, até o amanhecer do dia seguinte. Seria o último encontro na Cabana do Jacu, a ser desativada em seguida. Acertaram que o grupo que partisse deveria esperar o de Marcos até às 12 horas do dia seguinte, sábado. Passado esse horário, seria sinal de desastre. Como Vadinho estava exasperado, preocupado com sua família, o grupo recomendou que ele levasse, ainda naquele dia, a mulher e filhos para a casa de parentes em Mangaratiba. Dessa forma, aproveitava para ver se havia movimentação de militares na região. Combinaram que Vadinho voltaria às 17 horas, caso não houvesse problemas, ou seja, movimentação de militares.

A versão de Viegas não coincide com as de Adeildo e Capitani.

Capitani diz que receberam, em Jacu,

"uma carga com abastecimento, mas como o rádio trazia notícias de prisões em são Paulo, decidimos fazer mais uma reserva nas montanhas. Os outros ficaram esperando contato com a cidade e subiriam dois dias depois. No dia seguinte, quando o policial [Vadinho] e sua mulher voltaram para o sítio, notaram movimentos suspeitos. A mulher foi até o nosso primeiro esconderijo [Jacu]:

- houve quedas na cidade, parece que foi um tal de Zé Duarte.

Pouco depois, o marido apareceu também.

- estão chegando algumas lanchas cheiras de fuzileiros, lá na praia.

(...) os companheiros deixaram as mochilas preparadas e resolveram confirmar o objetivo do desembarque [se era apenas treinamento ou caçada] antes de irem ao nosso encontro" (CAPITANI, 1997, pp. 140 e 141).

Adeildo, por sua vez, diz que pouco conhecia Vadinho porque quase não subia para a Cabana do Jacu. Quando aconteceu a queda de André e Duarte, a "esquadra" dele, que era comandada por Capitani, encontrava-se noutro acampamento, na serra. Estavam com ele, além de Capitani, Godoy e Benedito. Contudo, tanto Adeildo, quanto Capitani confirmam que Marcos Antônio, Viegas e Antônio Duarte estavam aguardando contato programado para o sábado, que seria o último na Cabana do Jacu. O "umbigo", como denominavam a cabana, seria substituído por outro, mais interiorizado. 
O Coletivo não sabia, ainda, o tamanho da operação que estava sendo desenvolvida para capturá-lo. Como também nem desconfiava que os fuzileiros já estavam acampados em Monsuaba e Jacuecanga.

No dia 10 de agosto, o Correio da Manhã trouxe em sua primeira página: "Continua cerco a terroristas em Angra”. A matéria diz que

"mais de mil soldados do Corpo de Fuzileiros Navais, comandados pelo Capitão-de-Mar-eGuerra, Miguelle, do Batalhão Humaitá, estão fechando o cerco na localidade de Jacuacanga [Jacuecanga], situada a 25 quilômetros de Angra dos Reis, onde estaria localizado o quartel general de elementos subversivos, responsáveis por inúmeros assaltos e atentados de terror, praticados na Guanabara, Estado do Rio, Minas e São Paulo". 289

No dia seguinte à queda de Duarte e André, foi preso Flávio Tavares, quando chegava a seu apartamento. Ele conta como foi:

"No dia seguinte, fui preso pouco antes do meio-dia, numa cilada ingênua, na qual caí por auto-suficiência. Era minha terceira prisão desde a implantação da ditadura militar, mas dessa vez me apontam as metralhadoras, investem sobre mim com fúria, abrem-me a camisa e me descalçam um sapato. Um só, para que eu capengueie e não tente fugir. (...) na manhã seguinte ao tiroteio na avenida Brasil, no Rio, passo em frente à minha casa, na rua Paissandu, noto que abrem buracos na rua 'arrumando a rede elétrica' e entro no prédio ao lado, subindo ao $12^{\circ}$ andar, onde temos um esconderijo que só eu e outra pessoa conhecemos. O porteiro me acompanha, leva na mão um telegrama para entregar a alguém no prédio e desce comigo no mesmo andar, casualmente. Espia a que apartamento eu me dirijo, explica que se enganou de piso e volta ao elevador. Abro o apartamento e já na porta entendo tudo: o sofá da sala, virado e cortado de lado a lado, escancara aos olhos a presença da polícia. Tudo desparecera, inclusive Jarbas, que a essa hora me esperaria ali. Tento sair pela basculante da cozinha, mas levaram também a corda com que desceria ao pátio térreo. Atônito, saio rápido, desço pela escada meia dúzias de pisos e no 60 andar tomo o elevador social, sozinho.

No térreo, ao abrir-se a porta, três metralhadoras apontam para minha cabeça. 'É ele ou não é?', pergunta um homem enfatiotado, baixando os olhos para me comparar com as fotografias que tem nas mãos. São fotos do aniversário de minha filha, de anos atrás, em que

\footnotetext{
${ }^{289}$ Jornal Correio da Manhã. 10 de agosto de 1969, capa.
} 
eu apareço mais jovem. Percebo, assim, que minha residência (no edifício ao lado) foi invadida.

- É ele, sim - respondeu outro, rosto achinesado, o mesmo que na calçada, momentos antes, 'inspecionava' os trabalhos na rede elétrica defronte à minha casa. O porteiro do edifício move a cabeça, confirmando que eu é que entrei no apartamento. Dois policiais caem em sobre mim, me revistam e me descalçam um sapato. Logo, me algemam" (TAVARES, 2005, pp. 31 e 32).

Segundo Pedro Viegas, a queda de Flávio Tavares aconteceu quando a televisão noticiou a prisão de José Duarte, mostrando-o algemado. Uma vizinha de Tavares, amiga de sua mulher e casada com um oficial do Cenimar, reconheceu Duarte que, tal como ela, frequentava a casa de Flávio. Logo, ligou para o marido dando-lhe a informação.

No dia 12 de agosto, a operação na região de Angra dos Reis se ampliou ainda mais. Os jornais noticiaram a chegada de 4 aviões, portando bombas em suas asas. A Marinha já utilizava quatro helicópteros, que voavam bem baixo, dando cobertura aos fuzileiros e, ao mesmo tempo, avisando a eles onde havia lugares suspeitos. A matéria abaixo dá ideia da importância que as Forças Armadas estavam dando à caçada:

"Pela manhã de ontem, o aeroporto de Verolme que fica a uns dois quilômetros do chamado 'Centro de Operações' foi ocupado por aviões da Esquadrilha de Ligação e Observação da FAB. Às 9h25min desceu o primeiro avião L-19, no 3154, trazendo o capitão-aviador Valdir de Souza, comandante da Esquadrilha. (...) Minutos depois, descia outro L-19, o de no 3158, somente com o piloto, seguido de dois T-6, perfazendo um total de quatro aviões".290

A foto seguinte, estampada na primeira página do jornal Correio da Manhã, revela a mensagem que, muito provavelmente, os militares estavam querendo transmitir: o governo decretara guerra aos terroristas.

\footnotetext{
${ }^{290}$ Jornal Correio da Manhã. 12 de agosto de 1969, primeira página.
} 


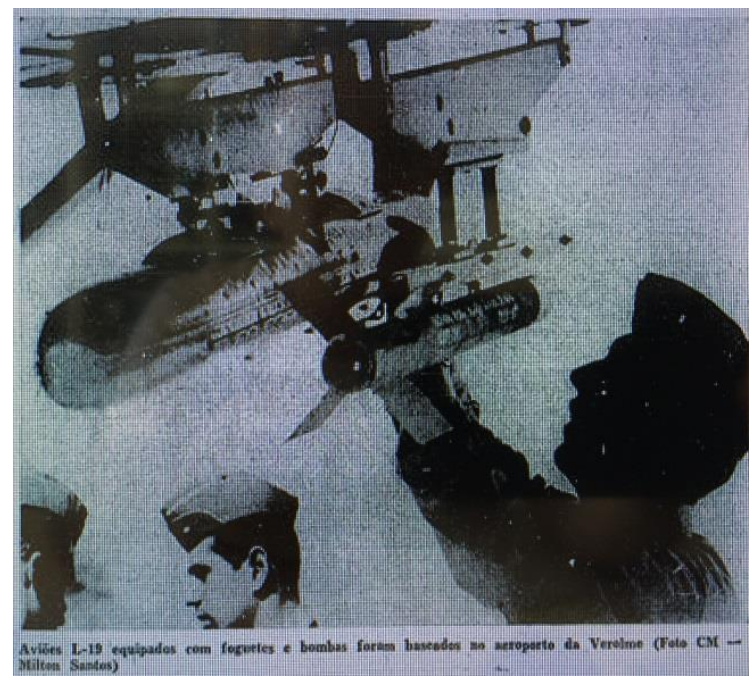

José Duarte e André Borges sofreram muito nas mãos dos oficiais das três Forças. Já na primeira noite, quebraram-lhes os dentes e deram choques elétricos em seus nervos expostos. Flávio Tavares conta o que fizeram com Duarte, no dia em que ele, Flávio, foi preso:

"Ele foi levado num helicóptero da Marinha. sobrevoaram toda a costa de Angra dos Reis para que ele apontasse onde era o acampamento do nosso grupo e, já de entrada, abriram a porta do helicóptero e o empurraram no ar. Com a perna esquerda amarrada ao aparelho por uma corda, ele balançou na vertical como um pêndulo, durantes minutos. O helicóptero voava lento, logo parava e se mexia de um lado a outro, de alto a baixo, e então o prisioneiro voava em círculos, como aqueles trapezistas voadores dos circos. Depois, ele foi içado a bordo, tonto e desnorteado, sem saber direito o que queriam dele, se esquartejá-lo vivo nas nuvens ou apenas mostrar que também se tortura no ar. Devolvido pela Marinha ao Exército, ele ficou imóvel três dias, deitado de bruços e só de tanga - sem qualquer movimento a não ser um leve piscar de olhos - no chão de cimento do calabouço, ao lado da minha cela, no quartel da rua Barão de Mesquita, no Rio" (TAVARES, 2005, p. 25).

Seguindo as pegadas de Viegas, que presenciou a chegada dos fuzileiros, quando Vadinho retornou, na hora marcada, os três ficaram aliviados. Viegas se manteve fazendo um farofão, com carne seca, cebola e ovos, enquanto Marcos Antônio continuava a olhar em direção à trilha. Vadinho, então, convidou Antônio Duarte para verificar uma espera de paca, espécie de armadilha a um animal tão arisco. 
De repente, Viegas ouviu um grito de Marcos Antônio: “- Ih, Viegas, os fuzileiros!,"291

Viegas conta que não entendeu o que estava acontecendo, mas viu que Marcos correu para dentro da Cabana, pegou sua arma M-1 e rapidamente sumiu no bananal. Ele fez o mesmo, tentando acompanhar Marcos e ouvindo atrás de si “- Fogo nos comunistas!", seguido de um tiroteio intenso.

Viegas e Marcos Antônio respondem aos fuzis FAL e M-16 dos fuzileiros, muito mais potentes do que os que tinham.

Deixemos Viegas narrar o que se sucedeu:

"[foi] Tudo muito rápido e nossa resistência era para forçar seu recuo. Estavam muito próximos e nossa posição era vulnerável, com pouca vegetação em torno para nos proteger. Tentavam a todo custo estabelecer um cerco sobre a cabana. Mas o terreno e a prudencia dificultavam sua tarefa. (...) Em dado momento ouvi um barulho seco de queda. Era o Marco Antônio. Estando ele mais próximo de uma das trilhas de retirada, tratei de dar-Ihe cobertura para que pudesse atingi-la. Para cobrir a sua retaguarda, mantinha-me de costas para ele, voltado para a direção de onde vinham os tiros dos fuzileiros. (...) Por algumas vezes tentei aproximar-me do local do presumivel tombo na tentativa de ajudá-lo caso estivesse ferido, mas não consegui alcançá-lo. Chovia balas. Na verdade ele havia se jogado e por ali conseguira escapar. Pensei resgatar a mochila que havia ficado para trás, no interior da cabana. Também não consegui. Foi quando senti tudo escurecer. A sensação foi de desmaio. Logo me recuperei, mas caía ao tentar deslocar-me. Corria e caía, sem entender o motivo. Tinha que abandonar o pequeno degrau do terreno onde me entrincheirava. Joguei-me de costas e caí num barranco, saindo do visual dos fuzileiros. Meu objetivo agora era romper o contato definitivo para dar inicio à retirada e tentar chegar ao ponto de reencontro com os companheiros que haviam partido pela manhã [o grupo de Capitani]. (...) Os fuzileiros ocuparam por fim a cabana, iniciando sua perseguição contra mim. Atiravam e eu, ora rastejando, ora correndo e caindo, ia me afastando em zigue-zague, tentando contê-los e ao mesmo tempo protegendo-me. Esta manobra repetiu-se até que o contato por fim rompeuse. O tempo entre o início do ataque e a ruptura do contato deve ter durado cerca de dez minutos, no máximo, embora parecesse horas" (VIEGAS, 2004. pp. 116 e 117).

Viegas foi atingido por uma bala, de ricochete, que lhe feriu a coxa acima do joelho e chegou até à virilha. Apesar de estar protegido pelo barranco e pela escuridão que começava a 
descer, Viegas estava, no entanto, imobilizado. Não tinha condições de continuar a caminhada, que seria num terreno íngreme. No meio do mato, escondido, passou a noite insone. No dia seguinte, com sol forte e céu sem nuvens, via os helicópteros passarem bem próximos dele. Tinha sede, mas não podia arriscar ir até o riacho, quando nestas ocasiões os beligerantes costumam fazer armadilhas. Encontrou coquinhos, que lhe amenizaram a sede com seus líquidos. Comeu muita banana, morangos silvestres e até limão, pensando serem tangerinas. E ali na mata ficou mais três noites e quatro dias. Podia ver grupos de fuzileiros passarem. Mas já não os temia, pois não pareciam preocupados em encontrar alguém naquela parte da Serra em que já haviam feito o pente fino, tanto que não tinham mais o cuidado de falarem baixo. Seguiam para dentro do continente.

Então, Viegas resolveu caminhar no sentido contrário aos dos fuzileiros. Pensou ir para Monsuaba, acreditando que os fuzileiros tinham partido de Conceição de Jacareí.

Esperou escurecer. Era dia doze de agosto, uma terça-feira. Depois de se desfazer do fuzil, por volta das $23 \mathrm{~h} 00$, desceu para Monsuaba em direção ao único bar aberto na cidade. Mas, chegando à praia, teve um grande susto: um enorme acampamento de fuzileiros navais. Estava próximo do bar, sendo observado pelas pessoas que ali estavam. Não tinha mais o que fazer. Tentando não mancar - a calça ele havia lavado durante a noite na mata -, ele entrou no bar. Viu ali civis, que o olharam "como a um espécime raro".

As pessoas que o rodeavam tinham postura de policiais. Até que ouviu o som de rádio de comunicação citando o nome de Capitani. Não havia mais do que duvidar: estava no centro da operação militar que viera para caçá-los.

Disfarçou pedindo um sanduíche de queijo e um refrigerante. Foi atendido e o dono do bar quis saber como ele conseguira chegar ali, passando pelas barreiras dos fuzileiros navais. Respondeu que era jornalista e estava ali, por recomendação de um capitão de comando, que lhe indicou Monsuaba como via de saída para Guanabara.

Segundo Viegas, seguiu-se o seguinte diálogo:

"- você tá frito! - disse-me ele. E continuou

- Há um bloqueio na entrada da cidade e está proibida a presença de estranhos na área, inclusive da imprensa. Você tem documentos?

- Tenho - respondi. Tirei do bolso uma carteira de sócio da ABI (vencida) e mostrei-Ihe. 
- Tuas chances de evitar dores de cabeça são mínimas, mas tens uma. Pela manhã muito cedo tenho que passar pelo bloqueio para buscar pão para toda essa gente. Vou de caminhonete. Se quiseres podes me acompanhar. Não costumam me revistar.

Tudo isto poderia ser ato de uma comédia. Mas arrisquei.

- Ótimo! Mas não há uma pensão por aqui? Preciso tomar um banho e comer alguma coisa.

- Não, não há. Podes ir para minha casa. Minha mulher foi para a maternidade e eu estou só. Indo será melhor, porque posso te acordar. Tenho algum coisa feita para enganar o estômago. Só um pedido: quando sair tua reportagem cita o nosso bar como o local que hospedou o comando da tropa.

Não só aceitei o convite como agradeci pela hospitalidade.

(...) tomamos um carro e a umas cinco quadras mais adiante estávamos em sua casa. A primeira coisa que fiz foi tomar um banho de ducha, o que há muito tempo não fazia. Preparava-me para fazer a barba por sua própria sugestão.

- 'É preciso não chamar a atenção', aconselhou-me.

Ouço um som de uma pancada violenta na porta da cozinha, onde estávamos. Ela voou longe e quando me dei conta já estava sem cinto, sem calçados, com os braços dobrados nas costas e seguro por alguns soldados. Estava preso" (VIEGAS, 2004, pp.121 e 122).

O Coletivo perdia mais um de seus membros.

Os militares não permitiam o acesso da imprensa próximo aos acampamentos e deslocamento de tropas. Na verdade, guardavam sigilo. Sobre a queda da Cabana de Jacu, praticamente não se falou. Os informes davam conta de que várias pessoas tinham sido presas, que um estudante de direito morrera em combate, que havia rádios transmissores potentes e armas modernas, mas não se apresentava sequer uma foto, não se comprovava nada. A Marinha, o Exército e a Aeronáutica trabalhavam juntos, com muito dispêndio de recursos humanos e materiais, passando a impressão de que o inimigo era poderosíssimo. Viegas era a primeira prova a ser mostrada, depois de cinco dias de operação. O Comandante do $1^{\circ}$ Distrito Naval, respondendo aos jornalistas sobre a prisão de Viegas, disse: "Por felicidade nossa, $e$ por coincidência, foi nos comunicado por um dos assaltantes de banco que lá haveria um foco de assaltantes e de fugitivos da Penitenciária Lemos de Brito. Tudo será revelado à 
imprensa ao término das manobras - declarou". ${ }^{292}$ Tudo indica que o Comandante - a matéria não traz seu nome -, se referiu à José Duarte. Também sobre a prisão de Viegas, o Jornal do Brasil noticiou: “o subversivo preso com uma bala na perna esquerda está servindo de informante das forças acampadas na praia de Monsuaba. A bala foi retirada em pleno comando das operações militares e seu estado é considerado regular, apesar da extração ter sido feita com uma faca de campanha". 293

Antônio Duarte estava entretido com Vadinho a ver a armadilha para paca, quando ouviu o tiroteio. Ele conta que suas pernas tremiam, "por puro reflexo, atirei-me ao chão, por entre as pedras. Rastejando, atravessei o riacho, escondi-me entre os arbustos da margem. $O$ cheiro de pólvora dominava o ar, interrompendo o tiroteio caótico. Os gritos ficaram abafados na garganta” (DUARTE, 2009, p. 350). Pensou logo em Marcos Antônio e Viegas. Teriam sobrevivido? O tiroteio cessou, ao mesmo tempo em que "retomava a paz da floresta, obscurecida pela neblina que caía naquela tarde sinistra”. Logo, Duarte viu os arbustos se mexerem. Era Marcos Antônio. “Deslocava-se, agachando-se por entre o matagal fechado”. Perguntava-se por Viegas. A última vez que Marcos o vira, estava de joelhos a atirar nos fuzileiros. Marcos queria esperar por Viegas. Mas, se estivesse vivo ele saberia para onde ir. Resolveram, então, seguir em frente, naquela neblina que ao mesmo tempo lhes protegia e dificultava os movimentos. Foram se arrastando, ajoelhados, se afastando cada vez mais da cabana do Jacu. Triste despedida. Nunca mais voltariam a revê-la. Quanto a Vadinho, Capitani conta que foi preso nesse dia, quando desceu para Conceição de Jacareí. Os demais dizem que desapareceu.

Na manhã seguinte, tiveram a companhia dos helicópteros, que voavam tão baixo que Duarte teve a impressão de que tinham sido descobertos. Quando novamente veio a neblina, os helicópteros desapareceram, e eles puderam esticar a marcha na subida da montanha. No final do dia, chegaram, enfim, ao acampamento do grupo de Capitani. O Coletivo se reunira novamente.

No depoimento de Godoy no IPM, ele conta uma versão muito diferente da de Viegas, Adeildo e Capitani.

Diz ele que presenciou a chegada dos fuzileiros navais, pois estava a duzentos metros de distância da cabana. Tinha sido escolhido para ir à cabana em

\footnotetext{
${ }^{292}$ Jornal do Brasil. 15 de agosto de 1969, página 14.

293 Idem.
} 
“missão de ligação. (...) Ao chegar perto, cerca de duzentos metros, viu fuzileiros avançando, em meia lua, em direção à cabana; que iniciou-se um tiroteio e o depoente, armado com um FO recuou, tendo visto "Otávio" caído e um outro correndo, o Marcos possivelmente, que os fuzileiros não os perseguiram e ocuparam a cabana; que se encontrou com o Marcos e pouco andaram nessa noite, ficando pelas proximidades, sendo surpreendidos pelo dia num taquaral e, com as patrulhas aéreas de helicópteros em ação, ainda ficaram ali todo o dia, sem que as patrulhas chegassem nas proximidades". ${ }^{294}$

Ele mentiu ao Encarregado do IPM. Antônio Duarte não cita Godoy no deslocamento até o local onde estava o grupo de Capitani. Adeildo, que estava lá, foi categórico em afirmar que Godoy não deixou o acampamento. Viegas e Capitani não confirmam o relato dele em suas narrativas. Possivelmente, Godoy quis preservar amigos com sua mentira.

Depois da queda de Viegas, a operação militar se intensificou ainda mais. A presença do Exército passou a ser mais efetiva. Bloquearam estradas e estações ferroviárias, principalmente em direção ao Rio de Janeiro. O Exército desembarcou em Itaguaí com milhares de soldados, que vasculhavam casas, proibiram o álcool, revistavam pedestres e automóveis. A foto abaixo é bem sugestiva do que se passava na região de Angra dos Reis, abrangendo uma área de 150 quilômetros quadrados. Os soldados dentro das casas e as crianças fora. A população ficou alarmada, porque não entendia o que estava acontecendo.

\footnotetext{
${ }^{294}$ AEL. BNM 414, caixa 1, $2^{\text {o }}$ Volume, Folha 393.
} 


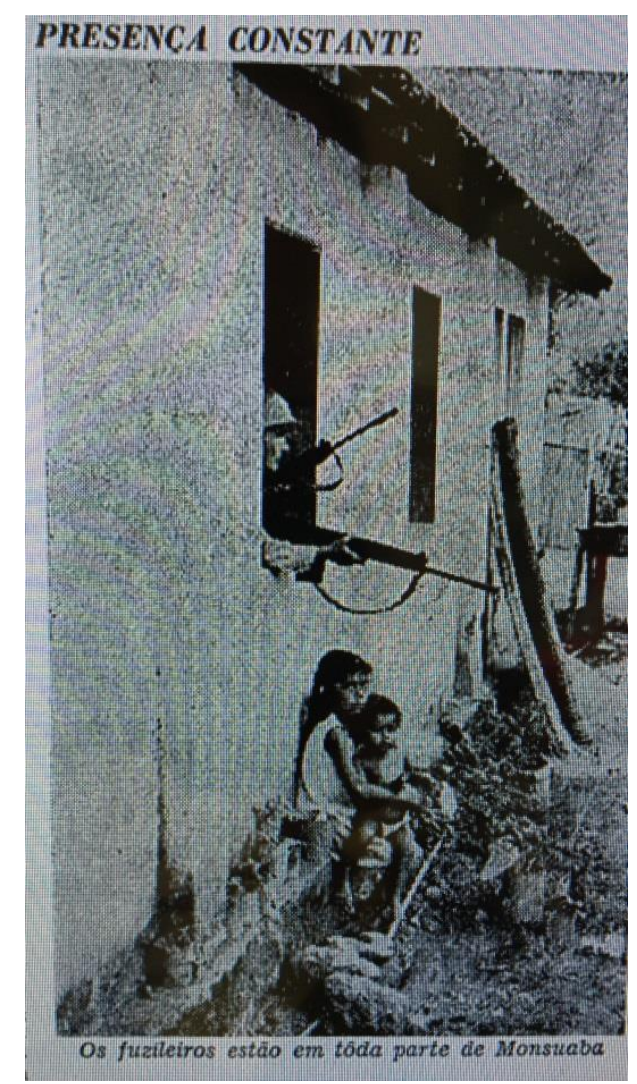

Jornal do Brasil, 15 de agosto de 1969, página 14

A matéria abaixo mostra a participação do Exército nas operações de caça ao Coletivo:

"Cerca de 1.500 soldados do 1ํ Batalhão de Engenharia e Combate, sediado em Santa Cruz, ocuparam na manhã de ontem todos os pontos estratégicos da cidade de Itaguaí, bloqueando as estradas em direção ao Rio. Segundo o comandante do Batalhão, Wilson Gomes da Silva, a operação visa somente o adestramento da tropa. (...) Esta ação é combinada com a dos fuzileiros navais que operam em Monsuaba e Caputera, na busca de assaltantes de bancos e foragidos da Penitenciária Lemos de Brito". ${ }^{295}$

Novamente reunido, mas desfalcado, seguiu o Coletivo na mata, em direção à Serra do Bocaina. Estudavam mapas da região e andaram semanas no topo das montanhas. $\mathrm{O}$ destino seria São Paulo, pois era quase impossível chegar ao Rio de Janeiro, com muitas barreiras do Exército.

O grupo chegou até uma pequena cidade chamada Lídice, que achava não estar nas preocupações dos militares, dada a sua distância. Estavam com fome e sem suprimentos. Precisavam se abastecer para seguir adiante.

295 Jornal do Brasil. 15 de agosto de 1969, página 14. 
Ficaram observando com binóculos a rotina da cidade e para certificarem-se de que não havia movimentação de tropas. Resolveram, então, que Antônio Duarte e Godoy desceriam até Lidice para observar de perto. E eles foram. Andaram pela cidade e não viram a presença de tropas. Voltaram e relataram aos companheiros.

Antônio Duarte conta que, na noite desse mesmo dia, o grupo realizou uma reunião, para traçar os próximos movimentos. Decidiram que Antônio Duarte e Benedito iriam para o Rio de Janeiro procurar os contatos. Estavam totalmente isolados e precisavam de informações, de homens e de comida. Marcaram o local de encontro no retorno dos dois. Se não chegassem até determinado dia, saberiam que houvera problemas. Duarte fala de sua impressão, ao chegar no Rio: “chegamos ao Rio de Janeiro e em alguns dias constatamos a destruição de quase toda a organização. Flávio Tavares, José Duarte, o grupo Mallet, toda a organização destruída” (DUARTE, 2009, p. 355). Duarte soube, também, que o Coletivo estava cercado, por um acampamento do Exército na cidade de Rio Claro. Ele não tinha como avisar-lhes, principalmente depois do sequestro do Embaixador dos Estados Unidos pelo Movimento Revolucionário 8 de outubro - MR-8, dissidência do Partido Comunista Brasileiro, juntamente com a Ação Libertadora Nacional - ALN, em cinco de setembro de 1969. Quanto a Benedito, desapareceu. No Rio, Duarte e Benedito ficaram em endereços diferentes. No dia do encontro marcado, ele não apareceu. Ninguém mais teve notícias dele. Nem na cidade dele apareceu. Foi preso? Morreu? Abandonou tudo e sumiu, por vontade própria? Não sabemos. E, por isso mesmo, pouco falamos dele nesta pesquisa.

Flávio Tavares fala em seu livro como o MAR se desfez na cidade. Um dia, os opressores de Tavares o forçaram a levá-los até à casa de José Ferreira. Chegando lá, não encontraram Ferreira, que mais tarde iria para o Uruguai, mas sua mulher e irmã. Levaram, pois, as mulheres para a Rua Barão de Mesquita. Ali, aquelas mulheres sofreram as piores torturas, que podemos imaginar, acusadas de “cumplicidade familiar” (TAVARES, 2005, pp. 41 a 45). Leonardo e Silvio, ligados a Ferreira, acompanharam o líder do grupo Mallet rumo a Montevidéu.

Foi nesse período que houve a morte de Cietto. E sobre ela, não há consenso. Adeildo fala que Cietto, ao colidir o carro próximo da casa onde estava o Embaixador dos Estados Unidos, foi reconhecido pelos militares que ali faziam vigia.

Levado para a Rua Barão de Mesquita, Cietto foi muito torturado. Flávio Tavares diz que ele se recusou a delatar. Mais do que isso, 
"após os primeiros choques elétricos, o magro e ágil Cietto abriu a boca, sim, abriu a boca com força e cuspiu na cara do major." Tavares diz, ainda, que ele "foi algemado e trancafiado na solitária e lhe apertaram o pescoço com um cinto, talvez o próprio cinto, para obriga-lo a falar ou só como tortura mesmo. Num 'acidente', foram além dos limites e chegaram ao estrangulamento e à asfixia" (TAVARES, 2005, 117).

Na mesma noite em que foi preso, ele morreu. A repressão divulgou a informação de que ele se suicidara com seu cinto. Mostrou fotos como prova. Viegas, no entanto, acha que tudo não passou de uma farsa criada pelos militares.

Quando Viegas foi preso, passou 18 dias na solitária, no Presídio da Marinha da Ilha das Cobras. Ao sair, estava totalmente estonteado. Levaram-no, nesse mesmo dia, para a Barão de Mesquita. Chegando lá, colocaram-no numa cadeira, em um salão bem grande. Buscaram, então, o Cietto para reconhecê-lo. Viegas conta que ele mesmo não reconheceu o Cietto, de tão inchado estava seu rosto. Cietto apenas abaixou a cabeça, como que confirmando. Depois de algum tempo, Viegas foi levado para a cela 4 e Cietto na cela vizinha, a 5. Viegas ouviu, então, o Cietto balbuciar, chamando o guarda. Quando o guarda chegou à sua frente, Cietto pediu-lhe para ver se Viegas tinha um palito de fósforo. Viegas achou estranho, e pediu para o guarda perguntar se ele queria também o cigarro. Cietto respondeu que só queria o fósforo. Pouco tempo depois, Viegas ouviu os passos de um guarda que foi até à cela de Cietto. A partir daí, juntaram várias pessoas e um dos guardas mandou Viegas ficar de costas no fundo da cela. Viegas ouviu o flash da máquina fotográfica. Em seguida, ouviu o som do que parecia ser um caixão posto no chão e o corpo de Cietto sendo arrastado e colocado nele. Os militares maldiziam Cietto.

Qual a suposição de Viegas? Como Cietto tinha realizado uma operação de úlcera e os pontos se soltaram, como já mencionamos, ao ser torturado, possivelmente agravou a ferida. Quando ele pediu o fósforo para Viegas, era para abrir ainda mais a costura, e causar uma hemorragia. Para Viegas, muito provavelmente, quando os guardas encontraram Cietto morto, pensaram que tinham exagerado "na dose", e montaram a farsa do suicídio com o cinto. Cietto pode ter tirado a própria vida, com o fósforo que Viegas lhe deu.

No campo, próximos de Lídice, Marcos Antônio resolveu que desceria até à cidade, juntamente com Michel Godoy, para comprar alimentos que estavam necessitando. 
Chegando à cidade, fizeram as compras normalmente e resolveram, na saída, tomar um café num bar. Godoy conta o que aconteceu:

"Na saída da cidade, em um bar, foram tomar café e foram abordados por um policial. Iniciou-se um tiroteio e o depoente, ficando entre dois fogos, caiu num buraco e foi preso; que o Marcos conseguiu fugir e, possivelmente, deverá estar indo em direção a São Paulo". ${ }^{296}$

Segundo Adeildo Ramos, o policial pediu os documentos e queria revistar Marcos Antônio, ocasião em que Marcos sacou a arma e atirou.

Michel Godoy foi preso, diminuindo ainda mais os integrantes do Coletivo. Não temos mais informações a respeito da queda de Godoy, além de seu depoimento. Lá no mato, aguardando os dois, estavam Adeildo e Capitani. Como o horário combinado "estourou", deram como certa a prisão dos dois. Foi nesse momento que Adeildo falou para Capitani: " $E$ agora, Capitani, só restou nós dois?”. Capitani resolveu, então, mudar de acampamento. Se Marcos estivesse vivo e solto, saberia onde encontrá-los.

A prisão de Godoy alertou o comando da operação. Para Lídice enviou dezenas de fuzileiros navais. Na mata, Marcos foi para o local combinado, não encontrando os dois, rumou para o seguinte. Não viu ninguém. Deu a senha (um assovio) e, escondidos num capão, Adeildo respondeu. Marcos se aproximou e assoviou de novo. Quando Adeildo ia responder, Capitani falou que não respondesse, pois não tinham certeza se era realmente Marcos, ou os fuzileiros, que conseguiram a senha através da tortura. Marcos continuou assoviando e, impaciente, falou: "Pô, dá a senha! sou eu, Marcos!",297

Não sabemos o que aconteceu com Godoy, enquanto estava com os militares. Mas, muito possivelmente, ele passou a senha para os fuzileiros. Seus companheiros contam que, enquanto estavam escondidos no capão, por eles passaram vários fuzileiros. Por muito pouco, não foram presos, porque os primeiros chegaram assoviando. Capitani comenta que Adeildo respondeu ao primeiro assovio, pensando que fosse Godoy. Quase ao mesmo tempo, outro fuzileiro assoviou também. O que salvou os três debaixo do mato fechado, porque os dois fuzileiros ficaram confusos, pensando que o assovio de Adeildo fosse os deles próprios.

Por um bom tempo, os três ficaram naquele capão. Ao anoitecer, saíram em direção à Serra do Mar. Noites e dias caminhando, mortos de fome. Chegaram acima do morro, bem

\footnotetext{
296 AEL. BNM 414, caixa 1, $2^{\text {o }}$ Volume, Folha 393.

${ }^{297}$ José Adeildo Ramos. Entrevista a Flávio Luis Rodrigues, em 24 de janeiro de 2017.
} 
cedo, ao amanhecer. Viram uma estrada de asfalto, que os levara até uma estrada de ferro. Seguindo os trilhos, avistaram uma pequena cidade, Rio Claro. Durante a caminhada pelos trilhos de trem, recolheram muita macaxeira para se alimentar. Mas era insuficiente para matar a fome. Resolveram descer até a cidade para comprar comida. Pensaram que, por estar muito distante do litoral, ali não haveria tropas militares. Ledo engano. Quando Adeildo desceu para a cidade, encontrou uma multidão de soldados do Exército. Estavam cercados, muito próximos de serem pegos. Capitani conta o que transcorreu:

"Não conhecíamos a cidade e acabamos no meio de um pequeno quartel que servia como acampamento da polícia rodoviária. Estava vazio, estavam todos atrás de nós. Foi uma gritaria, enormes cachorros latindo, o sino da cidade badalou dando o alarme. Disparamos alguns tiros e fomos embora. Enquanto isso, a polícia fazia barreira na estrada e iluminava as montanhas com faróis" (CAPITANI, 1997, pp. 144 e145).

Adeildo, por sua vez, narra que, ao pegar uma trilha para descer, foi parar numa casa, cuja dona ficou assustada com o estranho e chamou o marido. Adeildo se escondeu e viu a hora que o homem passou por ele de bicicleta, certamente para avisar a polícia. Foi um quiproquó. Os moradores começaram a acender os faróis dos carros para iluminar a mata. Sorte dos três que eles dirigiam os faróis para o lado contrário ao deles. ${ }^{298}$

Era preciso sair rápido dali. Os três resolveram esconder as armas grandes e ficar apenas com os revólveres, para não chamar a atenção e dar mais condições de mobilidade. A ideia era margear, pelo mato, uma trilha, de forma que pudessem, eventualmente, pedir comida a algum camponês.

Foi o que fizeram, por volta das $18 \mathrm{~h} 00$ de um dia no início de setembro. Pediram a um morador de uma pequena casa, próxima da represa de São João Marcos, se ele tinha algo para se alimentares, pois eram pescadores e estavam sem suprimentos. Eles pagariam. O dono da casa pediu para sua esposa fazer uma farofa com ovos. Enquanto a mulher cozinhava, chegou o genro do velho e saiu para conversar com o sogro. Adeildo diz que, quando o homem voltou, estava totalmente diferente. Marcos, então, pediu para a senhora embrulhar a farofa do jeito que estava mesmo - ainda meio crua -, pagaram e saíram. Pouco depois, seguindo a estrada pelo mato, viram o filho do casal passar rapidamente a cavalo em direção à Rio Claro.

Pegaram, sem pestanejar, o caminho oposto, em direção ao Rio de Janeiro, pela mata.

\footnotetext{
${ }^{298}$ Entrevista a Flávio Luís Rodrigues, em 04 de fevereiro de 2017.
} 
Pelo testemunho de Capitani percebemos que os três guerrilheiros estavam praticamente sem saída. Num determinado momento, viram um jipe do Exército percorrendo as casas e perguntando aos donos se estava tudo bem. Numa delas o motorista falou: - "Tá certo, então nos passaremos aqui, amanhã pela manhã".

Pensaram, então, que poderiam pedir comida para o dono daquela fazenda, já que o soldado só voltaria na manhã seguinte. Segundo Capitani, o dono saiu de muletas com uma criança no colo, pedindo pelo amor de Deus, que não lhe fizessem mal. Depois de conversarem, o homem serviu-lhes queijo e farinha. Fizeram questão de pagar e, quando viraram as costas, o homem largou a bengala e saiu correndo (CAPITANI, 2005, pp. 145 e 146). Possivelmente há um pouco de ficção da parte de Capitani, pois Adeildo lembra que o homem vendeu queijo para eles, "excelente", e continuaram a marcha. ${ }^{299} \mathrm{O}$ menino que fora a Rio Claro a cavalo, realmente avisou a polícia, pois apareceram vários jipes do Exército em direção a Mangaratiba. Precisavam confundir seus perseguidores. Então, tiveram uma ideia. Capitani conta:

"Era cada vez mais difícil furar o cerco policial. Decidimos usar uma velha tática muito simples e que acabou dando certo. Saímos na direção das montanhas voltando para a Serra do Mar e caminhando pelo meio da estrada onde todos nos viam. Alguns jagunços ajudavam as tropas, mas parecia que não queriam encontrar ninguém. Eram inteligentes e sabiam que o primeiro que nos visse levaria um tiro. Nossa saída foi muito notada. Subimos um pouco para a Serra do Mar, depois voltamos sobre nossos próprios passos pelo meio do mato. Passava caminhão, jipe, polícia, exército, jagunço. Todo mundo ia para a Serra do Mar atrás de nós. Caminhamos tranquilamente até a estrada Rio-São Paulo" (CAPITANI, 2005, p. 146).

Chegaram a um canavial. Cortaram algumas canas e comeram a farofa que a mulher fez. Foram para o mato e dormiram. Na manhã seguinte, chegaram os trabalhadores para cortar a cana. Os três ouviam a conversa dos homens. Era sobre eles. Diziam que havia na região bandidos perigosíssimos, estupradores, assassinos. O cachorro que viera com eles começou a latir em direção da mata onde estavam. Os donos gritaram para que o cão parasse de latir. E ele parou, para a sorte do trio.

E assim caminhavam: durante o dia escondidos na mata, à noite caminhando na estrada. Dessa forma, chegaram à Rodovia Presidente Dutra.

${ }^{299}$ Idem. 
Segundo Adeildo, na mochila tinham roupas limpas e sabonetes. Foram, então, a uma bica d'água, "fria que só" e se lavaram. Cada um fez a barba do outro, já que não tinham espelho.

Na própria Dutra, entraram num restaurante, jantaram - "excelente comida" - e perguntaram como poderiam chegar ao Rio de Janeiro. O senhor falou que ali mesmo passava ônibus. Era muito arriscado. Mas, falaram entre si, o que tinham a perder? "Era tudo ou nada”. Capitani, que não fala do banho na bica, diz:

"Aquele trio todo esfarrapado e sujo era uma coisa completamente estranha [ao ambiente do restaurante]. O nosso estado físico e psicológico beirava o colapso. Já não havia diferença entre trocar tiros ali no restaurante ou no meio do mato, morrer com fome ou comendo. A vida parecia ter perdido o sentido" (CAPITANI, 1997, p. 147).

Pegaram um ônibus para o Rio de Janeiro e desceram pouco antes, tomaram um táxi em Nova Iguaçu e, em seguida, o trem. Na chegada à estação, Marcos ligou para sua irmã pedindo para buscá-los. Foram todos para a casa dela.

Capitani conta que a chegada na casa foi coisa do outro mundo:

"Eles estavam com tudo pronto para nos receber mesmo sem termos avisado que faríamos a visita. A mãe de Marco Antônio era médium e recebia uma entidade eventualmente e de maneira reservada. Fizemos curativos e ligamos a televisão. Estavam noticiando que a RioSão Paulo fora interditada. Eles tinham nos descoberto, mas já era tarde, tínhamos passado" (CAPITANI, 1997, p. 147).

A irmã do Marcos Antônio pediu aos padres da igreja Nossa Senhora das Cabeças, onde participava dos cultos, para proteger aos três. Os padres concordaram e Capitani, Marcos Antônio e Adeildo ali ficaram por três dias. Mais tarde, Capitani voltará a pedir apoio aos padres novamente.

Essa moça era quem fazia os contatos, conforme orientação do irmão.

Ela encontrou Prestes de Paula e Antônio Duarte, ambos militantes do Partido Comunista Brasileiro Revolucionário - PCBR.

Provavelmente, foi Prestes de Paula quem levou Antônio Duarte a se incorporar ao PCBR, já que precisava de proteção, na ocasião de sua chegada ao Rio. 
Prestes de Paula tinha uma dívida com o grupo: no assalto em que André Borges e José Duarte caíram, o dinheiro roubado, mais de NCr\$50 mil, ficou com Prestes. No PCBR, organização criada por dissidentes do Partido Comunista Brasileiro, como Jacob Gorender, Apolônio de Carvalho e Mário Alves, incorporou-se o que sobrou do Coletivo: além de Antônio Duarte, Marcos Antônio, Avelino Capitani e Adeildo. Prestes, segundo Capitani, insistiu para que o Coletivo colaborasse com a organização, pois seus integrantes não tinham experiência em ações militares. Eram muito teóricos, mas totalmente desprovidos materialmente para uma guerrilha. Prestes dissera que entregara o dinheiro do assalto para a organização.

A experiência do Coletivo no PCBR foi catastrófica, levando os que restaram do Coletivo à morte ou ao exílio. Capitani fala que alguns membros de sua direção eram irresponsáveis, de um amadorismo inacreditável. Além de mentirosos. Queriam que os três fossem buscar as armas escondidas em Rio Claro. Seria correr muito risco. Fazia pouco tempo que tinham deixado a região. No entanto, alguns membros do PCBR, Capitani não cita nomes, mentiram para Marcos Antônio, dizendo que Capitani cumpriria aquela tarefa. Para Capitani, falaram que Marcos é quem decidira buscá-las. Somente a caminho de Rio Claro, dentro do carro, souberam da farsa. Não tinha retorno. Pegaram as armas durante a madrugada.

Chegando ao Rio, assim que entregaram as armas, os dirigentes do PCBR falaram que precisavam realizar expropriações de bancos, para levantar fundos. Capitani, admirado, perguntou pelo dinheiro que ficou com o Prestes e que pertencia, na verdade, ao MAR. Disseram que "gastamos tudo" (CAPITANI, 1997, p. 151).

Contrariados, os três foram para a expropriação. A função deles era dar cobertura ao primeiro carro, que sairia com o dinheiro. No último momento, souberam que o banco combinado fora substituído por outro e que não tinham trazido caixas para esconderem as armas grandes. Estava previsto, também, o transbordo para um segundo carro, mas, alterado, incluíram mais um transbordo. Ou seja, alteraram todo o plano que tinham traçado meticulosamente. Mais uma vez, não tendo como recuar, foram em frente e assaltaram o banco.

Depois do assalto, às 15:20, do dia 17 de dezembro de 1969, exatamente no dia da morte do Marechal Artur da Costa e Silva, os carros saíram juntos, passando pelo primeiro transbordo, correndo um grande risco, pois não providenciaram as caixas para as armas grandes. No segundo transbordo, no entanto, a sorte cansou e a tragédia aconteceu. Temos 
aqui duas versões. Primeira, a de Capitani: quando estavam saindo de um carro e andando em direção ao outro, passou uma camionete da polícia e os policiais viram as armas. Capitani alertou Adeildo, dizendo: “corre para o outro carro". Adeildo, rapidamente, entrou no carro onde estava Marcos e sumiram. Capitani entrou rápido e pediu para Paranhos, um jovem tido como o melhor motorista da organização, pisar fundo no carro. Começou, então, a perseguição. Segunda versão, a de Adeildo: saíram do banco em dois carros. O carro que levava os assaltantes, com o dinheiro, foi embora, enquanto o carro onde estavam os três, deveria fazer o transbordo. Estavam muito chateados com o "complicado esquema que o PCBR planejou”. Quando chegaram ao carro que os aguardava, Marcos foi para ele e mandou Adeildo descer com as armas - que estavam embrulhadas num saco -, e esperá-lo ali, enquanto Capitani e Paranhos iriam rapidamente embora no mesmo carro que realizara a cobertura. No entanto, no exato momento em que Adeildo estava descendo do carro, Capitani viu a viatura da polícia vindo ao sentido contrário. Capitani falou para Adeildo, que não podia lhe dar as armas, pedindo para o estudante pisar fundo, por que seriam perseguidos pelos policiais. De fato, os policiais retornaram e passaram por Adeildo, que estava andando naturalmente, e seguiram em frente, perseguindo o fusca. Quando Marcos chegou e perguntou pelas armas, Adeildo contou o que ocorrera. entrou no fusca e partiram. Ao passarem pela rua em que Capitani tinha virado, viram a perseguição, mas Marcos Antônio não acreditava que o carro velho da polícia pudesse alcançar o outro. E mandou seguir em frente.

Capitani, segurando seu fuzil M1, pediu para Paulo Sérgio Paranhos manter a calma. Mas, ele se desesperou. Não acertava sequer as marchas e começou a correr muito com o carro. Quando Capitani pediu para que ele diminuísse a marcha, para que pudesse acertar o pneu da camionete, o rapaz deu um grito:

"- Não faz isso!

Acelerou ainda mais e jogou o carro em cima de um ônibus" (CAPITANI, 1997, p. 154).

Seguindo a narrativa de Capitani, no momento da colisão, o rapaz saiu do carro de mãos para o alto. Capitani, que levara um tiro no braço, saiu atirando contra os soldados. Tinha um mais avançado, que tombou muito ferido. Capitani atribui o tiro ao desespero de seus colegas. Segundo o Jornal do Brasil, o soldado baleado morreu com um tiro na cabeça e outro no estômago, depois de 10 dias em coma. ${ }^{300}$

${ }^{300}$ Jornal do Brasil. 29 de dezembro de 1969, capa. 
Em relação ao momento do acidente, o Jornal do Brasil informou que o quartanista de Direito, Paulo Sérgio Paranhos, colidiu com outro Volks na estrada de Vicente de Carvalho, ao atravessar o sinal fechado. ${ }^{301}$ Isso foi confirmado por Adeildo e outros jornais.

Ainda segundo o jornal, uma camionete Ford do Grupo de Operações Especiais da Secretaria de Segurança, com o pessoal do DOPS, "tentavam localizar o aparelho de uma organização subversiva, em Irajá”. ${ }^{302}$ Os militares, ao verem o momento do transbordo, perceberam que os "elementos" ficaram muito assustados e tentaram sair rapidamente do local. Então, começaram a persegui-los.

Segundo o jornal, ainda, depois dos tiros do Capitani, Paranhos se desesperou, pedindo clemência aos policiais, dizendo "Eu conto tudo, eu conto tudo".

De fato contou, levando a uma série de quedas, que veremos mais à frente.

Sangrando muito, Capitani subiu o morro à sua frente, Morro do Juramento, sem ideia para aonde seguia. Não tinha escolha. Entrou num bar para tomar um refrigerante, pois estava com muita sede, por causa da hemorragia. Nesse momento, aconteceu algo que o emocionou. Uma mulher, com sua filha, levaram-no para o seu barraco e fizeram um curativo, e o filho dela deu a camisa que estava usando para que Capitani trocasse a que estava toda ensanguentada (CAPITANI, 1997, p. 155). Mais tarde, ela seria levada para o DOPS, onde reconheceu a foto do "estudante" Capitani. ${ }^{303}$ Foi aí que a polícia soube do nome de Capitani. Tudo indica que Paranhos não sabia do nome verdadeiro de Capitani, chamando-o de Genésio.

O repórter do Jornal do Brasil seguiu os militares na caçada. Ele conta que os moradores protegeram Capitani, não respondendo às perguntas dos agentes. Abaixo, uma passagem que ilustra isso:

"Os moradores da Rua Ibitinga [estavam] parados na calçada, como se estivessem esperando pela policia:

- vocês viram um homem com uma metralhadora? - perguntou um dos agentes.

Alguns resmungos de negativa e muitas cabeças baixas (como se fugissem da resposta) foi a reação dos que estavam parados na estreita e esburacada rua.

\footnotetext{
301 Jornal do Brasil. 18 de dezembro de 1969, página 21.

${ }^{302}$ Idem.

${ }^{303}$ Jornal do Brasil. 20 de dezembro de 1969, página 16.
} 
- É a lei do morro, ninguém sabe, ninguém viu - comentou Ferreira." ${ }^{1304}$

A passagem de Capitani pelo bar, demonstrando uma calma fora do comum pelas circunstâncias, foi relatada por uma garota de 12, que estava lá:

"Ele parou aqui e pediu uma Coca-Cola. Estava com um ar de cansaço e tinha uma das mãos (não lembro qual) sangrando e enrolada em um lenço. Na outra segurava uma metralhadora, que apontava para baixo, tentando esconder sob o balcão, para que eu não visse". ${ }^{305}$

Capitani conta que estava febril e com muita sede. Tinha sempre a sensação de que iria desmaiar. Percebendo a presença de muitos policiais, entrou em um buraco num matagal e se cobriu de terra e folhas. Ali ficou, ouvindo a conversa dos policiais, uma noite e o dia seguinte. Saindo no segundo dia, a comunidade o via como um herói. "É ele!”.

Desceu o morro e procurou a igreja em que estivera por intermédio da irmã de Marcos Antônio. Novamente, foi acolhido. "Ali, trataram meus ferimentos, deram-me roupas limpas e alimentação. Senti-me mais seguro. Naquela situação era, literalmente, estar em um pedacinho do céu” (CAPITANI, 1997, pp. 156 e 157). Mais uma escapada de Capitani! Quando estavam na casa da mãe do Marcos Antônio - tinham acabado de escapar ao cerco dos fuzileiros navais na Serra de Angra dos Reis -, fizeram uma pequena sessão. Ali, a entidade afirmou que Capitani "estava muito carregado, mas tinha um protetor muito forte, um príncipe indiano chamado Ubiratan”. O protetor Ubiratan devia ser mesmo muito forte para proteger Capitani de tantas ações!

$\mathrm{Na}$ edição do dia 22 de dezembro, o Jornal de Brasil trouxe uma revelação interessante: “Avelino Riani [Biden] Capitani é considerado pelos policiais como um guerrilheiro autêntico, e participou do primeiro grupo descoberto na Serra do Caparaó, em Minas Gerais. Chegou a ser considerado morto durante as operações realizadas pelas autoridades em Angra dos Reis para caçar os fugitivos da Penitenciária Lemos de Brito". 306

Por onde passava, Capitani deixava um rastro de sangue. Até que chegou a uma fonte, onde bebeu água e limpou o sangue. Ao virar-se, "vi o morro inteiro me olhando, parecia que a cidade toda estava em cima de mim”. Os policiais chegaram até essa fonte. A partir daí, não havia mais pista a ser seguida. E Capitani estava bem próximo deles. Abaixo, uma foto

\footnotetext{
304 Jornal do Brasil. 18 de dezembro de 1969, página 21.

305 Idem.

${ }^{306}$ Jornal do Brasil. 22 de dezembro de 1969, página 26.
} 
publicada no jornal $O$ Globo, mostrando o rastro da mão toda ensanguentava, enquanto tomava água. ${ }^{307}$

\title{
SANGUE NA PEDRA
}

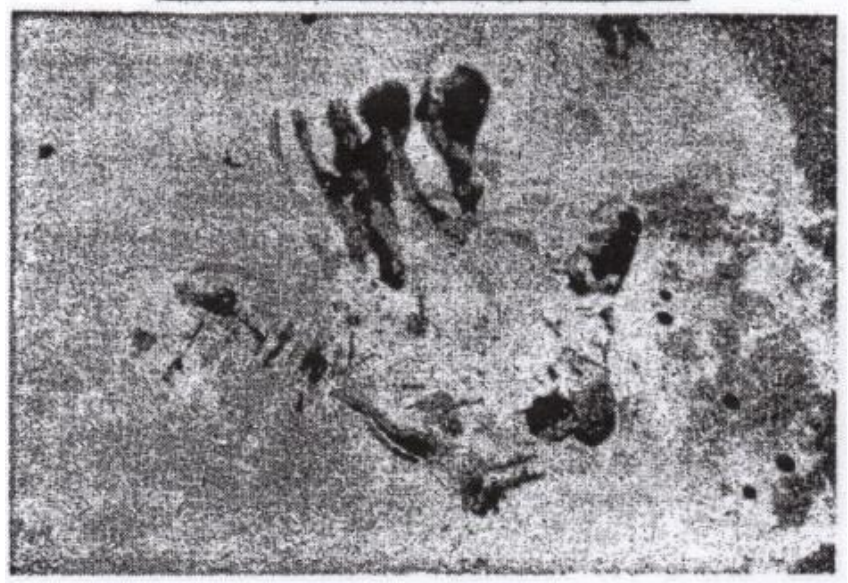

Na escalada do morro, a mäo do fugitivo baleado detrava na pedra a marca de sengue, $A$ outra mäo do bandido näo largava a metralhadora utilizada no assaito

A epopeia de Capitani foi muito divulgada pela imprensa e comentada na cidade do Rio de Janeiro. Logo, começaram a chamá-lo de "gatilho $\mathrm{n}^{\mathrm{o}}$ 1", "Charles anjo 45", "guerrilheiro", e outros. Alguns meses depois, os rádios começaram a tocar uma música que contava a aventura de Capitani, chamada Charles, anjo 45, de Jorge Ben Jor, que acreditava que Capitani tinha morrido. Abaixo, a letra:

\author{
Charles, Anjo 45 \\ Jorge Ben Jor \\ Ôba, ôba, ôba Charles \\ Como é que é \\ My friend Charles \\ Como vão as coisas Charles?
}

Charles, Anjo 45

Protetor dos fracos

E dos oprimidos

Robin Hood dos morros

Rei da malandragem

Um homem de verdade

Com muita coragem

Só porque um dia

Charles marcou bobeira

Foi sem querer tirar férias

Numa colônia penal...

Então os malandros otários

Deitaram na sopa

\footnotetext{
${ }^{307}$ Jornal O Globo. 18 de dezembro de 1969. Página 33.
} 


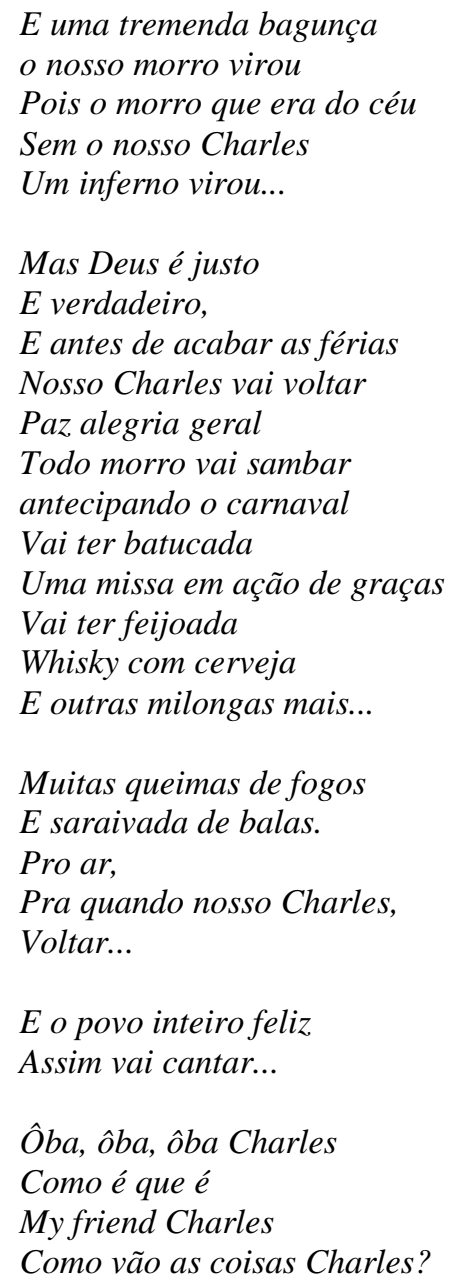

Jorge Ben Jor, depois que Charles "voltou", nunca confirmou que a música fazia referência a Capitani, muito provavelmente por causa dos tempos sombrios da ditadura.

Quais as evidências que permitem afirmar que o Charles da música era Capitani? Ele responde:

"E eu fiquei conhecido na imprensa como o Charles. Talvez pelo meu aspecto físico, meio gringo. Sei lá. Mas ficou Charles. Por que Anjo? Porque eu trabalhava no serviço social e lá, pois na época estava muito em moda o assistente social no Brasil, tinha muitas estagiárias. (...) E por que Anjo? Porque essas estagiárias queriam namorar... Prisioneiros políticos, né, tinham curiosidade, enfim, queriam paquerar. (...) Eu ouvia várias vezes o papo delas 'Esse loiro não quer paquerar com ninguém. Mas como? Eu vou conquistar, eu quero conversar com ele'. Então um monte de curiosidade, só que eu habilmente desconversava. (...) E aí, começaram a me apelidar 'Esse loiro aí deve ser um anjo!'. 'É um anjo loiro'. O meu apelido entre as estagiárias era 'anjo loiro'. Então Charles Anjo, porque depois o loiro foi sendo deixado e ficou só o Anjo. E Charles, Anjo 45. Bom, a 45 era a arma que eu usava logo depois de sair da prisão. Na verdade, não era uma 45, era uma $9 \mathrm{~mm}$ espanhola, que era igualzinha 
a 45, só o calibre era diferente. Então, Charles anjo 45 pela arma. Subi o morro, eu conto no livro toda a cena... 'Charles anjo 45 subiu o morro...' Então, nasceu ali. Eu subi o morro com uma $45^{\prime \prime 308}$

Capitani, enquanto estava "morto", nem desconfiava que o "Charles" era ele. Um dia ele fez contato com Daniel Aarão Reis Filho, militante do MR-8, que lhe contou a novidade:

"E ele, clandestinamente, veio e entrou em contato comigo. E ele:

- 'Tu tá vivo, que maravilha! O Jorge Ben te fez aquela música!'. Eu escutei e achei estranho.

- 'Como é que aquele cara sabe disso, sobre o Charles anjo 45?'.

- 'Mas tu não viu a imprensa, que publicou tudo?'

- 'Ele fez essa música para mim?'

- 'Lógico!'.

- 'Mas agora eu estou vivo...'. E o Aarão:

- 'Deixa a música, que isso é bom pra nós...'. 'não, não vamos dizer a ele que você está vivo'. $^{309}$

A prisão de Paranhos praticamente exterminou o PCBR, que já não contava com uma estrutura de segurança na clandestinidade eficiente.

Ao "abrir" vários endereços, segundo ainda o Jornal do Brasil, Paranhos permitiu que a polícia tivesse acesso ao material do aparelho de Copacabana, rico de informações sobre a organização. O jornal menciona "um completo dossiê das atividades e planejamento da organização subversiva. Também foram encontrados dois cadernos com vários nomes e endereços de aparelhos, a maioria localizada na Zona Sul. As autoridades não revelaram esses endereços, mas adiantaram que mais seis apartamento serão estourados." 310

Como se vê, o estrago foi enorme. Em 72 horas, a Polícia do Exército e o DOPS "estouraram" seis aparelhos e prenderam cerca de 50 pessoas, que seguiram a queda do aparelho da Rua Baronesa Uruguaiana, para onde Paranhos levou os policiais no mesmo dia da queda, dia 17 , por volta das $23 \mathrm{~h} 00$. Nessa operação, houve troca de tiros e um soldado da

\footnotetext{
${ }^{308}$ Entrevista a Flávio Luís Rodrigues. Porto Alegre, 12 de julho de 2011.

${ }^{309}$ Idem.

${ }^{310}$ Jornal do Brasil. 20 de dezembro de 1969, página 16.
} 
Polícia do Exército, Elias dos Santos, morreu. Santos integrava o Grupo do PIC - Pelotão de Investigações Criminais, treinado para combater organizações subversivas. Viegas diz que foi ele quem esteve em sua casa, pulando o muro. Era conhecido como destemido. A partir daí, a PE ficou ainda mais ensandecida. Nas fotografias do velório e da homenagem que fizeram a ele - cerca de 300 soldados e 50 oficiais -, alguns soldados da PE aparecem com a raiva estampada em suas faces. ${ }^{311}$

A imprensa abordou essa "queda" do aparelho da Rua Baronesa Uruguaiana, 70, de forma muito confusa. Provavelmente, não puderam contar a notícia por completo. O fato é que, quando Paranhos foi preso, muito rapidamente, os militares começaram a "estourar" os aparelhos. A PE trabalhava juntamente com o DOPS. Nesse dia, Prestes de Paula estava de calção, dentro daquele aparelho, quando ouviu a chegada dos militares na rua. Foi até à janela, segundo a imprensa, e começou a atirar contra os militares. Existem versões diferentes sobre a morte do soldado, que o governo tentou eleger como mártir nacional. A do jornal Diário de Notícias diz o seguinte:

"[na Rua Baronesa Uruguaiana, 70, no Lins e Vasconcelos] onde, de uma das janelas, um terrorista deu uma rajada de metralhadora contra um grupo de militares que perseguia os assaltante do Banco Soto Maior [o mesmo que Capitani, Marcos Antônio e Adeildo ajudaram a roubar], atingindo no peito o soldado Elias dos Santos, de 19 anos, que morreu no Hospital Salgado Filho. As autoridades imediatamente revidaram a agressão, penetrando no prédio, mas o autor do disparo conseguiu fugir, pulando por um muro existente nos fundos". ${ }^{312}$

Outra versão é a do Jornal do Brasil, que é a mesma do Exército, ou seja: os militares foram recebidos a bala e reagiram com bombas - a matéria não diz se eram de efeito moral - e granadas, para forçar os "terroristas" a saírem do "ninho". Elas foram jogadas através das janelas, no térreo. O soldado da PE estava protegendo uma das saídas. Com a fumaça das bombas lançadas, o guarda não enxergou a saída de Prestes, que o acertou no peito. Diz ainda a matéria que as bombas provocaram um início de incêndio. ${ }^{313}$

A versão de Adeildo diz que Prestes foi surpreendido pelos militares, que arrombaram a porta. Ele atirou e acertou o soldado Elias dos Santos no peito. Correu para os fundos, o apartamento era no térreo de um prédio de 3 andares, e pulou o muro da casa vizinha e dessa para outra, até sair na rua de trás, apenas de calção. Não deu tempo de recolher documentos,

${ }^{311}$ Jornal do Brasil. 19 de dezembro de 1969. Página 18.

312 Jornal Diário de Notícias. 19 de dezembro de 1969, página 13.

313 Jornal do Brasil. 19 de dezembro de 1969, página 18. 
roupa ou dinheiro. Na rua, pegou um táxi e foi para Copacabana. O taxista ainda perguntou se ele tinha sido "depenado" no jogo e fugia da polícia. Ele confirmou. O jogo de sorte ou azar, como hoje, era proibido. Quando chegou ao destino, Prestes de Paula deixou o relógio como pagamento da viagem. O taxista, admirado, falou: "mas este relógio é muito caro". 314

Viegas conta que Prestes de Paula teria dito que, quando chegara do assalto no aparelho, não sabia do que tinha ocorrido com Paranhos e Capitani. Como estava muito quente, tirou a roupa, colocou um calção (ou ficou apenas de cueca, Viegas não se lembra) e começou a tomar um refrigerante. Ouviu, então, barulhos de vozes, e uma pessoa enfiando a cabeça por dentro da janela, ou algo parecido. Neste momento, pegou sua arma e correu para a porta social. Os militares apagaram as luzes do prédio e Prestes deu de cara com o soldado Elias dos Santos. Segundo Viegas, a metralhadora de Elias não funcionou e Prestes de Paula atirou com uma $45 \mathrm{~mm}$, jogando o soldado Elias contra a parede. Ferido, o soldado já não conseguia segurar sua arma e Prestes percebeu que ele andou em sua direção, falando “Desgraçado, você me matou!'. Prestes, então, deu-lhe uma coronhada na testa, jogando-o no chão. Correu para os fundos do prédio, pulou o muro e caiu na casa vizinha, de um casal de velhos. Já não tinha arma, pois fora destruída por uma rajada de metralhadora, enquanto pulava o muro. Na rua de trás, pegou o primeiro táxi e foi para Copacana. ${ }^{315}$

Em nota oficial, O Exército divulgou sua versão da morte do soldado Elias dos Santos:

“(...) O soldado Elias, na disposição de prender vivo algum dos ocupantes do apartamento, correu para os fundos e tentou penetrar pela área de serviço. Foi recebido a bala por um subversivo que logrou fugir. Caiu, esvaindo-se em sangue, vindo a falecer momentos depois". Mais a frente, a nota diz: "Os assassinos do soldado Elias pertencem à Frente Popular Revolucionária, facção filiada ao Partido Comunista Brasileiro Revolucionário (PCBR). Constitui um bando que reconhece a hegemonia dos fugitivos da Penitenciária Lemos de Brito da Guanabara e elementos cassados do antigo Centro Acadêmico Cândido de Oliveira (CACO) da Faculdade de Direito da Universidade Federal do Rio de Janeiro (UFRJ). Abriga os remanescentes do Movimento Armado Revolucionário desbaratado pela Marinha de Guerra na região de Angra dos Reis - RJ. (...) A união em torno das autoridades para localizar e

\footnotetext{
${ }^{314}$ Entrevista a Flávio Luís Rodrigues, em 04 de fevereiro de 2017.

${ }^{315}$ Entrevista a Flávio Luís Rodrigues, em 06 de fevereiro de 2017.
} 
prender esses e outros terroristas é uma das necessidades vitais para a tranquilidade dos lares brasileiros e a consolidação da democracia em nosso país". ${ }^{316}$

Depois do assalto ao Banco Soto Maior, Marcos Antônio pediu ao motorista que levasse Adeildo para seu aparelho. Adeildo não concordou. E se Capitani tivesse caído na perseguição? Quem poderia confiar no estudante Paranhos? A negativa de Adeildo devia-se ao fato de ele dividir o aparelho com Capitani. Procuraram, então, um aparelho mais protegido para ficarem juntos.

Adeildo Ramos, Marcos Antônio e Leopoldo foram para uma granja do Tenente Ferro, segundo Adeildo, no Recreio das Bandeiras. Passaram a noite ali e, no dia seguinte o pessoal da organização foi tirá-los de lá, pois o local não oferecia segurança.

Como os militares agiram rapidamente, não havia lugar onde se pudesse ficar despreocupado. Marcos Antônio e Adeildo foram para aparelhos diferentes.

Adeildo conta que o levaram para uma casa em Guaratiba, de um médico Coronel do Exército, cuja filha era militante do PCBR. Ali ficou por uma semana, sendo transferido para uma pensão, onde se alugava quartos. Pediu para sair, já que não se sentia seguro. Foi, então, para uma casa em São Cristóvão, onde ficou com Maria Julieta Viana, a Eva. Começaram a namorar. Eva alugou uma casa na Vila Jeny, onde ficaram por um mês.

Um dia, o casal foi avisado do sumiço de uma militante. Julieta se prontificou em encontrá-la, no endereço que tinha. Se ela tivesse caído, não podiam mais permanecer no mesmo endereço, que era do conhecimento da militante.

Deixaram a casa e Julieta combinou com Adeildo que o encontraria no cinema, em Duque de Caxias, até às 17 horas. Para lá foi Adeildo, que chegou às 12 horas e assistiu por três vezes ao mesmo filme. Estava cansado e paranoico, pensando que os funcionários do cinema o estavam observando. Resolveu sair. Na porta do cinema, encontrou um militante do PCBR que o procurava, para passar-lhe o novo aparelho. Combinaram que Adeildo iria para tal endereço e o militante ficaria esperando Julieta para avisá-la. Não demorou muito, Julieta chegou com vários agentes. Foi um reboliço. Mandaram fechar o cinema, acender as luzes para fazer o reconhecimento. Julieta havia caído, ao chegar ao endereço da amiga, que estava sendo monitorado pelos militares. Adeildo escapou por um triz.

\footnotetext{
${ }^{316}$ Jornal Correio da Manhã. 15 de janeiro de 1970, página 7.
} 
Adeildo percebeu que não havia mais condições de ficar no Rio de Janeiro, principalmente quando, em janeiro de 1970, no período em que morava com Julieta, recebeu uma notícia trágica, que o abalou muito: Marcos Antônio morrera num tiroteio com a polícia do Exército.

A morte de Marcos Antônio atingiu todos. De certa forma, ele contribuía para reunir o Coletivo. Neguinho, já em julho, percebera que não havia condições de guerrilha no Brasil, naquele momento, e que as quedas na ALN chegariam a ele, era questão de tempo. Neguinho e Élio foram para Montevidéu e, em seguida, para a Suécia. Como já mencionamos, Neguinho retornou ao Brasil apenas em 2009.

Com as várias quedas de aparelhos, seguidas da prisão de Paranhos, Marcos Antônio achou por bem mudar-se da casa onde estava. A organização dera-lhe, então, a chave de outro aparelho. Para disfarçar, foi acompanhado da militante Ângela Camargo Seixas, como se fossem namorados. Quando chegaram ao prédio, na Rua Inhangá, 27, Copacabana, não notaram a presença de dois Volkswagen, ambos cor de chocolate, estacionados à frente ao bar Tom \& Jerry, em frente ao prédio, do outro lado da rua. O Jornal do Brasil conta que os ocupantes do primeiro fusca eram dois, o primeiro "um mulato alto e forte ia ao volante. $O$ outro, alto, de camisa branca, desceu e dirigiu-se ao edifício. O segundo automóvel, parado mais atrás, só tinha um jovem magro, cabelo cortado à escovinha. Neste carro estavam guardadas pelo menos três metralhadoras e outras armas". ${ }^{317}$ Os automóveis estacionaram às 15 horas e seus ocupantes não saíram deles.

O jornal diz, ainda, que "dentro do edifício estavam distribuídos em pontos estratégicos pelo menos 10 homens da PE”. Ali chegaram por volta das 15 horas e aguardaram, para entrar em ação, até às 23 horas. Possivelmente, a hora em que o casal chegou. Segundo o jornal, no bar, as pessoas já pressentiam que haveria uma ação a qualquer momento. E o momento foi às $22 \mathrm{~h} 45$, quando o moreno alto voltou ao automóvel e cochichou no ouvido do homem que estava no volante. Este saiu do automóvel, com uma pistola 45 na mão e seguiu com o colega para o edifício, "em passos rápidos. Fecharam a portaria e subiram no elevador. Um minuto após ouviram-se os tiros. Dez, doze no máximo. Nenhuma rajada de metralhadora". 318 "Dois minutos", desceram, o mulato forte segurando o moreno, "que segura o ombro direito ensanguentado”. Entraram no Volks e partiram rapidamente. O

\footnotetext{
${ }^{317}$ Jornal do Brasil. 15 de janeiro de 1970, página 4.

${ }^{318}$ Idem.
} 
segundo fusca avançou e ocupou o lugar do que partiu. Na portaria do prédio, muitas pessoas, algumas com metralhadora. De repente, saiu calmamente do prédio uma "jovem loura, com cabelo preso, 22 anos no máximo, vestindo com elegância uma roupa de noite”. Era Ângela, tentando passar pelos policiais. E quase conseguiu, se os militares não tivessem visto o sangue que havia em suas costas. Um deles dá ordem para ela parar, "a jovem olha desinteressada e com ar de espanto". O policial a segurou pelo braço e entraram no edifício. Pouco tempo depois retornaram. Ela estava com as mãos algemadas nas costas e caminhou em direção ao Volks, estacionado na frente do bar. Entraram no fusca e partiram.

Pouco tempo depois, chegou uma ambulância da Polícia do Exército. Duas macas foram retiradas e levadas para o prédio. Minutos depois, desceu a primeira maca. Os agentes não quiseram que as pessoas se aproximassem. Um policial sacou a arma e atirou para cima. Logo, "as luzes, em todo quarteirão são apagadas. A primeira maca ainda é notada: um jovem escuro, com o rosto todo ensanguentado. A segunda maca passa despercebida”.

A matéria do Jornal do Brasil não traz informações sobre o que ocorreu dentro do prédio. Nenhum policial falou com o jornalista. As informações foram tiradas, certamente, das pessoas que assistiram à ação de dentro do bar.

O Jornal da Noite, mais espetaculoso, fala em tiroteio de 15 minutos. A matéria é idêntica à do Jornal do Brasil. Traz, porém, uma informação que, se verdadeira, demonstra o amadorismo dos militantes do PCBR: “o local vinha sendo observado há vários dias, pois, os assaltos do Banco [Banco do Estado de Minas, assaltado uma semana antes], segundo o apurado, na fuga, não usaram carro. Do estabelecimento os bandidos teriam se dirigido a pé, para o local estourado pelas autoridades". 319 Acrescenta o jornalista que mais três pessoas foram presas nessa operação. Além delas, "dois casais foram levados presos pelas autoridades". Como se vê, a matéria é muito confusa em relação a quantidade de pessoas presas.

Pedro Viegas conta que a morte de Marcos se deu quando ele colocou a chave na porta do apartamento em que iria ficar e, de dentro, partiram vários tiros. Os militares estavam dentro do apartamento, esperando o "subversivo" que chegaria. Não temos informações sobre os agentes saberem da ida de Marcos Antônio àquele aparelho. Viegas conta a sua versão:

\footnotetext{
${ }^{319}$ Jornal da Noite. 15 de janeiro de 1970, página 2.
} 
"Ao tocar a chave na porta do apartamento que iria ocupar num edifício da rua Anhangá, as luzes se apagaram e o tiroteio começou. Do sexto andar ao térreo seria seu último combate. Muito ferido, sangrando em demasia e já sem forças para qualquer reação, recebera um tiro de misericórdia na testa ao atingir o térreo do edifício. A repressão comemorou ali mesmo com tiros para o ar e gargalhadas. Havia eliminado um autêntico revolucionário" (VIEGAS, 2004, 138).

O texto de Viegas dá a entender que "a repressão" sabia que era Marcos Antônio quem acabara de morrer. Caso contrário, por que a comemoração? Mas os militares não divulgaram o nome de Marcos Antônio para a imprensa. Pelo menos nos jornais que pesquisamos, nos dias posteriores à morte, não mencionaram o nome de Marcos. O Jornal do Brasil apenas informou que "o jovem que estava no aparelho e que morreu no tiroteio também não foi identificado. Seu corpo encontra-se no IML e não foi reclamado por nenhum parente, para ser providenciado o seu sepultamento". 320

Adeildo deixou o Rio de Janeiro e foi para o Nordeste. Integrando os quadros do PCBR, ficou aproximadamente um ano na Bahia. Depois, passou uma semana em Sergipe e, em seguida, foi para Fortaleza, onde permaneceu um ano. Quando pensava que estava num lugar tranquilo, em Vitória de Santo Antão, Estado de Pernambuco, aconteceu sua queda. A organização lhe dera mais ou menos $\mathrm{CNr} \$ 2.000,00$ para comprar um sítio no interior pernambucano. Ele repassou o dinheiro para um companheiro, recomendando muito cuidado com ele: que fosse direto para a casa guardá-lo. O amigo, no entanto, resolveu passar antes no prostíbulo. Divertiu-se e, na hora de pagar, sacou uma nota tão alta, que a dona do estabelecimento não tinha troco. Como tinha acontecido um assalto a banco naqueles dias, a mulher ligou para a polícia. O guerrilheiro não soube explicar onde tinha arranjado tanto dinheiro. Acabou abrindo tudo e a polícia, no dia 17 de dezembro de 1972, prendeu Adeildo na cidadezinha onde se encontrava. Foi para o Doi-Codi em Recife, ali ficando um mês, mais ou menos. Nesse interim, Adeildo recebeu uma visita inesperada. Era um graduado da Polícia do Exército que foi para Recife apenas para conversar com ele sobre Marcos Antônio. Disselhe que era o soldado que tinha matado Marcos Antônio. Falou que os dois desceram as escadas, do sexto andar ao térreo trocando tiros. Levou seis tiros de Marcos Antônio, no lado direito. Ou seja, Marcos não errou nenhum tiro, mas não acertou o lado esquerdo, do coração. Como Adeildo não acreditasse, o soldado tirou a camisa e mostrou as cicatrizes das balas. E falou:

\footnotetext{
${ }^{320}$ Jornal do Brasil. 15 de janeiro de 1970, página 4.
} 
“- Negão valente!

- Era um homem valente, de valor. Enquanto eu atirava, ele continuava atirando". ${ }^{321}$

A morte de Marcos Antônio coincide com o começo da crise da guerrilha. Muitas pessoas sendo presas e barbaramente torturadas, falavam o que sabiam. E mais pessoas eram presas e torturadas... A preocupação de muitas organizações passou a ser a retirada dos companheiros das cadeias, do domínio dos militares do Exército. O sucesso do sequestro do Embaixador dos Estados Unidos incentivou o planejamento de ações parecidas, através do entrosamento das organizações.

Capitani, ao deixar seu refúgio "sagrado", procurou Antônio Duarte que estava protegido pelo MR-8. Os dois começaram a questionar, dentro da organização, a viabilidade da guerrilha. Já não acreditavam que houvesse condições objetivas no país para sua implantação. O que viam em torno era uma realidade marcada pelo medo, pela institucionalização da tortura pelo Estado, através das Forças Armadas, principalmente do Exército. Antes, o torturado mantinha as informações, pelo menos, por 12 horas. Mas, com a brutalidade das torturas, a confissão se dava quase imediatamente. Vários aparelhos caíam, de várias organizações. Capitani conta que ele e Antônio Duarte quase caíram, quando marcaram um ponto com um terceiro. No dia, observaram de longe um carro cheio de policiais e o rapaz lá, os esperando. "outros carros cercaram o local, mas conseguimos fugir. Assim, nós fomos perdendo os contatos e ficando cada vez mais isolados" (CAPITANI, 1997, 166).

Antônio Duarte e Avelino Capitani resolveram ir a Goiás, onde Duarte tinha conhecidos e parentes. Chegando a Goiás, ficaram sabendo que conhecidos tinham sido presos. Permanecer ali seria perigoso. Então, surgiu uma proposta vinda do cunhado de Antônio Duarte:

"- Tenho um velho amigo, o Machadinho, ele tem um avião e viaja sempre para o interior da Bolívia. Ele estava em Cuiabá ou em Vilhena. Vou comprar uma velha DKV. Vocês podem me dar uma ajuda. Pegamos a DKV e saímos por aí comprando arroz, que é meu negócio. Vamos sempre pelo interior, conheço os caminhos" (CAPITANI, 1997, 167).

Aceitaram a proposta e foram para Cuiabá. Machadinho não estava lá, mas em Vilhena - Rondônia -, informaram. Foram para Vilhena, no DKV, em estradas precaríssimas. Chegando lá, Machadinho também não foi encontrado. Então, resolveram ir em frente, até à

\footnotetext{
${ }^{321}$ Entrevista a Flávio Luís Rodrigues, em 04 de fevereiro de 2017.
} 
fronteira. Mas, no meio do caminho, o carrinho não aguentou. Continuaram a viagem de carona em um caminhão, até Porto Velho, onde pegaram um ônibus que os deixou na cidade fronteiriça de Guajará Mirim. "Atravessamos o Rio Madeira em um pequeno bote e estávamos na Bolívia em uma cidade que também se chama Guajará Mirim” (CAPITANI, 1997, p. 168).

Depois de subornar as autoridades bolivianas, segundo Capitani, para conseguirem o visto de entrada (US\$ 50) e o de saída (US\$ 100), enfim chegaram à fronteira entre Bolívia e Chile. Antônio Duarte não menciona o suborno em seu livro. Tiveram problemas com os policiais chilenos. Pediram, então, asilo. As autoridades chilenas recusaram, pois eram muito procurados, mas ofereceram uma alternativa: que escolhessem um país e, se aceitos, eles deixariam partir. Não os devolveriam ao governo brasileiro (CAPITANI, 1997, 169).

Os dois pensaram em ir à Argélia, já que seria difícil irem para Cuba, que não tinha relações com o Chile. No entanto, depois de alguns dias, chegou a notícia de autoridades chilenas de que iriam para Cuba. A história é interessante, contada por Capitani: um comerciante de vinho, Don Pepe, amigo de Fidel interessou-se pelo caso deles e pediu a Fidel que os levasse para Cuba. Fidel aceitou:

"Fidel mandou um navio que estava em Hong Kong nos pegar na volta. O navio levou 18 dias para encostar no porto de Antofagasta. Ficamos emocionados com a solidariedade dos cubanos, que tinham desviado aquele enorme cargueiro para nos levar sãos e salvos até a Ilha" (CAPITANI, 1997, p. 170).

Em Havana, Duarte e Capitani se separaram. Antônio Duarte foi para Lund, Suécia, onde se encontrava Neguinho, Elinho e o ex-marinheiro Guilem Rodrigues da Silva. Capitani ficou em Cuba um tempo e, depois, passou por diversos países, inclusive em Lund, conversando com o pessoal sobre o retorno ao Brasil para realizar um trabalho diferente, conscientizando a população, organizando sindicatos, etc. Capitani abandonara o foquismo para sempre.

Em 7 de janeiro de 1971, a Vanguarda Popular Revolucionária, VPR, liderada também por Carlos Lamarca, sequestrou o Embaixador da Suíça, Giovanni Enrico Bucher, pedindo a liberação de 70 presos políticos, além de outras exigências. O governo endureceu e se negou a libertar 13 presos da lista da VPR e a divulgar, na mídia eletrônica, o manifesto da VPR. A negociação durou 40 dias. Dentre os setenta, estavam José Duarte, Pedro Viegas e Wilson 
Barbosa. Na madrugada do dia 14 de janeiro de 1971, exatamente um ano após a morte de Marcos Antônio, o avião levantou voo, levando para o Chile os três protagonistas desta narrativa.

No Chile, José Duarte, Viegas e Wilson Barbosa se reuniram na casa de José Ferreira, que ali morava com a família, para fazer, juntamente com outros que participaram da fuga da Lemos Brito e do MAR, "uma avaliação coletiva do que foi aquela experiência para nós”. Continua Viegas:

"Cada um fez seu relatório sobre o que tinha vivido no seu setor de atuação. A isto seguiu-se um breve debate. Presentes estávamos, José Duarte, Wilson Nascimento, Júlio Brandão, eu, nosso anfitrião e o que restou de seu pessoal, Sílvio e Leonardo.

O resultado não foi o que esperávamos. Não por culpa ou má vontade isolada de um ou outro de nós. A questão é que não tínhamos amadurecido o suficiente nossa compreensão sobre a vida efêmera do MAR, razões de sua existência e papel que desempenhara no torvelinho daqueles anos. Preponderou a emoção. E creio que nem poderia ser diferente. Tudo nos era muito recente e era de derrota que discutíamos e não de vitória. Muitas foram as resistências às críticas que por vezes vinham à tona. E era inevitável que aparecessem, tantos foram os erros coletivos e individuais no curso de nossa militância. Não se tratava de cair, um pouco adiante no tempo em que as coisas aconteceram - muito ainda haveria de acontecer - na tentação de cobranças de supostas dívidas morais ou apriorismos ideológicos. Era-nos importante - entendíamos assim- tentar naquela oportunidade, que suspeitámos impar, como de fato foi, um balanço de um contexto de infinita audácia em pretender mudar o mundo e de avaliar o grau do voluntarismo que assumimos nesse pretender mudar o mundo. Por não chegarmos à conclusão alguma, encerramos a discussão, preservando o que de melhor restou e que perdura até hoje entre os que sobreviveram e ao menos se comunicam: respeito e companheirismo" (VIEGAS, 2004, pp. 151 e 152).

A avaliação feita no Chile sobre a experiência do MAR era importante, pois aqueles homens não deixaram de acreditar na importância da Revolução Brasileira. Mas, discutia-se, retrospectivamente, os meios de atingi-la, e como ela deveria ser. Já falamos que a luta armada de guerrilha, através do Foco, estava sendo muito questionada, por não ser aplicável às condições sociais e econômicas brasileira. Mas, também, levavam em consideração que a política econômica dos últimos meses do governo, de baixar os juros e facilitar o crédito, mantendo a inflação controlada, contribuía para o aumento da popularidade dos ditadores. 
Com a vigência do AI-5 e a nova Lei de Segurança Nacional, que previa a prisão perpétua e a pena de morte, em casos de "traição" da pátria, dificultava-se ainda mais a ação das organizações guerrilheiras. No país que Viegas, Barbosa e Duarte deixaram, os que tinham poder eram aqueles que possuíam carteira de identificação de livre trânsito, com o Brasão da República estampado. Geralmente, pessoas do submundo da prostituição e justiçamentos, como o Delegado do DOPS, Sérgio Paranhos Fleury, que recebera a Medalha de Pacificador do Exército Nacional. Nesse país, vigorava o poder da força bruta, acima do Estado de Direito; a mediocridade, acima da inteligência; a delação, acima da solidariedade. Nesse país, Duarte era o "Japonês", ladrão facínora, que merecia pena de morte. Era como, infelizmente, a maioria da população pensava. Antônio Duarte fala da liberdade que sentiu, depois de tanto tempo, enquanto passava por vários países, até chegar à Suécia. Do respeito que recebia das outras pessoas; dos momentos de descontração e segurança que sentiu ao dividir cerveja, ou cigarros, com estranhos. Ou, indo a outro extremo, a experiência de Capitani em Cuba; a felicidade em sentir-se construindo um país sem desigualdades econômicas e a solidariedade dos cubanos nessa grande construção.

Nesta nossa narrativa, contamos a trajetória de um grupo de pessoas que tiveram origens comuns e a mesma formação política. Partimos de sua criação, que denominamos "Coletivo"; suas experiências parecidas e a solidariedade que havia entre seus membros. A experiência desse grupo é um pouco a história da resistência à ditadura, ou, por que não?, um pouco da história da guerrilha no Brasil.

Falta falar do destino dos presos comuns, que se tornaram presos políticos, que aderiram ao Coletivo.

Falamos da morte estranha de Cietto, depois de sessões de tortura. O que os militares fizeram com ele, podemos imaginar. A experiência que tivera junto com o Coletivo esvaírase, assim como a crença numa sociedade mais justa. O que seria dele agora? Voltaria certamente para a prisão, para o resto de sua vida.

A possível perda no sentido da vida, que afetou Cietto, provavelmente também atingiu Michel Godoy. Mas, posteriormente, depois que deixou a cadeia.

Depois de sua prisão, Godoy foi enviado para a Polícia do Exército, onde ficou um tempo e, em seguida, despachado para o Presídio da Ilha das Flores. Ali ficou, juntamente com André Borges, na galeria dos presos comuns. Edison ficara um tempo ali também. Mas, 
no caso dos dois primeiros, havia uma incoerência, pois respondiam a processos na Auditoria da Justiça Militar. Depois de um tempo, conseguiram ser transferidos para a galeria dos presos políticos. No entanto, segundo Borges, sem a permissão do banho de sol. O máximo que conseguiram foi a troca de cela, para uma onde batia sol.

Em 1984, em plena Campanha pelas Diretas Já, Michel Godoy se suicidou. Deixou uma carta, dizendo os motivos de seu ato e falando que era favorável às eleições diretas para a Presidência da República.

André Borges continuou no Rio de Janeiro, escrevendo poemas e contando sua experiência na política. Escreveu o livro A Fuga, muitas vezes citado nesta pesquisa. Seu último livro, A Viagem, conta, através de personagens fictícios, sua vida no cárcere.

Chegamos ao fim de uma longa narrativa, em que pretendemos nos aproximar do mundo daqueles que pretenderam derrubar a ditadura, através da luta armada. Jovens, a maioria na casa dos vinte, que quando deixaram suas famílias pobres, no interior deste imenso país, para trabalhar na Marinha do Brasil, não imaginavam que um dia pegariam em armas contra seus oficiais superiores. Pessoas que teriam certamente uma vida comum, como as demais de seu meio, e se tornaram singulares, conhecidos por quase todos militantes das diversas organizações, com respeito.

Na maior parte desta Tese, passamos a palavra para eles, propositalmente. Externamos seus consensos e divergências. Algumas vezes, por questão de memória. Outras, por ufania. Absolutamente normal entre homens comuns, que tiveram, contudo, uma juventude plena de ação. 


\section{CONCLUSÕES/ PERSPECTIVAS:}

\section{“UM DESERTO E SEUS TEMORES”}

Apresentamos nesta Tese a trajetória de um grupo de militares subalternos que participou ativamente dos acontecimentos políticos e militares no governo João Goulart. A este grupo, que fez parte da diretoria da AMFNB na ocasião em que houve o protesto dos marinheiros, em 25 a 27 de março de 1964, denominamos Coletivo, já que seus membros tiveram experiências sociais parecidas, oriundos de famílias pobres ligadas ao campo, como, também, a mesma experiência política, na gestão da Associação.

Identificamos as origens da formação do grupo e seu contato com a intensa mobilização política pela qual passava o país, no momento em que era fundada a Associação, assistindo a uma crescente radicalização entre os conservadores e as esquerdas. Relacionamos as ações dos diretores da Associação ao protesto dos subalternos, tendo à frente os sargentos, desde a tentativa de golpe em 1961. Daí, a defesa, pelos marinheiros, das Reformas de Base e seu alinhamento à liderança de Leonel Brizola. Como falou Érica Roth, eles tomaram partido.

E o caminho escolhido foi o das reformas, das mudanças necessárias para o Brasil se desenvolver. A consciência social que adquiriram, através dos contatos com estudantes, políticos e militares nacionalistas, fez com que esses homens refletissem sobre suas condições de militares da Marinha do Brasil, principalmente nas condições de trabalho e nas relações com seus oficiais. Pois eram bem conhecidas as precárias condições de trabalho e os regulamentos anacrônicos da Marinha.

Ao tomar partido do lado das reformas, o Coletivo entrou em rota de colisão com os oficiais conservadores da Marinha. Nesse momento, no entanto, a AMFNB já era a referência de grande parte dos marinheiros, pois a gestão do Coletivo trouxe resultados práticos para a melhoria da vida dos marinheiros e de suas famílias.

Após o protesto dos sargentos em setembro de 1963, houve uma inflexão na relação, que já não era boa, entre o Coletivo e a Administração Naval. Nesse movimento, os sargentos marinheiros e a própria AMFNB tiveram participação relevante. Começaram as perseguições aos diretores da Associação, através de transferências, prisões e a exigência de que mudassem os estatutos da entidade. A radicalização entre as partes chegou a seu ápice na Semana Santa de 1964, às vésperas do Golpe. 
Quando veio o Golpe seus adversários passaram a caçá-los, ávidos por destruí-los completamente. Desnorteados, os marinheiros procuraram os antigos aliados para prepararem a resistência. Perceberam que a destruição parecia total. Centenas de marinheiros foram expulsos da Marinha, muitos apenas porque participaram da Assembleia de março de 1964. A responsabilidade por isso pesou nos ombros daqueles jovens: eles tinham provocado aquele "rabo de foguete", como se expressou Antônio Duarte.

A terra arrasada, no entanto, não os separou. Continuaram quase sempre juntos. Às vezes, um se desgarrava, mas logo voltava a se encontrar com o antigo grupo da AMFNB. Parecia que estavam ligados a um compromisso acordado nos tempos da Associação.

A trajetória desse grupo, a partir do Golpe de 1964, foi marcada por intensa atividade política. Expulsos da Marinha, seus membros engajaram-se na guerrilha de resistência à ditadura, através da liderança de Leonel Brizola. Estavam envolvidos num projeto de libertação nacional. Alguns, mesmo antes de se aproximarem de Brizola, partiram para Cuba com o fito de prepararem-se para a guerrilha que, supunham, levaria à derrubada da ditadura.

A decepção com o recuo abrupto de Brizola e seu Movimento Nacionalista Revolucionário levou-os a procurarem outras organizações para se engajarem na luta armada. Sempre procurando manterem-se unidos.

Quando veio a prisão, numa penitenciária para presos comuns, a situação se agravou. Os primeiros a chegarem, como Antônio Duarte, se sentiam destruídos, vencidos pela força bruta de seus inimigos. Não havia esperança e, ao mesmo tempo, não aceitavam a nova situação de "marginais". Quando os outros integrantes do Coletivo desembarcaram na Lemos Brito, logo reagiram àquela apatia, envolvendo-se em um projeto coletivo complexo de se concretizar.

Mas foi aí, na Lemos Brito, que houve um amadurecimento político desse grupo, através de leituras e discussões. Passaram a não aceitar a condição de presos comuns, reivindicando a união em apenas um presídio das dezenas de marinheiros punidos com o Golpe de 1964. Conseguiram. Havia pelo menos três objetivos práticos: ajudar os presos comuns e a suas famílias a terem uma vida mais digna; preparar-se para a luta armada, através de leituras e contatos com organizações guerrilheiras e planejar, pacientemente, a fuga da Lemos Brito.

Por que esses homens atingiram os objetivos propostos? Entendemos que, em primeiro lugar, por terem dado um sentido a suas vidas. Seu projeto de ação era prospectivo. Haveriam de participar da luta para derrubar a ditadura e fundar uma sociedade igualitária e justa, através da revolução armada. Em segundo lugar, porque tinham uma formação militar, 
baseada no respeito à hierarquia e à disciplina. Como procuramos mostrar, entre os membros do Coletivo, havia uma hierarquia, principalmente no período que passaram na selva. Também eram rigidamente disciplinados. Aliás, em seus testemunhos sempre relacionavam as quedas à indisciplina, ao descuido no cumprimento de regras estabelecidas.

Capitani, sentindo-se admirado pelo êxito da fuga, diz:

"Pensando que essa fuga levou praticamente dois anos para ser organizada e executada, um trabalho de muita paciência, de muito tempo, muito estudo, enfim, de muita informação, de muito segredo, porque ninguém podia saber. Eles sabiam que estava sendo planejada uma fuga, mas não sabiam bem quem iria. Na hora que ia ser selecionado para ir. Até porque, lá tinha marujo que já estava cumprindo a pena [no final da pena], e não interessava fugir, iria sair legalmente. Mas é interessante que não vazou informação, segredo absoluto. A gente tinha uma disciplina muito forte. Até que deu para realizar". 322

Esses homens, que aparentavam tanta semelhança, na verdade, diante do perigo, eram bem diferentes. Por exemplo, a calma de Capitani enquanto subia o Morro do Juramento, ferido, sangrando muito. Parou no bar, tomou a Coca-Cola e, ao pagar, como a mulher não tinha troco, pegou outra nota e esperou o troco. José Duarte que, cercado pelos policiais, avançou atirando ao encontro deles (enquanto Flávio Tavares fazia o contrário). Antônio Duarte, ao ouvir o tiroteio na chegada dos fuzileiros navais na Cabana do Jacu, não conseguiu controlar as pernas, que "tremiam por puro reflexo (...) os gritos ficaram abafados na garganta” (DUARTE, 2009, p. 350). André Borges que, para furar o cerco dos policiais, fez uma criança de refém, quase sendo linchado pelos moradores. Prestes de Paula, tendo diante de si um dos melhores soldados da Polícia do Exército, foi "para cima” dele, atingindo-o no peito, ouvindo-o gritar: "desgraçado, você me matou”! Edison Mello, depois de participar do planejamento da fuga por mais de um ano, na hora ficou imobilizado, sem ação, perdendo a oportunidade de deixar a Lemos Brito. Esses homens eram diferentes porque eram humanos.

Não eram homens embrutecidos. Suas experiências afetivas, como mostramos, eram reconhecidas pelas parceiras. Mas mantinham princípios antigos, como declarou Kátia Valladares a respeito do Marcos, que tinha,

como bom nordestino, aquela noção patriarcal da família, em que o homem manda e desmanda e deve ser consultado antes de qualquer decisão. A depoente ter vindo de Cuba, com o filho, tendo comunicado somente à sua mãe, que foi, afinal, a pessoa que

\footnotetext{
${ }^{322}$ Entrevista a Flávio Luís Rodrigues. Porto Alegre, 12 de julho de 2011.
} 
deixou-lhe os dólares necessários à viagem de volta - já que ela fôra visitar em Cuba a depoente - era mais um motivo de humilhação para Marcos Antônio”. 323

No início de nossa pesquisa para Doutorado, tínhamos algumas questões que buscávamos responder. Procuramos entender como jovens militares subalternos, integrantes da AMFNB, tinham se mantido unidos, depois do Golpe de 1964 e do fechamento de sua entidade. Perguntávamos se seria possível, através da trajetória desses homens, pesquisarmos, ao menos superficialmente, a trajetória da guerrilha no Brasil. E, por fim, queríamos entender como aqueles jovens, que levavam uma vida comum no ambiente da Marinha, com seus futuros praticamente definidos, tinham se tornado singulares, bajulados pelos políticos, amados por belas estudantes, procurados pelas Forças Armadas, tendo suas fotos espalhadas pela cidade do Rio de Janeiro, com o dizer: "procura-se", e seus nomes estampados nas páginas dos jornais; cantados nos rádios pela voz de Jorge Ben Jor; conhecidos e respeitados por quase todas as organizações guerrilheiras, como também pelos soldados, seus perseguidores.

Se o leitor considerar que conseguimos responder às indagações iniciais, damos por atendidas nossas expectativas.

323 . AEL - BNM, 414, caixa 1, volume 1, números das folhas não identificados. 


\section{BIBLIOGRAFIA}

ALBERTI, Verena. História Oral: a experiência do CPDOQ. Rio de Janeiro: Centro de Pesquisa e Documentação de História Contemporânea do Brasil, 1989.

IDEM. Manual de história oral. Rio de Janeiro: FGV, 2005.

ALBERTI, Verena. "Histórias dentro da história". In: PINSKY, Carla Bassanezi (org.). Fontes Históricas. São Paulo: Contexto, 2014.

ALMEIDA, Anderson da Silva. Todo o leme a bombordo - marinheiros e ditadura civilmilitar no Brasil: da rebelião de 1964 à anistia. Dissertação de Mestrado. Universidade Federal Fluminense. Niterói, 2010.

ALMEIDA, Dinoráh Lopes Rubim. A guerrilha esquecida: Memórias do Caparaó (1966-67), o primeiro foco guerrilheiro contra a Ditadura Militar no Brasil. Mestrado apresentado à Universidade Federal do Espírito Santo. Vitória - ES, 2014.

ALVES, Marcio Moreira. Torturas e torturados. Rio de Janeiro: Idade nova, 1967.

AMADO, Janaína. "A culpa nossa de cada dia: Ética e História Oral”. In: Projeto História: Revista do Programa de Estudos Pós-Graduados em História. São Paulo, Nº15, abril de 1997.

AQUINO, Maria Aparecida. Censura, imprensa e Estado autoritário no Brasil (1968-1978). São Paulo: EDUSC, 2000.

IDEM. Caminhos cruzados: imprensa e Estado autoritário no Brasil. Tese de Doutorado. Departamento de História, FFLCH/USP, 1994.

ARAÚJO, Edna Del Pomo de. Prisão e Socialização: a Penitenciária Lemos Brito. Revista CEJ, Brasília, v. 36, p. 83-89, jan./mar.2007.

BORBA, Marco Aurélio. Cabo Anselmo: a luta armada ferida por dentro. São Paulo: Global, 1981.

BORGES, André. A Fuga: presos políticos fogem para participarem da luta armada contra a ditadura. Rio de Janeiro: Urbana, 2008.

BOSI, Ecléa. Memória e sociedade: lembranças de velhos. São Paulo: Companhia das Letras, 1994.

BLOCH, Marc. Apologia da história ou o ofício de historiador. Rio de Janeiro: Zahar, 2001.

BRASIL: NUNCA MAIS. Petrópolis, Vozes, 2001.

CAPITANI, Avelino Biden. A Rebelião dos Marinheiros. Porto Alegre: Artes e Ofícios, 1997.

CARDOSO, Cristina Leite Lopes. Memória, Trabalho e Identidade Social: a experiência prisional na Penitenciária Lemos Brito. Mestrado apresentado à Universidade Federal do Estado do Rio de Janeiro, 2008.

CARDOSO DE MELLO, João Manuel, e NOVAIS, Fernando A. "Capitalismo tardio e sociabilidade moderna". In: NOVAIS, Fernando A.: História da vida privada no Brasil: Contrastes da intimidade contemporânea. São Paulo: Companhia das Letras, 1998. 
CARVALHO, José Murilo de. Forças Armadas e política no Brasil. Rio de Janeiro: Jorge Zahar Editora, 2005.

IDEM. Os Bestializados: o Rio de Janeiro e a República que não foi. São Paulo: Companhia das Letras, 1987.

CASTRO, Celso. Exército e nação: estudos sobre a história do exército brasileiro. Rio de Janeiro: FGV, 2012.

CAVALHEIRO, Almoré Zoch. A legalidade, o golpe militar e a rebelião dos sargentos. Porto Alegre: AGE, 2011.

CHAUVEAU, Agnès; TÉTART, Philippe. Questões para a história do presente. Bauru: EDUSC, 1999.

CIAMBARELLA, Alessandra. "Do cristianismo ao maoísmo: a história da Ação Popular”. In: FERREIRA, Jorge; REIS, Daniel Aarão (orgs.). Revolução e democracia: 1964... Rio de Janeiro: Civilização Brasileira, 2007.

CONSERVA, Paulo. Navegando no Exílio (memórias de um marinheiro). [S.1.]: Gráficas do Nordeste, 1991.

COSTA, José Caldas da. Caparaó: a primeira guerrilha contra a ditadura. São Paulo: Boitempo, 2007.

D’ARAUJO, Maria Celina et alii. Visões do Golpe: A memória militar sobre 1964. Rio de Janeiro: Relume Dumará, 1994.

IDEM. Os anos de chumbo: a memória militar sobre a repressão. Rio de Janeiro: Relume Dumará, 1994.

DREIFUSS, René A. 1964: A Conquista do Estado. Rio de Janeiro: Vozes, 1981.

DUARTE, Antônio. A luta dos marinheiros. Rio de Janeiro: Diorama editora, 2009.

FEBVRE, Lucien. "O problema da descrença no século XVI" (trechos). In: MOTA, Carlos Guilherme (org.): Lucien Febvre. São Paulo: Ática, 1978.

FERREIRA, Jorge; DELGADO, Lucília de Almeida Neves (orgs.). O Tempo da ditadura: regime militar e movimentos sociais em fins do século XX. Coleção "O Brasil Republicano", v. 4. Rio de Janeiro: Civilização brasileira, 2012.

FERREIRA, Jorge; REIS FILHO, Daniel Aarão (orgs.). Revolução e democracia (1964...). Coleção “As esquerdas no Brasil”. Rio de Janeiro: Civilização Brasileira, 2007.

FERREIRA, Jorge et alii. "O nome e a coisa: o populismo na política brasileira". In: $O$ populismo e sua história. Rio de Janeiro: Civilização brasileira, 2001.

FERREIRA, Jorge e GOMES, Ângela de Castro. 1964: o golpe que derrubou um presidente, pôs fim ao regime democrático e instituiu a ditadura no Brasil. Rio de Janeiro: Civilização Brasileira, 2014.

FERREIRA, Jorge. João Goulart: uma biografia. Rio de Janeiro: Civilização Brasileira, 2011.

FERREIRA, Marieta de Moraes. "História Oral, comemorações e ética". In: Projeto História: Revista do Programa de Estudos Pós-Graduados em História. São Paulo, No 15, abril de 1997.

FERREIRA, Marieta de Moraes; AMADO, Janaína (orgs.). Usos e abusos da História Oral. Rio de Janeiro: Editora FGV, 2006. 
FICO, Carlos. Como eles agiam. Os subterrâneos da Ditadura Militar: espionagem e polícia política. Rio de Janeiro/São Paulo: Record, 2001

FICO, Carlos. "Espionagem, polícia política, censura e propaganda: os pilares básicos da repressão". In: FERREIRA, Jorge; DELGADO, Lucília de Almeida Neves (orgs). O tempo da ditadura: regime militar e movimentos sociais em fins do século XX. Rio de Janeiro: Civilização Brasileira, 2012.

FOUCAULT, Michel. Vigiar e punir: história da violência nas prisões. Petrópolis, RJ: Vozes, 2010.

FRANK, Robert. "Questões para as fontes do presente". In: CHAUVEAU, Agnès e TÉTART, Philippe: Questões para a história do presente. Bauru: EDUSC, 1999.

GABEIRA, Fernando. O que é isso, companheiro? Rio de Janeiro: Codecri, 1979.

GASPARI, Elio. A ditadura envergonhada. São Paulo: Companhia das Letras, 2002.

IDEM. A ditadura escancarada. São Paulo: Companhia das Letras, 2002.

GOMES, Ângela de Castro. A invenção do trabalhismo. Rio de Janeiro: FGV, 2005.

IDEM. Jango: as múltiplas faces/ Angela de Castro Gomes, Jorge Ferreira. Rio de Janeiro: FGV, 2007.

IDEM. "O populismo e as ciências sociais no Brasil: notas sobre a trajetória de um conceito". In: FERREIRA, Jorge: O populismo e sua história. Rio de Janeiro: Civilização brasileira, 2001.

GORENDER, Jacob. Combate nas trevas. A esquerda brasileira: das ilusões perdidas à luta armada. São Paulo: Editora Ática, 1987.

HOBSBAWM, Eric. A Era dos Extremos: o breve século XX: 1914-1991. São Paulo: Companhia das Letras, 1995.

HOLLANDA, Heloísa B. Impressões de viagem: CPC, vanguarda e desbunde, 1960/70. Rio de Janeiro: Aeroplano, 2004.

HOLlANDA, Heloísa B. e GONÇALVES, Marcos A. Cultura e participação nos anos 60. São Paulo: Brasiliense, 1982.

JUREMA, Abelardo: Sexta-feira, 13; Os Últimos Dias do Governo Goulart. Rio de Janeiro, Edições O Cruzeiro, 1966.

LACOUTURE, Jean. "A história imediata". In: LE GOFF, Jacques: A história nova. São Paulo: Martins Fontes, 1993.

LE GOFF, Jacques. “A política será ainda a ossatura da história?” In: $O$ maravilhoso e o quotidiano no ocidente medieval. Lisboa: Edições 70, 2010.

LE GOFF, Jacques. "A visão dos outros: um medievalista diante do presente". In: CHAUVEAU, Agnès e TÉTART, Philippe: Questões para a história do presente. Bauru: EDUSC, 1999.

LOWENTHAL, David. Como conhecemos o passado. In: Projeto história: revista do Programa de Estudos Pós-graduados em História, nº 17, São Paulo: novembro de 1998.

MACIEL, Luiz Carlos. Geração em transe: memórias do tempo do tropicalismo. Rio de Janeiro: Nova Fronteira, 1996. 
MACIEL, Wilma Antunes. Militares de esquerda: formação, participação política $e$ engajamento na luta armada (1961-1974). Tese de Doutorado. Universidade de São Paulo. Departamento de História da FFLCH, 2009.

MAIA, Clarissa Nunes et alii. História das prisões no Brasil. Rio de Janeiro: Rocco, 2009.

MEIHY, José Carlos Sebe Bom, Fabíola Holanda. História oral: como fazer, como pensar. São Paulo: Contexto, 2007.

MEIHY, José Carlos Sebe Bom. A revolução possível: história oral de soldados brasileiros na Guerra Civil Espanhola. São Paulo: Xamã, 2009.

MELLO, Edison Duarte. Novos Rumos. Material não publicado, datilografado, entregue pelo autor a Flávio Luis Rodrigues na ocasião de sua entrevista, em 10 de julho de 2012 . s/d.

MORAES, Denis. A esquerda e o Golpe de 64. Rio de Janeiro: Espaço e Tempo, 1989.

MORAES, João Quartim de. A esquerda militar no Brasil. São Paulo: Expressão popular, 2005.

MARQUES, Liliane de Almeida Fonseca. O mais novo retrato da Penitenciária Lemos Brito. Webartigos.com. 2007.

NAPOLITANO, Marcos. 1964: História do Regime Militar Brasileiro. São Paulo: Contexto, 2014.

NEVES, Lucília de Almeida. "Trabalhismo, nacionalismo e desenvolvimentismo: um projeto para o Brasil (1945-1964)". In: FERREIRA, Jorge: o populismo e sua história. Rio de Janeiro: Civilização brasileira, 2001.

NIETHAMMER, Lutz. "Conjunturas de identidade coletiva”. In: Projeto História: Revista do Programa de Estudos Pós-Graduados em História. São Paulo, nº 15, Abril de 1997.

PARUCKER, Paulo Eduardo Castello. Praças em pé de guerra: movimento político dos subalternos militares no Brasil (1961-1964) e a Revolta dos Sargentos de Brasília. São Paulo: Expressão popular, 2009.

PAZ, Carlos Eugênio. Viagem à luta armada: memórias da guerrilha. Rio de Janeiro: BestBolso, 2008.

PEIXOTO, Antonio Carlos. "Exército e política no Brasil: Uma crítica dos modelos de interpretação"._In: ROUQUIÉ, Alain: Os partidos militares no Brasil, Rio de Janeiro: Record, 1980.

PINHEIRO NETO, João. Jango: um depoimento pessoal. Rio de Janeiro: Record, 1993.

PLATÃO. Diálogos. Teeteto Crátilo. Tradução: Carlos Alberto Nunes. Belém: Editora Universitária, UFPA, 2001.

PORTELLI, Alessandro. "Tentando aprender um pouquinho. Algumas reflexões sobre a ética na história oral". In: Projeto História: Revista do Programa de Estudos Pós-graduados em história. São Paulo, no 15, abril de 1997.

RAMOS, Graciliano. Memórias do Cárcere. Rio de Janeiro: Record, 1998.

REIS, Daniel Aarão. "Classe operária, partido de quadros e revolução socialista: o itinerário da Política Operária - Polop (1961-1986)”. In: FERREIRA, Jorge; REIS, Daniel Aarão (orgs.). Revolução e democracia: 1964... Rio de Janeiro: Civilização Brasileira, 2007. 
REIS FILHO, Daniel Aarão. "O colapso do colapso do populismo ou a propósito de uma herança maldita". In: FERREIRA, Jorge: $O$ populismo e sua história. Rio de Janeiro: Civilização brasileira, 2001.

IDEM. Revolução faltou ao encontro. São Paulo: Brasiliense, 1990.

IDEM. Ditadura militar, esquerdas e sociedade. Rio de Janeiro: Zahar, 2002.

REIS FILHO, Daniel Aarão; SÁ, Jair Ferreira de. Imagens da Revolução: documentos políticos das organizações clandestinas de esquerda dos anos 1961-1971. Rio de Janeiro: Marco Zero, 1985.

REIS FILHO, Daniel Aarão, Marcelo Ridenti, Rodrigo Patto Sá Motta (orgs.). O golpe e a ditadura militar: quarenta anos depois (1964-2004). Bauru: Edusc, 2004.

RÉMOND, René. “O retorno do político". In: CHAUVEAU, Agnès e TÉTART, Philippe: Questões para a história do presente. Bauru: EDUSC, 1999.

IDEM. Por uma história política. Rio de Janeiro: FGV, 2003.

RIBEIRO, Darcy. Confissões. São Paulo: Companhia das Letras, 1998.

IDEM. Jango e eu. Rio de Janeiro: Fundação Darcy Ribeiro; Brasília, DF: UnB, 2010.

IDEM. Golpe e exílio. Rio de Janeiro: Fundação Darcy Ribeiro; Brasília, DF: UnB, 2010.

RIBEIRO, Octávio. Por que eu traí: confissões de Cabo Anselmo. São Paulo: Global, 1984.

RICOEUR, Paul. A memória, a história, o esquecimento. Tradução: Alain François [et al.]. Campinas, SP: Editora da Unicamp, 2007.

RIDENTI, Marcelo; REIS, Daniel Aarão; MOTTA, Rodrigo Patto Sá (orgs). A ditadura que mudou o Brasil. 50 anos do Golpe de 1964. Rio de Janeiro: Zahar, 2014.

RIDENTI, Marcelo. “As esquerdas e a ditadura civil-militar”. In: FERREIRA, Jorge; REIS, Daniel Aarão (orgs.). Revolução e democracia: 1964... Rio de Janeiro: Civilização Brasileira, 2007. (As esquerdas no Brasil; v.3). A.

RIDENTI, Marcelo; REIS FILHO, Daniel Aarão (orgs.). História do marxismo no Brasil. Campinas: Unicamp, 2007. B.

RIDENTI, Marcelo. “Esquerdas armadas urbanas: 1964-1974”. In: RIDENTI, Marcelo; REIS, Daniel Aarão (orgs.). História do marxismo no Brasil (partidos e movimentos após os anos 1960). Campinas: Unicamp, 2007. B

RIDENTI, Marcelo. O fantasma da revolução brasileira. São Paulo: UNESP, 1993.

RIOUX, Jean-Pierre. "Entre história e jornalismo". In: CHAUVEAU, Agnès e TÉTART, Philippe: Questões para a história do presente. Bauru: EDUSC, 1999.

RIOUX, Jean-Pierre. "Pode-se fazer uma história do presente?" In: CHAUVEAU, Agnès e TÉTART, Phillippe: Questões para a história do presente. Bauru: EDUSC, 1999.

ROUQUIÉ, Alain. Os Partidos Militares no Brasil. Rio de Janeiro: Record, 1980.

RODRIGUES, Flávio Luís. Vozes do Mar: a trajetória da Associação dos Marinheiros e Fuzileiros Navais do Brasil (1962-1964). Dissertação de Mestrado. Universidade de São Paulo. São Paulo: 2003.

IDEM. Vozes do Mar: O Movimento dos Marinheiros e o golpe de 64. São Paulo: Cortez, 2004. 
IDEM. “A Revolta dos Marinheiros de 1964: uma história mal contada". In: SILVA, Marcos (org.). Brasil, 1964/1968: a ditadura já era ditadura. São Paulo: LCTE, 2006.

ROLIM, César Daniel de Assis. Leonel Brizola e os setores subalternos das Forças Armadas Brasileiras: 1961-1964. Mestrado apresentado na Universidade Federal do Rio Grande do Sul. Porto Alegre, 2009.

ROLLEMBERG, Denise. O apoio de Cuba à luta armada no Brasil. Rio de Janeiro: Mauad, 2001.

ROLLEMBERG, Denise. "Carlos Marighella e Carlos Lamarca: memórias de dois revolucionários". In: FERREIRA, Jorge; REIS, Daniel Aarão (orgs.). Revolução $e$ democracia: 1964... Rio de Janeiro: Civilização Brasileira, 2007.

SANTOS, Stefan Freitas dos. Batalha pela democracia: 1961-1964. Outras visões, os sargentos $e$ o governo João Goulart. Mestrado apresentado ao Centro de Pesquisa e Documentação de História contemporânea do Brasil - CPDOC. Rio de Janeiro, 2010.

SEGATTO, José Antonio; SANTOS, Raimundo. "A valorização da política na trajetória pecebista: dos anos 1950 a 1991". In: RIDENTI, Marcelo; REIS, Daniel Aarão (orgs.). História do marxismo no Brasil - partidos e movimentos após os anos 1960. Campinas: Unicamp, 2007.

SILVA, Eduardo. Dom Obá II D’África, o príncipe do povo: vida, tempo e pensamento de um homem livre de cor. São Paulo: Companhia das Letras, 1997.

SILVA, Marcos. Contra a chibata: marinheiros brasileiros em 1910. São Paulo: Brasiliense, 2002.

SILVA, Marcos. "Jornalismo retrospectivo e quase-História: Imaginem se a ditadura fosse desavergonhada!". Resenha de A ditadura envergonhada, de Elio Gaspari (São Paulo: Cia. das Letras, 2002). Revista ADUSP. São Paulo: ADUSP, 34: 80/84, maio de 2005.

SILVA, Marcos (org.). Brasil, 1964/1968: a ditadura já era ditadura. São Paulo: LCTE, 2006.

SILVA, Mário Augusto Medeiros da. Os escritores da guerrilha urbana: literatura de testemunho, ambivalência e transição política (1977-1984). São Paulo: Annablume; Fapesp, 2008.

SODRÉ, Nelson Werneck. A Fúria de Calibã: memórias do Golpe de 64. Rio de Janeiro: Bertrand Brasil, 1994.

IDEM. Do Estado Novo à ditadura militar. Petrópolis: Vozes, 1987.

IDEM. História Militar do Brasil. São Paulo: Expressão popular, 2010.

SOUZA, Miliandre Garcia de. Do teatro militante à música engajada: a experiência do CPC da UNE (1958-1964). São Paulo: Perseu Abramo, 2007.

SOUZA, Percival de. Autópsia do medo: vida e morte do delegado Sérgio Paranhos Fleury. São Paulo: Globo, 2000.

IDEM. Eu, cabo Anselmo. São Paulo: Globo, 1999.

STEPAN, Alfred. Os militares na política. Rio de Janeiro: Artenova, 1975.

TAVARES, Flávio. Memórias do esquecimento: os segredos dos porões da ditadura. Rio de Janeiro: Record, 2005. 
IDEM. Meus 13 dias com Che Guevara (o homem-mito que conheci e retratei). Porto Alegre: L\&PM, 2013.

TÉTART, Philippe. Pequena História dos historiadores. Bauru: EDUSC, 2000.

THIESEN, Icléia (org.). Imagens da clausura na ditadura de 1964: informação, memória e história. Rio de Janeiro: 7 letras, 2011.

THOMSON, Alistair. Recompondo a memória: questões sobre a relação entre a História Oral e as memórias. In: Projeto História: Revista do Programa de Estudos Pós-graduados em História, São Paulo, nº 15, abril de 1997.

THOMPSON, Paul. A voz do passado: História Oral. Rio de Janeiro: Paz e Terra,1992.

TOLEDO, Caio Navarro (org.). 1964: visões do golpe: democracia e reformas no populismo. Campinas: UNICAMP, 1997.

VENTURA, Zuenir. 1968: o ano que não terminou. São Paulo: Círculo do Livro, 1988.

VIANNA, Martha. Uma tempestade como a sua memória: a história de Lia, Maria do Carmo Brito. Rio de Janeiro: Record, 2003.

VIEGAS, Pedro. Trajetória rebelde. São Paulo, Cortez, 2004. 


\section{ENTREVISTAS}

\section{Gravação em áudio, transcrita}

ANTÔNIO DUARTE DOS SANTOS: Rio de Janeiro, 11 de julho de 2012.

ANTÔNIO GERALDO COSTA: Maceió, 19 e 20 de julho de 2011.

AVELINO BIDEN CAPITANI: Porto Alegre, 12 de julho de 2011.

JOSÉ ADEILDO RAMOS: João Pessoa, 21 de julho de 2011; 23 e 24 de janeiro de 2017; 04 de fevereiro de 2017.

JOSÉ ANDRÉ BORGES: Rio de Janeiro, 18 de julho de 2011; 27 de janeiro de 2017.

EDISON DUARTE DE MELLO: Rio de Janeiro, 10 de julho de 2012.

ÉRICA BAYER IN ROTH: Teresópolis, 23 de novembro de 2003.

PEDRO FRANÇA VIEGAS: Iperó, 9 de outubro de 2008; 22, 23 e 31 de janeiro de 2017; 06 de fevereiro de 2017. 